\title{
OVER BESCHAVING EN BEDELING
}

De gemeentelijke armenzorg in Amsterdam tussen beschaven en bureaucratiseren van 1870 tot 1940
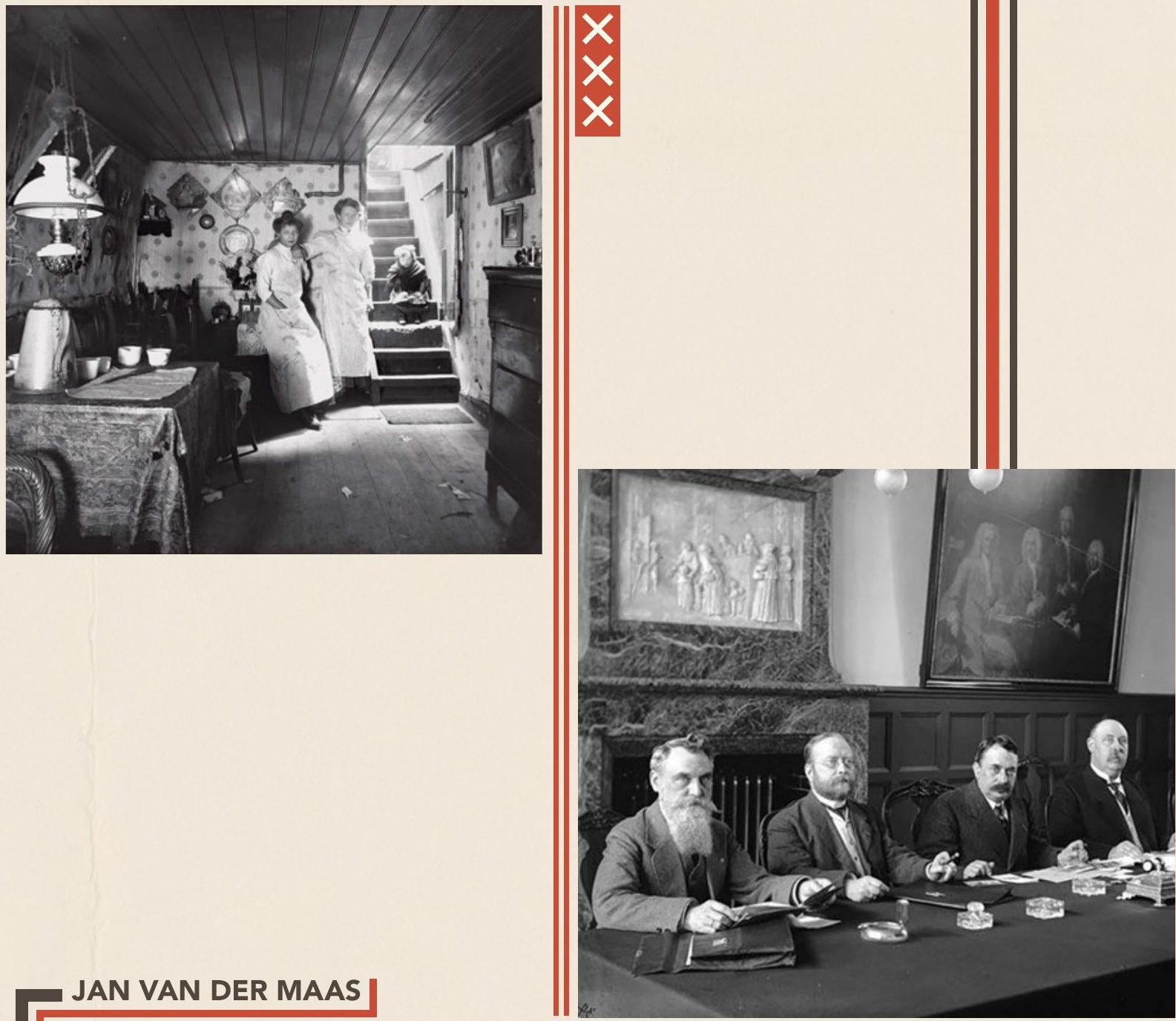



\section{OVER BESCHAVING EN BEDELING}

De gemeentelijke armenzorg in Amsterdam tussen beschaving en bureaucratisering van 1870 tot 1940

Jan A. van der Maas 
Vormgeving: Elbrich Steegstra - Grafisch Ontwerp en Illustratie

Drukwerk: Gildeprint

Afbeelding voorzijde boven: Groepsportret van de Staatscommissie voor de Armenverzorging in de Stelling Amsterdam in 1914. Bron: Nationaal Militair Museum Soesterberg. Serie: Verplegings-Commissie - Glasnegatieven bestemd voor J. Kooiman, De Nederlandsche Strijdmacht en hare Mobilisatie in 1914. Objectnummer 00108731.

Afbeelding voorzijde onder: Kelderwoning Zeedijk 58 in 1913. De onderkant van de zoldering was lager dan het straatoppervlak. Reproductie naar foto van de Gemeentelijke Dienst Volkshuisvesting. Onbekende fotograaf. Bron: SAA. Beeldbank. Afbeeldingsbestand 5293FO002025.

Afbeelding achterzijde: Mantelvel vragenlijst uit 1935. Bron: SAA 5256.

ISBN 978-90-393-7397-2

DOI https://doi.org/10.33540/528

(C) 2021 Jan A. van der Maas

Niets uit deze uitgave mag worden vermenigvuldigd en/of openbaar gemaakt worden door middel van druk, fotokopie of op welke wijze dan ook, zonder voorafgaande toestemming van de auteur. 


\title{
Over beschaving en bedeling
}

\section{De gemeentelijke armenzorg in Amsterdam tussen beschaven en bureaucratiseren van 1870 tot 1940}

\author{
Civilisation and Poor Relief \\ The municipal Poor Relief in Amsterdam between \\ Civilisation en Bureaucracy (1870-1940) \\ (with a summary in English)
}

\section{Proefschrift}

ter verkrijging van de graad van doctor aan de Universiteit Utrecht op gezag van de rector magnificus, prof.dr. H.R.B.M. Kummeling, ingevolge het besluit van het college voor promoties in het openbaar te verdedigen op

vrijdag 22 oktober 2021 des middags te 16:15 uur

door

Jan Adriaan van der Maas

geboren op 20 september 1951

te Amsterdam 


\section{Promotoren:}

Prof. dr. A.F. Heerma van Voss

Prof. dr. M.H.D. van Leeuwen

\section{Beoordelingscommissie:}

Prof. dr. A. Knotter

Prof. dr. J. Kok

Prof. dr. E.J.V. van Nederveen Meerkerk

Prof. dr. M.R. Prak

Dr. C.A.L. Smit 




\section{LIJST VAN AFBEELDINGEN, GRAFIEKEN EN \\ TABELLEN $\mathrm{xi}$}

PROLOOG 1

\section{HOOFDSTUK 1}

VRAAGSTELLING; OPZET VAN DE STUDIE 5

1.1 Inleiding 5

1.2 Vraagstelling: Gemeentelijke armenzorg in Amsterdam in de periode 1870-1940:

beschaven en bureaucratiseren 6

1.3 Opzet van de studie 7

HOOFDSTUK 2

BESCHAVING EN BUREAUCRATISERING 11

2.1 Inleiding 11

2.2 Beschaving 11

a Het civilisatieproces volgens Elias 11

b Het burgerlijk beschavingsoffensief 12

c De Regt over arbeidersgezinnen en beschavingsarbeid 13

2.3 Bureaucratisering 15

a Inleiding 14

b Aandachtspunten rond de bureaucratietheorie van Max Weber 16

c De bureaucratietheorie van Max Weber in hoofdpunten 17

2.4 Beschaven en bureaucratisering in de literatuur over armenzorg 19

HOOFDSTUK 3

BRONNEN EN ONDERZOEKSOPZET 25

3.1 Bronnen voor de gemeentelijke armenzorg in Amsterdam in de periode 1870-1940 25

3.2 Onderzoeksopzet 27
HOOFDSTUK 4

ARMOEDE EN ARMENZORG 33

4.1 Wat is armoede? 33

4.2 Wie waren de armen? 36

4.3 Hoe was de armenzorg van de middeleeuwse periode tot en met de twintigste eeuw opgezet? 37

a Inleiding 37

b De middeleeuwse periode van de elfde tot de vijftiende eeuw 38

c De vroegmoderne periode 38

d De negentiende en twintigste eeuw 40

\section{HOOFDSTUK 5}

AMSTERDAM 43

5.1 Inleiding 43

5.2 Armenzorg in Amsterdam van 1578 tot 181143

5.3 De landelijke ontwikkeling van armenzorg van 1811 tot 194046

5.4 De organisatie van de armenzorg in Amsterdam van 1811 tot 194050

5.5 Naar een moderne samenleving in Amsterdam 55

a Bevolkingsontwikkeling 56

b Van nijverheid naar industrie 57

c Handel, verkeer en de financiële sector 63

d Sociale verhoudingen: van statisch naar dynamisch 63

e De betekenis van de verandering van de structuur van de stad voor de armenzorg 65

f Samenvatting 66 
HOOFDSTUK 6

BESCHAVING 69

\subsection{Inleiding 69}

6.2 Visies op armenzorg en beschaving in de negentiende eeuw en begin twintigste eeuw 69

a Een traditionele visie vanuit de burgerij 69

b Een nieuwe visie vanuit de burgerij op de armen 69

c Een visie vanuit de sociaaldemocratie 72

\subsection{Beschaving binnen de Amsterdamse} gemeentelijke armenzorg: empirisch gedeelte 72

a Inleiding 72

b Het oordeel van de armbezoeker over de aanvragers 73

c De indruk van de armbezoeker van de welstandscriteria van de woning 78

d De indruk van de armbezoeker van de hygiëne van de woning; 82

e De afwijzingsgronden 84

6.4 Veranderende leefomstandigheden van de armen 92

a De huisvesting 93

b De medische gesteldheid 100

c De sociale stratificatie 102

d Het schoolbezoek 107

e Samenvatting 110

6.5 Conclusie 111

\section{HOOFDSTUK 7}

\section{BUREAUCRATISERING 115}

7.1 De praktijk van de Amsterdamse gemeentelijke armenzorg 115

a De ontwikkeling en groei van de bureaucratie 115

b De bureaucratie als onderdeel van de overheid 128

c De positie en de functie van de ambtenaar 128

d Het blijvende karakter van de bureaucratie 132 e Het rationaliteitsprincipe 133

f De structuur van de bureaucratie 138

$g$ Besluit 140

7.2 De bureaucratisering van de Amsterdamse gemeentelijke armenzorg in breder perspectief 141

a Het perspectief van het Rijk 141

b Algemeen kiesrecht en democratisering ("enkel de bonen waren taai") 142

c Frictie tussen hoge ambtenaren en de gemeenteraad 145

d Samenvatting 147

7.3 Conclusie 147

HOOFDSTUK 8

LEVENSVERHALEN 151

8.1 De gezinnen Schouten-RoelofsBroekhuijsen-Winkelaar 1886-1938 151

8.2 Catharina Marie Willemse en Nicolaas Christiaan Cornelisse, bijgenaamd Klaasje Zevenster 1896-1938 158

8.3 Jacob Kooseman en Cornelia Klipp 1888-1939 166

8.4 Het gezin Houben 1892-1899 169

8.5 Het gezin Groenevelt 1892- 1933/1943 172

8.6 Het gezin Aal 1898-1950 175

HOOFDSTUK 9

SLOTBESCHOUWING 183

SAMENVATTING 189

SUMMARY 193

BRONNEN 197

LITERATUUR 199 


\section{BIJLAGE 1}

Voorbeeld van een vragenlijst met instructie voor de armbezoeker 211

\section{BIJLAGE 2}

Voorbeeld van een vragenlijst volgens het oude model 213

\section{BIJLAGE 3}

Voorbeeld van een vragenlijst volgens het nieuwe model 214

\section{BIJLAGE 4}

Aantal vrijwillige armbezoekers 1910-1940 215

\section{BIJLAGE 5}

Maximale uitkeringen 1909-1932 218

\section{BIJLAGE 6}

Aantallen dubbel bedeelden Burgerlijk

Armbestuur Amsterdam 1896-1922 219

\section{BIJLAGE 7}

Taken van de gemeentelijke armenzorg en uitbreiding van werkzaamheden 220

\section{BIJLAGE 8}

Statistische bijlage 219 



\section{LIJST VAN AFBEELDINGEN, GRAFIEKEN EN TABELLEN}

\section{AFBEELDINGEN IN DE TEKST}

AFBEELDING 5.1 De armeninrichting "Toevlugt voor behoeftigen", 1850-1856, p. 54

AFBEELDING 5.2 Slaapzaal "Toevlucht voor behoeftigen", 1880-1900, p. 55

AFBEELDING 5.3 De annexaties van 1877 en 1896, p. 56

AFBEELDING 5.4 De annexatie van 1921, p. 58

AFBEELDING 5.5 Lijnennet Gemeentetram in 1914 , p. 60

AFBEELDING 6.1 J.F.L. Blankenberg (1852-1927), p. 71

AFBEELDING 6.2 Marie Geertruide Muller-Lulofs (1854-1954), p. 71

AFBEELDING 6.3 Goudsbloemgracht en Franschepad: situatie voor 1854, p. 96

AFBEELDING 6.4 Gang met gootsteen voor twee gezinnen in een krotwoning, Lindengracht 216 in 1894, p. 97

AFBEELDING 6.5 Boldootkar in de Slijkstraat, vermoedelijk tijdens het interbellum, p. 98

AFBEELDING 6.6 Kelderwoning Zeedijk 58 omstreeks 1913, p. 98

AFBEELDING 6.7 Jonkerstraat in 1927, p. 99

AFBEELDING 6.8 Krotwoning Korte

Koningsstraat 13 hs in 1934, p. 100

AFBEELDING 6.9 Twee mannen met handkar,
1887-1889, p. 104

AFBEELDING 6.10 Zakkendrager, 1887-1889, p. 105

AFBEELDING 6.11 Werkman, circa 1930, p. 106

AFBEELDING 6.12 Slapende Werkvrouw, 1890, p.107

AFBEELDING 6.13 Armenschool, 1850-1860, p. 109

AFBEELDING 6.14 Openbare Lagere School nr. 48, april 1904, p. 110

AFBEELDING 7.1 Onbewoonbaar verklaarde woning Willemsstraat, circa 1899, p. 123

AFBEELDING 7.2 Organogram van de gemeentelijke Armenzorg in 1871, p. 138

AFBEELDING 7.3 Organogram van de gemeentelijke Armenzorg in 1918, p. 139

AFBEELDING 7.4 Organogram van de gemeentelijke Armenzorg in 1928, p. 139

AFBEELDING 7.5 Alexander Lisser (1875-1943), p. 144

AFBEELDING 8.1 Slijkstraat, 1931, p. 157

AFBEELDING 8.2 Oude Braak, 1907, p. 159

AFBEELDING 8.3 Kromme Elleboogsteeg, circa 1900, p. 160

AFBEELDING 8.4 De Ridderstraat, 1928, p. 162 
AFBEELDING 8.5 Lindenstraat, 1920, p. 167

AFBEELDING 8.6 Elandsgracht, 1923, p. 168

AFBEELDING 8.7 Lindenstraat, 1879, p. 170

AFBEELDING 8.8 Lindenstraat, 1930, p. 171

AFBEELDING 8.9 Westerstraat, 1920, p. 173

AFBEELDING $\mathbf{8 . 1 0}$ Heideheuvel te Hilversum, 1924 , p. 175

AFBEELDING 8.11 Monnikenstraat, jaren 'vijftig, p. 176

AFBEELDING 8.12 Sint Pieterssteeg, 1906, p. 177

AFBEELDING 8.13 Czaar Peterstraat, 1910, p. 180

AFBEELDING 8.14 Czaar Peterstraat, 1936, p. 180

\section{AFBEELDINGEN AAN HET BEGIN VAN}

HOOFDSTUKKEN

AFBEELDING 1.A Achterzijde

Goudsbloemstraat 14 (circa 1900), p. 4

AFBEELDING 2.A Prentbriefkaart van het Burgerweeshuis circa 1905, p. 10

AFBEELDING 3.A Doktersattest uit 1872, p. 24

AFBEELDING 4.A Een bedelaar-spiritusdrinker op straat circa 1930, p. 32

AFBEELDING 5.A Het Paleis voor Volksvlijt in 1892 , p. 42

AFBEELDING 6.A Bewaarschool van de "Vereeniging Ter Verbreiding van de Waarheid" in 1883, p. 68
AFBEELDING 7.A Kantoor Burgerweeshuis Kalverstraat 92 circa 1904, p. 114

AFBEELDING 8.A Zwarte Bijlsteeg circa 1920, p. 150

AFBEELDING 9.A Gemeubileerde kamer op de eerste verdieping Lindengracht 238 circa 1895, p. 182

\section{GRAFIEKEN}

GRAFIEK 5.1 Inkomensverdeling naar belastinggegevens (1900, 1910, 1921 en 1931), p. 64

GRAFIEK 6.1 Mening armbezoekers over de afgewezen aanvragen (1871, 1911 en 1936), p. 76

GRAFIEK 6.2 Mening armbezoekers over de toegekende aanvragen (1871, 1911 en 1936), p. 77

GRAFIEK 6.3 Indruk armbezoekers van de woning van afgewezen aanvragers in 1871, p. 79

GRAFIEK 6.4 Indruk armbezoekers van de woning van toegekende aanvragers in 1871, p. 80

GRAFIEK 6.5 Indruk armbezoekers van de woning van afgewezen aanvragers in 1911, p. 80

GRAFIEK 6.6 Indruk armbezoekers van de woning van toegekende aanvragen in 1911, p. 81

GRAFIEK 6.7 Indruk armbezoekers van de hygiëne van de woning van de toegekende aanvragers in 1871, p. 83 
GRAFIEK 6.8 Indruk armbezoekers van de hygiëne van de woning van de afgewezen aanvragers in 1871, p. 83

GRAFIEK 6.9 Afwijzingsgronden naar categorieën (1871, 1911 en 1936), p. 91

GRAFIEK 6.10 Gemiddelde ondersteuning per huishouden (1917-1939), p. 93

GRAFIEK 6.11 Aard van de woning (1871, 1911, 1936), p. 94

GRAFIEK 6.12 Lichaamsgebreken aanvragers (1871, 1911 en 1936), p.101

GRAFIEK 7.1 Aandeel Burgerlijk Armbestuur in het totaal ondersteunde armen (1885-1905) , p. 116

GRAFIEK 7.2 Aandeel Burgerlijk Armbestuur in de totale bedeling (1917-1921), p. 116

GRAFIEK 7.3 Bedeelden door algemene en kerkelijke armenzorg in 1895, p. 116

GRAFIEK 7.4 Bedeelden door algemene en kerkelijke armenzorg in 1930, p. 117

GRAFIEK 7.5 Oorzaken armoede van wekelijks bedeelden 1886-1908 p. 118

GRAFIEK 7.6 Aantal steunaanvragen en aantal toegekende aanvragen per jaar 1886-1895, p. 119

GRAFIEK 7.7 Onderzoeken Burgerlijk Armbestuur naar huiszittenarmen (1905-1940), p. 124

GRAFIEK 7.8 Armbezoekers (1871-1916), p. 124
GRAFIEK 7.9 Werknemers armenzorg/ maatschappelijk hulpbetoon (1918-1940), p. 125

GRAFIEK 7.10 Uitgaven Burgerlijk Armbestuur (1871 - 1916), p. 125

GRAFIEK 7.11 Uitgaven ondersteuning per jaar (1917-1939), p. 126

GRAFIEK 7.12 Aandeel gemeente in de uitgaven van het Burgerlijk Armbestuur (18711926), p. 133

GRAFIEK 7.13 Afgewezen aanvragen naar aanvraag type hulp (1871, 1911 en 1936), p. 135

GRAFIEK 7.14 Toegekende aanvragen naar type hulp (1871, 1911 en 1936), p. 136

GRAFIEK 7.15 Burgerlijk overheidspersoneel in Nederland (1849-1930), p. 142 
TABEL 3.1 Geraadpleegde dossiers (1871,1911 en 1936), p. 28

TABEL 6.1 Afwijzingsgronden, p. 85

TABEL 6.2 Beroepen van aanvragers in 1871, 1911 en 1936 naar sociale klasse $(1871,1911$ en 1936), p. 103

TABEL 7.1 Onderzoeken gemeentelijke armenzorg tussen 1905 en 1910, p. 119

TABEL 7.2 Onderzoeken gemeentelijke armenzorg in 1936, p. 121

TABEL 8.1 Inkomensverdeling (1900, 1910, 1921 en 1931), p. 221

TABEL 8.2 Mening armbezoekers over de afgewezen aanvragen (1871, 1911 en 1936), p. 222

TABEL 8.3 Mening armbezoekers over de toegekende aanvragen (1871, 1911 en 1936), p. 223

TABEL 8.4 Indruk armbezoekers van de woning van afgewezen aanvragers (1871, 1911 en 1936), p. 224

TABEL 8.5 Indruk armbezoekers van de woning toegekende aanvragen (1871,1911 en 1936), p. 225

TABEL 8.6 Afwijzingsgronden (1871, 1911 en 1936), p. 226

TABEL 8.7 Afwijzingsgronden naar categorieën (1871, 1911 en 1936), p. 228

TABEL 8.8 Aard van de woning $(1871,1911$ en 1936), p. 228
TABEL 8.9 Lichaamsgebreken aanvragers (1871,1911 en 1936), p. 228

TABEL 8.10 Beroepen aanvragers (1871, 1911 en 1936), p. 229

TABEL 8.11 Scholingsgraad aanvragers, p. 229

TABEL 8.12 Uitgaven ondersteuning per jaar (1917-1939), p. 230

TABEL 8.13 Gemiddelde ondersteuning per huishouden (1917-1939), p. 231

TABEL 8.14 Uitgaven Burgerlijk Armbestuur (1871-1928), p. 232

TABEL 8.15 Aanvragen om ondersteuning; toegekende aanvragen; omvang huishoudens (1886-1895), p. 234

TABEL 8.16 Onderzoeken Burgerlijk Armbestuur naar huiszittenarmen (1905-1940), p. 235

TABEL 8.17 Aandeel Burgerlijk Armbestuur in het aantal ondersteunde armen (1885-1905), p. 236

TABEL 8.18 Aandeel Burgerlijk Armbestuur in totale bedeling (1917-1921), p. 236

TABEL 8.19 Bedeelden door gemeentelijke, particuliere en kerkelijke armenzorg (1895 en 1930), p. 237

TABEL 8.20 Bedeelden door algemene en kerkelijke armenzorg (1895 en 1930), p. 237

TABEL 8.21 Oorzaken armoede van wekelijks bedeelden 1886-1908, p. 238

TABEL 8.22 Armbezoekers/ ambtenaren voor sociale arbeid in vaste dienst (1871-1918), p. 239 
TABEL 8.23 Werknemers armenzorg/

maatschappelijk hulpbetoon (1918-1940), p. 239

TABEL 8.24 Afgewezen aanvragen (1871, 1911 en 1936), p. 240

TABEL 8.25 Toegekende hulp in 1871, p. 241

TABEL 8.26 Toegekende hulp in 1911 en 1936, p. 241

TABEL 8.27 Burgerlijk overheidspersoneel in Nederland (1849-1930), p. 242

TABEL 8.28 Woningen in Amsterdam (1859-

1930), p. 242 



\section{PROLODG}

De armenzorg, in Amsterdam en ook ver daarbuiten, had al heel lang mijn interesse, zelfs al voordat ik begon aan mijn studie geschiedenis. Als docent geschiedenis aan de lerarenopleiding van Hogeschool van Amsterdam ontwikkelde ik samen met mijn collega Herman Kaptein in de jaren '90 een curriculumonderdeel dat we "Leven in een archief" noemden. Tweedejaarsstudenten geschiedenis moesten aan de hand van dossiers van de gemeentelijke armenzorg het leven van een arm gezin in kaart brengen. Hiervoor stond het levensverhaal van Schelto Karper model, dat Frans Smits heeft geschreven. ${ }^{1}$ Deze cursus hebben we tot 2008 gegeven. Het gaf niet alleen voldoening, maar het was ook inspirerend om studenten in te wijden in het archiefonderzoek. Een al langer sluimerend verlangen om zelf studie te maken van het rijke, zeer omvangrijke archief van de gemeentelijke armenzorg kreeg een nadere impuls toen ik een dag in de week korter ging werken bij de Hogeschool. Vanaf die tijd was ik elke vrijdag te vinden op het Stadsarchief van de gemeente Amsterdam. Deze archiefwerkzaamheden kregen nog meer vorm nadat ik Marco van Leeuwen en spoedig daarna Lex Heerma van Voss bereid had gevonden als promotoren op te treden bij mijn onderzoek. Voor hun opbouwende kritiek en het geduld dat zij met mij, als buitenpromovendus, wisten op te brengen ben ik Marco en Lex zeer erkentelijk. Ik was ook vereerd door de uitnodiging van Marco om deel te nemen aan het ESSHC congres in Valencia in 2016. Voor het congres schreef ik een paper waarin de eerste contouren van mijn proefschrift zichtbaar werden.

Veel hulp kreeg ik van het Stadsarchief Amsterdam. In het bijzonder wil ik archivaris Harmen Snel bedanken en met hem ook de andere medewerkers van het archief die de vele dossiers voor mij naar de studiezaal Originelen brachten. Met hulp van Riëtte van Beek heb ik een database opgezet waarin ik de uitgebreide feitenverzameling kon onderbrengen. Zonder haar steun was er van de database niet veel terechtgekomen.

Het bestaan van een buitenpromovendus is soms een beetje eenzaam, maar mijn collega's van de Hogeschool van Amsterdam toonden veel belangstelling en waren altijd bereid naar mijn verhalen te luisteren. In het bijzonder wil ik Frans Groot en Herman Kaptein, mijn kamergenoten, en Frits Rovers, mijn leidinggevende, bedanken voor hun aandacht en bemoedigende woorden. En natuurlijk wil ik ook de collega's "van verder op de gang" bedanken voor hun interesse in het verloop: Dick van Straaten en Huub Oattes.

Veel profijt heb ik gehad van twee meelezers tijdens het schrijven. Bernard Kruithof was goed in het volgen van de grote lijn, terwijl Hans van Straalen vooral lette op de puntjes op de i. In een later stadium was Janet Luis zeer behulpzaam. Zij las de laatste conceptversie in haar geheel en voorzag deze tekst van veel kritisch commentaar. Hun werk heeft de leesbaarheid van mijn proefschrift hopelijk verbeterd en mij behoed voor inhoudelijke en taalkundige misstappen. Voor de resterende fouten in de tekst ben ik uiteraard zelf verantwoordelijk. Onmisbaar was de hulp bij de vormgeving van de gedrukte versie van mijn proefschrift door Elbrich Steegstra. Door haar vakbekwaamheid ligt er nu een fraai stuk drukwerk. Ten slotte 
bedank ik de leden van de beoordelingscommissie (Prof. Dr. A. Knotter, Prof. Dr. J. Kok, Prof. Dr. E.J.V. van Nederveen Meerkerk, Prof. Dr. M.R. Prak en Dr. C.A.L. Smit) voor hun kritisch commentaar.

$\mathrm{Na}$ mijn pensionering kreeg ik de gelegenheid om mijn onderzoek te voltooien. Een belangrijke voorwaarde hiervoor was ook de thuissituatie. Ik ben Mariëtte, Misha, Elaine en Madeleine dankbaar dat ik ruimte kreeg en tijd om mij aan het onderzoek te kunnen wijden. Mijn beide ouders zijn overleden, maar tijdens het onderzoek gingen mijn gedachten vooral uit naar mijn moeder. Het gezin waarin zij opgroeide was in de jaren '30, na het overlijden van haar vader in 1936, enige tijd bedeeld. Zij vertelde hier altijd bijzonder levendige verhalen over. Veel van haar bewoordingen vond ik terug in de antwoorden die de aanvragers gaven op de vragen van de armbezoekers.

Dit onderzoek is nu voltooid, maar het archief van de gemeentelijke armenzorg is zo rijk en veelomvattend dat nog menig onderzoek gedaan kan worden. Toekomstige onderzoeksvragen zullen weer een ander en nieuw licht werpen op de boeiende geschiedenis van de armenzorg in Amsterdam. 


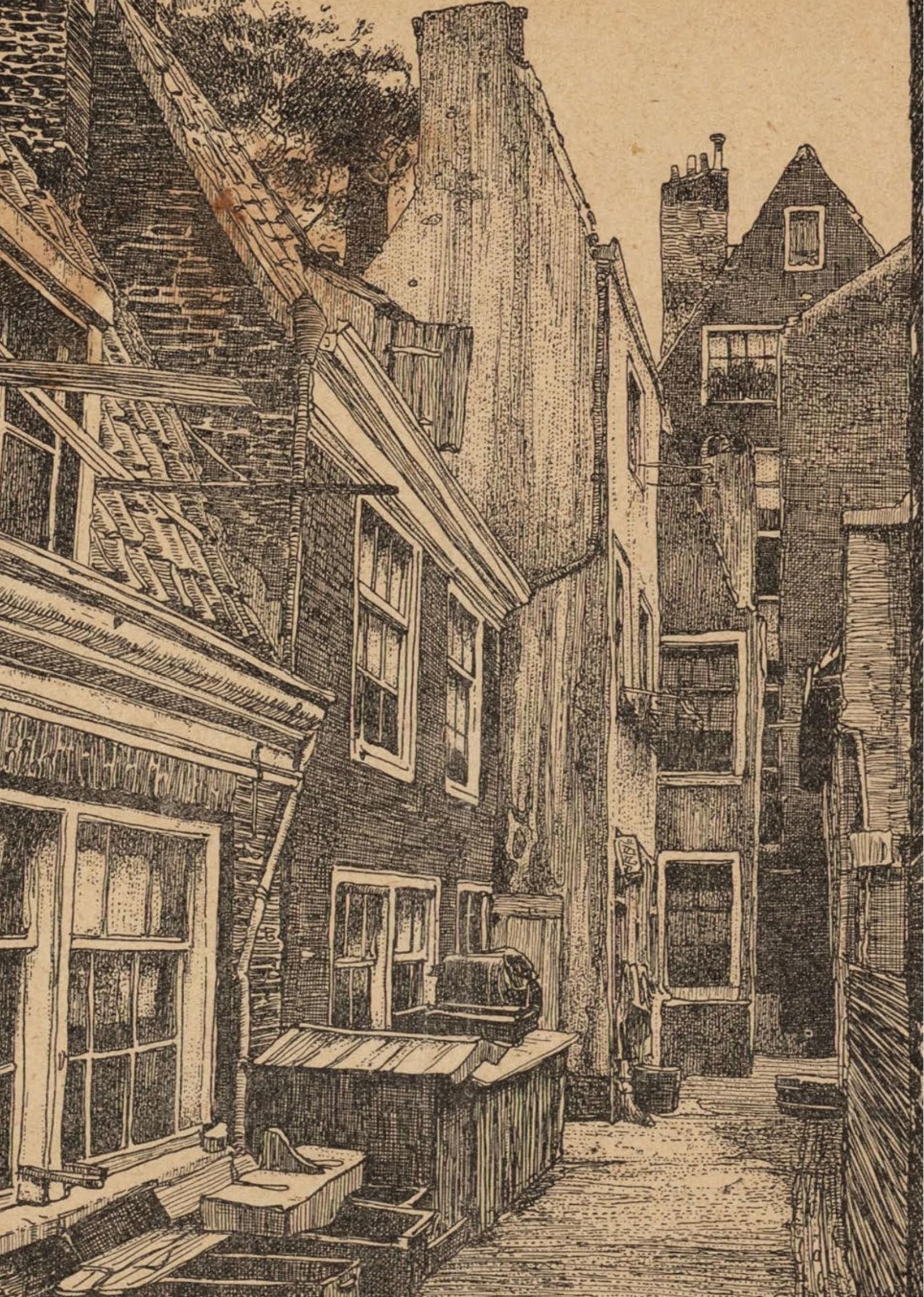


< 1.A Goudsbloemstraat achterzijde 14 (circa 1900) Willemsstraat 3-9 (links v.l.n.r.), de Willem Bakkersgang, gezien naar achterzijde Goudsbloemstraat 14. De gang lag tussen de Zevenkattengang (tussen Willemsstraat 1 en Brouwersgracht 137) en de Zevennaaldengang. Reproductie naar tekening van L.W.R. Wenckebach (1860-1937). Bron: SAA. Beeldbank. Afbeeldingsbestand 010194001465.
1 SAA 5256. Doos 1175A. Stamboeknummer 80. Een gangwoning was een afgesloten deel van een gang in een groter huis. Een gangwoning werd door één huishouden bewoond. Zie ook hoofdstuk 6 paragraaf $4 a$.

2 SAA 5256. Doos 7522.

Stamboeknummer 164053; uit privacyoverwegingen wordt enkel de initiaal van zijn achternaam weergegeven. Zie ook hoofdstuk 3 paragraaf 1.
HOOFDSTUK 1

\section{VRAAGSTELLNG, BRONNEN EN OPZET VAN DE STUDIE}

\subsection{INLEIDING}

In 1871 woonde Johanna Hendrica van Zweeden, een alleenstaande moeder van 35 jaar, met haar drie kinderen in de Goudsbloemstraat. Het gezin woonde niet in een huis, of op een etage, of in een kamer, maar in een gang. ${ }^{1}$ Het verblijf beschikte niet over een toilet. Een armbezoeker die de gangwoning inspecteerde, oordeelde dat het er "tamelijk zindelijk" uitzag. Johanna had af en toe verdiensten als werkster. Zij kreeg voor deze werkzaamheden één tot anderhalve gulden per week. Ter vergelijking: in deze periode bedroeg het modale dagloon van een werkman één gulden per dag, dus zes gulden per week. Johanna kon niet door de Hervormde diaconie worden ondersteund. De armbezoeker stelde vast "dat zij uit hoofde harer armoedigen toestand wel ondersteuning behoeft". Het gezin kwam in aanmerking voor zomerbedeling. Dat kwam neer op één brood per week.

In 1936 vroeg Wilhelm August van den D. zich af of hij in aanmerking kwam voor een extra gift ter gelegenheid van de verloving van prinses Juliana. ${ }^{2}$ Hij woonde op de begane grond in de Kuipersstraat. De woning, verbouwd in 1912, bestond uit een woonkamer, een keuken en twee slaapkamers. De woning beschikte over een toilet. Het gezin van Wilhelm August gezin telde vier leden: zijn echtgenote Aleida en hijzelf, dochter Johanna en zoon Marinus. Het gezin werd bedeeld omdat Wilhelm, bakker van beroep, wegens slapte in de branche nog maar één dag in de week werk had. Hij werkte alleen nog op zaterdag, voor hfl 20,00 per maand. Het gezin kreeg een reguliere steun van $\mathrm{hfl}$ 15,25 per week en daarnaast een brandstoftoeslag tijdens het stookseizoen. De verlovingsgift van hfl 2,50 werd toegekend.

Dit zijn twee bedeelde gezinnen, maar hun omstandigheden waren totaal verschillend: een schrijnende leef- en woonsituatie in 1871 tegenover veel nettere armoede in 1936. Beide gezinnen kregen steun van de gemeentelijke armenzorg in Amsterdam. Niet alleen de leefomstandigheden van de gezinnen, maar ook de gemeentelijke armenzorg was in die kleine zeventig jaar sterk veranderd. De motieven om te ondersteunen waren veranderd, maar ook de wijze waarop de hulp was georganiseerd. Deze studie richt zich op de motieven om te ondersteunen en op de veranderingen in de organisatie van de armenzorg.

In deze studie probeer ik te doorgronden welke ontwikkeling er te zien is in de motivering van de gemeentelijke armenzorg om minderbedeelden te ondersteunen in de periode 1870-1940. Het beschrijven van deze ontwikkeling is interessant omdat zo beter begrepen kan worden waarom en hoe er armenzorg werd verleend. Dat is niet alleen belangwekkend uit academisch, maar ook uit maatschappelijk gezichtspunt. Hoe gaat een samenleving door de jaren heen om met de minst bedeelde groepen die het 
economisch moeilijk hebben? Ik wil laten zien hoe mensen in de negentiende eeuw dachten over het vraagstuk van de armoede. In het begin van de twintigste eeuw waren er andere inzichten en maakte men andere keuzes om dit vraagstuk op te lossen. Ook in de eenentwintigste eeuw moeten nog steeds, bij de ondersteuning van on- en minvermogenden, zorgvuldige afwegingen gemaakt worden. De steunverlening kampt nog altijd met het dilemma dat men optimale steun zou willen bieden aan mensen die het (tijdelijk) moeilijk hebben, maar dat de financiële mogelijkheden beperkt zijn. Wat dat betreft heeft het armoedevraagstuk niets aan actualiteit verloren.

Actueel is ook de vraag naar de manier waarop de hulpverlening wordt georganiseerd. Biedt een bureaucratische opzet meer mogelijkheden dan een opzet die minder formeel van aard is? Er is daarom in dit onderzoek ook veel aandacht voor het bureaucratiseringsproces van de gemeentelijke armenzorg van Amsterdam.

\subsection{VRAAGSTELLING: GEMEENTELIJKE ARMENZORG IN AMSTERDAM IN DE PERIODE 1870-1940: BESCHAVEN EN BUREAUCRATISEREN}

In 1870 werd het Burgerlijk Armbestuur in Amsterdam ingesteld. ${ }^{3}$ Vanaf 1871 zijn de werkzaamheden van deze instelling zichtbaar in cliëntendossiers die bewaard worden in het Stadsarchief van de gemeente Amsterdam. In het begin had de organisatie maar enkele medewerkers, maar in de loop van de twintigste eeuw groeide de gemeentelijke armenzorg uit tot een instelling waar, vlak voor WO II, een kleine zevenhonderd medewerkers actief waren. In deze studie wil ik twee vragen stellen over de werkwijze van de gemeentelijke armenzorg in Amsterdam tussen 1871 en 1940:

1) Welke rol speelde het streven naar beschaving in de manier van werken van de gemeentelijke armenzorg?

2) Op welke wijze werd de organisatie van de gemeentelijke armenzorg gebureaucratiseerd?

Het streven naar beschaving wordt in deze studie opgevat als een manier om het gedrag van de armen te beïnvloeden. Er waren twee redenen om dat gedrag te willen beïnvloeden. In de eerste plaats werd de houding van de armen gezien als bedreigend voor de maatschappelijke orde. Door het gedrag van de armen te veranderen zou die dreiging kunnen verdwijnen. In de tweede plaats werd de houding van de armen als oorzaak van armoede gezien. Door de attitude van de armen te veranderen zou de armoede kunnen worden bestreden. Het is wetenschappelijk relevant te onderzoeken hoe de beschavingsdrang binnen de gemeentelijke armenzorg vorm kreeg en welk effect hij had.

Bij het beantwoorden van de vraag naar de bureaucratisering hoop ik duidelijk te kunnen maken hoe de gemeentelijke armenzorg de enorme groei van de werkzaamheden het hoofd heeft weten te bieden. Hoe kon de armenzorg doelmatig werken? Tussen 1870 en 1940 nam het aantal bedeelden van enkele duizenden toe tot zo'n vijftigduizend per jaar. Het ambtelijke apparaat dijde uit van een vijftal armbezoekers in de jaren zeventig van de negentiende eeuw tot zevenhonderd medewerkers in de twintigste eeuw. De uitbreiding van het bureaucratisch apparaat is een zichtbaar gevolg van de toenemende verantwoordelijkheid die de overheid voor de samenleving
3 De voorganger van het Burgerlijk Armbestuur, de Raadscommissie van het Burgerlijk Armbestuur, was werkzaam tussen 1856 en 1870. Op 1 oktober 1856 trad de 'Verordening op het Burgerlijk Armbestuur' in werking. Deze verordening droeg het Burgerlijk Armbestuur op aan Burgemeester en Wethouders. Tevens werd een Raadscommissie voor het Burgerlijk Armbestuur ingesteld. In 1870 trad een wijziging van de Armenwet in werking en als gevolg daarvan werd in de raadsvergadering van 9 november 1870 het besluit genomen tot opheffing van de Raadscommissie. Gelijktijdig werd het Burgerlijk Armbestuur ingesteld. Bron: SAA 350, 1-4. 
ging nemen. Welke rol speelde het bureaucratiseringsproces hierbij?

De antwoorden op de vragen naar beschaven en bureaucratiseren geven inzicht in de belangrijke rol die de gemeentelijke armenzorg in Amsterdam tussen 1870 en 1940 heeft gehad op maatschappelijk gebied. Ook geven de antwoorden op deze onderzoeksvragen ook inzicht in andere grote veranderingen die zich in Amsterdam tussen 1870 en 1940 voltrokken.

\subsection{OPZET VAN DE STUDIE}

Voor een goed begrip acht ik het noodzakelijk een context te geven. In hoofdstuk 2 schets ik een theoretisch kader. Eerst komen concepten over beschaving aan de orde. Het gaat om de civilisatietheorie van Norbert Elias, de opvattingen over het burgerlijk beschavingsoffensief van Bernard Kruithof en de beschouwingen over beschavingsarbeid van Ali De Regt. De ideeën van Max Weber over bureaucratie worden in het tweede deel van dit hoofdstuk behandeld

In hoofdstuk 3 behandel ik de geraadpleegde bronnen en de onderzoeksopzet. De opzet en het gebruik van een door mij opgestelde database komt tevens aan bod.

In hoofdstuk 4 probeer ik armoede nader te definiëren en de armenzorg door de eeuwen heen te belichten. Ik kijk naar de armoede in Europa. Wat is armoede? Wie waren de armen? Welke organisaties waren er actief op het terrein van armenzorg? Vervolgens schenk ik aandacht aan de armenzorg in Nederland en in Amsterdam. Ik begin met een schets van de organisatie van de armenzorg uit de tijd van de Republiek. Deze wijze van organiseren heeft namelijk tot diep in de twintigste eeuw een stempel gedrukt op de Amsterdamse armenzorg. In de negentiende eeuw was armenzorg nog steeds grotendeels een plaatselijke aangelegenheid, maar nationale ontwikkelingen werden steeds belangrijker. Er wordt aandacht geschonken aan deze landelijke ontwikkelingen. Met een uiteenzetting over de specifieke ontwikkeling van de armenzorg in Amsterdam in de negentiende en twintigste eeuw wordt dit hoofdstuk afgesloten.

De veranderingen in de armenzorg in de negentiende en twintigste eeuw zijn onderdeel van een groter proces: Amsterdam veranderde in de negentiende eeuw van een stad met een pre-industrieel karakter in een stad die je modern kunt noemen. ${ }^{4}$ Deze ontwikkeling wordt in hoofdstuk 5 beschreven. Dit moderniseringsproces zette in met een verandering in de demografische omstandigheden: de "demografische transitie". Vervolgens kwamen er wijzigingen in de top van de sociale structuur. Een elitaire standensamenleving veranderde in een samenleving gedragen door een nieuwe burgerij. De mechanisering van de nijverheid en de industrialisatie schreed voort. De totale structuur van de samenleving veranderde geleidelijk. Ik zal kort ingaan op de gevolgen van de modernisering van de samenleving voor Amsterdam.

De hoofdvragen over beschaven en bureaucratiseren behandel ik in

4 Het begrip 'modernisering' is niet geheel onomstreden. Een criticus is bijvoorbeeld Knöbl (2003), 96-107. hoofdstuk 6 en hoofdstuk 7. Deze twee hoofdstukken hebben een zelfde opzet. Het theoretische kader uit hoofdstuk 2 wordt gebruikt om het verzamelde empirische materiaal een context te geven. In hoofdstuk 6 wordt het burgerlijk beschavingsoffensief als kader gebruikt. In hoofdstuk 7 draait 
het om de bureaucratiseringstheorie. Vervolgens analyseer ik het empirische materiaal. Deze analyse is sterk cijfermatig. Het doel van de analyse is uit de gedetailleerde informatie uit de dossiers een trend tussen 1871 en 1940 te ontwaren. In welke richtingen ontwikkelden het beschaven en het bureaucratiseren?

In hoofdstuk 8 is een zestal levensverhalen opgenomen, waarin de geschiedenis van afzonderlijke huishoudens wordt verteld. Representatief voor de hele groep minderbedeelden zijn deze levensverhalen natuurlijk niet.

In een concluderend hoofdstuk, hoofdstuk 9, geef ik antwoord op de vragen in hoeverre beschavingsoffensief en bureaucratisering zichtbaar zijn in de gemeentelijke armenzorg van Amsterdam tussen 1870 en 1940. 



\section{HOOFDSTUK 2 \\ BESCHAVING EN \\ BUREAUCRATISERING}

$<2$.A Prentbriefkaart van het Burgerweeshuis Burgerweesmeisjes keren (waarschijnlijk) terug van de Nieuwe Kerk via de Nieuwezijds

Voorburgwal naar het Burgerweeshuis, Kalverstraat 92, circa 1905, Onbekende fotograaf Bron: SAA. Beeldbank Afbeeldingsbestand PBKD00357000019.

1 De Rooy (1979) 9; Kruithof (1983), 371-385.

2 Elias (1969).

3 Het begrip beschavingsoffensief is nog steeds actueel in de contemporaine literatuur over armenzorg in Nederland in de negentiende en twintigste eeuw. Zie ook paragraaf 4 van dit hoofdstuk.

4 De Regt (1984).

5 De ideeën van Weber over bureaucratie komen verspreid voor in zijn geschriften. Zijn gedachtegoed over bureaucratie is echter het meest samengebald te vinden in Deel I van Wirtschaft und Gesellschaft, dat weliswaar postuum is verschenen, maar waarvan Weber nog zelf de eindredactie heeft verzorgd. Johannes Winckelmann (een adept van Weber, die bij hem had willen studeren, maar vanwege diens overlijden in 1920 die wens niet meer in vervulling kon laten gaan) heeft veel werk van Weber bezorgd, zoals "Staatssoziologie:

Soziologie der rationalen

Staatsanstalt" uit 1956, een geannoteerde anthologie van teksten over bureaucratie. Ook Wirtschaft und Gesellschaft is door Winckelmann bezorgd: Weber, Max (1972), Wirtschaft und Gesellschaft. Grundriß der verstehenden Soziologie (Tübingen; J.C.B.Mohr (Paul Siebeck) \{5de editie,

\subsection{INLEIDING}

In het vorige hoofdstuk zijn twee vragen geformuleerd. De eerste vraag is die naar de rol van het streven naar beschaving in de manier van werken van de gemeentelijke armenzorg. De tweede vraag is hoe de organisatie van de gemeentelijke armenzorg werd gebureaucratiseerd. Voordat deze vragen nader aan de orde gesteld kunnen worden, moet ik duidelijk maken wat beschaving en bureaucratisering inhouden.

Om het streven naar beschaving te duiden is het concept van het burgerlijk beschavingsoffensief bruikbaar. Dit concept is geïntroduceerd door Piet de Rooy en daarna verder uitgewerkt door Bernard Kruithof.' Burgers hebben getracht armen beschaving bij te brengen, meer bepaald deugdzaam te maken, aannemende dat zij hierdoor uit hun armoede zouden kunnen ontsnappen. Beschaving houdt volgens dit concept beheersing van gedrag in. De ideeën over het beheersen van gedrag van De Rooy en Kruithof zijn gedeeltelijk ontleend aan de civilisatietheorie van Norbert Elias. ${ }^{2}$ Het burgerlijk beschavingsoffensief is vooral van toepassing op de Nederlandse situatie van ongeveer 1775 tot ongeveer 1900. Ik bespreek daarom dit beschavingsconcept in dit hoofdstuk. ${ }^{3}$ De opvattingen van Elias en elementen uit het burgerlijk beschavingsoffensief komen ook aan de orde in het proefschrift van Ali de Regt. ${ }^{4} \mathrm{Zij}$ behandelt daarin veranderingen in het gezinsleven van arbeiders in Nederland tussen 1870 en 1940. Haar onderzoek is zo relevant voor het mijne, dat ik ook haar opvattingen over beschaving bespreek.

Wie het over bureaucratisering heeft, heeft het over Max Weber. ${ }^{5} \mathrm{Hij}$ is de grote autoriteit op dit gebied. ${ }^{6}$ Daarom zal ik eerst ingaan op de visie van Max Weber op de bureaucratie - en op de problemen die zich kunnen voordoen bij het interpreteren van die visie. Ik zal vervolgens de kenmerken behandelen die Weber toekent aan bureaucratie. Hierbij staat Webers postuum verschenen Wirtschaft und Gesellschaft centraal. De beschouwingen van Weber zal ik gebruiken als leidraad om de werking van de Amsterdamse gemeentelijke armenzorg te analyseren.

\subsection{BESCHAVING}

\section{a) Het civilisatieproces volgens Elias}

Het civilisatieproces werd door de Duitse socioloog Norbert Elias (18971990) voor het eerst beschreven in Über den Prozeß der Zivilisation, dat in 1939 verscheen. ${ }^{7}$ Norbert Elias beschrijft hierin de veranderingen in persoonlijkheidsstructuren in West-Europa tussen de vroege middeleeuwen en 1900. Elias veronderstelt dat die veranderingen het gevolg zijn van de veranderingen in de sociale structuur van de samenleving. De sociale struc- 
tuur, op haar beurt, is veranderd onder invloed van de centralisatie van het staatkundige gezag. In de veertiende en vijftiende eeuw streefden in West-Europa overheden naar het instellen van orde en gezag. ${ }^{8}$ Vertegenwoordigende lichamen, zoals Statenvergaderingen, stonden voor dat doel belastingheffingen toe. Met de belastingopbrengsten werd een centraal bestuur en een staatsleger gefinancierd. Hierdoor werd de overheid in staat gesteld het geweld in de samenleving te monopoliseren. De rol van een zelfstandige militaire elite raakte uitgespeeld. Militairen kwamen onder het gezag van de overheid en hun sociale positie werd hierdoor gewijzigd. De opkomst van een geldeconomie veranderde de sociale structuur eveneens. Nieuwe, commercieel ingestelde groepen manifesteerden zich.

We zien dat een elite zich probeert te onderscheiden van andere sociale groepen door het eigen gedrag aan banden te leggen. Zij gedraagt zich beschaafd. Lagere sociale groepen proberen aansluiting te vinden bij deze maatschappelijk hoger geplaatsten door hun beschaafde gedragingen na te volgen. De elite maakt onderscheid (distinctie), waarop lagere sociale groepen volgen (imitatie).

Het gedachtegoed van Elias kunnen we in enige mate terugzien, zoals hieronder zal blijken, in het feitelijke handelen van de gemeentelijke armenzorg. Dat handelen kan in een algemener kader geplaatst worden en krijgt daarmee voor ons betekenis. Een maatschappelijke bovenlaag, zo zien we ook hier, reguleert haar eigen gedrag. Het is onderdeel van een onbewust proces om binnen een steeds complexer wordende samenleving zichzelf te definiëren binnen een bepaalde sociale groep en tegenover andere sociale groepen. De gedragsregulering van de bovenlaag wordt vervolgens opgelegd aan lagere sociale groepen. De bovenlaag kan dat doen omdat zij een economisch, cultureel en politiek overwicht heeft. De armenzorg wordt op die manier een instrument van de bovenlaag om lagere sociale groepen in het gareel te houden. Bij de bespreking van het empirische gedeelte in hoofdstuk 6 zullen we zien dat het handelen van de gemeentelijke armenzorg in 1871 voor een belangrijk deel in het bovengenoemde civilisatiekader geplaatst kan worden. Gewenst gedrag leidt tot ondersteuning, ongewenst gedrag leidt tot afwijzing van hulp. We zien echter ook dat gedragsregulering binnen de gemeentelijke armenzorg gaandeweg verdwijnt. Er worden in de gemeentelijke armenzorg steeds vaker rationele afwegingen gemaakt op louter materiële gronden om al dan niet steun te verlenen. De drang tot beschaven sterft langzaam maar zeker uit.

\section{b) Het burgerlijk beschavingsoffensief}

Piet de Rooy introduceerde in 1979 in zijn proefschrift over werkenlozenzorg het begrip beschavingsoffensief en meer in het bijzonder "het beschavingsoffensief van de gezeten burgerij". 'Dit begrip kreeg een jaar later nog meer gestalte door een artikel van Bernhard Kruithof De deugdzame natie. ${ }^{10}$ Het idee van het burgerlijk beschavingsoffensief vond ingang bij onderzoekers die zich richtten op de sociale geschiedenis van de negentiende en twintigste eeuw. Zowel De Rooy als Kruithof lieten zich inspireren door de ideeën van Norbert Elias over het civilisatieproces. ${ }^{11}$ Ik wil hier overigens niet de indruk wekken dat Kruithof het gedachtegoed van Elias klakkeloos heeft overgenomen. Er zijn duidelijke verschillen in zienswijze. Kruithof bezorgd door Johannes Winckelmann\} Eerste druk 1922. De vijfde editie wordt door mij aangeduid als $\mathrm{WuG}^{5}$. In het kader van een hernieuwde belangstelling voor Weber verschijnt vanaf 1984 de Max Weber-Gesamtausgabe. Dit is een historisch-kritische editie van alle werken van Weber. Er zijn inmiddels bijna vijftig delen verschenen. Deze editie, de MWG, heb ik voor mijn onderzoek niet gebruikt. Wel heb ik de zesdelige Studienausgabe van Wirtschaft und Gesellschaft bestudeerd, die tussen 2000 en 2014 verscheen. Hierin staat wel de bewerkte tekst uit de MWG, maar zonder het historisch-kritisch gedeelte. De basistekst over bureaucratie is te vinden in "Wirtschaft und Gesellschaft". Die Wirtschaft und die gesellschaftlichen Ordnungen und Mächte. Nachlaß". Teilband 4: Herrschaft. Studienausgabe der Max Weber-Gesamtausgabe. Band I/22 (2009; Tübingen: J.C.B. Mohr (Paul Siebeck) 12-46. Deze tekst citeer ik als WuG: Herrschaft, MWS 1/22-4. Webers theorie gebruik ik voor de duiding van mijn onderzoek, maar een volledige exploratie van Weber wordt niet beoogd. Ik treed enkel in de voetsporen van zeer bekwame interpretatoren als Van Braam, Van Mierlo en Raadschelders, en enkele Duitse sociologen als Kaesler en Peukert.

6 Deze opinie wordt ondergeschreven door onder meer Raadschelders (1990). "Van alle literatuur die over dit thema (=bureaucratisering) beschikbaar is moet met name Weber's Wirtschaft und Gesellschaft worden genoemd, temeer daar wel gezegd is dat onderzoek naar bureaucratie zonder dit werk niet goed denkbaar is", (21); Wagenaar (1999), 23-27; Van der Heijden, en Schmidt (2007), "Zijn (=Max Weber) kenmerken van bureaucratisering vonden wij voor 
vergelijkingen op lange termijn zeer bruikbaar. (32). 7 Elias (1969). Er is een overvloed aan beschouwende literatuur over het civilisatieproces van Elias.

De betekenis en de receptie van het civilisatieproces is een aparte studie waard. Een goede inleiding geeft Zwaan (2001), 36-60.

8 Slavin (1964); Goodman (1988).

9 De Rooy (1979), 9.

10 Kruith of (1983), 371-385

Het artikel verscheen oorspronkelijk in 1980.

11 Opmerkelijk is dat zowel bij Kruithof als De

Rooy de naam van Elias

in het notenapparaat niet terugkeert. In de toenmalige academische wereld van Amsterdam was Elias zeer 'en vogue', zodat Elias' invloed wel herkenbaar is. Kruithof (2015), 2 noemt wel Marx, Foucault en Lasch als inspiratiebronnen. 12 Kruithof (1983), 374 citaat naar Joh. Clarisse [samen met H.W. van der Ploeg] Middelen om de losheid in grondbeginselen en zeden te stuiten. Prijsverhandeling deel IX. SAA 211 Archief van de Maatschappij tot Nut van 't Algemeen. Bestanddeel 1326, 95. SAA Bestanddeel 21 1387. Oort, A.J.P. (1857)، Handleiding voor het patronaat over armen. 13 Kruithof (1983), 373. 14 De veranderde opvattingen over armoede in Nederland in de tweede helft van de negentiende eeuw worden op een toegankelijke wijze besproken door Smit (2019).

15 Kruithof (1983), 375.

16 De Regt (1984), 11 en

136.

17 Met 'emotie' wordt de cultuurbepaalde emotie bedoeld in de betekenis die Stearns en Stearns eraan hebben gegeven. Stearns en Stearns (1988), 7-8; 26-27.

18 De Regt (1984), 244. neemt een bewuste strategie waar van de burgerij om de armen beschaving bij te brengen, terwijl Elias de nadruk legt op een langdurig proces van distinctie en imitatie dat onbedoelde gevolgen had. Kruithof heeft één bepaalde sociale groep voor ogen: de burgerij, terwijl Elias gericht is op het doen en laten van de elite en het effect daarvan op lagere sociale groepen.

Het burgerlijk beschavingsoffensief had als kern dat "het arme volk" door de burgerij moest worden opgevoed. Aan een toenmalige bron ontleende Kruithof de uitspraak dat "de gemene man (...) ruw en onbeschaafd" zou zijn. Hij zou daarnaast ook nog eens "haveloos en morsig" zijn, "zinnelijk, zonder hogere gevoelens". Zijn inkomen verbraste hij aan liederlijke zaken: hij "verhoert en verzuipt zijn loon en jaagt bij thuiskomst zijn vrouw en kinderen de schrik aan; gezwegen wordt dan nog van de onbeschoftheid, die hem eigen is".12 In het burgerlijk beschavingsoffensief stond deugdzaamheid centraal, want deugd zou leiden tot geluk en welvaart. "Rampen, verpaupering, ziektes en plotseling optredende sterfgevallen troffen de onverstandigen die het pad van de deugd niet wilden gaan, ook al leek het hun aanvankelijk voor de wind te gaan. Hoogmoed kwam altijd voor de val"..$^{3}$

De burgerij hoopte beschaving te brengen bij "de gemene man" door de juiste opvoeding en goed onderwijs. ${ }^{14} \mathrm{Er}$ werden scholen gesticht. Luiheid en schaamteloosheid moesten worden bestreden om plaats te maken voor ijver en trots. Dan zou ook het volk uiteindelijk deugdzaam worden, een huiselijk en gezond leven leiden en in staat zijn tot zelfbeheersing. De verheffing was voltooid als het volk zou leven als brave burgers. Benadrukt moet worden dat het ideaal van de verheffing niet inhield dat er in de sociale structuur iets zou moeten veranderen. Het nut en de noodzaak van de standensamenleving spraken voor zich. Verheffing moest niet uitmonden in standsverwisseling. ${ }^{15}$

Het geheel van opvoedende activiteiten en onderliggende gedachten noemde Kruithof "het burgerlijk beschavingsoffensief". Het is een algemeen gebruikt begrip geworden onder historici en sociale wetenschappers.

\section{c) De Regt over arbeidersgezinnen en beschavingsarbeid}

In de dissertatie van Ali de Regt over arbeidersgezinnen en beschavingsarbeid in Amsterdam tussen 1870 en 1940 speelt het burgerlijk beschavingsoffensief een grote rol. Anders dan bij Kruithof is een theoretische onderbouwing vanuit de civilisatietheorie van Elias expliciet zichtbaar. De Regt onderschrijft diens theorie. ${ }^{16}$ Uit haar onderzoek bleek dat er binnen arbeidersgezinnen veranderingen optraden in het uiten van emoties. Ook bleken de gezinsleden steeds meer zelfbeheersing aan de dag te leggen. Deze veranderingen zag zij als resultaat van het civilisatieproces. ${ }^{17}$

Civilisering van de lagere bevolkingsgroepen had betrekking op orde, netheid, arbeidzaamheid, plichtsbetrachting, spaarzaamheid, passende vrijetijdsbesteding, bestrijding van alcoholmisbruik, onderwijs en legde een steeds grotere nadruk op huiselijkheid. ${ }^{18} \mathrm{Al}$ het bovengenoemde werd gestimuleerd door het beschavingsoffensief van de burgerij.

Deze civilisering was niet uitsluitend het gevolg van het burgerlijk beschavingsoffensief. De Regt wijst ook op de levensstandaard van de lagere groepen die geleidelijk hoger werd. Dat ging gepaard met een grotere ont- 
vankelijkheid voor de beschavingsgraad van de hogere klassen. Beschaving werd dus niet alleen van bovenaf opgelegd, maar ook economisch mogelijk gemaakt en van binnenuit omarmd door de lagere sociale groepen.

De Regt bestudeerde niet alleen Elias, maar nam ook kennis van de ideeën van Donzelot en Lasch. Het is echter in hoofdzaak Elias die haar inspireerde tot haar analyse van het effect dat de eerste industrialisatiefase van Nederland had op het burgerlijk beschavingsoffensief en de disciplinering van de lagere sociale groepen. De sleutelwoorden bij haar zijn civiliseren, distinctie en imitatie. Haar aandacht gaat uit naar de armenzorg. Daarbij richt zij zich in het bijzonder op de activiteiten van het genootschap Liefdadigheid naar Vermogen en op de volkshuisvesting. Speciale aandacht heeft zij voor ontoelaatbaar woongedrag, dat door woningopzichteressen bestreden wordt.

De Regt plaatst haar onderzoek in het kader van het ontstaan van een nieuwe, stedelijk-industriële arbeidersklasse, ten gevolge van urbanisatie en industrialisatie. ${ }^{19}$ Deze arbeiders moesten een plek zien te vinden in het nieuwe economische bestel van een industriële samenleving. Er was discipline nodig voor het inpassen van deze arbeid in hun dagelijks leven. In de pre-industriële samenleving werd vaak in gezinsverband werk aan huis verricht. ${ }^{20}$ In de industriële samenleving zijn wonen en werken gescheiden. ${ }^{21}$ De arbeid is dan heel anders georganiseerd. De echtgenoot wordt de enige kostwinner, als loonarbeider. De echtgenote gaat zich exclusief op het huishouden richten; de huisvrouw wordt in de negentiende eeuw geboren. ${ }^{22}$ De disciplinering werd deels afgedwongen door de burgerij in het kader van het burgerlijk beschavingsoffensief, maar kwam voor een ander deel tot stand omdat de arbeiders zich actief aanpasten aan de nieuwe industriële verhoudingen. ${ }^{23} \mathrm{Zij}$ imiteerden de levenswijze van burgerlijke groepen. De Regt komt hier tot dezelfde constatering als Elias, die als onderdeel van het civilisatieproces ziet dat de onderste sociale lagen zich spiegelen aan de normen en waarden van de hogere sociale lagen. ${ }^{24}$

De Regt besteedt veel aandacht aan het genootschap Liefdadigheid naar Vermogen bij haar bespreking van de bemoeienissen van de burgerij om de onderste lagen van de bevolking te disciplineren en beschaving bij te brengen. ${ }^{25}$ Het genootschap ontwikkelde nieuwe methoden om armoede te bestrijden. Nieuw was dat elke hulpaanvraag grondig en per geval werd onderzocht en dat er huisbezoek bij de aanvragers werd afgelegd door armbezoekers. Hierbij stond het gedrag van de aanvragers centraal. ${ }^{26}$ Er werd vooral gelet op het omgaan met geld. Daarnaast was er veel interesse voor de opvoeding van de kinderen, in de hoop dat deze kinderen later economische zelfstandigheid zouden verwerven.

Een ander aandachtspunt in het onderzoek van De Regt is de beschavingsarbeid van woningopzichteressen. Vanaf het midden van de negentiende eeuw was de huisvesting van de lagere sociale groepen een bron van zorg. Tijdgenoten legden een verband tussen slechte huisvesting en armoede, zonder zich altijd uit te spreken over oorzaak en gevolg. Aangenomen werd dat een goede woning arbeiders zou afhouden van alcoholmisbruik, verkwisting en uithuizigheid. ${ }^{27}$ Maar men ging er ook vanuit dat deze gedragsveranderingen niet helemaal vanzelf zouden gaan. Woningopzichteressen waren, naar de opvatting van tijdgenoten, bij uitstek geschikt
19 De Regt (1984), 49. 20 Van Zanden, De Moor en Carmichael (2019). 21 Scott en Tilly (1978). 22 Hall (1979) en Hall (1980).

23 De Regt (1984), 101. 24 De Regt (1984), 136-137. 25 De Regt (1984), 143-174. De Regt baseert haar onderzoek voornamelijk op de jaarverslagen van LNV. Blijkens noot 92 (De Regt (1984), 285) zijn de dossiers van alle door LNV gesteunden bewaard van 1892 tot 1940. De Regt onderzocht een aantal dossiers uit 1892.

26 De Regt (1984), 161. 27 De Regt (1984), 176. 
om bewoners tot het gewenste woongedrag aan te zetten, aldus De Regt. ${ }^{28}$ In Amsterdam werd naar mogelijkheden gezocht om ongewenst woongedrag te tegen te gaan. Bewoners die hun huis verwaarloosden, burenoverlast veroorzaakten en de huur niet betaalden werden als "ontoelaatbaar" bestempeld. Voor deze groepen werden in de jaren '20 van de twintigste eeuw aparte wooncomplexen ingericht. Gezinnen die hiervoor in aanmerking kwamen, werden thuis bezocht door inspectrices, die gezinsrapporten opmaakten. Als ze eenmaal waren ondergebracht in een van de twee wooncomplexen, Zeeburg in Amsterdam Oost of Asterdorp in Amsterdam Noord, werden de gezinnen wekelijks bezocht door woningopzichteressen in gemeentedienst. Ook deze opzichteressen maakten gezinsrapporten op. Veel van die rapporten zijn bewaard gebleven en De Regt heeft er uitgebreid studie van gemaakt. Zij plaatste de activiteiten rondom de wooncomplexen in het kader van de disciplinering van de lagere sociale groepen. Deze groepen zouden hiermee geschikt worden gemaakt voor het verrichten van industriële arbeid. ${ }^{29}$

De Regt heeft met haar onderzoek naar de activiteiten van Liefdadigheid naar Vermogen en naar de werkzaamheden van de gemeentelijke woningopzichteressen willen aantonen dat lagere sociale groepen van bovenaf tot gedragsverandering werden aangezet. Leidend bij de onderbouwing van dit onderzoek is de civilisatietheorie van Elias. Een accentverschil is dat De Regt meer dan Elias wijst op het afgedwongen karakter van de gedragsveranderingen en minder evidentie ziet voor een vrijwillige aanpassing van het gedrag. ${ }^{30}$ Hierin kunnen we enige invloed bespeuren van het gedachtegoed van de hierboven genoemde Donzelot.

\subsection{BUREAUCRATISERING}

\section{a) Inleiding}

In deze uiteenzetting over bureaucratisering baseer ik me - zoals hierboven al uiteengezet -op de ideeën van Max Weber. Hierbij staat zijn postuum verschenen Wirtschaft und Gesellschaft centraal. Deze beschouwing zal ik gebruiken als leidraad om de werking van de Amsterdamse gemeentelijke armenzorg nader te bestuderen.

De term bureaucratie wordt toegeschreven aan de Franse econoom Vincent de Gournay (1712-1759). Hij introduceerde de term in 1759. Het woord bureaucratie is een samenstelling van het Griekse kratos, dat heerschappij en sterkte betekent en het Franse bureau dat zowel kan duiden op een instantie als op een schrijfbureau. Bureaucratie is de machtsuitoefening vanuit een kantoor door aangestelde functionarissen. Gournay wilde met dit door hem bedachte woord de regeringsperiode van koning Lodewijk XIV (16611715) en diens belangrijkste minister Jean-Baptiste Colbert karakteriseren. Gournay rekende overheidsfunctionarissen tot de onproductieve klasse. Dat is kenmerkend voor zijn op productie gerichte, fysiocratische ideeën over economie. De politiek denker Alexis de Tocqueville (1805 -1859) zag in de jaren '30 van de negentiende eeuw de verzorgingsstaat ontstaan door een overmaat aan overheidsbemoeienis. In de "voortschrijdende centralisering, bureaucratie en de ongebreidelde overheidsexpansie", zag hij "het begin van wat wij nu de verzorgingsstaat noemen". Bureaucratie, in de tus- 
sentijd een gangbaar woord geworden, heeft hierin een minder positieve bijklank. ${ }^{31}$ Het is Max Weber (1864-1920) geweest die het begrip bureaucratie heeft verzakelijkt en wetenschappelijk afgebakend. De belangstelling voor zijn werk was een tijdlang tanende, maar is de laatste jaren weer helemaal herleefd. Door zijn zeer grondige theorievorming kan nog steeds niemand die het over bureaucratie heeft om hem heen. ${ }^{32} \mathrm{Er}$ is veel literatuur over Max Weber en bureaucratie. In Nederland zijn de publicaties van Van Braam en Raadschelders over Weber toonaangevend. Van Braam en Raadschelders maken een zinvol onderscheid tussen bureaucratie en bureaucratisering. ${ }^{33}$ Bureaucratie is dan een verzameling van organisatiekenmerken van staatsbestuur. Bureaucratisering is de toename van het bureaucratisch gehalte van een bestuurs- of overheidsorganisatie. Raadschelders acht het ideaaltype van bureaucratie en bureaucratisering dat Weber heeft opgesteld een bruikbaar analytisch instrument. ${ }^{34}$ Zuurmond stelt dat een bureaucratische organisatie een noodzaak is om de samenleving te laten voortbestaan. ${ }^{35}$ Kruiter wijst op De Tocqueville als voorloper van Weber. Vanuit een meer historisch standpunt is door Hoffer het proces van centralisatie en bureaucratisering voor de Verenigde Staten beschreven. Bruikbaar zijn ook de inzichten van Abram de Swaan. Hij ziet de toename van het aantal staatsarrangementen in de sociale zekerheid tussen 1880 en 1930 als het gevolg van staatsvorming. Ook de opkomst van het kapitalisme, de urbanisatie en de secularisatie speelden naar zijn mening een belangrijke rol. Door de bureaucratisering kreeg de sociale zekerheid gestalte. ${ }^{36}$

\section{b) Aandachtspunten rond de bureaucratietheorie van Max Weber}

Bij het nader beschouwen van Max Webers bureaucratietheorie zijn er twee aandachtspunten die eerst behandeld moeten worden voordat we kunnen ingaan op zijn eigenlijke theorie. Het gaat om de ideaaltypische benadering van Weber en zijn visie op het rationaliseren van het overheidsgezag.

Een van die aandachtspunten is dat Weber gebruik maakt van een door hem zelf bedacht ideaaltype. In dat ideaaltype worden de fundamentele kenmerken van het fenomeen bureaucratie gegeven. Dat ideaaltype is dus geen weergave van de werkelijkheid en ook niet een na te streven ideaal, maar een hulpmiddel om de werkelijkheid te begrijpen. ${ }^{37}$

Een ander aandachtspunt is dat in Webers visie bureaucratie een onderdeel is van de rationalisatie van het overheidsgezag. In de moderne samenleving is er geen traditioneel gezag (traditionale Herrschaft) meer op basis van overerving en standen, maar is er een wettig gezag (legale Herrschaft). In de moderne samenleving neemt de overheid steeds meer beslissingen op basis van rationele overwegingen. Deze beslissingen worden op bureaucratische wijze uitgevoerd. De moderne samenleving is op alle fronten verzakelijkt. Deze rationalisering is, in de ogen van Weber, ten koste gegaan van iets betoverends: een magisch wereldbeeld als verklarings- en handelingsmodel. Weber noemt dat die Entzauberung der Welt: de onttoverde wereld. ${ }^{38}$ Ooit stelden we ons de wereld voor als een magisch oord, waarin niet alleen mens en natuur, maar ook goddelijke en andere bovennatuurlijke wezens een rol speelden. Met onttovering drukt Weber uit dat de wereld steeds minder magisch is geworden en steeds rationeler. De magische krachten zijn vervangen door natuurwetenschappelijke en wiskundige verklaringen. ${ }^{39}$
31 Kruiter (2010), 151. $32 \mathrm{Er}$ is geen doorlopende lijn. In het interbellum was er relatief weinig aandacht voor Weber in Europa, terwijl onder invloed van Talcott Parsons juist in Amerika Webers' gedachtegoed werd verspreid, al kreeg het daar een duiding die afweek van de oorspronkelijke ideeën van Weber. Na WO II hebben Europese interpretatoren als Johannes Winckelmann en Renate Mayntz de Amerikaanse interpretatie gecorrigeerd. In het laatste kwart van de twintigste eeuw valt, vooral vanuit het Duitstalige gebied, een hernieuwde oriëntatie op Weber te bespeuren. Dirk Kaesler is een belangrijke initiator van deze hernieuwde belangstelling. Hierdoor is Weber opnieuw centraal komen te staan en werd zijn complete werk uitgegeven: Max Weber-Gesamtausgabe (verschenen vanaf 1984, in 2020 was de uitgave voltooid) Van belang is ook de publicatie van één van de redacteuren van dat volledig werk: Hübinger (2019). De hernieuwde belangstelling zien we ook terug in Nederland. Ik verwijs naar publicaties van Van Braam (1977), Raadschelders (1990), Zuurmond, (1994); Netelenbos (2014); Netelenbos (2016); Netelenbos (2018). 33 Van Braam (1977), 458; Raadschelders (1990), 21-22.

34 Raadschelders (1990), 164.

35 Zuurmond (1994), 44, "Het huidige kapitalistisch democratisch bestel met zijn massaproductie en consumptie is dermate complex dat zij slechts kan functioneren bij de gratie van een uiterst hoge graad van bureaucratisering (volgens Weber's uiteenzetting)".

36 Van Braam en Bemelmans-Videc (1986); Hoffer (2007); Kruiter.(2010); Van Leeuwen (2007); Mierlo (1995); Raadschelders. (1998); Raadschelders 
(2008); Raadschelders. (2010); Raadschelders. (2011); De Swaan (1989). Een goede achtergrond biedt Derlien, Böhme, en Hiendl (2011); Mayntz (1965).

37 Raadschelders zegt hierover: "His (=Webers) ideal type of bureaucracy did not, does not and never will exist, but combines various elements from ancient, medieval and early modern administrative practices and ideas. Despite Weber's warnings, the notion of ideal type was frequently misunderstood...". (Raadschelders.(2000), 37.)

38 Lehmann (2008); Dassen (1999); Hübinger (2019),

80-83; Winckelmann (1980),

12-53; Winckelmann

beklemtoont dat rationa-

liseren in het verlengde

ligt van "Entzauberung"

"Abschließend möchte ich

nochmals in Erinnerung

rufen, daß ich in diesem

Beitrag versucht habe, die

Wege zu rekonstruieren,

auf denen Max Weber

zu seiner Konzeption der

,Entzauberung' und sodann dem Begriff der okziden-

talen 'Rationalisierung'

gelangt ist". (42).

39 Illustratief is in dit verband het verdwijnen van het geloof in het bestaan van heksen. Goodare (2016); ook: Voltmer (2012). 40 Het gaat om het tekstdeel "Wesen, Voraussetzungen und Entfaltung der Bürokratischen Herrschaft" $W_{u} G^{5} 551-579 ;$ 650-678 in de eerste editie van 1922 Ik verwijs naar de vijfde editie: WuG ${ }^{5}$.In WuG: Herrschaft, MWS 1/22-4 draagt dit tekstdeel een door de tekstbezorgers bedachte titel: [Bürokratismus], 12-46. Van Braam (1977), 459,

hanteert de uitdrukking

"dimensies van (een) bureaucratische bestuursorganisatie" die hij in twintig kenmerken ontleedt. 41 Van Braam (1977), 459, noemt deze aanpak "een dimensieanalyse". 42 Weber, WuG ${ }^{5}$, 558; WuG: Herrschaft, MWS I/22-4, 21; Weber, WuG ${ }^{5}$,

\section{c) De bureaucratietheorie van Max Weber in hoofdpunten}

Zoals hierboven aangegeven gebruik ik de uiteenzetting over bureaucratie in Wirtschaft und Gesellschaft als basistekst. Ik geef hieronder een samenvatting van Webers' ideaaltype van bureaucratie in zes hoofdpunten. ${ }^{40} \mathrm{De}$ indeling in zes hoofdpunten is niet van Weber, maar van mijzelf, om een bruikbare structuur te geven aan die samenvatting. In hoofdstuk zeven over de praktijk van de Amsterdamse gemeentelijke armenzorg ga ik na in hoeverre de praktijk van de armenzorg overeenkomt met de door mij genoemde hoofdpunten. ${ }^{41}$

\section{i) De ontwikkeling en groei van de bureaucratie}

Tussen de zestiende en de achttiende eeuw is een uitbreiding te zien van de administratieve taken van de overheid. ${ }^{42}$ De overheid wil met die uitbreiding meer controle krijgen over de samenleving. Die controle wordt door een bureaucratisch systeem uitgevoerd. Er komt law and order in de staat, waardoor de samenleving wordt gepacificeerd. De overheid brengt met behulp van door haar aangestelde functionarissen rust en veiligheid in de samenleving. Volgens Weber is dit bureaucratische systeem ingevoerd omdat het superieur is aan oudere organisatievormen. ${ }^{43}$ Wat maakt een bureaucratisch systeem superieur? In collegiale bestuursorganisaties waar besluitvorming door consensus plaatsvindt, is die besluitvorming traag. Dit geldt ook voor systemen waarin met ereambten wordt gewerkt. Een ereambt is onbezoldigd. Er wordt daardoor niet in volledige dienst gewerkt. Deskundigheid ontbreekt vaak. Ambtenaren zijn nauwkeuriger en komen sneller tot een meer eenduidige besluitvorming. Deze eigenschappen maken de bureaucratie superieur aan oudere administratieve systemen, zoals die bijvoorbeeld in de Republiek gangbaar waren. Weber hecht groot belang aan een systeem waarin op een redelijke en rationeel-onderbouwde manier elke handelwijze binnen een bureaucratisch stelsel kan worden verantwoord. Bureaucratie is een voorwaarde, meent Weber, voor een goed functionerende democratie. Het oude bestuur stond in het teken van de patrimoniale overheersing van de standensamenleving. Binnen dat bestuur werden willekeurige persoonlijke beslissingen genomen. Binnen het bureaucratische systeem is er gelijkheid voor de wet en objectiviteit van bestuur.

ii) De bureaucratie als onderdeel van de overheid

De bureaucratie is onderdeel van een overheid, die haar gezag ontleent aan wetten. In deze vorm komt bureaucratie alleen voor in de moderne staat zoals die in de negentiende en twintigste eeuw is ontstaan.

iii) De positie en de functie van de ambtenaar

Ambtenaren worden benoemd door een hoger gezag. Ze worden dus niet gekozen. Ambtenaren worden voor het leven benoemd. Daardoor hebben ze een onafhankelijke positie. Die onafhankelijkheid wordt ook bevorderd door inkomenszekerheid. Ambtenaren functioneren in een bureaucratisch systeem volgens vaste principes die gebaseerd zijn op wettelijke bepalingen. Ze opereren uitsluitend bin- 
nen de kaders van deze bepalingen. Ambtenaren moeten geschoold zijn om de wettelijke bepalingen en dienstvoorschriften uit te kunnen voeren. Ze beschikken over dossierkennis op basis van archiefvorming. Een bureaucratische organisatie wordt gekenmerkt door continuïteit. In een bureaucratische organisatie wordt behoedzaam opgetreden en is de werkwijze eenduidig. Hierdoor blijft onderlinge wrijving binnen het bureaucratische apparaat beperkt. Conflicten en competentiegeschillen tussen ambtenaren onderling worden binnen de perken gehouden door hiërarchische verhoudingen en dankzij de onderlinge dienstbaarheid. Ambtenaren volgen een bepaalde loopbaan. Er zijn binnen een bepaalde functie oplopende salarisschalen. Verder zijn er promotiemogelijkheden door het behalen van examens. Ambtenaren werken in een hiërarchisch systeem van boven- en ondergeschiktheid. Ambtelijke functies zijn niet persoonsgebonden, maar worden overgedragen aan een opvolger, zodat er continuïteit is. Ambtenaren werken in volledig dienstverband en hebben geen nevenfuncties. Hierdoor wordt belangenverstrengeling voorkomen. De werkzaamheden zijn strikt gescheiden van het privédomein van de ambtenaren.

iv) Het permanente karakter van de bureaucratie

Als een bureaucratische organisatie eenmaal is gevestigd, dan is het een bijna onneembaar bastion. ${ }^{44}$ Bureaucratie is daarom een machtsinstrument van de eerste orde voor degene die dat bureaucratisch apparaat leidt. Het is bijna onmogelijk zich tegen de bureaucratie te verzetten. Ook de individuele ambtenaar kan niet aan het systeem ontsnappen. Hij is er met handen en voeten aan gebonden. De machinerie blijft altijd draaien. Ook de gewone burgers kunnen er niet zonder. Buiten de bureaucratie dreigt de chaos. ${ }^{45}$

v) De machtspositie van de bureaucratie

De macht van een bureaucratie is overweldigend. Overal in de moderne staat neemt het aantal ambtenaren toe, maar of dat ook betekent dat de macht van de bureaucratie toeneemt, vraagt Weber zich af. ${ }^{46}$ Het groeiend aantal ambtenaren is weliswaar onontbeerlijk om het groeiend aantal overheidstaken uit te kunnen voeren, maar binnen het ideaaltype van Weber kan geen uitspraak over een navenant groeiende macht van de bureaucratie gedaan worden. ledere bureaucratie probeert haar superioriteit te bewaren door bepaalde kennis en bepaalde bedoelingen geheim te houden. Het woord ambtsgeheim is hiervoor uitgevonden. Van nature verwelkomt een bureaucratie een slecht geïnformeerde volksvertegenwoordiging die daardoor tandeloos kan worden. ${ }^{47}$ In de moderne staat is het streven naar macht van de bureaucraten ongebreideld. Bureaucraten willen ongehinderd hun eigen weg inslaan. ${ }^{48}$ Weber ziet hierin een tegenstelling tussen bureaucratie en democratie. In het ideaaltype van Weber moeten de bureaucraten in de concurrentie met de volksvertegenwoordigers het onderspit delven. ${ }^{49}$ De tegenstelling tussen bureaucratie en democratie werk ik voor Amsterdam uit in de paragraaf waarin ik de bureaucratisering van de Amsterdamse gemeentelijke armenzorg in een breder perspectief plaats.
560, WuG: Herrschaft, MWS I/22-4, 23, spreekt van "Entfaltung des Aufgabenkreises der Verwaltung", het proces van vergroting aanduidend.

43 Weber WuG ${ }^{5}, 561$; WuG: Herrschaft, MWS I/22-4, 24, stelt: "Der entscheidende Grund für das Vordringen der bürokratischen Organisation war von jeher ihre reine technische Überlegenheit über jede andere Form."

44 Weber brengt dit idee als volgt naar voren: "Eine einmal voll durchgeführte Bürokratie gehört zu den am schwersten zu zertrümmernden sozialen Gebilden." (WuG5 , 569; WuG: Herrschaft, MWS I/22-4, 34).

45 Als uiterste consequentie voorspelt Weber: "Ein rational geordnetes $\mathrm{Be}$ amtensystem funktioniert, wenn der Feind das Gebiet besetzt, in dessen Hand unter Wechsel lediglich der obersten Spitzen tadellos weiter, weil es im Lebensinteresse aller Beteiligten, einschließlich vor allem des Feindes selbst, liegt, daß dies geschehe". (WuG 5, 570; WuG: Herrschaft, MWS I/22-4, 35).

46 "Es soll daher hier auch unentschieden bleiben, ob gerade die modernen Staaten, deren Bürokratisierung überall fortschreitet, dabei auch ausnahmslos eine universelle Zunahme der Macht der Bürokratie innerhalb des Staatswesens aufweisen." Weber, WuG ${ }^{5}$, 572; WuG: Herrschaft, MWS I/22-4, 37.

47 Weber, WuG ${ }^{5}, 573$ : WuG: Herrschaft, MWS I/22-4, 38.

48 "Bürokratische Verwaltung ist ihrer Tendenz nach stets Verwaltung mit Ausschluß der Öffentlichkeit. Die Bürokratie verbirgt ihr Wissen und Tun vor der Kritik, soweit sie irgend kann". Weber, WuG ${ }^{5}, 572$; WuG: Herrschaft, MWS I/22-4, 38.

49 Weber, WuG 5 , 569; WuG: Herrschaft, MWS I/22-4, 34. 
vi) Rationaliteitsprincipe

Bureaucratisering bevordert een verzakelijking van het bestuur. ${ }^{50}$ Dat betekent volgens Weber dat beslissingen steeds minder beïnvloed worden door morele of persoonlijke waardeoordelen en steeds meer door waardevrije en objectiveerbare oordelen op basis van de ratio. De rationalisering van het bestuur wordt bevorderd door een onpersoonlijke vervulling van de ambtelijke functie. ${ }^{51}$ Ambtenaren oordelen niet op basis van persoonlijke meningen, maar zonder aanzien des persoons.

\subsection{BESCHAVEN EN BUREAUCRATISERING IN DE LITERATUUR OVER ARMENZORG}

Beschaven en bureaucratisering zijn uitgangspunten bij het bestuderen van de gemeentelijke armenzorg tussen 1870 en 1940. Dat roept de vraag op: hoe verhouden beschaven en bureaucratiseren zich tot elkaar? Zijn beschaven en bureaucratiseren elkaars tegenpool? Zo eenvoudig is dat niet. Aan het streven naar beschaving ligt de opvatting ten grondslag dat een deugdzaam leven de mogelijkheid biedt zich te bevrijden van een armoedig bestaan. Een deugdzaam leven kan worden bevorderd door opvoeding, maar ook worden afgedwongen door disciplinering. Beide elementen zien we terug in de armenzorg. Zij propageert om opvoedkundige redenen dat kinderen naar school worden gestuurd, maar stelt het ook verplicht. Ouders die in gebreke blijven, worden gestraft met het stopzetten van de steun. $\mathrm{Al}$ in 1871 komen we deze verplichting tegen. ${ }^{52}$ De neiging tot disciplinering is ook te zien in het afstraffen van ongewenst gedrag, bijvoorbeeld drankmisbruik. Constateerde een armbezoeker dat er in bepaalde gezinnen veel werd gedronken, dan werd soms geen steun verleend. De Regt merkt op in een hoofdstuk over armenzorg en disciplinering dat "moderne armverzorgers" zich ten doel stelden de armoede op te heffen "door beschaving van de lagere klassen". ${ }^{53}$ Vooruitlopend op hoofdstuk 6 wil ik hieraan toevoegen dat sporen van deze beschavingsdrang ook in het handelen van de gemeentelijke armenzorg van Amsterdam terug te vinden zijn. In de eenentwintigste eeuw zijn we geneigd een dergelijke handelwijze als moralistisch te beschouwen. Omdat bureaucratiseren in de opvatting van Weber rationaliseren betekent, waaraan geen morele oordelen te pas komen, zou hier gesproken kunnen worden van een tegenstelling tussen beschaven en bureaucratiseren. Het oordelen op basis van morele motieven zou dan als negatief en het oordelen op basis van rationele motieven als

50 Weber zegt hierover:

"Sie war eines der stärksten Erziehungsmittel für die "Sachlichkeit" der Verwaltung"; Weber, WuG ${ }^{5}, 575$;

WuG: Herrschaft, MWS

1/22-4, 40.

51 Weber, WuG ${ }^{5}, 576$;

WuG: Herrschaft, MWS

I/22-4, 42.

52 Zie ook de passage over schoolbezoek in hoofdstuk 6.

53 De Regt (1984), 169. positief kunnen worden opgevat. Uit historisch oogpunt moet een zodanige voorstelling van zaken worden afgewezen. Het is historisch juister het morele oordelen als een spiegel te zien van de toenmalige samenleving. Aan moraliteit werd door de burgerij een grote waarde toegekend. Pas ten tijde van de modernisering van de samenleving verdrong het rationaliteitsprincipe steeds meer de morele principes. Moraliteit en rationaliteit zijn dus niet zozeer elkaars tegenpolen, maar liggen juist in elkaars verlengde.

Als we kijken naar de secundaire literatuur van de laatste ongeveer veertig jaar over armenzorg in Nederland in de negentiende en twintigste eeuw, dan zien we dat de kwestie van het beschaven met enige regelmaat aan de 
orde komt. Ik wil hier in het kort enkele onderzoeken belichten. De Rooy wees op het disciplinerende karakter van de armenzorg in de negentiende eeuw. Hij stelde vast dat de gezeten burgerij even na 1800 het beschavingsoffensief had geopend op de arbeidersklasse. De repressieve kant van de armenzorg trad in het midden van de negentiende eeuw steeds nadrukkelijker naar voren. ${ }^{54}$

In het overzicht dat Van Loo geeft van de armenzorg in Nederland wordt eveneens gewezen op de opkomst van een beschavingsgedachte halverwege de negentiende eeuw. Het gebrek aan normbesef bij de armen werd gezien als oorzaak van hun armoede. Verbetering van de moraal werd door de toenmalige armenzorg gezien als remedie voor het armoedeprobleem. ${ }^{55}$

De Regt stelt dat in de werkwijze van armenzorg in Amsterdam door het genootschap Liefdadigheid naar Vermogen het beschavingsoffensief zichtbaar was. De Regt beweert dat de armen werden gesteund als zij tekenen vertoonden van arbeidzaamheid, spaarzaamheid en soberheid. ${ }^{56}$ Als zij 'goed' gedrag vertoonden, leidde dat tot steunverlening. Kok trekt in zijn dissertatie over het ontstaan van de sociale zekerheid in Leeuwarden tussen 1880 en 1930 het standpunt van De Regt in twijfel dat in de uitvoering van armenzorg in Amsterdam door het genootschap Liefdadigheid naar Vermogen het beschavingsoffensief zichtbaar was. Kok meent dat De Regt zich baseert op de geboekstaafde doelstellingen van het genootschap waarin het burgerlijk beschavingsoffensief doorklinkt, maar dat deze doelstellingen niet door haar aan de praktijk zijn getoetst. De Kok concludeert daaruit dat "het onderzoek van De Regt dus een eventuele disciplinerende invloed van de 'moderne armenzorg' (lees Liefdadigheid naar Vermogen JAM) niet aantoont". ${ }^{57}$ In Leeuwarden, zo stelde Kok in zijn eigen onderzoek vast, speelde disciplinering bij de voogden van de Stadsarmenkamer (de bestuurders van de burgerlijke armenzorg) "geen rol van importantie". ${ }^{58}$

Ook Van Leeuwen constateert in zijn onderzoek naar de Amsterdamse armenzorg tussen ca. 1800 en 1850 dat men de armen discipline wil bijbrengen. "Armenzorg in Amsterdam", zo luidt zijn conclusie, "was in een aantal opzichten een beheersingsstrategie van de Amsterdamse financieel-commerciële elite". ${ }^{59}$ Ook buiten Amsterdam bespeurde Van Leeuwen die neiging tot disciplinering. In het gewest Holland weerden armbestuurders de armen die blijk gaven van onzedelijk gedrag. ${ }^{60}$ Het verzet van de armen tegen het stellen van gedragseisen kwam volgens Van Leeuwen in Nederland, althans in de negentiende eeuw, niet op grote schaal voor. ${ }^{61}$

Een andere benadering van de armenzorg heeft Sleebe. ${ }^{62}$ Hij plaats het begrip beschavingsoffensief in het bredere kader van sociale controle. Het concept sociale controle heeft vorm gekregen door een publicatie van de Amerikaanse socioloog Ross. ${ }^{63}$ Sociale controle is het geheel van mechanismen waardoor de samenleving wordt gereguleerd. Menselijk gedrag wordt geconformeerd aan de orde van de samenleving. Hierdoor kan de samenleving continuïteit verkrijgen omdat sociale controle afwijkend gedrag corrigeert. Zoals Elias voor de West-Europese geschiedenis heeft aangegeven kan de ontwikkeling van civilisatie worden gezien als een geleidelijke transformatie van sociale controle naar zelfcontrole.

Het begrip sociale controle kwam op in de jaren zestig van de twintigste eeuw onder sociale wetenschappers. ${ }^{64} \mathrm{Bij}$ sociale controle gaat het
54 De Rooy (1979), 9-10. 55 Van Loo (1981), 71-72 56 De Regt, (1984), 169. $57 \operatorname{Kok}(2000), 91$.

$58 \operatorname{Kok}(2000), 227$ 59 Van Leeuwen (1992), 161.

60 Van Leeuwen (2003), 453.

61 Van Leeuwen (1998)a, 314.

62 Sleebe (1994), 26-31.

63 Ross, E.A. (1901).

64 Spierenburg (2004), 1-22;

Van Leeuwen (2000),194, houdt in een bijlage in de Engelstalige vertaling van zijn proefschrift een pleidooi onderzoek te doen naar sociale controle, ondanks de vaagheid van dit begrip. Onderzoek naar sociale controle geeft inzicht in de lijnen waarlangs macht wordt uitgeoefend. Drie vragen kunnen worden geformuleerd. Ten eerste: wie oefent sociale controle uit?Ten tweede: wat zijn de motieven om te controleren? En ten derde: welke middelen worden ingezet om te controleren?Daarnaast moet een onderzoeker zich realiseren dat degenen waarop de sociale controle wordt uitgeoefend geen willoze slachtoffers zijn, maar dat zij ook over alternatieven kunnen beschikken om zich aan de sociale controle te kunnen onttrekken. 
65 In de betekenis die Burke (1978), xi-xii, 21-22 en 199-204, eraan heeft gegeven.

$66 \mathrm{Er}$ is volgens Sleebe (1994), 26-31, niet één beschavingsoffensief, maar er zijn verschillende beschavingsoffensieven. Verder zegt Sleebe dat het gebruik van het woord offensief "nogal...riekt naar een vooropgezette planning" Voort suggereert het woord offensief "dat de rol van bevolkingsgroepen gereduceerd zou worden tot een volkomen passieve." 67 Sleebe (1994), 1-31; 171. 68 Sleebe (1994), 447. 69 De Regt (1984), 245-248. 70 Kort (2001), 252-260. 71 Kort (2001), 255. 72 Smit (2015), 12 73 Smit (2015), 12. 74 Smit (2015), 12. om de macht die door sommige groepen of instanties wordt uitgeoefend over anderen met een beroep op hoger belang. Sleebe onderscheidt drie vormen van sociale controle. Ten eerste is er de informele sociale controle die ingebed is in de volkscultuur. ${ }^{65}$ Ten tweede is er de semi-formele sociale controle door kerken. Als laatste is er de overheid die een controlerende rol speelt: de meest formele vorm van sociale controle. Het handhaven heeft twee kanten: een disciplineringskant en een beschavingskant. Sleebe heeft de nodige bezwaren tegen het begrip beschavingsoffensief, maar hij gebruikt het wel. ${ }^{66}$ Een drang tot beschaving ziet Sleebe terug in de armenzorg, namelijk de drang om armen deugdzaamheid en fatsoen bij te brengen in de hoop daarmee de armoede te bestrijden. ${ }^{67}$ Sleebe verruimt het begrip beschavingsoffensief door een drietal specifieke offensieven te behandelen. Daarbij gaat het om zijn onderzoeksgebied het Groningse kleigebied. Er was een offensief in de zeventiende en achttiende eeuw vanuit de Hervormde kerk dat nauwelijks effect heeft gehad. Een tweede offensief diende zich aan in de eerste helft van de negentiende eeuw, specifiek gedragen door de boerenstand in Noord Groningen om zich te onderscheiden van de landarbeiders. Ten slotte was er een offensief in de tweede helft van de negentiende eeuw. Dat derde offensief ging uit van de middengroepen. Dit offensief had het meeste succes, omdat de groepen waarop het offensief zich richtte, open stonden voor beïnvloeding. Het doel was om de samenleving meer fatsoen bij te brengen. ${ }^{68}$ De beschrijving van het derde beschavingsoffensief doet denken aan de zienswijze van De Regt, die immers net als Sleebe wees op de bereidheid van een deel van de arbeidersklasse de normen van de burgerij over te nemen. ${ }^{69}$ In het onderzoek van Kort over de armenzorg op Zuid-Beveland tussen 1850 en 1940 komen we veel voorbeelden tegen van de drang naar beschaving. ${ }^{70}$ De armbestuurders, zo stelt Kort, weten de armoede vrijwel altijd aan de armen zelf. Armenzorg werd alleen verleend als de bedeelden zich vele verplichtingen en een nauwkeurige controle lieten welgevallen. Hierbij werd de dorpsveldwachter ingeschakeld. Kort vermeldt dat de dorpsveldwachter vaak het gedrag van de armen in de gaten moest houden. ${ }^{71}$ Het betoog van Kort sluit nauw aan bij dat van De Regt: armenzorgverlening ging hand in hand met disciplinering.

Smit onderzocht de invloed die sociale hervormers, de zogeheten volksverheffers, hadden tussen 1870 en 1914. Volksverheffers waren leden van de burgerij die zich inzetten voor een ideale samenleving, waarin de kloof tussen de verschillende maatschappelijke standen zoveel mogelijk was gedicht. Smit mengt zich in het debat over armenzorg en disciplinering. Zij erkent dat volksverheffing onderdeel is van een algemeen civilisatieproces, maar zij vindt dat vervolgens "een weinig interessante constatering". ${ }^{2}$ Het verband met de disciplineringsgedachte dat De Regt heeft gelegd, wijst Smit resoluut van de hand. Smit vindt deze gedachte "nauwelijks (...) stroken met de werkelijkheid". ${ }^{73}$ Het gelegde verband zou meer worden ingegeven door sociologische veronderstellingen van de onderzoeker dan door de "reële uitgangspunten van de actoren zelf", aldus Smit. ${ }^{74}$

In hun monografie over het genootschap Liefdadigheid naar Vermogen zoeken Limperg en Van der Linden eveneens aansluiting bij de beheersingsgedachte van De Regt. Volgens hen zagen "veel LNV'ers, zo niet ie- 
dereen (...) 'het toegeven aan de eerste opwelling' (...) als hoofdoorzaak van armoede en achteruitgang". ${ }^{75}$ Zelfbeheersing werd als de oplossing gezien. Meer expliciet werden destijds zuinigheid genoemd, sparen voor de kwade en de oude dag, en het idee dat alleen eigen inspanning tot vooruitgang leidt. Limperg en Van der Linden laten zien dat de visie van Liefdadigheid naar Vermogen over de oorzaak van armoede genuanceerd was. Het genootschap huldigde in beginsel wel de gedachte dat het de "eigen schuld" was van hun protegés dat ze arm waren, maar gaandeweg kregen LNV'ers steeds meer oog voor omstandigheden waar de door armoede getroffenen geen invloed op hadden. In een situatie waarin "omstandigheden", zaken van buitenaf, de armoede veroorzaakten, bood zelfbeheersing geen soelaas. ${ }^{76}$

Het debat over de rol van de beschavings- en disciplineringsdrang van de armen binnen de armenzorg is nog altijd gaande. Veel onderzoekers zien die beschavingsdrang terug, al is die bewering niet altijd gestoeld op eigen onderzoek. Veel onderzoekers die expliciet naar eigen brononderzoek verwijzen (De Regt, Van Leeuwen, Sleebe, Van Loo, Kort, Limperg en Van der Linden) constateren een drang naar disciplinering en beschaving. Kok en Smit echter wijzen het verband tussen disciplinering en zorg af. In deze discussie kan mijn hoofdstuk over beschaving geplaatst worden.

Anders dan het beschavingsoffensief komt het thema bureaucratisering weinig aan bod in de literatuur over armenzorg in de negentiende en twintigste eeuw. Sporadisch komen we in de literatuur vermeldingen tegen, die in de richting van bureaucratisering wijzen. Zo werd in Leeuwarden in 1898 de eerste bezoldigde armbezoeker benoemd. ${ }^{77}$ In Alkmaar werd na 1912 een bezoldigde functionaris aangesteld. ${ }^{78}$ In Goes verscheen in 1936 een gesalarieerde controleur-armbezoeker ten tonele. ${ }^{79}$ Het zijn summiere aanwijzingen voor een beginnend bureaucratiseringsproces waarin vrijwilligers plaats maken voor betaalde en professionele werknemers. Kappelhof, een kenner van de armenzorg, wees op al eerdere tekenen van bureaucratisering van de armenzorg in de negentiende eeuw: het aanleggen van een kaartsysteem in Den Bosch in 1854 en het gebruik van voorgedrukte vragenlijsten in Leeuwarden en Amsterdam. ${ }^{80}$ De enige meer systematische beschrijving van bureaucratie en armenzorg die ik ken is van de hand van Van Leeuwen, over de tijd van de Republiek. ${ }^{81}$ Een afzonderlijke studie naar bureaucratisering in de armenzorg tussen 1870 en 1940 is bij mijn weten niet eerder is uitgevoerd.
75 Limperg en Van der Linde (2019), 154; De Regt (1984), 148-149.

76 Limperg en Van der Linde (2019), 149. 77 Kok (2000), 166. 78 Van Loo (1986), 87; het betrof de secretaris van de armenraad, die overigens door het Rijk werd bezoldigd. 79 Kort (2001), 259; deze functionaris werd pas aangesteld nadat het Rijk subsidie voor deze functie had toegezegd.

80 Kappelhof (2005), 25-26. 81 Van Leeuwen (2007). 
MIIS.

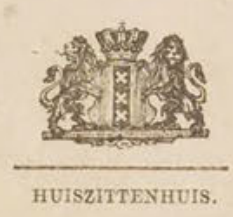

De Ondergeteekende Stads $\frac{\text { GenessheEr }}{\text { HeELMEester }}$ verklaart dat ligchaamsgebreken

5
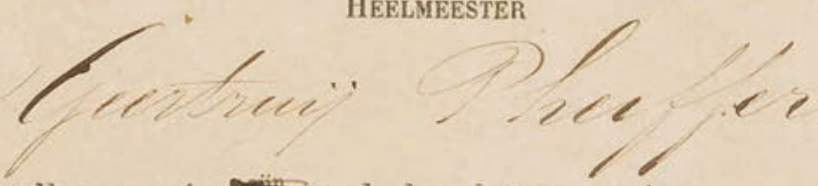

buiten staat stellen om in onderhoud te voorzien.
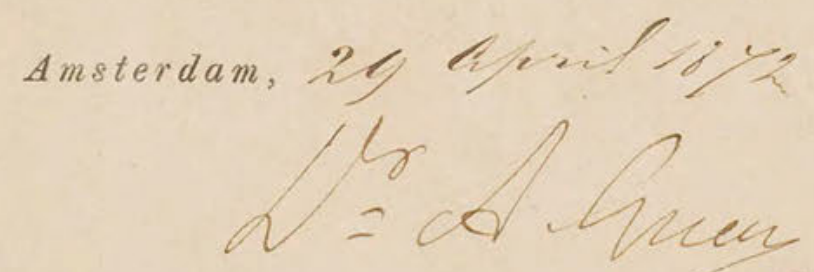

om in onderhoud te voorzien. 
< 3.A Doktersattest uit 1872 ten behoeve van Anna Geertruij Pheiffer Bron: SAA 5256, doos 992.
1 Zie tabel 8.16 in bijlage 8, Knotter (1997), 68, wijst op de groei van het aantal dossiers in de jaren '20 en '30 van de twintigste eeuw. 2 Knotter (1997), 65; Knotter en Kok (2005), 83, volgens Persoonsdossiers: een geval apart(2005) 32, kunnen dossiers twintig jaar na beëindiging (van het afhandelen van de hulpvraag) worden vernietigd.

3 Knotter en Kok (2005), 101, in Nijmegen is één dossier bewaard.

4 Mededeling van Harmen Snel, archivaris in het Stadsarchief Amsterdam; Knotter (1997), 74, vermeldt dat bij de brand van april 1943, waarbij het hoofdkantoor in de Reguliersdwarsstraat in de as werd gelegd na het neerstorten van een vliegtuig, een relatief klein aantal dossiers verloren zijn gegaan ("gesproken wordt over 1000"). In mijn steekjaren 1871, 1911 en 1936 heb ik geen lacunes aangetroffen.

5 SAA. Archief van de Sociale Dienst en rechtsvoorgangers. Toegangsnummer 5256.

6 Knotter (1997), 71-73,

wijst eveneens op de historische waarde van deze dossiers.
HOOFDSTUK 3

BRONNEN EN

ONDERZOEKSOPZET

\subsection{BRONNEN VOOR DE GEMEENTELIJKE ARMENZORG IN AMSTER- DAM IN DE PERIODE 1870-1940}

Mijn onderzoek steunt hoofdzakelijk op twee bronnen: de dossiers van de armbezoekers en de jaarverslagen van de gemeentelijke armenzorg. Als iemand steun aanvroeg bij de gemeentelijke armenzorg, kreeg hij of zij bezoek aan huis door een armbezoeker die in dienst was bij het Burgerlijk Armbestuur (vanaf 1927 de Burgerlijke Instelling voor Maatschappelijken Steun). Het doel was na te gaan of de persoon of het gezin inderdaad in aanmerking kwam voor hulp. Hiertoe werd een uitgebreide vragenlijst ingevuld. Elke aanvrager kreeg een dossier. Omdat er bij elke nieuwe steunaanvraag een nieuwe vragenlijst werd ingevuld door de armbezoeker, zijn die dossiers erg uitvoerig. Eén dossier omvat dus alle aanvragen van één aanvrager. Sommige dossiers strekken zich uit over decennia. In deze dossiers valt na te lezen hoe het leven van de aanvrager en zijn gezin eruit zag gedurende de periode van onderstand. Op het niveau van de huishoudens is te zien welke maatstaven er werden gehanteerd bij het verstrekken van hulp. In mijn onderzoek worden deze dossiers geanalyseerd. Het aantal aanvragen en dus ook het aantal onderzoeken is zeer aanzienlijk. Zo bedroeg het totaal aantal onderzoeken in 1910 meer dan 50.000, terwijl in de jaren '30 jaarlijks een half miljoen onderzoeken werden verricht. ${ }^{1}$

De in Amsterdam bewaarde dossiers vormen een bijzondere bron. In de eerste plaats is het bijzonder dat ze er nog zijn. Volgens de geldende archiefvoorschriften hadden ze vernietigd kunnen worden. ${ }^{2}$ In Amsterdam is dat, net als in dertien andere Nederlandse gemeenten niet gebeurd. ${ }^{3}$ In de tweede plaats is het bijzonder dat zo goed als alle dossiers nog aanwezig zijn. ${ }^{4}$ De dossiers uit de periode van 1871 tot 1965 worden bewaard in het archief van de Gemeentelijke Sociale dienst van Amsterdam en rechtsvoorgangers. ${ }^{5}$ De dossiers bevatten rapporten van de armbezoeker en afzonderlijke bewijsstukken zoals medische attesten, brieven van aanvragers en mededelingen van werkgevers. Verder vinden we in de dossiers soms briefwisselingen met andere hulpverlenende instanties. Een aparte vermelding verdienen de klikbriefjes waarin vertrouwelijke mededelingen over de aanvrager worden gedaan. De dossiers leveren een overstelpende hoeveelheid gegevens van diverse aard op. Ze maken een deel van het persoonlijke leven van de aanvrager en de eventuele andere leden van zijn huishouding zichtbaar. Er is mij geen andere historische bron bekend die zo veel inkijk geeft in het dagelijkse leven van een zo groot aantal heel gewone Amsterdamse mensen. ${ }^{6}$

De rapporten van de armbezoeker lijken een nauwkeurige afspiegeling te geven van de werkelijkheid, omdat zij zich richten op individuele huishoudens en een hoge mate van nauwkeurigheid vertonen door de frequentie 
van de bezoeken, het systeem van de uitvoerige vragenlijsten en het interne controlesysteem. De vraag is natuurlijk of de rapporten kloppen. ${ }^{7}$ Waren de antwoorden van de armen waarheidsgetrouw? Kan het zijn dat er door de cliënten fraude werd gepleegd? Aan de rapporten valt af te lezen dat er veel controles waren door de steeds terugkerende bezoeken. Verder was de armbezoeker niet de enige die oordeelde: de aanbevelingen in de rapporten werden ook nog eens door iemand anders bekeken. Vanaf 1896 was er het fenomeen van de vrijwillige armbezoeker. Dat bracht extra controle met zich mee. Ten slotte werd er door armbezoekers wel navraag gedaan in de buurt en bij een eventuele werkgever over de hulpaanvrager. We zien dat terug in de rapporten. In een enkel geval komen we ook de eerder al genoemde klikbriefjes tegen, waarin buurtgenoten de aanvrager beschuldigen van malversaties. Naar de motieven van de klikspanen valt alleen maar te gissen. Bij al die honderdduizenden aanvragen zal er zeker wel eens fraude zijn voorgekomen. ${ }^{8}$ Het systeem, met zijn vele controlemogelijkheden, wekt bij deze onderzoeker intussen allerminst de indruk dat het een janboel is geweest.

Wie komen er voor in de dossiers van de armbezoekers? Het is goed te weten dat de door het Burgerlijk Armbestuur gesteunde armen maar een deel vormden van alle gesteunde armen in Amsterdam. Er waren in die tijd nog veel instellingen voor kerkelijke armenzorg. In 1919 waren er maar liefst 90 kerkelijke instellingen actief in Amsterdam. ${ }^{9}$ Omdat het er zoveel zijn en omdat het archiefmateriaal van al deze instellingen maar zeer fragmentarisch is overgeleverd, richt ik mij uitsluitend op het archief van de gemeentelijke armenzorg.

De armen waren aanvankelijk in eerste instantie aangewezen op kerkelijke hulp. Dat was vastgelegd in de Armenwet van 1854. Kwamen de aanvragers niet in aanmerking voor kerkelijke steun, dan kon pas daarna om hulp van het Burgerlijk Armbestuur gevraagd worden. Vanaf 1896 was dubbele bedeling mogelijk: aan een individuele arme kon naast kerkelijke hulp ook steun van het Burgerlijk Armbestuur worden gegeven. De uitdrukking "dubbel" kan een verkeerde indruk geven van een ruime uitkering. In werkelijkheid waren de uitkeringen van kerkelijke zijde zeer karig te noemen.

Interessant is de vraag welke armen in aanraking komen met het Burgerlijk Armbestuur. De grootste groep vormden zelfstandige huishoudens. Ook binnen deze groep waren er verschillende categorieën, als we kijken naar de oorzaak van de armoede. Het zijn bijvoorbeeld mensen die te oud zijn om in hun onderhoud te kunnen voorzien. Of het zijn gezinnen die getroffen zijn door (tijdelijke) werkloosheid, of waarvan de man is weggelopen, overleden, of in hechtenis genomen. Wat voor al deze armen geldt, is dat zij een zelfstandig huishouden voeren, de meesten in gezinsverband, maar sommigen ook wel als alleenstaanden.

Daarnaast vallen onder het Burgerlijk Armbestuur de gestichtsarmen. Het gaat onder meer om weduwen die zijn opgenomen in het Weduwenhof. Vergeleken met de gehele stedelijke bevolking gaat het daarbij om geringe aantallen. Voorts gaat het om kinderen: de stadsbestedelingen en de burgerwezen. Mensen die maatschappelijk ongeschikt waren verklaard, vielen tevens onder de verzorging van het Burgerlijk Armbestuur. Ook waren er armen die geen eigen thuis hadden, maar opgenomen waren in het
7 Zie ook de opmerkingen bij Knotter en Kok (2005),94-99; Van Eijl, de Groot, en Sanders (1990), 54-76. Over de controlemogelijkheden zie ook hoofdstuk 7, paragraaf 1 a. 8 Groot (1987), 267.

9 Statistisch jaarboek der gemeente Amsterdam 1919, 117 
armenhuis. Ten slotte kunnen de krankzinnigen genoemd worden. Ik wil niet alle categorieën die onder het Burgerlijk Armbestuur vallen, in het onderzoek betrekken. Hun diversiteit is nogal groot, waardoor zij moeilijk te onderzoeken zijn. In mijn onderzoek richt ik mij dan ook op de zelfstandige huishoudens, de zogeheten huiszittenarmen.

De tweede bron die ik gebruik wordt gevormd door de jaarverslagen van de gemeentelijke armenzorg. Aanvankelijk zijn de jaarverslagen onderdeel van de Gemeenteverslagen. Later worden het bijlagen bij de Gemeenteverslagen. Uiteindelijk groeien de jaarverslagen uit tot zelfstandige publicaties..$^{10}$ In de jaarverslagen werd verantwoording afgelegd aan de Gemeenteraad in opdracht van de politiek verantwoordelijke wethouder, die het armwezen in zijn portefeuille had. We kunnen ervan uitgaan dat de openbaarheid van het bestuur, de kritische houding van de gemeenteraadsleden en de interne financiële controle van het gemeentelijke apparaat hebben bijgedragen aan een hoge graad van betrouwbaarheid van de jaarverslagen.

De informatie uit de gemeenteverslagen is vooral cijfermatig van aard, maar er wordt ook wel melding gemaakt van het hoe en waarom van de manier van werken. Deze cijfers dragen bij aan het structureren van de gegevens uit de dossiers van de armbezoekers. Beleidsstukken van het Burgerlijk Armbestuur zijn niet voorhanden. Het beleidsarchief van de Burgerlijk Armbestuur/Burgerlijke Instelling voor Maatschappelijken Steun is grotendeels verloren gegaan bij de brand die het hoofdkantoor in de Reguliersdwarsstraat in de as legde, na het neerstorten van een vliegtuig in april 1943.

Ter afsluiting een opmerking over de wijze van vermelding van de aanvragers. De voor- en achternamen van de personen uit de jaargroepen 1871 en 1911 heb ik volledig weergegeven omdat hun dossiers openbaar zijn. Op de dossiers van de jaargroep 1936 berust echter nog een openbaarheidsbeperking. Het Stadsarchief gaf mij toestemming tot raadpleging onder de voorwaarde dat ik de achternamen van deze cliënten alleen met een initiaal zou vermelden. Deze beperking van de naamgeving heb ik ook in de database doorgevoerd.

\subsection{ONDERZOEKSOPZET}

Zoals hierboven aangegeven heb ik in hoofdzaak twee bronnen gebruikt voor mijn onderzoek: de rapporten van de armbezoeker en de jaarverslagen. De rapporten van de armbezoeker zijn zo goed als volledig bewaard gebleven. Het gaat om grote hoeveelheden dossiers. Over de periode 1871 - 1940 gaat het om zo'n 200.000 dossiers. Deze grote aantallen maken een selectie noodzakelijk. Gekozen is voor de jaren 1871, 1911 en 1936. In 1871 wordt het Burgerlijk Armbestuur opgericht. Het jaar 1911 gaat vooraf aan de invoering van de nieuwe Armenwet van 1912. Dit maakt een vergelijking mogelijk met de populatie van 1871. Het jaar 1936 markeert het einde van

10 De jaarverslagen zijn terug te vinden in het Archief van de Gemeentelijke Sociale Dienst en rechtsvoorgangers, SAA. Toegangsnummer 5256 . de crisis van de jaren '30. Mijn onderzoeksperiode eindigt in 1940, als door de Duitse bezetting een nieuw tijdperk in de Nederlandse en Amsterdamse geschiedenis intreedt.

De opzet van mijn onderzoek is dat van elke onderzoeksjaar een aantal dossiers van het betreffende jaar op dezelfde manier wordt onderzocht. 
Hierdoor komt een lange termijnontwikkeling in beeld. Deze keuze brengt een beperking met zich mee. De onderzochte groepen worden niet longitudinaal gevolgd: dat wil zeggen dat ik niet alle dossiers van een specifiek huishouden dat een beroep deed op de armenzorg onderzoek. De analyse van de dossiers is dus gericht op de jaren 1871, 1911 en 1936. De onderzochte dossiers zijn voor elke jaar weer in twee delen uitgesplitst. Er worden toegekende en afgewezen steunaanvragen onderzocht. De verdeling is in tabel 3.1 weergegeven.

Tabel 3.1 Geraadpleegde dossiers (1871,1911 en 1936)

\begin{tabular}{|l|r|r|r|r|}
\hline & 1871 & 1911 & 1936 & \multicolumn{1}{|l|}{ Totalen } \\
\hline $\begin{array}{l}\text { Toegekende steunaanvragen naar } \\
\text { huishoudens }\end{array}$ & 61 & 60 & 60 & 181 \\
\hline $\begin{array}{l}\text { Afgewezen steunaanvragen naar } \\
\text { huishoudens }\end{array}$ & 63 & 75 & 63 & 382 \\
\hline Totaal aantal onderzochte huishoudens & & & & 541 \\
\hline $\begin{array}{l}\text { Toegekende steunaanvragen naar per- } \\
\text { sonen }\end{array}$ & 209 & 177 & 155 & 663 \\
\hline $\begin{array}{l}\text { Afgewezen steunaanvragen naar perso- } \\
\text { nen }\end{array}$ & 278 & 260 & 125 & 1204 \\
\hline Totaal aantal onderzochte personen & & & & \\
\hline
\end{tabular}

Hoewel, zoals eerder aangegeven, alle rapporten van de armbezoeker zo goed als volledig bewaard zijn was het raadplegen van de dossiers niet zonder problemen. De dossiers voor 1871 zijn gearchiveerd op de achternaam van de aanvrager. Deze wijze van archivering is kennelijk in de jaren '90 van de negentiende eeuw aangebracht, vermoedelijk in opdracht van Jurrema, in zijn functie als Directeur van het Armbezoek. Het betekende dat het vinden van dossiers uit 1871 een omslachtige en tijdrovende aangelegenheid was. Om het beoogde aantal 120 dossiers, 60 toegekende en 60 afgewezen aanvragen te verzamelen werden ook een aantal dossiers uit 1872 gebruikt. Het vroegste dossier dat is onderzocht dateert van 5 april 1871. ${ }^{11}$ Uit januari, februari en maart 1872 zijn 22 dossiers onderzocht. ${ }^{12}$ Hierdoor konden alle seizoenen worden bestudeerd. De wisseling van de seizoenen kon hierdoor in beeld worden gebracht. Om het aantal van 120 dossiers te bereiken zijn uit de periode april tot december 1872 vijftien dossiers onderzocht. ${ }^{13}$ Uit opmerkingen in de dossiers komt naar voren dat een aantal aanvragers al voor 1871 door de gemeentelijke armenzorg was bedeeld. Het was niet na te gaan welke aanvragers voor het eerst in 1871 een aanvraag deden. Omdat het beoordelen van de aanvragen in 1871 plaatsvond kan gesteld worden dat voor de beantwoording van de gestelde vragen dat weinig problematisch is.

De aanvragen uit 1911 die zijn bestudeerd zijn afkomstig van aanvragers die al eerder een aanvraag hadden ingediend. Op de eerste aanvragen uit 1911 berust namelijk nog een beperking van de toegankelijkheid die in 2041 zal worden opgeheven. Sinds de jaren ' 90 van de negentiende eeuw is het principe van het archiveren gewijzigd. ${ }^{14}$ De dossiers zijn bewaard in chronologische volgorde van aanvraag. Eerste aanvragen sinds de jaren '90 van
11 SAA 5256.Doos 1175A. Stamboeknummer 78. Het gaat om het eenoudergezin van Anna Maria Henriette Ruck.

12 Het gaat om de stamboeknummers 251, 256, 257, 258, 259, 285, 288, 500, 1301, 1304, 1642, 2014, $2017,2019,2021.4650$ 4654, 4656, 4657, 4659, 4660 en 4670.

13 Het gaat om de maanden april (1 dossier), mei (1 dossier), juni (2 dossiers), oktober (1 dossier), november (7 dossiers) en december (3 dossiers). $14 \mathrm{Er}$ is geen beleidsstuk aanwezig om deze bewering te staven, maar wie de dossiers veelvuldig raadpleegt doorziet het uitgangspunt. Bij de eerste aanvraag wordt een stamboeknummer toegekend dat gebruikt wordt zolang de aanvrager leeft. Er zijn uitzonderingen op deze regel. Als iemand die al bedeeld wordt, een huwelijk aangaat met iemand die ook al bedeeld wordt, dan wordt de bedeling voor beiden en eventuele kinderen voortgezet onder het stamboeknummer van de kostwinner. Eén dossier wordt gesloten. In de regel blijft het dossier van de mannelijke kostwinner bestaan. Een andere uitzondering waardoor een dossier gesloten wordt, is als de mannelijke kostwinner overlijdt. Het achtergebleven gezinslid, de weduwe, wordt onder een nieuw stamboeknummer bedeeld. Een weduwnaar behoudt zijn oorspronkelijke stamboeknummer. In de levensverhalen in hoofdstuk acht komen deze uitzonderingen ter sprake. Alle aanvragen en alle overige bescheiden worden in een fysiek dossier bewaard. Bij de hierboven aangehaalde herschikking van het archief in de jaren '90 hebben alle dossiers nieuwe stamboeknummers gekregen: hoe lager hoe ouder, hoe hoger hoe recenter. 
negentiende eeuw tot het begin van de twintigste eeuw zijn wel toegankelijk. Deze dossiers zijn geraadpleegd voor het jaar 1911. De onderzochte dossiers omvatten alle kalendermaanden van 1911.

Voor 1936 zou op deze wijze ook aanvragen kunnen worden bestudeerd. Dat zou bezwaarlijk zijn omdat dan alleen oudere aanvragers in het onderzoek zouden worden betrokken. Voor het jaar 1936 heb ik dan ook om opheffing van de beperking van de toegankelijkheid gevraagd. Het duurde enkele jaren voor de toestemming werd gegeven. Vervolgens was het voor de archivarissen erg moeilijk om de gevraagde dossiers uit 1936 te vinden. Uiteindelijk slaagde Harmen Snel in het vinden van deze dossiers. Ik heb voor het jaar 1936 steeds de eerste aanvragen kunnen inzien. Het gaat dus om armen die in 1936 voor het eerst een verzoek om steun deden.

De uitsplitsing in toegekende steunaanvragen en afgewezen steunaanvragen brengt verschillen aan het licht tussen de subgroepen per jaar. Er is daarom gekozen voor een gelijk getal toegekende steunaanvragen en afgewezen steunaanvragen. Voor sommige subgroepen is het beoogde aantal van 60 dossiers overschreden. Dat komt door de wijze van raadplegen. De dossiers zijn per doos verzameld. Om zoveel mogelijk spreiding te verkrijgen is een dossier aan het begin van de doos, een dossier uit het midden van de doos en een dossier aan het eind van de doos bestudeerd. ${ }^{15}$ Het getal van 120 dossiers per jaar leek groot genoeg te zijn om een trend te kunnen zien tussen 1871, 1911 en 1936. Daarbij moet wel in ogenschouw worden genomen dat de onderzochte dossiers een steeds kleinere fractie omvatten van de totale hoeveelheid aanvragen. Zo bedroeg in 1869 het aantal huishoudingen dat door de gemeente met winterbededeling of met zomerbedeling werd geholpen 586 partijen. ${ }^{16}$ In 1936 werden 52.365 huishoudens wekelijks ondersteund..$^{17}$ Voor het jaar 1871 zijn twintig procent van de beschikbare dossiers onderzocht. Als dat percentage ook voor 1936 zou zijn aangehouden, dan had ik ruim tienduizend dossiers moeten onderzoeken. Dat was niet uitvoerbaar, zodat ik mij met uiteindelijk 123 dossiers tevreden moest stellen.

De aanvraag wordt per huishouden, per woonadres, gedaan. De gemeentelijke armenzorg sprak destijds van "partijen". Een partij is een alleenstaande of meerdere personen die - in de regel - als gezin samenleven op één adres. Omdat het interessant is zowel gegevens te hebben op gezinsniveau als op individueel niveau, is het cijfermatige materiaal gerangschikt op huishoudens en personen. In voorkomende gevallen is onder huishouden de kostwinner te verstaan, omdat die persoon het hoogste inkomen inbrengt. Kostwinners zijn meestal mannen, maar ook vrouwen kunnen kostwinner zijn.

De rapporten zijn ondergebracht in een database. In de database is van elk rapport een volledige transcriptie opgenomen. De kwalitatieve gegevens uit de database zijn verwerkt tot kwantitatieve data. Hiertoe heb ik de

15 K. Mandemakers maakte mij attent op deze werkwijze, die hij heeft gebruikt voor de historische steekproef van Nederland. 16 SAA 15030. Inventarisnummer 133270, 88.

17 Tabel 8.12. kwalitatieve gegevens ondergebracht in categorische systemen. Daardoor is het mogelijk de kenmerken van de onderzochte verschijnselen te tellen. Als voorbeeld noem ik de aard van de woning van de aanvragers. Er zijn verschillende soorten woningen: in kelders en gangen, kamerwoningen en twee- en meer kamerwoningen. Door te rubriceren wordt inzicht verworven in de woongeschiedenis van de aanvragers door de jaren heen. Het maken 
van de transcripties en het verwerken van de cijfermatige gegevens was erg arbeidsintensief. Zo kostte het ongeveer een maand om de tabel te vervaardigen met de beroepen van de aanvragers.

Het kwantitatieve materiaal wordt weergegeven in tabellen en grafieken (lijngrafieken, kolomdiagrammen en cirkeldiagrammen). De grafieken zijn in het tekstgedeelte opgenomen. Zij zijn bedoeld om de cijfers wat aanschouwelijker te maken. Verreweg de meeste tabellen zijn als bijlagen opgenomen. Die tabellen hebben, zou je kunnen zeggen, het "laatste woord".

De tweede bron die ik heb geraadpleegd zijn de jaarverslagen, waarin de gemeentelijke armenzorg verantwoording aflegt van de werkzaamheden. Deze verslagen heb ik integraal doorgenomen met een focus op kwantitatieve gegevens en de werking van het apparaat van de gemeentelijke armenzorg. De kwantitatieve gegevens vormen een aanvulling op de kwantitatieve gegevens uit de rapporten van de armbezoeker. De werking van het apparaat wordt zichtbaar in mededelingen over nieuwe functies, veranderingen in de organisatie van het zorgsysteem en andere zaken. In de beginjaren hebben de jaarverslagen een bescheiden omvang. In latere jaren, in het bijzonder in de periode tussen de beide wereldoorlogen, neemt de omvang fors toe. De kwaliteit van de jaarverslagen loopt uiteen. In de eerste decennia zijn ze vooral opsommend. In een latere fase, vooral onder het bewind van Jurrema (1896-1932), krijgen ze een meer analytisch karakter, en is er een duidelijk verband te zien tussen de opeenvolgende jaarverslagen. 


\section{HOOFDSTUK 4 \\ ARMOEDE EN ARMENZORG}

$<4$.A Een bedelaar-spiritusdrinker op straat circa 1930 Onbekende fotograaf. Bron: SAA. Beeldbank. Afbeeldingsbestand: ANWG00676000001.

1 Zowel Van der Valk (1986), 1, als Van Leeuwen (1992), 61, gebruiken deze veelzeggende beeldspraak. 2 SAA 5256. Doos 1176. Stamboeknummer 190; zo werd de armoede van de dertigjarige Willem Louweris in 1871 omschreven door de armbezoeker. Willem woonde met zijn vrouw en twee zonen in de Wagenstraat.

3 Spaans (1997), 40-43.

4 Lis en Soly (1980), 106-

107.

5 Bridewell gevangenis (https://www.londonlives. org/static/Bridewell.jssp). 6 Abel (1974), 302: Massenarmut als Dauererscheinung. De term pauperisme met zijn negatieve lading (paupers zijn gevaarlijke marginalen van de samenleving) ontstond in het publieke debat in Frankrijk na 1815. Zie Gouda (1995), 35-38. Ook: Chevalier (1958), 451-469.

7 Hufton (1974), 25-68.

8 De Bosch Kemper (1860)

5 . Ik refereer aan de tweede druk uit 1860, (eerste druk 1851).

9 Seebohm Rowntree, (2000), 133-134. (herdruk/ eerste druk 1901)

10 Blockmans en Prevenier (1975), 502

\section{"Armoede is een veelkoppig monster". ${ }^{1}$}

\subsection{WAT IS ARMOEDE?}

"Er heerscht doodelijke armoede". 2

Armoede is een onderwerp waar verscheidene historici onderzoek naar hebben verricht. Veel aandacht gaat daarbij dan meestal uit naar de toename van de armoede in de pre-industriële periode in West-Europa en de afname van het armoedeprobleem in de industriële tijd. Naast de traditionele armen uit de middeleeuwse periode, wezen, weduwen, weduwnaars en gehandicapten, deden vanaf het begin van de zestiende eeuw ook dagloners een beroep op zorg. De last die de samenleving nu in toenemende mate moest dragen probeerden de autoriteiten te verlichten door armen strenger te bejegenen. ${ }^{3}$ De "lust" van de charitas werd een last. De houding tegenover armen werd steeds repressiever. Ze werden onder druk gezet door het instellen van bedelverboden. Ook werden armen verjaagd die niet geboren waren in de steden en dorpen waar zij om hulp vroegen. ${ }^{4}$ Aan het eind van de zestiende eeuw nam de druk op de samenleving toe door toename van de armoede. De repressie nam daardoor eveneens toe. De periode begon die door Foucault "de grote opsluiting" is genoemd. Marginalen in de samenleving werden afgezonderd in gestichten en werkhuizen. Engeland lijkt met de oprichting in 1553 van de Bridewell Prison and Hospital de primeur te hebben gehad. ${ }^{5}$ De oprichting in 1596 van het Rasphuis en in 1597 van het Spinhuis in Amsterdam past eveneens in het kader van deze opsluiting. De armoede bereikte in de achttiende en negentiende eeuw, de tijd van het pauperisme, een hoogtepunt, volgens de Duitse historicus Wilhelm Abel. ${ }^{6}$ Olwen Hufton vat deze ontwikkeling samen in de titel van haar klassieke studie: From poverty to indigence. ${ }^{7}$ Het industrialisatieproces dat op het continent in de negentiende eeuw in steeds meer landen zijn beslag kreeg, maakte op den duur een eind aan dit armoedeprobleem.

Wat is armoede eigenlijk? Het is niet eenvoudig om op deze vraag een bevredigend antwoord te geven. In 1851 plaatste De Bosch Kemper arm tegenover rijk. ${ }^{8}$ Arm is degene die niet in zijn eerste levensbehoeften kan voorzien: voedsel, kleding en huisvesting zijn ontoereikend. Dit is een materiële benadering van armoede die nog steeds door historici wordt gebruikt. Dit soort armoede werd gekarakteriseerd door Benjamin Seebohm Rowntree in zijn werk over York uit 1901 als primaire armoede. ${ }^{9}$ Het onderschrijden van de primaire armoedegrens is uiteindelijk levensbedreigend.

Om deze ondergrens te bepalen, stelden Blockmans en Prevenier een vuistregel op, de zogenaamde 44\%-systematiek..$^{10}$ Als $44 \%$ van het huishoudbudget opgaat aan brood, dan is er armoede in de zin van een biologisch existentieniveau. Het biologische existentieniveau kan ook worden gemeten als naar de calorische opbrengst wordt gekeken van voedsel dat met een beperkt budget kon worden aangeschaft. In de armenzorg in de 
pre-industriële periode is het biologische existentieniveau eveneens de maatstaf: armen krijgen, met andere woorden, net genoeg om te overleven. Voor Amsterdam in de eerste helft van de negentiende eeuw heeft Marco van Leeuwen, ruw samengevat, kunnen aantonen dat de verleende zorg ongeveer de 44\% norm van Blockmans en Prevenier weerspiegelt. ${ }^{11}$ De zorg is gericht op overleven. Voor Antwerpen in 1850 komen Lis en Soly tot soortgelijke uitkomsten. Ook daar leefden de gesteunde armen "bestendig ( ...) op de rand van de hongersnood". 12

Armoede is zoals boven uitgelegd het gevolg van een te laag inkomen, zodat niet in de dagelijkse levensbehoeften kan worden voorzien. Wilhelm Abel formuleerde het in zijn studie Stufen der Ernährung net weer even anders. Armoede was volgens hem het gevolg van het tekort aan betaalbare voedingsmiddelen. Deze primaire armoede was tijdelijk afwezig in de veertiende eeuw, in de periode na de Zwarte Dood, toen "De Gouden Tijd van de ambachtsman" was aangebroken. ${ }^{13}$ Lang duurde deze gouden era niet. De in de vijftiende eeuw ingezette transformatie van de Europese economie naar een markteconomie, soms aangeduid als "de commerciële revolutie", zette de levensstandaard van de lagere sociale groepen onder druk. Abel geeft verschillende bewijzen voor de dalende levensstandaard. Deze daling is wellicht het meest overtuigend te zien is in een daling van het vleesverbruik. ${ }^{14}$ Rond 1400 is het geschatte vleesverbruik onder ambachtslieden 65 KG per hoofd per jaar, rond 1800 bedraagt de vleesconsumptie onder ambachtslieden $20 \mathrm{KG}$ per hoofd per jaar. ${ }^{15}$ In de negentiende eeuw nam het vleesverbruik weer toe. Het gaat in de studie van Abel om "Midden-Europa". In Nederland verdubbelde tussen de jaren '50 van de negentiende eeuw en 1910 het percentuele aandeel in de budgetten dat arbeiders uitgaven aan vlees. Het industrialisatieproces dat in Europa in de negentiende eeuw in steeds meer landen op gang kwam, maakte op den duur een eind aan het primaire armoedeprobleem. ${ }^{16}$ Een mooie illustratie van deze verbetering is te zien in de dissertatie van L. Frank van Loo over Alkmaar. ${ }^{17}$ De koopkracht nam toe, de levensduur werd verlengd en de huisvesting verbeterde.

Primaire armoede is, zoals boven beschreven, een kwestie van inkomens die ontoereikend zijn om in de dagelijkse levensbehoeften te kunnen voorzien. Om de oorzaken van armoede te duiden wordt in de regel een neomalthusiaanse verklaring gebruikt. Malthus waarschuwde in 1798 voor de gevolgen van een te grote bevolkingsgroei. ${ }^{18} \mathrm{Er}$ is in zijn visie een permanente spanning tussen bevolkingsgroei en de productie van voedingsmiddelen. Theoretisch groeit de bevolking sneller dan de productie van deze voedingsmiddelen. Het gevolg is een toenemende schaarste aan voedingsmiddelen. Een stijging van de kosten voor voeding is dan het logische gevolg. De bevolking kan hierdoor nog minder voedingsmiddelen aanschaffen. Dit leidt tot ondervoeding. De ondervoede bevolking is verzwakt en daardoor sneller ten prooi aan ziekten. Sterfterisico's nemen toe. In dit stadium is een kleine afname van de beschikbaarheid van voedsel al genoeg om te leiden tot hongersnood op grote schaal. Uiteenlopende rampen kunnen de situatie nog eens verslechteren: misoogsten, oorlogen en epidemieën. Er is dan sprake van een bestaanscrisis. Massale sterfte is aan de orde van de dag. Niet alleen de laagste sociale groepen worden getroffen, maar indirect ook de ambachtslieden. De stijging van de kosten
11 Van Leeuwen (1992), 62-69.

12 Lis en Soly (1977), 479; Lis en Soly (1980), 22. 13 Lis en Soly (1980), 42. 14 Abel (1981), 64. 15 Voor Amsterdam in 1810 schatte ik zelf het vleesverbruik op $30 \mathrm{KG}$ vlees per hoofd. Van der Maas (1981); Van der Maas en Noordegraaf (1983), 214. 16 Abel (1974), 394: "Erst seit den $1850^{\text {er Jahre be- }}$ ginnt der Aufschwung". 17 Van Loo (1986), 229-230. 18 Malthus (1798). "I said that population, when unchecked, increased in a geometrical ratio, and subsistence for man in an arithmetical ratio." 
19 De uitdrukking stamt van Meuvret (1946), 643. 20 Abel (1966), 265-267; in Frankrijk Annales d'histoire économique et sociale, in 1929 opgericht onder redactie van Marc Bloch en Lucien Febvre. Ernst Labrousse omarmde ook het gedachtegoed van dit vooroorlogse tijdschrift. Zie verder lggers (1978), Burke (2015) en Stoianovich (1976)

21 Te onzent bijvoorbeeld Drukker (2003). Het gaat om kritiek op de 'seriële geschiedenis' die door Abel en de meeste historici rond de Annales wordt gebruikt.

22 Het meten van armoede in de industriële tijd, met name na 1945, wordt uitvoerig uiteengezet door Delsen (2019). Delsen (2019), 35-36, stemt in met de relevantie van het onderscheid tussen absolute en relatieve armoede, zoals door Seebohm Rowntree uiteengezet is. 23 Vranken (2006), 31. 24 Engbersen (2000), 15. 25 Engbersen (1991), 7-23. voor voedsel hollen de uitgaven voor andere benodigdheden ook uit. Op kleding wordt bezuinigd. In het algemeen wordt bezuinigd op goederen die door de ambachten worden voortgebracht. Zo wordt dus ook de nijverheid getroffen. Dit is een zo typisch verschijnsel in pre-industrieel Europa dat dit soort crisissituatie de benaming "crise de type ancien" heeft gekregen. ${ }^{19}$

Deze neomalthusiaanse verklaring voor bestaanscrises is in de eerste helft van de twintigste eeuw door historici omarmd. Waarschijnlijk onafhankelijk van elkaar hebben Wilhelm Abel en Franse historici rondom het tijdschrift Annales de geldigheid van de bevolkingsleer van Malthus voor pre-industrieel Europa aangetoond. ${ }^{20}$ Sinds de jaren '60 van de twintigste eeuw hebben deze opvattingen algemeen ingang gevonden in de geschiedwetenschap, al is er ook kritiek geuit op deze benaderingswijze. ${ }^{21}$

We hebben het tot dusver alleen over primaire armoede gehad in de periode die vooraf ging aan de industriële samenleving. In een industriële samenleving is de primaire armoedegrens, het biologisch existentieniveau, een minder bruikbaar begrip. In zo'n samenleving komt niemand meer om van de honger. Daarom kan voor de industriële samenleving beter het begrip secundaire armoede worden gebruikt. ${ }^{22}$ Gesteld kan worden dat een gemiddeld pakket aan goederen beschikbaar moet zijn om te kunnen functioneren binnen een samenleving. Degenen die niet kunnen beschikken over dat pakket aan goederen, noemen we arm, maar deze armoede is relatief, want zij wordt afgemeten aan het gemiddelde welstandspeil. De secundaire armen kunnen door hun situatie niet volledig deelnemen aan de samenleving. "Armoede is een netwerk van sociale uitsluitingen", aldus Jan Vranken, "dat zich uitstrekt over meerdere gebieden van het individuele en collectieve bestaan. Het scheidt de armen van de algemeen aanvaarde leefpatronen van de samenleving. Deze kloof kunnen zij niet op eigen kracht overbruggen". ${ }^{23}$ Het armoedebegrip wordt hier voor de samenleving als geheel geduid. Godfried Engbersen vat het veel individueler op: "(de) relatieve armoedegrens is een gestandaardiseerd huishoudinkomen van minder dan $50 \%$ van het gemiddelde of mediane inkomen in een land". ${ }^{24}$ Engbersen heeft het ook over "moderne armoede", die hij globaal beschrijft als een situatie waarin burgers structureel worden uitgesloten van maatschappelijke deelname, "die gepaard gaat met permanente afhankelijkheid van de overheid". ${ }^{25}$

Secundaire armoede gaat dus niet (meer) over het biologische existentieniveau, maar om de beperkte deelname aan het maatschappelijk verkeer. Armen worden beperkt door een laag inkomen. Mede hierdoor krimpt het sociale netwerk. Secundaire armoede hangt ook samen met een laag opleidingsniveau, dat op zich weer een drempel opwerpt om te kunnen profiteren van bepaalde overheidsvoorzieningen.

Samengevat: armoede in de pre-industriële samenleving wil zeggen dat de armen onvoldoende in staat zijn in primaire levensbehoeften te voorzien, zoals eten, kleden en wonen. Zonder hulp zullen zij aan hun armoede sterven. Dit is primaire armoede. In de industriële samenleving worden armen deels uitgesloten van het maatschappelijk verkeer. De armen hebben onvoldoende middelen om toegang te hebben. Zij gaan niet dood aan armoede, maar raken wel in een isolement. Deze vorm van armoede noemen we secundaire armoede. 
De vraag wie precies de armen waren, is verplichte kost voor alle onderzoekers naar armoede. ${ }^{26}$ Interessant is een indeling uit de zestiende eeuw in drie categorieën. ${ }^{27}$ De eerste categorie is arm door onmacht. Te denken valt aan wezen, weduwen, ouden van dagen, lammen en blinden. De tweede categorie is slachtoffer geworden en daardoor arm. Het gaat om personen als oorlogsinvaliden en ernstig zieken. Jütte merkt op dat alleen deze twee categorieën onderwerp zijn van armenzorg. Voor de derde en laatste categorie geldt dat niet: de marginalen in de samenleving, zoals relschoppers, zwervers en schurken.

Het eerste nadeel van deze benadering, en dat geldt ook voor veel bronnen over de armen uit deze periode, is dat zij een momentopname laat zien, terwijl een individu vaak een traject van verarming doorloopt van enigszins arm tot heel erg arm, of zich juist omgekeerd ontworstelt aan armoede. Vaak zie je een soort gezinscyclus van armoede. ${ }^{28}$ Een jonge alleenstaande die werkt zou je rijk kunnen noemen. Als een huwelijk wordt aangegaan dan kunnen er voor één huishouden twee inkomens zijn. Dit huishouden is nog rijker. Met de komst van een steeds grotere kinderschare treedt een verarmingsproces in. Er moeten meer monden worden gevoed. Huisvesting wordt een probleem. ${ }^{29}$ De armoede vermindert weer als inwonende kinderen ook iets gaan verdienen. Hebben alle kinderen het ouderlijk huis verlaten, dan blijft een ouderpaar achter, voor zover niet verweduwd, dat oud en versleten is en niet meer in staat iets te verdienen, in steeds armelijker toestand. ${ }^{30}$

Een tweede nadeel dat kleeft aan dit bronnenmateriaal is dat de bronnen veelal zijn aangelegd met een ander oogmerk dan om te bepalen wie de armen waren. Te denken valt aan tellingen van inwoners die geen belasting betalen (maar die niet allemaal arm hoeven te zijn). De koppeling van geldlonen aan voedselprijzen laat buiten beschouwing dat juist in de pre-industriële periode het inkomen ook niet-geld bestanddelen telde (denk aan kost en eventueel inwoning). Verder dient in ogenschouw te worden genomen dat er veel tellingen worden gehouden juist als de nood hoog is. Hierdoor kan een vertekend beeld ontstaan.

Ondanks alle voorbehouden is het toch wel mogelijk om aan de hand van bronnen uit de pre-industriële periode een beeld te krijgen van de toenmalige armoede. Dienstig is het concept van Pullan, zoals uitgelegd door Stuart Woolf. ${ }^{31}$ Pullan schetst drie concentrische ringen van armoede. De eerste ring is de kern van de armoede. De armen in deze kring zijn structureel arm in alle omstandigheden. Ze zijn arm vanwege een chronische ziekte, een handicap of door ouderdom. In de regel gaat het om vier tot acht procent van de bevolking. Een tweede ring wordt gevormd door conjuncturele armen. Deze armen verdienen lage lonen met losse arbeid, die maar zo nu en dan kan worden verricht. Zij worden arm in een periode van economische crisis. Deze armen worden ook wel "crisis-armen" genoemd. Zij maken een vijfde deel van de bevolking uit. Zowel de armen uit de eerste ring als de armen uit de tweede ring betalen geen belasting. Een derde ring van armen bestaat uit ambachtslieden, kleine winkeliers en lage ambtenaren. Zij worden aangeslagen in de laagste trap van de belastingtarieven. Er
26 Woolf (1986), 4

27 Jütte (1994), 11, ontleent zijn categorieën aan de indeling in drie soorten armen die de zestiende-eeuwse schrijver William Harrison maakte in hoofdstuk IX van Of provisions made for the poor (1577): "There is no commonwealth at this day in Europe, wherein there is not great store of poor people, and those necessarily to be relieved by the wealthier sort, which otherwise would starve and come to utter confusion. With us the poor is commonly divided into three sorts, so that some are poor by impotence, as the fatherless child, the aged, blind, and lame, and the diseased person that is judged to be incurable; the second are poor by casualty, as the wounded soldier, the decayed householder, and the sick person visited with grievous and painful diseases; the third consisteth of thriftless poor, as the rioter that hath consumed all, the vagabond that will abide nowhere, but runneth up and down from place to place (as it were seeking work and finding none), and finally the rogue and the strumpet, which are not possible to be divided in sunder, but run to and fro over all the realm, chiefly keeping the champaign soils in summer to avoid the scorching heat, and the woodland grounds in winter to eschew the blustering winds." 
28 Knotter (1998), 390-391, vergeleek de gezinsinkomsten van losse (haven)arbeiders in Amsterdam voor de Tweede Wereldoorlog met hun gezinscyclus. In de eerste fase van het huwelijk is het aandeel van de echtgenote betrekkelijk hoog, om in het verdere verloop van het huwelijk af te nemen. Na 15 jaar huwelijk nam het aandeel dat inwonende kinderen hadden in het gezinsinkomen fors tot ongeveer $60 \%$. Voor deze groep arbeiders was de armenzorg in de eerste fase van het huwelijk van groot belang. Dat belang nam af in een middenfase als inwonende kinderen ook hun bijdrage aan het gezinsinkomen leverden. In een eindfase werd de hulp vanuit de armenzorg weer belangrijker als de kinderen niet meer inwoonden en de ouders minder goed in staat waren iets te verdienen.

29 Dat kan leiden tot deze paradoxale uitspraak: Ik moet naar een kleinere woning omzien want mijn gezin wordt te groot. Ottens (1975).

30 Stavenuiter (1993), 94-100.

31 Woolf (1986), 6; Woolf (2013), 187.

32 In de winter van 1816/1817 (de winter na

"het jaar zonder zomer") werd circa $57 \%$ van de Amsterdamse bevolking bedeeld. Van Leeuwen (1992), 64. In 1847, toen de levensmiddelen extreem duur waren, werd in Amsterdam een derde van bevolking door een bijzondere bedeling geholpen.

Clercq (1848), 369-380 is geen financiële reserve om een noodsituatie op te vangen. Bij serieuze problemen, zoals het overlijden van de kostwinner, handelsblokkades en dergelijke, zakt deze groep al snel onder het bestaansminimum. Deze derde groep beslaat een kwart van het inwonerstal. Als je de drie ringen bij elkaar optelt dan wordt bij een diepe crisis ongeveer de helft van de bevolking door armoede getroffen. Bedacht moet worden dat al deze onderzoeksgegevens betrekking hebben op een stedelijke omgeving, en dan vooral ten tijde van een economische crisis. ${ }^{32}$

Op het platteland is de armoede nog ernstiger. Ook hier treffen we een harde kern van structurele armoede aan. In tijden van nood vinden migratiebewegingen plaats: armen denken elders hun heil te kunnen vinden. De familieband is vaak hecht in een dorp. Dominante samenlevingsvormen zijn grootfamilies en extended households. In grootfamilies wonen grootouders, ooms en tantes samen met ouders en kinderen. In een extended household worden ook nog eens inwonende knechten en meiden tot de wooneenheid gerekend. In deze samenlevingsvormen worden vaak arme en/of werkeloze familieleden opgenomen. Gesproken kan worden van verborgen werkloosheid. Verder vindt een eindeloze versnippering van landbezit plaats, waardoor de keuterboer amper te onderscheiden is van de dagloner. Het gaat bijna altijd om gemengde bedrijven waardoor de opbrengsten laag blijven. In deze groep vallen daardoor de economische klappen van de commercialisering van de zestiende en zeventiende eeuw. Sociaal gezien wordt ook het vangnet van de hechte lokale dorpsgemeenschap doorbroken. Meer nog dan de stedelingen zijn de plattelanders kwetsbaar voor rampen, zoals mislukte oogsten, besmettelijke ziekten en militair geweld. Welbeschouwd is er geen decennium voorbijgegaan zonder ramp. Pas in de eerste helft van de negentiende eeuw zien we in West-Europa de laatste rampen, namelijk 1816: het jaar zonder zomer en 1847: het meest rampzalige jaar van de Hungry Forties. In dat jaar mislukte in grote delen van West-Europa de aardappeloogst. Aardappelen waren destijds het volksvoedsel bij uitstek.

Samengevat: wie waren de armen? Er is een harde kern van armen die permanent arm zijn: de structurele armen. We vinden hen in de stad en op het platteland. Dan zijn er de conjuncturele armen die lijden bij een economische crisis. Omdat in de dorpen nog enige vorm van opvang is (die je ook verborgen werkloosheid kunt noemen), die in de steden ontbreekt, zijn de stedelijke armen er nog slechter aan toe. In de stad kan in ongunstige economische omstandigheden de helft van de bevolking getroffen worden door armoede.

\subsection{HOE WAS DE ARMENZORG VAN DE MIDDELEEUWSE PERIODE TOT EN MET DE TWINTIGSTE EEUW OPGEZET?}

\section{a) Inleiding}

Om de vraag naar de opzet van de armenzorg te kunnen beantwoorden is het zinvol de volgende periodisering te maken:

1. de middeleeuwse periode van de elfde tot de vijftiende eeuw;

2. de vroegmoderne periode van de zestiende tot de achttiende eeuw;

3. de negentiende en twintigste eeuw. 
Tijdens de middeleeuwse periode stond de armenzorg in het teken van de christelijke charitas. Deze charitas kwam vanaf de late middeleeuwen onder druk te staan. In de vroegmoderne periode, tussen ruwweg 1520 en 1540, veranderde de armenzorg fundamenteel: niet langer de charitas, maar dwang stond centraal. Pas in de negentiende eeuw maakte repressie plaats voor een andere bejegening van de armen. De dwang verdween en maakte plaats voor gedragsregulering. In de twintigste eeuw zou zorg voor armen een van de vele zorgarrangementen worden in de samenleving: de verzorgingsstaat ontstond. Aan het einde van de twintigste eeuw, op de drempel van de nieuwe eeuw, was er weer een omslag: veel collectieve arrangementen werden versoberd: er kwam een einde aan de zorgzame samenleving. "Vom Sozialstaat zum Nationale Wettbewerb Staat", zoals Hirsch het kernachtig uitdrukt. ${ }^{33}$ De aandacht werd verlegd naar de individuele verantwoordelijkheid van de burger.

\section{b) De middeleeuwse periode van de elfde tot de vijftiende eeuw}

In het klassieke werk van Michel Mollat wordt benadrukt dat het de plicht van christenen is de toestand van de armen te verlichten (soulage les pauvres), verwijzend naar een cartularium uit 1093. ${ }^{34}$ Armoede of "paupertas" werd positief geduid. ${ }^{35}$ De organisatie van de armenzorg had een christelijk karakter. Het waren de parochies die door middel van steun door de Tafels van de Heilige Geest armen verzorgden. Men moet hierbij bedenken dat de parochies geen kerkelijke, maar staatsrechtelijke instellingen waren. Aan het hoofd van de Tafel stond een Geestmeester, die door wereldlijke autoriteiten was aangesteld. Beheer van onroerende goederen, collectes, schenkingen en legaten waren de geldelijke bronnen om deze zorg te financieren. Naast de Tafels was er ook armenzorg door particulieren en de gilden, maar de zorg vanuit de Tafels was het meest belangrijk.

Aan het einde van de middeleeuwse periode kwam de welwillende houding ten opzichte van de armen onder druk te staan. ${ }^{36}$ Er kwamen te veel armen en de samenleving kon de kosten daarvoor niet langer dragen. Armen werden niet langer met goedgunstigheid bekeken, maar met argusogen. De lust werd tot een last. De Tafels van de Heilige Geest bezweken onder de toenemende vraag om hulp.

\section{c) De vroegmoderne periode}

Aan het begin van de vroegmoderne periode werden naast de kerkelijke organisaties stedelijke instellingen opgezet voor de armen. Deze instellingen oefenden druk uit op de armen als gevolg van hun steeds groeiende aantal. Juan Luis Vives' publicatie De subventione pauperum wordt vaak gezien als symbool van deze toenemende repressie. ${ }^{37}$ De uitspraken van Vives zijn dubbelzinnig. Aan de ene kant waarschuwt hij voor het gevaar van grote aantallen arme mensen, maar aan de andere kant roept hij ook op tot solidariteit met de zwakkere leden van de samenleving. In de praktijk kwam de repressie erop neer dat valide armen niet langer geholpen werden. Wie lichamelijk fit was kon werken. Het was aan de arme zelf te wijten als hij geen werk had. Dat hield in dat er van de armenzorg een arbeidsdwang uitging. Bedelaars werden niet langer van aalmoezen voorzien, maar uit de stad of het dorp verjaagd. In sommige gevallen mochten bedelaars die geboren
33 Hirsch (1995).

34 Mollat (1978), 112-113.

35 Scott (2016), 188.

36 Mollat (1978), 281.

37 Vives (2015), (eerste druk 1526). 
38 Boele (2013), 111, 257, ziet wel een omslag, maar bespeurt naast veranderingen ook continuïteit. 39 Kriedte (1980), 28 40 Hickey (1997), 18. 41 Bridewell gevangenis (https://www.londonlives. org/static/Bridewell.jsp) 42 Virtutis est domare quae cuncti pavent (wilde beesten moet men temmen) stond er dan ook te lezen op de toegangspoort tot het Rasphuis. Men kan zich afvragen of deze tekst niet cynisch is bedoeld.

43 Er bestaat een overvloed aan secundaire literatuur over Engelse werkhuizen. De website http://www.workhousus. org.uk/ (geraadpleegd 3 januari 2018) geeft veel informatie. Verder: Lis en Soly (1975), 141-157 over de werkhuizen in (West-) Europa.

44 Wolff (1986), 29.

45 Dat is althans de uitkomst van een uitvoerig onderzoek naar de Parijse omstandigheden in de achttiende eeuw Romon (1982), 729-763.

46 Lis en Soly (1975), 156.

47 Zie ook de analyse in De Swaan (2004). waren in de stad of het dorp nog wel doorgaan met hun praktijken. Speciale aandacht ging uit naar wezen. Veelal werden zij in weeshuizen opgenomen. Voor jongens en meisjes waren er aparte weeshuizen. In de weeshuizen werden de wezen voorbereid op een toekomstig beroep. Niet alleen ten opzichte van de armen, maar ook ten opzichte van pelgrims nam de welwillendheid af.

De repressieve maatregelen die zich in een eerste golf tussen 1520 en 1540 voordeden hebben een stedelijk karakter: stedelijke autoriteiten namen het voortouw. De kerkelijke instellingen bleven naast de stedelijke instellingen bestaan, maar stonden nu veel minder op de voorgrond. Voor de omslag die zich tussen 1520 en 1540 voordeed kunnen drie oorzaken worden genoemd. ${ }^{38}$ Allereerst moet gewezen worden op de strubbelingen op religieus en institutioneel terrein die het gevolg waren van de Reformatie. Ten tweede nam de armoede toe met de bevolkingsgroei die zich in Europa voordeed. Tussen 1450 en 1500 nam de bevolking met maar liefst 50 procent toe. ${ }^{39}$ Ten derde kan worden gewezen op het tekort aan (geschoolde) arbeid. Tot de repressieve maatregelen behoorde arbeidsdwang, ofwel tewerkstelling, die dat tekort in enige mate kon opvangen.

Een tweede golf van repressie deed zich voor tussen circa 1575 en circa 1625. Groepen armen werden gehospitaliseerd: opgenomen in gestichten. Bedelaars werden eveneens opgesloten. Model stond de organisatie zoals die in Lyon met het Aumône Général in 1534 was opgezet. ${ }^{40}$ Speciaal voor criminelen in Londen werd in 1553 de Bridewell Prison and Hospital geopend. ${ }^{41}$ Daarmee had het meteen ook de primeur van dwangarbeid op deze grote schaal. Amsterdam zou in de jaren negentig van de zestiende eeuw volgen met het Rasphuis voor mannen in 1596 en het Spinhuis voor vrouwen in 1597. Deze vorm van opsluiting heeft ook nog een heropvoedende achtergrond. Door de tewerkstelling zouden deze marginalen weer een arbeidsritme opbouwen. ${ }^{42}$ In Engeland kwam in de zeventiende eeuw een systeem van werkhuizen (workhouses) op gang. Het eerste als zodanig geregistreerde werkhuis was in Abingdon in 1631, maar er zijn beslist eerdere - ongeregistreerde - voorgangers geweest. ${ }^{43}$

Op deze ronde van hospitalisering volgde globaal tussen 1690 en 1720 nog een derde golf van opsluiting. ${ }^{44}$ De repressie richtte zich nu alleen nog op de verwijdering van ongewenste elementen uit de samenleving. Zwervers en bedelaars werden aangepakt. Zij werden in gestichten ondergebracht en te werk gesteld. Zwervers en bedelaars die aan opsluiting wisten te ontkomen, werden van elke andere zorg uitgesloten. ${ }^{45}$ De tewerkstelling was nu vooral een bezigheid zonder enig vooruitzicht. Of deze arbeid winstgevend is geweest, zoals wordt beweerd door Lis en Soly, kan betwijfeld worden. ${ }^{46}$ Voor de overheid waren er in ieder geval hoge kosten gemoeid met het oprichten en exploiteren van de werkhuizen. ${ }^{47}$ Enkele ondernemers konden ervan profiteren, maar dat geringe profijt woog niet op tegen de maatschappelijke kosten.

Tot dusver ging het bij de ontwikkelingen binnen de organisatie van de armenzorg in de vroegmoderne periode om de gestichts- of buitenarmen. Deze armen hadden geen eigen woonplaats. Daarnaast waren er armen die zelfstandig woonden. Dat waren de zogeheten huiszittenarmen. Deze organisatie van armenzorg is in de vroegmoderne periode bij uitstek te vinden in 
Engeland en in de Nederlanden. Het is goed de zorg voor de huiszittenarmen te zien als complementair aan de gestichtszorg. Wel zijn er in de benadering van deze armen twee grote verschillen: het gesticht moet toch vooral als een strafinrichting worden beschouwd, terwijl de zorg voor de huiszittenarmen als gunst kan worden omschreven. Het tweede verschil is dat er voor gestichtsarmen geen gezinsleven mogelijk was. De huiszittenarmen bleven in hun familiale omgeving: huishoudens bleven in tact.

Als we de organisatie van de armenzorg in de middeleeuwse en vroegmoderne periode samenvatten, dan zien we dat in de middeleeuwse periode de organisatie van de armenzorg een kerkelijke basis had. De parochie was de spil van de organisatie. Aan het einde van de middeleeuwse periode en in het begin van de vroegmoderne periode nam het armoedeprobleem toe. Als reactie daarop werd een stedelijke organisatie opgericht, die naast de kerkelijke organisatie bestond. Niet alleen nam het getal der armen toe, maar armoede werd ook steeds meer als een last beschouwd. De bestrijding van het probleem werd gezocht in onderdrukking van de armen.

\section{d) De negentiende en twintigste eeuw}

In de negentiende eeuw werden in veel West-Europese landen de lokale organisaties vervangen door nationale instellingen. De staat ging zich bemoeien met de organisatie van de armenzorg. De zorg werd geseculariseerd: de kerkelijke invloed nam af. Vier min of meer parallelle processen werden zichtbaar. ${ }^{48}$

1. De overheid nam de verantwoordelijkheid op zich voor de armenzorg;

2. zakelijke criteria werden vastgelegd waarom zorg werd verleend. De hulp werd geobjectiveerd. Er was sprake van rationalisering;

3. er kwam een ambtelijke instelling voor de organisatie van de armenzorg. De organisatie werd bureaucratisch van aard;

4. armenzorg was niet langer de enige sociale zorg. Er kwamen diverse zorgarrangementen om maatschappelijke risico's te bestrijden.

Ad 1) Het ontstaan van een verantwoordelijke overheid moet in een breed perspectief geplaatst worden. In de negentiende eeuw was de staat, in de optiek van het klassieke liberalisme, als enige verantwoordelijk voor de veiligheid van zijn burgers. Politie, justitie en het leger moesten op die veiligheid toezien. De optimale maatschappelijke situatie was die waarin burgers in volledige vrijheid over hun eigendommen konden beschikken. De zogenaamde nachtwakersstaat was een ideaal van de klassieke liberalen. In de tweede helft van de negentiende ontstond een nieuwe politiek ideaal, uitgedragen door sociaalliberalen: burgers moesten in volledige vrijheid kunnen leven. De staat moest voor alle burgers randvoorwaarden scheppen om dit vrijheidsideaal mogelijk te maken. De staat werd verantwoordelijk voor de gezondheid, de beschaving en het inkomenspeil van zijn burgers. In Nederland werd de staat pas heel laat in de negentiende eeuw verantwoordelijk en dan nog maar heel gedeeltelijk. ${ }^{49}$ In de praktijk zien we dat in de meeste Europese landen de randvoorwaarden eerst door een particulier burgerinitiatief vorm kregen en dat pas later de staat deze zorg overnam. Deze ontwikkeling ligt aan de wortel van het ontstaan van de latere verzorgingsstaat.
48 Sachsse en Tennstedt (1998); Geremek (1991) en Rathmayer (2014). 49 Van Leeuwen, (1998)b, 520-521. 
Ad 2) Voor een adequate hulpverlening is het nodig vast te stellen of een aanvrager hulp nodig heeft. Het vaststellen van de hulp wordt een rekensom. Welk inkomen is minimaal nodig om van te leven? Welke middelen staan de aanvrager verder nog ter beschikking? Het zijn rationele maatstaven zonder morele oordelen. Een uitkering moest de aanvrager in staat stellen naar de maatstaven van de tijd maatschappelijk te kunnen functioneren. Verder moest de aanvrager in staat worden gesteld zich te ontworstelen aan de armoede. Hulp bieden bij het zoeken naar werk en scholing waren de meest gebruikte methoden. De zorg werd al met al gerationaliseerd. Voor de aanvragers had de rationalisering, naast zekerheid, het voordeel dat er bezwaar kon worden gemaakt tegen een bepaalde beslissing.

Ad 3) Rationalisering betekende ook dat voor alle aanvragers dezelfde criteria werden gehanteerd. De uitvoering van de zorg werd door de overheid gebureaucratiseerd. Uitvoerders werkten volgens vaste voorschriften. Uitvoerders kregen scholing en ze werden bezoldigd, waardoor zij in een onafhankelijke positie kwamen te staan tegenover de aanvragers. Ook werden ze door die scholing geprofessionaliseerd. Zij werden beoordeeld door superieuren; hun werk werd gecontroleerd in een hiërarchische omgeving. Het hoogste gezag was uiteindelijk de staat.

Ad 4) Eeuwenlang was armenzorg de belangrijkste instelling voor sociale zorg. ${ }^{50}$ In de tweede helft van de negentiende eeuw kwamen naast de armenzorg andere zorgarrangementen tot stand. Deze veranderingen moeten worden gezien in het licht van het ontstaan van de industriële samenleving en de urbanisatie. Dat verhaal is te veelomvattend om hier te kunnen worden verteld. Van belang is om hier aan te stippen dat oude vangnetten geleidelijk verdwenen in de negentiende eeuw, waardoor nieuwe netwerken moesten worden gecreëerd. Zo betekende het uiteenvallen van de lokale dorpsgemeenschap dat informele hulp uit de directe omgeving niet meer beschikbaar was. ${ }^{51}$ Restanten van deze oude overlevingsstrategieën bleven overigens nog lang bestaan, ook in een stedelijke context. Door de industrialisatie nam de afhankelijkheid van betaalde arbeid toe. Om de risico's van deze afhankelijkheid te verkleinen kwam een stelsel van verplichte sociale verzekeringen tot stand. Regelingen voor ongevallen op het werk, ouderdom, werkloosheid en ziekte kwamen in de meeste West-Europese landen al voor WO I tot stand. Aanvankelijk was niet iedereen verzekerd en waren de uitkeringen niet ruim, maar na WO II vond een dusdanige verruiming plaats dat sindsdien voor West-Europa van het ontstaan van een verzorgingsstaat kon worden gesproken.

Samengevat: armenzorg was eeuwenlang de belangrijkste vorm van sociale zorg, waarvan de organisatie aanvankelijk via kerkelijke lijnen verliep. Vanaf het begin van de vroegmoderne periode ging de overheid, naast de kerkelijke organisaties, een rol spelen in de uitvoering van de armenzorg. Tot die tijd was de armenzorg een lokale aangelegenheid geweest. In de negentiende eeuw kwamen er regelingen op nationaal niveau naast de bestaande lokale instellingen. In de twintigste eeuw werd de overheid de belangrijkste verantwoordelijke instantie voor de zorg. Deze zorg werd gerationaliseerd en gebureaucratiseerd. Naast de armenzorg kwamen er diverse andere zorgarrangementen tot stand. Deze werden ondergebracht

50 Van Leeuwen (1994), 8 51 Braun (1979), 309 in verplichte sociale verzekeringen, die na WO II een groot deel van de burgers vangnetten boden voor de onzekerheid van het bestaan. 


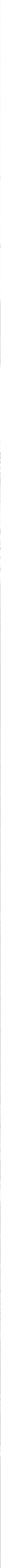




\section{HOOFDSTUK 5 AMSTERDAM}

$<$ 5.A Het Paleis voor Volksvlijt in 1892 Paleis voor Volksvlijt Weteringschans 263 t/m 275 (links, v.l.n.r.) (voorheen $259 \mathrm{t} / \mathrm{m}$ 267). Gezien vanaf balkon Weteringschans 116 naar Paleis voor Volksvlijt, Frederiksplein en Westeinde. Uiterst rechts is ingang Huidekoperstraat. Op de voorgrond zijn heistellingen voor de bouw van Weteringschans 120-122124. Foto door Jacob Olie (1834-1905). Bron: SAA. Beeldbank. Afbeeldingsbestand 10019A000717.

1 Een borgbrief is een garantie om steungeld te krijgen als iemand binnen een bepaalde tijd armlastig zou worden. De belanghebbende kreeg deze borgstelling mee als hij ging verhuizen. Het stelsel van borgbrieven voor de hele Republiek is in enkele resoluties van de Staten-Generaal uit 1725 en 1731 vastgelegd. Van Leeuwen, (1996), 153, wijst erop dat Amsterdam geen deel uitmaakte van deze regeling. Uitvoeriger bij van Leeuwen, (1996), 148-160 en Lauwen (2017).

2 Van Leeuwen, (1996),

132-161.

3 In de tijd van de

Republiek werd van de

Nederduits Gereformeerde Kerk gesproken. Sinds 1816 heette deze kerk Nederlands Hervormde Kerk. Afsplitsingen van deze Hervormde Kerk werden in 1892 samengevoegd tot de Gereformeerde Kerken in Nederland.

4 Spaans (1999), 105.

\subsection{INLEIDING}

In dit hoofdstuk komt de armenzorg in Amsterdam aan de orde. Eerst geef ik een indruk van de Amsterdamse situatie tussen 1578 en 1811. In de negentiende eeuw was de armenzorg, net als daarvoor, nog steeds vooral een plaatselijke aangelegenheid, maar werden landelijke ontwikkelingen steeds belangrijker. Daarom wil ik ook aan de nationale ontwikkelingen apart aandacht schenken. Ik sluit de beschouwing over armenzorg af met een beschrijving van de typisch Amsterdamse organisatie van de armenzorg van 1811 tot 1940. In een laatste paragraaf komt het ontstaan van een moderne samenleving in Amsterdam aan de orde.

In 1578 werd in Amsterdam het katholieke stadsbestuur vervangen door een calvinistisch stadsbestuur: de zogeheten Alteratie van Amsterdam. Hiermee ving niet alleen een nieuwe periode aan voor Amsterdam, maar ook voor de armenzorg. Het einde van die periode is lastiger aan te geven. Je zou kunnen denken aan 1795, het jaar dat de Republiek ten einde kwam, maar de erfenis van de Republiek op het terrein van de armenzorg is zo groot dat beter een later jaartal kan worden gehanteerd. De invloed van de Republiek op de organisatie van de armenzorg zou nog tot in de twintigste eeuw merkbaar blijven. In 1811 kwam de eerste landelijke wetgeving tot stand op het gebied van armenzorg: de Wet op het Domicilie van Onderstand. Deze wet verving een stelsel van borgbrieven, dat voor de hele Republiek gold, maar waarvan Amsterdam was uitgezonderd. ${ }^{1}$ Daarvoor waren alle regelingen, op de borgbrieven na, lokale aangelegenheden. Ik beschouw daarom 1811 als het begin van de negentiende-eeuwse ontwikkeling binnen de armenzorg. In de Wet op het Domicilie van Onderstand van 1811 werd bepaald dat de gemeente waarin iemand geboren was gold als de onderstandsgemeente. Wanneer de arme verhuisde, werd de nieuwe verblijfsgemeente na een jaar de onderstandsgemeente. ${ }^{2}$ In 1818 werd de verblijfstermijn tot vier jaar verlengd. Vanaf 1818 moest men vier jaar in een andere gemeente gewoond hebben voordat men in de nieuwe gemeente onderstand kreeg.

\subsection{ARMENZORG IN AMSTERDAM VAN 1578 TOT 1811}

Vanaf 1578 viel de armenzorg onder kerkelijk toezicht en stedelijke supervisie. In dat kerkelijk toezicht speelt de Gereformeerde kerk een bijzondere rol. ${ }^{3}$ Volgens Joke Spaans was de stedelijke Gereformeerde kerk "een steunpilaar van het stadsbestuur, legitimeerde (zij) zijn gezag en fungeerde (zij) als cement van de samenleving". ${ }^{4}$ Hulp werd geboden door het kerkgenootschap waarvan de arme lid was. Elk kerkgenootschap beschikte over een eigen armenzorg. Degene die niet door een kerkgenootschap kon worden bedeeld, omdat hij of zij bij voorbeeld geen lidmaat was, kon om hulp vragen bij een van de twee Huiszittenhuizen. Aanvankelijk konden deze 
armen ook een beroep doen op het Aalmoezeniershuis, maar vanaf 1682 richtte het Aalmoezeniershuis zich nog uitsluitend op kinderen. ${ }^{5}$ Vanaf 1682 waren alleen nog de Huiszittenhuizen het aanspreekpunt voor hulpbehoevenden die niet door een eigen kerkgenootschap werden bedeeld. Dat waren het Oudezijds en het Nieuwezijds Huiszittenhuis. Deze tweedeling was een uitvloeisel van de middeleeuwse parochie-indeling van de stad: de Sint Nicolaasparochie voor de Oudezijde en de Onze Lieven Vrouwe Parochie, die in 1419 als nieuwe parochie werd gesticht. Om zich te onderscheiden van de Sint Nicolaasparochie werd die parochie Nieuwezijde genoemd. De Huiszittenhuizen waren weliswaar voor iedereen bedoeld, maar de hulpvrager moest ten minste zeven jaar in Amsterdam hebben gewoond. ${ }^{6} \mathrm{De}$ Huiszittenhuizen werden ingesteld door het stadsbestuur en ook volledig door de stad gesubsidieerd. De regentencolleges van de huizen konden zelfstandig opereren. De Huiszittenhuizen verleenden niet alleen hulp aan niet-kerkelijke armen, maar vervulden ook een algemene taak: zij zorgden ervoor dat alle kerkelijke bedeelden en uiteraard ook alle huiszittenarmen van turf werden voorzien.

Er werd in Amsterdam dus niet alleen stedelijke zorg geboden, maar het stadsbestuur had daarnaast ook invloed op de kerkelijke zorg. Zo stond de Vroedschap, het stadsbestuur, in 1588 toe dat de lutheranen een apart genootschap oprichtten, waardoor zij zich kerk-organisatorisch konden afsplitsen van het Nederduits Gereformeerd genootschap, de latere Hervormde Gemeente. Hierdoor ontstond een lutherse diaconie die ook de armenzorg voor lutheranen organiseerde, mits zij lidmaat waren. Het stadsbestuur verleende hulp bij de huisvesting van de kerkelijke zorg, bij voorbeeld door toewijzing van gebouwen die tot 1578 door katholieke instanties waren gebruikt. Ook bij nieuwbouw bood het stadsbestuur een helpende hand. Zo ontwierpen de stadsbouwmeesters Hans Jansz. van Petersom en Elias Bouman het Diaconie Oude Vrouwen- en Mannenhuis, het huidige Amstelhof, dat in 1683 werd geopend. Ook het nieuwe gebouw voor katholieke weesmeisjes, het Maagdenhuis, werd door een stadsbouwmeester ontworpen: Abraham van der Hart. In 1787 opende het RC Maagdenhuis zijn poorten. De stad bood dus hulp bij de huisvesting, maar de kerkgenootschappen bleven autonoom: de diaconie was en bleef het hoogste gezagsorgaan.

We zien dus dat de armenzorg in Amsterdam na 1578 naast een kerkelijke ook een stedelijke component had. Dat komt overeen met wat er gebeurde binnen de stedelijke overheden in de rest van Europa, zoals in hoofdstuk 4 is uiteengezet. Ook de druk op armen om te gaan werken, vinden we in Amsterdam terug. Ik hoef in dit verband enkel maar te wijzen op het bestaan van het Rasphuis en het Spinhuis.

Wat de organisatie van de armenzorg betreft is het goed te wijzen op het al eerder gememoreerde verschil tussen armenzorg in brede en in engere zin. De armenzorg in brede zin heeft betrekking op de armen die niet zelfstandig wonen: de gestichtsarmen. Hier zien we het onderscheid tussen kerkelijk bedeelden en bedeelden van stadswege terug. De hoeveelheid kerkelijke genootschappen was zo groot dat het in deze beknopte inleiding niet mogelijk is al die genootschappen te benoemen en te behandelen. Bovendien is er bijna geen statistisch materiaal bewaard gebleven. "Over de kerkelijke bedeling (in de achttiende eeuw) zijn geen cijfers meer te vinden",
5 SAA, 343 Inventaris Archief van de Regenten van het Aalmoezeniersweeshuis en rechtsvoorganger Versie 160.2 - 7 februari 2018,1. 6 Resolutie van de Vroedschap van 23 oktober 1675 geciteerd door Jansen (1975), 619 
7 Jansen (1975), 619.

8 SAA 347, Oldewelt, Inventaris Archief van het Spin- en Nieuwe Werkhuis Versie 41.2 - 7 juli 2017, 1. 9 Van Leeuwen (1996), 152-53.

10 Teeuwen (2016), 41-71.

Driekwart van de inkomsten kwam van donaties, erfenissen en een geraffineerd systeem van collectes.

Haar dissertatie maakt deel uit van het Giga- project: Giving in the Golden Age. Zie: https://socialhistory. org/en/projects/giving-golden-age ; Verder: Heerma van Voss en Van Leeuwen (2012), 175-197. Voor het systeem van collectes in Amsterdam zie ook het indringende beeld dat Van Leeuwen (1996), 138-143, daarvan heeft geschetst. 11 Faber (1976), 7-8.

12 Uitvoerig beschreven in mijn doctoraalscriptie: Van der Maas (1981) (De bijlagen omvatten circa 2 kg aan tabellen); beknopter Van der Maas en Noordegraaf (1983), 188-221.

13 Van Leeuwen (1992),

307-308, heeft berekend dat het aantal ondersteunden bij het Huiszittenhuis aan het begin van de jaren '80 van de achttiende eeuw drie procent van de stadsbevolking uitmaakte. Rondom de eeuwwisseling van de achttiende en de negentiende eeuw was dat aantal verdubbeld, terwijl tussen 1815 en 1855 het percentage relatief hoog: vijf procent van de stadsbevolking. Illustratief is ook de toename van het aantal huishoudens dat voor winterbedeling in aanmerking kwam: in 1765 zeven duizend en in 1800 twaalf duizend, terwijl het inwonerstal van Amsterdam in die periode juist daalde. aldus Peter Jansen. ${ }^{7}$ Gestichtsarmen van stadswege vinden we terug in het Rasphuis uit 1596 en het Spinhuis uit 1597. In hoofdstuk 4 zijn deze instellingen al ter sprake gekomen. In 1782 werd het Spin- en Nieuwe Werkhuis geopend, waarin een duizendtal armen onderdak vonden. ${ }^{8}$ De gestichtsarmen werden in de instellingen verzorgd. Zij werden gevoed, gekleed en gehuisvest en waren dus niet zelfstandig.

In engere zin gaat armenzorg over bedeling. De buitenarmen, ook wel huiszittenarmen genoemd, hadden een heel ander leven dan de gestichtsarmen. Zij voerden zelfstandig een huishouding. Zij beslisten zelf over hun huisvesting, kleding en voeding. De hulp die ze kregen was aanvullend. Er was zomerhulp in de vorm van broodbedeling. In de winter kregen de armen naast brood ook turf. Deze hulp in de winterperiode duurde twaalf weken. In een aantal gevallen werd ook kleding verstrekt. Aan deze hulp, zowel in de zomer als in de winter, waren voorwaarden verbonden. Zo moesten de armen, als zij niet in Amsterdam geboren waren, een minimaal aantal jaren in de stad hebben gewoond. De Huiszittenhuizen hanteerden een termijn van minimaal zeven jaar. In de Republiek als geheel werd gewerkt met borgbrieven, waarmee migranten hun steun konden verhalen op de plaats van herkomst. In Amsterdam was dat anders: de armen hoefden geen borgbrief te tonen om een beroep op zorg te kunnen doen.?

Amsterdam was de enige plek in Nederland waar niet met borgbrieven werd gewerkt om in aanmerking te komen voor hulp. Als gevolg van die uitzonderingspositie viel de stroom migranten (lees: goedkope arbeidskrachten) naar Amsterdam nooit droog. In de Gouden Eeuw was de vraag naar arbeidskrachten in de stad zo groot, dat niet gevreesd hoefde te worden voor een vloedgolf van hulpbehoevende armen.

De geboden hulp in de Republiek aan armen was ruim te noemen, zeker vergeleken met de situatie in pre-industrieel Europa in het algemeen. De bereidheid onder de hogere en middengroepen om de hulpbehoevenden van geld en andere middelen te voorzien was groot. Daniëlle Teeuwen rekende uit dat twee tot drie procent van het nationaal inkomen in de tijd van de Republiek aan zorg werd besteed..$^{10}$ In Amsterdam zal dat niet heel anders zijn geweest.

Het relatief hoge peil van zorg leidde ertoe dat tijdens de Republiek bijna niemand van de honger omkwam. Dit hoge peil bleef intact tot het laatste kwart van de achttiende eeuw. De crisis van 1771/72 en de Vierde Engelse Oorlog (1780-1784) markeerden een kentering. De voedselprijzen stegen. De graanprijzen waren al eerder structureel omhoog gegaan, al vanaf het begin van de Zevenjarige Oorlog in 1756. In de tweede helft van de achttiende eeuw verdubbelden de graanprijzen. De lonen daarentegen bleven lange tijd op hetzelfde peil steken. Faber heeft het voor de periode 1650-1850 over de rigiditeit van de lonen. ${ }^{11}$ De afgenomen koopkracht had gevolgen voor de levensstandaard: er trad verpaupering op. Enige verlichting bracht wel dat naast brood steeds meer aardappelen werden gegeten. Aardappelen waren aanzienlijk goedkoper en bovendien gezond, vanwege het vitamine C-gehalte. ${ }^{12}$ In de eerste jaren van de negentiende eeuw werden ongeveer $140 \mathrm{~kg}$ aardappelen per hoofd per jaar geconsumeerd.

Door het verpauperingsproces werd de druk op de armenzorg steeds groter..$^{13}$ De Bataafs-Franse tijd dompelde het systeem van armenzorg in 
een zware crisis, waaraan het zich maar ternauwernood kon ontworstelen. Het systeem bleef dus wel intact. Van Leeuwen heeft kunnen aantonen dat de stelling van De Swaan over het van tijd tot tijd instorten van het pre-industriële zorgsysteem van Amsterdam en vermoedelijk van de hele Republiek niet juist is. ${ }^{14}$ Voor de instandhouding moest wel een prijs worden betaald. Instellingen teerden in op hun reserves. Uitkeringen werden drastisch verlaagd.

Vatten we de periode 1578-1811 samen, dan zien we dat er zorg was van stadswege en vanuit de kerkgenootschappen, maar dat dit systeem niet waterdicht was. Stad en gereformeerde kerk speelden de eerste viool. De stad gaf steun aan andere kerkgenootschappen die hooguit de tweede viool konden spelen. Armen werden geholpen, maar dat was niet alleen uit menslievendheid. Er speelde voor de bovenlaag ook eigenbelang mee. Het bieden van hulp verminderde het gevaar van oproer van de arme onderlaag. De hulpverlening bond de armen bovendien aan de stad, zodat goedkope arbeidskrachten behouden bleven.

\subsection{DE LANDELIJKE ONTWIKKELING VAN ARMENZORG VAN 1811 TOT 1940}

Volgens Marco van Leeuwen, die verschillende bijdragen leverde aan de beschrijving van de armenzorg na 1800, was "armenzorg gedurende eeuwen de belangrijkste zorginstelling in Nederland". ${ }^{15}$ In de twintigste eeuw zien we de betekenis van de armenzorg in de totale institutionele zorg overigens teruglopen. In 1900 was de armenzorg de dominante zorginstelling, in 1935 leverde de armenzorg nog maar een bijdrage van iets minder van een derde van de totale institutionele zorg. ${ }^{16}$ Voor de negentiende eeuw gold dat de organisatie van de armenzorg een erfenis was van de Republiek. Het was een plaatselijke aangelegenheid. De armenzorg was voornamelijk op kerkelijke leest geschoeid. Geloofsgemeenschappen zorgden voor hun eigen armen. De hervormde kerk nam zo'n dominante plaats in binnen de armenzorg dat het gebruikelijk was dat armen die niet bij een kerkelijke instantie konden aankloppen onder de zorg vielen van de hervormde diaconie.

In de Bataafs-Franse tijd (1795-1813) was er steeds meer kritiek op de bestaande, plaatselijke regelingen. Armenzorg was een te dure aangelegenheid geworden. Er kwam steeds meer behoefte aan een landelijke regeling. Armenzorg hoorde niet meer bij de kerken te berusten, maar moest een publieke dienst worden in het kader van de scheiding van kerk en staat.

De pogingen tot het vestigen van zo'n landelijke regeling in de Bataafse en in de Franse tijd, werden in het Koninkrijk der Nederlanden van Willem I goeddeels weer teniet gedaan. De zorg bleef kerkelijk en plaatselijk georganiseerd. Toch kwamen er geleidelijk barsten in de plaatselijke autonomie. Ik wees al eerder op de Wet op het Domicilie van Onderstand van 1811. ${ }^{17}$ Deze wet werd in 1818 aangescherpt. Die aanscherping bestond erin dat in de Wet op het Domicilie van Onderstand uit 1818 werd bepaald dat "iedereen die in werkelijke nood verkeerde 'een recht' op onderstand had". ${ }^{18}$ Deze wet schreef voor dat de kosten van de bijstand voor rekening zouden komen van de domiciliegemeente: de plaats waar de arme was geboren of de laatste vier jaar had gewoond. ${ }^{19}$ In latere jaren kwamen er nieuwe aanpassin-
14 Van Leeuwen (1996), 161.

15 Van Leeuwen (1998)a, 276.

16 Van Leeuwen (1998)c, 539.

17 Zie hoofdstuk 5, paragraaf 1. 18 Van Holthoon (1985), 176. 19 Van Leeuwen (1992), 81. 
20 Gedetailleerd te vinden in Van Leeuwen (1996), 157-158.

21 Verkade (1974), 99.

22 Van Leeuwen (1998)a,

284.

23 Oud (1971), 38-39.

24 Van Holthoon (1985),

178.

25 Van der Valk (1986), 11.

26 Stavenuiter (1993), 172.

27 Aan het Palingoproer

ging een woelig jaar 1885

vooraf. Gedetailleerd bij

Bos (2001), 192-221. gen. ${ }^{20}$ In 1870 werd het verhaalrecht opgeheven. Tot die tijd werden er vaak oeverloze correspondenties gevoerd tussen gemeenten over het al dan niet terecht terugvorderen van gelden die aan bedeling waren besteed.

Thorbecke vond dat armenzorg geen kerkelijke aangelegenheid moest zijn, maar een taak van de staat. Thorbecke volgde hier het gedachtegoed van de patriotten aan het einde van de achttiende eeuw. ${ }^{21}$ De ideeën van Thorbecke over armenzorg vonden weerklank in de gewijzigde grondwet van 1848, die in hoofdzaak door hem is geformuleerd. Een poging om zijn ideeën over de armenzorg in een organieke wet te concretiseren strandde. ${ }^{22}$ Enerzijds was er felle oppositie van de antirevolutionair Groen van Prinsterer. Hij zag de kerk als een goddelijk werktuig, als de ruggengraat van de samenleving. Staatsbemoeienis met de armenzorg, in welke vorm dan ook, was uit den boze. Daarnaast was er tegenstand van de hervormde Aprilbeweging van 1853, die leidde tot de val van het eerste kabinet-Thorbecke. ${ }^{23}$

Een volgend kabinet kwam wel tot een nieuwe wet: de Armenwet van 1854. Essentieel was dat deze wet het primaat van de armenzorg bij kerken en particulieren liet. De burgerlijke armbesturen mochten alleen "bij volstrekte onvermijdelijkheid" bijstand verlenen. In de praktijk werd de zorg voor armen echter te kostbaar om uitsluitend door de kerken en particulieren gedragen te kunnen worden. De rol van de (stedelijke) burgerlijke armenzorg werd steeds groter. Bedroegen in 1853 de gemeentelijke subsidies aan de armen nog $38 \%$ van de totale uitgaven, in 1870 was dat tot $50 \%$ gestegen. ${ }^{24}$

Zoals hierboven al aangegeven werd de wet op het Domicilie van Onderstand in 1870 opgeheven. De gemeente waarin de armlastigen waren ingeschreven, moest de kosten dragen. Deze regeling gold niet alleen voor de burgerlijke armenzorg, maar was tot 1870 ook van toepassing op de kerkelijke armenzorg.

In de jaren '80, vooral na 1885, nam het aantal armen dat bedeeld werd door de burgerlijke armenzorg nog verder toe. ${ }^{25}$ Volgens Van der Valk had die toename verschillende oorzaken. Het proces van verstedelijking maakte de armoede zichtbaarder. Op het platteland kon de armoede meer toegedekt worden en de vorm krijgen van verborgen werkloosheid. Door de stijging van de gemiddelde leeftijd nam het aantal armen toe. Voor ouderen die niet meer konden werken was armenzorg het enige vangnet. ${ }^{26}$ De op gang komende industrialisatie leidde tot een grotere bestaansonzekerheid. Dat kwam doordat andere inkomstenbronnen dan loonarbeid wegvielen. De opvattingen over de (minimale) levensstandaard veranderden. Ook de armbestuurders namen geen genoegen meer met het minimum van het minimum. Verder zorgde ook de economische recessie van de jaren ' 80 van de negentiende eeuw voor een toename van het aantal armen. Arbeiders werden gemakkelijker ontslagen. Er waren grote groepen arbeiders zonder vast werk. De jaren '80 waren dan ook een periode van grote sociale onrust, waarvoor in Amsterdam het Palingoproer van 1886 symbool stond. ${ }^{27}$ De "sociale quaestie" werd onderwerp van een brede maatschappelijke discussie.

Er was ook onrust binnen het liberale kamp. Het idee van staatsonthouding van doctrinair-liberalen als Thorbecke maakte plaats voor het idee van 
een zorgende en corrigerende overheid bij de sociaalliberalen. Sam van Houten bracht met de Kinderwet uit 1874 de eerste sociale wetgeving tot stand. ${ }^{28}$ Goeman Borgesius beijverde zich van de jaren '70 tot het begin van de twintigste eeuw om de vernieuwende gedachte uit te dragen dat de staat verantwoordelijk was voor het welzijn van de burgers. ${ }^{29}$ Het ging Van Houten en Goeman Borgesius niet alleen om de armenzorg, maar om een veel bredere maatschappelijke verantwoordelijkheid van de overheid voor haar burgers. ${ }^{30}$

De jaren '90 van de negentiende eeuw en het eerste decennium van de twintigste eeuw laten, volgens Van Leeuwen, een werkelijke ommekeer zien in de visie op de armenzorg. ${ }^{31}$ Het idee dat armoede eigenlijk de schuld was van de armen zelf, werd gelogenstraft door de crisis van de jaren '80. De schellen vielen toen velen van de ogen: industriële arbeiders konden buiten hun schuld werkloos en dus arm worden. ${ }^{32}$ Een ander idee dat in die tijd opkwam is de verheffingsgedachte: armen moesten zich ontplooien, zodat zij aan hun armoede konden ontkomen. Die nieuwe gedachten werden onder woorden gebracht door onder meer de Vereeniging van staatshuishoudkunde. Van der Valk ziet in een rede van de voorzitter van de Vereeniging, N.G. Pierson, in 1891 een omslagpunt. ${ }^{33}$ Daarnaast moet het invloedrijke Nutsrapport uit 1895 worden genoemd. ${ }^{34}$ Goeman Borgesius was één van de opstellers van dit rapport.

Volgens Van Leeuwen is het Nutsrapport "een mijlpaal in de geschiedenis van de armenzorg". ${ }^{35}$ Van der Valk omschrijft dit rapport als "de meest evenwichtige veroordeling van de bestaande armenzorg". ${ }^{36}$ In de visie van de opstellers was de toenmalige armenzorg niet planmatig, maar willekeurig. De omvang van de armenzorg werd ontoereikend bevonden en vooral de kerkelijke armenzorg werd bekritiseerd. De oplossing van de problemen moest worden gezocht in nieuwe wetgeving. De armenzorg, zo vonden de samenstellers van het Nutsrapport, moest een wettelijke taak van de overheid worden. Kerken en particulieren zouden niet langer de leiding over deze zorg moeten hebben. Verder moest er, vonden zij, meer individuele aandacht komen voor de armen. Zij bepleitten de instelling van een armenraad per gemeente, een koepel waaronder alle armzorginstellingen van die gemeente zouden vallen. Die armenraad zou ook alle bedeelde armen moeten registreren. De hoogte van de uitkeringen, ook die van de kerk, zou door de gemeenteraad worden bepaald. Gezonde armen werden geacht te gaan werken. Verder moesten de armen de mogelijkheid krijgen om in beroep te gaan tegen bepaalde beslissingen. ${ }^{37}$

De ideeën van het Nutsrapport kregen weerklank in het ontwerp voor een nieuwe armenwet, dat opgesteld was door Goeman Borgesius, de "vader van de verzorgingsstaat". ${ }^{38}$ In zijn wetsontwerp wilde hij de invloed van de gemeente op het Burgerlijk Armbestuur vergroten. Als het aan hem lag zou het Burgerlijk Armbestuur een gemeentelijke dienst worden. Het Burgerlijk Armbestuur zou in zijn werkzaamheden bijgestaan moeten worden door vrijwillige armbezoekers. Dubbele bedeling zou ook tot de wettelijke mogelijkheden behoren. Het gezag over de armenzorg zou bij het Burgerlijk Armbestuur komen te liggen, zodat de bepaling "alleen bij volstrekte onvermijdelijkheid" overboord kon worden gezet. Alle zorginstellingen zouden in een koepelorganisatie, de armenraad, moeten gaan samenwerken.
28 Schenkeveld (2003) beschrijft deze wet uitvoerig. 29 Van Leeuwen (1998)a, 289. 30 Wartena (2003), 275. 31 Van Leeuwen (1998)a, 289. 32 Van der Valk (1986), 16. 33 Van der Valk (1986), 16. 34 Prominent naar voren gebracht door Van Leeuwen (1998)a, 289.

35 Van Leeuwen (1998)a, 291.

36 Van der Valk (1986), 17. 37 Dit recht zal in Amsterdam, als eerste gemeente in Nederland, in 1927 worden ingevoerd. Van der Valk, 318, noot 78. 38 Wartena, (2003). Deze dissertatie heeft als ondertitel: "Vader van de verzorgingsstaat". 
39 Oud (1971), 179

40 Van der Valk (1986),

21-27, beschrijft de wet uitvoerig.

41 Van Leeuwen (1998)b,

521.

42 In het Kamerdebat erkende de verantwoordelijke minister dat "in de praktijk het Burgerlijk Armbestuur niemand van de honger zou laten omkomen", citaat bij Van Leeuwen (1998)b, 523. Het beroep op de Kroon is een vorm van administratief recht, waarbij tegen bepaalde beschikkingen van een bestuursorgaan wordt geprotesteerd. De rechtmatigheid van de beschikking moet dan worden beoordeeld. De aangevochten beschikking kan worden vernietigd, zowel in zijn geheel als gedeeltelijk. Na een dergelijke vernietiging moet opnieuw een beschikking worden genomen.

43 Van der Valk (1986), 28 44 Van der Valk (1986), 63. 45 Van der Valk (1986), 64
De voorgenomen wetgeving over armenzorg moet in een breder kader gezien worden, namelijk in het licht van de zogeheten "laatste tien liberale jaren" 1891-1901. Drie achtereenvolgende kabinetten hadden veel wetgeving tot stand gebracht. In die wetten gaf de overheid er blijk van zich te bekommeren om de welvaart en het welzijn van de burgers. Het laatste liberale kabinet, het kabinet Pierson (1897-1901), kreeg zelfs de bijnaam "ministerie van sociale rechtvaardigheid". ${ }^{39}$

Het wetsontwerp van 1901 werd door de beëindiging van het kabinet Pierson niet meer behandeld in de Staten-Generaal. Er was een einde gekomen aan het politieke tijdperk van de liberalen. De verkiezingen van 1901 brachten de confessionelen aan de macht. Confessionele partijen zouden decennialang het politieke toneel beheersen. In de verzuilde Nederlandse samenleving bleef het gezag van de armenzorg bij de kerkelijke en particuliere instellingen berusten. Wel was er nog steeds behoefte aan een nieuwe wetgeving, die uiteindelijk door minister Heemskerk in 1912 werd gerealiseerd.

De armenwet van 1912 is een typisch Nederlands compromis. ${ }^{40}$ Terwijl er in het Nutsrapport en de ontwerp-armenwet van Van Heemskerk voorstellen werden gedaan voor ingrijpende veranderingen in de armenwet, werden er in 1912 in de praktijk maar kleine wijzigingen doorgevoerd. Minister van Heemskerk stond met deze wet, volgens Van Leeuwen, "met de rug naar de toekomst". ${ }^{41}$ In grote lijnen bleef het uitgangspunt van 1854 van kracht, waarbij kerken en particulieren in de eerste plaats steun verlenen, terwijl pas daarna het Burgerlijk Armbestuur aan bod komt. Hiermee werden de verzuilde armzorginstellingen beschermd. Nieuw was wel de vestiging, op vrijwillige basis weliswaar, van een overlegkoepel tussen de diverse armzorginstellingen per gemeente: de armenraad. Het Burgerlijk Armbestuur moest een centraal register bijhouden van de bedeelden. In het algemeen kwamen er meer regels. Verder werd de dubbele bedeling toegestaan; de armen konden zowel ondersteund worden door kerk of particulieren als door het Burgerlijk Armbestuur. Hoewel de wet van 1912 geen wettelijk recht op onderstand gaf en ook geen beroepsrecht, werd het toch mogelijk dat een afgewezene bij de Kroon bezwaar kon aantekenen. ${ }^{42}$ Voor het idee van verheffing van de armen werd in de wet van 1912 de deur op een kier gezet, maar "het was een illusie dat de werkelijke opheffing van de armoede binnen de armenzorg zou kunnen worden gerealiseerd", aldus Van der Valk. ${ }^{43}$

In theorie zag het instellen van een overlegkoepel voor de armenzorginstellingen er goed uit, maar in de praktijk bleek vooral het overleg tussen het Burgerlijk Armbestuur en de kerkelijke instellingen moeizaam. Versplintering en onwil frustreerden een effectieve samenwerking.

In de dagelijkse praktijk werd de betekenis van de kerkelijke en particuliere zorg steeds kleiner, in vergelijking met die van de openbare armenzorg. In 1913 droeg de openbare zorg 43\% bij aan de kosten voor de armen. Dat aandeel was in 1922 opgelopen tot $61 \% .{ }^{44}$ Het totale niveau van uitkeringen, in de eerste jaren na de invoering van de wet, lijkt intussen "eerder achter- dan vooruit gegaan te zijn". ${ }^{45}$ Een verschraling van de uitkeringen was niet wat de opstellers van de wet voor ogen had gestaan.

In het interbellum, de tijd tussen de twee wereldoorlogen, was het voor 
de overheid niet langer werkbaar dat de armenzorg vooral in handen was van kerkelijke en particuliere instellingen. Het werd nu een taak van de overheid om "een minimum om te bestaan" te garanderen voor de armen. ${ }^{46}$ Daarbij daagde ook bij de kerkelijke en particuliere armenzorg het besef dat hun instellingen niet waren berekend op deze taak. ${ }^{47}$ Mevrouw Muller-Roelofs, een ingewijde in de particuliere zorg, tekende bovendien aan dat de "beter gesitueerden een dalende sympathie hadden voor de arbeidende stand". 48

In het oude zorgsysteem was het wettelijk bepaald dat de naaste familie: broers en zusters, ouders en eventueel nog levende grootouders, maar ook getrouwde en buitenshuis wonende kinderen, de armen zouden ondersteunen. Verleende armenzorg werd als een voorschot beschouwd, dat later, in geval van nood, verhaald kon worden op de familie. In het interbellum zien we deze onderhoudsplicht en het verhaalrecht op de familie in de dagelijkse praktijk steeds meer verzwakken. In 1929 werd nog geprobeerd het tij te doen keren met een wetswijziging, maar de praktijk bleek weerbarstiger. De opkomst van het kerngezin, van ouders en kinderen, was daar debet aan. ${ }^{49}$ Onderhoudsplicht en verhaalrecht verloren daarmee geleidelijk hun maatschappelijke basis en draagvlak.

\subsection{DE ORGANISATIE VAN DE ARMENZORG IN AMSTERDAM VAN 1811 TOT 1940}

Hoewel in de negentiende eeuw kerkelijke en particuliere instellingen de boventoon voerden in de armenzorg, had de Amsterdamse gemeentelijke overheid substantiële taken op het gebied van de armenzorg. In 1808 werd het beheer van het Oudezijdshuiszittenhuis en het Nieuwezijdshuiszittenhuis samengevoegd. ${ }^{50}$ Er kwam één college van regenten over de huiszittende stadsarmen. ${ }^{51} \mathrm{Bij}$ een hervorming van de gemeentelijke administratie in 1827 werd er een afzonderlijke subafdeling Armwezen en Onderwijs opgericht.

De Amsterdamse armenzorg was niet geheel autonoom. De invloed van de rijksoverheid was merkbaar. Dat valt onder meer af te lezen aan de wetten op het Domicilie van Onderstand uit 1811 en 1818. In alle gemeenten van Nederland gold dezelfde minimale verblijfsduur in een bepaalde gemeente om voor hulp in aanmerking te komen. Illustratief voor de invloed van het Rijk is de ontruiming van het Aalmoezeniersweeshuis in $1824 .{ }^{52} \mathrm{Bij}$ Koninklijk Besluit was voorgeschreven hoeveel de verzorging van weeskinderen mocht kosten. De gemeente Amsterdam wilde de weeskinderen binnen de stad houden, ook al werd het door het Rijk toegestane maximum aan zorgkosten overschreden. Het Rijk eiste echter dat de weeskinderen in kinderkolonies buiten de stad werden geplaatst. Onder dwang van de hogere autoriteiten werden de kinderen afgevoerd. Enkel de minkinderen (die nog borstvoeding kregen) bleven tot 1828 onder toezicht van de regentessen van het Aalmoezeniershuis. ${ }^{53}$ Ook de Armenwet van 1854 deed verdere afbreuk aan de lokale autonomie. Er kwamen landelijke voorschriften die ook door Amsterdam moesten worden opgevolgd.

De ambtenaren van Armwezen, de gemeentelijke armenzorg, hadden tot taak toe te zien op het beheer van de instellingen van weldadigheid,
46 Van der Valk (1986), 74 47 Van Leeuwen (1998)b, 528.

48 Van Leeuwen (1998)b, 528-529.

49 Zwaan (1993), 240, Van der Valk 79-95.

50 Deze passages zijn grotendeels ontleend aan Hagoort (z.j.).

51 Inventaris: Archief van het Nieuwezijds en het Oudezijds Huiszittenhuis en van de Regenten over de Huiszittende Stadsarmen. SAA 349

52 Van Leeuwen (1992), 277-280; Oldewelt (1969), 126-140.

53 Oldewelt (1969), 14; er waren 'natte minnen' die borstvoeding gaven en 'droge minnen' die een ouder kind tot de leeftijd van vier jaar in huis namen, Geuzebroek (2020), 69-84. 
54 Stadsbestedelingen zijn wezen die voor hun zorg werden uitbesteed aan derde partijen. Meestal ging het om agrarische bedrijven in het oosten van het land. De bestedelingen kregen kost en inwoning, maar zij moesten ook agrarische werkzaamheden verrichten.

55 Van Tijn (1965), 115.

56 Bovenstaande passages zijn grotendeels ontleend aan Hagoort (z.j.), Knotter (1997), 65-71 bespreekt de organisatie van de gemeentelijke armenzorg van het begin van de twintigste eeuw tot 1996, de invoering van de Nieuwe Algemene Bijstandswet. 57 SAA 15030. Bestanddeel 133297. Gemeenteverslag 1895; raadsbesluit 4 december 1895 .

58 SAA 15030. Bestanddeel 133297. Gemeenteverslag 1895, 189.

59 Zie bijlage 6 (tabel) op basis Jaarverslagen Burgerlijk Armbestuur. die niet kerkelijk van aard waren, en subsidies van gemeentewege ontvingen. Het ging om de Binnen- en Buitengasthuizen, het Werkhuis, de Huiszittenhuizen en het Weduwenhof, de Inrichting voor Stadsbestedelingen (de opvolger van het Aalmoezeniersweeshuis), de bedelaars en de kindergestichten, de inrichtingen voor krankzinnigen als Meerenberg, en de koloniën buiten Amsterdam van de in 1818 opgerichte Maatschappij van Weldadigheid. ${ }^{54}$

De afdeling Armwezen oefende ook toezicht uit op kerkelijke en particuliere instellingen, die subsidies uit de stadskas ontvingen. Deze instellingen moesten rekening en verantwoording afleggen aan het stedelijk bestuur. Een andere taak van de afdeling was het beheer van de Stadsbank van Lening, die zowel charitatief als winstgevend was.

Daarnaast hield de afdeling toezicht op de geneeskundige kant van de armenzorg. Dit werd in handen gegeven van de Plaatselijke Commissie van Geneeskundig Toezicht. Tot de geneeskundige verzorging behoorde onder meer koepokkenvaccinaties, opname in Gasthuizen, en bijstandsverlening bij geboorte en dood. Buurtcommissarissen waren onder andere belast met het afgeven van bewijzen van onvermogen, en bewijzen ter verkrijging van geneeskundige hulp.

Het Burgerweeshuis, de Gasthuizen, het Huiszittenhuis, de Stadsbestedelingen en het Werkhuis werden in 1856 bij raadsbesluit gemeentelijke instellingen volgens de Armenwet van 1854. Op 1 oktober 1856 trad de "Verordening op het Burgerlijk Armbestuur" in werking en als uitvloeisel daarvan het "Reglement voor het Huiszittenhuis". Deze verordening droeg het Burgerlijk Armbestuur op aan Burgemeester en Wethouders. In de raadsvergadering van 9 november 1870 werd het besluit genomen tot opheffing van de colleges van regenten. Er kwam ook een nieuwe gemeenteverordening. ${ }^{55}$ Bepaald werd dat het toezicht over het beheer van de instellingen over zou gaan naar het Burgerlijk Armbestuur, bestaande uit de wethouder van Armenzorg en twintig leden. Voor de verzorging van de huiszittende armen werd het Burgerlijk Armbestuur bijgestaan door het bureau Armbezoek.

De armbezoekers van het Burgerlijk Armbestuur namen in 1871 de taken over van de buurtcommissarissen. De betrekking van buurtcommissaris werd in 1872 opgeheven. ${ }^{56}$

In 1896 stond de gemeenteraad toe dat armen dubbel bedeeld konden worden. ${ }^{57} \mathrm{Zij}$ oordeelde dat dat binnen de wettelijke bepalingen mogelijk was: "Onderstand aan armen, die eenigen, doch onvoldoenden onderstand van kerkelijke of bijzondere instellingen van weldadigheid genieten, wordt niet geacht in strijd te zijn met artikel 21 dier Wet". ${ }^{58}$

Armen konden gelijktijdig door zowel particuliere of kerkelijke instellingen als door het Burgerlijk Armbestuur worden bedeeld. Het betekende dat ze niet langer op één instantie waren aangewezen voor zorg (de kerkelijke en particuliere zorg eerst, pas daarna 'bij volstrekte onvermijdelijkheid' de zorg van het Burgerlijk Armbestuur). In de eerste decennia van de twintigste eeuw werd ongeveer een kwart van de voor zorg in aanmerking komende gezinnen dubbel bedeeld. ${ }^{59}$ In het gemeenteverslag over het jaar 1899 wordt gemeld dat er verschillen zijn tussen de kerkelijk bedeelden en de bedeelden van het Burgerlijk Armbestuur. Tot de kerkelijk bedeelden, zo 
lezen we daar, "behooren alleen die partijen die hetzij door ouderdom of lichaamsgebreken, hetzij door Weduwenstaat een vaste bedeeling genieten, die slechts in betrekkelijk zeldzame gevallen wordt ingetrokken". Het Burgerlijk Armbestuur daarentegen bedeelt "een groot aantal partijen, die door bijzondere omstandigheden, als tijdelijke ziekte, werkloosheid, enz. gedurende eenigen tijd onderstand genieten, maar zoo spoedig mogelijk weder van de lijst van bedeelden worden afgevoerd". ${ }^{60}$

Tot 1896 kon brood en geld afgehaald worden bij het kantoor van de Huiszittende Armen. Vanaf 1896 kon er nog wel brood worden afgehaald, maar werd het geld voortaan thuis afgeleverd door "onbezoldigde armverzorgers". ${ }^{61}$ De armen werden door iemand van de eigen geloofsrichting bezocht. Particuliere armverzorgers behartigden de materiële en de geestelijke belangen van de bezochte gezinnen. Zij hielpen met zoeken naar werk, zodat de gezinnen zich "uit hunnen staat van verval" op konden richten. Door voortdurende controle zouden de verzorgers beter in staat zijn te beoordelen of de verstrekte bedeling wel nuttig werd besteed. Na afloop van elke termijn zou een rapportage plaatsvinden door de armverzorger. Deze rapportages zijn overigens niet in de dossiers terug te vinden. Het onderzoek naar de wenselijkheid de steun voort te zetten blijf een taak van de gemeentelijke armbezoekers. Op 3 juni 1896 werd een regeling getroffen met de Wijkverenigingen van de Nederduitsch Hervormde Gemeente. Daarna volgde op 15 oktober 1896 De Evangelisch-Luthersche Wijkvereenigen met een regeling. Een regeling voor rooms-katholieke vrijwillige armbezoekers werd op 9 december 1896 getroffen met De Conferentiën van de H. Vincentius à Paulo. Deze regelingen maakten het mogelijk dat de onbezoldigde armbezoekers huisbezoeken konden afleggen en werkzaamheden konden verrichten voor de armen. Het thuisbezorgen van geld was niet verplicht. Armen konden als vanouds - als zij dat willen - het geld op kantoor komen halen, al maakten "slechts zeer enkelen (...) van dit recht gebruik".62

In Amsterdam werd zoals gezegd vanaf 1896 toegestaan dat armen dubbel bedeeld werden. ${ }^{63}$ De kerkelijke steun was overigens minimaal. Het Burgerlijk Armbestuur diende rekening te houden met de hoogte van de andere uitkering. Al snel werd duidelijk dat het Burgerlijk Armbestuur te weinig personeel had voor deze controle. De werkdruk werd wel enigszins verlicht omdat dubbel bedeelden ook door vrijwillige armbezoekers werden bezocht. Deze vrijwilligers brachten bij hun wekelijkse bezoek meteen ook het steungeld voor de bedeelden mee. In bijlage 4 is een overzicht te vinden van de aantallen vrijwillige armbezoekers en de aantallen bezochte gezinnen.

De Eerste Wereldoorlog, die in 1914 uitbrak, maakte het oprichten van een aantal comités noodzakelijk. Grote aantallen werkloos geworden arbeiders dreigden te verarmen. In 1914 werd het Algemeen Steuncomité Amsterdam opgericht, gesubsidieerd door de gemeente en het Koninklijk Nationaal Steuncomité. De gemeentelijke armenzorg controleerde het Algemeen Steuncomité Amsterdam. In 1919 werden de werkzaamheden van het Steuncomité beëindigd.

In 1918 vonden er ingrijpende wijzigingen plaats bij de gemeentelijke armenzorg. Bepaald werd dat de bemoeienissen met het ziekenhuiswezen ondergebracht werden bij de afdeling Openbare Gezondheid, die vanaf
60 SAA 15030. Bestanddeel 133300. Gemeenteverslag 1899; bijlage X, 15. 61 SAA 15030. Bestanddeel 133298. Gemeenteverslag 1896.

62 SAA 15030. Bestanddeel 133298. Gemeenteverslag 1896.

63 SAA 15030. Bestanddeel 133297. Gemeenteverslag 1895; raadsbesluit 4 december 1895. 
64 SAA 5256. Bestanddeel 833. Jaarverslag Burgerlijk Armbestuur van Amsterdam 1925.

65 In de jaren '90 strandde een eerdere poging tot opheffing van het Burgerlijk Armbestuur: SAA 15030, Bestanddeel 133297, Gemeenteverslag 1895, 188-192.

66 Het was een administratieve procedure buiten de gewone rechter om.

67 Van der Valk, (1986), 318, noot 78 . dat moment Openbare Gezondheid en Ziekenhuiswezen heette. De gemeentelijke armenzorg werd herdoopt tot Maatschappelijke steun en Armenzorg. Deze dienst moest zich bezighouden met de uitvoering van de Armenwet, de Krankzinnigenwet en de Pandhuiswet, en had daarnaast allerlei bemoeienissen met het Burgerlijk Armbestuur en zijn instellingen. De afdeling Ziekenhuiswezen en Openbare Gezondheid werd belast met het toezicht op het beheer van de gemeentelijke gast- en ziekenhuizen en zag ook toe op particuliere ziekenhuizen, wanneer daarin patiënten van gemeentewege waren opgenomen. Voorheen was dit een taak geweest van de gemeentelijke armenzorg. In juni 1920 werden de twee bovengenoemde afdelingen samengevoegd tot de afdeling Openbare Gezondheid, Ziekenhuiswezen, Maatschappelijke Steun en Armenzorg. In de jaren '20 werd de dienst gedecentraliseerd. Er kwamen vijf wijkkantoren. ${ }^{64}$

Maatschappelijke steun was een vorm van ondersteuning, die zich vanaf 1918 naast de armenzorg had ontwikkeld, als uitvloeisel van de van rijkswege beschikbaar gestelde steun voor werklozen. De bedoeling van deze ondersteuning was dat er onderscheid zou worden gemaakt tussen 'gewone' behoeftigen en mensen die vanwege economische omstandigheden tijdelijk zonder werk en daardoor zonder inkomsten zaten. Door de gewijzigde maatschappelijke omstandigheden was het niet langer vanzelfsprekend dat een elite de boventoon voerde. Hierdoor werd de positie van het Burgerlijk Armbestuur, een college dat zichzelf kon aanvullen en onbeperkt zitting kon houden, steeds minder vanzelfsprekend. Het werd wenselijk geacht de praktische uitvoering van steunregeling en armenzorg bij een gemeentelijke dienst onder te brengen. Op 1 januari 1927 werd het Burgerlijk Armbestuur opgeheven. ${ }^{65}$

De verzorging van de huiszittenarmen en andere taken kwamen in handen van de in 1927 opgerichte Burgerlijke Instelling voor Maatschappelijken Steun, bijgestaan door het gemeentelijk Bureau voor Maatschappelijken Steun, dat weer een voortzetting was van het bureau Armbezoek. De reorganisatie van de zorg ging, mede als gevolg van de veranderende maatschappelijke situatie, gestaag door. In 1928 kwamen er opnieuw twee afdelingen, Openbare Gezondheid en Ziekenhuiswezen en een afdeling Maatschappelijken Steun; de toevoeging Armenzorg verdween.

Een belangrijke verandering was de invoering van een officieel beroepsrecht in 1927. Zoals eerder aangegeven was sinds 1912 een beroep op de Kroon mogelijk, terwijl vanaf 1927 aanvragers die het niet eens met een beslissing waren in beroep konden gaan. ${ }^{66}$ Amsterdam was de eerste gemeente die deze regeling invoerde. ${ }^{67} \mathrm{De}$ afdeling kreeg er een aantal taken bij: de behandeling van zaken betreffende de Vereniging Hulp voor Onbehuisden (tot dan toe behandeld door de afdeling Algemene Zaken) en de aangelegenheden betreffende de Federatie van instellingen van kinderbescherming.

Een aantal andere taken echter werd overgedragen aan de afdeling Openbare Gezondheid en Ziekenhuiswezen: de organisatie van de geneeskundige armenverzorging (de verpleging van krankzinnigen, maatschappelijk ongeschikten en zieken) en de behandeling van zaken betreffende het Amsterdams Genootschap voor Werkverschaffing aan Onvolwaardigen. Ook kreeg de afdeling te maken met twee nieuw opgerichte stichtingen: 
de Amsterdamse Stichting voor Vereenigde Woekerbestrijding (1935) en de Stichting Amsterdamsch Borgstellingsfonds voor den Middenstand (1937).

De aangelegenheden betreffende de werkverschaffing voor hoofdarbeiders (tot dan toe behandeld door de afdeling Volkshuisvesting) werden in 1941 overgedragen aan de afdeling Maatschappelijke Steun. In dat jaar werd besloten de naam Maatschappelijke Steun te veranderen in Sociale Zaken. In bijlage 7 zijn alle bekende taken van de gemeentelijke armenzorg beschreven.

Na deze gedetailleerde beschrijving van de organisatie van de armenzorg in Amsterdam tussen 1811 en 1940 is het goed om ook de grote lijn nog even te benoemen, ook al is die welllicht voor discussie vatbaar. De oude benaming armenzorg werd in het begin van de twintigste eeuw vervangen door de algemenere noemer maatschappelijke steun. In 1941, een jaar dat niet meer in mijn onderzoeksperiode valt, werd weer een nieuwe naam bedacht: sociale zaken. In deze naamsveranderingen zie ik dieperliggende veranderingen. In het woord armenzorg klinkt, naar mijn idee, een paternalistische visie door op personen en groepen mensen die een lagere status op de maatschappelijke ladder bekleden dan degenen die deze zorg verstrekken. Oort had het in 1857 over het patronaat over armen. ${ }^{68}$ In de noemer maatschappelijke steun spelen sociale statusverschillen tussen steunverleners en gesteunden geen doorslaggevende rol meer. Er is sprake van meer gelijkheid en er wordt gewerkt met uniforme uitkeringen. Ook is er beroep mogelijk tegen bepaalde beslissingen. Het is mogelijk, maar dat is een interpretatie van mijn kant, dat met de benaming sociale zaken, vanaf 1941, nog een stap verder wordt gezet. De hulp die gegeven wordt, draagt bij aan de sociale zekerheid van de aanvrager. Op deze hulp heeft in beginsel elke staatsburger recht. Met de invoering van de bijstandswet in 1965 zou dit recht een officieel wettelijk recht worden.

Afbeelding 5.1 De armeninrichting "Toevlugt voor behoeftigen",1850-1856

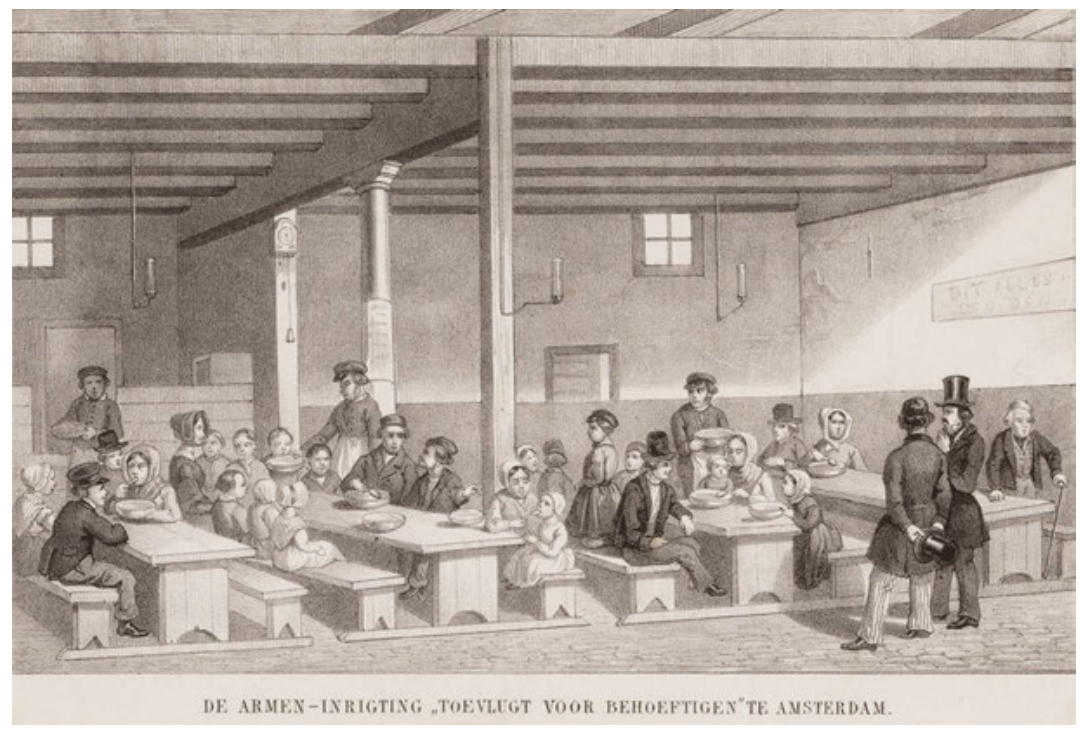

Passeerdersgracht 19, interieur van de armeninrichting: "Toevlugt voor Behoeftigen". Prent door H.G. ten Cate (1803-1856). Bron: SAA. Beeldbank. Afbeeldingsbestand 010097004448. 


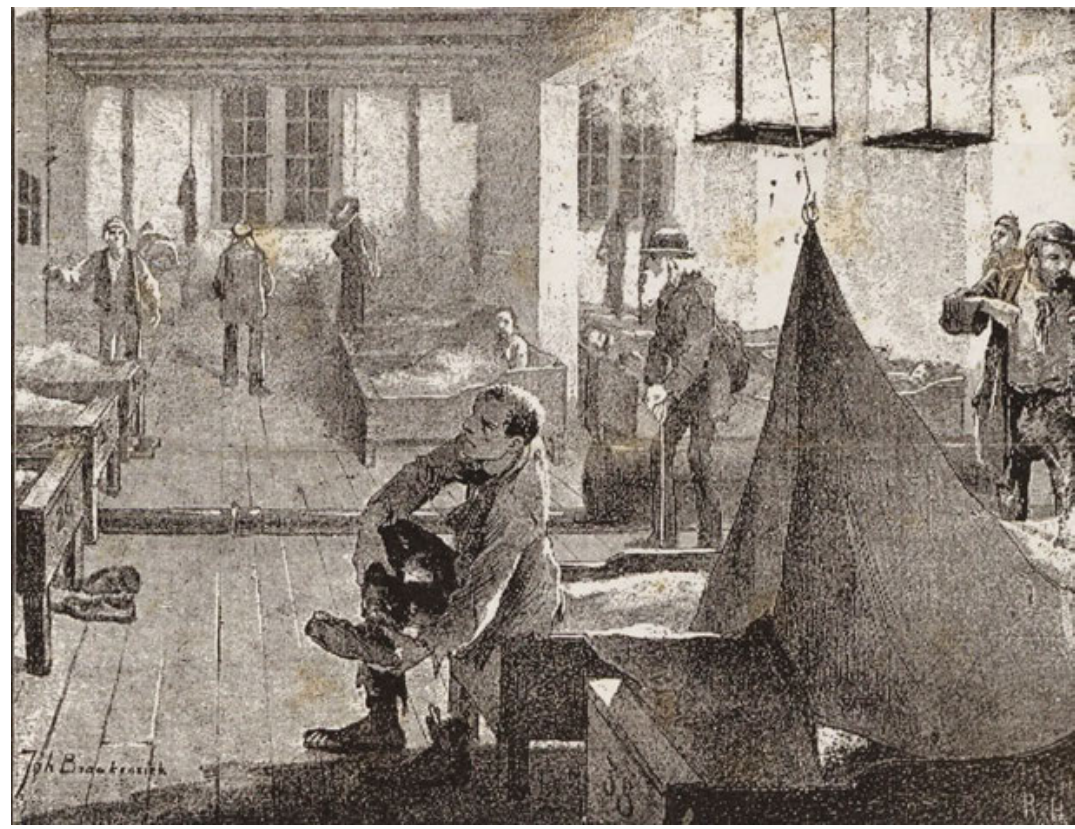

Passeerdersgracht 19.Toevlucht voor Behoeftigen. Slaapzaal. Prent door J.C. Braakensiek (1858-1940). Bron: SAA. Beeldbank. Afbeeldingsbestand 010194001419.

\subsection{NAAR EEN MODERNE SAMENLEVING IN AMSTERDAM}

In de onderzoeksperiode, tussen 1870 en 1940, veranderde Amsterdam van een stad met nog veel pre-industriële trekken geleidelijk in een moderne stad. Een belangrijk kenmerk van een moderne stad is het lage sterftecijfer. Drinkwatervoorziening, riolering en een gereguleerde vuilnisophaaldienst dragen daaraan bij, maar vooral het hoge(re) inkomensniveau is bepalend, evenals het hoge voorzieningenniveau. De economie is geïndustrialiseerd; het ambacht speelt er een steeds kleinere rol in. De economie van de stad is binnenstebuiten gekeerd: grootschalige bedrijvigheid vindt niet meer plaats in het centrum, maar aan de randen van de stad. Dat gaat gepaard met zogeheten cityvorming: een proces waarbij in de binnensteden steeds minder mensen komen te wonen en er in plaats van woonhuizen steeds meer (grote) winkels en kantoren gevestigd worden. De keerzijde van deze cityvorming is de residentiële segregatie: de vorming van wijken die sociaal gezien gescheiden zijn, omdat mensen met meer inkomen het zich kunnen veroorloven om in minder drukke buitenwijken te gaan wonen. Cityvorming en segregatie zijn mogelijk geworden door vervoerssystemen die het stadscentrum met de buitenwijken verbinden. ${ }^{69}$

Hieronder zal ik kort ingaan op de bevolkingsontwikkeling van Amsterdam, op de ontwikkeling van nijverheid naar industrie, op de handel, op de financiën en de sociale samenstelling. Het veranderingsproces dat de hele stad doormaakte vormt het decor waartegen de Amsterdamse armenzorg haar ancien régime-trekken langzaam maar zeker verloor en een moderne organisatie werd. 


\section{a) Bevolkingsontwikkeling van Amsterdam}

Ten tijde van de pre-industriële situatie van de Amsterdamse bevolking, rond 1870, was het sterftecijfer relatief hoog. In 1870 bedroeg de mortaliteit 24,8 en het jaar daarop was het zelfs $33,4 .^{70}$ Deze cijfers kunnen aanzienlijk genoemd worden. In 1899 was dat cijfer zo ongeveer gehalveerd tot 15,7. De mortaliteit vertoonde een typisch pre-industriële "zaagtandcurve", waarbij de piek van 1871 door een pokkenepidemie werd veroorzaakt. ${ }^{71}$ De nataliteit in 1869 kan met 27,5 ook in vergelijking met geboortecijfers uit de twintigste eeuw, relatief hoog genoemd worden. ${ }^{72}$ Het geboortecijfer in Amsterdam bleef nog geruime tijd hoog. In 1899 bedroeg de nataliteit nog altijd 27,9.73 In Amsterdam was een demografische transitie gaande, die samen hing met de bevolkingsontwikkeling in heel Nederland. Demografische transitie is de overgang van een oud demografisch patroon, met hoge geboortecijfers en hoge sterftecijfers die een onregelmatig patroon vertonen, naar een nieuw demografisch patroon, waarbij geboorte- en sterftecijfers op een lager niveau stabiel blijven. In de transitiefase daalt het sterftecijfer sterk, maar blijft het geboortecijfer aanvankelijk nog op een hoog peil. Het resultaat is een forse toename van de bevolking. Een typisch Nederlands kenmerk van deze transitie is de late daling van de huwelijksvruchtbaarheid, waardoor de bevolkingsgroei tijdens de transitie langer aanhield dan in andere Europese landen. ${ }^{74}$

Afbeelding 5.3 De annexaties van 1877 en 1896

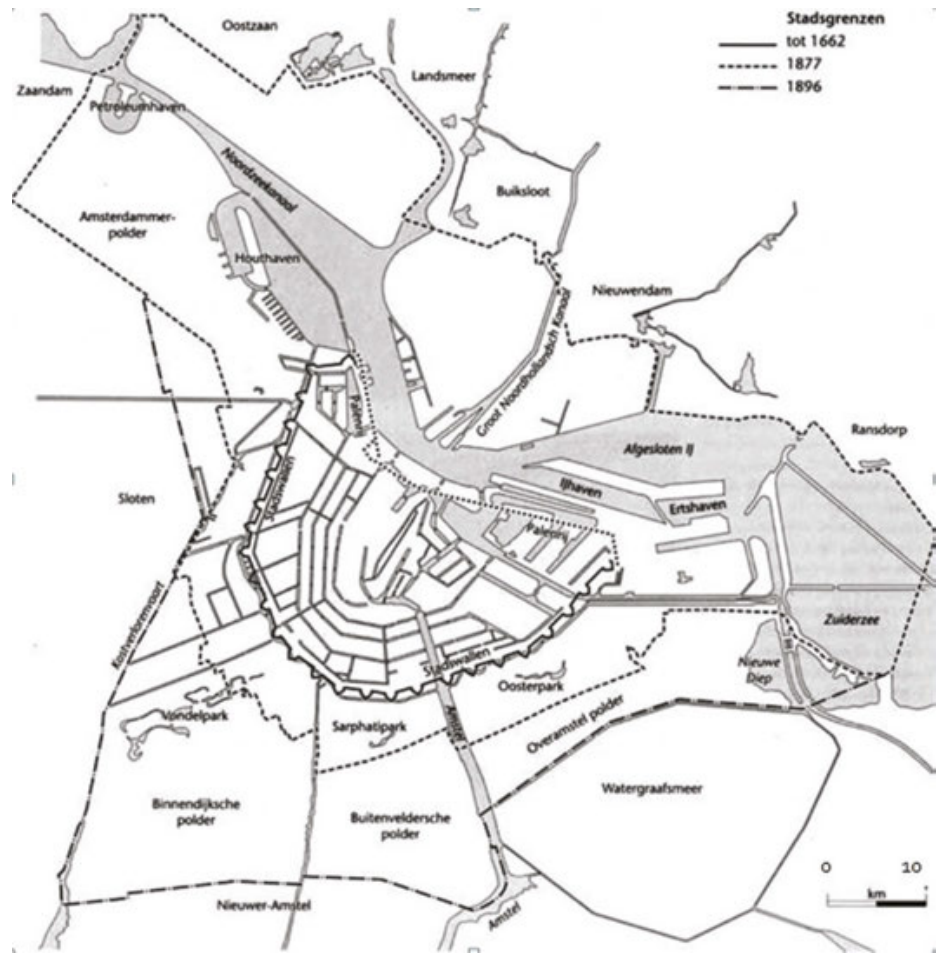

Bron: http://www.theobakker.net/pdf/annexaties.pdf.
70 Verdoorn (1965), 39. 71 Verdoorn (1965), 47. 72 Berekend aan de hand van het CBS, Volkstelling 1869 en Van Tijn (1965), 110.

73 Berekend aan de hand van het CBS, Volkstelling 1899.

74 Schuurman (1991), 24; Van der Woude (1985), 38 
75 Berekend aan de hand van het CBS Volkstelling 1930.

76 CBS Volkstelling 1869

en 1930.

77 Een meer theoretische achtergrond van de migratie in Kooy (1987); Van Dijk (1976), 13-28 en 194-256. 78 Verdoorn, (1965); Van der Velden (1993).

79 Van Zanden en Van Riel (2000), 344; Van Zanden (2000), De Jong en Van Zanden (2014); Van Riel (2018).

80 Van Zanden en Van Riel (2000), 344.

81 Van Zanden (1997), tabel op 152

82 De Vries (1979), 122-123.

$83 \mathrm{De}$ industrialisatie van

Amsterdam wordt besproken door Knotter, (1991);

Van Zanden (1987).

84 De diepgaande studie van Kaptein (2017), 471 -

474 , toont onder meer aan dat pas na 1870 windkracht het definitief moest afleggen tegen stoomkracht als mechanische aandrijfkracht in nijverheid en industrie.
Uit de volkstelling die in 1930 is gehouden, blijkt dat het sterftecijfer is gedaald, evenals het geboortecijfer. In Amsterdam bedroeg de nataliteit in 1930 16,8, terwijl de mortaliteit 8,4 was. $^{75}$ Het inwonertal van Amsterdam is explosief gestegen van 265.000 in 1869 tot 757.00 in 1930: bijna een verdriedubbeling. ${ }^{76}$ Behalve door natuurlijke aanwas en migratie is deze stijging door drie andere factoren te verklaren: stadsuitbreidingen, economische groei en een verbetering van de gezondheidszorg. De stadsuitbreidingen waren het gevolg van de zogeheten annexaties van 1877, 1896 en 1921, waardoor de oppervlakte van de stad aanzienlijk werd vergroot. Zie ook de afbeeldingen 5.3 De annexaties van 1877 en 1896 en 5.4. De annexatie van 1921.

Vooral de grote stroom migranten naar de stad zorgde voor een groei van de bevolking. De agrarische crisis, die duurde van 1878 tot in de jaren '90, zette veel boeren ertoe aan huis en haard te verruilen voor de grote steden in het westen van het land. Door de groei van de Amsterdamse economie trok de arbeidsmarkt aan. De toenemende vraag naar arbeid was een tweede reden voor de forse migratie. ${ }^{77}$

Als derde factor voor de bevolkingstoename kan de verbetering van de gezondheidszorg genoemd worden. Besmettelijke ziekten als cholera verdwenen door verbeteringen aan het drinkwaterstelsel. De aanleg van een rioleringsstelsel droeg eveneens bij aan een grotere hygiëne. Door de toename van de welvaart kwam bovendien medische zorg voor velen binnen bereik. ${ }^{78}$

\section{b) Van nijverheid naar industrie}

In de secundaire sector voltrok zich een ontwikkeling van nijverheid op ambachtelijke schaal naar moderne industrialisatie. De timing van deze overgang in Nederland was lang onderwerp van discussie onder economisch historici. Studies van Jan-Luiten van Zanden en Arthur van Riel hebben voorlopig het pleit beslecht. ${ }^{79}$ In Nederland vond, volgens deze historici, tussen 1860 en 1880 "de beslissende doorbraak van de industrialisatie plaats". ${ }^{80}$ Er brak een periode aan van economische groei, die zo krachtig was dat zelfs de agrarische crisis van 1878 tot de jaren '90 ermee kon worden opgevangen. Onder economische groei moet een trendmatige groei worden begrepen van het nationaal inkomen per hoofd van de bevolking. Structureel ontwikkelde zich naast een lichte industrie nu ook een zware industrie. Met een onderbreking van de Eerste Wereldoorlog (1914-1918) houdt deze economische groei aan tot in het interbellum. De jaren '30 laten vervolgens een teruggang zien. In 1931 is de daling van het bruto binnenlands product het sterkst, terwijl in 1936 de werkloosheid een piek bereikt. ${ }^{81}$ In de tweede helft van de jaren '30 krabbelt de economie weer op. De impact van de crisis was groot voor de toenmalige burgers, maar gezien over een langere termijn zou de slechte economische reputatie van het interbellum flink gerelativeerd kunnen worden. ${ }^{82}$

Hoe heeft het industrialisatieproces in Amsterdam zich voltrokken? ${ }^{83}$ Eerst moet natuurlijk de vraag worden beantwoord wat industrialisatie nu eigenlijk is. Industrialisatie is de mechanisatie van werk dat eerst met de hand werd gedaan. Ook treedt er bij industrialisatie een energietransitie op: de "verstoming" van de nijverheid. ${ }^{84}$ Door beide ontwikkelingen wor- 


\section{Afbeelding 5.4}

De annexatie van 1921

De annexatie van 1921. In geel de oppervlakte van Amsterdam voor 1921. Links in het roze de voormalige gemeente Sloten, aan de onderkant in oranje het van de gemeente Nieuwer-Amstel geannexeerde gebied. De overige annexaties van respectievelijk de gemeenten Ouder-Amstel (groen), Watergraafsmeer (roze) en Diemen (groen). Ten noorden van het IJ werden de gemeenten Buiksloot (oranje), Nieuwendam (groen) en Ransdorp (roze) in hun geheel geannexeerd. Van Oostzaan werd een deel geannexeerd (groen). Het grondgebied van de gemeente Amsterdam werd vier keer zo groot. Kaart: Dienst der Publieke Werken.Bron: http:// vaneesterenmuseum. $\mathrm{nl} / \mathrm{nl} /$ de-stad-voor-het-aup/

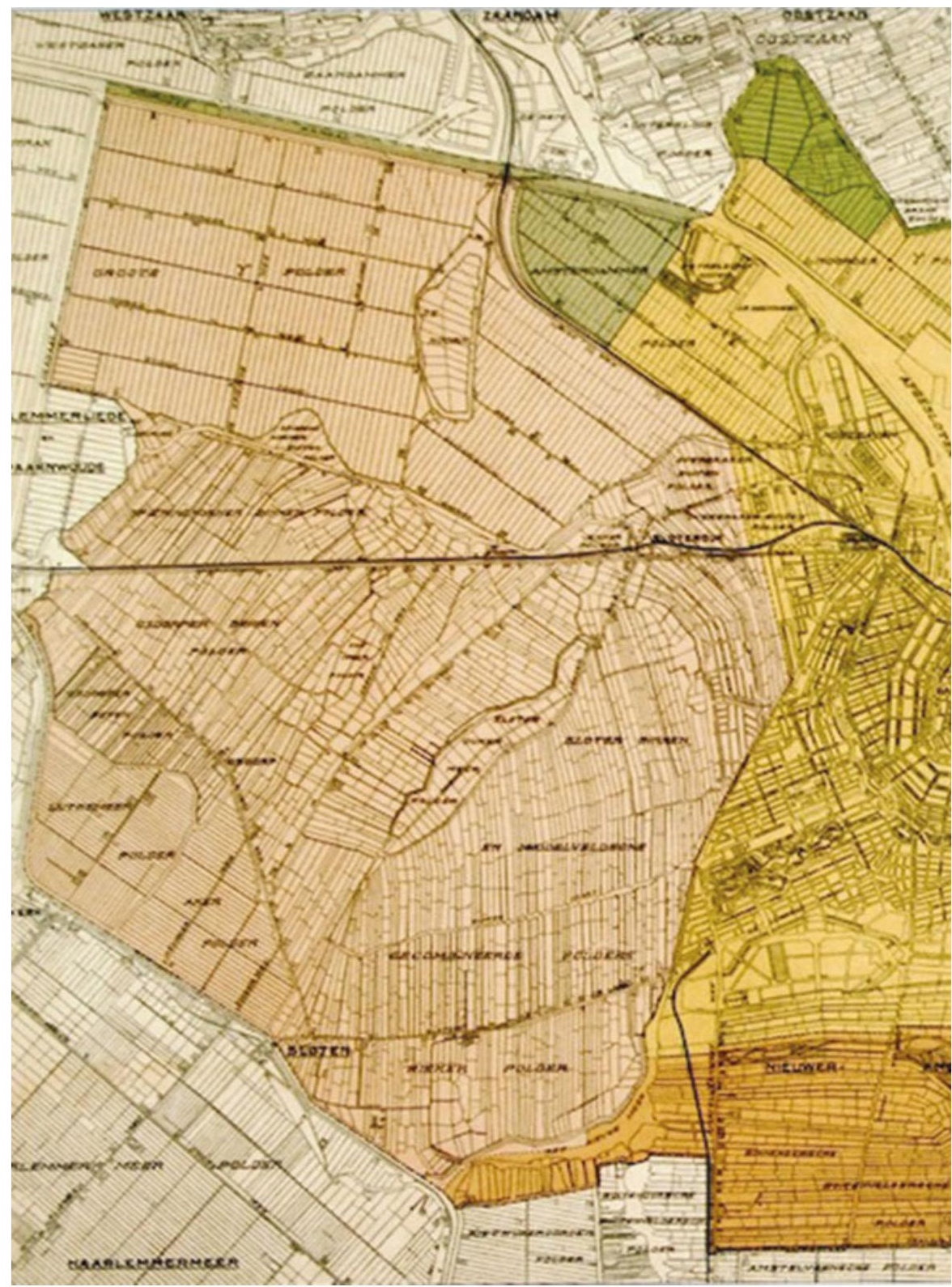




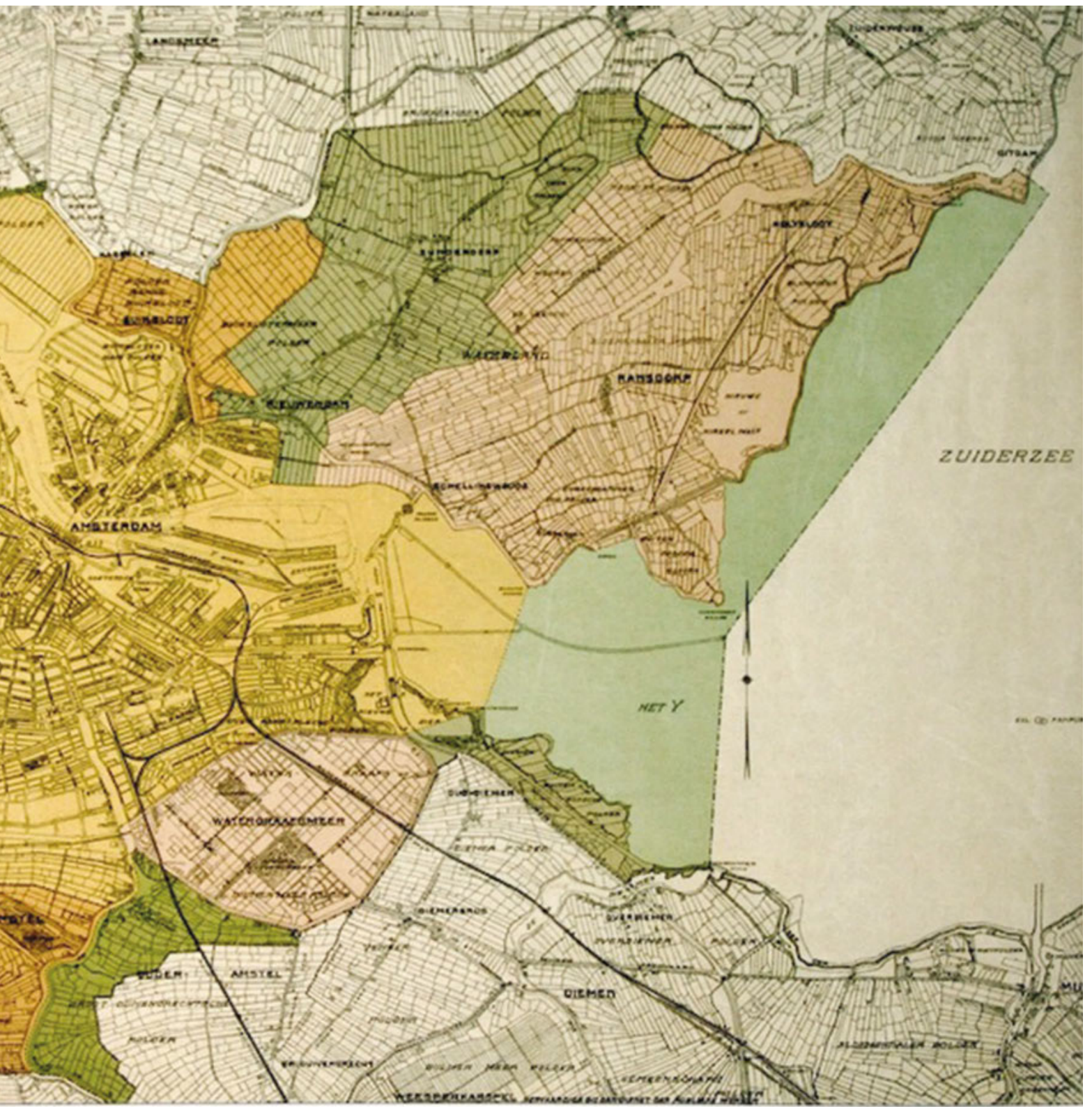


Afbeelding 5.5 Lijnennet

Gemeentetram in 1914

Bron: http://www.amsterdamsetrams.nl/netkaarten/ tramwegnet/1914.htm.

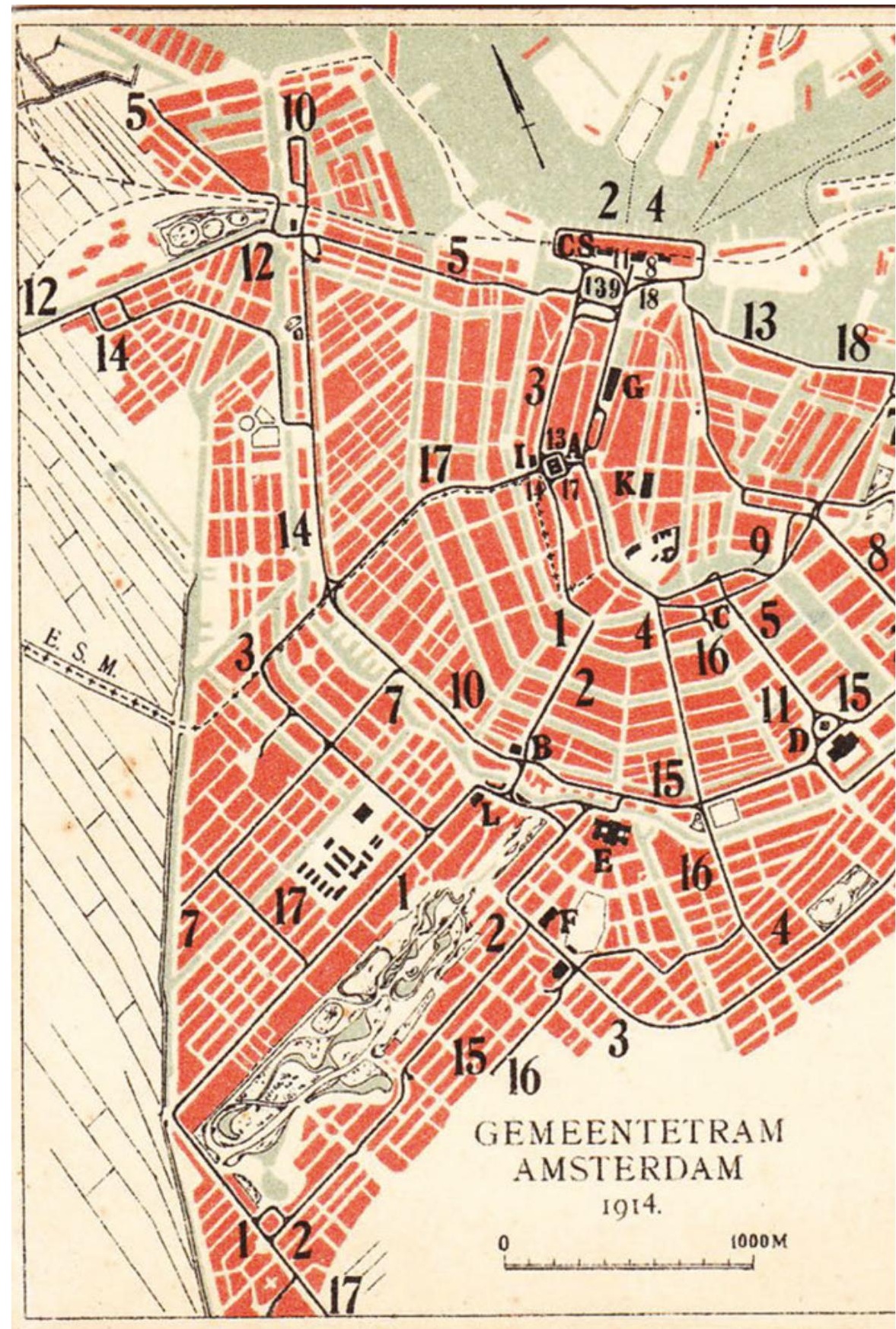




\section{IJ NEN.}

* 1 Amstelv.weg-Leidschepl-Stationsplein.

18.13

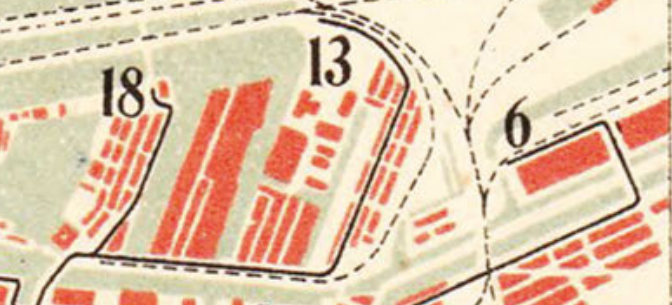

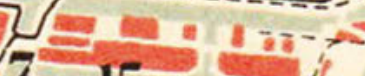

TF 5

H

\section{7}
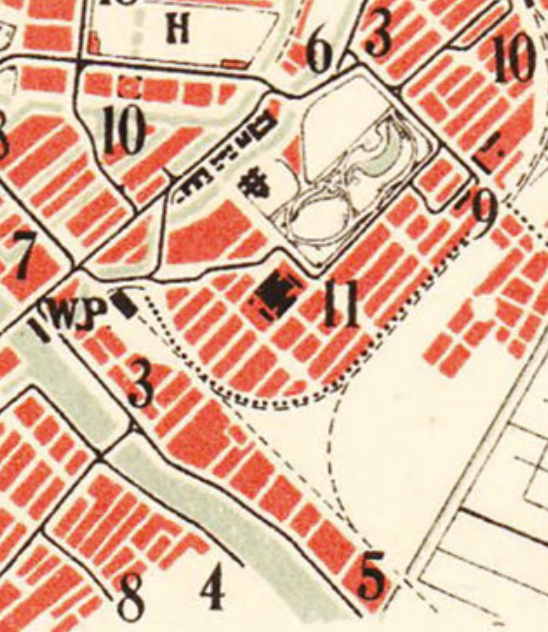

* 2 Koning.weg-Leidschepl.De Ruyterkade.

* 3 Linnaeusstr.Ceintuurbaan-Stationsplein.

* 4 Amsteldijk-Dam-De Ruyterkade.

* 5 Weesperzijde-Dam- $\mathrm{r}^{\text {se }}$ Spaarnd.straat.

- 6 Cruquiusweg-Mauritskade.

* 7 Rapenb.plein-Leidscheplein-Kinkerstr.

* 8 Van Woustraat-Weesperplein-Stat.plein.

* 9 Linnaeusstr.Plantage-Dam-Stationspl.

*10 Zoutkeetsgr.Leidscheplein-Station M.P.

* 11 Station M.P.Frederikspl.-Dam-Centr.Stat.

ol2 Nassauplein-Sloterdijk.

*13 Czaar Peterstraat-P. Hendrikkade-Dam.

*14 Van Hallstraat-Marnixstr.Rozengr.Dam.

*15 De Lairessestraat-Frederikspl..Y.erklaan.

*16 De Lairessestr.Alb. Cuypstr.Rembr.pl.

*17 Amstelvweg-Bilderdijkstraat-Dam.

ol8 Mariniersplein-P. H. kade-Stationsplein.

Tarief: $\mathbb{X}_{5}$ cent; $\mathrm{O}_{2} \%$, cent. 
den bedrijven kapitaalintensiever: het beroep op de kapitaalmarkt wordt dus groter. Productie en productiviteit nemen toe. Bedrijven breiden uit en er worden meer mensen in dienst genomen. Het midden- en het grootbedrijf komen op ten koste van het kleinbedrijf.

Tot de jaren '70 van de negentiende eeuw kan Amsterdam beschouwd worden als een vroegkapitalistische handels- en consumptiestad. Vanaf ongeveer 1870 verandert de stad geleidelijk in een modern-kapitalistisch centrum van handel en industrie. ${ }^{85}$ De economische crisis van de jaren ' 80 is de katalysator in deze ontwikkeling. De bedrijven concentreren zich steeds meer. Het grootbedrijf zal uiteindelijke een dominante positie innemen in het economische spectrum. De internationale conjunctuur wordt steeds meer voelbaar in Amsterdam. Dat is terug te zien in de werkloosheid; werkloosheid wordt meer en meer een verschijnsel dat aan de internationale conjunctuur kan worden gekoppeld. Er ontstaat een nieuw type werklozen: fabrieksarbeiders die door economische crises, veelal tijdelijk, werkloos worden. Voor deze groepen komen nieuwe zorgarrangementen, naast de bestaande armenzorg in Amsterdam. Piet de Rooy heeft deze ontwikkeling helder samengevat. ${ }^{86}$ Deels heeft die zorg, stelt hij, betrekking op arbeidsbemiddeling in de geest van Taylor: the right man in the right place. ${ }^{87}$ Daarnaast is er ook geldelijke ondersteuning: een werkloosheidsverzekering vanuit de vakverenigingen. Deze moderne vorm van werkloosheid werd door Domela Nieuwenhuis, zo merkt De Rooy op, treffend omschreven. Vroeger was werkloosheid, volgens Domela Nieuwenhuis, "een epidemie, die nu en dan eens uitbreekt om af te nemen en te verdwijnen", maar tegenwoordig is het "een chronische (slepende) ziekte, die in alle jaargetijden wordt aangetroffen". ${ }^{88}$ Dat wat men ooit een "crise de type ancien" noemde, is een moderne conjuncturele crisis geworden. ${ }^{89}$

Historici zijn er niet helemaal over uit wanneer de industrialisatie inzette in Amsterdam. Van Tijn ziet in de jaren '60 een aarzelende omslag in het verstarde Amsterdam. ${ }^{90}$ Ook Ad Knotter laat de transformatie in de jaren '60 beginnen. ${ }^{91}$ Deze gedachtegang vinden we ook terug bij Jan Luiten van Zanden. ${ }^{92}$ Het proces van verandering begint volgens hem omstreeks 1870.

De definitieve omslag naar een industriële economie vond plaats in de tweede helft van de jaren '80. In de periode van 1885 tot 1914 deed zich in veel bedrijfstakken (de machinebouw, de scheepsbouw, de suikerraffinage, de bierbrouwerij en de gasfabricage) een concentratieproces voor: het grootbedrijf kwam op. Al die bedrijven deden een beroep op de kapitaalmarkt, die steeds toegankelijker werd, waardoor het lucratief was om te investeren en de kostprijs per productie-eenheid laag bleef. Hierdoor konden deze bedrijven betrekkelijk hoge lonen betalen. ${ }^{93}$ Bovendien was het aantal arbeidsuren per week laag en de productiviteit hoog, in vergelijking met vroegere, arbeidsintensievere omstandigheden.

Het midden- en kleinbedrijf hadden minder middelen, en dus ook minder toegang tot de kapitaalmarkt. Het investeren in kapitaalgoederen was hierdoor niet goed mogelijk, hetgeen een hogere kostprijs per eenheid met zich meebracht. Het midden- en kleinbedrijf konden zich nog net staande houden door de lonen laag te houden en de werknemers lange dagen te laten maken. ${ }^{94}$ Maar de arbeidsproductiviteit was relatief laag.

Kort samengevat kan worden vastgesteld dat in de onderzoeksperio-
85 Knotter (1991), 69. 86 Voor de Tweede Wereldoorlog zijn in Amsterdam een negental organisaties, gemeentelijke commissies en een fonds, op het gebied van de werkloosheid actief geweest. Zij wilden de werkloosheid bestrijden en de gevolgen van werkloosheid verlichten. In de inventaris van SAA 5408 Archief van de Werkloosheidscommissies worden deze organisaties heel helder beschreven. Wals (2001), 82-89, bespreekt regelingen op het gebied van de werkloosheid in Amsterdam over de periode van het einde van de negentiende eeuw tot circa 1925. Over het Interbellum is veel informatie te vinden bij De Rooy (1979); De Rooy (2007)c, 207. 87 De Rooy (1979), 18. 88 De Rooy (1979), 14, het gaat om 1895.

89 De Jonge (1976), 245 -

248; 270-272; 288-290.

90 Van Tijn (1965), $269-272$.

91 Knotter, (1991), 52-54.

92 Van Zanden (1997) 15; Van Zanden (1987), 93 Van Zanden (1987), 71. 94 Deze redenering sluit aan bij de anticyclische conjunctuurtheorie van Ridder (1935). Sandick levert hier commentaar op (1936). 
95 Knotter en Muskee (1986), spreken van een "traditionele agrarische conjunctuur" in plaats van "vroeg-kapitalistische oriëntatie".

96 De Jonge (1976), 347.

97 Brugmans (1961), 366.

98 Nusteling (1974).

99 Zie ook Filarski (2014).

100 Deze passage steunt sterk op Wagenaar (1990), 91-92. de van 1870 tot 1940 de economische structuur van Amsterdam sterk wijzigde. Van een vroegkapitalistische situatie waarin handel en consumptie plaatsgebonden waren, aldus Knotter, veranderde Amsterdam in een stad met een modern-kapitalistische structuur, waarin het grootbedrijf dominant werd en waarin de internationale conjunctuur zich steeds meer liet gelden. ${ }^{95}$ Werkloosheid is voor een deel een verschijnsel geworden dat aan de internationale conjunctuur moet worden gekoppeld. Voor deze werkloosheid nieuwe stijl werden zorgarrangementen ontwikkeld die los stonden van de traditionele armenzorg.

\section{c) Handel, verkeer en de financiële sector}

De opening van het Noordzeekanaal in 1876 betekende een belangrijke impuls voor de scheepvaart met het buitenland. Amsterdam werd dé haven in Nederland voor Indische producten, die zeven jaar eerder, in 1869, ook al op de kaart was gezet door de opening van het Suezkanaal. ${ }^{96} \mathrm{Na} 1890$ nam de scheepvaartbeweging explosief toe, sterker dan het wereldverkeer. De totale bruto tonnage vervijfvoudigde tussen 1876 en $1910 .{ }^{97}$ Niet alleen "Indië" was van belang voor de toename. Amsterdam profiteerde ook van de groei van de transitohandel met het Duitse achterland, ondanks het feit dat juist in deze periode (1890 - 1910) Rotterdam zich begon te profileren als de belangrijkste havenstad van Nederland. ${ }^{98}$ In de jaren die volgden kon Amsterdam steeds minder goed concurreren met Rotterdam, ook door de slechte bereikbaarheid van de Rijn voor de Amsterdamse scheepvaart. Pas met de openstelling van het Amsterdam-Rijnkanaal in 1952 verbeterde de situatie weer.

Naast de buitenlandse scheepvaarthandel maakte ook de binnenscheepvaart een sterke groei door. ${ }^{99}$ Amsterdam was al vanaf de vijftiende eeuw een belangrijk centrum voor Noord- en Midden-Nederland. De groei van de Nederlandse economie na 1895 kwam ook de mobiliteit van de binnenvaart ten goede.

De ontwikkeling van spoor- en landwegen versterkte de betekenis van Amsterdam als handelsknooppunt. De handelsbewegingen zorgden voor veel werkgelegenheid. Die was er niet alleen in de haven, maar ook bij de Amsterdamsche Droogdok Maatschappij, een scheepswerf die actief was op het gebied van scheepsreparatie, scheepsverbouwingen en machinebouw en Werkspoor, destijds de grootste machinefabriek van Nederland.

De verschillende wijken van de zich uitbreidende stad werden met elkaar verbonden door het openbaar vervoer. Zie ook afbeelding 5.5 waarop het lijnennet van de Amsterdamse Gemeentetram in 1914 wordt afgebeeld. Amsterdam was niet langer een walking city.

In het laatste kwart van de negentiende eeuw versterkte Amsterdam zijn centrale rol in de tertiaire sector in Nederland. Amsterdam was al van oudsher leidend in de financiële en commerciële dienstverlening. De handel, het assurantiewezen en het bankwezen ontwikkelden zich zodanig, dat je kunt vaststellen dat er niet alleen een grote industriële groei plaatsvond, maar dat de Amsterdamse economie zich breed ontwikkelde, over meerdere sectoren. ${ }^{100}$

\section{d) Sociale verhoudingen: van statisch naar dynamisch}

In de eerste helft van de negentiende eeuw waren de sociale verhoudin- 
gen in Amsterdam weinig elastisch. De meeste onderzoekers bestempelen de toenmalige Amsterdamse samenleving als verstard. Boudien de Vries is daarin het meest uitgesproken: "De sociale groepen, de standen, werden beschouwd als erfelijk, onbeweeglijk en onveranderlijk en in de praktijk waren ze dit ook vrijwel. Het standsbewustzijn was daarom sterk ontwikkeld en de standsverschillen breed uitgemeten". ${ }^{101}$ Van Leeuwen omschrijft de sociale structuur in het Amsterdam van de eerste helft van de negentiende eeuw als "een statische, hiërarchische, standenstructuur". ${ }^{102}$ Van Tijn had het al eerder over een "langdurig stagnerende samenleving" als hij probeert de periode van de jaren '50 van de negentiende eeuw tot 1866 te karakteriseren. ${ }^{103}$

De verstarde sociale verhoudingen in de eerste helft van de negentiende eeuw waren in heel Nederland zichtbaar. Nederland was toen nog grotendeels een standensamenleving, die bepaald werd door herkomst en komaf. In de tweede helft van de negentiende eeuw veranderde dat. Er ontwikkelde zich geleidelijk aan een klassenmaatschappij, die niet langer door komaf, maar steeds meer door economische status werd bepaald. De sociale verhoudingen binnen een klassenmaatschappij zijn veel dynamischer dan binnen een standenmaatschappij. De nieuwe verhoudingen waren het gevolg van de economische ontwikkelingen. ${ }^{104}$ Burgers behoorden niet meer tot een stand, maar tot een bepaalde klasse. Arbeiders ontwikkelden een klassenbewustzijn. Volgens Giele vond deze omslag plaats in het laatste kwart van de negentiende eeuw. ${ }^{105}$

Grafiek 5.1 Inkomensverdeling naar belastinggegevens (1900, 1910, 1921 en 1931) in percentages

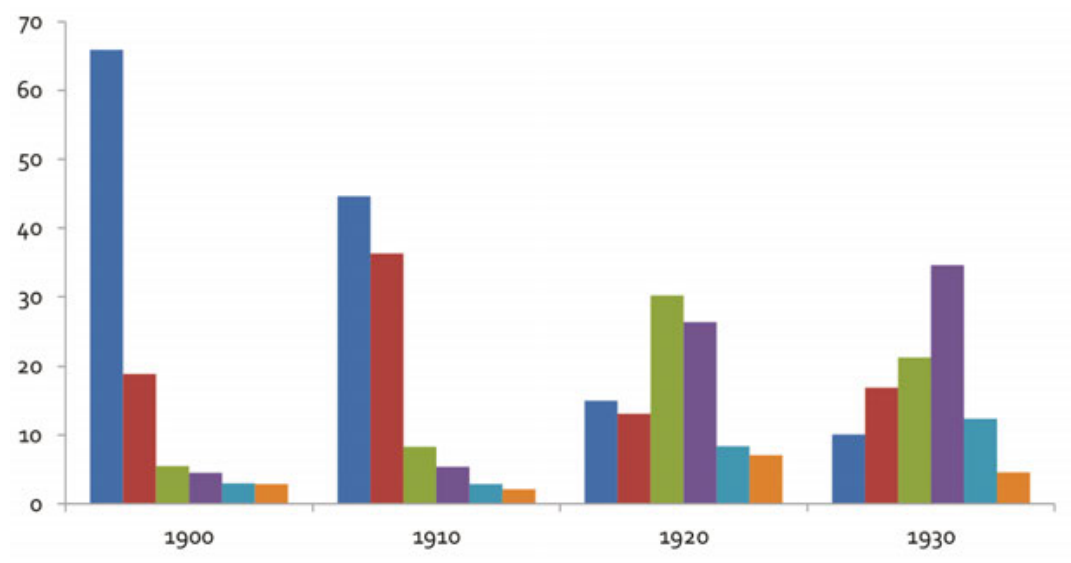

$\|$ Onvermogend $=$ laagst aangeslagen $\| 1.001-1.501=1.501-2.500=2.501-5.000=5.000$

Bron: Van der Velden (1993), 153.

Deze veranderingen in de sociale verhoudingen werden na circa 1870 zichtbaar. Er voltrok zich een proces van suburbanisatie, dat trouwens niet alleen in Amsterdam, maar in heel Nederland te zien was. ${ }^{106}$ De welgestelden gingen zich buiten de stadsgrenzen vestigen. Mannelijke kostwinners werden forensen. Dit forensisme werd mogelijk door verbetering en uitbrei-
101 De Vries (1986), 10.

102 Van Leeuwen (1992), 89.

103 Van Tijn (1965), 111. 104 De Regt (1984), 17; Giele (2019), 98. 105 Giele (2019), 109. 106 Kooij (1985), 105; Wagenaar (1990), 52. Voorts: Kooij (1987).

107 Forensisme is er richting Gooi en richting Noord-Holland benoorden het Noordzeekanaal. In 1874 werd de Gooilijn Amsterdam-Amersfoort geopend. Vanaf 1878 werd de rest van Noord-Holland door middel van de Zaanlijn met Amsterdam verbonden. Forensisme werd ook bevorderd door veel buurtspoorverbindingen in de vorm van stoomtrams, zoals de "Gooische moordenaar" en de "Blauwe tram". 
108 In detail is dat terug te zien in de levensverhalen, hoofdstuk 8. Zie in het bijzonder het levensverhaal van Jacob Kooseman en Cornelia Klipp.

109 Dat is terug te zien in tabel 8.13: grafisch voorgesteld in grafiek 6.10. Wel moet worden opgemerkt dat de stijging van het uitkeringsniveau in de jaren '30 ook werd veroorzaakt doordat aan georganiseerde werklozen een hoger steunbedrag werd uitgekeerd dan aan de ongeorganiseerden. Het uitkeringsniveau van de ongeorganiseerden was gelijk aan die van de "armlastigen". Het stijgen van het uitkeringsniveau heeft betrekking op heel de periode van het Interbellum. De kortingen op de steun in de jaren '30 hebben, met de wijsheid van achteraf, maar een tijdelijke terugval betekent. De steuntrekkenden zelf hebben de kortingen als zeer traumatisch ervaren. Een voorbeeld van deze belevingen is te vinden in de afstudeerscriptie bij een rechtsvoorganger van de Hogeschool van Amsterdam, Lerarenopleiding geschiedenis van Janine ter Linde en Sascha van der Zon. In 1998 hebben zij aan de hand van interviews van bewoners van het Flevohuis in Amsterdam, een verzorgingshuis, belevenissen over de leefomstandigheden voor de Tweede Wereldoorlog verzameld. Het gaat er om hoe deze mensen in 1998 de jaren voor de Tweede Wereldoorlog hebben beleefd. 110 In hoofdstuk 5 paragraaf b wees ik hier al op. 111 Verhelderend over de verhouding tussen armenzorg en werklozenzorg is Van der Valk (1986), 30-50. ding van de spoorwegen. ${ }^{107}$ Het proces van suburbanisatie voor de gegoeden en vervolgens ook voor de middengroepen bleef in de eerste helft van de twintigste eeuw aanhouden. Vanaf ongeveer 1870 kwamen grote groepen minder welgestelden naar Amsterdam, aangetrokken door de verbeterde economische omstandigheden. Amsterdam werd een arbeidersstad. Deze "nieuwe" burgers zorgden op maatschappelijk gebied, ook voor de armenzorg, voor een nieuw elan.

Interessant is te zien in grafiek 5.1 dat door de economische groei het aantal mensen dat niet door de belasting wordt aangeslagen wegens een laag inkomen, in de twintigste eeuw sterk is gedaald. Hiermee is het "moderne" karakter van het armoedeprobleem in beeld gebracht. Van primaire armoede is geen sprake meer. Armoede is secundair en daarmee relatief geworden.

\section{e) De betekenis van de verandering van de structuur van de stad voor de armenzorg}

De stad veranderde van een vroegkapitalistische handels- en consumptiestad in een moderne stad, waarin handel en industrie op een modern-kapitalistische leest waren geschoeid. In paragraaf 5 b beschreef ik deze ontwikkeling. In sociaal opzicht veranderde de stad van een standenmaatschappij in een arbeidersstad, zoals in paragraaf $5 d$ is aangegeven. Deze ontwikkelingen hadden hun weerslag op de armenzorg. Zoals in hoofdstuk 4 uiteengezet werden traditioneel twee groepen bediend door de armenzorg: de structurele en de conjuncturele armen. De eerste groep gesteunden werd de gehele periode 1870-1940 vaak langdurig geholpen door de gemeentelijke armenzorg. ${ }^{108}$ De tweede groep gesteunden, veelal afhankelijk van losse arbeid, werd in hoofdzaak door seizoenswerkloosheid getroffen. De hulpverlening aan deze groep gesteunden was in de regel van kortere duur. Voor beide groepen zien we een verandering van primaire naar secundaire armoede, wat gevolgen had voor de hoogte van de steunverlening. ${ }^{109}$ De nieuwe maatschappelijke structuur en het industrialisatieproces zorgden voor het ontstaan van een nieuwe kwetsbare groep: de loonarbeiders, die in tijden van economische laagconjunctuur werkloos werden. ${ }^{110}$ Nieuwe zorgarrangementen ontstonden er voor deze groep loonarbeiders om de gevolgen van werkloosheid te verlichten. ${ }^{111}$ Vakverenigingen speelden een rol bij deze nieuwe arrangementen, maar de bestaande gemeentelijke armenzorg werd eveneens betrokken bij de nieuwe arrangementen. Er waren werklozen die waren aangesloten bij een vakvereniging. Deze vakbondsleden konden via een werkloosheidsverzekering, gefinancierd uit werknemerspremies en overheidssubsidies, een uitkering ontvangen. Deze leden ontvingen hun steun via de vakbond. Vakbondsfunctionarissen zorgden ook voor de registraties op formulieren. Naderhand controleerde de gemeentelijke dienst, de Burgerlijke Instelling voor Maatschappelijken Steun, deze formulieren. Huisbezoek vond niet plaats. Dan was er een tweede groep werklozen: de "uitgetrokken" georganiseerden. Bij hun werkloosheidsverzekering konden zij niet meer aankloppen. Zij vielen vervolgens onder een rijkssteunregeling. Deze steun ontvingen zij via hun vakbond. Achteraf werd hun steunverlening gecontroleerd door de gemeentelijke armenzorg. Ook 
bij deze groep vond geen huisbezoek plaats. Ongeorganiseerden vormden een derde groep werklozen. ${ }^{112} \mathrm{Zij}$ waren niet bij een vakbond aangesloten. Hun positie is te vergelijken met de oude groep werklozen die door seizoenswerkloosheid werd getroffen, de conjuncturele armen. De ongeorganiseerden waren aangewezen op de gemeentelijke armenzorg, vanaf 1928 de Burgerlijke Instelling voor Maatschappelijken Steun. Zij vielen geheel onder het régime van de armenzorg zodat huisbezoek plaatsvond. Daarnaast werd in 1931 het "Crisis comité Amsterdam 1931" actief. ${ }^{113}$ Bij de uitvoering was eveneens de Burgerlijke Instelling voor Maatschappelijken Steun actief. ${ }^{114}$ In de jaren '30 van de twintigste eeuw met zijn hoge werkloosheid hield de Amsterdamse gemeentelijke armenzorg, de Burgerlijke Instelling voor Maatschappelijken Steun zich intensief met het bestrijden van de gevolgen van werkloosheid bezig, zonder dat de oude taak van zorg voor de meer traditionele en permanent kwetsbaren uit het oog werd verloren. ${ }^{115}$ Wel kan gesproken worden van tweesporigheid in de uitvoering. ${ }^{116}$ Armen en ongeorganiseerde werklozen ontvingen individuele zorg door huisbezoek, terwijl georganiseerde werklozen, of zij nu wel rechtstreeks van de vakbond steun ontvingen, dan wel waren "uitgetrokken" onderworpen waren aan een voor hen anoniem ambtenarenapparaat. Pas in 1949, met de invoering van de Werkloosheidswet, werd de tweesporigheid van armenzorg en werklozenzorg verlaten.

\section{f) Samenvatting}

Tussen 1870 en 1940 veranderde Amsterdam van een stad met nog veel pre-industriële trekken in een moderne stad. Veranderingen op het gebied van de bevolkingsgroei, bevolkingssamenstelling, de economie en de sociale verhoudingen zijn hierboven besproken.

Het effect van de modernisering is te zien aan de veranderingen in de geboorte- en sterftecijfers. Hoge sterftecijfers maakten plaats voor veel lagere sterftecijfers. Plotselinge hoge sterfte, zo typisch voor een pre-industriële samenleving, verdween. Ook in een ander opzicht was er een verandering: een hoog geboortecijfer maakte plaats voor een veel lager geboortecijfer. Omdat het geboortecijfer hoger was dan het sterftecijfer groeide de bevolking van Amsterdam. De bevolkingsgroei was intussen meer nog het gevolg van de grote aantrekkingskracht die de stad op migranten had, waardoor velen naar Amsterdam trokken. Daarnaast speelde in de bevolkingsgroei mee dat Amsterdam omliggende gemeenten annexeerde in 1877, 1896 en 1921. Al met al resulteerden de verschillende ontwikkelingen in een verdriedubbeling van het inwonertal van de stad tussen 1870 en 1940.

Tussen 1870 en 1940 werd de nijverheidssector geïndustrialiseerd. Arbeid werd gemechaniseerd. Er vond een concentratie van bedrijven plaats. De gemiddelde arbeidsproductiviteit en de productie namen fors toe. De Amsterdamse economie werd onderdeel van een internationale conjunctuur. De beweging van deze conjunctuur had haar weerslag op de Amsterdamse werkgelegenheid. Als er een internationale laagconjunctuur ontstond veroorzaakte die conjuncturele werkloosheid. De internationale en nationale handel trok tussen 1870 en 1940 sterk aan, maar Amsterdam bleef als havenstad duidelijk achter bij concurrent Rotterdam. Het openbaar ver-
112 Groot (1987), 247-248 113 Een uitvoerige beschrijving van de werkzaamheden van het Crisis-Comité Amsterdam 1931 is te vinden in: SAA 5379.[= Archief van het Crisis-Comité Amsterdam 1931] Bestanddeel 5, 10. 114 De relatie tussen armenzorg oude stijl en werklozenzorg wordt aangegeven door Van der Valk(1986); De Rooy (1979) schetst deze relatie voor het Interbellum. $115 \mathrm{Om}$ al de werkzaamheden voor de ongeorganiseerde werklozen te stroomlijnen werd in de zomer van 1937 een centraal administratiegebouw in de Marnixstraat 317 in gebruik genomen, De Rooy (1979), 165.

116 Groot (1987), 250. 
voer maakte tussen 1870 en 1940 een flinke ontwikkeling door. Spoorlijnen en buurtspoor zorgden voor een forse toename van het personenvervoer. Ook werd de uitdijende stad door tramwegen ontsloten. De economische ontwikkeling voltrok zich over een breed terrein: naast de industrie ontwikkelden handel, bankwezen en dienstensector zich krachtig.

De economische transformatie van pre-industriële naar moderne stad weerspiegelde zich in de veranderende sociale verhoudingen. Het statische karakter van de samenleving werd doorbroken. Een groep "nieuwe" burgers ontwikkelde zich tot een zelfbewuste klasse. Door de gewijzigde arbeidsverhoudingen in de nieuwe economie van industrie, handel en dienstensector ontstond een arbeidersklasse. Een deel van de gegoede burgers verdween uit de stad ten gevolge van een proces van suburbanisatie. De groeiende werkgelegenheid bracht grote groepen minder welgestelden naar de stad. Door deze twee tegengestelde bewegingen werd Amsterdam een arbeidersstad. De opkomst van de nieuwe economie bracht voor alle groepen een welstandsverbetering met zich mee. Voeding, kleding en huisvesting gingen erop vooruit. Naar verhouding kregen veel mensen toegang tot goede medische zorg. Ook nam de scholingsgraad toe.

De aard van het armoedeprobleem veranderde, omdat in de moderne stad de welstand was toegenomen. Was in 1870 armoede nog vooral een fysiek gegeven dat de arme aan de grens bracht van het biologisch existentieniveau, tegen 1940 was armoede een relatief begrip geworden. Armoede was nu vooral iets dat de arme belemmerde om deel te nemen aan een maatschappelijk gewenst leefpatroon. Armenzorg was niet langer hongerbestrijding, maar bood een mogelijkheid om volwaardig deel te kunnen nemen aan de maatschappij. 

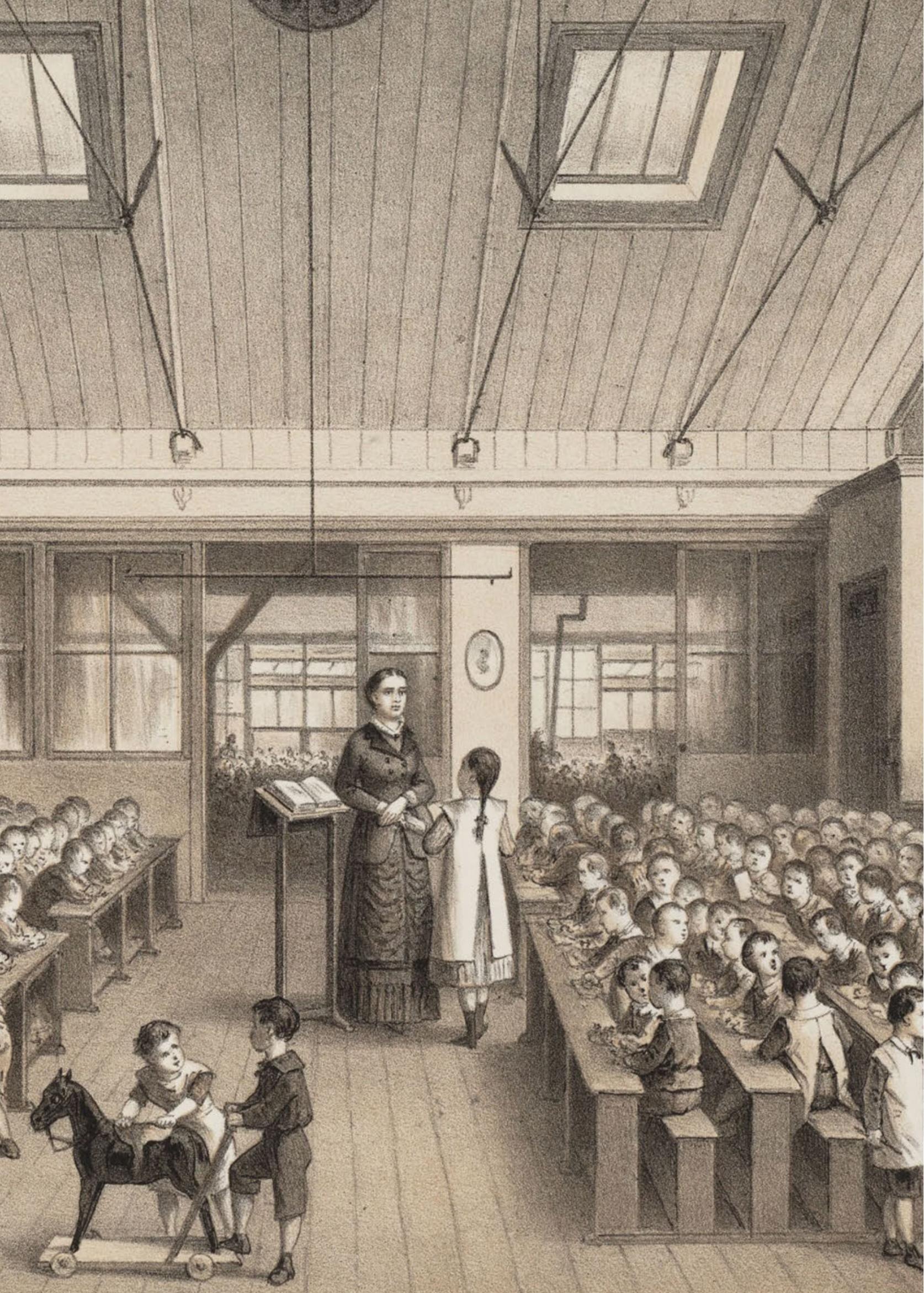

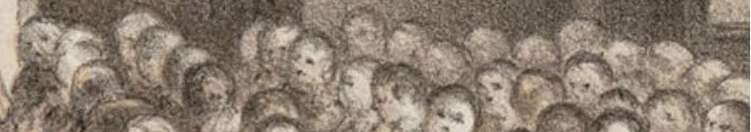
$-246760^{\circ}$

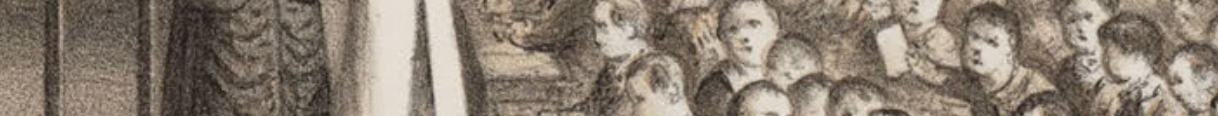
- ran ma las action $9021 / 96$ -3) 2 1 


\section{HOOFDSTUK 6 \\ BESCHAVING}

< 6.A Bewaarschool van de "Vereeniging Ter Verbreiding van de Waarheid" in 1883 Interieur van de bewaarschool van de "Vereeniging Ter Verbreiding van de Waarheid", Rozengracht 191. Ter gelegenheid van het 25-jarig bestaan tussen 17 Mei 1858 en 17 mei 1883. Prent. Maker onbekend. Bron: SAA. Beeldbank. Afbeeldingsbestand 010097011676.
1 Van Tijn, (1965), 126; Van Leeuwen, (1992), 19, 41-42, letterkundigen uit de eerste helft van de negentiende eeuw citerend.

2 Heldring, (1844), 4, de andere oorzaken op 4-8: 2)" de dwaze giften der rijken", armenzorg houdt armoede in stand. 3) "beginselloos handelen bij de bedeeling der armen", er wordt te weinig onderzocht waarom de arme arm is. 4) "men helpt ... niet ... , waar nog te helpen is", voordat iemand arm wordt zou enige hulp moeten worden geboden om erger te voorkomen. 5) "belastingen" Om het modern te zeggen: de verbruiksbelastingen drukken zwaar op de budgetten van de armen. De opheffing van de accijnzen op het verbruik in 1854 zou inderdaad soelaas bieden.6) "de meerdere uitbreiding der machinerieën", machines nemen de plaats in van menselijke

\subsection{INLEIDING}

In dit hoofdstuk bespreek ik eerst drie negentiende en twintigste-eeuwse visies op armenzorg en beschaving: een traditionele visie, de nieuwe visie van de burgerij op armoede en een visie vanuit een sociaaldemocratisch standpunt. Vervolgens ga ik in op de vraag welke sporen van het burgerlijk beschavingsoffensief terug te vinden zijn in de rapporten van de armbezoekers van de gemeentelijke armenzorg. Als laatste komen de veranderende leefomstandigheden van de armen tussen 1871 en 1940 aan de orde.

\subsection{VISIES OP ARMENZORG EN BESCHAVING IN DE NEGENTIENDE EEUW EN BEGIN TWINTIGSTE EEUW}

\section{a) Een traditionele visie vanuit de burgerij}

In de visie van het Amsterdamse patriciaat in de eerste helft van de negentiende eeuw lag het aan de armen zelf dat ze arm waren. Mensen die gezond waren, werden in staat geacht te kunnen werken. Dat sommigen desondanks niet in hun eigen onderhoud konden voorzien, moest dan wel hun eigen schuld zijn. ${ }^{1}$ Dat is de traditionele visie op armoede en armlastigen. In 1844 somde Otto Gerhard Heldring, behorend tot het Nederlandse patriciaat, zeven oorzaken op van armoede. Bovenaan zijn lijstje stond de twijfelachtige instelling van de arme mensen zelf: "den eigen boozen wil der armen". ${ }^{2}$ Een paar jaar later, in 1847, zag de "Algemeene commissie ter ondersteuning van behoeftigen" een paar andere oorzaken voor armoede. Ten eerste was dat "het veelvuldig gebruik van sterken drank" en ten tweede waren dat de "onevenredig hooge kamer- en kelderhuren". ${ }^{3}$ Volgens de Winkler Prins uit 1870 waren er natuurlijke oorzaken voor armoede, waar de armen geen invloed op hadden, maar lag het toch ook vaak aan hun individuele tekortkomingen: "maar ook zijn onverstand, onwil, luiheid, vadzigheid, ligtzinnigheid, verkwisting, spilzucht, en de verslaafdheid aan menigen boozen hartstogt dikwijls als evenzoo vele bronnen van armoede aan te merken". ${ }^{4}$

Het patriciaat was van mening dat armoede eigen schuld was, maar spande zich desondanks in om de ergste nood te lenigen. Waarom was dat? Armoedebestrijding was in hun eigen belang. Boven is al vermeld dat Van Leeuwen deze vorm van armoedebestrijding als een sociaal beheersingsproces zag. De benadering van de armen was defensief: de maatschappelijke status quo moest verdedigd worden en gehandhaafd blijven.

\section{b) Een nieuwe visie vanuit de burgerij op de armen}

De nieuwe visie van de burgerij op de armenzorg viel in Amsterdam vooral te bespeuren binnen het genootschap Liefdadigheid naar Vermogen. ${ }^{5}$ Dit genootschap werd in 1871 opgericht door een aantal jonge Amsterdammers, aanvankelijk onder de naam "Liefdadigheid, Nut, Vermaak". De toen 
achttienjarige Louis Blankenberg was de man van het eerste uur. Medeoprichters waren zijn jongere broer, zijn zuster en een vriend. Een jaar later, in 1872, werd de naam van het genootschap gewijzigd in Liefdadigheid Naar Vermogen. Het hoofddoel was het ondersteunen van armlastigen. De initiatiefnemers lieten zich inspireren door Charity Organisation Cross uit Londen, dat in 1869 was opgericht. ${ }^{6}$ Een van de uitgangspunten was dat er onderzoek werd gedaan voordat steun werd verleend. Belangrijk was ook het afleggen van huisbezoeken. De opzet van Liefdadigheid Naar Vermogen (LNV) was, net als bij Charity Organisation Cross, om de armen zelfstandig te maken en niet om ze permanent te blijven ondersteunen. Dat probeerde men te bereiken door persoonlijke begeleiding en advisering. Geldelijke ondersteuning stond niet voorop. Eerst werd getracht mensen aan werk te helpen, of door het verstrekken van een renteloos voorschot enige financiële armslag te geven. Verder werd bevorderd dat de kinderen binnen het gezin scholing zouden krijgen. ${ }^{7}$

Voor de financiering van deze liefdadigheid was LNV afhankelijk van donateurs, hoofdzakelijk afkomstig uit de Amsterdamse burgerij. De meesten van hen hadden sociaalliberale ideeën. ${ }^{8}$ In het algemeen kan worden gezegd dat de sociaalliberalen in de jaren ' 80 en '90 niet alleen vernieuwende ideeën hadden over het opheffen van sociale misstanden, maar die ideeën ook in de praktijk brachten. ${ }^{9}$ Wat betreft de armenzorg stonden zij voor dat arme mensen zelfstandig werden en niet permanent afhankelijk zouden worden van steun. Het LNV maakte sinds 1891 gebruik van het 'Elberfelder stelsel' waarbij vrijwillige armbezoekers werden ingezet. We kunnen hierin de bakermat zien van het latere professionele maatschappelijke werk. ${ }^{10}$ De pionier van deze hulpverlening was Marie Muller-Lulofs (1854-1954). Ook voor haar was de economische zelfstandigheid van de armen het hoofddoel. "leder gezin", zo meende zij, "dat er door inspanning van eigen kracht had kunnen komen en toch door hulp van buiten zijn onafhankelijkheid prijs geeft, berokkent een onberekenbare schade, niet slechts aan zich zelf en zijn nakomelingschap, maar aan geheel de maatschappij".11 De wens om de armen zelfstandig te maken kan niet los worden gezien van de wens om hen beschaving bij te brengen. ${ }^{12}$ Een voorwaarde voor zelfstandigheid is immers dat men zijn impulsen kan beheersen.

Vatten we de nieuwe visie op armen samen, dan valt op dat er in Amsterdam vanaf 1870 naar oplossingen werd gezocht. Repressie van de armen, in de oude visie, maakte plaats voor opvoeding van de armen in het kader van het burgerlijk beschavingsoffensief. Die opvoeding was niet vrijblijvend, want degenen die zich, ondanks alle begeleiding, niet goed wisten te gedragen, kregen geen steun. arbeid, waardoor er geen werk meer is. 7) "de toenemende bevolking", door de toename van de bevolking wordt het aanbod van arbeid groter dan de vraag ernaar.

3 Rapport van de Algemeene commissie ter ondersteuning van behoeftigen aan Heeren Burgemeester en Wethouderen der stad Amsterdam (1847), 16. 4 Winkler Prins (1870), lemma Armoede.

5 Liefdadigheid Naar Vermogen wordt uitvoerig beschreven door De Regt (1984), 143-174. De Regt baseert zich op de jaarverslagen van LNV die vanaf het begin zijn opgesteld. Deze jaarverslagen zijn thans ondergebracht bij het Archief van de Stichting Zorg en Bijstand, SAA, toegangsnummer 509 . Limperg en Van der Linde (2019), 149-157, wijzen op de vernieuwingen die LNV in de armenzorg heeft doorgevoerd.

6 Initiatiefnemers waren Helen Bosanquet en Octavia Hill.

7 Van der Linde (2016), 186; Limperg en Van der Linde (2019),203-207.

8 Anders dan de doctrinair liberalen stonden de sociaalliberalen inmenging van de overheid toe. De sociaalliberalen vonden dat de overheid hulp mocht bieden aan individuele burgers zodat zij voldoende inkomen, een opleiding en een goede gezondheid konden genieten. In Nederland waren de "Radicalen" verenigd in de Radicale Bond uit 1892 onder leiding van de Amsterdammer Wim Treub. Slijkerman, (2016), 27-56. Nog steeds onmisbaar is de dissertatie van Taal (1980). NB Men verwarre deze radicalen niet met de radicalenbeweging in $\mathrm{Ne}$ derland uit de jaren '40 van de negentiende eeuw. 9 Smit (2015), 8, wijdt bijzondere aandacht aan deze groep sociale hervormers. 10 Van der Linde (2016), 187-188. 


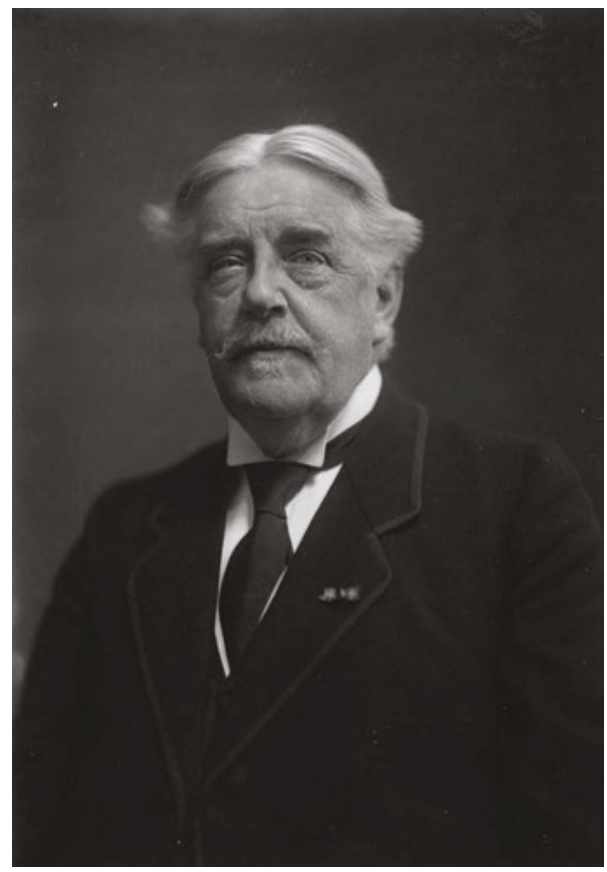

J.F.L. Blankenberg was voorzitter van Liefdadigheid naar Vermogen. Foto zonder datering, onbekende fotograaf. Bron: SAA. Beeldbank. Afbeeldingsbestand OSIM00006002140.

Afbeelding 6.2 M. G. Muller-Lulofs (1854-1954)

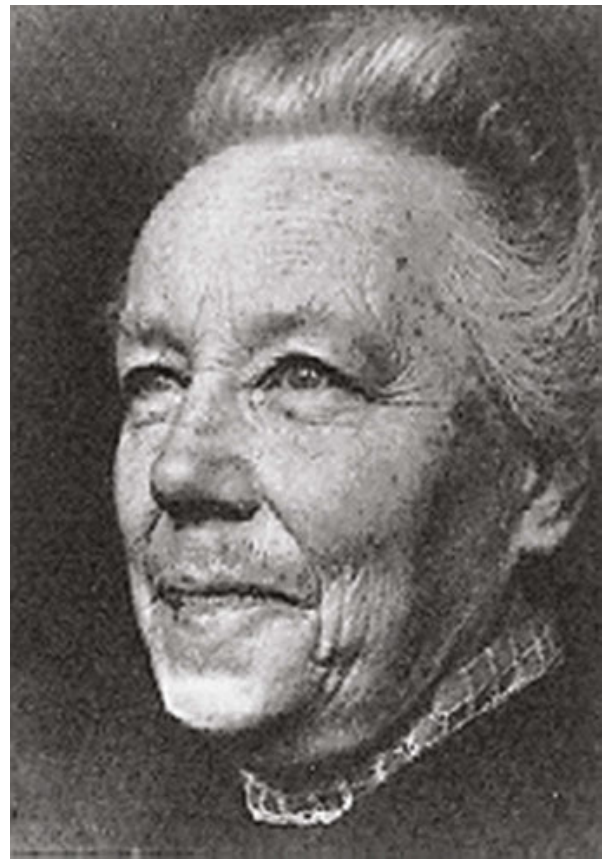

11 Eenige grondregels voor de praktijk der armverzorging. Rede gehouden op 11 december 1904 voor het genootschap Liefdadigheid naar Vermogen. Deze rede is gepubliceerd als M.G. Muller-Lulofs (1905).

12 De Regt (1984), 148-169.

Marie Geertruide Muller-Lulofs was de oprichtster van de eerste school voor maatschappelijk werk in Nederland. Foto zonder datering, onbekende fotograaf. Bron: Hogeschool van Amsterdam Muller-Lulofshuis. 


\section{c) Een visie vanuit de sociaaldemocratie}

Het beschavingsoffensief werd, zoals boven aangegeven, geïnitieerd door de nieuwe burgerij. Het waren de sociaalliberaal georiënteerde burgers die het voortouw namen. Daarnaast moet gewezen worden op de opkomst van de sociaaldemocratie, een politieke beweging die binnen de bestaande orde een sociale wetgeving voorstond. De Sociaal-Democratische Arbeiderspartij (SDAP) was, de naam zegt het al, een arbeiderspartij. Toch waren er ook veel burgers die zich tot de sociaaldemocratie voelden aangetrokken, ook al behoorden ze tot een hogere sociale laag dan de arbeiders. Deze groep vervulde een belangrijke rol binnen de SDAP. Bert Altena telde onder de 101 plaatselijke partijsecretarissen in 1903 maar 41 arbeiders. ${ }^{13}$ Zeker vanuit de groep van burgers binnen de sociaaldemocratie, ging een impuls uit tot beschaven. ${ }^{14}$ Ook sommige voormannen binnen de SDAP, zoals Wibaut, hadden een burgerlijke herkomst. Omdat na de invoering van het algemeen kiesrecht de sociaaldemocraten vooral in de grote steden voet aan wal kregen, kon het beschavingsideaal soepel opgenomen worden in het gemeentelijk beleid. Daardoor kon bijvoorbeeld het initiatief van de sociaaldemocraat Keppler om in Amsterdam verblijven te bouwen voor "ontoelaatbare" gezinnen geplaatst worden in het kader van het beschavingsoffensief. ${ }^{15}$

Uit het onderzoek van Selma Leydesdorff naar het Joodse proletariaat van Amsterdam tussen 1900 en 1940 blijkt dat het beschavingsoffensief vanuit sociaaldemocratische hoek opmerkelijk veel weerklank vond bij Joodse arbeiders. Zij stonden open voor disciplinering en voegden zich naar het beschavingsoffensief. Het onderzoek, dat past in de traditie van de oral history, is vooral gebaseerd op interviews met direct betrokkenen. "De interviews die hierover gehouden werden geven vooral een beeld van het succes van het beschavingsoffensief", merkt Leydesdorff op. ${ }^{16}$

\subsection{BESCHAVING BINNEN DE AMSTERDAMSE GEMEENTELIJKE AR- MENZORG: EMPIRISCH GEDEELTE}

\section{a) Inleiding}

Sporen van het burgerlijk beschavingsoffensief vinden wij terug in de rapporten van de armbezoeker van de gemeentelijke armenzorg. Op grond van deze rapporten werd over toekenning beslist. Het gaat om vragen en antwoorden over de staat van de woning, het gedrag van de gezinsleden en over de indruk die de armbezoeker heeft van het gezin. ${ }^{17}$ Tot slot bevatten de rapporten een advies over het toewijzen of afwijzen van de steunaanvraag. ${ }^{18}$ Het advies kon nog door een leidinggevende worden veranderd. In de praktijk ben ik niet tegengekomen dat het advies werd genegeerd. Dat betekent dat het advies van de armbezoeker als bindend kan worden beschouwd. ${ }^{19}$ De gegevens uit de rapporten heb ik integraal opgeslagen in een database. Deze gegevens zijn kwalitatief van aard, maar ik heb ze omgewerkt tot kwantitatieve data. In de tekst is overwegend beeldstatistiek weergegeven, terwijl in bijlage 8 cijfermatig materiaal in de vorm van tabellen te vinden is. Om deze statistische mededelingen meer concreet te maken heb ik citaten van de armbezoekers toegevoegd. Deze citaten illustreren de meningsvorming van de armbezoeker in een specifiek geval. De
13 Altena (1994), 540.

14 Een heldere uiteenzetting over de problematiek is te vinden in het proefschrift van Adang (2008), 51-69.

15 De Regt (1984), 215; Steinmetz, (2016). Ook in een recente biografie van Karsten (2019), 100-103, over A.H. Gerard, één van de twaalf oprichters van de SDAP in 1894, wordt de maatschappijvisie van Gerhard in verband gebracht met het burgerlijk beschavingsoffensief. 16 Leydesdorff (1987), 91-93.

17 Een overzicht van de geraadpleegde rapporten van de armbezoekers is te vinden in de opgave van bronnen.

18 Zie ook bijlage 1: Voorbeeld van een vragenlijst. $19 \mathrm{Na} 1936$ is dat mogelijk veranderd. Onder druk van crisis van de jaren ' 30 vergrootte het Rijk zijn invloed op het Amsterdamse beleid betreffende steunverlening. Het advies van de armbezoeker was niet langer zo bindend als voorheen; op kantoor werd de definitieve beslissing genomen. Uitspraak van Frans van Meurs (SDAP), wethouder belast met Maatschappelijke Steun en Levensmiddelen, in de gemeenteraad van 20 april 1939, geciteerd door De Rooy (1979), 203. 
meer algemene trend heb ik afgeleid uit het cijfermatig materiaal.

Ik heb vier elementen uit de rapporten geanalyseerd. Ik heb erop gelet in hoeverre die elementen meewegen als criterium om de arme steun toe te kennen of niet. Voorts heb ik geprobeerd na te gaan of de elementen in de loop van de tijd een andere betekenis kregen. Het gaat om de volgende elementen:

- het oordeel van de armbezoeker over de aanvragers;

- de indruk van de armbezoeker van de welstandscriteria van de woning;

- de indruk van de armbezoeker van de hygiëne van de woning;

- de motieven om een aanvraag af te wijzen: de afwijzingsgronden.

\section{b) Het oordeel van de armbezoeker over de aanvragers}

"De man doet weinig moeite om met wat meer werk iets te verdienen en zit meestal thuis. M.i. is het niet gewenscht hier hulp te verlenen." 20

Op het aanvraagformulier moest de armbezoeker onder meer verslag doen van de indruk die het gezin op hem makte. Uit de antwoorden valt op te maken dat onder "indruk" begrepen moet worden dat de armbezoeker zijn oordeel gaf over het gedrag van de steunaanvrager en zijn of haar gezinsleden. De armbezoeker verstrekt niet alleen cijfers, maar noteert ook wat hij waarneemt in het huishouden van de steunaanvrager. Aan de citaten valt af te lezen hoe de armbezoeker aankeek tegen de situatie.

Zo werd op 13 april 1871 een bezoek gebracht aan de weduwe Aleida Brandouw, die met haar vijf kinderen ongehuwd samenwoonde met een zekere J. Bon. De indruk die de armbezoeker van haar kreeg was "eene zeer ongunstige". Aleida werd verwezen naar de Hervormde Diaconie, die haar aanvraag op 9 mei 1871 afwees. ${ }^{21}$ De zeer ongunstige indruk leidde tot een afwijzing van de steunaanvraag.

Op 14 april 1871 had de 69-jarige David de Gee, die met zijn vrouw in de Baafjessteeg woonde, meer geluk. Dit gezin makte "een zeer nette indruk" en werd met een brood per week bedeeld. Bovendien werd door de armbezoeker opgemerkt dat hij het "door zijn ouderdom" wel verdiende "onderstand te incasseren". ${ }^{22}$ De zeer nette indruk die het gezin op de armbezoeker maakte en de hoge leeftijd van de aanvrager brachten de armbezoeker tot het advies om onderstand te verlenen.

Op 12 november 1871 werd een bezoek gebracht aan Hendrik Esselman, "los werkman nogal aan het Vriese Veem; ook spuitgast". Hij woonde met zijn vrouw en vijf kinderen aan de Lijnbaansgracht in "een vuile, ondiepe, waterachtige kelder". De armbezoeker kreeg geen gunstige indruk van

20 SAA 5256. Doos 1045. Stamboeknummer 12984. Dit was de indruk die de armbezoeker in 1911 kreeg van Johannes Wilhelmus Maria Warnier, een 32-jarige bakker.

21 SAA 5256. Doos 993.

Stamboeknummer 255. 22 SAA 5256. Doos 1175A. Stamboeknummer 13. 23 SAA 5256. Doos 1005. Stamboeknummer 1655. Hendrik, die op zondag "zijn kerkplichten" niet vervulde. Bovendien had de armbezoeker zijn licht opgestoken bij de werkgever van de steunaanvrager: "door informatie aan het Vriese Veem heeft de Heer Eilers verklaard dat Esselman wel hfl 8 tot 9 weeks kan verdienen als hij altijd bekwaam was om te werken, doch is veeltijds niet het geval door misbruik van sterken drank". Vanwege zijn drankmisbruik kreeg Hendrik geen steun. De armbezoeker had door het drankmisbruik van de aanvrager geen zicht op een gunstige verandering. ${ }^{23} \mathrm{Bij}$ de afwijzing speelde waarschijnlijk ook mee dat dat Hendrik op zondag niet naar de kerk ging.

Op 5 januari 1911 werd de aanvraag van de toen 32-jarige Geertrui- 
da Siepman afgewezen. Zij woonde met twee zonen en een dochter in de Czaar Peterstraat. De armbezoeker gaf een negatief oordeel, waarbij naast suggesties over de zedelijkheid het querulante gedrag en het in zijn ogen niet goed met geld omgaan van de aanvraagster een belangrijke rol speelde. Hij zag weinig hoop op verbetering.

"Aanvraagster heeft een ongunstig verleden. Tijdens haar huwelijk had zij reeds omgang met andere mannen en (dat) is (de) oorzaak dat haar man, die als bootwerker ruime verdiensten had, haar verliet en met een andere vrouw in onecht is gaan leven met wie hij nu gehuwd is. Van af dien tijd leeft aanvraagster samen met een zekere Van der Linden, rijwielhandelaar met 'n goed bestaan. Volgens opgaaf is laatstgenoemde bij haar als kostganger in huis en geeft hij hfl 6.00 per week wat volgens stellige informatien onjuist is. Deze vrouw is in de omgeving bekend als ruziemaakster en verkwistend." 24

Eveneens afgewezen werd op 1 augustus 1911 de aanvraag van de timmermansknecht Franciscus Gerardus Nicolaas Heerden. Hij was toen 76 jaar. De timmermansknecht woonde op de Rozenstraat met zijn vrouw en zijn 42-jarige ongehuwde zoon. Het drankmisbruik van beide mannen gaf weinig hoop op verbetering van hun toestand. De armbezoeker gaf de volgende karakteristiek:

"De man is timmermansknecht, de buren hebben hem nooit zien werken, doch wel drinken. Zij wonen reeds vele jaren aan dit adres. (De diaconie van de Hervormde kerk heeft steun) afgewezen wegens onchristelijke levenswandel. Zoolang vader en zoon misbruik maken van sterken drank is hulp m.i. niet noodig." 25

De steunaanvraag van Anna Maria Hôtes van 12 mei 1911 werd wel gehonoreerd. Anna Marie werd door de armbezoeker omschreven als "suffig en achterlijk". Zij woonde in een achterhuis op de Binnen Wieringerstraat met haar twee zonen van dertien en vijftien jaar. De armbezoeker noteerde:

"Wegens gebreken kan de vrouw niet het werk van een werkster in den vollen omvang verrichten. Als hulp in de huishouding hfl 3.25 met eenige kost. Vroeger heeft zij in onecht geleefd, doch werd door den man verlaten. Omtrent tegenwoordig gedrag geen bemerking geïnformeerd. De 15-jarige zoon is ziekelijk en achterlijk. Blijkens aangehecht bewijs gaat hij nog op school".26

Het gezin Hôtes werd gesteund met zomerbedeling tot 8 november 1911, bestaande uit hfl 1,75 en drie broden per week. Na 8 november 1911 kwam er nog winterbedeling bij, wat inhield dat het gezin bovenop de 1,75 en de drie broden ook briketten kreeg toebedeeld. In dit geval gaf bij de armbezoeker het gebrek aan inkomsten de doorslag en niet de onzedelijke levenswandel van de aanvraagster.

In de jaargroep van 1936 zien we nog maar zeer sporadisch dat de armbezoeker een oordeel geeft. In een enkel geval geeft de armbezoeker een oordeel, maar kennelijk speelt het geen rol in de beslissing.

Zo oordeelde de armbezoeker dat de 32-jarige alleenstaande Tjepke, een bouwkundig tekenaar bij de gemeente Amsterdam, weliswaar dat de "indruk gunstig" was, maar in de motivering van de beslissing om zijn hulpaanvraag toe te staan op 12 oktober 1936 worden alleen zakelijke argumenten gebruikt.
24 SAA 5256. Doos 1044. Stamboeknummer 12634. 25 SAA 5256. Doos 1045. Stamboeknummer 12872. 26 SAA 5256. Doos 1070. Stamboeknummer 11378. 
27 SAA 5256. Doos 7521. Stamboeknummer 164019 Ouderdomsrente werd in 1913 ingevoerd. Afhankelijk van de hoeveelheid ingelegde zegels konden personen vanaf 70 jaar een uitkering van bescheiden omvang ontvangen. In 1919 werd de leeftijd verlaagd tot 65 jaar

28 SAA 5256. Doos 7525. Stamboeknummer.164136. Uit overwegingen van privacy zijn enkel de initialen van de eerste voornaam van de betrokken weergegeven. Ook is afgezien van de vermelding van adresgegevens. In de bron zijn deze gegevens wel aanwezig. Het WG was het Wilhelmina Gasthuis, een ziekenhuis dat gevestigd was in de Eerste Helmersstraat.
"Aanvrager bouwkundig teekenaar van beroep werkte van 21-041926 tot 01-01 1930 als zodanig bij de Gemeente Amsterdam. Ontslag weegens overcompleet. Daarna bij diverse particuliere architecten. Wanneer hij bij zijn ouders was werkte hij vaak tijdelijk bij de Hollandsche Stoombootmaatschappij tussen 20-10-1932 tot 29-081936 met diverse onderbrekingen. De tusschenliggende tijd werkte hij meestal als colporteur, volgens opgaaf o.a. Pfaff naaimachines en Nilfisk stofzuigers. Na zijn ontslag op 29-08-1936 heeft de man geen verdiensten meer gehad en heeft hij nog eerst getracht met solliciteren een andere werkkring te bekomen. Reden waarvoor hij eerst 30-09-1936 MS (= Maatschappelijke Steun) werd aangevraagd. Volgens opgaaf woont de man vanaf Januari 1936 op zichzelf. Moeder overleden; vader 73 jaar. (Deze) geniet OR (= Ouderdomsrente) en woont bij gehuwde zuster te Leeuwarden. Volgens opgaaf geen levensverzekering, geen spaargelden. Indruk gunstig. Bij zijn ontslag op 31-08-1936 had aanvrager nog circa hfl 13.00. Hier is hij thans geheel doorheen en verzoekt spoedig hulp. Besluit: hfl 8,50 week geen brandstoftoeslag." 27

In de afhandeling van de fraude die de hoogzwangere 28-jarige $\mathrm{G}$. in het najaar van 1936 pleegde, komt geen spoor van een oordeel voor. Op 20 oktober 1936 maakte de armbezoeker dit zakelijke rapport op:

"Aanvraagster werkster van beroep is als zoodanig $4^{1 / 2}$ jaar werkzaam geweest bij de NV Vereenigde Maatschappij der Nederlanden Muntplein verdiende hfl 4,81 per week en werd in Maart jl. wegens reorganisatie ontslagen. Daarna heeft de vrouw geen verdiensten meer gehad en woonde tot voor vier weken steeds bij haar ouders. Zij heeft thans een slaapkamer gehuurd bij J. op vorenstaand adres, doch alleen met de bedoeling om voor steun in aanmerking te komen. Overdag is zij steeds bij haar ouders waar zij ook elken dag eet. De vrouw is hoogst zwanger en zal begin December voor bevalling in het WG worden opgenomen. (In december beviel de aanvraagster van een dochter, JAM). De verwekker zou een zekere W. zijn, die inmiddels is gehuwd (met een andere vrouw). Woont (in) de (...)straat en geniet steun MS. Het gesprek dat de zuster van maatschappelijk werk, Zr. Mengenberg, met de ouders had, is komen vast te staan dat de vrouw pro forma een kamertje huurde om onderstand te verkrijgen, terwijl er geen noodzaak aanwezig was, om uit huis te gaan. Besluit: afwijzen, ging afzonderlijk wonen om steun te krijgen, doch verblijft steeds bij haar ouders." ${ }^{28}$

Het oordeel van de armbezoeker zegt iets over zijn persoonlijke observaties. Het gaat niet om een objectieve vaststelling van de feitelijke toestand van de steunaanvragers. Daar zijn andere gegevens uit de aanvraag voor, zoals inkomsten, hoogte van de huur en huurschuld. Het geuite oordeel is dus subjectief te noemen. De bewoordingen van de verschillende armbezoekers lopen sterk uiteen. Om deze bewoordingen te kunnen duiden heb ik de uitspraken in twee categorieën verdeeld: positief en negatief.

Als de armbezoeker zich positief uitliet over de arme, dan hield dat in dat de aanvrager, volgens de armbezoeker, er blijk van gaf zijn armoedige 
toestand aan te willen pakken. Hij dacht na over een oplossing en deed pogingen zijn situatie te verbeteren. Hij of zij verdiende het daarom om geholpen te worden. De armbezoeker zag mogelijkheden bij de aanvrager. In zijn mening over de aanvrager klonk waardering door, wat tot uiting kwam in woorden als: "gunstig", "fatsoenlijk", "geen bemerkingen", "heel gunstig", "niets ongunstig", "niets dan gunstigs", "van onbesproken gedrag", "vrij gunstig", "werkende lieden".

Als de armbezoeker zich negatief uitliet over de arme, dan hield dat in dat de aanvrager, volgens de armbezoeker, zich niet of onvoldoende inzette om zijn armoedige toestand te verbeteren. Het gedrag van de arme gaf geen aanleiding om te denken dat er aan een oplossing werd gewerkt. Er was weinig uitzicht op verbetering. Als ongunstige factoren werden onder meer drankzucht en luiheid aangemerkt. De armbezoeker gebruikte bewoordingen als "hooghartig", "ongunstig", "ordeloos", "zeer ongunstig", "zeer vuil".

Had de mening van de armbezoeker invloed op de beslissing om al dan niet steun te verlenen? Om deze vraag te kunnen beantwoorden heb ik de mening van de armbezoekers over afgewezen aanvragen vergeleken met de mening van armbezoekers over toegekende aanvragen. In bijlage 8 zijn deze gegevens in tabelvorm terug te vinden (tabel 8.2 en tabel 8.3). In onderstaande grafieken 6.1 en 6.2 zijn de meningen van de armbezoeker samengevat.

Grafiek 6.1 Mening armbezoekers over de afgewezen aanvragen (1871, 1911 en 1936).

in percentages

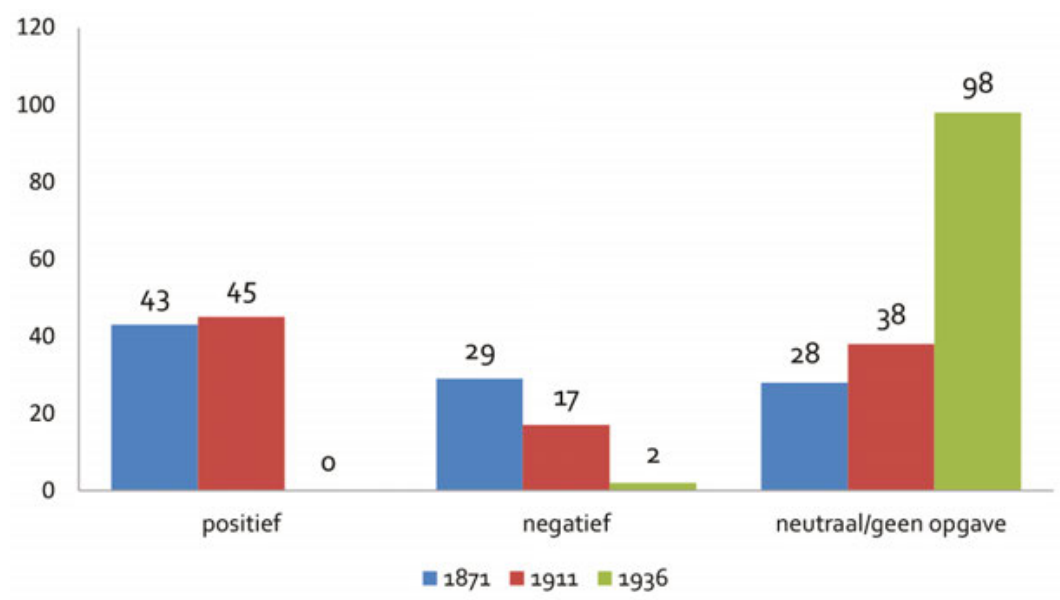

Bron: bijlage 8, tabel 8.2. 


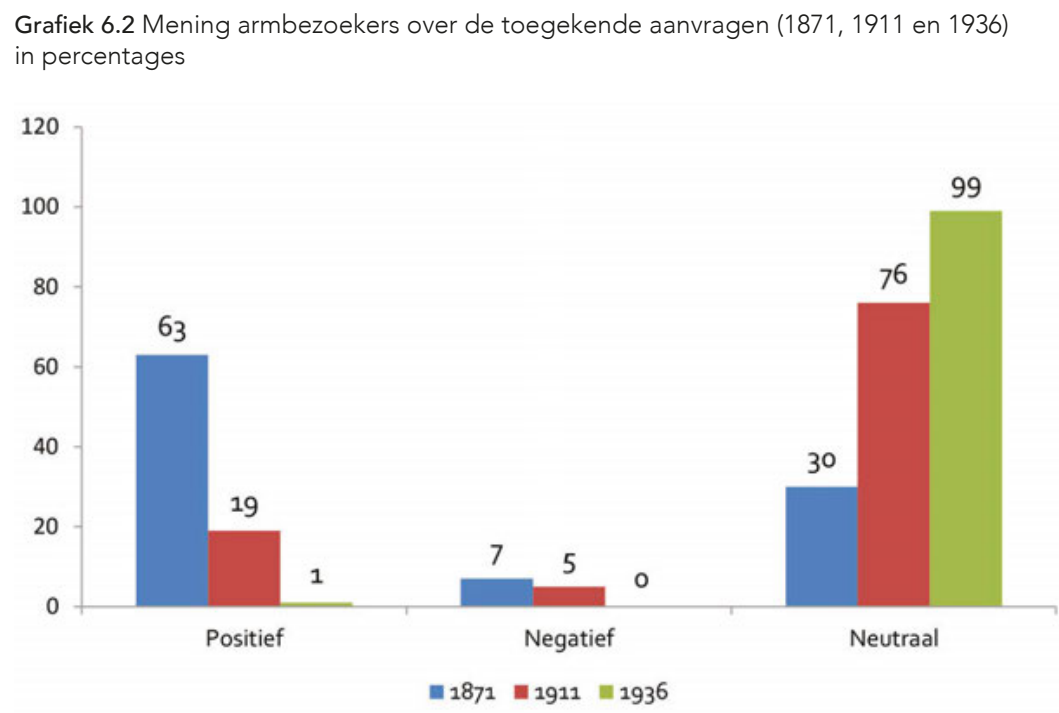

Bron: bijlage 8, tabel 8.3.

In 1871 hadden de armbezoekers over 29\% van de afgewezen aanvragen een negatief oordeel, terwijl het oordeel over de toegekende aanvragen in $7 \%$ van de gevallen negatief was. Dat betekent dat in 1871 een negatief oordeel een grotere kans op een steunafwijzing opleverde. De negatieve mening van de armbezoekers speelde een grote rol in de afweging een aanvraag (niet) toe te kennen. Als we kijken waarop precies werd gelet, dan zien we een meningsvorming die correspondeert met normen en waarden vanuit het burgerlijk beschavingsoffensief. Twee voorbeelden kunnen het verband met het burgerlijk beschavingsoffensief toelichten. Over het éénoudergezin van de 33-jarige Anna Maria Henriette Ruck ontving op 5 april 1871 de armbezoeker "niets dan gunstigen berichten". ${ }^{29}$ De inlichtingen van buren en werkgevers wezen op goed gedrag. De aanvrager was niet lui en verzorgde zichzelf en de woonomgeving goed. De aanvrager leidde volgens de normen van het burgerlijk beschavingsoffensief een deugdzaam leven. De aanvraag werd toegekend.

Het hanteren van de normen van het burgerlijk beschavingsoffensief kon ook tot afwijzing leiden. Over het gezin van Adriaanse de Groot, 62 jaar en uit Brabant afkomstig, meldde de armbezoeker op 12 april 1871 "dat zij zuiniger moesten leven, maar dat niet kunnen door (...) hun (...) vroegere leefwijze als poldergasten. ${ }^{30}$ In de ogen van de armbezoeker waren het "goede menschen", maar paste hun leefwijze niet bij hun verdiensten. Zij leidden volgens hem een verkwistend bestaan. Daarom werd het gezin niet deugdzaam bevonden. De aanvraag werd afgewezen.

In 1911 was het, net als in 1871, zo dat een negatief oordeel eerder leidde tot een afwijzing en een positief oordeel vaker leidde tot een toekenning, maar het is ook duidelijk dat de persoonlijke mening van de armbezoeker over de aanvrager inmiddels minder belangrijk was geworden. In

29 SAA 5256. Doos 1175A. Stamboeknummer 78. 30 SAA 5256. Doos 1000 . Stamboeknummer 2026. 1936 speelde de mening van de armbezoeker over de aanvrager amper nog een rol in de toekenning of afwijzing. Armbezoekers gaven in 1936 dergelijke oordelen ook nog maar hoogst zelden. 
Deze bevindingen wijzen op een ontwikkeling in de besluitvorming. De mening van de armbezoeker over het gedrag van de aanvrager werd steeds minder doorslaggevend. Uiteindelijk was die mening helemaal geen factor meer in de toekenning of afwijzing van hulp. Het oordelen op basis van gedrag, of sterker nog: het onthouden van steun vanwege ongewenst gedrag, een aanvankelijk zo belangrijk element uit het burgerlijk beschavingsoffensief, speelt geen enkele rol meer. Deze ontwikkeling wil ik ook aanvoeren als bewijs voor de rationalisering van de armenzorg. Objectieve gegevens zijn de basis geworden waarop toewijzingen en afwijzingen gegrondvest zijn. Deze ontwikkeling is ook terug te zien in de bewoordingen die de armbezoekers gebruikten bij hun beoordeling van de gezinssituatie: steeds neutraler en steeds minder aan waarden gebonden.

\section{c) De indruk van de armbezoeker van de welstandscriteria van de wo- ning}

Armbezoekers deden in 1871 en in 1911 nog verslag van de indruk die de woning van de aanvrager op hen maakte. In 1936 ontbraken deze observaties in de rapporten van de armbezoeker. De observaties lopen nogal uiteen. Er is een reeks typeringen die iets zegt over de welstand van de woning van de aanvrager, of het ontbreken daarvan. De typeringen die voor welstand werden gebruikt waren: "armoedig", "bekrompen en armoedig", "bijna niets aanwezig", "eenvoudig", "ellendige kuil", "gering", "goed gemeubeld", "in slechte staat", "redelijk gemeubeld", "weinig meubelen", "zeer arm" en "zonder meubelen".

Daarnaast waren er observaties die iets zeiden over de hygiëne van de woning van de aanvrager. Armbezoekers noteerden: "knap", "netjes", "niet knap", "nogal knap", "smerig", "tamelijk zindelijk", "vies", "vies en waterachtig", "zeer nette indruk", "zeer slordig" en "zindelijk".

In deze paragraaf ga ik in op de welstand van de woning van de aanvrager. In de volgende paragraaf komt de hygiëne van de woning aan de orde. Om te kunnen interpreteren welke indruk de woning maakte op de armbezoeker, heb ik een onderscheid gemaakt in woningen die als "armoedig" omschreven kunnen worden en woningen waarin "tekenen van welstand" te bespeuren waren. Deze tweedeling duid ik hieronder nader aan. Deze door mij gemaakte indeling moet naar de woonomstandigheden van het betreffende jaar worden geïnterpreteerd. Wie in 1871 en 1911 een "armoedige" woning had, leefde in armzalige omstandigheden, terwijl degene die in 1871 of in 1911 woonde in een huis dat "tekenen van welstand" vertoonde, beter af was.

Als "armoedig" beschouw ik woningen die door de armbezoeker zijn getypeerd als "armoedig", "bekrompen en armoedig", "bijna niets aanwezig", "ellendige kuil", "gering", "in slechte staat", "weinig meubelen", "zeer arm", en "zeer arm en zonder meubelen". Woningen die door de armbezoeker gekenschetst zijn als: "goed gemeubeld" en "redelijk gemeubeld" vertonen naar mijn opvatting "tekenen van welstand".

De notities van de armbezoeker over de welstand van de woning laten zien dat de woonomstandigheden meestal zeer matig waren. Dat is ook wat uit de literatuur bekend is. ${ }^{31}$ In de onderstaande citaten wordt een indruk gegevens van die woonomstandigheden.

31 Ottens (1975), 24. 
Bella Reguliers, een alleenstaande vrouw van 65 jaar (van "hoogbejaarde ouderdom") woonde in 1871 op de Kleersloot in een "bekrompen en armoedig kamertje". Zij probeerde in haar onderhoud te voorzien door te bedelen. Zij kreeg steun in de vorm van een brood per week. ${ }^{32}$

Matroos Jebbe Karman woonde in 1871 met zijn vrouw en drie kinderen op een achterkamer op de Achtergracht. De achterkamer was "bijna zonder meubelen". Het gezin kreeg hfl 1,00 steun per week. ${ }^{33}$

In 1911 woonde Antoinette Daken, weduwe van Jurriaan van Ankeren, in de Conradstraat. Een half jaar na het overlijden van haar man vroeg zij om hulp. De armbezoeker beschreef de woning als "zeer gering". De weduwe, die vijf kinderen had, kreeg bedeling in de vorm van geld, hfl 3,50 per week, zes broden en briketten voor de winter. ${ }^{34}$

De gegevens over de welstand van de woningen heb ik voor 1871 en 1911 in onderstaande grafieken 6.3, 6.4, 6.5 en 6.6 aanschouwelijk gemaakt. In bijlage 8 zijn de tabellen 8.4 en 8.5 te vinden, die voor deze grafieken de basis vormen.

Grafiek 6.3 Indruk armbezoekers van de woning van afgewezen aanvragers in 1871

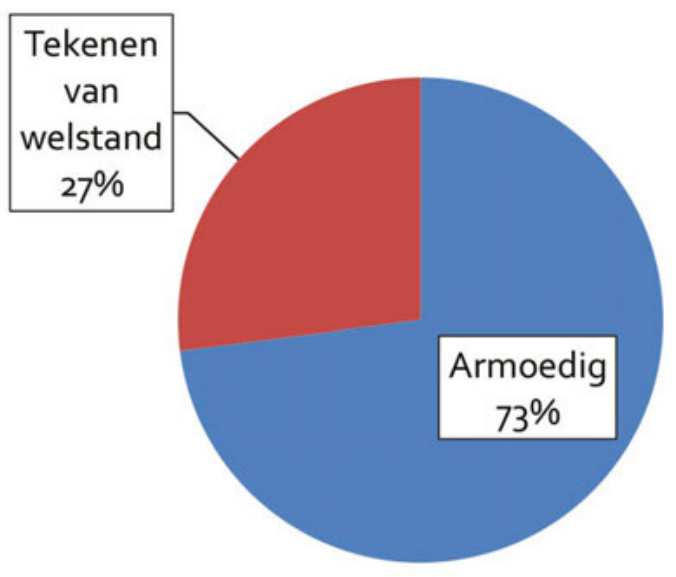

In 1871 zijn 63 huishoudens onderzocht, waarmee 278 personen zijn gemoeid. Van 13 huishoudens, 63 personen omvattend, deed de armbezoeker geen opgave.

Bron: bijlage 8 , tabel 8.4 . 


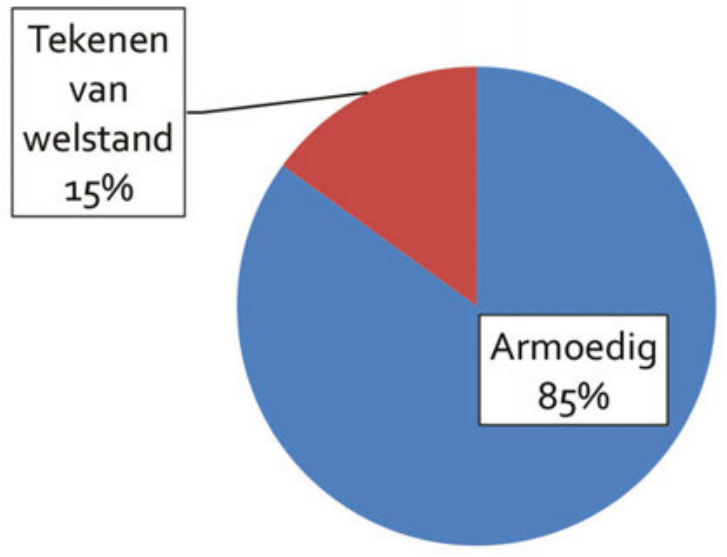

In 1871 zijn 61 huishoudens onderzocht, waarmee 209 personen zijn gemoeid. Van 25 huishoudens, 63 personen omvattend, deed de armbezoeker geen opgave.

Bron: bijlage 8, tabel 8.5 .

Grafiek 6.5 Indruk armbezoekers van de woning van afgewezen aanvragers in 1911

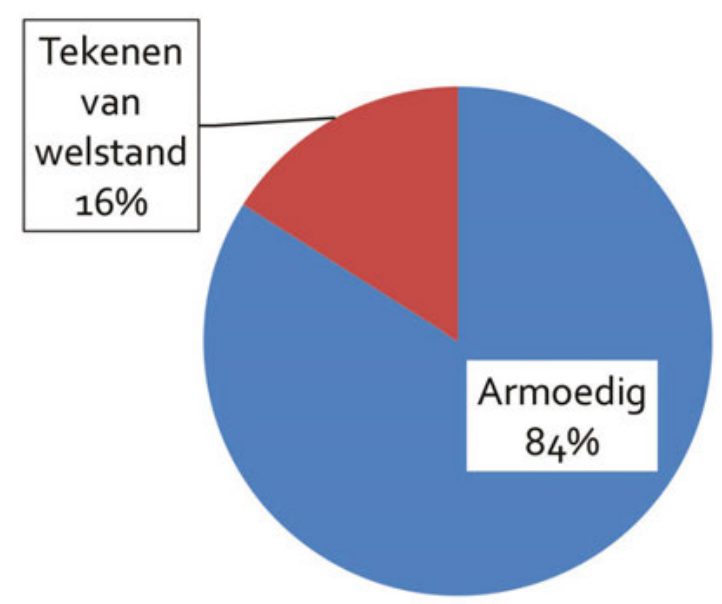

In 1911 zijn 75 huishoudens onderzocht, waarmee 260 personen gemoeid zijn.

Bron: bijlage 8, tabel 8.4. 


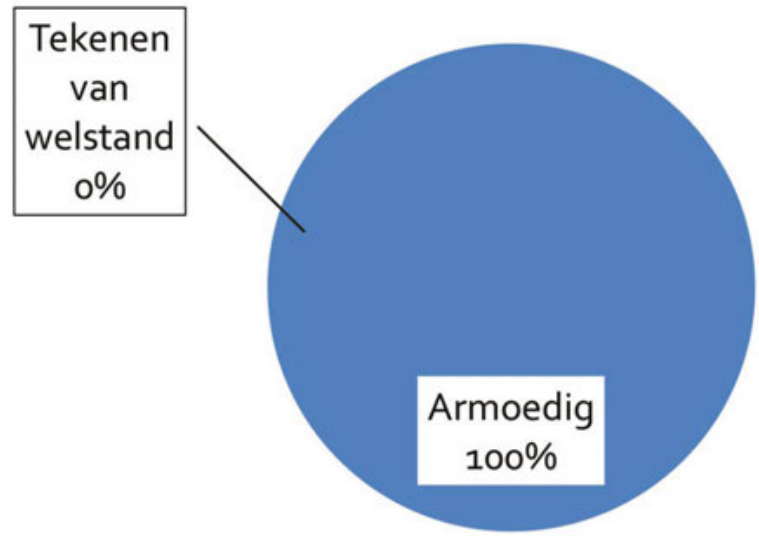

In 1911 zijn 60 huishoudens onderzocht, waarmee 177 personen gemoeid zijn. Bron: bijlage 8, tabel 8.5.

In 1871 vertoonden de woningen van de afgewezen aanvragers volgens de armbezoekers meer tekenen van welstand dan die van de toegekende aanvragers. Woningen van toegekende aanvragers vertoonden daarentegen een geringere welstand dan de woningen van de afgewezen aanvragers. Hoe meer tekenen van welstand door de armbezoeker werden bespeurd, hoe kleiner de kans dat de aanvragen werden toegekend. Omgekeerd gold ook dat tekenen van een armoedige woonomgeving de kans vergrootten dat een steunaanvraag werd gehonoreerd. De door de armbezoeker gehanteerde welstandscriteria waren subjectief. Zij weerspiegelden zijn opvattingen. ${ }^{35}$ Dat betekent dat er weinig zakelijke argumenten gebruikt werden bij de beslissing over een aanvraag.

Voor 1911 geldt hetzelfde als voor 1871: volgens de indrukken van de armbezoeker vertoonden de woningen van de afgewezen aanvragers meer tekenen van welstand dan die van de toegekende aanvragers. Ook in 1911 werden persoonlijke opvattingen van de armbezoekers aangevoerd in de besluitvorming omtrent een aanvraag.

In 1936 werden geen indrukken van de welstand van de woning meer vermeld. De indruk die de armbezoeker kreeg van de toestand van de woning speelde geen rol meer in de besluitvorming over toekennen of afwijzen. Je zou kunnen zeggen dat hierdoor de uiteindelijke beslissing verzakelijkt werd. Omdat welstand verband houdt met het bestedingspatroon van de aanvrager, zou het kunnen dat een oordeel over het bestedings-

35 Hierboven is al aangegeven dat in de praktijk het advies van de armbezoeker werd overgenomen. 36 De Regt (1984), 170 meldt dat armbezoekers onder andere signaleerden dat aanvragers "verkwistend" leefden. patroon ook niet meer werd uitgesproken. In het beschavingsoffensief van Liefdadigheid Naar Vermogen, was verstandig met geld omgaan nog een belangrijk beoordelingscriterium. ${ }^{36}$ Als er niet meer wordt geoordeeld over het bestedingspatroon, dan wijst dat op het afnemen van het belang van het element beschaving in de hulpverlening. Ook in dit opzicht vond verzakelijking plaats. 


\section{d) De indruk van de armbezoeker van de hygiëne van de woning;}

Er werd aandacht geschonken aan hygiëne omdat er verband werd gezien tussen hygiëne en bepaalde ziektebeelden. Vooral medici zagen een verband tussen huisvesting en gezondheid. ${ }^{37}$ De armbezoekers geven een indruk van de hygiëne van de woning van de aanvrager. Die indrukken laten een tweedeling zien: sommige woningen waren "onverzorgd", andere "hygiënisch". Ik beschouw de woningen als onverzorgd als er in de rapporten sprake is van "niet knap", "smerig", "vervuilde staat", "vies", "vies en waterachtig" en "zeer slordig". Ik beschouw de woningen als hygiënisch als er in de rapporten van de armbezoekers sprake is van woorden als "knap", "netjes", "nogal knap", "rein", "tamelijk zindelijk", "zeer nette indruk" en "zindelijk". Hieronder volgt een selectie uit de opmerkingen over hygiëne door de armbezoeker.

Zo woonde Ernst Geck in 1871 in een kelder waarover de armbezoeker opmerkte: "ziet er smerig uit". ${ }^{38}$ Zijn aanvraag werd afgewezen.

De 77-jarige Maria de Witte, die bij haar dochter inwoonde in de Kromelleboogsteeg kreeg in 1871 broodbedeling. "Door de hoog bereikte ouderdom en rein huis is (voor) deze persoon (...) bedeeling (...) noodzakelijk". 39

De 37-jarige weduwe Johanna Margaretha Monnik woonde in 1871 met drie zonen en een dochter op een achterkamer in de Egelantiersstraat. Deze achterkamer was "in een slechte en vervuilde staat". ${ }^{40}$ Omdat zij al door de Evangelisch-Luthersche gemeente werd bedeeld, kreeg zij geen steun van de gemeente.

Het gezin van Arnold Bruijnje woonde in 1871 in een "knappe kelder (...) die (...) zeer zindelijk was" volgens de armbezoeker. De kelder op de Kleine Wittenburgerstraat werd door zeven personen bewoond. Het gezin kreeg per week twee broden en turven toegekend. ${ }^{41}$

De woning van Pieter Commandeur Slijkerman in de Foeliedwarsstraat werd in 1871 door de armbezoeker omschreven als "behoeftig doch zindelijk". Het uit zes personen bestaande gezin kreeg bedeling in de vorm van geld. ${ }^{42}$

Het gezin van Klaas Egbertz Bulder woonde in 1872 in een "groote vuile achterkamer" in de Buiten Brouwersstraat. Het echtpaar woonde er met vijf kinderen. De aanvraag van Klaas werd mede afgewezen omdat hij, volgens een mededeling van zijn werkgever, een "groot liefhebber van sterken drank" was. ${ }^{43}$

De gegevens over de hygiëne van de woningen heb ik voor 1871 in onderstaande grafieken 6.7 en 6.8 aanschouwelijk gemaakt. In bijlage 8 zijn de tabellen 8.4 en 8.5 te vinden, die hiermee corresponderen.
37 Houwaart (1991), 264. 38 SAA 5256. Doos 1000. Stamboeknummer 2027. 39 SAA 5256. Doos 1175A. Stamboeknummer 16. 40 SAA 5256. Doos 1010. Stamboeknummer 4657. De wanhoop van de aanvrager is zichtbaar in de opmerking van de armbezoeker: "Ik was nog niet wel de kamer op of ze overstroomde mij met spulletje onder uit elkaar gooijen van oud kleed en de wollen deken met de bijvoeging 'ik heb het hoog noodig. Dit is alles wat ik heb om te slaapen en dan komt het er ook al niet in', maar naar het uiterlijk zou men zeggen dat zij ziek is en niet of ze drie maal daags niet goed eet". 41 SAA 5256. Doos 1010. Stamboeknummer 4657. 42 SAA 5256. Doos 1177 Stamboeknummer 207. 43 SAA 5256. Doos 993. Stamboeknummer 263. 
Grafiek 6.7 Indruk armbezoekers van de hygiëne van de woning van de toegekende aanvragers in 1871

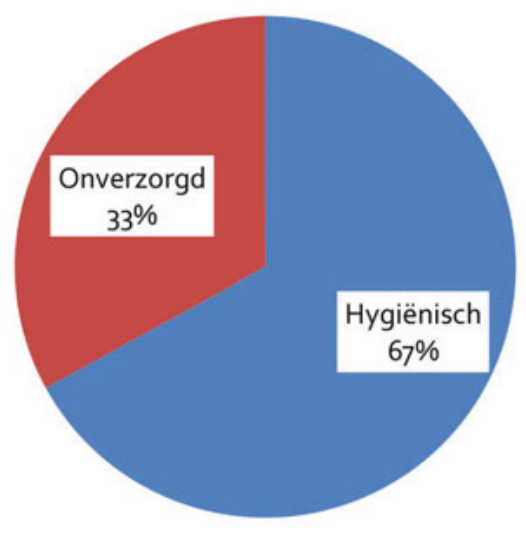

Bron: bijlage 8 , tabel 8.5 .

Grafiek 6.8 Indruk armbezoekers van de hygiëne van de woning van de afgewezen aanvragers in 1871

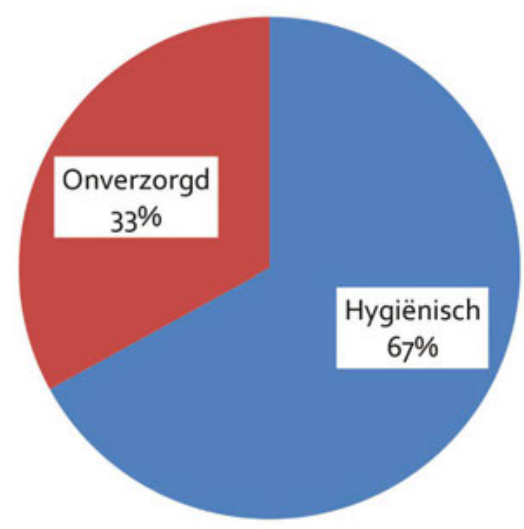

Bron: bijlage 8, tabel 8.4

Uit de hier gepresenteerde gegevens over de indruk die de armbezoekers kregen van de hygiëne van de woning blijkt, dat de geconstateerde hygiëne niet bepalend was voor het toekennen of afwijzen van aanvragen. In beide gevallen zijn de percentages gelijk. De armbezoekers waren wel geïnteresseerd in de hygiëne, maar de hygiënische toestand speelde kennelijk geen doorslaggevende rol in het toekennings- of afwijzingsbeleid. In 1911 en in 1936 werd de indruk over de hygiëne niet meer vermeld, zeer uitzonderlijke gevallen daargelaten. Dat zien we terug in het levensverhaal van Nicolaas Christiaan Cornelisse. Zijn woning werd in 1933 wegens ernstige vervuiling kosteloos gedesinfecteerd. Hij kreeg zelfs geld om nieuw beddengoed aan 
te kunnen schaffen. ${ }^{44}$ Omdat hygiëne meer zegt over het gedrag van de bewoner dan over de feitelijke armoede, zou ik willen beweren dat het verdwijnen van de beoordeling door de armbezoeker van de hygiënische situatie betekende dat er op een zakelijker manier naar de omstandigheden van de aanvragers werd gekeken in 1911 en 1936 dan in 1871.

\section{e) De afwijzingsgronden}

"Het is m.i. niet gewenscht deze jonge lieden te helpen". 45

In de rapporten van de armbezoeker worden bijna dertig argumenten gegeven om een aanvraag af te wijzen. In onderstaande tabel 6.1 zijn deze afwijzingsgronden verwerkt. Deze afwijzingsgronden heb ik in vier categorieën ondergebracht:

1) dubbele bedeling;

2) morele motieven;

3) neutrale motieven;

4) zakelijke motieven.

De Armenwet van 1854 bepaalde dat in eerste instantie de kerk steun verleende. Het primaat van de zorg lag dus bij de kerkelijke hulpinstanties. Verleende de kerk geen steun, dan kon de gemeente enkel "bij volstrekte onvermijdelijkheid" hulp verlenen. ${ }^{46}$ Hierdoor konden levensbedreigende situaties worden voorkomen. De gemeenteraad van Amsterdam nam in 1895 een besluit aan dat toestond dat een arme door meerdere instanties kon worden gesteund. Deze dubbele bedeling (1) was vanaf 1896 in Amsterdam van kracht. Dat hield in dat een arme tegelijk steun kon krijgen van de kerkelijke bedeling, van particuliere instellingen, zoals Liefdadigheid naar Vermogen, en van de gemeentelijke armenzorg.

De morele motieven (2) om geen steun te verlenen kwamen overeen met de idealen van het burgerlijk beschavingsoffensief. Gelet werd op het vertonen van goed gedrag. Wie niet in staat bleek te zijn zich conform deze idealen te gedragen, kreeg geen hulp. Het gaat onder meer om alcoholmisbruik, luiheid en onzedelijke gedragingen van de aanvrager of zijn familieleden. Als de kinderen niet naar school werden gestuurd, kon een aanvraag ook worden afgewezen. ${ }^{47}$ Op deze wijze was de armenzorg een instrument om "beschaafd" gedrag af te dwingen. De Amsterdamse handelswijze kwam overeen met een landelijk beleid, maar de "zwaarte van de gedragseisen verschilde van plaats tot plaats", aldus Van Leeuwen. ${ }^{48}$

De neutrale motieven (3) om af te wijzen zijn te typeren als administratieve motieven, die noch met beschaving noch met rationalisatie van doen hebben.

De zakelijke motieven (4) zijn motieven met een feitelijke achtergrond. $\mathrm{Er}$ is een zakelijk-objectiveerbare reden om een aanvraag af te wijzen. Deze motieven wijzen op een proces van rationalisatie en bureaucratisering.
44 Zie hoofdstuk 8. 45 SAA 5256. Doos 1044. Stamboeknummer 12639, met deze woorden wees in 1911 de armbezoeker de aanvraag van Harmen van der Meulen af. Harmen was los sjouwer in steenkolen. Hij woonde met zijn vrouw en drie kinderen op twee hoog achter in de Bloemstraat.

46 Volgens artikel 21 van de Armenwet van 1854:

"Geen burgerlijk bestuur mag onderstand verlenen aan armen dan na zich voor zoover mogelijk, te hebben verzekerd, dat zij dien niet van kerkelijke of bijzondere instellingen van weldadigheid kunnen erlangen, en dan slechts bij volstrekte onvermijdelijkheid". 47 In de verordening op het Burgerlijk Armbestuur over 'onderstand aan huiszittende armen' uit 1871 (SAA 5256) staat in artikel 22: "Het Burgerlijk Armbestuur kan aan het verlenen van onderstand aan personen met kinderen de voorwaarde verbinden dat zij verplicht zijn hun kinderen getrouw onderwijs te doen bijwonen". In de onderwijswet van 1878 werd deze bepaling voor heel Nederland nog eens aangescherpt: "gemeenten werd de plicht opgelegd de bedeling in te houden van hen, die hun kinderen onterecht de school lieten verzuimen." Boekholt en De Booy (1987), 153. 48 Van Leeuwen (1998)a, 314. 


\begin{tabular}{|l|l|}
\hline $\begin{array}{l}\text { Afwijzingsgrond in de } \\
\text { bron genoemd }\end{array}$ & Toelichting \\
\hline Dubbele bedeling & \multicolumn{2}{|l|}{$\begin{array}{l}\text { Kerk kan steunen of } \\
\text { verwijzen naar de kerk. }\end{array}$} & $\begin{array}{l}\text { Het is de armbezoeker gebleken bij navraag bij het kerk- } \\
\text { genootschap dat de aanvrager vermoedelijk voldeed } \\
\text { aan de voorwaarden om door zijn kerkgenootschap te } \\
\text { worden ondersteund. Deze voorwaarden verschilden } \\
\text { per kerkgenootschap. Voor de protestantse genoot- } \\
\text { schappen was het doen van belijdenis een voorwarde. } \\
\text { Na de belijdenis was de gelovige lidmaat. Men moest } \\
\text { een minimaal aantal jaren al lidmaat zijn om voor steun in } \\
\text { aanmerking te komen. Deze duur verschilde per kerkge- } \\
\text { nootschap. Katholieken waren minder streng. Wie trouw } \\
\text { zijn kerkelijke plichten vervulde, kwam in aanmerking } \\
\text { voor steun. }\end{array}$ \\
\hline Kerk steunt & $\begin{array}{l}\text { De gemeentelijke armenzorg vroeg informatie aan over } \\
\text { de steunverlening bij het kerkgenootschap van de aan- } \\
\text { vrager. Als er steun werd verleend, dan kreeg de aan- } \\
\text { vrager geen steun van gemeentewege. In voorkomende } \\
\text { gevallen kon de administratie van het kerkgenootschap } \\
\text { aangeven dat de aanvrager niet aan de voorwaarden van } \\
\text { het kerkgenootschap voldeed. In dat geval verleende de } \\
\text { gemeente alsnog steun. }\end{array}$ \\
\hline
\end{tabular}

\begin{tabular}{|l|l|}
\hline Morele motieven & $\begin{array}{l}\text { Op het "misbruik" van sterke drank stond als sanctie dat } \\
\text { er geen hulp werd verleend. De armbezoeker kwam vaak } \\
\text { achter dit misbruik door navraag te doen bij buren of de } \\
\text { werkgever van de aanvrager. }\end{array}$ \\
\hline Geen schoolbezoek & $\begin{array}{l}\text { De aanvrager moest briefjes laten zien van het Hoofd } \\
\text { der School dat de kinderen in de leeftijd van vijf tot } \\
\text { twaalf jaar de school geregeld bezochten. Dat gold ook } \\
\text { al in 1871 toen de leerplicht nog niet bestond. In Ne- } \\
\text { derland trad in 1901 een wettelijke leerplicht in werking } \\
\text { voor kinderen van zes tot twaalf jaar. Bij jonge kinderen in } \\
\text { de leeftijd van vier tot vijf jaar werd genoegen genomen } \\
\text { met een verzoek tot inschrijving bij een school. }\end{array}$ \\
\hline Luiheid & $\begin{array}{l}\text { Hier was het oordeel van de armbezoeker doorslagge- } \\
\text { vend. Was hij van mening dat de aanvrager zou kunnen } \\
\text { werken, maar te lui was om uit werken te gaan, dan werd } \\
\text { geen steun verleend. }\end{array}$ \\
\hline Ongunstig gedrag & $\begin{array}{l}\text { De armbezoeker won inlichtingen in over "ongunstig } \\
\text { gedrag" bij buren en werkgevers. Het veroorzaken van } \\
\text { overlast werd gezien als ongunstig gedrag, net als het } \\
\text { laten vervuilen van de woning, brutaliteit en het plegen } \\
\text { van huiselijk geweld. }\end{array}$ \\
\hline $\begin{array}{l}\text { Ontslag door eigen } \\
\text { schuld }\end{array}$ & $\begin{array}{l}\text { Als een aanvrager was ontslagen werd bij de werkgever } \\
\text { geinformeerd naar de reden van het ontslag. Was de } \\
\text { aanvrager door "eigen schuld" ontslagen, dan werd er } \\
\text { geen hulp geboden. }\end{array}$ \\
\hline
\end{tabular}




\begin{tabular}{|l|l|}
\hline Deelname staking & $\begin{array}{l}\text { Als bleek dat een aanvrager had deelgenomen aan een } \\
\text { staking, dan werd hem of haar geen steun verleend. } \\
\text { Staken werd door de overheid niet als deugdzaam be- } \\
\text { schouwd. In mijn onderzoekspopulatie waren het alle- } \\
\text { maal aanvragen uit 1911 die werden afgewezen. De aan- } \\
\text { vragers hadden deelgenomen aan de Spoorwegstaking } \\
\text { van 1903. }\end{array}$ \\
\hline Onzedelijkheid & $\begin{array}{l}\text { Het overtreden van de seksuele normen werd gezien als } \\
\text { onzedelijk gedrag. Overspel, mits bewezen, behoorde } \\
\text { hiertoe. De armbezoeker had er ook bezwaar tegen als } \\
\text { oudere broers en zusters in dezelfde kamer sliepen. }\end{array}$ \\
\hline
\end{tabular}

\begin{tabular}{|c|c|}
\hline \multicolumn{2}{|l|}{ Neutrale motieven } \\
\hline $\begin{array}{l}\text { Aanvrager heeft ande- } \\
\text { re uitkeringsinstantie }\end{array}$ & $\begin{array}{l}\text { In de loop van de twintigste eeuw kwamen naast de } \\
\text { traditionele armenzorg andere zorgarrangementen tot } \\
\text { stand. Het was niet de bedoeling dat de aanvrager die } \\
\text { al steun genoot ook nog eens door de gemeente zou } \\
\text { worden gesteund. }\end{array}$ \\
\hline $\begin{array}{l}\text { Aanvrager weggelo- } \\
\text { pen }\end{array}$ & $\begin{array}{l}\text { Het kwam voor dat de armbezoeker bij zijn bezoek aan } \\
\text { de aanvrager moest constateren dat de kostwinner was } \\
\text { weggelopen. In zo'n geval werd de aanvraagprocedure } \\
\text { niet voortgezet. }\end{array}$ \\
\hline $\begin{array}{l}\text { Door aanvrager be- } \\
\text { dankt }\end{array}$ & $\begin{array}{l}\text { Het kwam voor dat de armbezoeker bij zijn bezoek aan } \\
\text { de aanvrager te horen kreeg dat er geen behoefte meer } \\
\text { was aan steun. Het kon zijn dat intussen de omstandig- } \\
\text { heden waren verbeterd. Soms leidde de uitleg van de } \\
\text { armbezoeker over de procedure ertoe dat de aanvrager } \\
\text { besloot af te zien van verdere hulp. }\end{array}$ \\
\hline $\begin{array}{l}\text { Komt niet opdagen op } \\
\text { kantoor }\end{array}$ & $\begin{array}{l}\text { Tijdens het bezoek stelde de armbezoeker vragen om } \\
\text { tot een advies te komen. Soms was er nog aanvullende } \\
\text { informatie nodig. De aanvrager werd dan uitgenodigd } \\
\text { ten kantore te verschijnen om nadere inlichtingen te ver- } \\
\text { strekken. Het kwam voor dat een aanvrager om welke } \\
\text { reden dan ook niet verscheen. In dat geval werd de aan- } \\
\text { vraagprocedure stopgezet. }\end{array}$ \\
\hline Niet de juiste instantie & $\begin{array}{l}\text { In } 1911 \text { en in } 1936 \text { kwam het voor dat er andere instanties } \\
\text { waren voor de zorgvraag en dat men bij de armenzorg } \\
\text { niet aan het juiste adres was. }\end{array}$ \\
\hline Terug in gezin & $\begin{array}{l}\text { Als de kostwinner van het gezin, meestal de echtgenoot, } \\
\text { het gezin had verlaten, kon het achtergebleven volwas- } \\
\text { sen gezinslid een beroep doen op de gemeentelijke ar- } \\
\text { menzorg. Soms keerde de kostwinner terug naar het ge- } \\
\text { zin. Dan hoefde er niet langer steun te worden verleend. } \\
\text { De armbezoeker stelde pogingen in het werk om deze } \\
\text { terugkeer te bevorderen, omdat het gezin als de ideale } \\
\text { samenlevingsvorm werd gezien. }\end{array}$ \\
\hline
\end{tabular}

Zakelijke motieven

Aanvrager nam zelf ontslag

Als de aanvrager ontslag had genomen, kon hij geen aanspraak maken op steun. Hij had zelf deze nadelige situatie veroorzaakt.

Aanvrager heeft inmiddels werk

Als bij het bezoek van de armbezoeker bleek dat dat de aanvrager inmiddels werk had, werd de steunaanvraag stopgezet. 


\begin{tabular}{|c|c|}
\hline Overlijden aanvrager & $\begin{array}{l}\text { Bij de komst van de armbezoeker kon blijken dat de } \\
\text { aanvrager inmiddels was overleden. De steunprocedure } \\
\text { werd dan niet voortgezet, maar soms was het nodig, bij } \\
\text { gebrek aan geld, dat de overledene van gemeentewege } \\
\text { werd begraven. }\end{array}$ \\
\hline $\begin{array}{l}\text { Aanvrager verstrekt } \\
\text { geen inlichtingen }\end{array}$ & $\begin{array}{l}\text { De armbezoeker vroeg tijdens het bezoek om inlichtin- } \\
\text { gen om de aanvraag te beoordelen. Als hij geen ant- } \\
\text { woord kreeg op relevante vragen, bijvoorbeeld naam en } \\
\text { adres van de werkgever, of geen loonopgave kreeg te } \\
\text { zien, dan werd de aanvraag niet voortgezet. }\end{array}$ \\
\hline Fraude in opgaven & $\begin{array}{l}\text { Als een aanvrager onjuiste opgaven verstrekte, bijvoor- } \\
\text { beeld over de loonhoogte, dan werd de aanvraag niet } \\
\text { voortgezet. Omdat de aanvraagformulieren altijd wer- } \\
\text { den bewaard, was het voor de armbezoeker een reden } \\
\text { om extra alert te zijn op fraude als deze aanvrager een } \\
\text { hernieuwde aanvraag indiende. }\end{array}$ \\
\hline Vermoeden van fraude & $\begin{array}{l}\text { De armbezoeker heeft een sterk vermoeden dat er door } \\
\text { de aanvrager fraude is gepleegd. Ook als de fraude niet } \\
\text { werkelijk kon worden bewezen, kon de armbezoeker, na } \\
\text { goedkeuring door de leidinggevende, besluiten de aan- } \\
\text { vraag af te wijzen. }\end{array}$ \\
\hline $\begin{array}{l}\text { Aanvrager kan (tijde- } \\
\text { lijk) inwonen bij familie }\end{array}$ & $\begin{array}{l}\text { De noodsituatie waarin de aanvrager verkeerde kon (tij- } \\
\text { delijk) worden opgelost door bij familie te gaan inwonen. }\end{array}$ \\
\hline Ziekenhuisopname & $\begin{array}{l}\text { Indien de aanvrager in een ziekenhuis werd opgenomen, } \\
\text { werd de steun - tijdelijk - opgeschort. In de regel werd } \\
\text { de steun bij terugkeer naar huis weer voortgezet. }\end{array}$ \\
\hline $\begin{array}{l}\text { De aanvrager kan wor- } \\
\text { den opgenomen }\end{array}$ & $\begin{array}{l}\text { De omstandigheden van de aanvrager waren zodanig } \\
\text { dat hij of zij moest worden verpleegd. Van de huiszitten- } \\
\text { de armenzorg ging de aanvrager naar de gestichtsver- } \\
\text { zorging. De aanvraag om hulp door de gemeentelijke } \\
\text { (huiszittende) armenzorg kon daardoor worden stopge- } \\
\text { zet. }\end{array}$ \\
\hline $\begin{array}{l}\text { Onderhoudsplichtigen } \\
\text { (kunnen) steunen }\end{array}$ & $\begin{array}{l}\text { Formeel moesten familieleden in de eerste en tweede } \\
\text { graad verarmde familieleden steunen. In de praktijk } \\
\text { kwam dat maar sporadisch voor: de familieleden van } \\
\text { de eerste of tweede graad waren zelf vaak ook arm of } \\
\text { hadden een groot gezin. Het kwam ook voor, vooral in } \\
1871 \text {, dat uitstedige familieleden niet traceerbaar wa- } \\
\text { ren. In enkele gevallen werden familieleden gedwongen } \\
\text { tot steunverlening. Deze procedure was omslachtig en } \\
\text { kostbaar. Wel kwam het voor dat de arme af en toe mee } \\
\text { kon eten bij familieleden. Dat leidde meestal niet tot het } \\
\text { onthouden van steun. }\end{array}$ \\
\hline $\begin{array}{l}\text { Verwezen naar wees- } \\
\text { huis }\end{array}$ & $\begin{array}{l}\text { Verweesde kinderen werden door de armbezoeker naar } \\
\text { een weeshuis gestuurd. Alleen in } 1871 \text { kwamen deze ge- } \\
\text { vallen voor in mijn onderzoekspopulatie. }\end{array}$ \\
\hline Aanvrager kan werken & $\begin{array}{l}\text { De armbezoeker zag geen reden waarom de aanvrager } \\
\text { niet zou kunnen werken. }\end{array}$ \\
\hline
\end{tabular}




\begin{tabular}{|c|c|}
\hline $\begin{array}{l}\text { Aanvrager woont nog } \\
\text { geen jaar zelfstandig }\end{array}$ & $\begin{array}{l}\text { Als in } 1936 \text { een jongere het ouderlijk huis had verlaten } \\
\text { om zelfstandig te gaan wonen, dan had hij of zij pas na } \\
\text { een jaar de mogelijkheid om steun te verkrijgen. Op } \\
\text { deze categorie aanvragen werd speciaal gelet, omdat } \\
\text { er bij de armenzorg wel eens woonadressen werden op- } \\
\text { gegeven waar de aanvrager niet bleek te wonen. Hij/zij } \\
\text { woonde in de praktijk nog thuis en niet bij de oom of } \\
\text { tante waar hij/zij voorgaf te wonen. De armbezoeker kon } \\
\text { dit eenvoudig controleren door navraag te doen bij de } \\
\text { burgerlijke stand. (Dat was overigens in alle gevallen - in } \\
1871,1911 \text { en in } 1936 \text { - een standaardprocedure: bij alle } \\
\text { aanvragen werd gecontroleerd bij de burgerlijke stand } \\
\text { of de aanvrager daadwerkelijk op het door hem of haar } \\
\text { opgegeven woonadres woonde volgens de toenmali- } \\
\text { ge gemeentelijke basisadministratie. Bij de burgerlijke } \\
\text { stand kon ook het opgegeven kindertal worden gecon- } \\
\text { troleerd. Al in } 1871 \text { stond de burgerlijke stand als zo } \\
\text { betrouwbaar bekend, dat deze controle waterdicht te } \\
\text { noemen is.) }\end{array}$ \\
\hline Leeftijd & $\begin{array}{l}\text { In } 1871 \text { kwam het voor dat de armbezoeker de leeftijd } \\
\text { van de aanvrager te laag vond om te worden onder- } \\
\text { steund. }\end{array}$ \\
\hline Voldoende inkomsten & $\begin{array}{l}\text { De armbezoeker berekende bij zijn bezoek de inkom- } \\
\text { sten van de huishouding. Wanneer de inkomsten als toe- } \\
\text { reikend werden beoordeeld, werd geen steun verleend. }\end{array}$ \\
\hline
\end{tabular}

Na deze lange opsomming van afwijzingsgronden die ik in de door mij geraadpleegde bronnen heb teruggevonden, volgen enkele voorbeelden van afwijzingen.

Op 12 april 1871 werd aan het gezin van Adrianus de Groot, bestaande uit "goede menschen", geen steun verleend door het Burgerlijk Armbestuur. Het werd verwezen naar het Roomsch Catholijk Oude Armen Kantoor. ${ }^{49}$

Eveneens in april 1871 werd de aanvraag van Pieter Geukens afgewezen. $\mathrm{Hij}$ was inwonend bij Maria Wilhelmina van Velzen op het Lange Hol. ${ }^{50} \mathrm{Hij}$ was door haar "uit medelijden hier ingenomen". Hoewel Pieter in een "in eene behoeftigen omstandigheid" verkeerde, kreeg hij geen steun omdat hij "zijn echtgenote Grietje Smit verlaten had". ${ }^{51}$ Pieter leefde buitenechtelijk samen, en pleegde dus overspel, waardoor hij de toenmalige zedelijke normen overtrad.

De afwijzing van Anna Christina Meyer op 20 december 1871 werd door de armbezoeker als volgt onderbouwd:

"Bij mijn aantreden reeds een slechte indruk gewaar geworden, door een meisje of vrouw, dat mij verdacht voorkwam. De partij was niet te huis, werd dadelijk ingelicht dat zij in de kelder niet lang zou wonen en naar het Wijngaardstraatje zou verhuizen. Spoedig kwam zij te huis en vernam van haar dat zij er een man op na had gehouden. Doch om zijn drinken sedert had weggezonden. Wel dadelijk begrijpende dat het daar van Sint Anna onderliep, ben ik daarna spoedig bij fatsoenlijke bovenburen gaan informeren en ben tot de waarheid gekomen dat het hier een hoerenhoek is dat er vandaag hier morgen soms zeven of acht meiden daar komen konkelen. Dat haar man wel misschien in bed zou leggen of aan de Nieuwe Brug zou staan en dat de partij een hoerenwaard is. En dat het zonde zou indien dat
49 SAA 5256. Doos 1000 Stamboeknummer 2026. 50 Het Lange Hol, ook wel kortweg Hol genoemd, was een steeg in de Sint Nicolaasstraat.

51 SAA 5256. Doos 1000. Stamboeknummer 2063. 
52 SAA 5256. Doos 1010. Stamboeknummer 4651; de verwijzing naar Sint Anna, de moeder van de Heilige Maagd en patrones der zwangeren, maakt duidelijk dat hier iets niet in de haak is met de zedelijkheid en de kuisheid. Destijds, in de negentiende eeuw, luidde het spreekwoord "Daar loopt iets van St. Anna onder". Hiermee werd bedoeld dat een ongehuwde vrouw zwanger zou zijn wat in strijd was met de goede zeden. (Uitgebreide uitleg in Stoett (1923-1925), 35-36.)

53 De Land van Beloftesteeg was een steeg in de Duvelshoek, een buurtje tussen de Vijzelstraat, de Reguliersbreestraat, het huidige Rembrandtplein en de Reguliersdwarsstraat. 54 SAA 5256. Doos 997.

Stamboeknummer 1305. 55 SAA 5256. Doos 1045. Stamboeknummer 12879 56 SAA 5256. Doos 1045. Stamboeknummer 12922 57 SAA 5256. Doos 1045. Stamboeknummer 12930. 58 SAA 5256. Doos 1045. Stamboeknummer 12986 dit volk ondersteuning kreeg". ${ }^{52}$

De indruk van onzedelijkheid die de armbezoeker kleurrijk verbeeldde, was het belangrijkste argument om niet te steunen.

In het volgende voorbeeld speelde een zedenkwestie ook een doorslaggevende rol bij het afwijzen van de aanvraag. Op 28 november 1871 werd de aanvraag van Barbara Duyves, een ongehuwde moeder van 41 jaar, niet gehonoreerd. Zij woonde met drie kinderen in een "klein huisje" in de Land van Beloftesteeg. ${ }^{53}$ De afwijzing werd gemotiveerd vanwege de "zeer ongunstige indruk met het oog op de levenswandel van haar thans achttienjarige dochter". Bovendien werd door de armbezoeker opgemerkt, volgens informatie van buren, dat Barbara "thans nogal werk maakt om den wijkpredikant". ${ }^{54}$

Op 18 augustus 1911 werd de aanvraag van Nicolaas Antonius Claassen afgewezen. "Hij geniet een levenslange rente van de RVB (Rijksverzekeringsbank)". Verder merkte de armbezoeker op dat Nicolaas lichaamsgebreken vertoonde: "mist een oog, loopt gebrekkig; en (is) veel bedlegerig". Over de huiselijke situatie werd gemeld:

"Een ruw wanordelijk huishouden. Ondanks dat de man zeer gebrekkig is ten gevolge van een hem vroeger overkomen ongeval is hij een liefhebber van een borrel. Een en ander is oorzaak dat zij bij een inkomen van ongeveer hfl 14.00 per week niet kunnen rondkomen en schijnt deze aanvraag om onderstand meer op initiatief van den 20 -jarigen zoon te hebben plaatsgevonden".

Volgens de armbezoeker was hier "bedeeling dan ook geheel misplaatst. Zij kunnen zich zelf best redden". ${ }^{55}$ Dat betekent dus dat er een zakelijk, financieel motief als doorslaggevend argument werd aangevoerd voor de beslissing.

Willem Hoogkamp vroeg in 1911 voor zijn vrouw versterkende middelen. Deze aanvraag werd afgewezen. De vrouw was al geruime tijd ziek, wat het gezin op extra uitgaven was komen te staan, maar dat leek de armbezoeker niet onoverkomelijk:

"het gezin is niet groot (echtpaar met twee kinderen) en het gemiddelde inkomen is van dien aard ( $\mathrm{nl}$. hfl 15,25 per week) dat men m.i. daarvan de voorgeschreven versterkende middelen zelf wel kan bekostigen". ${ }^{56}$

De gescheiden Wilhelmina Kobus, 58 jaar oud, kreeg in 1911 geen steun. Als reden gaf de armbezoeker op dat zij een weekinkomen had van hfl 2,00 door haar werkzaamheden als werkster en breister. ${ }^{57} \mathrm{Zij}$ kon zichzelf wel bedruipen, meende hij:

"De vrouw, die er voor haar leeftijd nog flink uitziet, kan zich m.i. in verband met hare verdiensten, wel buiten hulp dezerzijds redden".

Ook de gezusters Alida en Johanna Maria Bakker die samenwoonden in de Schoolstraat, kregen geen steun. Alida was "gebocheld, rheumatisch en leed aan nierziekte". De wekelijkse verdiensten bedroegen hfl 5,75, "bestaande uit hfl 0.75 steun van de RK kerk; de inwonende zuster Johanna Maria verdient als werkster $\mathrm{hfl} 3.00$ week; er is een legaat $\mathrm{hfl} 2.00$ per week." De armbezoeker oordeelde:

"Volgens de houding dezer beide vrouwen komt men tot de overtuiging dat hier de nood nog niet zoo nijpend is. Volgens de omgeving is hiervan ook niets merkbaar, ondanks dat zij reeds verscheidende jaren aan dit adres woonen". ${ }^{58}$ 
Het verzoek om hulp voor het gezin van Thomas Jan Christiaan Blom, die door de echtgenote IJtje Zoeteman in 1911 werd gedaan, vond evenmin gehoor.

"De man is van beroep boekbinder bij de firma J.H. de Buys. Hij maakt nu en dan misbruik van sterken drank. De vrouw is zonder beroep. Zij verzoekt lossen van panden, nl. kindergoed. Volgens opgaaf verdient haar man hfl 13.00 per week en heeft zij meermalen goed naar de bank van leening moeten brengen, omdat zij niet uitkwam met haar huishoudgeld. Volgens informatie werkt de man al 15 jaar bij dezelfde firma en verdient hfl 15.00 week".

De armbezoeker kwam tot deze, zakelijk gefundeerde conclusie:

"Waar een vaste verdienste is van hfl 15.00 week, komt het mij zeer ongewenscht voor hun aanvraag toe te staan. Met het oog op een op handen zijnde bevalling verzoekt de vrouw een spoedige beslissing." ${ }^{19}$

Voor zijn motivering van de afwijzing van de aanvraag van Neeltje R. had deze armbezoeker in 1936 wel erg veel tekst nodig.

"Aanvraagster is sedert 02-08-1913 weduwe. Na de dood van haar echtgenoot, die bode bij de Gemeente Telefoon was, ontving zij pensioen. Op het ogenblik bedraagt dat hfl 320.00 per jaar. Van 1914 tot 1930 had zij samenleving met Klaas L., geb. 15-02-1886. In 1914 vertrok zij met genoemde L. naar IJmuiden waar men een waschinrichting begon. Dit vrije huwelijk, waaruit twee kinderen werden geboren, werd in 1930 verbroken, toen L. een relatie met een 21-jarig meisje aanknoopte. De vrouw heeft nadien in eigen onderhoud voorzien. Met haar thans 21-jarige dochter werkte zij eenige jaren bij de Wasscherij Verschoor, Snelliusstraat 36 te IJmuiden. Toen zij daar in 1934 zonder (inkomsten) kwam, ging zij kamers verhuren en kostgangers houden, terwijl de dochter van 02-03-1935 tot 28-08-1936 werkzaam was bij de stoomwasscherij "Femina", Regentesselaan 40 Haarlem ad hfl 11.50 per week. Toen aanvraagster met het verhuren van kamers niet langer in haar onderhoud kon voorzien trok zij in April 1936 naar Amsterdam, in de veronderstelling hier spoedig werk te vinden. Inderdaad kwam zij als huishoudster in betrekking bij mej. J.A.M. op de Ceintuurbaan, een onderwijzer. Salaris had zij hier niet, alleen kost en inwoning. Werkgeefster deed de ondervinding op dat aanvraagster geregeld familieleden ten eten vroeg en daar dit door haar niet volgehouden kon worden, deelde zij aanvraagster mede dat zij alleen de woning en broodkost in ruil kon geven. Hiermede ging de aanvraagster niet accoord. Zij nam, medio Augustus 1936, ontslag en huurde een woning aan ommestaand adres. (Eerste van der Helststraat, JAM) Haar 21-jarige dochter Klasina die in Haarlem werkte als hierboven vermeld, nam op 29-08-1936 ontslag, omdat zij liever in Amsterdam wilde wonen. Zij heeft zich nog steeds niet laten afschrijven in Haarlem, staat ter stede NIET ingeschreven."

$\mathrm{Na}$ dit lange relaas besloot de armbezoeker tot afwijzing van de steunaanvraag omdat beide vrouwen vrijwillig ontslag hadden genomen. "Zowel aanvraagster als haar dochter namen ontslag uit hun betrekking. Het komt mij gewenscht voor voorloopig hulp af te wijzen".60

Deze afwijzing is zakelijk te noemen.

In de jaargroep 1936 heb ik één geval gevonden waarin een aanvraag op morele gronden werd afgewezen. Het betrof de afwijzing van mevrouw N. ${ }^{61}$ Deze aanvraagster was toen 26 jaar. Zij werkte als buffetjuffrouw, maar
59 SAA 5256. Doos 1045. Stamboeknummer 12989. 60 SAA 5256. Doos 7520. Stamboeknummer 163986. 61 Uit overwegingen van privacy gebruik ik enkel de initiaal van de achternaam van de betrokkene. In de bron worden wel al haar persoonlijke gegevens vermeld. 
62 Koninklijke Nederlandsche Stoomboot-Maatschappij.

63 De Paardenstraat en de Wagenstraat behoorden in 1936 tot het uitgangsgebied van het Rembrandtplein. Dit gedeelte van het plein had destijds een minder gunstige reputatie. 64 Het GAB is de Gemeentelijke Arbeidsbeurs. Werkzoekenden konden zich bij deze instantie inschrijven. 65 SAA 5256. Doos 7521. Stamboeknummer 164022. kon haar werkzaamheden niet voortzetten, naar eigen zeggen wegens hartklachten.

"Aanvraagster geeft op voor haar huwelijk in diverse zaken gewerkt te hebben als winkeljuffrouw. Op 26 Februari 1931 gehuwd met de heer G. kantoorbediende bij de KNSM. ${ }^{62}$ Haar kind werd geëcht, de man beweert echter dat het kind niet van hem is. De vrouw was veel uithuizig, waardoor men dikwijls oneenigheid had. Echtscheiding werd aangevraagd en uitgesproken 30-11-1934. De vrouw verliet het gezin en ging wonen aan de Paardenstraat no. 9 inwonend bij Moddi. Bij onderzoek bleek dat aan dit adres gevestigd is een bar met minder goede reputatie. De vrouw voorzag hier in eigen onderhoud als buffetjuffrouw. Zij was o.a. werkzaam in 't café van mevr. Bakker, Wagenstraat t.o. no 10 waarbij zij volgens opgaaf 7 tot $8 \mathrm{hfl}$ week verdiende. ${ }^{63}$ De vrouw is in Maart 1935 weer met haar gescheiden man gaan samenleven. Man en vrouw konden echter niet met elkaar opschieten, men had herhaaldelijk ruzie. Aanleiding hiertoe was dat de vrouw 's avonds nooit thuis was en de huishouding niet naar behoren verzorgde. Gevolg was dat de vrouw voor eenige weken met het kind haar man verliet. Thans vraagt zij voor zich en haar kind steun aan. De vrouw toont flink, zou zeer wel weer aan 't werk kunnen gaan als buffetjuffrouw, staat echter niet bij de GAB ingeschreven. ${ }^{64} \mathrm{Zij}$ wil niet meer naar haar man terug. Ook haar man wil de vrouw niet meer in huis nemen."

De aanvraag werd afgewezen, waarbij de armbezoeker het volgende opmerkte: "hoewel de vrouw niet direct bekend staat als prostituée, wijst het etablissement waar zij werkzaam was, erop dat zij daar als animeerjuffrouw fungeerde. Onderzoek had als resultaat dat zij 'in het Milieu' nog connecties heeft, zoodat m.i. gewenscht is de vrouw voorloopig af te wijzen". ${ }^{65}$

De argumenten die door de armbezoekers werden opgevoerd om niet tot bedeling over te gaan, heb ik in onderstaande grafiek 6.9 aanschouwelijk gemaakt. In tabel 8.7 wordt deze grafiek cijfermatig onderbouwd.

Grafiek 6.9 Afwijzingsgronden naar categorieën (1871, 1911 en 1936)
in percentages

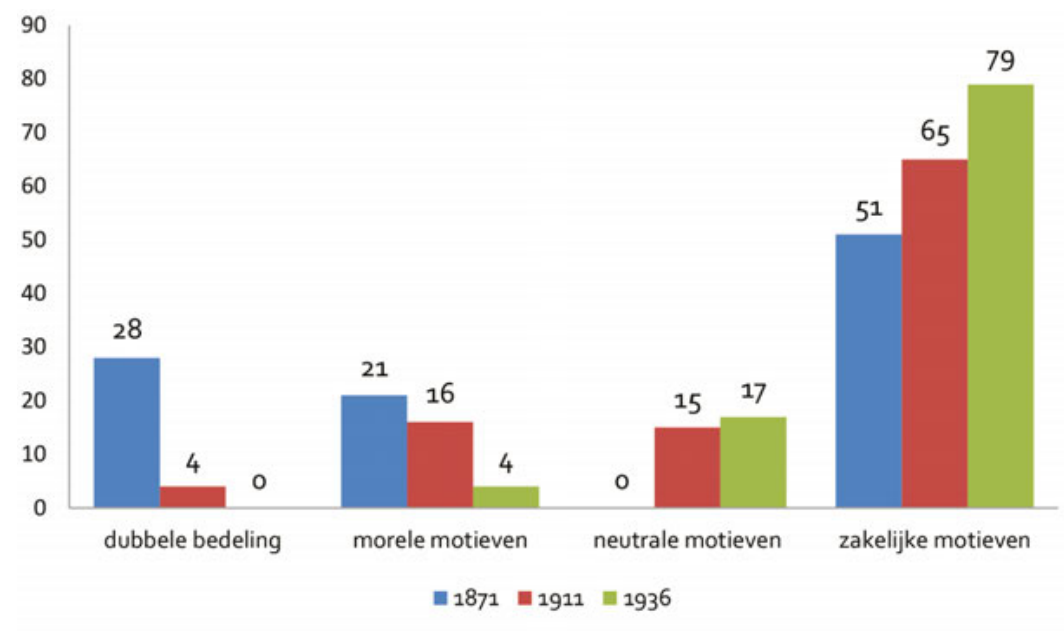

Bron: bijlage 8, tabel 8.7 . 
Overzien we de verschillende criteria dan valt op dat in 1871 de helft van de steunafwijzingen was gebaseerd op zakelijke gronden. Duidelijk is dus dat al in 1871 zakelijke, rationele besluitvorming plaatsvond. Afwijzing van hulpaanvragen op basis van morele motieven kwam in bijna een kwart van de gevallen voor. Omdat volgens de armenwet van 1854 gemeenten verplicht waren "bij volstrekte onvermijdelijkheid", dus in levensbedreigende situaties, hoe dan ook steun te verlenen, zijn het aantal afwijzingen op morele gronden in 1871 hoog te noemen.

In 1911 nam de zakelijk gefundeerde motivatie om steunaanvragen af te wijzen toe: $65 \%$ van de aanvragen werd op zakelijke gronden afgewezen. In deze ontwikkeling zie ik een proces van verzakelijking van de afwijzingsgronden. Kerkelijke, morele en zedelijke motieven werden steeds minder belangrijk. In 1936 voerden zakelijke motieven de boventoon in de afwijzingsgronden. Morele motieven kwamen nog amper ter sprake. De steunverlening werd rationeel en uniform, zonder aanzien des persoons.

\subsection{VERANDERENDE LEEFOMSTANDIGHEDEN VAN DE ARMEN}

De leefomstandigheden van de armen zijn tussen 1870 en 1940 sterk veranderd. Hun algemene ontwikkelingspeil is flink toegenomen, maar dat is niet alleen toe te schrijven aan de activiteiten van de gemeentelijke armenzorg. Er waren meer dragers van het beschavingsoffensief. Allereerst waren er de zogeheten volksverheffers, een benaming die Christianne Smit heeft gegeven aan een groep particulieren die zich inzette voor sociale zorg in de breedste zin van het woord voor de onderste lagen van de samenleving. ${ }^{66}$ Deze volksverheffers waren vooral actief vanaf de jaren zeventig van de negentiende eeuw. De overheid, in eerste instantie op gemeentelijk niveau, nam allengs de werkzaamheden van deze particulieren over. De nachtwakersstaat van rond 1850 werd in de twintigste eeuw langzaam maar zeker een verzorgingsstaat. Naast de volksverheffers zijn kerkorganisaties altijd al hoeders van de beschaving geweest. Voor gelovigen was de morele standaard een belangrijk richtsnoer in het dagelijks leven. De voor deze studie geraadpleegde bronnen laten niet toe iets te zeggen over de precieze invloed van de kerkorganisaties.

Leefomstandigheden zijn ook veranderd door de toename van de welvaart tussen 1870 en 1940. De arbeidersbeweging had een belangrijk aandeel in de verandering van de leefomstandigheden van de lagere sociale groepen, de armen daarbij inbegrepen.

Een van de oorzaken van de veranderde leefomstandigheden is de ontwikkeling van het reële loon. ${ }^{67}$ Vanaf de jaren zestig van de negentiende eeuw steeg het reële loon substantieel. Deze stijging hield in de onderzoeksperiode 1870-1940 nog geruime tijd aan, met een onderbreking tijdens de Eerste Wereldoorlog. Ten gevolge van de economische crisis kwam er aan die stijging een einde tijdens de jaren dertig van de twintigste eeuw. ${ }^{68}$ Volgens Van Zanden daalden de reële lonen na 1933. ${ }^{69}$

Mede onder invloed van de arbeidersbeweging verbeterden de arbeidsomstandigheden gedurende de onderzoeksperiode 1870-1940. Hierbij valt te denken aan de beperking van de lengte van de arbeidsdag en aan zaken die de veiligheid op de arbeidsplek verbeterden.

De geldelijke steun aan armen in Amsterdam door de gemeentelijke ar-
66 Smit (2015), De volksverheffers, 378-386. 67 De Jonge (1968), 290295; Van Riel (2018), 544: "sustained gains in real earnings did not get underway until the $1860 \mathrm{~s}^{\prime \prime}$. 68 De onderbreking in de jaren dertig zien we terug in de daling van de loonvoet. De loonvoet is de gemiddelde ontwikkeling van de verdiende lonen bij de bedrijven. Voor de periode 1933 tot 1939 is een negatieve ontwikkeling van de loonvoet berekend: Drukker (1990), 300-303. 69 Van Zanden (1997), 110. 
menzorg werd aanzienlijk verruimd vanaf de jaren twintig van de twintigste eeuw tot aan 1933. Dat wordt in onderstaande grafiek 6.10 aanschouwelijk gemaakt. De cijfers geven de steunbedragen per jaar aan. De armen ontvingen elke week steun. Ik moet erop wijzen dat deze grafiek impressionistische trekken heeft en niet meer dan een globale indicatie geeft van de uitkeringsverruiming. Om meer te kunnen zeggen over de fluctuaties in de steunbedragen door de jaren heen zou nader onderzoek verricht moeten worden.

Grafiek 6.10 Gemiddelde ondersteuning per huishouden (1917-1939)

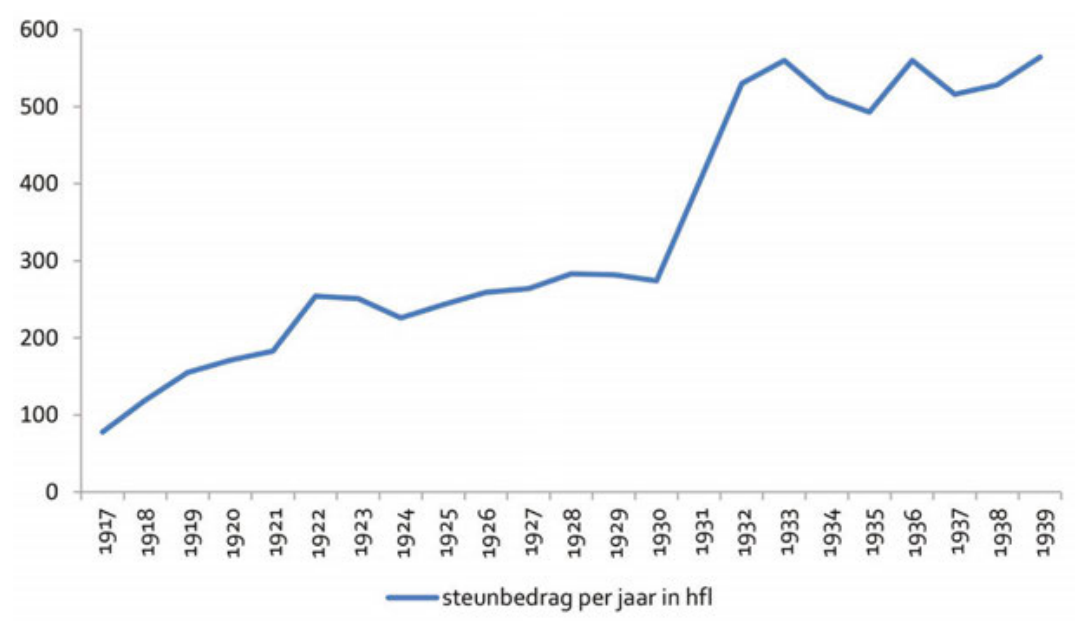

Bron: bijlage 8, tabel. 8.13.

Aan de hand van het archiefmateriaal dat ik heb bestudeerd wil ik vier terreinen nader belichten, waarin een toenemende mate van beschaving en een verbetering van de leefomstandigheden valt te bespeuren. Ik schenk aandacht aan de volgende zaken: de huisvesting van de armen, de medische gesteldheid van de armen, de scholingsgraad van de armen en het schoolbezoek door kinderen van de armen.

\section{a) De huisvesting}

"Staat der woning: zeer klein en donker in een gang, bijna zonder meubelen". ${ }^{70}$

In de rapporten van de armbezoeker werd onder het kopje "staat der woning" informatie gegeven over de woonomstandigheden van de aanvrager. Zo bewoonde in 1871 wagenmaker Bernardus Dijkman "een huisje in een slop, maar nogal ruim zoodat er een werkbank aan het raam staat". ${ }^{71}$

70 SAA 5256. Doos 1177. Stamboeknummer 201, zo werd de woning van Neeltje Rauchbaar omschreven in 1871. Zij woonde met vier dochters in deze gang. 71 SAA 5256. Doos 997. Stamboeknummer 1307.
De 31-jarige Cornelia Veldhuis woonde in december 1871 in een gang. Zij was in januari 1871 door haar echtgenoot Saake Kraak verlaten. Zij bleef achter met uit een vorige buitenechtelijke relatie voortgekomen negenjarige dochter en een vijfjarige zoon. Na de verlating werd op 1 augustus 1871 een tweede kind, een dochter, uit het huwelijk met Saake geboren. De arm- 
bezoeker meldt in december 1871 dat de gangwoning weinig comfortabel was. "De woning (een gang) ziet er doodarmoedig uit. Haar jongste kind (van vijf maanden) ligt midden op de grond bij een komfoor met vuur in een doek gewikkeld (om) dit te verwarmen. De uiterste armoede heerscht". ${ }^{72}$

Willem Frederik Kramer woonde in 1871 in een achterkamer op het Kattengat. Deze achterkamer werd bevolkt door zeven personen: het echtpaar Kramer en hun vijf kinderen. ${ }^{73}$ Johan Andries Burger woonde in 1871 in een huisje in een gang. Dit gezin telde acht personen: het echtpaar Burger en zes kinderen. ${ }^{74}$ Martinus van de Meij woonde in 1917 op één hoog in een huurwoning in de Kanaalstraat met zijn vrouw en drie kinderen. ${ }^{75}$. In 1936 woonde Fije $\mathrm{O}$. in een huurwoning op drie hoog aan de Jacob van Lennepkade. Hij woonde daar met zijn vrouw en dochter. ${ }^{76}$

De gegevens over de woning van zowel afgewezen als toegekende aanvragen zijn hieronder in grafiek 6.11 aanschouwelijk gemaakt. De corresponderende tabel 8.8 is te vinden in bijlage 8 .

Grafiek 6.11 Aard van de woning (1871, 1911, 1936)

in percentages

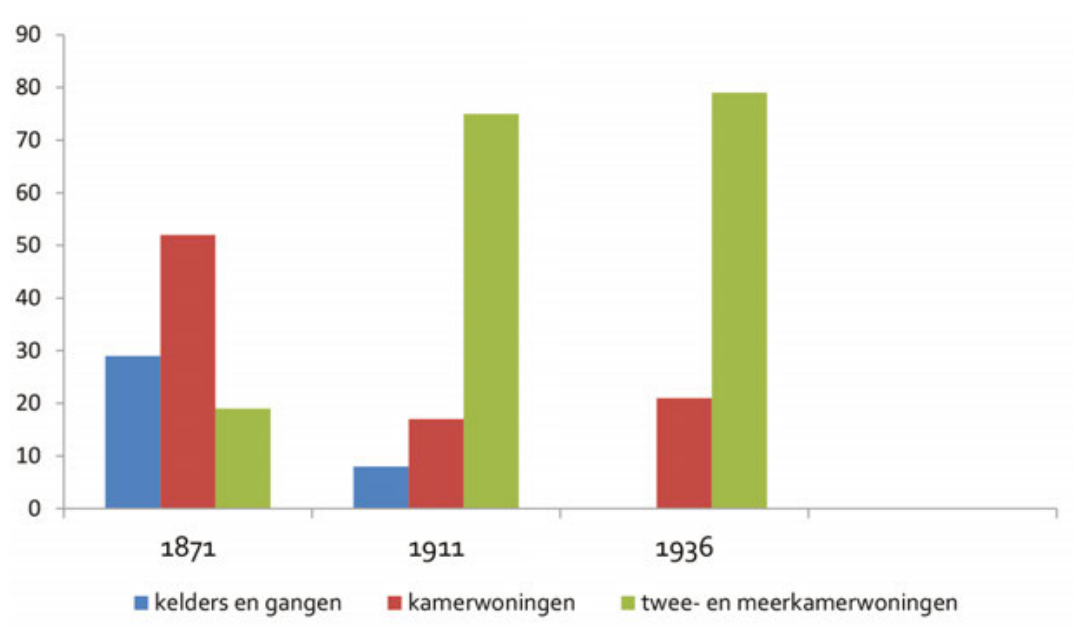

Bron: bijlage 8, tabel 8.8 .

De woonomstandigheden van de hulpzoekenden zijn tussen 1871 en 1936 drastisch veranderd. In 1871 woonde bijna een derde van de aanvragers nog in kelders en gangen die ook naar de maatstaven van die tijd als onwenselijke woonplekken werden beschouwd. ${ }^{77}$ Een gang was letterlijk een afgesloten deel van een gang in een meestal groter huis. Deze ruimte werd door een compleet gezin bewoond.

Een kamerwoning is een woonruimte bestaande uit één vertrek, waarin alle woonfuncties moesten worden vervuld. Onder een twee- of meerkamerwoning wordt een woonruimte verstaan waarin een scheiding van woonfuncties mogelijk is. In 1936 woonde bijna driekwart van de aanvragers in dit soort woningen.

Tussen de aanvragers die wel hulp kregen en de aanvragers die werden afgewezen bestonden verschillen in zowel 1911 als 1936. In 1911 woonden meer afgewezen dan toegekende aanvragers in kamerwoningen. Hetzelfde
72 SAA 5256. Doos 1177. Stamboeknummer 243. 73 SAA 5256. Doos 1177. Stamboeknummer 266. 74 SAA 5256. Doos 993. Stamboeknummer 260. 75 SAA 5256. Doos 1045. Stamboeknummer 12995. 76 SAA 5256. Doos 7525. Stamboeknummer 164141. 77 Van Tijn (1965), 115-116; 281-283. 
gold voor 1936.

De ontwikkeling van de woonomstandigheden in Amsterdam heeft verschillende achtergronden. Van Tijn wees er in zijn dissertatie op dat rond 1850-1860 de woningen waarin de lagere sociale groepen woonden, verkrot genoemd konden worden. ${ }^{78}$ Sommige beter gesitueerde tijdgenoten waren zich bewust van deze situatie. In 1851 richtten de Amsterdamse notabelen mr. J. Messchert van Vollenhoven (officier van justitie), J. van Eik (pakhuismeester) en C.P. van Eeghen (bankier) een zogeheten adres, een verzoekschrift, aan een aantal vooraanstaande Amsterdammers. Het doel was de slechte woonomstandigheden in de stad te verbeteren. Het ging om een materiële verbetering, maar het achterliggende motief was het bestrijden van onzedelijkheid en ander ongewenst gedrag. Deze motivering hoort thuis in het burgerlijk beschavingsoffensief. Het drietal meende dat "het gebrekkige der woningen" ervoor zorgde dat gezonde mensen vaak de hort op gingen en dat door het gebrek aan ruimte "de onzedelijke zamenwoning een broeibed wordt van zoo menige schrikelijke zonde". ${ }^{79}$ Het resultaat van hun adres was de oprichting in 1852 van een particuliere bouwmaatschappij onder de naam "Vereeniging ten behoeve der Arbeidersklasse te Amsterdam". Deze vereniging, de eerste woningbouwvereniging van Nederland, had als doel geschikte woningen tegen redelijke huurprijzen beschikbaar te stellen aan arbeiders. Het initiatief van de Vereniging kreeg een vervolg. Al in 1853 werd in Amsterdam woningbouwvereniging Salerno opgericht. In latere jaren kwamen daar de bouwmaatschappijen Concordia, de Bouwkas en Maatschappij tot het verkrijgen van Eigen Woningen nog bij. Tijdens de jaren '90 van de negentiende eeuw nam de invloed van de Vereniging af. De stijgende grondprijzen maakten het haar moeilijk om op grote schaal te bouwen. Daar kwam nog bij dat in 1902 de Woningwet, aangenomen in 1901, van kracht werd. Vanaf die tijd werd de mogelijkheid geboden om met overheidssteun huizen te bouwen. Naast deze financiële injectie van overheidswege was voor de kwaliteit van de woningen van groot belang dat de gemeente een nieuw instrument in handen kreeg: de bevoegdheid om een woning onbewoonbaar te verklaren. De betekenis van de Woningwet is verregaand: het particuliere initiatief werd overgenomen door de overheid. $\mathrm{Na}$ de invoering van de Woningwet maakte de gemeente Amsterdam zich sterk voor de volkshuisvesting. Men wilde dat de lagere sociale groepen ook goed kwamen te wonen. Ik hoef alleen maar te wijzen op de uitbreiding van de stad volgens het tweede plan van Berlage uit 1917, het Plan West uit 1922 en het Algemeen Uitbreidingsplan van 1936.80

De woonomstandigheden van de steunaanvragers moeten verder gezien worden tegen de achtergrond van de ontwikkeling van de woningvoorraad. In tabel 8.27 van de statistische bijlage is die ontwikkeling tussen 1859 en 1930 goed te zien. De huizenvoorraad is verdubbeld, waarbij wel aangetekend moet worden dat een huis door meer dan één huishouden bewoond kan zijn, bijvoorbeeld als het gaat om een huis met etages. Het

78 Van Tijn (1965), 113-114 79 Beekers (2012), 23. Overgenomen citaat van Beekers uit het adres van 1851.

80 Een eerste indruk biedt De Rooy, (2007)c. percentage onbewoonde huizen is afgenomen. De druk op de huizenvoorraad is toegenomen. Deze druk is nog eens vergroot omdat de gemiddelde gezinsomvang aanzienlijk is gedaald. Er worden steeds minder kinderen geboren en die daling zou na de Tweede Wereldoorlog alleen maar voortgezet worden. Het aantal kinderen per gezin nam af, terwijl tegelijk het aantal 
alleenstaanden (vrijgezellen, maar ook weduwen en weduwnaars die niet hertrouwden) toenam. De woningvoorraad werd niet alleen groter, maar ook nam de kwaliteit van de woningen toe. Deze kwalitatieve ontwikkeling komt overigens in de tabel niet aan bod.

Om een idee te krijgen van de aanvankelijk vaak zo povere woonomstandigheden van de aanvragers zijn enkele afbeeldingen toegevoegd. Deze afbeeldingen zijn niet representatief voor de groep aanvragers als geheel. De foto's tonen vooral de minder gunstige woonsituaties.

Afbeelding 6.3 Goudsbloemgracht en Franschepad: situatie voor 1854

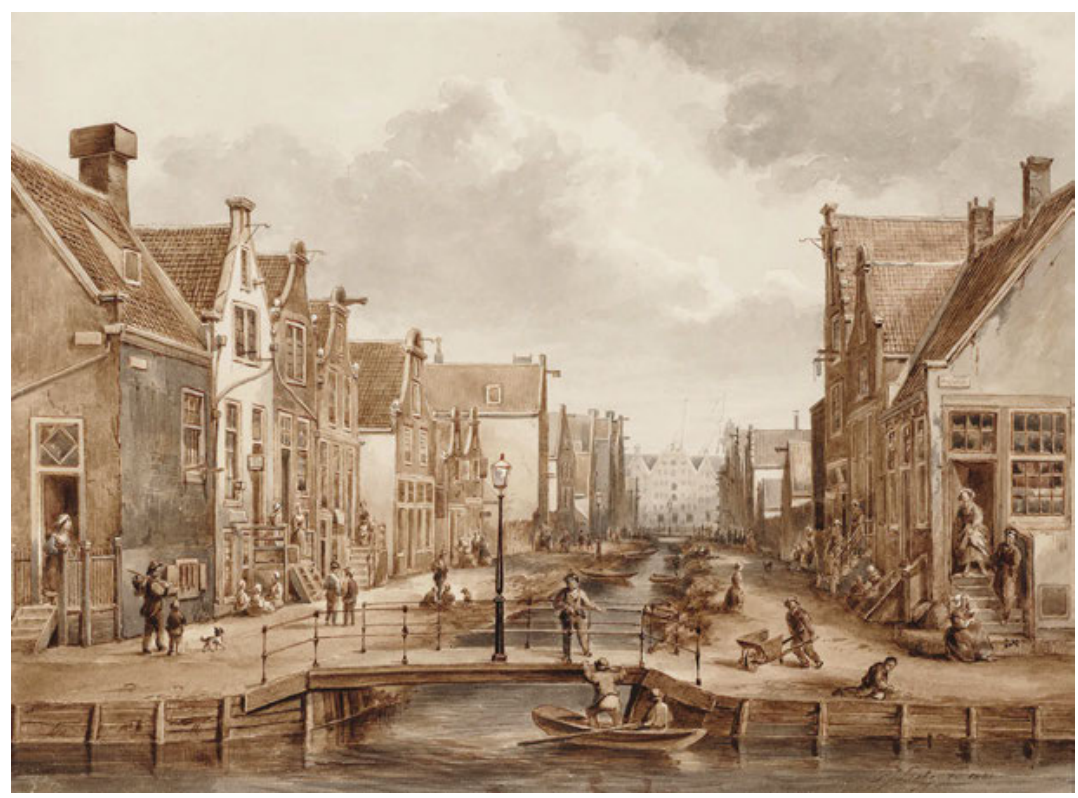

Gezicht vanaf de Lijnbaansgracht op de nog ongedempte Goudsbloemgracht. De kade aan de noordzijde van de Goudsbloemgracht, links voor de toeschouwer, werd wel Franschepad of Oude Franschepad genoemd. De kade aan de zuidzijde, rechts voor de toeschouwer, heette, net als het water, Goudsbloemgracht. Na de demping in 1854 veranderde de naam in Willemsstraat. Tekening van Petrus Josephus Lutgers (1808-1874). Bron: SAA. Beeldbank. Afbeeldingsbestand 010055000497. 
Afbeelding 6.4 Gang met gootsteen voor twee gezinnen in een krotwoning, Lindengracht 216 in 1894

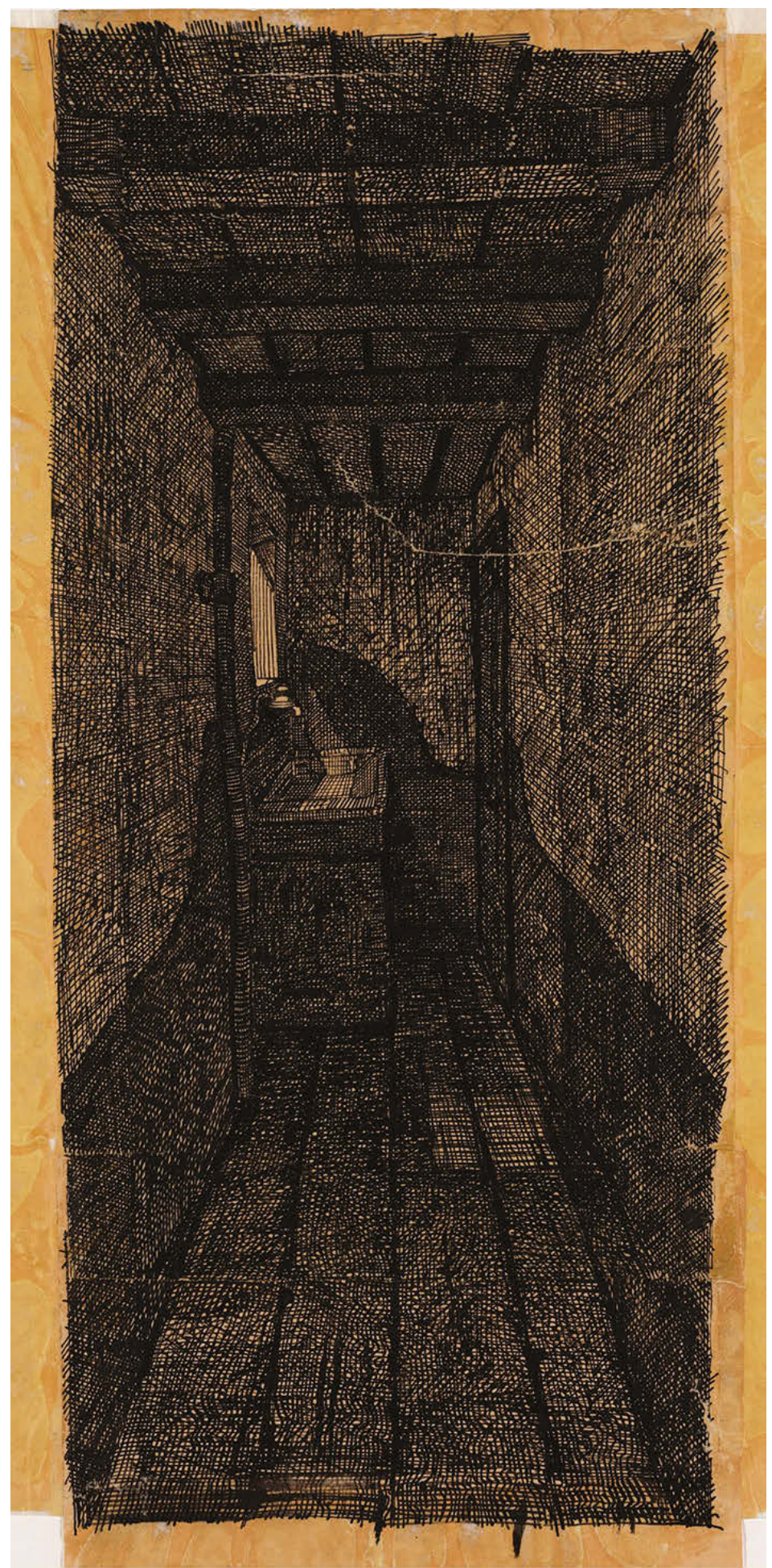

Onbekende tekenaar. Bron: SAA. Beeldbank Afbeeldingsbestand 010097014838. 


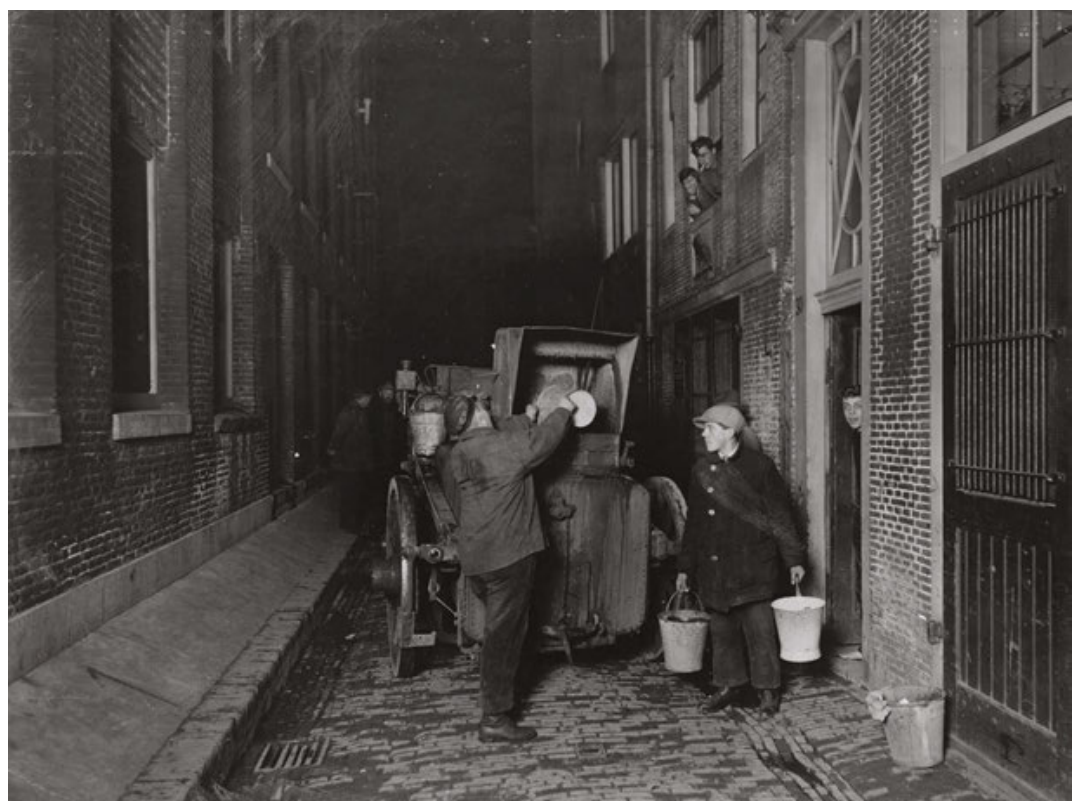

Slijkstraat ter hoogte van no. 30 en 32. Geen datering (vermoedelijke tijdens het interbellum). Verzamelwagen voor uitwerpselen. In de volksmond "de Boldootkar" genaamd. Bij woningen zonder rioolaansluiting werden de fecaliën wekelijks opgehaald. ${ }^{81}$ Onbekende fotograaf. Bron: SAA. Beeldbank. Afbeeldingsbestand OSIM00002000012.

Afbeelding 6.6 Kelderwoning Zeedijk 58 in 1913

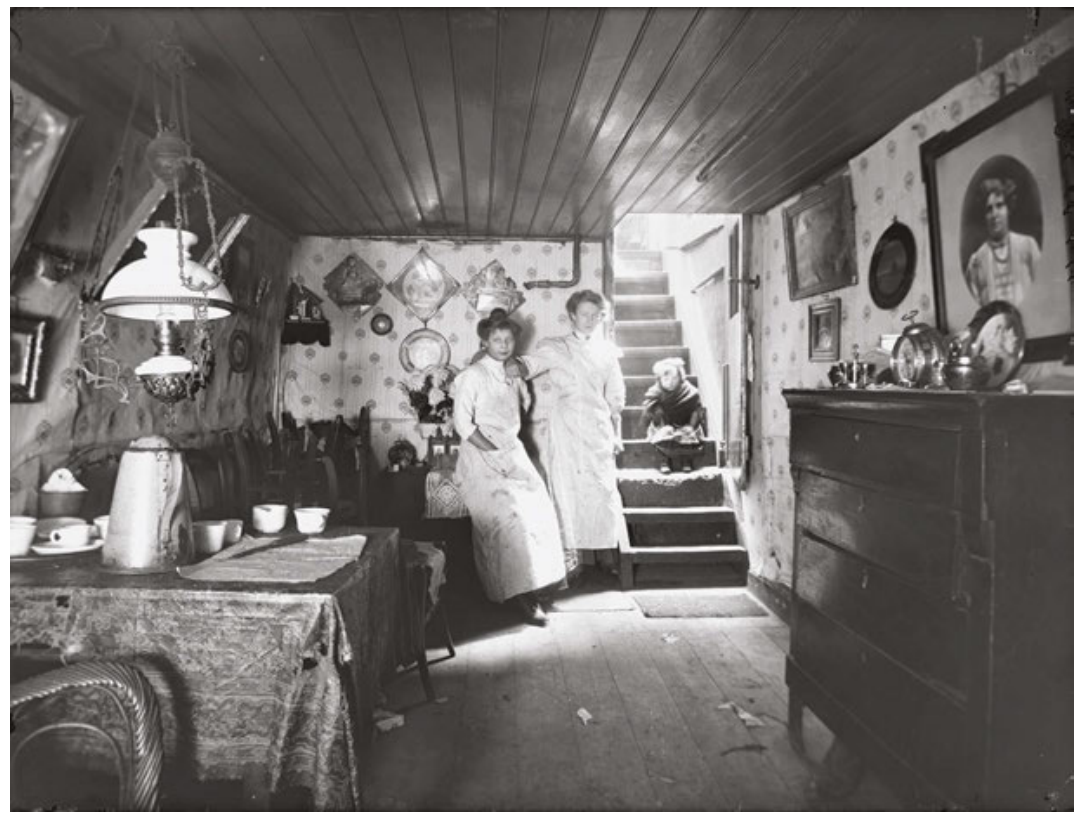

De onderkant van de zoldering was lager dan het straatoppervlak. Reproductie naar foto van de Gemeentelijke Dienst Volkshuisvesting. Onbekende fotograaf. Bron: SAA. Beeldbank. Afbeeldingsbestand 5293FO002025. 


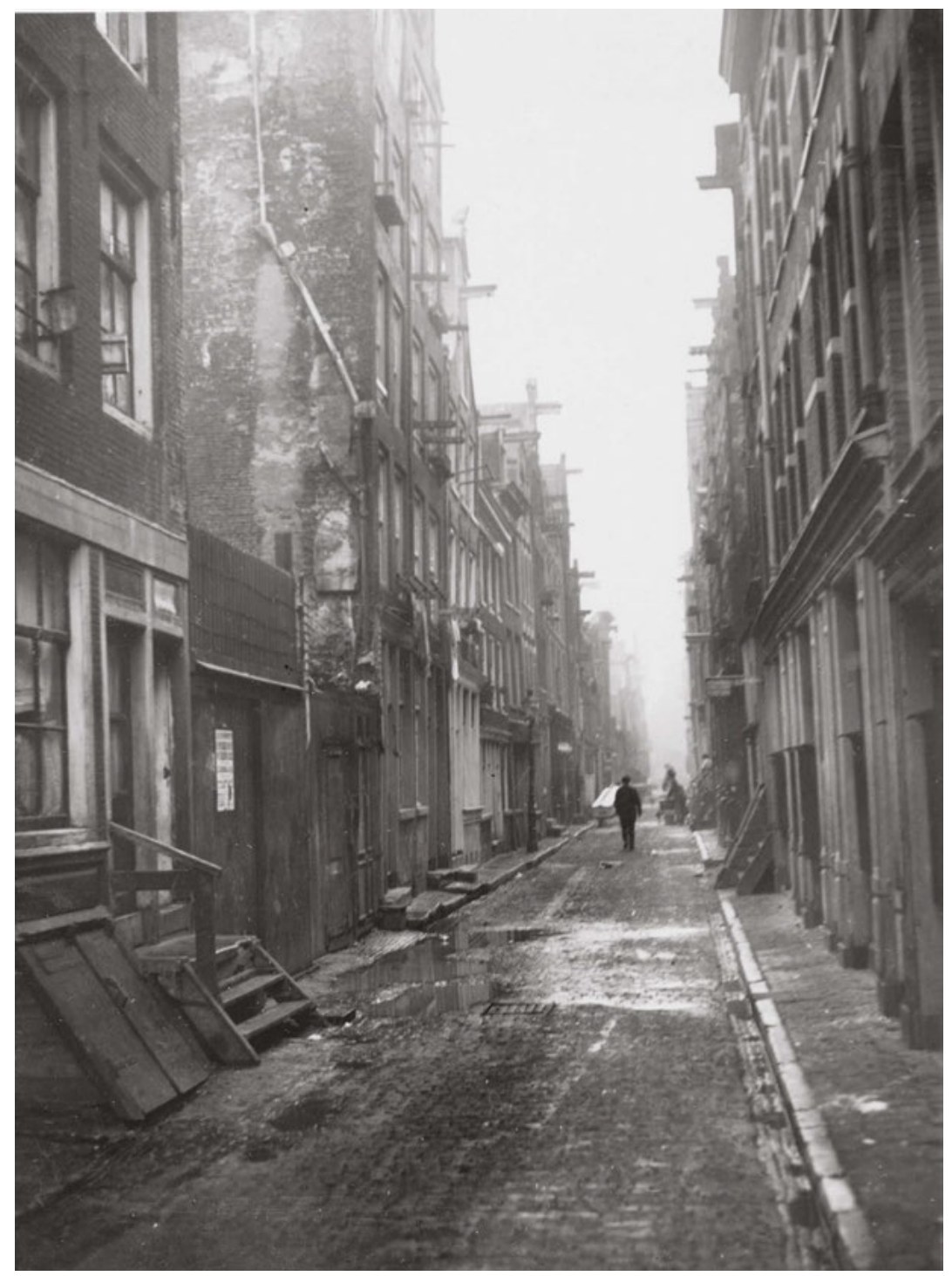

Jonkerstraat gezien in westelijke richting naar de Geldersekade. Links no. 66 en lager; rechts no. 71 en lager. Foto gemaakt door Internationaal Persfoto Bureau N.V. Bron: SAA. Beeldbank. Afbeeldingsbestand OSIM00001004745. 


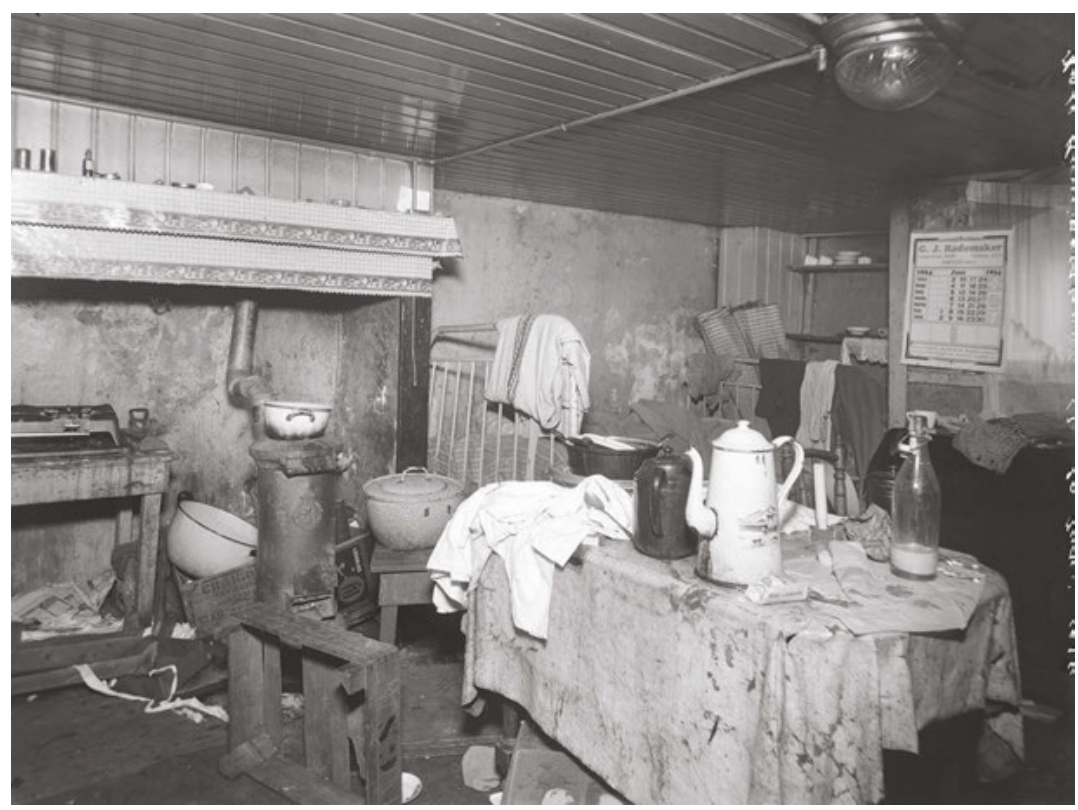

Korte Koningsstraat 13 huis juni 1934. Interieur van een woning. Onbekende fotograaf. Bron: SAA Beeldbank. Afbeeldingsbestand 5293FO002079.

\section{b) De medische gesteldheid}

"Heeft een uitwas op de rug, een verlamming der beenen, wegens ziekte in 't ruggemerg niet in staat in zijn onderhoud te voorzien". 82

De rapporten van de armbezoekers werpen enig licht op de medische gesteldheid van de armen. Armbezoekers informeerden naar eventuele lichaamsgebreken. In geval van een lichaamsgebrek werd vaak steun aangevraagd omdat de aanvrager om medische redenen niet in staat was een inkomen te verwerven. Als hij of zij een medisch attest kon overleggen, dan erkende de armbezoeker het lichaamsgebrek als een geldige reden om niet te kunnen werken. In alle andere gevallen was de observatie van de armbezoeker doorslaggevend. Welke medische klachten werden zoal gemeld?

Jan Manché leed in 1871 aan een oogziekte. Hij kon echter geen attest van het ziekenhuis overleggen. De buren verklaarden bovendien desgevraagd dat "ze" het "nog zoo kwaad niet" hadden. Daarom oordeelde de armbezoeker dat steun niet nodig was. ${ }^{83}$ Het lichaamsgebrek stond kennelijk inkomensverwerving niet in de weg.

Salomon Jacobs was in 1911 weliswaar doof, maar de aanvraag om hulp van deze kleermaker werd afgewezen. ${ }^{84}$ Salomon kon zijn werk ook doof verrichten, oordeelde de armbezoeker.

Hartpatiënte Johanna K. kreeg in 1936 wel steun, omdat zij een medische verklaring kon laten zien. Zij was, aldus het armbezoekersrapport, een "zenuwzieke hartpatiënt (met attest)". ${ }^{85}$

Hoe bepalend was de medische gesteldheid voor het al dan niet verkrijgen van steun? In onderstaande grafiek 6.12 is aangegeven hoeveel procent
82 SAA 5256. Doos 1117. Stamboeknummer 204; zo werd de gezondheidstoestand van matroos Johann Christoph Sablonski in mei 1871 door de armbezoeker omschreven. Johann was toen 22 jaar. Hij was tijdens een zeereis naar Japan uit de mast gevallen. 83 SAA 5256. Doos 1010. Stamboeknummer 4674. 84 SAA 5256. Doos 1045. Stamboeknummer 13041. 85 SAA 5256. Doos 7521. Stamboeknummer 164025. 
van de aanvragers lichaamsgebreken vertonen, volgens de rapporten van de armbezoeker. De bijbehorende tabel 8.9 is te vinden in bijlage 8 .

Grafiek 6.12 Lichaamsgebreken aanvragers (1871, 1911 en 1936)

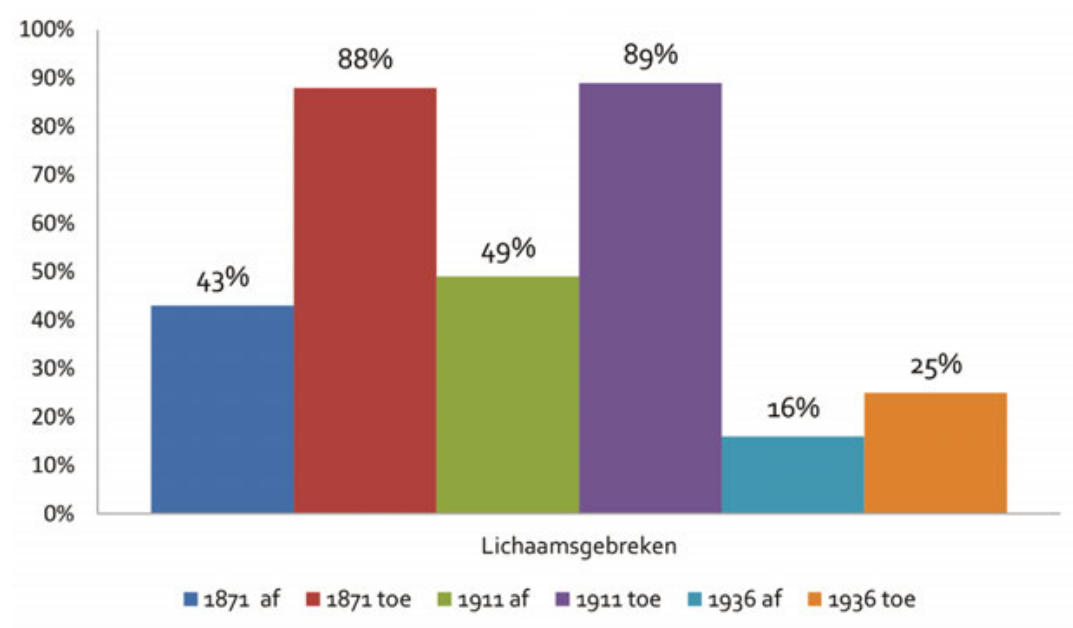

Legenda: af = afgewezen aanvragers; toe= toegekende aanvragers Bron: bijlage 8, tabel 8.9

Uit deze gegevens blijkt dat de aanvragers die hulp kregen vaker lichaamsgebreken vertoonden dan de aanvragers van wie het hulpverzoek was afgewezen. Wie geen gebreken had, werd geacht te kunnen werken en daarmee in zijn onderhoud te voorzien. In 1871 en in 1911 werden nog bij negen op de tien toegekende aanvragen lichaamsgebreken opgegeven: een hoog gedeelte In 1936 zien we dat de gezondheidssituatie kennelijk verbeterd was: er werd minder melding gemaakt van gebreken. Als verklaring voor deze verbetering van de gezondheid kan gewezen worden op de verbetering van de algehele levenstandaard. Verder is er meer geld beschikbaar voor gezondheidszorg, ook voor de lagere sociale klassen. Tevens moet erop gewezen worden dat in 1936 naast armenzorg meer aan zorg in het algemeen werd gedaan. Te denken valt aan de arbeidsinspectie, de veiligheidswet, de ongevallenwet, de verkorting van de werkweek, de ziektewet, de invaliditeitswet en meer van dergelijke regelingen die de volksgezondheid hebben bevorderd. Er ging niet alleen preventie van uit, maar de zieken en gehandicapten kregen ook een betere behandeling.

Het beeld dat oprijst uit mijn onderzoek wordt bevestigd door Lex Heerma van Voss en Henk van der Velden, die zich bogen over de gezondheidssituatie in Nederland in de jaren dertig. ${ }^{86}$ Uit hun studies blijkt dat in de jaren dertig, in vergelijking met de decennia die eraan voorafgingen, de Nederlandse gezondheidstoestand sterk is verbeterd. Heerma van Voss en

86 Heerma van Voss (1992); Van der Velden (1992). Zie ook: Rommelse, (2011),

54-58.

87 Heerma van Voss (1992), 121.

88 Velden, van der (1992), 114. van der Velden vragen zich wel af in hoeverre de crisis van de jaren dertig deze ontwikkeling negatief heeft beïnvloed en of de gezondheid toen toch weer achteruitging. ${ }^{87}$ Voor de werklozen gold dit wel, zo betoogt Van der Velden. Hun voedingstoestand hield niet over. ${ }^{88}$ Omdat echter de kwaliteit van de door hun gebruikte voedingsmiddelen goed was, veel beter dan bijvoorbeeld in 1871, viel het nog mee met de ondervoeding. Er zijn wel 
aanwijzingen dat onder werklozen ondervoeding in enige mate voorkwam. Gebleken is dat kinderen van werklozen, die afhankelijk waren van schoolvoeding, kleiner waren en minder wogen dan kinderen die thuis voldoende te eten kregen. ${ }^{89}$ Een verdere aanwijzing is dat werklozen een lagere levensverwachting hadden dan andere bevolkingsgroepen. Volgens Heerma van Voss strekten de slechtere kansen van werklozen zich uit "tot de dood". 90 Niet alleen de voedingssituatie en het sterfterisico van werklozen vroeg aandacht, maar ook hun moeizame verhouding met de gezondheidszorg. Werklozen konden door geldgebrek niet deelnemen aan een ziekenfonds en waren daardoor aangewezen op de gezondheidszorg van het armenwezen. Deze zorg was van mindere kwaliteit dan de zorg vanuit de ziekenfondsen, maar deze zorg ging er in de jaren '30 niet op achteruit. Ook op dit medische terrein viel de toestand wel mee, met de inzichten die we nu hebben. Samengevat: de medische gesteldheid van werklozen stond in de jaren '30 wel onder druk, maar van een enorme verslechtering was geen sprake.91

De medische gesteldheid van de ondersteunden in 1936 was vanwege het niveau van de uitkeringen te vergelijken met die van de werklozen. Hun gezondheidstoestand houdt niet over, maar vergeleken met hoe het was voor de armen tot de jaren dertig, was hun perspectief in 1936 beduidend beter. De werklozen en de ondersteunden zelf zullen hun situatie intussen bepaald niet als rooskleurig hebben ervaren.

\section{c) De sociale stratificatie}

\section{"Repareert oude vogelkooien, vent met bloementafeltjes".92}

Omdat in de rapporten van de armbezoekers de beroepen van de aanvragers worden vermeld kan op basis van deze vermeldingen iets gezegd worden over de sociale stratificatie van de aanvragers. Sinds 1959 is er veel discussie over de sociale stratificatie in Nederland in de negentiende en twintigste eeuw. ${ }^{93}$ I.J. Brugmans hield voor de jaarvergadering van het Historisch Genootschap in dat jaar een voordracht waarin hij stelde dat "gedurende de eerste helft der 19e eeuw (...) in Nederland de middenstand (ontbrak)". ${ }^{44}$ Hoe zagen de sociale verhoudingen er volgens Brugmans dan verder uit? Brugmans is daar stellig in "Twee standen waren er dus in het Nederland in de eerste helft der negentiende eeuw: het volk en de aanzienlijken". ${ }^{95}$ Eerst het industrialisatieproces deed een middengroep ontstaan, aldus Brugmans. ${ }^{96}$ In de discussie na de voordracht van Brugmans werd in 1974 door Giele en Van Oenen een nog steeds gebruikte indeling van de sociale verhoudingen rond 1850 opgesteld. Middengroepen zijn in deze indeling aanwezig. ${ }^{97}$ Stuurman geeft een theoretische uiteenzetting over de discussie tot $1979 . .^{98}$ De groei van de middengroepen is onderwerp van het proefschrift van Berting dat in meer detail aangeeft dat "het maatschappelijk midden... een zeer heterogeen geheel is"..$^{99}$ Eén van de conclusies van het onderzoek van Mandemakers naar de sociale structuur in Nederland rond 1900 is eveneens dat er groei is van het midden. ${ }^{100}$ Het tamelijk recente onderzoek van Van Leeuwen en Maas waarbij gebruik werd gemaakt van resultaten van volkstellingen en onderzoek naar huwelijksakten bevestigde het beeld van Brugmans van opkomende middengroepen: "Beide bron-
89 Heerma van Voss (1992), 129

90 Heerma van Voss (1992), 131.

91 Heerma van Voss (1992), 125.

92 SAA 5256. Doos 1473.

Stamboeknummer 11041.

Zo werden de werkzaam-

heden van Dirk Laurentius

Cevat omschreven. Hij

moest in 1911 een gezin

van negen personen zien te onderhouden.

93 Leeuwen, Van en Maas (2007), 196-198, geven een kernachtige samenvatting. Stuurman geeft een theoretische uiteenzetting tot 1979 in Stuurman, Siep, (1979).

94 Brugmans (1960), 33. 95 Brugmans (1960), 41. 96 Brugmans (1960), 47 plaats het begin van het industrialisatieproces vanaf het midden van de negentiende eeuw; de datering van het industrialisatieproces die Brugmans aanbracht houdt in het recente historische onderzoek geen stand. Zie Van Riel (2018). 97 Giele en Van Oenen (2019), 58-95.

98 Stuurman, Siep (1979), 705-708.

99 Berting (1968), 18, en Berting (1985), 134. 100 Mandemakers (2001), 201: "Van de structurele veranderingen die de Nederlandse samenleving heeft doorgemaakt is de opkomst van de white-collar-beroepen en de inkrimping van zowel de oude middenstand als de 'oude arbeidersklasse' het meest opvallend." Mandemakers dateert het veranderingsproces in de gehele twintigste eeuw. 
101 Van Leeuwen en Maas (2007), 203. Omdat de huwelijksakten beroepen vermelden kunnen deze akten een licht werpen op de sociale groepen waar de huwelijkspartners deel van uitmaakten; Van Leeuwen en Maas (2011), 16-26, bespreken de afbakening van sociale groepen. 102 Van Vught (2015), 96. 103 Berting (1985), 119-138. $104 \mathrm{De}$ indeling in beroepen en sociale klassen is gebaseerd op het systeem van beroepsclassificatie HISCO, dat door Van Leeuwen, Maas en Miles is ontwikkeld. (Van Leeuwen, Maas, Miles, 2002). In een aansluitende publicatie is aan de beroepsclassificatie een sociale classificatie, HISCLASS gekoppeld, ontworpen door Van Leeuwen en Maas.(2011). Omdat zowel HISCO als HISCLASS op de negentiende eeuw en de eerste decennia van de twintigste eeuw zijn gebaseerd, zijn deze indelingen voor mijn onderzoek relevant. Alle beroepen die in de door mij geraadpleegde bronnen vermeld werden, heb ik gerangschikt naar HISCO en HISCLASS. In mijn database komt een klein honderdtal zeer uiteenlopende beroepen voor. nen laten echter duidelijk de door Brugmans geponeerde groei zien van een nieuwe middenklasse van technisch en administratief personeel", zo stellen Van Leeuwen en Maas. ${ }^{101}$ Veranderingen in de sociale status onder arbeiders werd ook waargenomen in Maastricht door Van Vught die constateerde dat tussen 1829 en 1904 dagloners plaats maakten voor meer geschoolde fabrieksarbeiders in een "arbeidersbuurt onder de rook van 'De Sphin $x^{\prime \prime} .{ }^{102} \mathrm{Al}$ deze onderzoeken laten zien, zonder te willen suggereren dat mijn opsomming compleet is, dat sinds de tweede helft van de negentiende eeuw er een groei te bespeuren is van middengroepen en dat er sprake is van een dalende betekenis van de groepen met de laagste sociale status.

Deze veranderingen in de sociale gelaagdheid in Nederland zien we terug in de manier waarop de sociale stratificatie van de aanvragers in Amsterdam zich tussen 1871 en 1936 ontwikkelde. ${ }^{103} \mathrm{Om}$ inzicht te krijgen in de sociale stratificatie van de aanvragers heb ik gebruik gemaakt van de classificaties die Van Leeuwen, Maas en Miles hebben gemaakt. ${ }^{104}$ De verwerking van de gegevens uit de rapporten van de armbezoeker zijn hieronder in tabel 6.2 weergegeven.

Tabel 6.2 Beroepen van aanvragers in 1871, 1911 en 1936 naar sociale klasse $(1871,1911$ en 1936)

In percentages

\begin{tabular}{|l|r|r|r|}
\hline Sociale klasse & 1871 & 1911 & 1936 \\
\hline Hogere professionals en leidinggevenden & 0 & 0 & \\
\hline $\begin{array}{l}\text { Lagere professionals, administratief, verkoopperso- } \\
\text { neel lagere bedienden en voormannen }\end{array}$ & 8 & 10 & 24 \\
\hline Middelgeschoolde werknemers & 18 & 15 & 20 \\
\hline Laaggeschoolde werknemers & 18 & 20 & 20 \\
\hline Ongeschoolde arbeiders & 48 & 34 & 18 \\
\hline Aanvragers zonder beroep & 8 & 100 & 100 \\
\hline Totaal & & 21 & \\
\hline
\end{tabular}

In 1871 behoorde de helft van de aanvragers tot de ongeschoolde arbeiders. In 1911 was dat aandeel gedaald tot een derde van het totaal. In 1936 was het aantal ongeschoolde arbeiders geslonken tot een vijfde van het totale aantal aanvragers. Tegenover de daling van het aantal ongeschoolde arbeiders tussen 1871 en 1936 staat de opkomst van de middengroepen (lagere professionals die een middelbare opleiding hebben genoten, administratieve medewerkers, verkooppersoneel en lagere bedienden) onder de aanvragers. Het is duidelijk dat de beroepen uit de drie hoogste sociale lagen sterk zijn toegenomen, namelijk van een kwart in 1871 naar 
bijna de helft in 1936. In 1936 deden zelfs hogere professionals die hoogopgeleid zijn een beroep op de armenzorg van de gemeente. Dit laatste onderstreept de bijzondere omstandigheden op de arbeidsmarkt: de hoge werkloosheid van de jaren '30.

Het gemiddelde sociale peil van de aanvragers steeg tussen 1871 en 1911, en opnieuw - en nog sterker - tussen 1911 en 1936. Dat heeft te maken met twee factoren. In de eerste plaats veranderde de samenstelling van de Amsterdamse beroepsbevolking, een ontwikkeling die gelijke tred hield met de overgang van een nog bijna pre-industriële naar een industriële stad. In de tweede plaats kreeg Amsterdam in de jaren '30 te maken met economische omstandigheden die beïnvloed werden door een internationale crisis. Daardoor ontstond er een grote werkloosheid. Anders dan bij vorige economische crises werden nu ook hoger geplaatsten zwaar getroffen. ${ }^{105}$

Afbeelding 6.9 Twee mannen met handkar, 1887-1889

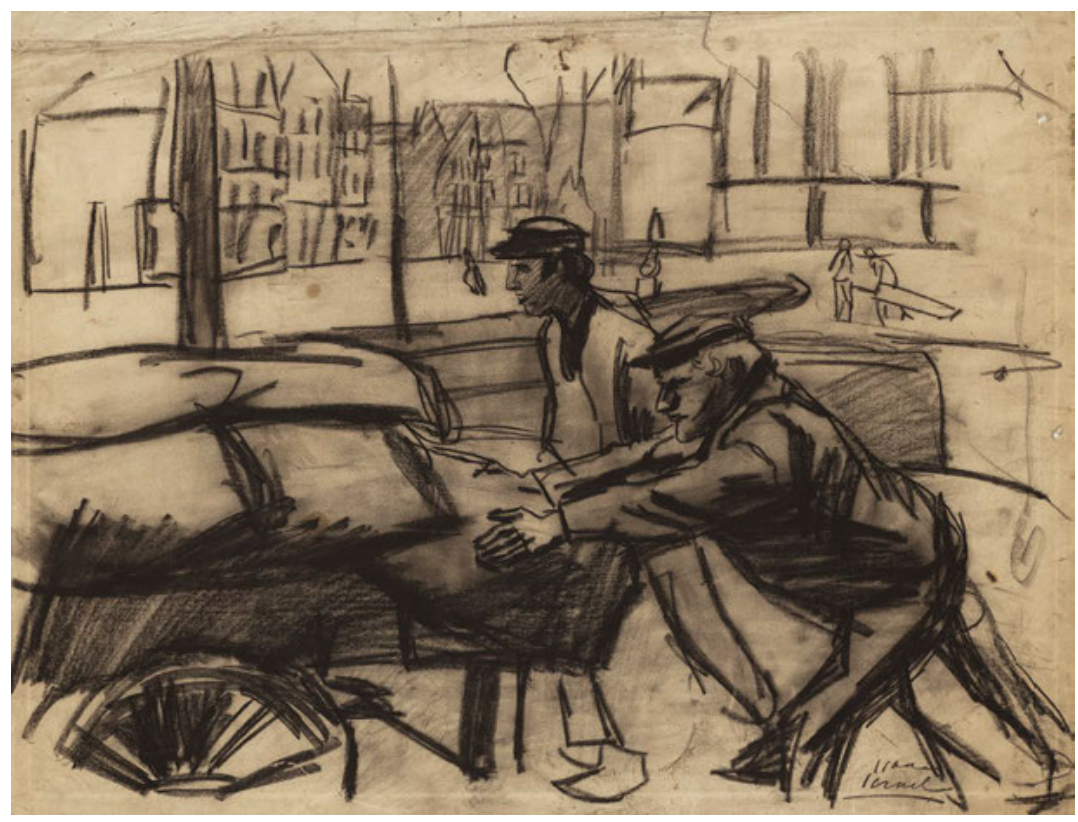

Twee karrenvoerders op de Prinsengracht ter hoogte van het Van Brienenhofje, gezien naar de Noordermarkt ter hoogte van no. 89-133. Op de achtergrond de Noordermarkt, met, van rechts naar links, de no 29-43 en rechts de Noorderkerk. Geheel links ingang Westerstraat. Tekening door I.L. Israels (1865-1934). Bron: SAA. Beeldbank. Afbeeldingsbestand 010094008293.
105 In mijn database komen in 1936 ook een bouwkundige, een fabrikant, een praktisch orthopeed en een scheepskapitein voor. Deze beroepen worden in HISCLASS als higher en lower managers aangeduid. Van Leeuwen en Maas.(2011), 57, 131, 134, 135 en 142. (Conversie HISCO naar HISCLASS: $0-42.30=3$; $2-11.10=1 ; 0-61.05=2$ en $-22.10=2$ ) 


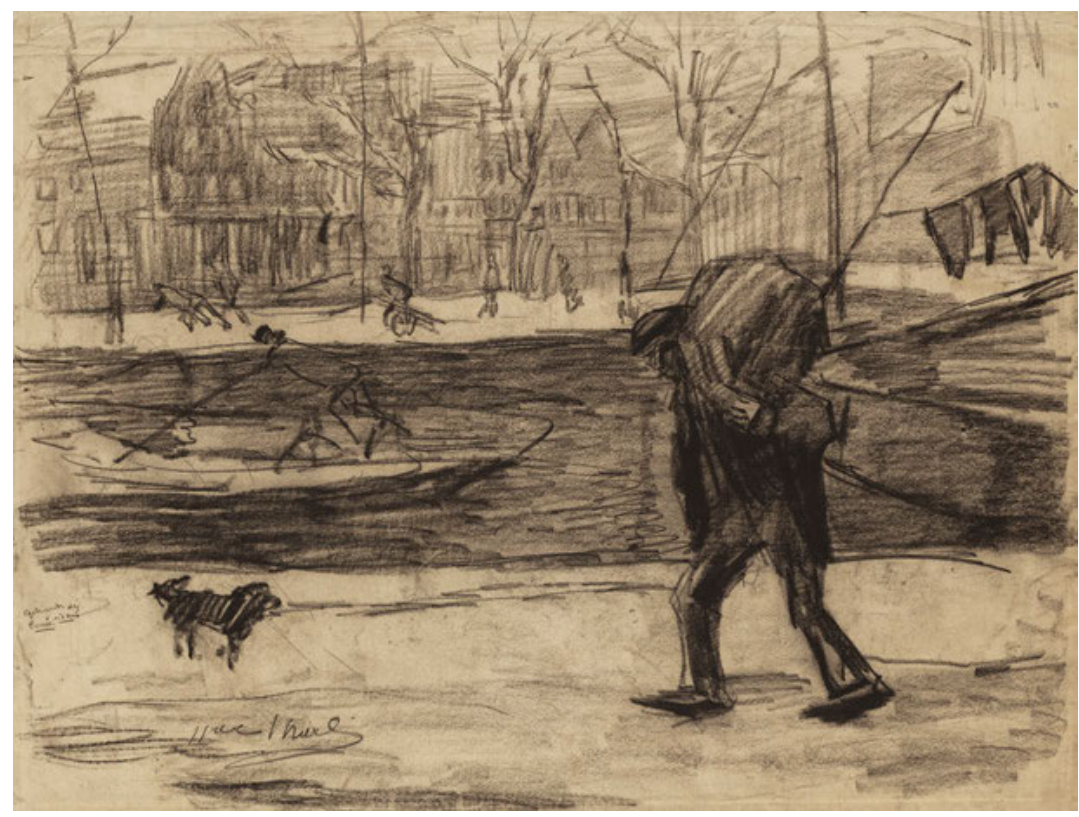

Een zakkendrager op de Prinsengracht ter hoogte van het Van Brienenhofje gezien naar de Noordermarkt ter hoogte van no. 89-133, met, van rechts naar links, de no 29-43 en rechts de Noorderkerk. Geheel links ingang Westerstraat. Tekening door I.L. Israels (1865-1934). Bron: SAA. Beeldbank Afbeeldingsbestand 010094008292. 
Afbeelding 6.11 Werkman, circa 1930

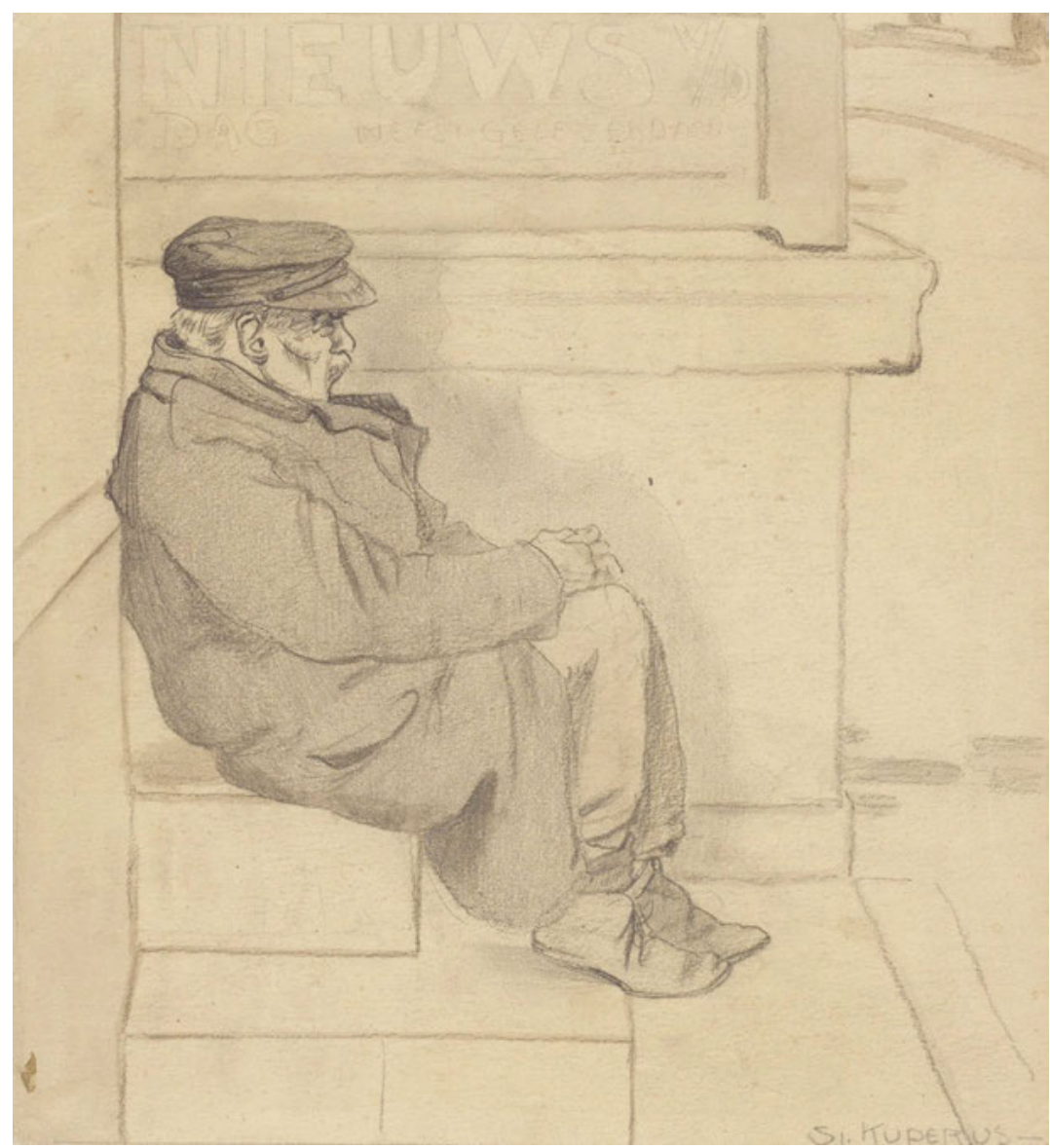

Zittende werkman voor het Centraal Station; boven zijn hoofd reclame voor het Nieuws van den Dag. Tekening door Sjoerd Kuperus (1893-1988). Bron: SAA. Beeldbank. Afbeeldingsbestand ANWJ00036000001. 


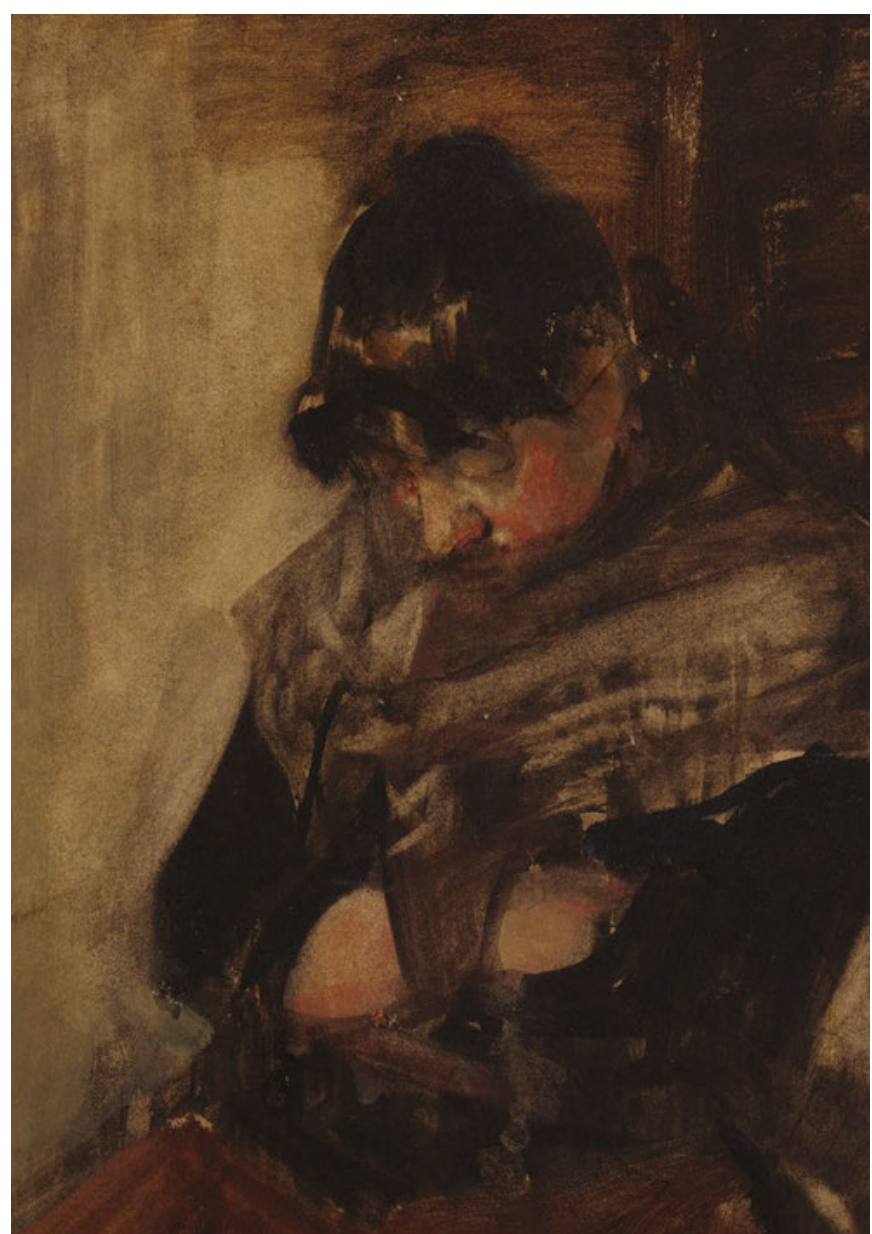

Slapende Amsterdamse werkvrouw. Aquarel door Hobbe Smithe (1862-1942). Bron: SAA. Beeldbank. Afbeeldingsbestand 010097012703.

\section{d) Het schoolbezoek}

Vanaf het begin van de negentiende eeuw streefde de landelijke overheid naar schoolbezoek voor alle kinderen tussen zes en twaalf jaar.106 "Vanaf 1815 zouden steeds meer kinderen in het lager onderwijs worden opgevangen", meldde De Wolf. ${ }^{107}$ Het is niet goed traceerbaar hoeveel kinderen daadwerkelijk in het eerste deel van de negentiende eeuw de school bezochten. Weliswaar zijn er verschillende cijfers, maar bij de betrouwbaarheid ervan kunnen vraagtekens worden gezet. De schatting is dat er in 1825 zo'n 65\% van de kinderen "voor kortere of langere tijd" onderwijs hebben genoten. In de jaren '50 van de negentiende eeuw waren er plannen voor het invoeren van leerplicht. Maar een voorstel tot invoering van leerplicht haalde het niet, bij de behandeling van een onderwijswet in de Staten-Generaal in 1857. Het schoolbezoek bleef gedurende de gehele negentiende

106 Te Boekholt en De Booy (1987), 116. 107 De Wolf (1983), 108 eeuw toenemen, ook zonder leerplicht. In 1862 zouden, volgens iets betrouwbaardere cijfers, $76 \%$ van de kinderen schoolgaand zijn geweest. De onderwijswet van 1878 bepaalde dat scholen het schoolbezoek moesten 
registreren. Ouders die hun kinderen niet naar school lieten gaan, mochten geen bijstand van de gemeente ontvangen. ${ }^{108}$ Aan het eind van de negentiende eeuw, vlak voor de invoering van de leerplicht in 1901, ging in $\mathrm{Ne}$ derland $90 \%$ van de kinderen van zes tot en met twaalf naar school. Zeven procent van de kinderen was "geoorloofd afwezig". 109

Het schoolbezoek was een van de aandachtspunten van de armbezoeker. ${ }^{110}$ In de rapporten van de armbezoeker werd schoolbezoek geregistreerd. De ouders moesten een bewijs van schoolgaan kunnen tonen, ondertekend door het hoofd van de school. Het is opvallend dat al voor de invoering van de leerplicht de kinderen uit de jaargroep 1871 in de leeftijd van zes tot twaalf in groten getale naar school gingen. Vanaf zes jaar was schoolbezoek heel gebruikelijk. Wie zijn kinderen niet naar school stuurde, kreeg geen steun. In een enkel geval volstond een bewijs van inschrijving. Kennelijk was er niet altijd meteen plaats op school voor nieuwe leerlingen. In zulke gevallen ging het om kinderen van vier of vijf jaar. In mijn database is het schoolbezoek zo alomtegenwoordig dat ik geen afzonderlijke statistiek heb gemaakt. Kinderen van toegekende aanvragers gingen altijd naar school, bij afgewezen aanvragers ging het om hoogst enkele kinderen die niet naar school gingen.

Toch is enige behoedzaamheid geboden bij het interpreteren van deze statistieken. Omdat het niet schoolgaan een afwijzingsgrond was in 1871, zou je kunnen veronderstellen dat ouders die hun kinderen niet naar school stuurden, op voorhand al afzagen van een steunaanvraag omdat die geen kans van slagen zou hebben. Dat zou kunnen, al is het niet heel aannemelijk.

Het idee dat schoolgaan gebruikelijk was geworden, wordt bevestigd door bestudering van de volkstellingen en van het aantal schoolgaande kinderen. In Amsterdam ging in 1857 82\% van de kinderen in de leeftijd tussen de zes en twaalf jaar naar school. ${ }^{111}$ In 1869 ging 81\% van deze leeftijdsgroep naar school. ${ }^{112}$ Volgens Van Tijn gingen in 1876 ongeveer 33.000 kinderen naar school. ${ }^{113}$ Naar berekening gaat het dan om $84 \%$ van de kinderen in de leeftijdsgroep zes tot twaalfjarigen. ${ }^{114}$

In Amsterdam werd in de tweede helft van de negentiende eeuw schoolbezoek als iets vanzelfsprekends beschouwd, ook onder de laagste sociale groepen. Dit veelvuldige schoolbezoek kan worden gezien als een triomf van het burgerlijk beschavingsoffensief. Het idee van het burgerlijk beschavingsoffensief was immers dat opvoeding en onderwijs belangrijke voorwaarden waren voor een deugdzaam leven waardoor armoede zou worden uitgebannen.
108 Bakker, Noordman en Rietveld-Van Wingerden, (2010), 576.

109 De Rooy, (2018), 83. 110 Artikel 22 van de verordening uit 1871 over het Burgerlijk Armbestuur over de' onderstand aan huiszittende armen' luidde: "Het Burgerlijk Armbestuur kan aan het verlenen van onderstand aan personen met kinderen de voorwaarde verbinden dat zij verplicht zij hun kinderen getrouw onderwijs te doen bijwonen. De overlegging van een bewijs dat zijn ten deze aan hunne verplichtingen voldoen, kan worden gevorderd". Bron: SAA 5256 Gemeenteblad 1870 Afd. 3 Volgnummer 21. 111 Van Tijn (1965), 111 en 113.

112 In Amsterdam ging in $185782 \%$ van de kinderen in de leeftijd tussen de zes en twaalf jaar naar school.( Van Tijn (1965), 111 en 113). Ik ontleen dit gegeven aan data die Van Tijn verstrekt. In 1857 waren 23.827 leerlingen van zes tot en met twaalf jaar schoolgaand, terwijl er volgens de volkstelling van 1859 bijna 29.000 kinderen in die leeftijdsgroep in Amsterdam woonden. Het ging toen om ongeveer 23.800 leerlingen. Bij de volkstelling van 1859 vormde de leeftijdsgroep van zes tot twaalfjarigen 13,5\% van de bevolking. In de gepubliceerde gegevens van de volkstelling van 1869 werden de leeftijdsgroepen niet vermeld. Wel de totale bevolking, namelijk 265.000. Als we het percentage uit 1859 van 13,5 voor de leeftijdsgroep van zes tot twaalfjarigen ook voor 1869 aanhouden, dan zouden er 35.775 kinderen moeten zijn. Verder weten we dat in 186929.000 kinderen naar school gingen. Combineren we beide gegevens (totaal aantal kinderen van zes tot twaalf en het aantal schoolgaande kinderen) dan gingen in $186981 \%$ van de kinderen naar school. 
113 Van Tijn (1965), 319.

114 Aan de hand van het door Van Tijn berekende inwonertal van Amsterdam op 1 januari 1876, namelijk 288.000, en rekening houdend met een aan de hand van de volkstellingen geschatte leeftijdsopbouw in 1876 bezocht $84 \%$ van de kinderen in de leeftijdsgroep zes tot twaalfjarigen een school. Van Tijn (1965), 275; Volkstelling 1859 en 1879. De percentuele groei was ook een gevolg van het feit dat sinds 1871 de wachttijden voor de openbare armenscholen waren verlaagd. In 1874 konden de meeste kinderen tussen zes en zesenhalf geplaatst worden. Van Tijn (1965), 319.

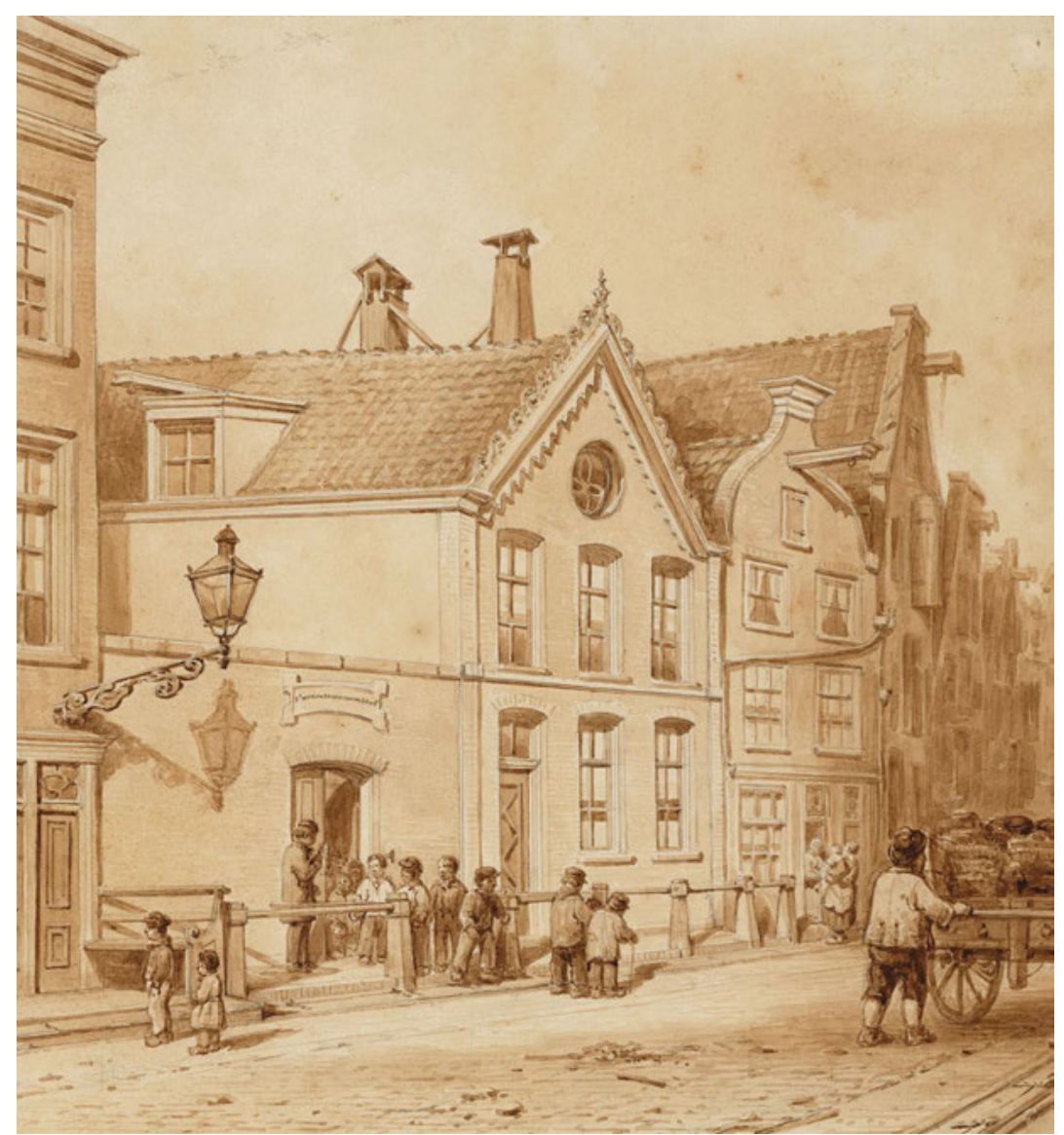

De ingang van de Sint-Vincentius Armenschool, Nieuwe Leliestraat 169, met een stoet kinderen die de school verlaat. Op nr. 171 de bijbehorende woning. Geheel rechts een man met een handkar. Tekening door Petrus Josephus Lutgers (1808-1874). Bron: SAA. Beeldbank. Afbeeldingsbestand 010097000060. 


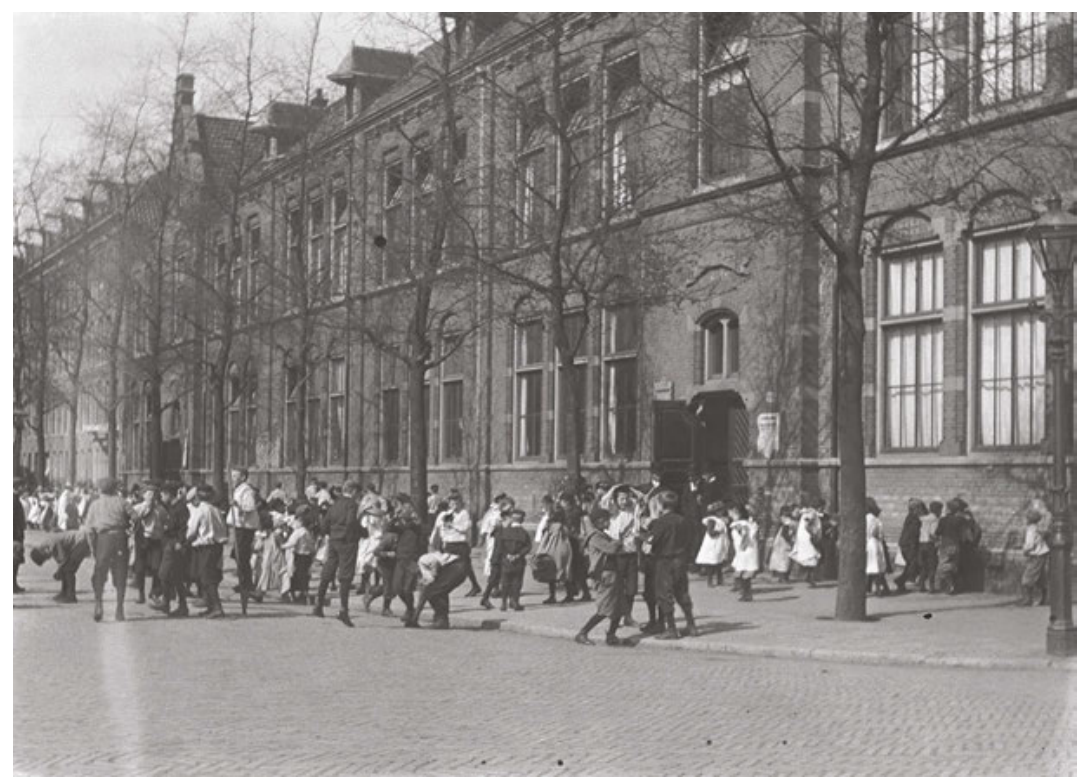

Eerste van Swindenstraat 135. Openbare Lagere School nr. 48, tijdens het speelkwartier. Gezien naar de Dapperstraat. Foto door Jacob Olie (1834-1905). Bron: SAA. Beeldbank. Afbeeldingsbestand 10019A001071.

\section{e) Samenvatting}

Overzien we de vier aspecten van de leefomstandigheden die ik hierboven heb belicht, dan moeten we wel vaststellen dat de Amsterdamse armen het in alle opzichten beter hebben gekregen in de loop van een kleine zeventig jaar. De woonomstandigheden in 1871, door tijdgenoten als ongeschikt en ongewenst omschreven, zijn verbeterd. In 1936 wonen ook de armen in woningen die naar de maatstaven van die tijd als geschikt en fatsoenlijk omschreven kunnen worden. Dat was de nieuwe norm. De gemeentelijke woningdienst nam de verantwoordelijkheid op zich voor de woonomstandigheden. Overigens was men zich er terdege van bewust dat er ruimte voor verbetering bleef. Niet voor niets nam de Amsterdamse gemeenteraad in 1936 het ambitieuze Algemeen Uitbreidingsplan (AUP) aan, dat uiteindelijk in de jaren '50 en '60 zou worden gerealiseerd.

De Amsterdamse armen zijn gezonder geworden in de onderzoeksperiode. Niet enkel het beschavingsoffensief, maar ook de uitgebreidere medische zorg, het aanbod van gezond en voldoende voedsel, de arbeidsinspectie en de gestegen levensstandaard hebben bijgedragen aan een verbetering van de volksgezondheid. Net als bij de huisvesting en de scholing zien we een toenemende invloed van de overheid, die de gezondheid in het algemeen, maar zeker ook die van de armen heeft bevorderd.

Het is onmiskenbaar dat de scholingsgraad onder de armen is toegenomen. In 1936 is het aandeel ongeschoolde arbeiders, arbeiders dus zonder enige vervolgopleiding, nog maar een vijfde. Iln 1871 was nog meer dan de helft van de arbeiders die een steunaanvraag indienden ongeschoold In 1936 is het aandeel ongeschoolde arbeiders, arbeiders dus zonder enige vervolgopleiding, nog maar een vijfde. Zoals uit de ontwikkeling van de 
scholingsgraad kan worden opgemaakt nam de betekenis van de laagste sociale klassen af in de groep bedeelden, terwijl een middengroep aan importantie won. De veranderingen in de scholingsgraad moeten in verband worden gebracht met veranderingen in de sociale stratificatie. Lagere sociale groepen schoven tussen 1870 en 1940 op naar het midden. Verder gingen in 1871 al bijna alle kinderen in de leeftijdscategorie van zes tot twaalf naar school. Na de invoering van de leerplicht nam dat aantal verder toe. Voor de jaren '30 zou, met een variant op Kruithof, van een geschoolde natie gesproken kunnen worden. ${ }^{115}$

Uit alles blijkt, kortom, dat het burgerlijk beschavingsoffensief, op de vleugels van de algemene welvaartsverbetering tussen 1870 en 1940, positieve gevolgen heeft gehad. De Amsterdamse gemeente heeft in die beschaving een aantoonbare rol gespeeld. Het valt niet in percentages uit te drukken hoe groot die rol was, maar duidelijk is wel dat de gemeentelijke armenzorg heeft bijgedragen aan een verheffing van het volk.

\subsection{CONCLUSIE}

Aan het begin van dit hoofdstuk werden twee vragen gesteld. Ten eerste was er de vraag over de rol die het beschavingsoffensief speelde in de Amsterdamse gemeentelijke armenzorg. En ten tweede was de vraag of dat offensief ook effect heeft gehad? Welke antwoorden kunnen we geven op deze vragen?

De rol van het beschavingsoffensief is beoordeeld aan de hand van deze vier elementen uit de rapporten van de armbezoekers:

a) de mening van de armbezoeker over het gedrag van de aanvragers;

b) de indruk van de armbezoeker van de welstandscriteria van de woning;

c) de indruk van de armbezoeker van de hygiëne van de woning;

d) de afwijzingsgronden van een aanvraag.

ad a) In 1871 hadden de armbezoekers over 29\% van de aanvragen die werden afgewezen een negatieve mening, terwijl hun mening over aanvragen die waren toegekend slechts in $7 \%$ van de gevallen negatief was. Een negatieve mening van de armbezoeker over het gedrag van de aanvrager leidde eerder tot een afwijzing dan een positieve. In 1911 kwam dit verband tussen het negatieve oordeel van de armbezoeker en het aantal afwijzingen in verzwakte vorm terug. In 1936 speelde de beoordeling van het gedrag amper nog een rol in afwijzing of toekenning. De mening van de armbezoeker over het gedrag van de aanvrager werd tussen 1871 en 1936 steeds minder doorslaggevend. Terwijl het burgerlijk beschavingsoffensief erop gericht was het gedrag van de arme te reguleren, verdween bij de gemeentelijke armenzorg langzaam maar zeker de gerichtheid op het gedrag van de aanvragers. Het beschavingsoffensief speelde uiteindelijk nog amper een rol in de gemeentelijke armenzorg.

ad b) De indruk die de armbezoeker kreeg van de welstand van de woning speelde aanvankelijk mee in de onderbouwing van het besluit op een

115 Kruithof (1983), 371 385. aanvraag. Hoe armoediger de woning eruit zag, des te groter de kans dat de aanvraag werd toegekend. Omgekeerd gold ook dat de kans groter 
was dat de aanvraag werd afgewezen als de woning er minder armoedig uitzag. De armbezoeker hanteerde hierbij zakelijke argumenten. Dat was althans het geval in 1871 en in 1911. In 1936 werd geen melding meer gemaakt van de toestand van de woning. Ik heb hieruit geconcludeerd dat in 1936 welstand kennelijk geen criterium meer was bij de beoordeling van de steunaanvragen. Als men een oordeel geeft over welstand, dan klinkt daar impliciet ook een oordeel in mee over het bestedingspatroon van de aanvrager. Klaarblijkelijk vond ook dat oordeel niet meer plaats. Als er, zoals in 1936, geen oordeel meer plaatsvindt over het besteden van het gezinsinkomen, dan wijst dat op het afnemen van de behoefte om het gedrag van armen te reguleren. De houding tegenover armoede is verzakelijkt.

ad c) De indruk die de armbezoeker kreeg van de hygiënische toestand van de woning speelde aanvankelijk een rol in de beslissing of er al dan niet steun zou worden gegeven. Aanvragers met een onhygiënische woning, volgens het oordeel van de armbezoeker, kregen in meer dan de helft van de gevallen geen steun. In 1911 en in 1936 werd er niet meer gelet op de hygiëne. Kennelijk speelde het geen rol meer in de besluitvorming. Hygiëne is ook een slecht objectiveerbaar criterium en zegt meer over het gedrag van de aanvrager dan over de feitelijke armoede. Het verdwijnen van het oordeel over hygiëne als criterium kan betekenen dat het gedrag van de aanvrager niet meer ter discussie staat, maar dat zakelijke overwegingen in de besluitvorming nu de doorslag geven. Een smerige woning is geen reden meer een aanvraag af te wijzen.

ad d) Deze verzakelijking zien we ook terug in de afwijzingsgronden. De armbezoeker vermeldde expliciet waarom een aanvraag niet werd gehonoreerd. De afwijzingsgronden heb ik ondergebracht in vier categorieën: afwijzing wegens dubbele bedeling, morele motieven, neutrale afwegingen en zakelijke gronden. In 1871 werd al de helft van de afwijzingen gemotiveerd door zakelijke motieven. In 1911 gaven zakelijke motieven in twee op de drie aanvragen de doorslag. In 1936 kwam het nog maar sporadisch voor dat er bij een afwijzing een morele overweging aan te pas kwam. De afwijzingsgronden waren praktisch helemaal verzakelijkt.

De vraag naar de rol van het beschavingsoffensief in de gemeentelijke armenzorg kan als volgt worden beantwoord. In 1871 was die beschavingsdrang nog duidelijk aanwezig. Het gedrag van de arme was een belangrijk criterium voor het af- of toewijzen van hulp. Gaandeweg werd het idee dat de arme aan allerlei normen en waarden moest voldoen, steeds minder belangrijk bij de besluitvorming. In 1936 was het beschavingsoffensief zo goed als voorbij. Een proces van verzakelijking was voltooid.

De drang om de armen beschaving bij te brengen, speelde geen rol meer in de besluitvorming om een aanvraag al dan niet te honoreren, maar het liet wel zijn sporen na op het vlak van de huisvesting, de gezondheidszorg, de scholingsgraad van de aanvrager en het schoolbezoek van de kinderen.

De huisvesting van de armen is sterk verbeterd. In 1936 behoorde het wonen in kelders en gangen geheel tot het verleden, terwijl in 1871 nog bijna een derde van de aanvragers in toen ook al onwenselijk geachte krochten moest leven. Steeds meer armen kregen een kamerwoning of zelfs een volledige woning tot hun beschikking. De kamerwoning had één ruimte 
voor alle woonfunctie, terwijl in een volledige woning een scheiding van woonfuncties mogelijk is. Naast beschavingsdrang speelden ook andere factoren een rol in de veranderende woonsituatie van de armen. Gewezen moet worden op de initiatieven van woningbouwverenigingen, de invloed van de woningwet van 1901, het gemeentelijke volkshuisvestingsbeleid en de toegenomen welvaart.

Grote veranderingen tussen 1871 en 1936 zijn er op het terrein van de gezondheidstoestand van de armen. In 1871 en in 1911 vertoonden drie van de vier aanvragers lichamelijke gebreken, die hen verhinderden een inkomen te verwerven. In 1936 bleek hun gezondheidssituatie sterk verbeterd te zijn. Optimaal was de situatie in 1936 overigens zeker niet: de levensverwachting van de armen was lager dan gemiddeld. Ten slotte moet worden opgemerkt dat deze veranderingen niet alleen op het conto van het beschavingsideaal kunnen worden geschreven, hoewel het zeker heeft meegespeeld.

De initiatiefnemers van het burgerlijk beschavingsoffensief zagen opvoeding en scholing als belangrijke middelen om de toestand van de armen te verbeteren. Het stimuleren van scholing zien we terug op twee terreinen: de verschuiving in de sociale laag van de aanvragers en het toenemende schoolbezoek van kinderen. Ongeschoolde arbeid voerde in 1871 nog de boventoon, terwijl in 1936, ook onder de armen, een middenkader van meer geschoolden tot de meerderheid was gaan behoren. De scholingsgraad nam in de loop der jaren dus aanzienlijk toe. In 1871 was schoolbezoek van kinderen van armen in de leeftijdsgroep van zes tot en met twaalf jaar al vanzelfsprekend. Het grote aantal kinderen dat naar school ging kan zeker als een triomf van het beschavingsoffensief worden beschouwd.

De grote veranderingen tussen 1871 en 1936 op het gebied van huisvesting, medische gesteldheid, verschuiving in de sociale laag en schoolbezoek kunnen we deels aan het beschavingsoffensief toeschrijven. Daarnaast zijn ook andere factoren van belang, zoals onder meer de verbetering van de levensstandaard.

De eindconclusie die ik hier wil trekken is dat de drang tot beschaven zijn sporen heeft nagelaten, terwijl in de besluitvorming van de Amsterdamse gemeentelijke armenzorg omtrent de steunvragen een geleidelijk proces van verzakelijking plaatsvond. Morele oordelen, ingebed in het burgerlijk beschavingsoffensief, maakten langzaam maar zeker plaats voor rationele overwegingen en zakelijke motieven. 



\section{HOOFDSTUK 7 \\ BUREAUCRATISERING}

< 7.A Kantoor Burgerweeshuis Kalverstraat 92 circa 1904 Het kantoor met links G.A. Haringman (toen nog Boekhouder waarnemend directeur) en rechts J.v.d. Buske, bode.

Fotograaf onbekend. Bron: SAA. Beeldbank. Afbeeldingsbestand OSIM00002001512.
1 Weber zegt hierover: "Die bürokratische Struktur ist überall spätes Entwickelungsprodukt." WuG ${ }^{5}$. 578; WuG: Herrschaft, MWS I/22-4, 45.

2 Zie hiervoor hoofdstuk 5.

3 Zie de tabellen 18.17,

$18.18,18.19$ en 18.20 in

bijlage 8 .

\subsection{DE PRAKTIJK VAN DE AMSTERDAMSE GEMEENTELIJKE ARMEN- ZORG}

Als we, aan de hand van het ideaaltype van Weber, zoals uiteengezet in hoofdstuk 2, de organisatie van de Amsterdamse gemeentelijke armenzorg bekijken, dan valt op dat vanaf het begin, in 1871, deze instelling al veel kenmerken had van een Weberiaanse bureaucratie. Na de oprichting van het Burgerlijk Armbestuur ging de instelling nog meer bureaucratische trekken vertonen. In de jaren '20 en '30 waren bijna alle trekken van Webers ideaaltype zichtbaar in de organisatie van de Amsterdamse gemeentelijke armenzorg. ${ }^{1}$

\section{a) De ontwikkeling en groei van de bureaucratie}

Als we kijken naar de ontwikkeling en groei van de bureaucratie dan valt de grote toename van het aantal aanvragen op. In de jaren '80 van de negentiende eeuw gaat het om enkele duizendtallen per jaar, terwijl in de jaren '30 van de twintigste eeuw meer dan een half miljoen aanvragen per jaar wordt geteld. Voor de groei van de bureaucratie van de Amsterdamse gemeentelijke armenzorg kunnen vier verklaringen worden gegeven:

- de toename van het inwonertal;

- de toename van de zorg;

- de achteruitgang van de betekenis van de kerkelijke armenzorg;

- de toename van de aandacht voor werklozen door de gemeentelijke armenzorg.

Het toenemende inwonertal van Amsterdam zorgde voor de groei van aanvragen om hulp. Tussen 1871 en 1940 was er sprake van bijna een verdriedubbeling van het aantal inwoners. ${ }^{2}$

Daarnaast moet gewezen worden op de toenemende zorg die de gemeente voor haar inwoners noodzakelijk achtte. Het algemene welvaartspeil was gestegen.

Een derde verklaring van de groei is dat aanvankelijk het Burgerlijk Armbestuur in de hulpverlening achterbleef bij de kerkelijke en de particuliere armenzorg. Het gaat hierbij om het aantal huishoudens. Per huishouden was de kerkelijke en particuliere steun relatief laag. De gemeentelijke armenzorg verstrekte een ruimere steun. Tot de jaren '90 van de negentiende eeuw was het aandeel van de Burgerlijk Armbestuur in de hulpverlening aan huishoudens gering. Het aandeel bedroeg nog geen tien procent. In de jaren '90 van de negentiende eeuw steeg dat aandeel naar ongeveer vijftien procent. Aan het begin van de twintigste eeuw was er een sterke groei en nam het Burgerlijk Armbestuur een derde van alle hulp voor zijn rekening. Deze groei zette door. Rond 1920 was het aandeel van de burgerlijke armenzorg al meer dan de helft, terwijl in de jaren '30 de gemeentelijke armenzorg het leeuwendeel van de zorg op zich had genomen. ${ }^{3}$ Het toenemende aandeel van de gemeentelijke armenzorg wordt uitgebeeld in de grafieken 7.1, 7.2, 7.3 en 7.4. 
Grafiek 7.1 Aandeel Burgerlijk Armbestuur in het totaal ondersteunde armen (1885-1905) in percentages

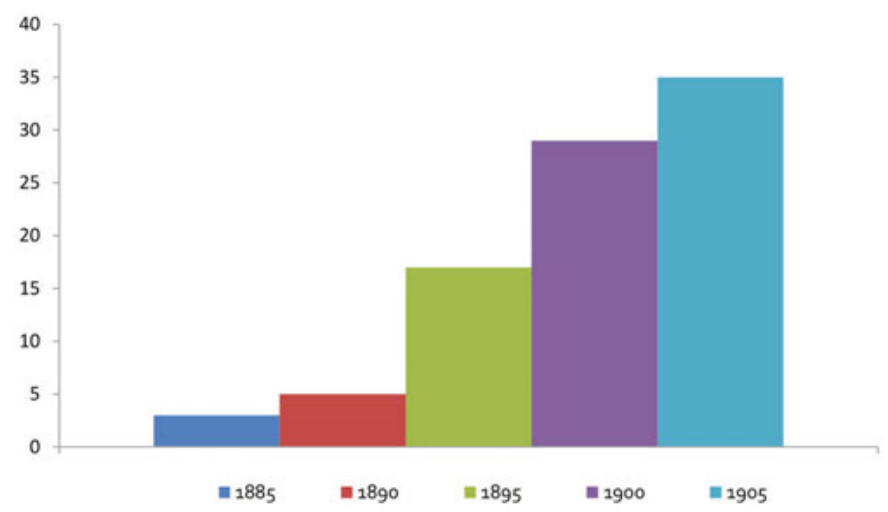

Bron: bijlage 8, tabel 8.17.

Grafiek 7.2 Aandeel Burgerlijk Armbestuur in de totale bedeling (1917-1921) in percentages

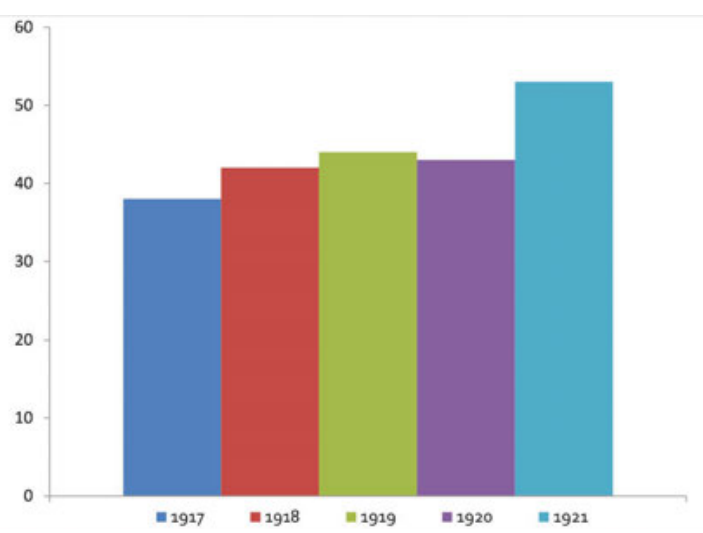

Bron: bijlage 8, tabel 8.18.

Grafiek 7.3 Bedeelden door algemene en kerkelijke armenzorg in 1895 in percentages

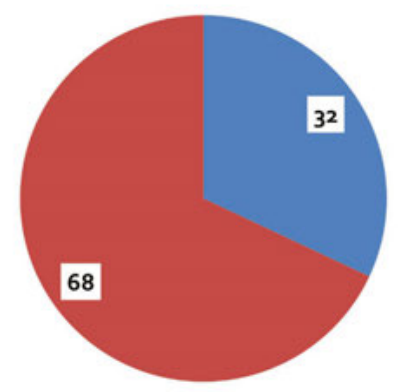

=Algemene instelligen $\quad$ Kerkelijke instellingen

Bron: bijlage 8, tabel 8.20 


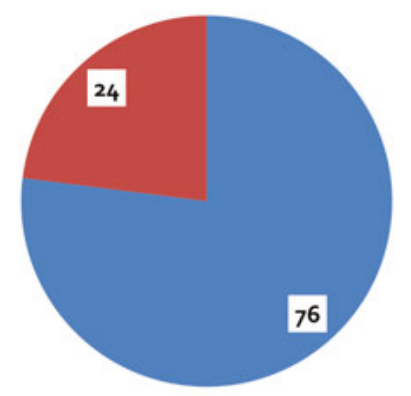

= Algemene instellingen $\quad$ Kerkelijke instellingen

Bron: bijlage 8, tabel 8.20

Als vierde verklaring voor de groei van de gemeentelijke armenzorg moet er op worden gewezen dat onderzoeken naar werklozen van grotere betekenis zijn geworden voor de gemeentelijke armenzorg. In hoofdstuk 5 wees ik hier al op. Naast de traditionele werklozen, meestal "losse arbeiders", die geen geregeld dienstverband hadden en vooral in de winter geen werk konden vinden, ontstond er als gevolg van het industrialisatieproces een nieuw type werkloosheid: een moderne conjuncturele werkloosheid, die verband houdt met de economische golfbeweging. Vanuit de gemeente en het Rijk werd zorg voor deze nieuwe werklozen geleverd. De groei van de werkloosheid in het crisisdecennium, de jaren '30 van de twintigste eeuw, betekende een forse toename van de werkzaamheden van de gemeentelijke armenzorg. ${ }^{4}$

De toenemende aandacht voor werklozen is terug te vinden in de door mij verzamelde dossiers. Hoewel de focus van mijn onderzoek is gericht op de rol van beschaving en het bureaucratiseringsproces mag deze aandacht niet onvermeld blijven. Werklozen werden altijd al gesteund. In de jaargroep 1871 was $15 \%$ van de aanvragen hulp bij werkloosheid. Vaak betrof het de voor een pre-industriële samenleving zo typerende seizoenswerkloosheid. De overige $85 \%$ van de aanvragen betrof wat destijds armlastigheid werd genoemd. Het ging hierbij om vele soorten van hulp (zie ook tabel 7.1). De bronnen die ik heb bestudeerd vermelden hulpverzoeken vanwege weduwestaat, het overlijden van een gezinslid, een kostwinner die zijn/haar gezin had verlaten, opname in het Armenhuis, kraambedeling, versterkende middelen, kleding, schoeisel, schipbreuk, verblijf in Hulp voor Onbehuisden, verblijf in De Toevlucht. In de jaargroep 1911 was de verhouding 22\% aanvragen vanwege werkloosheid en $78 \%$ aanvragen vanwege armlastigheid.

4 Drukker (1990), 156, meldt dat in 1928 de werkloosheid in Nederland $1,6 \%$ van de totale beroepsbevolking bedroeg. Het topjaar was 1936 toen $11,9 \%$ van de totale beroepsbevolking werkloos was. In 1931 werd ook de ondersteuning van werkloze "uitgetrokken" leden van vakverenigingen met een werklozenkas aan de taken van de armenzorg toegevoegd. Hiertoe werd een commissie ingesteld: de Commissie voor de ondersteuning van georganiseerde werklozen. Daarnaast was een tweede commissie actief: Commissie voor ondersteuning van werklozen, niet vallend onder de Commissie voor de ondersteuning van georganiseerde 
werklozen. De archiefstukken van de eerste commissie zijn pas vanaf 2041 openbaar en konden daarom niet door mij worden geraadpleegd. In de door mij onderzochte jaargroep 1936 komen wel de aanvragers voor uit de tweede commissie en de armlastigen. $56 \%$ van de aanvragers was werkloos, terwijl $44 \%$ van de aanvragers tot de armlastigen behoorde. Het beeld kan compleet gemaakt worden, omdat de dienst de totalen van wekelijks gesteunden vermeldt. ${ }^{5}$ In 1936 in Amsterdam vormden georganiseerde werklozen $27 \%$ van de aanvragen, de ongeorganiseerde werklozen $45 \%$ van de aanvragen, terwijl $28 \%$ van de aanvragers tot de armlastigen gerekend moet worden. Ook in deze cijfers wordt het uitzonderlijke karakter van de jaren '30 van de twintigste eeuw zichtbaar.

Het beeld dat het bestrijden van de gevolgen van werkloosheid aanvankelijk een minder belangrijke rol speelde in de hulpverlening blijkt ook uit een overzicht van oorzaken van armoede tussen 1886 en 1908. Grafiek 7.5 maakt dat zichtbaar. Tussen 1886 en 1895 werd "tijdelijk gebrek aan werk door buitengewone oorzaken" in ongeveer een derde van de gevallen als oorzaak voor armoede van de wekelijks bedeelden aangewezen. ${ }^{6}$ Tussen 1896 en 1908 werd ongeveer een zesde deel van de wekelijks bedeelden door armoede getroffen omdat er een tijdelijk gebrek aan werk door buitengewone omstandigheden was. ${ }^{7}$ Voor het gehele tijdvak 1886-1908 werd als oorzaak van armoede in driekwart van de gevallen omstandigheden buiten werkloosheid aangewezen.

Grafiek 7.5 Oorzaken armoede van wekelijks bedeelden 1886-1908 in percentages

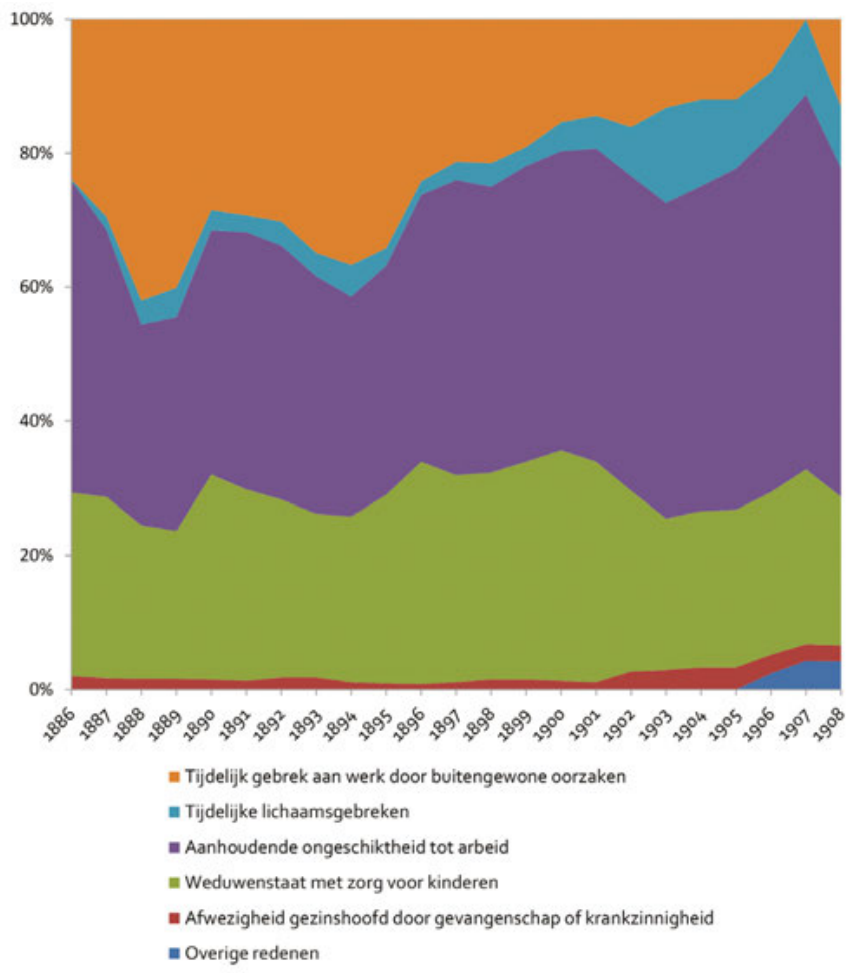

Bron: bijlage 8, tabel 8.21.
5 Zie tabel 8.12.

6 De terminologie "tijdelijk gebrek aan werk door buitengewone oorzaken" is opmerkelijk. Zie ook hoofdstuk 5 paragraaf b Van nijverheid naar industrie waarin de "nieuwe" werkloosheid wordt besproken. 7 De daling van het " tijdelijke gebrek aan werk door buitengewone oorzaken" na 1895 kan grotendeels op conto worden geschreven van de aantrekkende conjunctuur na 1895. Het meest recente onderzoek van Van Riel vat deze ontwikkeling voor geheel Nederland als volgt samen: "After a limited industrial deceleration, a further likewise limited acceleration across all sectors followed from the latter half of the 1890s"; Van Riel (2018), 434. Voor Amsterdam is Knotter (1991) nog steeds goed bruikbaar. Ook in de periode van conjuncturele opgang tussen 1895 en 1914 bleef in Amsterdam werkloosheid bestaan. Knotter stelt: " dat er een hardnekkig overaanbod van arbeidskrachten bleef bestaan" Knotter (1991), 244. In het bijzonder "half-werkloze losse arbeiders en marginale kleine ambachtslieden" werden getroffen Knotter (1991), 244. 
Tussen 1886 en 1895 verviervoudigde het aantal aanvragen, zoals in grafiek 7.6 is terug te zien.

Grafiek 7.6 Aantal steunaanvragen en aantal toegekende aanvragen per jaar 1886-1895

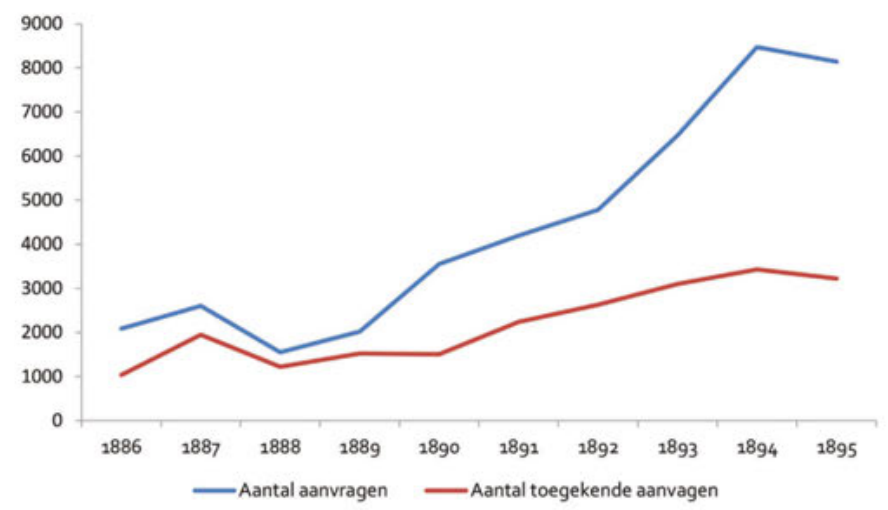

Bron: bijlage 8, tabel 8.15.

Voor de jaren 1905-1910 is er een uitvoeriger overzicht beschikbaar van de onderzoeken die waren verricht. Tabel 7.1 geeft dat overzicht weer.

Tabel 7.1 Onderzoeken gemeentelijke armenzorg tussen 1905 en 1910

\begin{tabular}{|c|c|c|c|c|c|c|}
\hline & 1905 & 1906 & 1907 & 1908 & 1909 & 1910 \\
\hline \multicolumn{7}{|l|}{ AANVRAGEN OM: } \\
\hline Onderstand & 2824 & 2345 & 3817 & 5453 & 5262 & 5566 \\
\hline $\begin{array}{l}\text { Voortzetting van de geldbede- } \\
\text { ling }\end{array}$ & 4460 & 4519 & 4930 & 5905 & 6073 & 6243 \\
\hline Versterkende middelen & 1226 & 1026 & 1033 & 1339 & 1410 & 1344 \\
\hline Winterbedeling & 444 & 321 & 503 & 311 & 441 & 453 \\
\hline Zomerbedeling & 19 & 18 & 23 & 58 & 10 & 56 \\
\hline Opneming in het Armenhuis & 335 & 312 & 829 & 402 & 397 & 398 \\
\hline Plaatsing op het Weduwenhof & 31 & 82 & 77 & 82 & 45 & 35 \\
\hline $\begin{array}{l}\text { Boekjes voor geneeskundige } \\
\text { hulp }\end{array}$ & 1181 & 1210 & 1246 & 1733 & 1831 & 1615 \\
\hline $\begin{array}{l}\text { Tijdelijke bewijzen voor genees- } \\
\text { kundige hulp }\end{array}$ & 18434 & 19481 & 20385 & 23049 & 21371 & 21196 \\
\hline $\begin{array}{l}\text { Plaatsing op openbare lagere } \\
\text { scholen }\end{array}$ & 1803 & 768 & 248 & 221 & 198 & 228 \\
\hline $\begin{array}{l}\text { Procedures, rekesten, huwelijken } \\
\text { enz. (pro Deo) }\end{array}$ & 5965 & 7685 & 7284 & 7079 & 7002 & 6996 \\
\hline Schuttersuniformen & 43 & 4 & - & - & - & - \\
\hline $\begin{array}{l}\text { Ontheffing of uitstel van den } \\
\text { werkelijke dienst of vergoeding } \\
\text { voor militie- en landweerverplich- } \\
\text { tingen }\end{array}$ & 1114 & 2141 & 1463 & 3019 & 1832 & 2821 \\
\hline $\begin{array}{l}\text { Vergoeding bij onbewoonbaar } \\
\text { verklaren van woningen }\end{array}$ & - & - & 13 & 192 & 207 & 232 \\
\hline Kindervoeding & - & - & - & - & 1965 & 2327 \\
\hline
\end{tabular}




\begin{tabular}{|c|c|c|c|c|c|c|}
\hline $\begin{array}{l}\text { ONDERZOEK NAAR DE FINAN- } \\
\text { CIELE TOESTAND VAN: }\end{array}$ & & & & & & \\
\hline $\begin{array}{l}\text { Verpleegden in gestichten voor } \\
\text { zenuwlijders, maatschappelijk } \\
\text { ongeschikten enz. }\end{array}$ & 388 & 816 & 604 & 479 & 663 & 600 \\
\hline $\begin{array}{l}\text { Houders van boekjes voor ge- } \\
\text { neeskundige hulp }\end{array}$ & 2201 & 2321 & 1799 & 730 & 528 & 1319 \\
\hline \multicolumn{7}{|l|}{ DIVERSE ONDERZOEKEN: } \\
\hline $\begin{array}{l}\text { Naar aanleiding van ingekomen } \\
\text { missiven }\end{array}$ & 564 & 509 & 344 & 648 & 1190 & 1317 \\
\hline TOTAAL & 41.032 & 43.503 & 44.098 & 50.700 & 50.425 & 52.746 \\
\hline
\end{tabular}

Bron: SAA 15030. Bestanddeel 133312. Gemeenteverslag 1910. Bijlage X, 15.

Ook voor de jaren 1905-1910 is de toename van de werkzaamheden fors te noemen. Het aantal onderzoeken nam met een kwart toe.

Tabel 7.1 maakt tevens zichtbaar welke diversiteit er is aan onderzoeken die de gemeentelijke armenzorg heeft verricht. Ongeveer een kwart van de onderzoeken gaat over directe steunverlening. Bijna de helft van de onderzoeken heeft betrekking op geneeskundige hulp, hetzij voor langere duur (de boekjes) hetzij voor een korte periode (de tijdelijke bewijzen). De tijdelijke bewijzen waren voor aanvragers die verzuimd hadden hun boekje te laten afstempelen. Door het afstempelen was het boekje weer twaalf maanden geldig. Verder waren er tijdelijke bewijzen voor personen die zich in de gemeente hadden gevestigd en vergeten waren zich in te schrijven bij een ziekenfonds. Ten slotte waren er tijdelijke bewijzen voor de categorie weigerachtigen, die zich na intrekking van een boekje niet bij een ziekenfonds aansloten, in de zekerheid dat, in geval van ziekte, een tijdelijk bewijs toch niet zou worden geweigerd. Om het wat minder makkelijk te maken, besloot de armenzorg voor deze categorie de geldigheidsduur van het tijdelijk bewijs te beperken tot een week. In andere gevallen bedroeg de geldigheidsduur een maand. ${ }^{8}$

De overige onderzoeken gaan over heel verschillende zaken, waarbij de onderzoeken naar de financiële toestand als een extra controle moet worden opgevat. Zelfs in deze korte periode tussen 1905 en 1910 zien we verschuivingen in de onderzoeken. Onderzoeken over aanvragen voor schuttersuniformen verdwenen uit beeld, terwijl onderzoeken naar kindervoeding en naar vergoeding voor het onbewoonbaar verklaren van woningen aan het toch al uitgebreide takenpakket werden toegevoegd. Het onderzoek naar kindervoeding is een toevoeging op de aanvraag voor versterkende middelen. Versterkende middelen werden ook aan volwassen verstrekt op doktersattest. In de regel ging het dan om de kosteloze verstrekking aan één persoon van een liter melk of een ei per dag. Woningen konden onbewoonbaar verklaard worden. In Amsterdam kon dat sinds 1865 op aangeven van de toen ingestelde gezondheidscommissie. ${ }^{9}$ Met de inwerkingtreding in 1902 van de Woningwet kregen gemeenten een ruimere bevoegdheid om een woning onbewoonbaar te verklaren. Bewoners die om die reden hun woning moesten verlaten, konden een vergoeding aanvragen.

Knotter stelt dat "tussen 1914 en 1940 de armenzorg vooral werklozenzorg" was. ${ }^{10}$ Dat is zonder meer juist als gekeken wordt naar het bedrag van
8 SAA 5256. Bestanddeel 832. Jaarverslag 1899 Burgerlijk Armbestuur, 21 bijlage $X$. 9 SAA 5269. Archief van de Gezondheidscommissie; Van der Woud (2010), 161. 10 Knotter (1997), 65. 
de uitkeringen en het aantal betrokken huishoudens. In 1936 werd iets meer dan zeventig procent van de uitgaven van de Burgerlijke Instelling voor Maatschappelijken Steun aan georganiseerde en ongeorganiseerde werklozen besteed. Ongeveer een kwart van de uitgaven ging naar de armlastigen. ${ }^{11}$ Uit tabel 8.12 blijkt dat in 1936 72\% van de gesteunde huishoudens uit huishoudens van werklozen bestond. In de door mij onderzochte dossiers is de verhouding, zoals boven al aangegeven, dat $56 \%$ van de aanvragers tot de ongeorganiseerde werklozen behoorde, terwijl $44 \%$ van de aanvragers tot de armlastigen behoorde. In tabel 7.2 wordt het aantal onderzoeken dat in 1936 is verricht door de gemeentelijke dienst weergegeven.

Tabel 7.2 Onderzoeken gemeentelijke armenzorg in 1936

\begin{tabular}{|l|r|}
\hline Soort & Aantal \\
\hline Ondersteuning* & 136.360 \\
\hline Voortzetting van de ondersteuning & 9.2787 \\
\hline Versterkende middelen & 9.420 \\
\hline Opname in verzorgingshuizen voor ouden van dagen & 1.527 \\
\hline Boekjes voor geneeskundige hulp & 955 \\
\hline Tijdelijke bewijzen voor geneeskundige hulp & 33.007 \\
\hline Bewijzen voor verloskundige hulp & 4.184 \\
\hline Bewijzen voor verloskundige hulp & 36.186 \\
\hline Bewijzen voor ziekenhuisverpleging & 11.775 \\
\hline $\begin{array}{l}\text { Ontheffing of uitstel van de werkelijke dienst of vergoeding voor } \\
\text { dienstplichtigen of vergoeding wegens kostwinnerschap van dienst- } \\
\text { plichtigen }\end{array}$ & 1.946 \\
\hline Kindervoeding en kleding & 2.764 \\
\hline Verminderd tarief was in gemeentelijke washuizen & 8.083 \\
\hline Brieven van ondersteunden, verpleegden enz. & 34.557 \\
\hline Verpleging van zenuwlijders, maatschappelijk ongeschikten enz. & 2.255 \\
\hline Huisverzorging & 2.141 \\
\hline Diverse onderzoeken & 17.221 \\
\hline Ondersteuning werklozen & 117.032 \\
\hline Ondersteuning werklozen Crisiscomité 1931 subcommissie A\# & 133 \\
\hline TOTAAL & 512.333 \\
\hline & \\
\hline & \\
\hline
\end{tabular}

11 SAA 5256. Bestanddeel 834. Jaarverslag 1936, 18. Hoe omvangrijk de zorg wel was blijkt als de uitgaven voor zorg voor werklozen en armlastigen wordt afgezet tegen de totale gemeentelijke uitgaven. In 1936 bedroegen de uitgaven aan zorg voor werklozen en armlastigen ongeveer een derde van de totale uitgaven, te weten $f 115$ miljoen in totaal waarvan $f 36$ miljoen aan zorg (Statistisch Jaarboek der Gemeente Amsterdam 1936-1937, 142-145). In de jaren '20 van de twintigste eeuw waren de uitgaven aan zorg eveneens aanzienlijk. Zo bedroeg in 1924 de steun aan werklozen $3 \%$ van de gemeentelijke uitgaven, terwijl aan de "behoeftigen" 29\% van de gemeentelijke uitgaven werd gespendeerd.

(Statistisch Jaarboek der

Gemeente Amsterdam

1924-1925, 178)
*Inbegrepen de onderzoeken voor het Crisiscomité Amsterdam 1931 subcommissie B (voor een uitvoerige beschrijving van de werkzaamheden: SAA 5379. [= Archief van het Crisis-Comité Amsterdam 1931] Bestanddeel 5, 10.) De subcommissie B was belast met "Het zoveel mogelijk verlenen van aanvullende steun, uitsluitend in natura, aan ondersteunde werklozen, in wier gezinnen ernstige achterstand aan kleeding, dekking en schoeisel bestaat" \{SAA 5379. Bestanddeel 5, 11.\}

\# Deze subcommissie A behandelde de meer eenvoudige gevallen (SAA 5379. Bestanddeel $5,7)$.

Bron: SAA 5256. Bestanddeel 388, 17.

De verandering in de steunverlening tussen het begin van de twintigste eeuw en de jaren '30 wordt ook zichtbaar als we tabel 7.1, betreffende onderzoeken tussen 1905 en 1910, vergelijken met tabel 7.2, betreffende 
onderzoeken in 1936. Winter- en zomerbedeling zijn verdwenen als middelen om te steunen. Verder valt de toegenomen aandacht voor werklozen op in het aantal onderzoeken. Tot slot springt de continuïteit van de zorgverlening in het oog. Verzoeken om versterkende middelen, opname in verzorgingshuizen voor ouden van dagen, medische hulpverlening en verpleging van zenuwlijders en maatschappelijk ongeschikten zien we zowel in het begin van de twintigste eeuw als in 1936. Wel is er een wijziging in terminologie. Wat bijvoorbeeld voorheen "plaatsing op het Weduwenhof" werd genoemd, heet in 1936 "opname in verzorgingshuizen voor ouden van dagen".

Vergelijken we de situatie van 1936 met die van het begin van de eeuw, zoals in tabel 7.1 is weergegeven, dan nam het aantal onderzoeken met het tienvoudige toe: een zeer forse stijging. Het bureaucratiseringsproces werd erg bevorderd door de groei van de werkzaamheden en de toegenomen complexiteit van de zorg.

Een onderzoek was in de regel tijdrovend. Bij de meeste aanvragen verrichtte een armbezoeker een huisbezoek. Hij nam een uitvoerige vragenlijst door. ${ }^{12}$ Navraag werd gedaan bij buurtbewoners en werkgevers. Aanvankelijk liep de armbezoeker al die adressen af. Sinds 1885 mocht ook gebruik worden gemaakt van de tram. ${ }^{13}$ Kerkgenootschappen werden aangeschreven om inlichtingen over mogelijk verstrekte steun. Bij de burgerlijke stand werd nagegaan of de aanvrager stond ingeschreven op het bezochte adres. Bij de burgerlijke stand kon ook het opgegeven kindertal worden gecontroleerd.

Als er een verdenking was van fraude kon tot posten bij het woonadres worden overgegaan. ${ }^{14}$ Voor het opsporen van fraude waren informanten aangesteld. Deze medewerkers hadden dezelfde bevoegdheden als politieambtenaren. Zij mochten processen-verbaal opstellen. ${ }^{15} \mathrm{Er}$ waren nog meer controlemogelijkheden. Uit 1950 is een overzicht van controlemogelijkheden beschikbaar. Zo werden aanvragers gecontroleerd door middel van politierapporten. ${ }^{16}$ Er was controle op het uitbetalen van postwissels via de PTT. ${ }^{17}$ Er werd samengewerkt met de Rijksverzekeringsbank om fraude met dubbele uitkeringen te bestrijden. ${ }^{18}$ Gegevens van Het Centraal Bureau voor Maatschappelijk Hulp (Bureau van den Armenraad) werden gekoppeld. ${ }^{19}$ Er werd gecontroleerd bij werkgevers of zij ondersteunden in dienst hadden, die mogelijk ten onrechte een uitkering genoten. ${ }^{20}$ Er was controle op de verdiensten van krantenbezorgers. ${ }^{21}$ Ook langdurig verpleegden werden in de gaten gehouden. ${ }^{22}$

Omdat de gemeentelijke armenzorg een instelling was die van de overheid uitging, kon, anders dan voor de kerkelijke en particuliere steunverleners, van bovengenoemde overheidsdiensten gebruik worden gemaakt. Dat betekende dat de mogelijkheid tot frauderen bij de gemeentelijke armenzorg kleiner was dan bij de kerkelijke en particuliere steunverleners. Formeel werden de armbezoekers ook zelf gecontroleerd door hun leidinggevende. In de praktijk werd het toe- of afwijzingsvoorstel van de armbezoeker bijna altijd opgevolgd.
12 Zie ook bijlage 2 en bijlage 3 .

13 SAA 15030. Bestanddeel 132021. Jaarverslag Burgerlijk Armbestuur 1885 "om tijd (te) sparen van de armbezoekers door hen nu en dan verlof te geven van de tramwagens gebruik te maken."

14 In hoofdstuk 8 waarin het levensverhaal wordt beschreven van het gezin Aal wordt een voorbeeld van het posten gegeven. 15 SAA 5256. Bestanddeel 834. Verslag van de Burgerlijke Instelling voor Maatschappelijke Steun 1938. In 1938 waren zes informanten in dienst. 16 SAA 5256. Bestanddeel 11.

17 SAA 5256. Bestanddeel 12.

18 SAA 5256. Bestanddeel 13.

19 SAA 5256. Bestanddeel 14.

20 SAA 5256. Bestanddeel 15.

21 SAA 5256. Bestanddeel 16.

22 SAA 5256. Bestanddeel 17. 


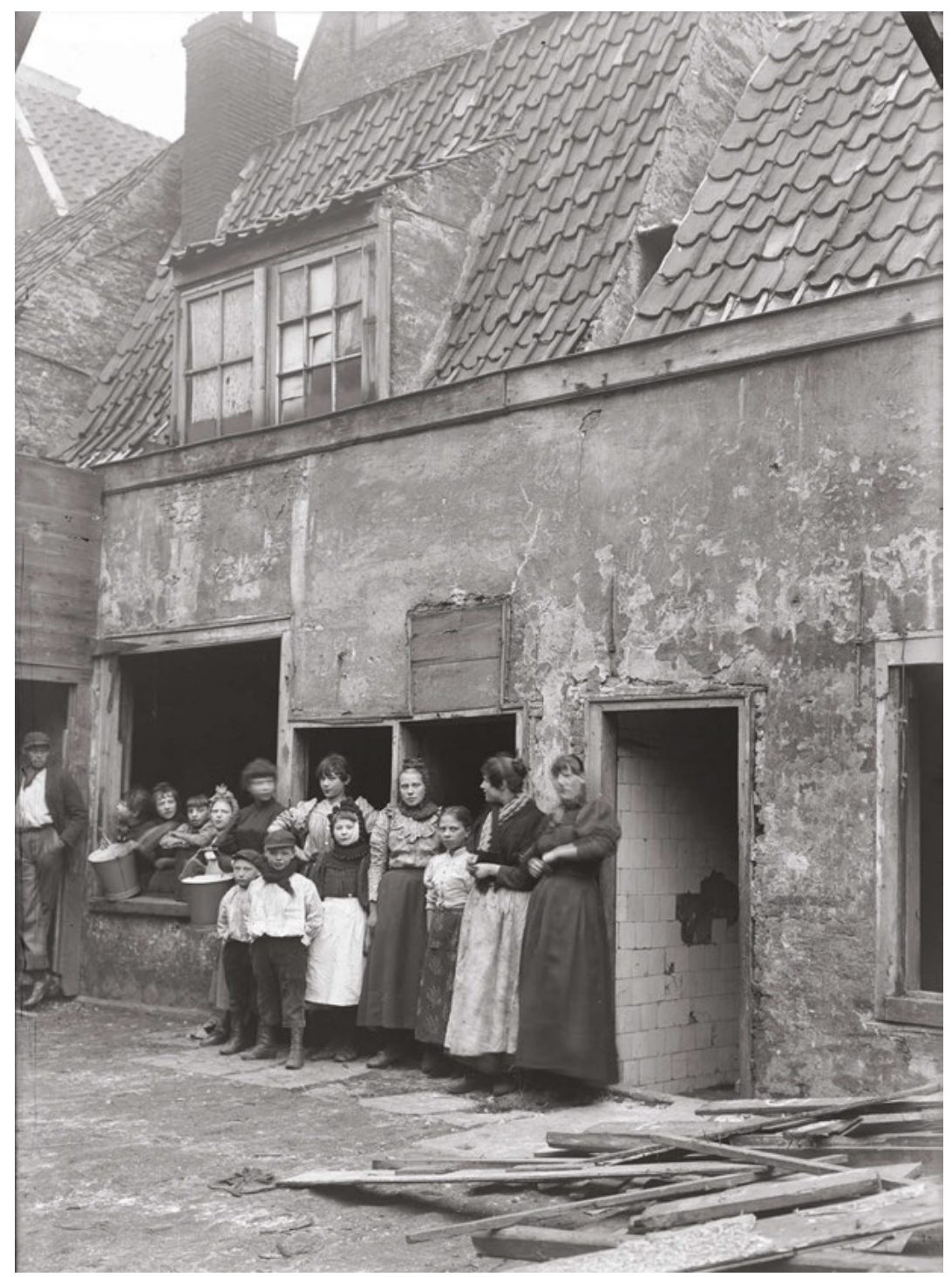

Foto door C.J. Schmidt Az. in opdracht van de Gezondheidsdienst in het kader van de voorbereiding van onbewoonbaar verklaring.

Bron: SAA. Beeldbank. Afbeeldingsbestand 5293FO004979.

Zoals blijkt uit grafiek 7.7 nam in het wat langere tijdvak 1905 - 1940 het aantal onderzoeken onder steunaanvragers nog sterker toe: van ongeveer 40.000 naar 600.000; een toename van 1500 procent De sterkste stijging deed zich in de jaren '30 voor, wat natuurlijk te maken heeft met het crisiskarakter van dit decennium. Tegelijkertijd moet ook op de uitbreiding van de maatschappelijke zorg gewezen worden. De inspanningen van de gemeentelijke maatschappelijke zorg zijn in twee opzichten toegenomen in de jaren '30. Niet enkel in kwantitatieve, maar ook in kwalitatieve zin. Met deze constatering loop ik overigens vooruit op de kwaliteit van de uitvoering van de administratieve taken. Deze kwalitatieve ontwikkeling komt in de volgende paragraaf aan bod. 


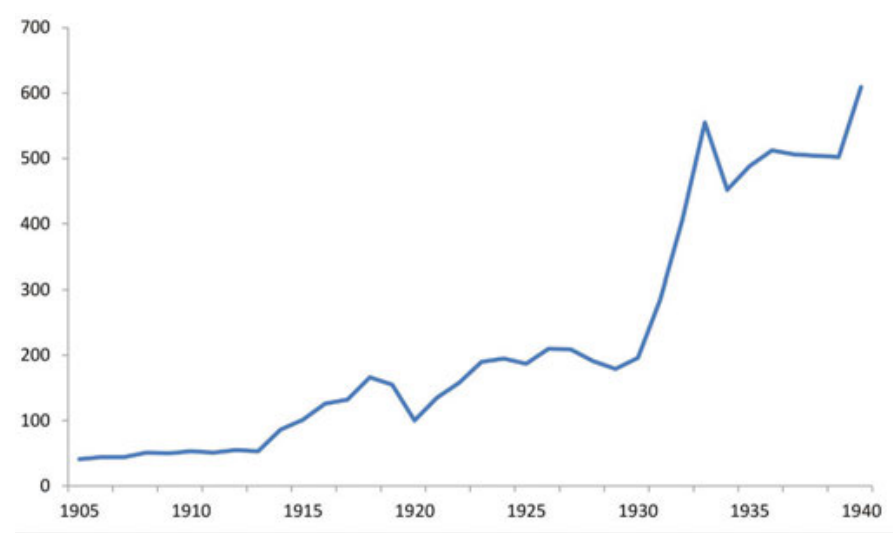

Bron: bijlage 8, tabel 8.16 .

De sterke toename van het aantal administratieve taken, door de groei vooral van het aantal steunaanvragen, zorgde ook voor een uitbreiding van het ambtelijk apparaat. Tot de eeuwwisseling had de armenzorg enkele tientallen personeelsleden in dienst; tijdens het interbellum ging het om honderden personeelsleden. De jaren '30 laten de grootste stijging zien. In onderstaande grafieken 7.8 en 7.9 is deze ontwikkeling aanschouwelijk gemaakt.

Grafiek 7.8 Armbezoekers (1871-1916)

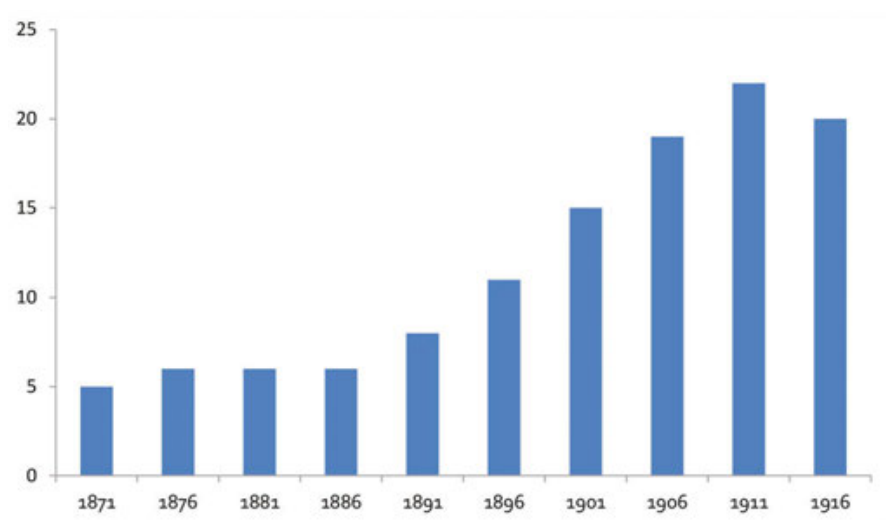

Bron: bijlage 8, tabel 8.22. 


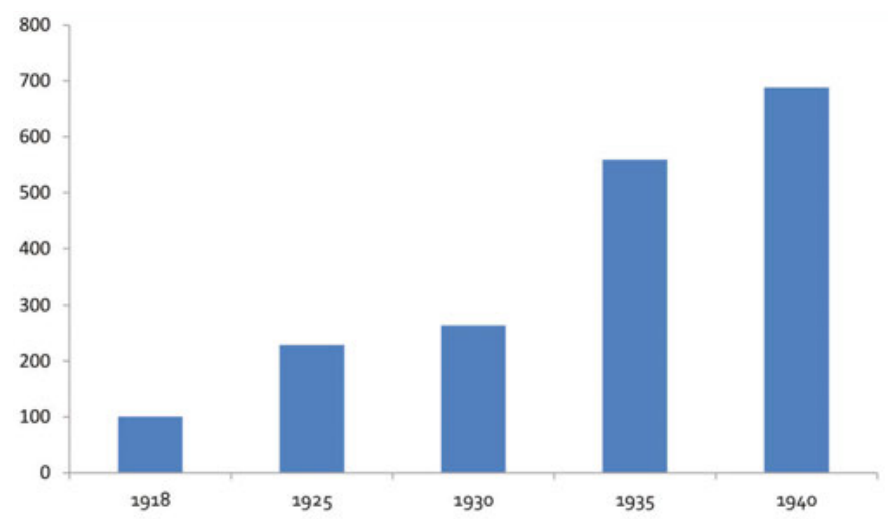

Bron: bijlage 8, tabel 8.23. (Sinds 1918 werd armenzorg aangeduid als maatschappelijk hulpbetoon, ook wel als maatschappelijke steun)

De toename van de werkzaamheden en de groei van het aantal werknemers is ook terug te zien in de stijgende uitgaven. De totale uitgaven van het Burgerlijk Armbestuur stegen van 39 duizend gulden in 1871 tot meer dan zes miljoen gulden in 1928. De uitgaven aan wekelijkse ondersteuning bedroegen in 1916 bijna één miljoen gulden. In 1938 waren deze uitgaven opgelopen tot bijna 29 miljoen gulden. ${ }^{23}$ Grafiek 7.10 en grafiek 7.11 beelden deze ontwikkelingen uit. Opgemerkt moeten worden dat in grafiek 7.10 alle uitgaven worden vermeld, terwijl in grafiek 7.11 enkel de uitgaven per jaar aan wekelijkse ondersteuning worden weergegeven.

Grafiek 7.10 Uitgaven Burgerlijk Armbestuur (1871 - 1916) in hfl 1.000

23 De totale gemeentelijke uitgaven beliepen in 1938 $f 66$ miljoen, zodat het aandeel van de uitgaven in zorg $29 \%$ bedroeg. bedroeg (Statistisch Jaarboek der Gemeente Amsterdam 1938-1939, 155). Overigens was dat een fractie minder dan in 1934 toen de uitgaven voor zorg met $f 24$ miljoen een derde, exact $32 \%$, van de totale uitgaven van $f 75$ miljoen omvatten.

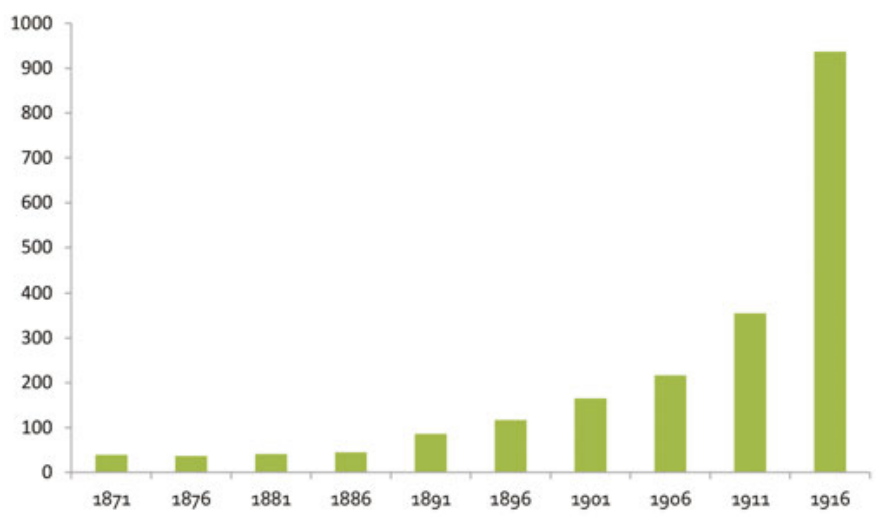

Bron: bijlage 8, tabel 8.14. 


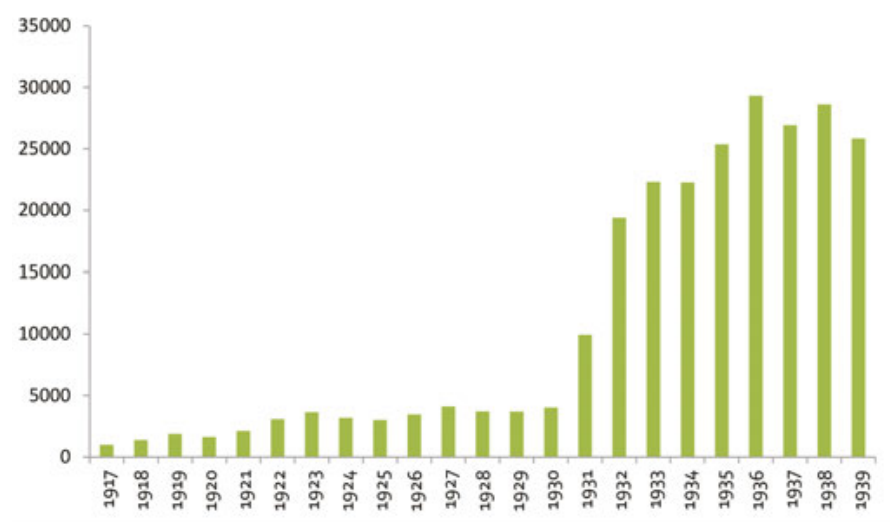

Bron: bijlage 8, tabel 8.12.

Bij de oprichting van het Burgerlijk Armbestuur in 1871 komen we een element tegen uit de oude organisatievorm. Behalve de wethouder zijn de leden namelijk allemaal onbezoldigd. Het zijn mensen afkomstig uit de elite voor wie deze functie een erebaan is. Bij de opheffing van het Burgerlijk Armbestuur in 1927 verdwijnen deze erebanen. De elite maakt plaats voor een toenemend aantal bezoldigde ambtenaren. Wij kunnen hier een vernieuwing van het bureaucratisch systeem in zien.

Het bureaucratiseringsproces tussen 1871 en 1940 bracht verzakelijking met zich mee, maar er bleef ook ruimte bestaan voor barmhartigheid. In een aantal gevallen wordt blijk gegeven van medemenselijkheid. Met twee voorbeelden wil ik dat illustreren. Hieruit kunnen we opmaken dat de gemeentelijke armenzorg zeker niet alleen een onpersoonlijke machinerie is geweest.

Mededogen met mensen die het moeilijk hebben lijkt mee te spelen in het toekennen van steun aan de ongehuwde 51-jarige Gesina Baarschert (1836-1898). Zij werd opgenomen in het Armenhuis op 27 juni $1888 .{ }^{24} \mathrm{Ge}$ sina woonde in bij haar zuster in de Hasselaerssteeg. Zij was prostituée geweest, maar oefende dit beroep in 1888 niet meer uit. De armbezoeker noteerde:

"Deze vrouw is publieke vrouw. Zij is in begin Januari van de trap der woning gevallen, naar haar voorgeven van een zenuwaanval. Is toen naar het Binnen Gasthuis vervoerd en daar gebleven tot het laatst van April. Ten gevolge van den val kan zij niet loopen dan met een stok, zoodat zij niet in staat is om in haar onderhoud te voorzien en geen raad meer weet."

Als lichaamsgebrek constateerde de armbezoeker dat deze vrouw "(een) gekneusd been (heeft), loopt met een stok leunende". Voor dit gebrek toonde zij ook een medisch attest. Door het gebrek was zij was zonder verdienste. Zij verzocht om "opname in het armenhuis daar haar zuster haar niet langer in huis hebben wil, en de omgeving waar zij thans verkeert, is niet van dien aard haar zonder eenige vergoeding te doen verblijven." De indruk die de armbezoeker van de aanvraagster had was "met het oog op 
haar vorige levenswandel ongunstig, zij is echter ten einde raad". Volgens de maatstaven van het burgerlijk beschavingsoffensief kwam de vrouw niet voor steun in aanmerking vanwege haar onzedelijke levenswandel. Op strikt zakelijke gronden, het ontbreken van een inkomen, kon wel een positieve beslissing genomen worden. Met de zinsnede "ten einde raad" gaf de armbezoeker blijk van empathie en hij willigde het verzoek van Gesina in.

Klaas Kuyl, een schippersknecht, geboren op 19 juni 1832, is getrouwd met Wabegie Veen in $1861 .^{25}$ Wabegie is twee jaar ouder dan haar man. In 1898 treffen we het echtpaar aan in een kelder in de Haarlemmerstraat. Nicolaas, dan 66 jaar, heeft ouderdomsgebreken waardoor hij niet meer kan werken. Het echtpaar vraagt om winterbedeling, die ook wordt toegekend. Vanaf dat moment blijft het echtpaar steun van de gemeentelijke armenzorg ontvangen. In 1911 viert het bejaarde echtpaar zijn gouden bruiloft. Dat leidt zelfs tot een krantenbericht.

\section{Een gouden echtpaar}

Klaas Kuyl en Wabegie Veen, wonende Zoutkeetsgracht 28, herdenken heden ten dage (4 mei 1911) dat zij een halve eeuw geleden in het huwelijksbootje stapten. En omdat beide oudjes in behoeftige omstandigheden verkeren en het gouden feest hen dus waarschijnlijk weinig vreugd zou brengen, hebben de heeren $\mathrm{H}$. de Graaf en C. Boolen zich er maar eens flink voorgespannen. Bij de buurtgenoten werd gecollecteerd, ieder stond af wat te missen kon en op die manier kwam er een sommetje gelds bijeen, waarvan het comité de oudjes wekelijks een gedeelte ter hand zal stellen, zoodat zij voorlopig niet ongerust hoeven zijn over het betalen van de huur. Ook de feestdag zelf, gaat niet onopgemerkt voorbij. De woning der oudjes is keurig met groen en bloemen versierd. Tal van vrienden kwamen in de loop van den dag de hand drukken en vanavond is er een groot concert voor hun woning, zal een muziekcorps misschien wel tot elf uur zijn vrolijke wijsjes doen weerklinken, zoodat ook de buurtgenoten er nog een pretje van hebben.

(Het krantenknipsel geeft geen bron aan).

De armbezoeker heeft dit krantenknipsel bij het dossier gevoegd. Hieruit spreekt betrokkenheid bij het wel en wee van het echtpaar. De buurtcollecte wordt door de vingers gezien en de steun wordt onveranderlijk voortgezet. In 1914 overlijdt Wabegie, op 84-jarige leeftijd. Klaas blijft gesteund door de gemeentelijke armenzorg. In 1920 beschrijft de armbezoeker Klaas als "een zeer oude man". In het voorjaar van 1923 geeft de armbezoeker blijk van bezorgdheid als hij in zijn rapport vermeldt dat "de man (...) zichtbaar (...) achteruit gaat". Op 15 november 1923 overlijdt Klaas op 91-jarige leeftijd.

Bij de gemeentelijke armenzorg zien we een toenemende bureaucratisering tussen 1871 en 1940. Dat zien we onder meer terug in de gestage uitbreiding van het aantal taken en de stijging van de uitgaven. In bijlage 7 is de uitbreiding van het takenpakket aangegeven. Het aantal steunaanvra-

25 SAA 5256. Doos 1479. Stamboeknummer 11808 gen tussen 1871 en 1940 groeide sterk waardoor het volume van de werkzaamheden ook toenam. Om al die aanvragen te kunnen behandelen werd 
het ambtelijk apparaat flink uitgebreid. De praktijk van de Amsterdamse armenzorg paste, met zijn explosieve groei, bij het bureaucratische ideaaltype dat Weber schetste.

\section{b) De bureaucratie als onderdeel van de overheid}

Laten we de armenzorg als bureaucratisch systeem nader beschouwen. In 1871 werd het Burgerlijk Armbestuur ingesteld. De wethouder die belast was met armenzorg had zitting in het bestuur. Hierdoor werd een verband gelegd met de gemeente. Het Burgerlijk Armbestuur kan daardoor als een semi-overheidsinstelling worden beschouwd.

In 1927 kwam er verandering. Het Burgerlijk Armbestuur werd opgeheven. De armenzorg, nu onder de naam Burgerlijke Instelling voor Maatschappelijken Steun, werd een volledig gemeentelijke dienst. Formeel is met deze verandering een belangrijke stap gezet. In 1941 kreeg de dienst de naam Gemeentelijk Bureau voor Sociale zaken. Hieruit is de Gemeentelijke Sociale Dienst voortgekomen.

\section{c) De positie en de functie van de ambtenaar}

De ambtenaren van de gemeentelijke armenzorg waren aanvankelijk in dienst van een semi-overheidsinstelling: het Burgerlijk Armbestuur. Bij de armenzorg werden aanvankelijk vacatures intern vervuld. Zo werd in 1879, nadat een armbezoeker was ontslagen (de reden van ontslag wordt niet vermeld), via een interne benoeming een nieuwe armbezoeker aangesteld. ${ }^{26}$ Dat gebeurde ook in 1885 toen er na het overlijden van een klerk een vacature ontstond. ${ }^{27}$ De nieuwe klerk werd benoemd zonder dat er een vacature was geplaatst. In 1891 nam de Chef van Inschrijving en Armbezoek ontslag wegens zijn "lichamelijke gesteldheid". ${ }^{28}$ In november 1891 werd een vacature geplaatst in de dagbladen. Er kwamen meer dan vierhonderdvijftig sollicitanten op af. J.W. Jurrema kreeg deze functie. Daarvoor was hij administrateur van Liefdadigheid naar Vermogen. Hij werd benoemd per 1 maart 1892. ${ }^{29}$ Twee jaar later veranderde Jurrema van baan. Hij werd op 1 mei 1894 aangesteld als Boekhouder van het Burgerlijk Armbestuur en Hoofdbeambte aan het Bureau der Huiszittende armen. Daardoor ontstond er een vacature voor de betrekking Chef inschrijvingen. Er kwamen 416 sollicitanten op af. ${ }^{30}$ In 1896, weer twee jaar later, werd Jurrema Directeur van het Armbezoek. Tot zijn pensionering op 1 oktober 1932 zou hij in deze functie in dienst blijven van de gemeentelijke armenzorg. Tijdens zijn veertigjarige dienstvervulling heeft hij zijn stempel gedrukt op de gemeentelijke armenzorg. ${ }^{31}$

In de jaren '90 werd het gebruikelijk om via een openbare sollicitatieronde personeel te werven. ${ }^{32}$ Sinds 1900 werd bepaald door de gemeenteraad dat ook vrouwen deel konden uitmaken van de gemeentelijke armenzorg. ${ }^{33}$ Ook zij konden solliciteren naar een betrekking binnen de gemeentelijke armenzorg. In 1913 werd de eerste vrouwelijke armbezoeker aangesteld. ${ }^{34}$

De beoordeling van het personeel werd gaandeweg geprofessionaliseerd. Voor de beambten kwam er vanaf 1897 een beoordelingssysteem aan de hand van conduitestaten. Elke drie maanden rapporteerde de Directeur van het Armbezoek aan het Burgerlijk Armbestuur. ${ }^{35}$ Het personeel werd aangesproken op niet passend gedrag. Als het gedrag niet verbe-
26 SAA. 15030. Bestanddeel 132015 Jaarverslag Burgerlijk Armbestuur van Amsterdam 1879. 27 SAA. 15030. Bestanddeel 130121 Jaarverslag Burgerlijk Armbestuur van Amsterdam 1885.

28 SAA. 15030. Bestanddeel 132024 Jaarverslag Burgerlijk Armbestuur van Amsterdam 1891.

29 SAA. 15030. Bestanddeel 132025 Jaarverslag Burgerlijk Armbestuur van Amsterdam 1892. 30 SAA. 15030. Bestanddeel 132027 Jaarverslag Burgerlijk Armbestuur van Amsterdam 1894.

31 Schreuder (1932), 3389 3394.

32 SAA. Bestanddeel 130232 Jaarverslag Burgerlijk Armbestuur van Amsterdam 1900.

33 Op 7 februari 1900 nam de gemeenteraad een motie aan: "De raad (is) van oordeel dat vrouwen niet behooren uitgesloten te worden uit het Burgerlijk Armbestuur." SAA 15030. Bestanddeel 132032. Jaarverslag Burgerlijk Armbestuur van Amsterdam 1900

34 SAA 5256. Bestanddeel 833. Jaarverslag Burgerlijk Armbestuur van Amsterdam 1914. A.H. Boissevain werd als eerste vrouwelijke armbezoeker aangesteld. 35 SAA 15030. Bestanddeel 132030 Jaarverslag 1897 Burgerlijk Armbestuur van Amsterdam. 
36 SAA 15030. Bestanddeel 132031 Jaarverslag 1899 Burgerlijk Armbestuur van Amsterdam, bijlage $X, 6$. 37 SAA 15030. Bestanddeel 132032 Jaarverslag 1900 Burgerlijk Armbestuur van Amsterdam.

38 SAA 15030. Bestanddeel 132033 Jaarverslag 1901

Burgerlijk Armbestuur van Amsterdam.

39 SAA 15030. Bestanddeel 132034 Jaarverslag 1902

Burgerlijk Armbestuur van Amsterdam.

40 SAA 400 Archief van de Sociale Raad en rechtsvoorgangers. Bestanddeel 280.

41 In een brief d.d. 10 maart 1924 schreef de directeur van het Armbezoek (Jurrema) aan de voorzitter van de raadscommissie tot reorganisatie van het Burgerlijk Armbestuur (Vos) dat voor zover hij zich kon herinneren nooit een armbezoeker misbruik had gemaakt van zijn positie. "Na klachten volgde altijd een onderzoek. Deze klachten gaven altijd een negatief resultaat: er was geen sprake van misbruik." SAA. Toegangsnummer 5154 Archief van de Commissie inzake Reorganisatie van het Burgerlijk Armbestuur. Bestanddeel 2, stuk nr. 16 (Kenmerk verzender 278.c 2 bijlagen -).

42 Zie ook bijlagen 1, 2 en 3 .

43 SAA 15030. Bestanddeel 132020. Jaarverslag Burgerlijk Armbestuur van Amsterdam 1884.

44 Althans volgens de dossiers ik onder ogen heb gehad. Er is geen reden te veronderstellen dat bij de dossiers die ik niet heb gezien van de methodiek is afgeweken. terde kon er een schorsing volgen of een loonsverlaging. Ook ontslag behoorde tot de mogelijkheden. In 1899 werd een armbezoeker ontslagen vanwege "hoogst ongunstig levensgedrag en daaruit voortvloeiend plichtsverzuim". ${ }^{36}$ In 1900 werd in het jaarverslag geconstateerd dat de armbezoekers hun arbeid met grote toewijding en plichtsbetrachting vervullen, op twee na, van wie de conduitestaten "somtijds reden tot ontevredenheid" gaven. ${ }^{37}$ De driemaandelijkse conduitestaten waren in 1901 gunstig op één geval na. Deze armbezoeker werd in 1901 voor drie maanden geschorst wegens onbehoorlijk gedrag. Hij werd gedurende die drie maanden aan de schrijvers toegevoegd met het daarbij horende (lagere) salaris. ${ }^{38}$ In 1902 kreeg een armbezoeker demotie op grond van zijn conduitestaat: hij werd tijdelijk gedegradeerd tot schrijver. ${ }^{39}$ Sinds 1913 werden de conduitestaten systematisch in personeelsdossiers vastgelegd. ${ }^{40}$ Op grond hiervan kwam het tot een oordeel over het functioneren van de betrokken medewerker. In een brief uit 1924 maakt de directeur van het Armbezoek duidelijk dat de armbezoekers zich in elk geval nooit schuldig hebben gemaakt aan machtsmisbruik. ${ }^{41}$

Al meteen in 1871 waren er bij de gemeentelijke armenzorg standaardprocedures en algemene regels in de afhandeling van de aanvragen. De cliënt meldde zich aan. Op grond van de aanmelding werd een huisbezoek afgelegd. Tijdens het bezoek werd de situatie van de aanvrager in kaart gebracht aan de hand van een gedrukte standaardvragenlijst. ${ }^{42} \mathrm{Op}$ basis van deze vragenlijst kwam de armbezoeker tot een aanbeveling voor het al dan niet verlenen van steun. Het was zijn leidinggevende, de Chef van het Armbezoek, die deze aanbeveling moest toetsen en accorderen. De eindbeoordeling van die aanvragen werd gedaan door een Commissie uit het Burgerlijk Armbestuur, die ten minste uit acht en ten hoogste uit tien leden moest bestaan..$^{43}$ Overigens werd de aanbeveling van armbezoeker bijna altijd opgevolgd. De verleende steun kon van korte duur zijn, enkele weken bij voorbeeld, maar gebruikelijker was een half jaar of het gehele jaar. $\mathrm{Na}$ het verstrijken van de termijn moest de aanvrager opnieuw een aanvraag doen om steun te krijgen. Bij elke nieuwe aanvraag vond een huisbezoek plaats.

Van deze in 1871 ingevoerde methodiek is geen enkele keer afgeweken. ${ }^{44}$ De continuïteit van de werkwijze is dan ook zeer groot te noemen. In 1911 en in 1936 is deze werkwijze niet wezenlijk veranderd. Wel wordt vanaf de jaren '20 de manier van werken efficiënter. Tot die tijd werd bij elk bezoek de hele vragenlijst weer afgenomen, maar daarna werden alleen bij een eerste bezoek alle noodzakelijke gegevens geadministreerd. Bij vervolgaanvragen werd dan alleen gelet op veranderingen in de omstandigheden die konden leiden tot een herziening van een eerder genomen besluit. De vervolgaanvragen werden altijd beoordeeld in het licht van de vorige aanvragen. De documenten werden daarom in hun oorspronkelijke staat bewaard.

De medewerkers die na de oprichting van het Burgerlijk Armbestuur in 1871 als armbezoekers functioneerden, hadden wel ervaring in het omgaan met armen, maar waren er niet in geschoold. Aanvankelijk waren er geen diploma's nodig om te kunnen worden aangesteld. In de jaren negentig van de negentiende eeuw kwam daar verandering in. Via een voordrachtency- 
clus ontstond er een vorm van bijscholing voor zittende armbezoekers. De in 1900 opgerichte Vereeniging van armbezoekers bij het Burgerlijk Armbestuur te Amsterdam "Onderlinge Steun" ging cursussen geven voor een betere beroepsuitoefening. Uiteindelijk kwam er een externe beroepsopleiding, waar men in twee jaar het diploma armenzorg kon halen en werd opgeleid tot armbezoeker. Dit was de Opleidingsinrichting voor Socialen arbeid, in 1899 opgericht door onder anderen M.G. Muller-Roelofs. De naam van de opleiding veranderde in 1905 in School voor Maatschappelijk Werk. ${ }^{45}$ Alleen gediplomeerden konden nog worden aangesteld als armbezoeker.

Vanaf het begin, in 1871, waren er hiërarchische gezagsverhoudingen binnen de armenzorg. Door de ontwikkelingen binnen de armenzorg nam dat hiërarchische karakter nog toe. Specialisaties in functies bevorderden de hiërarchische verhoudingen. In 1881 werd niet alleen een Hoofd-Beambte aangesteld, maar ook een Chef voor de Inschrijving van het Armbezoek. ${ }^{46}$ De armbezoeker had een zware taak. Dat valt af te lezen aan het jaarverslag van 1882:

"Dat die taak van onderzoek, in het bijzonder aan de armbezoekers opgedragen, niet altijd even gemakkelijk is, zal niemand verwonderen, die zich enigszins met oordeelkundige armverzorging heeft bezig gehouden. De verstrekte opgaven door de hulpbehoevenden zelven zijn veelal verward, de verleiding tot onware mededelingen is groot; een misplaatst medelijden, te vergeven, doet op de getuigenissen van de werkgevers zijn invloed gelden. Bovendien heeft de controle op de bronnen van inkomsten veel bezwaren, is zelfs nu en dan onmogelijk, omdat in den regel zij, die bedeling vragen, geen vaste werkgevers hebben, maar nu hier dan daar iets verdienen hetzij in een kleine nering, of met geringe werkzaamheden thuis, het zij met (een) los(se) plaats bij verschillende werkgevers, welke die losse lui ternauwernood kennen en letterlijk van de straat opnemen". ${ }^{47}$

In het jaarverslag van 1885 werd een indruk gegeven van de arbeidsintensieve taken van de armbezoeker:

"Eén onderzoek omvat veelal tal van bezoeken en eischt herhaalde wandelingen door de stad. Niet slechts het gezin zelf, of den persoon, die aanvraag deed om hulp, moet worden opgezocht en gesproken, ook den werkbazen die hem in dienst hadden en hebben, den personen, die aangaande zijn toestand en zijn verleden inlichtingen kunnen geven, moet een bezoek gebracht worden. Aan bevolkingsregister en bij buurtsecretaris moeten de opgaven der personen worden vergeleken met de aanteekeningen aldaar gehouden". 48 De werkdruk bleef een terugkerend onderwerp. Het jaarverslag van 1891 maakt melding van het sterk stijgende aantal steunaanvragen:

"Bedroevend is het inderdaad telken jare waar te nemen met welke reuzenschreden dit cijfer van aanvragen klimt." ${ }^{49}$

Het aantal steunaanvragen was in dat jaar met negen procent gestegen.

Om de taak van de armbezoeker te verlichten vond er specialisatie plaats. Er werden binnen de armenzorg nieuwe functionarissen aangesteld: klerken, ook wel schrijvers genaamd. Waar de armbezoekers op pad gingen, bleven de schrijvers op het bureau voor het verrichten van administratieve taken. Het uitschrijven van de rapporten van de afgelegde bezoeken werd overi-
45 Deze opleiding bestaat nog steeds als hbo-opleiding bij de Hogeschool van Amsterdam.

46 SAA 15030. Bestanddeel 132018. Jaarverslag Burgerlijk Armbestuur van Amsterdam 1881. 47 SAA 15030. Bestanddeel 132019. Jaarverslag Burgerlijk Armbestuur van Amsterdam 1882. NB nummering. Het SAA beschikt niet over een afzonderlijk verslag over 1883. Het verslag is wel opgenomen in het Gemeenteverslag; daarom volgt op bestanddeel 132019 over 1882, bestanddeel 132020 over 1884.

48 SAA 15030. Bestanddeel 132021. Jaarverslag Burgerlijk Armbestuur van Amsterdam 1885. 49 SAA 15030. Bestanddeel 132024. Jaarverslag Burgerlijk Armbestuur van Amsterdam 1891. 
50 De werkdruk blijkt uit het jaarverslag van 1901 dat meldde: "dat (vanwege het vele werk) meestal elken avond door hen(=armbezoekers) veel schrijfwerk mede naar hunne woning genomen moest worden." SAA 15030. Bestanddeel 132033. Jaarverslag Burgerlijk Armbestuur van Amsterdam 1901.

51 SAA 15030 Bestanddeel 133297. Gemeenteverslag 1895.

52 In 1902 bedroegen de verdiensten per jaar voor de kantoorbedienden eerste klasse hfl 750 tot 1000 en voor kantoorbedienden tweede klas hfl 500 tot 750 De hoogte was afhankelijk van de anciënniteit. SAA 15030 Bestanddeel 132034. Jaarverslag Burgerlijk Armbestuur van Amsterdam 1902.

53 Zie tabel 8.16 in bijlage 8.

54 Werklieden zijn handarbeiders.

55 Van Braam (1957), 114; wijst erop dat Amsterdam met de invoering van een "werkliedenreglement" al eerder voorop liep.

56 Van IJsselmuiden (1988), 259. gens vaak ook nog door de armbezoekers thuis gedaan, in de avonduren. ${ }^{50}$ De aansturing van de armbezoekers en de schrijvers was in handen van de Boekhouder van het Burgerlijk Armbestuur. In 1881 werd de Boekhouder formeel ook Hoofdbeambte van de Huiszittende armen. Voor de dagelijkse leiding werd een Chef voor de inschrijving aangesteld. Hierdoor ontstonden er een extra laag binnen de hiërarchie. In 1895 werd de Hoofdbeambte van de Huiszittende armen omgedoopt tot Directeur van het Armbezoek tevens Boekhouder van het Burgerlijk Armbestuur. ${ }^{51}$ In 1902 werd vervolgens de functie van Hoofd-armbezoeker in het leven geroepen. De namen van functies veranderden nog wel eens. Zo werden de klerken of schrijvers vanaf 1902 als kantoorbedienden aangeduid. Kantoorbedienden werden in twee categorieën ingedeeld: eerste klasse, met een hogere jaarwedde en tweede klasse, met een lager jaarsalaris. ${ }^{52}$ In 1905 ging een klerkkassier zich uitsluitend met de financiële administratie bezighouden.

Tussen 1905 en 1919 nam het aantal onderzoeken dat verricht werd toe van zo'n veertigduizend per jaar naar honderdzestigduizend per jaar. ${ }^{53}$ Een verviervoudiging. Door deze groei werd een nieuwe organisatievorm noodzakelijk. In 1918 werden veranderingen doorgevoerd. Een nieuwe functieaanduiding kwam tot stand. De hoogste leidinggevende werd de Directeur van het Armbezoek. Hij werd ondersteund door de Chef van het Armbezoek. Hieronder waren vier Hoofden van Afdeling werkzaam en een Hoofd-Boekhouder-Kassier. De Afdelingen waren vier verschillende wijken voor het armbezoek, waar Ambtenaren voor sociale arbeid op huisbezoek gingen, de voormalige armbezoekers. In 1918 waren er 29 van deze ambtenaren in dienst. Het dienstverlenend (centraal) bureau stond onder leiding van een Hoofdklerk, die kantoorbedienden als ondergeschikten had. Er waren in 1918 vijf klerken en vier schrijvers. De nieuwe structuur bleef tot aan de Tweede Wereldoorlog in stand.

Een gebruikelijke carrièremogelijkheid was dat schrijvers opklommen tot armbezoekers. Zij moesten dan wel over het diploma armbezoeker beschikken. Omdat in 1943 het beleidsarchief door oorlogshandelingen is vernietigd, is niet veel bekend over carrièrepatronen. De bezoldiging van de functionarissen geschiedde via vaste salarisschalen. Vanaf 1907 werden voor het personeel de salarisschalen en overige arbeidsvoorwaarden gehanteerd die ook voor de ambtenaren in gemeentedienst golden. Per 1 augustus 1913 vielen de werknemers onder het Gemeentelijk Werkliedenreglement. ${ }^{54}$ Zes jaar later, vanaf 1 januari 1919, mochten ook de medewerkers van het Burgerlijk Armbestuur zich gemeenteambtenaren noemen. In 1927, met de oprichting van de Burgerlijke Instelling voor Maatschappelijken Steun, werd de positie van gemeenteambtenaar nog strikter vastgelegd.

Door veranderingen in de rechtspositie van de ambtenaren was het moeilijker geworden hen te ontslaan. Nog meer dan te voren konden zij daardoor opereren zonder aanzien des persoons. Met deze arbeidsvoorwaarden, waarmee Amsterdam voorop liep, functioneerde de armenzorg al ver voor 1927 als een gemeentelijke dienst. ${ }^{55}$ Pas in 1931 werd voor de rijksambtenaren een Algemeen Rijksambtenarenreglement vastgesteld. ${ }^{56}$

Vatten we de positie en de functie van de ambtenaar samen, dan geldt dat die positie en functie steeds meer trekken zijn gaan vertonen van het ideaaltype dat Weber van de ambtenaar heeft geschetst. De armbezoe- 
kers kregen op zeker moment scholing en werden via een openbare sollicitatieprocedure aangesteld. Hun functioneren werd beoordeeld aan de hand van een bepaald systeem. Op niet passend gedrag kon ontslag uit de dienst volgen. Er kwamen vaste salarisschalen en een pensioenvoorziening. Ambtenaren werkten in een hiërarchisch verband en er ontstonden steeds meer specialisaties. In 1907 kregen de functionarissen een gemeentelijke ambtenarenstatus. Hiermee liep Amsterdam voorop. Een ander belangrijk moment is de opheffing van het Burgerlijk Armbestuur, dat in 1927 plaats maakte voor de Burgerlijke Instelling voor Maatschappelijken Steun.

\section{d) Het blijvende karakter van de bureaucratie}

Het door Weber gepostuleerde blijvende karakter van de bureaucratie is ook zichtbaar bij de gemeentelijke armenzorg. Aanvankelijk was de armenzorg nog wel in enige mate een onafhankelijke organisatie, maar deze onafhankelijkheid verdween in 1927 definitief.

De armenzorg opereerde al vanaf het begin onder een hoger gezag. In eerste instantie was dat het Burgerlijk Armbestuur. ${ }^{57}$ De Armenwet van 1854 bepaalde dat er een bestuur moest komen, maar in de praktijk werd het Burgerlijke Armbestuur in Amsterdam pas ingesteld in $1871 .{ }^{58}$ Het bestuur kreeg het beheer over de instellingen van sociale zorg van gemeentewege. De wethouder van Armenzorg had zitting in het Burgerlijk Armbestuur, samen met twintig andere leden, die veelal uit de gegoede burgerij afkomstig waren. Zij werden benoemd door de gemeenteraad. Het Burgerlijk Armbestuur functioneerde als een autonoom instituut, maar werd wel gesubsidieerd door de gemeente. Hoewel de band met de gemeenteraad dus hecht was, was het Burgerlijk Armbestuur formeel geen gemeentelijk instelling. Dat veranderde in 1927. De Burgerlijke Instelling voor Maatschappelijken Steun kwam in de plaats van het Burgerlijk Armbestuur. ${ }^{59}$ Deze nieuwe instelling was formeel wel een gemeentelijke dienst. Er wijzigde in 1927 in de dagelijkse praktijk heel weinig in de uitvoering van de armenzorg, maar de verandering was wel principieel. De gemeenteraad oefende vanaf 1927 het hoogste gezag uit over de Amsterdamse armenzorg. ${ }^{60}$ Hiermee was zij blijvend verankerd in de ambtelijke kaders van de gemeente.

Dat de Amsterdamse armenzorg veranderde van een semi-officiële instantie in een compleet gemeentelijke dienst, is ook zichtbaar in de financiën. Als het Burgerlijk Armbestuur geld te kort kwam, dan werd dat uit de gemeentekas aangevuld. Na 1910 kwamen de kosten grotendeels voor rekening van de gemeente. Deze ontwikkeling is zichtbaar in grafiek 7.12. Na 1928 kwamen de kosten volledig voor rekening van de gemeente. De stijging van het aandeel van de gemeente Amsterdam in de financiering van de armenzorg staat niet op zichzelf. Het was een landelijke tendens dat gemeenten hun invloed op de armenzorg vergrootten. Financiering door de gemeente was een van de middelen om meer invloed te krijgen. ${ }^{61}$
57 Kappelhof en Kingma (2004).

58 Overigens werd al in 1856 de eerste uitwerking zichtbaar van de Armenwet in Amsterdam toen het Burgerweeshuis, de Gasthuizen, het Huiszittenhuis, de Stadsbestedelingen en het Werkhuis als gemeentelijke instellingen geplaatst werden onder het beheer van de gemeenteraad (SAA Toegangsnummer 4186. Inventaris Archief van de Secretarie; Afdeling Sociale Zaken en rechtsvoorgangers). Stadsbestedelingen waren wezen, verlatenen en vondelingen die, in tegenstelling tot de burgerwezen, werden verpleegd door het armenkinderhuis (het Aalmoezeniershuis).

Stadsbestedelingen werden vanaf 1811 uitbesteed op het platteland. Na 1865 vond weer gestichtsverpleging plaats.

59 Officiële bekendmaking: 1926-88 Gemeenteblad,

Derde afdeling, vastgestelde verordeningen 1926 Volgnummer 88 (verschenen 18 december 1926) Opheffing Burgerlijk Armbestuur Besluit op 5 november 1926 (goedgekeurd door Gedeputeerde Staten van Noord-Holland op 10 maart 1926).

60 Dat blijkt uit de verordening van 1926: Verordening op het Gemeentelijk Bureau voor Maatschappelijken steun (gepubliceerd: 1926-89 Gemeenteblad,

Derde afdeling, vastgestelde verordeningen 1926 Volgnummer 89 (verschenen 18 december 1926). 61 Uitvoeriger bij Van Leeuwen (1998)b, 526-527. 


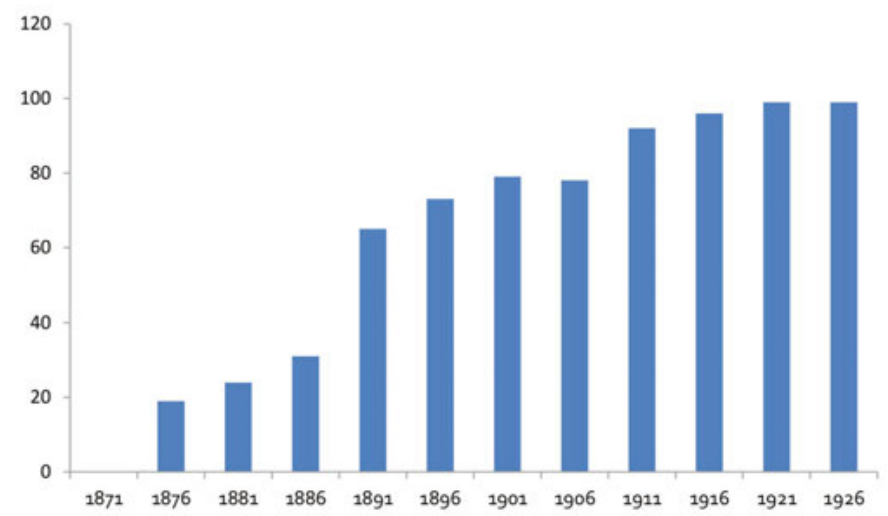

Bron: bijlage 8, tabel 8.14

62 De Rooy (1979), 16-17. 63 SAA 15030. Bestanddeel 132017 Jaarverslag Burgerlijk Armbestuur van Amsterdam 1880. 64 SAA 15030. Bestanddeel 132017 Jaarverslag Burgerlijk Armbestuur van Amsterdam 1880.

65 De overgang van roggebrood naar tarwebrood kwam moeizaam tot stand. Al in 1899 trachtte de Nederduitsch hervormde diaconie tarwebrood in te voeren, maar deze poging stuitte op weerstand. In 1901 deed de wethouder een poging tot invoering van tarwebrood, maar dat mislukte eveneens. In 1907 werd eindelijk roggebrood vervangen door tarwebrood. SAA Toegangsnummer 5256 Bestanddeel 833 Jaarverslag Burgerlijk Armbestuur van Amsterdam 1920.

66 Tot 1 januari 1907 ontving een gemiddeld gezin drie roggebroden van elk 2 kg. Dat komt in 2021 overeen met $71 / 2$ broden met het huidige standaardgewicht van 800 gram per brood. Na 1 januari 1907 werd tarwebrood à $3 / 4 \mathrm{~kg}$ verstrekt tot een maximum van tien broden per gezin.

\section{e) Het rationaliteitsprincipe}

Naast de uitbreiding van het aantal taken en de vergroting van het ambtenarenapparaat waren er ook inhoudelijke veranderingen, die geleidelijk aan binnen de armenzorg zichtbaar werden. Bij veel van die veranderingen speelde een toenemende rationalisering een rol. In het begin van de twintigste eeuw werden er, naast de armenzorg, andere instellingen opgericht die zorg verleenden. De overheid speelde een belangrijke rol in de vestiging van die zorgarrangementen. Zo werd in 1908 de Gemeente Arbeidsbeurs (GAB) ingesteld. Deze arbeidsbeurs was de opvolger van de particuliere Maatschappij voor de Werkende stand uit 1886 die de eerste openbare arbeidsbemiddeling in Nederland tot stand bracht. ${ }^{62}$

In 1871, na de instelling van het Burgerlijk Armbestuur, nam de Commissie voor Huiszittende armen de brood- en turfbedeling en de bedeling in geld en goederen over. ${ }^{63}$ Het onderzoek naar bewijzen van onvermogen kwam daar in 1872 bij. In datzelfde jaar ging de Commissie toezien op de kosteloze plaatsing op openbare scholen voor kinderen van arme ouders. Er kwamen steeds meer taken bij. In 1875 werd er een onderzoek ingesteld naar personen die in het Armenhuis opgenomen wilden worden. Drie jaar later werd gekeken naar aanvragen voor kosteloos ziekenvervoer (per vigilante of per draagbaar). Het jaar daarop, in 1879, werd het takenpakket van de Commissie uitgebreid met onderzoek naar gezinnen waarvan een of meer leden tot de miliciens, de dienstplichtigen behoorden. ${ }^{64}$

Het belangrijkste doel van de Commissie was het verlenen van materiele zorg. Globaal waren er drie vormen van zorg: winterbedeling, zomerbedeling en bijzondere zorg. Bij de winterbedeling werden roggebrood en turf, en vanaf 1907 tarwebrood en kolen voor de winterperiode verstrekt. ${ }^{65}$ Bij de zomerbedeling werd enkel brood verstrekt. ${ }^{66}$ Tot de bijzondere zorg behoorde de kraamzorg en het verstrekken van kleren, beddengoed en versterkende middelen (melk en eieren). In sommige gevallen werd ook handelsgeld verstrekt, waarmee de aanvrager in het eigen levensonderhoud kon voorzien en een nering kon op- of voortzetten. De steunverlening verschoof in de loop van de tijd steeds meer van uitkeringen in natura naar 
geldbedeling. In 1913 werd de afzonderlijke broodbedeling afgeschaft. ${ }^{67}$ In de winter van 1920/1921 werd voor het laatst brandstof uitgedeeld. ${ }^{68}$ In plaats daarvan kwam een brandstoftoeslag van hfl 1,00 per week. ${ }^{69} \mathrm{Ik}$ zie in de verschuiving naar geldbedeling een proces van verzakelijking. De armenzorg probeerde steeds meer de aanvragers in hun eigen onderhoud te laten voorzien. Armbezoekers verwezen naar patroons die werk zouden kunnen verschaffen. Het doel van de zorg was vooral ook verheffing, in de zin van een toekomstige onafhankelijkheid van de zorg..$^{70}$ In de jaarverslagen wordt verwezen naar concrete gevallen waarin geslaagde verheffingspogingen waren gedaan. Gezien het bovenstaande kan de gemeentelijke armenzorg tussen 1871 en 1940 een doelgerichte organisatie genoemd worden.

De verstrekkingen gingen uit van het gelijkheidsbeginsel: een rationeel uitgangspunt. Alle aanvragers die in aanmerking kwamen, kregen dezelfde uitkering. Het niveau van de uitkeringen werd aanvankelijk door de gemeenteraad vastgesteld. ${ }^{71}$ Vanaf de jaren '20 ging de landelijke overheid zich bemoeien met het uitkeringsniveau, waarbij de invloed van het Rijk op de gemeente steeds groter werd. De steun, zowel in natura als in geld, werden op vaste tijdstippen uitgekeerd. Een formeel recht van beroep op een beslissing bestond niet. ${ }^{72}$ In de dossiers zijn echter wel brieven te vinden waarin de afgewezen aanvrager, soms met succes, bezwaar maakte tegen een besluit. De correspondentie werd in de regel gevoerd met de directeur, die vaak bij zijn dienst navraag deed voordat hij reageerde op het bezwaar. ${ }^{73}$ Daarnaast bestond er een bezwaarschriftencommissie die door de aanvrager kon worden aangeschreven. In het levensverhaal van Klaasje Zevenster in hoofdstuk 8 komen we deze commissie tegen.

Uit mijn onderzoek blijkt dat in de loop der tijd de uitkeringen van aard veranderden. Aanvankelijk, in 1871, werd er vooral steun in natura verleend. Uiteindelijk, in 1936, was het leeuwendeel van de steunverlening veranderd in geldbedeling. In onderstaande grafieken 7.13 en 7.14 is de ontwikkeling van natura naar geld aanschouwelijk gemaakt.
67 Zie bijlage 5 .

68 Zie bijlage 5 .

69 SAA 5256. Bestanddeel 833 Jaarverslag Burgerlijk Armbestuur van Amsterdam 1920

70 In de armenwet van 1912 wordt daar uitdrukkelijk naar verwezen: artikel 29: "indien ondersteuning wordt verleend, wordt zij verstrekt in zoodanige vorm en zoodanige mate, als met het oog op de behoeften en de persoonlijke omstandigheden van den arme het meest gewenscht is om hem wederom in staat te stellen, in het onderhoud van zich en zijn gezin te voorzien". Dit was een belangrijke vernieuwing ten opzichte van de wet van 1854, waarin stond dat hulp alleen "bij volstrekte onvermijdelijkheid" kon worden verleend. Dat betekende in de praktijk: alleen in uiterste noodzaak, zodat de hulpvrager niet van honger om zou komen. 71 In bijlage 5 staat een overzicht van de maximumuitkeringen.

72 Over het recht van beroep is een hele discussie gevoerd. Zie Van Leeuwen (1998)b, 522-523.

73 In eerste instantie waren de contacten mondeling.

Pas in tweede instantie ging het om een schriftelijke correspondentie. De praktijk van schriftelijk verweer tegen een besluit vinden wij ook terug in het onderzoek van Van Dalen en Smits, (1996), waarin 171 brieven uit 1906, 1907 en 1908 zijn onderzocht van steunaanvragers gericht aan gemeentelijke autoriteiten. 

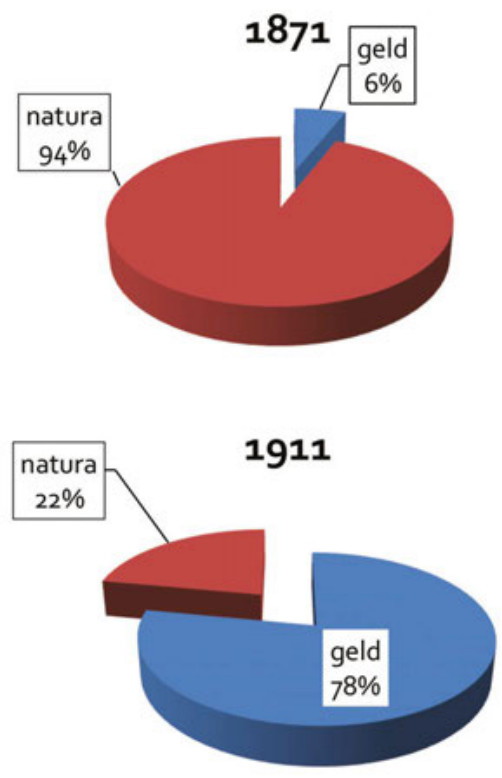

1936

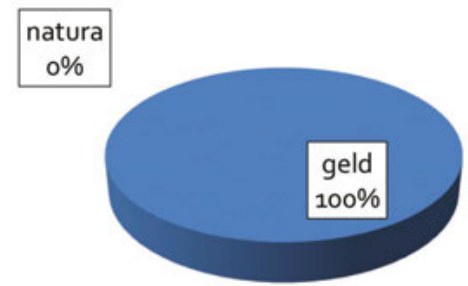

Bron: bijlage 8, tabel 8.24 

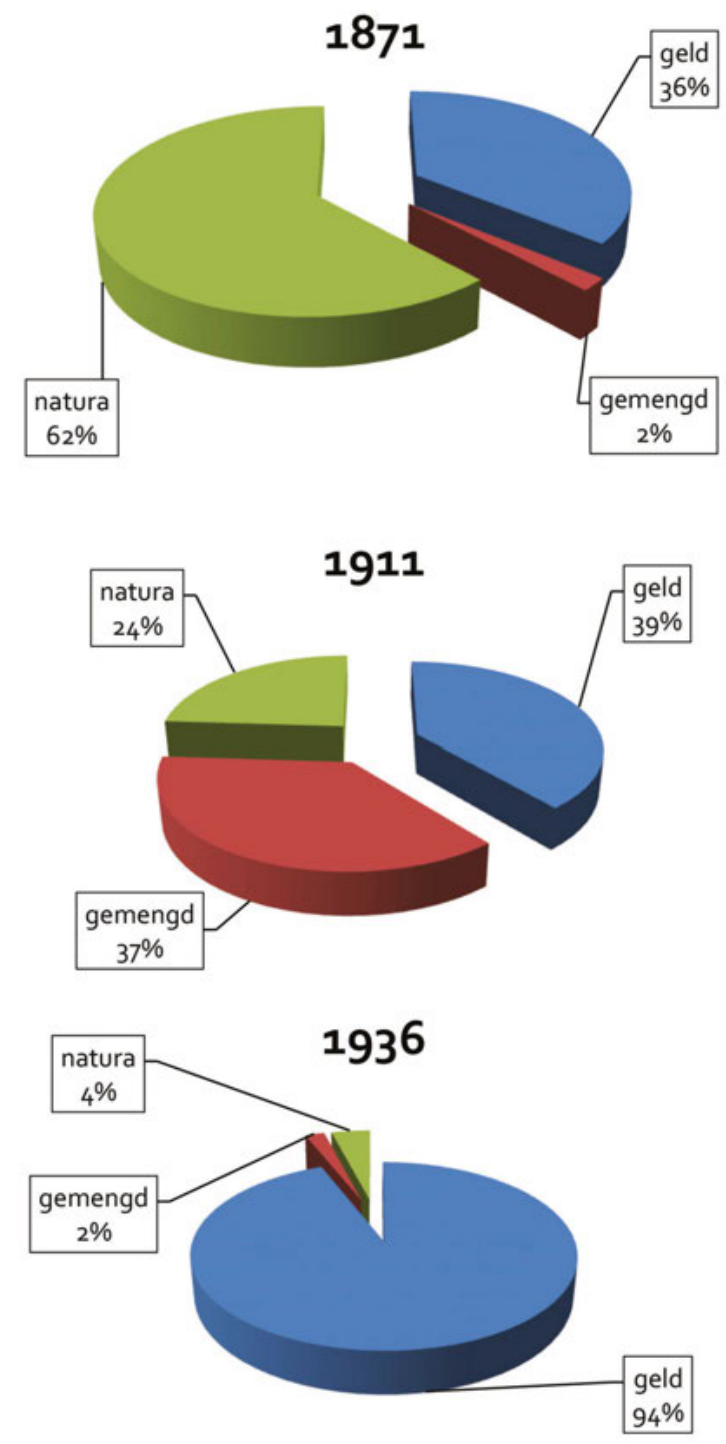

Bron: bijlage 8 , tabel 8.25 en tabel 8.26 .

In 1871 ging het bij de steunaanvragen in natura om brood en turf. Deze vorm van hulp in natura was ook in de tijd van de Republiek, in de zeventiende en achttiende eeuw, gebruikelijk. Winterbedeling kwam het meest voor. In 1871 ging de helft van de steunaanvragen over winterbedeling. In de tijd van de Republiek omvatte de winterbedeling een periode van twaalf weken van december tot en met februari. In de loop van de negentiende eeuw werd ook de maand maart opgenomen in de winterbedeling. ${ }^{74}$ Deze verruiming was een verbetering voor de armen. Ten eerste waren in maart de prijzen voor levensmiddelen hoger dan die van april tot oktober. In de tweede plaats waren de lonen in maart nog laag door het systeem van zomer- en winterlonen. Het ging hierbij om daglonen. In de wintertijd is de lengte van de werkdagen beperkt door het lagere aantal uren met daglicht.
74 Dat gebeurde voor het eerst in 1883. SAA 15030. Bestanddeel 133285 (Gemeenteverslag 1883, Bijlage IX) Jaarverslag Burgerlijk Armbestuur van Amsterdam 1883.

75 De maand maart 1845 was zeer koud, met een etmaalgemiddelde van 2,3 Celsius. In Amsterdam werden in dat jaar met Pasen, 23 maart, eieren op het ijs van de Amstel verkocht. Dat was wel zeer extreem. Ook de winter van $1844 / 45$ was erg koud. Op 18 februari 1845 werd een collecte gehouden "ten behoeve der Noodlijdenden door de hervatte koude en stilstand van werk". (Volgens een strooibiljet van de regenten der huiszittende stadsarmen d.d. 12 februari 1845.) Na 1850 trad een langzame stijging van de wintertemperatuur in. Deze stijging was ook in maart zichtbaar: (Labrijn, 1945). In de koude winter van 1890/1891 nam de vraag naar bedeling fors toe. "De hevige, vroeg ingevallen en langdurige vorst deed menigeen, die anders zich nog redden kon, tot deze Commissie een verzoek om hulp richten". (Bron: SAA 15030. Bestanddeel 133291: Verslag van den toestand der gemeente Amsterdam gedurende het jaar 1890, Bijlage IX,4) Deze winter begon eind november 1890 met dagen met een negatief etmaalgemiddelde. Eind januari 1891 werd het iets warmer, maar daarna kwamen de negatieve etmaalgemiddelden weer terug tot het begin van maart 1891 . 76 Aanvankelijk kon het brood op donderdag worden afgehaald bij het armenhuis in de Roeterstraat. Vanwege de drukte werd er een systeem met dranghekken bedacht. In 1899 werd een controle ingesteld op het broodgebruik, omdat men vermoedens had van fraude. Besloten werd om "stelselmatig en geregeld in de gezinnen onderzoek 
in te stellen". Elke week werd op de tweede dag na de bedeling aan verschillende gezinnen door de armbezoekers een bezoek gebracht. Er werd dan gekeken of er nog brood aanwezig was. "Geconstateerde gevallen van broodverkoop worden door de Commissie streng bestraft; onmiddellijke inhouding van alle bedeeling is gewoonlijk het gevolg." Bron: SAA 15030. Bestanddeel 133300: "Verslag van den toestand der gemeente Amsterdam gedurende het jaar 1899", Bijlage X, 19. Uit de door mij geraadpleegde rapporten van de armbezoeker blijkt overigens niet of en hoe deze maatregel werd gehandhaafd.

77 Het jaarverslag Over 1907 van het Burgerlijk Armbestuur meldde over deze verandering: "Tot 1908 bestond de gewoonte, dat alle bedeelden, zowel zij die met brood, als die tevens met geld ondersteund werden - eenmaal per week hunne bedeeling afhaalden aan het Bureau Huiszittende Armen in het Armenhuis." Het Armenhuis was gevestigd aan de Roeterstraat. Eenmaal aangekomen wachtte de bedeelde "een weg van ongeveer 150 meter, afgelegd met de snelheid van een wachtende file: de paden gescheiden door traliewerk van houten latten. Op deze wandeling kwam men 14 maal dezelfde personen tegen. Men kan zich dit alles niet zonder hevigen weerzin voorstellen. Toch bedenke men, dat zij die deze inrichting ontwierpen, inderdaad op practische wijze oplosten het vraagstuk, hoe in een beperkte ruimte op één middag 2 tot 3000 personen te doen in- en uitgaan, zonder de voor de hand liggende meest hopelooze wanorde." De centrale bedeling kwam per 1 januari 1908 te vervallen. In plaats daarvan kwamen op een groot aantal plaatsen in de stad lokalen waar
In de zomertijd konden langere werkdagen gemaakt worden. Bovendien was het aantal dagen waarop in de open lucht gewerkt kon worden in de zomer groter dan in de winter. De algemene regel was dat tot 21 maart winterlonen werden uitbetaald. De laatste tien dagen van maart werden als zomerse dagen beschouwd, waarop het hogere zomerloon werd uitbetaald. Gebruikelijk was dat de winterlonen 5/8 bedroegen van de zomerlonen. Verder was de maand maart, meteorologisch gezien, ruim voor de huidige klimaatverandering, nog vaak een echte wintermaand. Maandgemiddelden onder nul waren voor maart in de negentiende eeuw geen zeldzaamheid. ${ }^{75}$ In de derde plaats waren de verdiensten in maart laag omdat het aanbod van werk in maart klein was. In de zomerperiode werd er beduidend meer werk aangeboden.

Winterbedeling hield in dat dat er wekelijks roggebrood, vanaf 1907 tarwebrood, werd uitgedeeld. Het brood moest op een centraal punt worden afgehaald. ${ }^{76}$ In 1908 kwam daar een ander systeem voor. Op diverse plaatsen in de stad kon het brood worden afgehaald. Dat was een aanzienlijke verbetering. ${ }^{77}$ Aan het begin van de winter werd een partij turf verstrekt. Vanaf het begin van de twintigste eeuw werden steenkolen of briketten als brandstof gegeven.

De winterbedeling was ook bedoeld om degenen die afhankelijk waren van losse arbeid de winter door te loodsen, zodat ze in de zomerperiode hun goedkope diensten weer konden aanbieden. Naast winterbedeling was er ook zomerbedeling, maar om deze vorm van hulp werd door een veel kleinere groep armen gevraagd. Zomerbedeling bestond alleen uit brood.

In 1871 werd voor het leeuwendeel hulp in natura verstrekt. Een derde deel van de armen kreeg geld. In 1911 is er een overgangsfase te zien van bedeling in natura naar bedeling in geld. In 1936 werd bijna alleen nog geld gegeven aan de armen. In 1871 waren de aanvragers zodanig hulpbehoevend dat een uitkering in natura meteen de ergste nood lenigde. In 1936 waren de bestedingspatronen dusdanig gewijzigd dat een uitkering in geld een zelfstandige afweging mogelijk maakte van de uitgaven door de ontvanger. Anders dan in 1871 besliste in 1936 de ontvanger zelf. Voor de uitkerende instantie is het geven van geld meer objectiveerbaar dan giften in natura. In geld is de waardebepaling exacter uit te drukken. Hierdoor kan de hoogte van de uitkering veel rationeler worden vastgesteld. De hulpverlening werd hierdoor verzakelijkt. In de overgang van hulpverlening in natura naar hulpverlening in geld zie ik een toenemende rationalisering van de armenzorg. In deze rationalisering is niet alleen de invloed van de bureaucratisering te zien, maar ook het afnemen van de beschavingsdrang. Het is niet langer de hulpverlener die beslist over het uitgavenpatroon; de ontvanger bepaalt zelf wat hij met zijn uitkering doet. Uitdelingen in natura moesten 'verkeerde' uitgaven van de armen voorkomen. Bij uitdelingen in geld zijn de verstrekkers minder huiverig voor, of staan ze zelfs onverschillig tegenover zo'n 'verkeerd' bestedingspatroon. De rationalisering is onderdeel van de bureaucratisering van de armenzorg. Interessant is dat die rationalisering niet enkel bij de armenzorg zichtbaar is. Ook bij de aanvragers trad een verzakelijking op in de steunaanvragen. In 1871 werd voor het leeuwendeel steun in natura aangevraagd. In 1911 was dat aandeel nog maar een vijfde. In 1936 werd bijna uitsluitend om geld gevraagd. 


\section{f) De structuur van de bureaucratie}

Het bureaucratische karakter van de gemeentelijke armenzorg kunnen we ook zichtbaar maken door de bestuursstructuur onder te brengen in een organogram. In 1871 werd de gemeentelijke armenzorg gereorganiseerd. ${ }^{78}$ De structuur was op dat moment nog tamelijk eenvoudig. Sturend onderdeel was het Burgerlijk Armbestuur dat formeel geen deel uitmaakte van de gemeente.

Afbeelding 7.2 Organogram van de gemeentelijke armenzorg in 1871

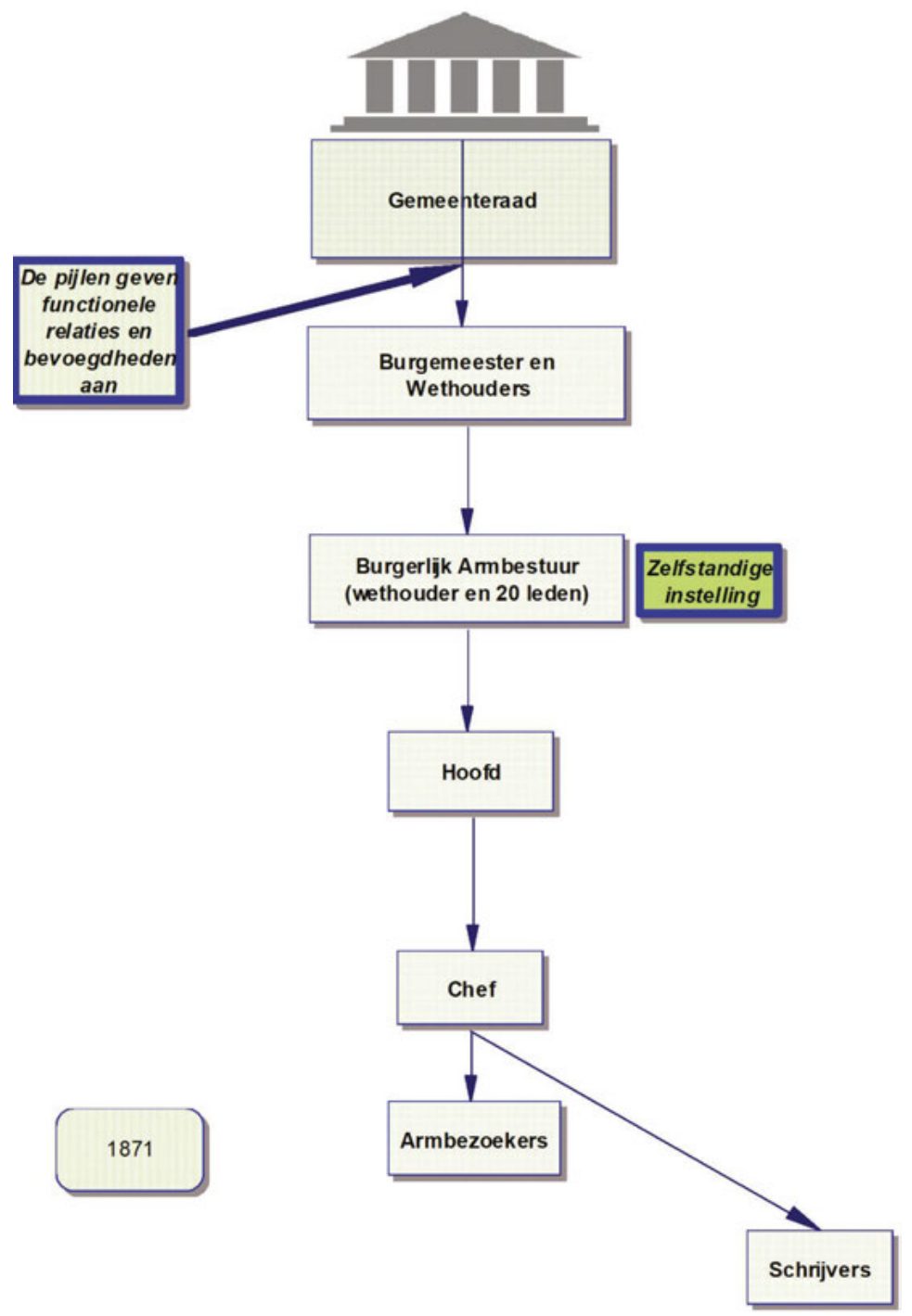

In 1918 is de structuur uitgebreid met enkele functies, zoals een directeur en een chef, en sommige taken zijn nu verder opgesplitst. Het apparaat van de gemeentelijke armenzorg bestaat nu uit meer geledingen. In formeel opzicht is de rol van het Burgerlijk Armbestuur nog steeds sturend en blijft de gemeenteraad op de achtergrond. iedere bedeelde op een bepaalde dag in de week de gehele dag terecht kon. "De groote bezwaren, aan deze wijze van uitdeeling verbonden, waarvan wel de voornaamste waren: de ongunstige invloed, uitgaande van een gedurende eenige uren wachtende menigte, het groot tijdverlies voor de bedeelden, die van alle deelen der stad hier samen kwamen, en het gemis aan alle controle op hetgeen met de verstrekte hulp gedaan werd, werd reeds geruime tijd door de Commissie gevoeld." Daarmee kwam een eind aan de lange wachtrijen, "in dicht opeengepakte menigten, een der treurigste vertooningen, die bemoeienis met de armen nog zoo vaak vergezellen. (...). Men veroorlove ons dit resultaat van het jaar 1907 niet zonder ingenomenheid te boekstaven." SAA 15030. Bestanddeel 132037. Jaarverslag Burgerlijk Armbestuur van Amsterdam 1907.

78 Gemeenteblad 1870, afd. 3, volgnummer. 21; raadsbesluit van 28 september 1870. Op 9 november 1870 werd door de gemeenteraad het besluit genomen tot instelling van het Burgerlijk Armbestuur. Bron: SAA 350, 1-4. 


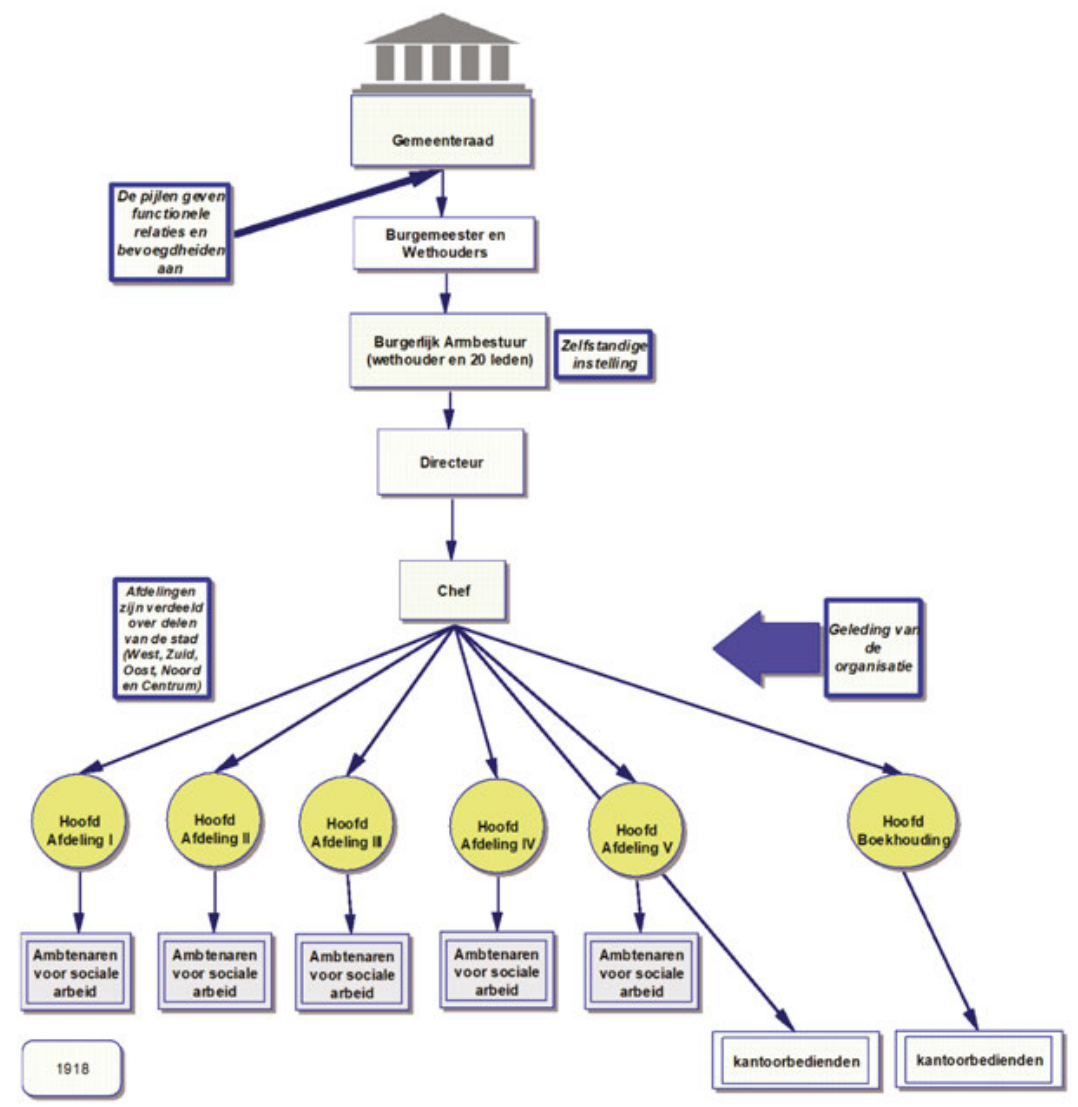

Afbeelding 7.4 Organogram van de gemeentelijke armenzorg in 1928

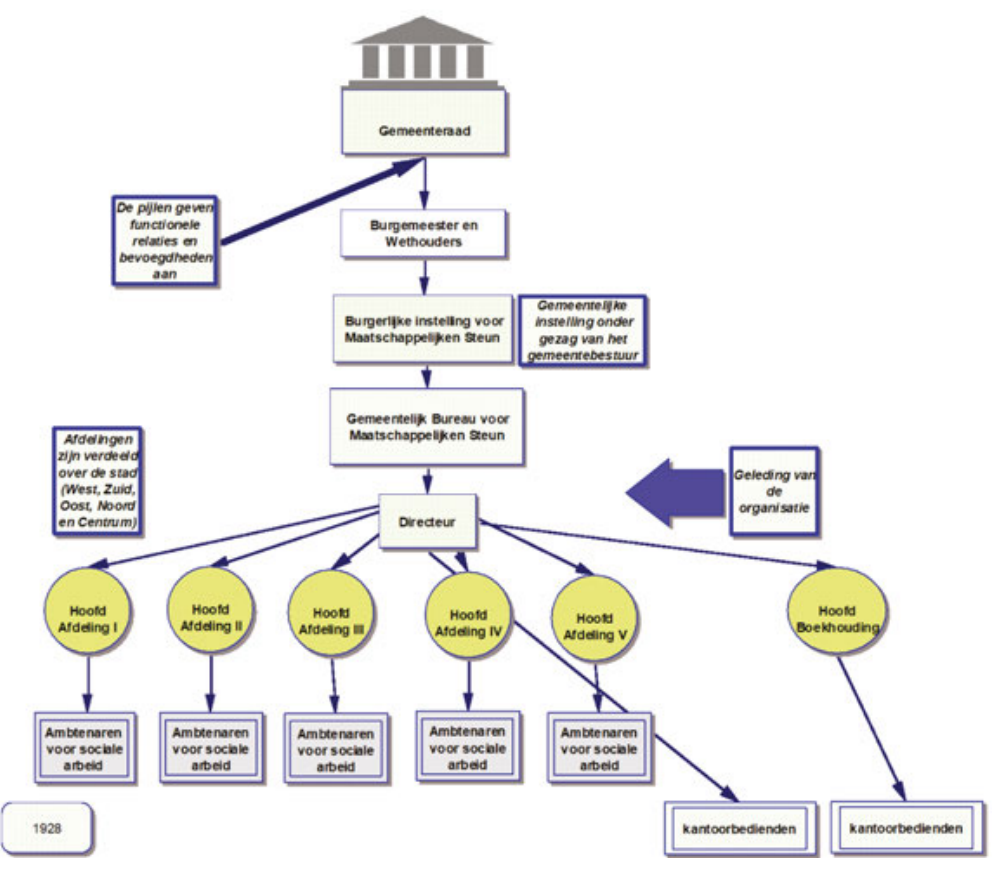


In 1927 werd de het Burgerlijk Armbestuur opgeheven. In het organogram komt heel helder naar voren dat armenzorg een gemeentelijke dienst is geworden onder de benaming Burgerlijke Instelling voor Maatschappelijken Steun. Het hoogste gezag is nu de gemeenteraad. Zoals in paragraaf 3 (De bureaucratisering van de Amsterdamse gemeentelijke armenzorg in breder perspectief) uiteengezet zal worden, betekent dit dat een tegenwicht zal worden geboden tegen een al te ongebreidelde bureaucratie.

\section{g) Besluit}

De bureaucratisering van de gemeentelijke armenzorg kwam in 1871 niet uit de lucht vallen. In paragraaf 2 van dit hoofdstuk wees ik hier al op. Het is goed hier te memoreren dat de armenzorg ten tijde van de Republiek al bureaucratische trekken vertoonde. In Amsterdam was dat eveneens het geval. ${ }^{79}$ Dit bureaucratiseringsproces werd voortgezet in de eerste helft van de negentiende eeuw. ${ }^{80}$ De werkwijze van het Amsterdamse bestuur van de armenzorg, vanaf 1871, paste dus in een lange traditie.

In de voorafgaande paragrafen zijn de werkwijze en de organisatie van de Amsterdamse gemeentelijke armenzorg tussen 1871 en 1940 vergeleken met wat Max Weber zag als het ideaaltype van de bureaucratie. We zien dat de gemeentelijke armenzorg steeds meer op dit ideaaltype is gaan lijken. Aan het begin van de twintigste eeuw zijn veel Weberiaanse kenmerken al aanwezig. In de armenzorg werd een standaardprocedure gevolgd, die door de jaren heen in grote lijnen dezelfde is gebleven. Armbezoekers werkten in een hiërarchisch verband. Hun positie werd steeds meer geformaliseerd. Aanvankelijk waren ze ongeschoold, maar later kwamen er cursussen en ten slotte een tweejarige opleiding. Mettertijd werden scholing en het halen van diploma's verplicht gesteld. De medewerkers van de armenzorg werden continu beoordeeld. Vacatures werden via openbare sollicitatierondes vervuld. Op den duur werden de armbezoekers van weleer ambtenaren in bureaucratische zin. De bureaucratische machinerie had een blijvend karakter gekregen.

Tussen 1871 en 1940 nam de hoeveelheid taken van de gemeentelijke armenzorg enorm toe. Met behulp van het bureaucratisch apparaat konden deze activiteiten geordend worden uitgevoerd. Bij de uitvoering stond het rationaliteitsprincipe voorop. Bekeken werd per individuele aanvraag welke steun het meest adequaat was, afgemeten ook aan het totale beschikbare budget. Het rationaliteitsprincipe is ook goed zichtbaar in de geleidelijke overgang van ondersteuning in natura naar ondersteuning met geld. ${ }^{81}$

De oprichting van de Burgerlijke Instelling voor Maatschappelijken Steun in 1927 is een belangrijke stap in het proces van bureaucratisering. Het Gemeentelijk Bureau voor maatschappelijke steun werd een uitvoeringsorgaan. De Burgerlijke Instelling voor Maatschappelijken Steun kwamen in de plaats van het Burgerlijk Armbestuur, dat als een semi-overheidsinstelling kon worden getypeerd. De ondergeschiktheid van de nieuwe instelling aan de wethouder c.q. de gemeenteraad was nu compleet. Zowel in formeel als in financieel opzicht was de armenzorg een gemeentelijke bureaucratische organisatie geworden.
79 Van Leeuwen (2007). 80 Van Leeuwen (1992), 113-119.

81 Weber spreekt van "der Vormarsch des Rationalismus"; Weber, WuG5, 579; WuG: Herrschaft, MWS I/22-4, 45 . 


\subsection{DE BUREAUCRATISERING VAN DE AMSTERDAMSE GEMEENTE- LIJKE ARMENZORG IN BREDER PERSPECTIEF}

Om de bureaucratisering van de Amsterdamse gemeentelijke armenzorg beter te kunnen begrijpen wordt dit proces in een breder perspectief geplaatst. In de eerste plaats wordt bekeken of deze Amsterdamse ontwikkeling gelijke tred houdt met de bureaucratisering op rijksniveau. In de tweede plaats wordt belicht hoe de bureaucratisering van de Amsterdamse armenzorg zich verhoudt tot de vernieuwing van de democratie na de invoering van het algemeen kiesrecht. In de derde plaats wordt de poging beschreven van Amsterdamse ambtenaren om hun onafhankelijkheid te bewaren ten opzichte van de gemeenteraad.

\section{a) Het perspectief van het Rijk}

Tussen 1871 en 1940 ontwikkelde de Amsterdamse armenzorg zich tot een moderne bureaucratische organisatie in de betekenis die Weber daaraan heeft gegeven. Hoe verhoudt de Amsterdamse situatie zich tot de landelijke ontwikkeling? Aan de hand van Binnenlandse zaken, de dissertatie van Van IJsselmuiden, laat zich dit helder beschrijven. ${ }^{82}$ In de eerste helft van de negentiende eeuw had de bestuursorganisatie van de rijksoverheid nog vooral patriarchale trekken. ${ }^{83}$ Rijksambtenaren waren letterlijk "dienaren des Konings", waarbij de ambtenaren in direct persoonlijk verband stonden met koning Willem I. De ambtenaren waren de uitvoerders van de vele Koninklijke Besluiten. Deze autocratische bestuursvorm eindigde definitief met de grondwetswijziging van 1848. ${ }^{84}$ Tussen 1848 en 1918 kreeg de moderne bureaucratie van de rijksoverheid bijna volledig vorm. ${ }^{85}$ In de eerste decennia van de twintigste eeuw werd het proces voltooid: "De bureaucratisering van het Nederlandse overheidsapparaat in Weberiaanse zin (...) werd (...) vóór de Tweede Wereldoorlog (...) besloten", aldus Van IJsselmuiden. ${ }^{86}$

De Amsterdamse situatie laat zich goed in deze ontwikkeling plaatsen. In 1871 werd het Burgerlijk Armbestuur opgericht. Op dat moment vertoonde het Burgerlijk Armbestuur nog patriarchale trekken, omdat de bestuursleden niet alleen persoonlijke banden hadden met, maar zelf ook afkomstig waren uit Amsterdamse elitaire kringen. In de jaren die volgden begon

82 Van IJsselmuiden (1988). 83 Van IJsselmuiden (1988), 95.

84 Het is Bornewasser, die er met veel scherpzinnigheid op heeft gewezen dat de grondwetswijziging van 1840 al enigszins in de richting van 1848 wees. Bornewasser (1975). Verder moet gezegd worden dat het einde van de autocratische bestuursvorm eerder in 1853 of zelfs 1868 dan in 1848 zelf gezocht zou moeten worden.

85 Van IJsselmuiden (1988), 190.

86 Van IJsselmuiden (1988), 271. de organisatie van de armenzorg steeds meer bureaucratische trekken te krijgen, volgens de typering van Weber. Het vervangen van het Burgerlijk Armbestuur in 1927 door de Burgerlijke Instelling voor Maatschappelijken Steun, die als een volledig gemeentelijke dienst zou gaan fungeren, voltooide dit bureaucratiseringsproces.

Ook de groei van het ambtenarenapparaat (hierboven aangegeven: van vijf armbezoekers in vaste dienst in 1871 naar een personeelsbestand van 688 medewerkers in 1940) in Amsterdam komt in grote lijnen overeen met de groei van het burgerlijk overheidspersoneel in heel Nederland. Deze groei is te zien in grafiek 7.15 . 


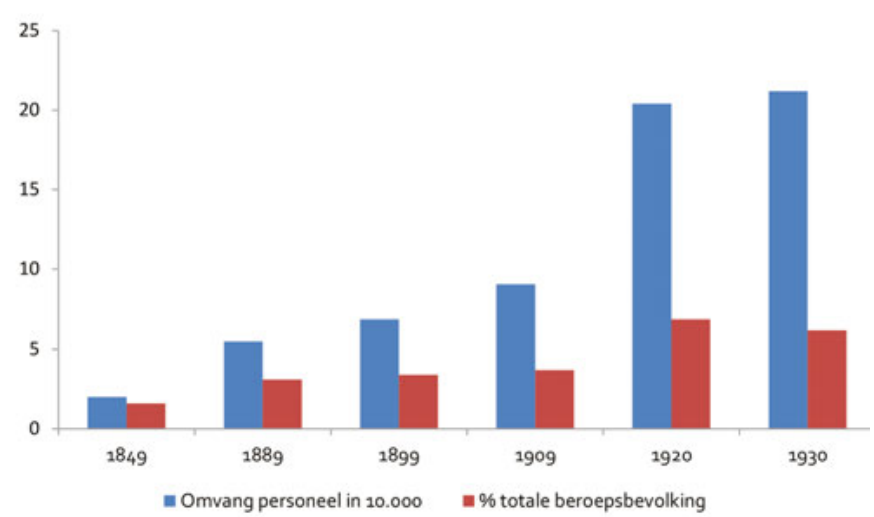

Bron: Van Braam (1957), 22 en 25 (tabel opgenomen in bijlage 8, tabel 8.27)

De bureaucratisering van de armenzorg in Amsterdam en de ontwikkeling van de overheidsbureaucratie in heel Nederland vertoonden tussen 1871 en 1940 grote overeenkomsten, zowel naar vorm als naar omvang. Zoals eerder beschreven valt op dat Amsterdam op het gebied van de rechtspositie van de ambtenaar een pioniersrol vervulde.

De verhouding tussen de gemeente en het Rijk ontwikkelde zich nog in een ander, belangrijk opzicht. De autonomie van de gemeente was in 1871 relatief groot. De uitvoering van de armenzorg en de hoogte van de steunverlening werden door de gemeente vastgesteld. Tijdens het interbellum brokkelde de autonome positie van de gemeente af. Rijksvoorschriften werden steeds dwingender. Onder druk van de economische crisis van de jaren '30 werden de steunregelingen voor werklozen, en daarvan afgeleid ook voor armen, onder de controle van het Rijk geplaatst. ${ }^{87}$ Gemeentelijke instellingen verloren hun zelfstandigheid door de invoering van landelijke regels. ${ }^{88}$ Ook Amsterdam kwam in financieel opzicht onder curatele van het Rijk te staan. ${ }^{89}$

\section{b) Algemeen kiesrecht en democratisering ("enkel de bonen waren taai")}

Nadat het algemeen kiesrecht in 1919 was ingevoerd, ontstond in Nederland en dus ook in Amsterdam een massademocratie. Daardoor veranderde de sociale samenstelling van de gemeenteraad. ${ }^{90}$ Er werd sindsdien anders aangekeken tegen de bureaucratische organisatie van de armenzorg. Raadsleden stonden kritischer dan voorheen tegenover dit ambtelijke apparaat. Een prominente vertegenwoordiger van die nieuwe houding was het communistische raadslid Alex Lisser. Naar aanleiding van een zelfmoordgeval in het Armenhuis interpelleerde Lisser op 12 maart 1923 in de gemeenteraad en op 22 maart 1923 diende hij een raadsadres in. Op 2 en 3 mei 1923 vond in de gemeenteraad een debat over de toestand in het armenhuis plaats.91 Deze kwestie gebruik ik als voorbeeld voor de gewijzigde verhoudingen tussen de bureaucratische organisatie en de volksvertegenwoordiging.

Lisser klaagde over de gang van zaken in het armenhuis. Pesterijen hadden geleid tot een geval van zelfmoord. Cliënten in het armenhuis werden
87 De Rooy (1979), 72-73. 88 Van Leeuwen (1998)b, 526 . 89 Kaal (2008), 129 en 137 Burgemeester De Vlugt heeft in 1931 en 1932 tevergeefs getracht Amsterdam aan deze wurggreep te onttrekken. Het Rijk bleek te machtig. (Kaal (2008), 137-138). De wurggreep kwam tot stand door de wetgeving van minister De Geer. (Van der Kaaij (2014), 242). Ook Wibaut, in zijn functie als Eerste Kamerlid, probeerde de onafhankelijke financiële positie van de gemeente te behouden, maar was evenzeer kansloos (Borrie (1968), 205). De teruggang van de financiële autonomie van de gemeente in de jaren '20 en '30 beschrijft Leydesdorff (1987), 89-90. 90 Hofland (1998), 61-62,70. 911923 Gemeenteblad, Tweede afdeling, verslag van de vergaderingen van den gemeenteraad enz. SAA Toegangsnummer 5079. Inventaris Gemeenteraad Bestanddeel 123. Band I 530-539 (2 mei 1923) 539-561 (3 mei 1923) 
belast met corvees. Zij hadden geen beschikking meer over hun eigen geld. Er werden straffen uitgedeeld zonder mogelijkheid tot verweer van de gestraften: het personeel werd klakkeloos geloofd. Het werk van de cliënten, tabakstrippen en mattenvlechten, was eentonig en werd slecht beloond: 20 tot 30 cent per dag. Er was brood weggenomen van de cliënten. Het personeel zou ruw met hen omgaan. Lissers klachten kregen weinig gehoor, ondanks de artikelen die hij daarnaast ook nog publiceerde in De Tribune, de communistische partijkrant. ${ }^{92}$ De verantwoordelijke wethouder Vos was niet ontvankelijk voor de klachten, die in zijn ogen algemeen en vaag waren, want zonder getuigen met naam en toenaam. De klachten hadden betrekking op wel 1050 verpleegden. Een systeem van massaverpleging riep nu eenmaal weerstand op, meende Vos. De bewoners van het armenhuis waren, in zijn bewoordingen, "het afval van de samenleving". ${ }^{93}$ Vos citeerde wat zijn voorganger, in 1892, bij een soortgelijke klacht over de behandeling van de bewoners van het armenhuis zoal onder dat 'afval' had geschaard:

"Personen na langdurige gevangenschap ontslagen;

onbehuisden en personen van de straat genomen;

teruggekomen van bedelaarsgestichten;

personen verstoten uit kerkelijke gestichten vanwege dronkenschap of wangedrag;

personen verstoten door de familie wegens verslaafdheid aan alcohol; lieden die nergens anders onder dak geraken."

Wethouder Vos merkte op dat in het armenhuis zeer uiteenlopende mensen woonden, waardoor strenge tucht noodzakelijk was. Het armenhuis was geen gesticht voor eerlijke armoede, meende hij. Als bewijs daarvoor haalde hij een statistiek aan uit 1919 waaruit bleek dat 32\% van de bewoners zwerver was geweest en $25 \%$ alcoholist. Uit de verslagen van het armenhuis bleek telkens weer hoe moeilijk het was de tucht te handhaven. De Tribune had een willig oor voor de klachten zonder dat naar het gehalte van de klagers werd gevraagd.

Werkbezoeken aan het Armenhuis hadden Vos geleerd dat er inderdaad streng werd opgetreden en terecht in zijn ogen (want "anders wordt het een janboel") en dat ondanks de massaverpleging orde en tucht werden gehandhaafd. Volgens hem kwamen er geen misstanden voor in het armenhuis en hadden de bewoners maar zes uur corvee per drie maanden. De zelfmoord had pas vijf jaar na de aangehaalde pesterijen plaatsgevonden, zodat een

92 De Tribune was de partijkrant van de communisten in Nederland. Deze partij heette van 1918 tot 1935 Communistische Partij Holland.

931923 Gemeenteblad, Tweede afdeling, verslag van de vergaderingen van den gemeenteraad enz. SAA Toegangsnummer 5079 Inventaris Gemeenteraad Bestanddeel 123 Band I 530-539 (2 mei 1923) 539561 (3 mei 1923), hier 534. direct verband niet kon worden aangetoond. Het wegnemen van overtollig brood was een hygiënemaatregel wegens schimmel. Over het schamele loon dat de verpleegden zouden krijgen merkte hij op dat ze kost en inwoning kregen. De verdiensten moesten enkel worden gezien als een zakcentje. Er was in zijn ogen geen sprake van een ruwe bejegening of van mishandeling.

Op 3 mei 1923 vond een verdere behandeling van het raadsadres van Lisser plaats. Raadslid Van Zutphen, een sociaaldemocraat, betichtte De Tribune van "leugen en laster". Lisser zou "de meest troebele bronnen" hebben geraadpleegd. De bewoners van het Armenhuis waren in zijn ogen niet alleen "wrakken van de kapitalistische samenleving", maar ook "morele en psychische defecten". 
Raadslid Tamsma, van de Christen Democratische Partij, had eigen onderzoek gedaan door tijdens de bezoekuren van het armenhuis vragen te stellen aan de verpleegden. ${ }^{94} \mathrm{Hij}$ zag weinig terug van de klachten. Het ging om 1050 verpleegden, vaak met een zeer twijfelachtige achtergrond. De behandeling was zo goed als onder de gegeven omstandigheden mogelijk was. Wel was er in zijn ogen enige verbetering mogelijk, want de armen waren ondergebracht in een oud gebouw. Tamsma had verschillende keren geproefd van de maaltijden die in het armenhuis werden aangeboden en kwam tot deze conclusie: "enkel de bonen waren taai". Bij de omgang met de verpleegden kwam in zijn ogen meer pedagogische tact en liefde te pas dan Lisser wilde toegeven.

Lisser handhaafde zijn standpunt over de klachten, maar zijn motie om inzage te krijgen in officieuze stukken redde het niet: er waren maar twee stemmen voor: Lisser zelf en Wijnkoop, beiden van de communistische fractie.

\section{Afbeelding 7.5 Alexander Lisser (1875-1943)}

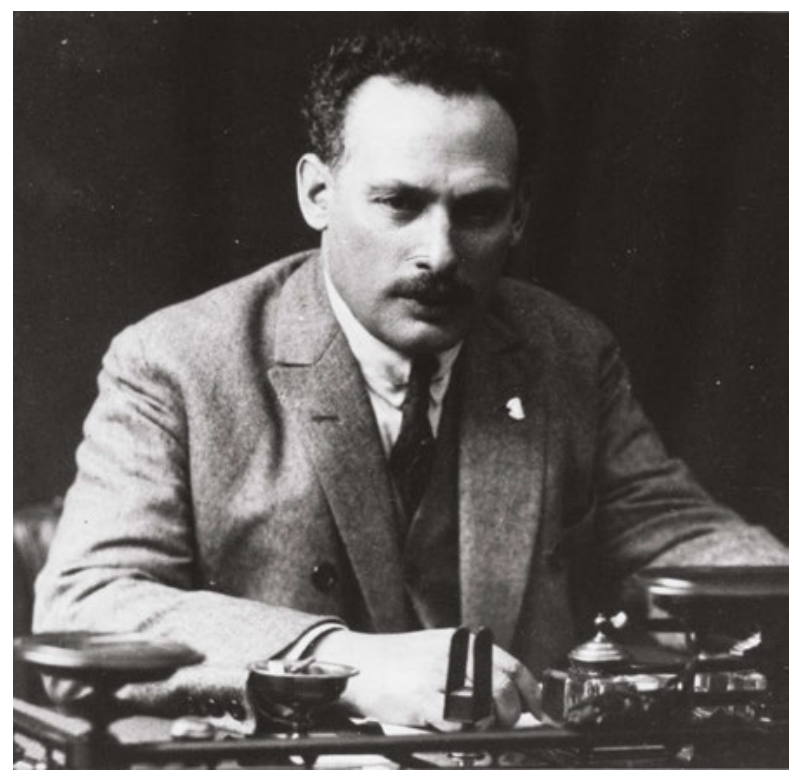

Lisser was van 1919 tot 1931 gemeenteraadslid. Van 1919 tot 1930 lid van de fractie van de CPH (Communistische Partij Holland); van 1930 tot 1931 als onafhankelijk raadslid. ${ }^{95}$ Onbekende fotograaf. Afbeelding ongedateerd.

Bron: SAA. Beeldbank. Afbeeldingsbestand OSIM00008000100.

Nog één keer zou Lisser zich uitlaten over de gemeentelijke armenzorg. In een brief van 13 juli 1924 aan B\&W doet Lisser een krasse uitspraak namens de communistische raadsfractie. ${ }^{96}$ In die brief zegde hij zijn lidmaatschap op van de raadscommissie tot reorganisatie van het Burgerlijk Armbestuur. Hij was zo teleurgesteld in de houding van het bestuur tegenover arbeiders in nood, dat hij niet langer in de commissie wilde zitten:

"Gezien de stugge en hartelooze houding die in Uwe college, en in de meerderheid van den Raad, gecamoufleerd achter een masker van schijnheilige liefde tegenover de arbeiders in het algemeen, en in het bijzonder tegenover dat deel van de arbeiders, wier eenigen
94 Hofland (1998), 277. 95 Hofland (1998), 213-214. 96 SAA. Toegangsnummer 5154. Archief van de Commissie inzake Reorganisatie van het Burgerlijk Armbestuur bestanddeel 2 d.d. 13 juli 1924. 
hoop en vertrouwen op het B.A. is gevestigd, wordt aangenomen, maakt het mij onmogelijk langer lid van bovengemelde commissie (raadscommissie tot reorganisatie van het Burgerlijk Armbestuur) te blijven."

Ik heb met deze schermutselingen uit 1923 en 1924 willen laten zien hoe een bureaucratische macht zich verhoudt tot een volksvertegenwoordiging. Daarbij moet wel worden aangetekend dat de toenmalige communistische fractie een geïsoleerde positie innam in de Amsterdamse gemeentepolitiek en daarom op weinig steun kon rekenen van de andere gemeenteraadsleden. Volgens Weber probeert een bureaucratische organisatie de gelederen gesloten te houden zodat zij niet kan worden ondermijnd door de openbare mening van een volksvertegenwoordiging. ${ }^{97}$ Toch heeft een gemeenteraad het recht om een bureaucratische organisatie ter verantwoording te roepen. Hierdoor kan zij grenzen stellen aan de bureaucratie. Een democratisch bestel staat kritisch tegenover een bureaucratie.

\section{c) Frictie tussen hoge ambtenaren en de gemeenteraad}

Max Weber wees op de neiging van een bureaucratische organisatie om haar macht en invloed uit te willen breiden. ${ }^{98} \mathrm{lk}$ stipte dat al eerder aan. In Amsterdam kwam dit streven naar machtsuitbreiding prominent aan het licht door het optreden van het Instituut van Directeuren. ${ }^{99}$ Deze directeuren hadden, aldus historicus Stefan Couperus "koninkrijkjes binnen de gemeente" geschapen. ${ }^{100}$ Ze stonden aan het hoofd van de gemeentelijke diensten en bedrijven. Hoe kwamen de directeuren aan hun koninkrijkjes?

Vanaf het einde van de negentiende eeuw ontstond volgens Couperus een discrepantie tussen het gemeentebestuur de jure en het stadsbestuur de facto. ${ }^{101}$ Het gemeentebestuur bestuurde Amsterdam volgens de wettelijke kaders van de Gemeentewet van Thorbecke uit 1851, maar het stedelijk dienstenapparaat gaf er in de praktijk uitvoering aan.

De gemeenteraad werd een "levendig forum" voor partijpolitiek. De dagelijkse praktijk van het besturen van de stad werd verricht door een uitdijend ambtelijk apparaat. De dissertatie van Couperus laat zien dat het besturen van Amsterdam niet enkel een kwestie was van de gemeenteraad en het college van Burgemeester en Wethouders.

De uitbreiding van het kiesrecht zorgde ervoor dat de samenstelling van de gemeenteraad tussen de jaren '90 van de negentiende eeuw en de eerste decennia van de twintigste eeuw wijzigde. De politieke kleur werd minder behoudend doordat veel meer politieke stromingen hun intrede deden; de maatschappelijke bovenlaag verloor haar positie deels aan de middenklasse en deels aan arbeiders. Deze ontwikkeling ziet Couperus als verklaring voor het ontstaan van de discrepantie tussen gemeentebestuur en stadsbestuur. ${ }^{102}$

Tekenend is het aftreden van wethouder N. M. Josephus Jitta in 1917, die genoeg had van de kritiek die de gemeenteraadsleden over hem uitstortten. De raadsdebatten hadden een felle toon gekregen. De gemeenteraad was een politiek strijdperk geworden. ${ }^{103}$

Allerlei meer technische en specialistische bestuurskwesties werden in afzonderlijke raadscommissies behandeld. Directeuren en hoofden van gemeentelijke diensten en instellingen waren hierbij meestal aanwezig en 
spraken een duchtig woordje mee. Hier konden zij hun invloed laten gelden. Deze topambtenaren kunnen volgens Couperus gezien worden als "nieuwe ambtenaren", professionals die de dagelijkse leiding hadden bij de uitvoering van het Amsterdamse gemeentebeleid en zo hun koninkrijkjes binnen de gemeente konden beheren. ${ }^{104}$ De Rooy zag de opkomst van deze topambtenaren als het gevolg van de zich snel uitbreidende diensten en bedrijven. "Daardoor vergde het beheer van de organisatie nieuwe bekwaamheden, zoals er soms ook besloten moest worden over ingewikkelde technische problemen of aanzienlijke investeringen. Dit leidde tot een groter zelfbewustzijn bij sommige hoofdambtenaren, die ervan overtuigd waren dat zij over aanzienlijk meer inzicht beschikten dan de wethouders." ${ }^{105}$ De rechtspositie van de directeuren was overigens kwetsbaar, omdat hun plaats in het bestuursapparaat niet was verankerd in de gemeentewet. Hun invloed was groot door hun deskundigheid op hun specifieke vakgebied en door hun langdurige staat van dienst. Verreweg de meesten bleven tientallen jaren aan de gemeente verbonden. Om hun positie te verbeteren werd in 1916 het Instituut van Directeuren opgericht. ${ }^{106}$

Jurrema, het gezicht van de gemeentelijke armenzorg, is een goed voorbeeld van zo'n "nieuwe" ambtenaar. Hij was van 1892 tot 1932 in dienst van de gemeente. In 1919 werd hij tot het Instituut van Directeuren toegelaten. Dit Instituut was nodig omdat de directeuren geen goede rechtspositie hadden, maar wel als zondebok aangewezen konden worden bij grote of kleine schandalen bij de gemeente-instellingen. Daardoor moesten ze soms vrezen voor hun baan. De groep directeuren was overigens weinig eensgezind. Moest het Instituut een adviserende rol blijven spelen, of een lobbygroep worden? Uiteindelijk gaven de zakelijke en persoonlijke belangen de doorslag en werd het Instituut een lobbygroep. Vanwege deze koerswijziging bedankte burgemeester De Vlugt in 1929 voor het erevoorzitterschap. Het Instituut verloor zijn invloed en ook de topambtenaren hadden zich voortaan te schikken naar de wethouder, die bestuurlijk gezien hun meerdere was. Dat schikken ging niet vanzelf omdat de directeuren andere ambtelijke instellingen en de gekozen macht "veelal als tegenspelers" zagen, zoals Couperus het uitdrukt, en dus niet als collega's. ${ }^{107}$ De positie van de wethouder werd nog versterkt door een wijziging van de gemeentewet in 1931. Vanaf die tijd waren de wethouders niet meer degenen die alleen bijstand verleenden aan de burgemeester bij het dagelijks bestuur, maar die samen met hem het college van burgemeester en wethouders vormden. ${ }^{108}$

Het stadsbestuur had zich tussen 1900 en 1940 ontwikkeld binnen de kaders van de gemeentewet van Thorbecke. Er was een hoogstaand gemeentelijk voorzieningenniveau gerealiseerd. De macht van de directeuren van al die gemeente-instellingen was weliswaar groot, maar "over de machinerie van de stad (werd) uiteindelijk door gekozen politici beslist". ${ }^{109}$ Het streven naar nog meer macht door hoge ambtenaren werd afgeremd door de gekozen volksvertegenwoordiging: de gemeenteraad van Amsterdam.

De door Couperus gesignaleerde discrepantie tussen gemeentebestuur de jure en stadsbestuur de facto is ook in de armenzorg van de gemeente zichtbaar. In de uitvoering was er grote zelfstandigheid, maar de beleidslijnen werden democratisch vastgesteld. We zien dat terug in de herhaalde klachten van de top van de armenzorg over de werkdruk. Uitbreiding van
104 Couperus (2009), 153 en 154

105 Rooy, P. de (2007)a, 64.

106 Couperus (2009),

153-182.

107 Couperus (2009), 178 en 182.

108 Kaal (2008), 133.

109 Couperus (2009), 64. 
personeel liet vaak lang op zich wachten. ${ }^{110}$ De gemeenteraad heeft het laatste woord. Dat werd duidelijk zichtbaar bij de instelling van het Burgerlijk Armbestuur in 1871, bij de mogelijkheid om dubbele bedeling toe te passen in 1896 en bij de opheffing van het Burgerlijk Armbestuur en de oprichting van de Burgerlijke Instelling voor Maatschappelijken Steun in 1927. Ook hier was het de gemeenteraad, op aangeven van de wethouder, die het beleid bepaalde.

\section{d) Samenvatting}

In het voorafgaande hebben we gezien dat de bureaucratisering van de Amsterdamse armenzorg niet op zichzelf staat en goed te vergelijken is met de bureaucratisering op rijksniveau. Een patriarchaal overheidsapparaat maakte plaats voor een meer bureaucratische bestuursvorm die als Weberiaans getypeerd kan worden. Bureaucraten konden een grote macht uitoefenen. Met de democratisering van het gemeentebestuur die in 1919 werd geëffectueerd, werd een dam opgeworpen tegen een al te grote macht van de bureaucraten. In de gemeenteraad kon een bureaucratische organisatie ter verantwoording worden geroepen. Het gezag van de gemeenteraad gold ook voor de hoogste ambtenaren, de directeuren, die een eigen beleid probeerden te ontwikkelen. Deze directeuren meenden het beter te weten dan de wethouders, maar ook zij moesten ervaren dat de gemeenteraad het voor het zeggen heeft. Ook in Amsterdam heeft de massademocratie een tegengewicht gevormd tegen een al te zelfstandig opererende en machtige bureaucratische organisatie.

\subsection{CONCLUSIE}

In dit hoofdstuk is de vraag opgeworpen in hoeverre de Amsterdamse armenzorg gekenschetst kan worden als bureaucratisch. Daarvoor moest eerst het begrip bureaucratie gedefinieerd worden. De vervolgvraag was welke ontwikkeling er te zien is in de praktijk van de gemeentelijke armenzorg tussen 1871 en 1940. Tot slot kwam het bredere kader van de Amsterdamse armenzorg aan de orde.

Onze uitleg van het begrip bureaucratie steunt sterk op de uitleg die Max Weber eraan gaf. Weber ontwierp een ideaaltype van bureaucratie die nog steeds als een standaard wordt gehanteerd. Volgens dit ideaaltype zijn ambtenaren opgeleid voor hun specifieke beroep. Zij werken in een vast dienstverband, dat hiërarchisch van opzet is. Zij hebben een rechtspositie die hun onafhankelijkheid garandeert, zowel ten opzichte van steunaanvragers als ten opzichte van hun leidinggevende. Op deze wijze kunnen

110 SAA 15030. Bestanddeel 132024 Jaarverslag Burgerlijk Armbestuur van Amsterdam 1891; SAA 15030. Bestanddeel 132033. Jaarverslag Burgerlijk Armbestuur van Amsterdam 1901; in een brief van Jurrema, directeur van de armenzorg, aan de wethouder van 21 maart 1929, geciteerd door De $\operatorname{Rooy}(1979), 38$. ambtenaren onpersoonlijk en onafhankelijk opereren, zonder aanzien des persoons. Zij hanteren een strikt rationaliteitsbeginsel. Hierdoor nemen ambtenaren op objectiveerbare gronden en op basis van duidelijke criteria beslissingen over het al dan niet honoreren van een aanvraag.

Als een bureaucratische organisatie eenmaal is gevestigd, dan wordt de macht van de beambten steeds groter. Er is ook een streven naar vergroting van die macht. Door de verantwoording die ambtenaren moeten afleggen aan het wettig gezag wordt dit machtstreven ingeperkt. De beambten staan als uitvoerende macht tegenover de wetgevende macht. In een democratische rechtsorde is het apparaat van de armenzorg onderworpen aan de 
controle van wetgevende organen.

Uit mijn onderzoek naar het apparaat van de gemeentelijke armenzorg tussen 1870 en 1940 is gebleken dat de organisatie van het apparaat al vanaf 1871 bureaucratische trekken vertoonde. De armenzorg ontwikkelde zich in de loop van zestig jaar tot een compleet bureaucratische organisatie. De oprichting van de Burgerlijke Instelling voor Maatschappelijken Steun in 1927 versterkte dit proces. De armenzorg werd een volledige gemeentelijke dienst.

De noodzaak tot bureaucratisering van het apparaat van de gemeentelijke armenzorg was drieërlei. Het aantal taken van de gemeentelijke armenzorg nam flink toe. In de tweede plaats was er de forse toename van het aantal steunaanvragen. Als gevolg daarvan was er ten derde ook een forse groei van het aantal ambtenaren dat werkzaam was voor de gemeentelijke armenzorg. Een bureaucratisering van de werkwijze maakte het mogelijk dit grote aantal aanvragen zakelijk en objectief af te handelen.

Door de opkomst van de massademocratie, na de invoering van het algemeen mannen- en vrouwenkiesrecht, werd het onderscheid tussen uitvoerende en wetgevende macht scherper aangezet. Zelfs in de meer monistische gemeentelijke bestuurlijke verhoudingen werd het verantwoorden van beleid en uitvoering een belangrijke kwestie.

De bureaucratisering van het apparaat zien we ook terug in de vorm waarin hulp werd verleend. De hulp in natura maakte grotendeels plaats voor financiële steun. Deze ontwikkeling is geïnterpreteerd als een rationalisering van de armenzorg.

De bureaucratisering van de Amsterdamse armenzorg, zo hebben we gezien, is onderdeel van een algemeen bureaucratiseringsproces in Nederland. Het aantal ambtenaren in rijksdienst nam tussen 1870 en 1940 flink toe. Ook in Amsterdam was dat het geval.

Het verschil in inzicht tussen uitvoerende ambtenaren en bestuurders in dienst van een volksvertegenwoordiging, zijn we ook in Amsterdam tegengekomen. Dit verschil in inzicht is beslecht in het voordeel van de bestuurders, omdat de gemeenteraad het laatste woord bleek te hebben. Een al te voortvarende opmars van de bureaucratie werd daarmee een halt toegeroepen. 


\section{HOOFDSTUK 8 \\ LEVENSVERHALEN}

< 8.A Zwarte Bijlsteeg circa 1920. De Zwarte Bijlsteeg gezien naar de achtergevel van Groot Hemelrijk 22, met rechts Zwarte Bijlsteeg 14-18 (v.r.n.I.). Foto gemaakt door W.C. Ladiges (1895-1956). Bron: SAA. Beeldbank. Afbeeldingsbestand ANWA00042000001.

In 1919 woonde Klaasje Zevenster (verhaal 8.2) op nummer $18^{\prime}$.
1 Het al eerder aangehaalde artikel van Smits (1993) bevat een in meerdere opzichten voorbeeldig levensverhaal; Knotter (1998), 385-388 en 398-399 levert zakelijke gegevens over het levensverhaal van het gezin B. tijdens het Interbellum. 2 De gegevens van dit levensverhaal zijn gebaseerd op het onderzoeksverslag van Uddhava Rozendal en Lawrence Gharib op basis van SAA 5256. Doos 1004. Stamboeknummer 3166.
Het materiaal van onderstaande levensverhalen is gedeeltelijk verzameld door studenten geschiedenis van de Hogeschool van Amsterdam die onder mijn begeleiding enkele dossiers van de armbezoekers bestudeerd hebben. De levensverhalen worden in deze studie niet geanalyseerd. Ze zijn opgenomen om de lezer een gevoel te geven in de levens van de bedeelden. Ze laten meer van de samenhang van die levens zien dan de losse citaten uit de rapporten van de armbezoekers en geven op een andere manier zicht op de levensomstandigheden van de besproken armen dan de statistische gegevens die in de analyse betrokken zijn. ${ }^{1}$

\subsection{DE GEZINNEN SCHOUTEN-ROELOFS-BROEKHUIJSEN-WINKE- LAAR 1886-1938²}

Behalve het veelbewogen leven van de besproken gezinnen, een soap waardig, valt in dit levensverhaal het verschijnsel van het tweede huwelijk op. Een alleenstaande arme had het vaak moeilijk en koos daarom soms, bij wijze van overlevingsstrategie, voor een gedeeld leven. Opvallend zijn ook de vele verhuizingen. Hierin kunnen we eveneens een overlevingsstrategie zien: er moest zo goedkoop mogelijk worden gewoond. Omdat de inboedels bescheiden waren, was verhuizen niet erg kostbaar. Een kleine inboedel paste op een simpele handkar. In dit verhaal komt naar voren dat de armbezoeker ook let op het bestedingspatroon van de aanvrager. Als er - in de ogen van de armbezoeker - te luxueuze uitgaven zijn, dan wordt de aanvraag afgewezen. Er zijn dan, zo is de redenering, voldoende inkomsten om in het dagelijkse levensonderhoud te kunnen voorzien. Ook komen andere controlemogelijkheden van de armenzorg binnen dit levensverhaal ter sprake. Buren en werkgevers geven desgevraagd nadere inlichtingen over de financiële situatie. Tijdens het huisbezoek van de armbezoeker wordt ook gecontroleerd of de inlichtingen kloppen die de aanvrager heeft verstrekt. De armenzorg probeert soms de gegeven steun te verhalen op naaste familieleden. In dit verhaal zien we hoe moeizaam dit verhaalrecht in de praktijk werkte. De vraag is wat deze procedures in de praktijk hebben opgeleverd. In het verhaal zien we ook dat de armenzorg langdurig blijft steunen. De partijen worden niet zomaar in de steek gelaten. De geldelijke ondersteuning houdt niet over, maar in dit levensverhaal kunnen we lezen dat in de jaren '20 de steun werd verhoogd. De algemene verhoging van het welvaartspeil komt ook aan de gesteunden ten goede. De jaren '20 zijn in dit opzicht een keerpunt.

Het verhaal begint in 1886. Jacoba Johanna Maria Roelofs, geboren op 26 augustus 1854, is dan net negen jaar getrouwd. Zij is sinds 22 augustus 1877 getrouwd met Martin Schouten, geboren op 6 januari 1850. Martin is kleermaker bij Carvallier in de Zwanenburgstraat. Martin is hervormd, terwijl Jaco- 
ba katholiek is. Het koppel heeft drie kinderen: Margaretha is zeven, Jacoba is drie en Johanna is één jaar oud. Het gezin woont in de Lijnbaanstraat. Martin is al zeven weken ziek en Jacoba kan niet werken vanwege een stijve linkerarm. Hierdoor heeft het echtpaar een huurschuld opgelopen van hfl 9,00. Al eerder kregen Martin en Jacoba bedeling om hun vijfjarige dochtertje Berendina te kunnen begraven. Het gezin krijgt in 1886 geldbedeling van hfl. 1,00 per week. De armbezoeker beoordeelt het gezin als "netjes".

In maart 1887 gaat het iets beter met het gezin. Margaretha gaat naar school en Martin is hersteld en heeft werk gevonden waarmee hij hfl. 2,50 per week verdient. Vanwege dit inkomen en omdat Martin familieleden heeft waarop hij kan terugvallen, wordt zijn hernieuwde aanvraag om bedeling afgewezen.

Op 5 september 1891, ruim vier jaar later, vraagt het gezin opnieuw bedeling aan. Van 1887 tot 1891 heeft het gezin in Parijs gewoond. Na terugkeer in Amsterdam heeft Martin niet meteen werk kunnen vinden. Het gezin is uitgebreid met een zoon, Johannes, die in Parijs is geboren. Alle kinderen gaan nu in Amsterdam naar school. De armenzorg besluit tot hernieuwde steunverlening, zij het dat het oorspronkelijke bedrag wordt gehalveerd: hfl. 0,50 per week. De relatie tussen Jacoba en Martin houdt geen stand. Op 11 november 1891 doet Jacoba bij de armenzorg aangifte van verlating door haar echtgenoot. De armbezoeker bevestigt deze verlating op 11 december 1891. Voor de wintermaanden krijgt het eenoudergezin nog wat turf toebedeeld. Het is onduidelijk of Martin nog zal terugkomen.

In 1901 dient het gezin, dat inmiddels op het adres Elandsstraat 2 woont, opnieuw een steunaanvraag in. Bij heronderzoek blijkt dat Martin en Jacoba in december 1891 alweer waren herenigd. In januari 1892 vertrekt het gezin andermaal naar Parijs. Daar blijven ze wonen totdat in 1899 het noodlot toeslaat. Op een dag wil Martin op de tram springen, maar hij mist de treeplank. Hij belandt op straat, wordt overreden en verliest een been tot boven de knie. Om onbekende redenen keert het gezin terug naar Amsterdam. Mogelijk is het gezin daartoe aangezet door de Franse autoriteiten, omdat het in Parijs niet in aanmerking komt voor bedeling. De Nederlandse overheid betaalt de terugreis. Pech blijft het gezin achtervolgen. Onderweg gaat niet alleen het houten been van Martin stuk, maar ook de meegenomen naaimachine.

Bij terugkeer strijkt het gezin neer in de Laurierstraat. Totdat de naaimachine gerepareerd is, krijgen ze geldbedeling. De armbezoeker noteert dat de kinderen hondsbrutaal zijn en het gezin niet meer erg ordelijk is.

Een steunaanvraag in 1902 leidt tot een nieuw armbezoek. Zoon Johannes is inmiddels aan de slag bij een drukker. Jacoba en haar gelijknamige dochter zijn naaister geworden. Martin moet in het OLVG worden opgenomen vanwege beenklachten. Daarom wordt het gezin vanaf februari bedeeld met hfl. 1,50 per week. In maart wordt Martin uit het ziekenhuis ontslagen. Zijn been is nog verder geamputeerd. In het voorjaar van 1902 gaat dochter Margaretha, dan 23 jaar, alleen terug naar Parijs. Naar verluidt leidt zij in Parijs een "onzedelijk leven". Dochter Jacoba, dan 19 jaar, wordt naar een katholiek opvoedingsgesticht gezonden. Dochter Johanna, dan 17 jaar, wordt dienstbode. Zij woont nog thuis. Omdat het ontbreekt aan spaargeld en er zelfs geen huisraad meer is om te verkopen, wordt de bedeling voortgezet, voorlopig tot mei 1902. 
Het gezin weet de bedeling nog te rekken tot november 1902. Dan wordt toch maar de naaimachine verkocht. Met het geld dat ze ervoor krijgen zetten ze een kruidenierswinkeltje op. Hoewel ze met deze nering amper iets verdienen, wordt de bedeling wel alvast stopgezet. Een paar maanden later, op 3 maart 1903, overlijdt Martin, op 53-jarige leeftijd.

In oktober 1903 wordt dochter Jacoba ontslagen uit het opvoedingsgesticht. Zij krijgt een betrekking als dienstbode. Moeder Jacoba beproeft andermaal haar geluk in Parijs, door in te trekken bij haar dochter Margaretha, samen met zoon Johannes en dochter Johanna. Omdat ze ziek wordt en Parijse artsen haar adviseren om terug te gaan, gezien haar zwakke gestel, keert ze in november 1903 terug naar Amsterdam. Het weinige spaargeld dat er nog over was van het winkeltje is inmiddels helemaal op. De broer van Martin stopt het gezin soms iets toe. Van de gemeentelijke armenzorg krijgt het eenoudergezin tot mei $1904 \mathrm{hfl}$. 1,25 per week.

In maart 1904 gaat dochter Johanna het huis uit. Jacoba werkt bij Krasnapolsky. Zoon Johannes werkt bij een tante, een zuster van Martin. Het verzoek van Johanna om bedeling wordt afgewezen vanwege de verdiensten van haar kinderen.

In februari 1905 doet Jacoba opnieuw een aanvraag. Haar zoon Johannes moet het leger in. Johanna is weer teruggekeerd naar huis zodat er nog steeds twee inwonende kinderen zijn.

In oktober 1905 verhuist het gezin naar de Rozenstraat. Johannes dient nog steeds in het leger. Johanna waagt een nieuwe poging om op eigen benen te staan. Het gezin krijgt hfl. 1,00 per week en turf voor het stookseizoen. Op 5 december 1905 gaat Jacoba het huis uit, maar dan is Johanna intussen alweer teruggekeerd in het gezin. De bedeling wordt verlengd tot januari 1906.

In februari 1906 vraagt moeder Jacoba, inmiddels 52 jaar oud, wederom bedeling aan, maar deze keer niet alleen voor zichzelf of haar gezin. Zij heeft iemand ontmoet, een matroos die Wilhelm Broekhuijsen heet. Hij voer op een Duitse boot, maar heeft de zee ingeruild voor het vasteland en Jacoba. Samen gaan ze in de Korte Keizersstraat wonen. Alle kinderen zijn nu het huis uit. Haar steunaanvraag wordt in april afgewezen, omdat er geen kinderen meer zijn om voor te zorgen en Wilhelm verdiensten zou hebben. Een nieuw verzoek om steun in oktober 1906 wordt eveneens afgewezen omdat Wilhelm bij de aanvraag te weinig gegevens verstrekt.

In december 1906 vindt Wilhelm werk in de haven, waarmee hij hfl. 16,00 per week kan verdienen. Voor die tijd is dat een fors loon. Probleem is alleen dat hij in de haven maar heel af en toe aan de slag kan. De kinderen van Wilhelm uit een vorig huwelijk zijn inmiddels bij het stel ingetrokken: Margaretha van 22 jaar, Petrus van 13 jaar en Wilhelmina van 8 jaar. De kinderen van Jacoba staan hun moeder niet meer bij. Margaretha woont nog steeds in Parijs, met ene Constantijn. Johannes is na zijn diensttijd ook naar Parijs vertrokken. Johanna werkt als dienstbode en woont alleen. Jacoba is getrouwd met Bernard Peel. De steunaanvraag van Jacoba en Wilhelm wordt toegekend. Het nieuwe gezin van Jacoba krijgt hfl. 5,00 per week.

Op 1 juni 1907 wordt een nieuwe steunaanvraag afgewezen. Wilhelm monstert aan op een Engels schip en zal een jaar wegblijven. Jacoba blijft daardoor verstoken van inkomsten en trekt zolang bij haar dochter in, zo blijkt 
uit het commentaar bij haar steunaanvraag van maart 1908. Haar aanvraag wordt toegekend. In de zomer van 1908 keert Wilhelm terug naar Amsterdam. Zijn gage heeft hij besteed aan kleding en drank. Hij drinkt nu erg veel. Toch vindt hij werk in de haven als sjouwer. Jacoba en Wilhelm keren terug naar de Rozenstraat. De dochter van Wilhelm, Wilhelmina, woont bij hen. Zij is dan tien jaar.

Hun steunaanvraag in augustus 1908 wordt afgewezen. Dat heeft niet alleen te maken met het drankmisbruik van Wilhelm, maar ook met de verdiensten die hij af en toe heeft. Het gezin verhuist naar de St. Pieterssteeg. Dochter Jacoba is intussen ook naar Parijs verhuisd. Jacoba en Wilhelm laten zich niet ontmoedigen door de steunafwijzing; de volgende dag dienen ze alweer een nieuwe aanvraag in, die om dezelfde redenen wordt afgewezen.

Omdat de gezondheid van het stel achteruitgaat, krijgt het gezin vanaf oktober 1908 toch weer steun: hfl. 0,50 per week en broodbedeling. Wilhelm gaat steeds slechter zien en Jacoba loopt nu met een kruk.

De twee volgende jaren weet het stel zich te redden, gezien de afwezigheid van steunaanvragen. Het gezin verhuist naar de Laurierstraat en in april 1909 zelfs naar Antwerpen. Wilhelm kan daar een baan krijgen als "opperman". Als het werk ineens ophoudt, keren ze terug naar Amsterdam. Daar zitten Wilhelm en Jacoba beiden zonder werk en inkomsten. Ze krijgen dan opnieuw ondersteuning: hfl. 0,50 per week.

Omdat Wilhelm blijft drinken, besluit Jacoba hem in december 1910 te verlaten. Wilhelm had beterschap beloofd, maar komt zijn beloften niet na. Zijn dochter Wilhelmina wordt in een weeshuis ondergebracht. Ook nu duurt de scheiding van het stel niet lang. In januari 1911 zijn ze alweer bij elkaar, hoewel Wilhelm blijft drinken. Hij werkt af en toe in de haven als sjouwer. In maart 1911 wordt Wilhelm bedeeld met nieuwe schoenen. In juni van dat jaar verhuist dochter Jacoba naar Antwerpen. De bedeling voor Wilhelm en Jacoba wordt voortgezet en gaat in september zelfs iets omhoog. Het stel verhuist naar de Slijkstraat. Wilhelm vindt werk bij een vishandel als "loopknecht". Jacoba en Wilhelm blijven bedeeld: in februari 1912 wordt de bedeling vastgesteld op hfl. 2,75 per week tot oktober 1912.

De gezondheid van Jacoba gaat verder achteruit. Zij lijdt al geruime tijd aan suikerziekte. Sinds 1908 loopt Jacoba al met een kruk, maar zij wordt steeds slechter ter been. Ook krijgt ze last van haar arm. Eind 1918 ligt Jacoba geruime tijd in het gasthuis. Op 3 januari 1919 overlijdt ze, op 64-jarige leeftijd. De begrafenis van Jacoba slokt het laatste geld van Wilhelm op. Als los werkman in de havens verdient hij ongeveer hfl 1,50 per week. Omdat Wilhelm alleen achterblijft en hij inmiddels 66 jaar oud is, biedt Maatschappelijke Steun, de nieuwe naam voor de armenzorg, hem een plaats aan in het Mannenhuis van het Sint Jacobsgesticht aan de Plantage Middenlaan. Wilhelm weigert het aanbod pertinent. Hij licht zijn weigering toe in een brief aan het armbestuur:

(Amsterdam 6 Februwarie 1919)

Weledele.

Ik ben een oud Zeeman sesensestig jaar nu ben ik met mijn vrouw

ondert Steunt Geweest van het armen bestuur maar nu hep ik voor 
vijf weken mijn vrouw verloren toen is de bezoek heer van het armen bestuur bij mij gekomen en heeft mij die steun afgenomen toen heb ik mij met nevenstaat Bewijs aan het stuen komiete (steuncomité) vervoeg om stuen Toen is die selfde heer gesegt ik was telang zonder werk en kan aan mijn verzoek niet worden voldaan want hij see ik moest maar naar het besjeshuis Gaan en dat wil ik niet want als (de) tijd Normaal is kan ik mijn brood noch wel verdienen. Hopende dat Wedle mij een wijnig Zoudt Willen geven dat ik niet van de honger omkom. Zo noem ik met hoog agting

Wedle onderdanige dienaar W.P. Broekhuijsen

\section{Slijkstraat 26s}

Vermoedelijk is het bewijs waarover Wilhelm spreekt een verklaring van een werkgever, gedateerd 20 januari 1919. Daarin wordt gemeld dat Wilhelm een eerlijk en trouw werknemer is, maar dat er op het moment geen werk voor hem is, omdat er in de haven geen tabak binnenkomt. Deze verklaring is afkomstig van Gebroeders Kramer \& Co Tabak.

In januari 1919 is een van zijn dochters, de dan twintigjarige Petronella, weer bij Wilhelm ingetrokken in de Slijkstraat, nadat zij enkele jaren in een Belgisch gesticht heeft gezeten. Vanwege de Eerste Wereldoorlog was het niet mogelijk om België eerder te verlaten. $\mathrm{Na}$ de wapenstilstand van november 1918 komt zij terug naar Amsterdam. In het rapport van de armbezoeker wordt melding gemaakt van een verzoek om kleding voor Petronella. Zij heeft de kleding nodig om werk te vinden. Het verzoek wordt ingewilligd. Petronella krijgt kleding ter waarde van $\mathrm{hfl} 14,20$. Wilhelm zelf krijgt geen bedeling, omdat hij weigert naar het oudemannenhuis van Sint Jacob te gaan.

Omdat Petronella nog minderjarig is, hoeft Wilhelm niet meer naar het oudemannenhuis. Was het toeval dat zijn dochter juist toen bij hem kwam wonen of had Willem er bewust op aangestuurd? In juni 1919, als Petronella bijna meerderjarig is, dient Willem een nieuwe steunaanvraag in. In het rapport van de armbezoeker valt te lezen dat Willem voornemens is opnieuw te trouwen. Vermoedelijk probeerde hij daarmee te voorkomen dat hij alsnog naar het Oudemannenhuis van het Sint Jacob zou moeten. Ook de nieuwe aanvraag wordt afgewezen door Maatschappelijke Steun. Wel krijgt hij enige ondersteuning van de kerk. Zijn kinderen kunnen hem niet helpen met geld, maar ze stoppen hem soms iets toe in natura.

Op 15 oktober 1919 trouwt Willem voor de derde keer. De gelukkige is Petronella Winkelaar, een kinderloze Amsterdamse weduwe. Gezien de korte rouwperiode en de financiële situatie van het stel, bestaat het vermoeden dat dit huwelijk vooral een zakelijke achtergrond had. De nieuwbakken echtgenote is een bekende van Maatschappelijke Steun. Petronella werd bedeeld onder nummer 18760. Nu zij niet langer alleenstaand is, wordt deze bedeling stopgezet. Maatschappelijke Steun maakt er melding van dat haar boekje is ingenomen.

$\mathrm{Na}$ de huwelijksvolstrekking wordt de bedeling hervat. In het voorjaar van 1920 stelt een arts vast dat Willem definitief blind is aan een oog. Zijn dossier wordt overgedragen aan de afdeling blinden. Maatschappelijke Steun maakt er melding van dat hij overdag nog wel alleen over straat kan. 
Petronella wordt eveneens onderzocht. De desbetreffende arts stelt vast dat Petronella, ondanks haar zwakke gezondheid, nog best een paar dagen per week zou kunnen werken. Maatschappelijke Steun weet niet goed met welk bedrag het koppel bedeeld moeten worden. Willem staat aangeschreven als goed werkman bij tabakshandelaren in de buurt, maar er is bijna geen werk. Zijn eventuele inkomsten zijn niet te controleren. Er is geen extra geld beschikbaar voor blinden.

Maatschappelijke Steun probeert Wilhelm in een werkverschaffingsproject voor blinden te krijgen. De verwachting is niet dat hij nog een nieuw vak kan leren, maar misschien kan hij als loopjongen werken. Maar als de maand proeftijd voorbij is, wordt hij weggestuurd. Het werkverschaffingsproject heeft geen emplooi voor blinden ouder dan 65 jaar en Wilhelm is 66 . Toch ziet de armbezoeker nog mogelijkheden: als het project wordt uitgebreid, komen er misschien meer middelen beschikbaar. Dit blijkt ijdele hoop te zijn. De steun was stopgezet toen Wilhelm ging deelnemen aan het werkverschaffingsproject, maar wordt nu weer hervat.

Petronella komt niet in aanmerking voor ouderdomsrente omdat zij geen zegels heeft geplakt. ${ }^{3}$ Om nog wat extra inkomsten te vergaren, verzamelt Willem lege conservenblikken bij hotels. Hij voorziet ze van een hengsel en verkoopt ze aan schilders. Omdat de opbrengst hiervan zo gering is, worden deze inkomsten niet op zijn bedeling ingehouden. Petronella overweegt om als aardappelschilster aan de slag te gaan, maar de armbezoeker ziet hier weinig heil in. Vervolgens ligt Wilhelm geruime tijd in het ziekenhuis. Uit het rapport van september 1920 blijkt dat zowel Willem als Petronella niet meer tot werken in staat zijn. De bedeling wordt vastgesteld op hfl 9,00 per week. Tot december 1924 blijft het koppel dit bedrag ontvangen.

Familieleden van gesteunde armen zijn formeel verplicht om ook steun te verlenen. In de praktijk zijn die familieleden vaak niet bij machte om bij te springen. In het rapport van de armbezoeker uit 1925 komt een schoonzoon van Wilhelm in beeld, die hem zou moeten steunen, omdat hij volgens een werkgeversverklaring genoeg verdient. De schoonzoon weigert dat. Enkele dagen later blijkt dat hij niet verplicht is Wilhelm te steunen. Nader onderzoek van Maatschappelijke Steun wijst namelijk uit dat de schoonzoon een belastingschuld heeft. Daardoor wordt een deel van zijn loon al ingehouden. Dochter Petronella is wel bereid het echtpaar te steunen met een bedrag van hfl 1,00. Dit bedrag wordt op de bedeling in mindering gebracht. Het steunbedrag is nu hfl 8,00 per week.

In april 1928 vraagt het stel om een verhoging van de bedeling. Deze verhoging wordt afgewezen. Petronella en Wilhelm houden er begrotelijke liefhebberijen op na: zij hebben een grote hond en kanaries.

Op 14 mei 1928 verhuizen de twee naar een andere woning. Zij hebben dan 15 jaar in de Slijkstraat gewoond. Zo lang heeft Wilhelm nog nooit ergens gewoond. Heel ver is de reis niet. Ze gaan om de hoek wonen, aan de Oudezijds Achterburgwal, op nummer 189 hs. Volgens het rapport van de armbezoeker is dit een betere woning, die ook nog eens op de begane grond is. De huur is wel hoger. Hiervoor krijgen ze compensatie. De bedeling gaat omhoog naar hfl 11,00.

Omdat hun ouders dat zelf niet meer kunnen, komen de kinderen de was doen. Uit het rapport van oktober 1928 blijkt dat de kinderen het steeds be-
3 Ouderdomsrente was in 1913 ingesteld voor ouderen vanaf 70 jaar. In 1919 werd de leeftijd verlaagd naar 65 jaar. Om in aanmerking te komen moesten rentezegels worden gekocht. 
ter krijgen. Daarom moet zoon Petrus zijn vader steunen in het onderhoud, meent Maatschappelijke Steun, maar Petrus weigert dat. Hij krijgt vrijstelling omdat hij kinderen uit een eerder huwelijk moet onderhouden.

In april 1929 hoopt Wilhelm in aanmerking te komen voor een paar nieuwe schoenen. Hij heeft een dergelijk verzoek al vaker gedaan en tot dan toe werd het altijd ingewilligd. Deze keer echter niet. Uit gesprekken die de armbezoeker voert met de buren blijkt namelijk dat er regelmatig een vrouw mee komt eten bij het echtpaar Broekhuijsen, tegen betaling van hfl 0,30 per maaltijd. Deze inkomsten heeft het stel nooit bij Maatschappelijke Steun opgegeven. Daarom krijgt Wilhelm deze keer geen nieuwe schoenen.

Slijkstraat. Wilhelm Broekhuijsen woonde in de Slijkstraat tussen 1913 en 1928. Hieronder een afbeelding uit 1931.

Afbeelding 8.1 Slijkstraat, 1931

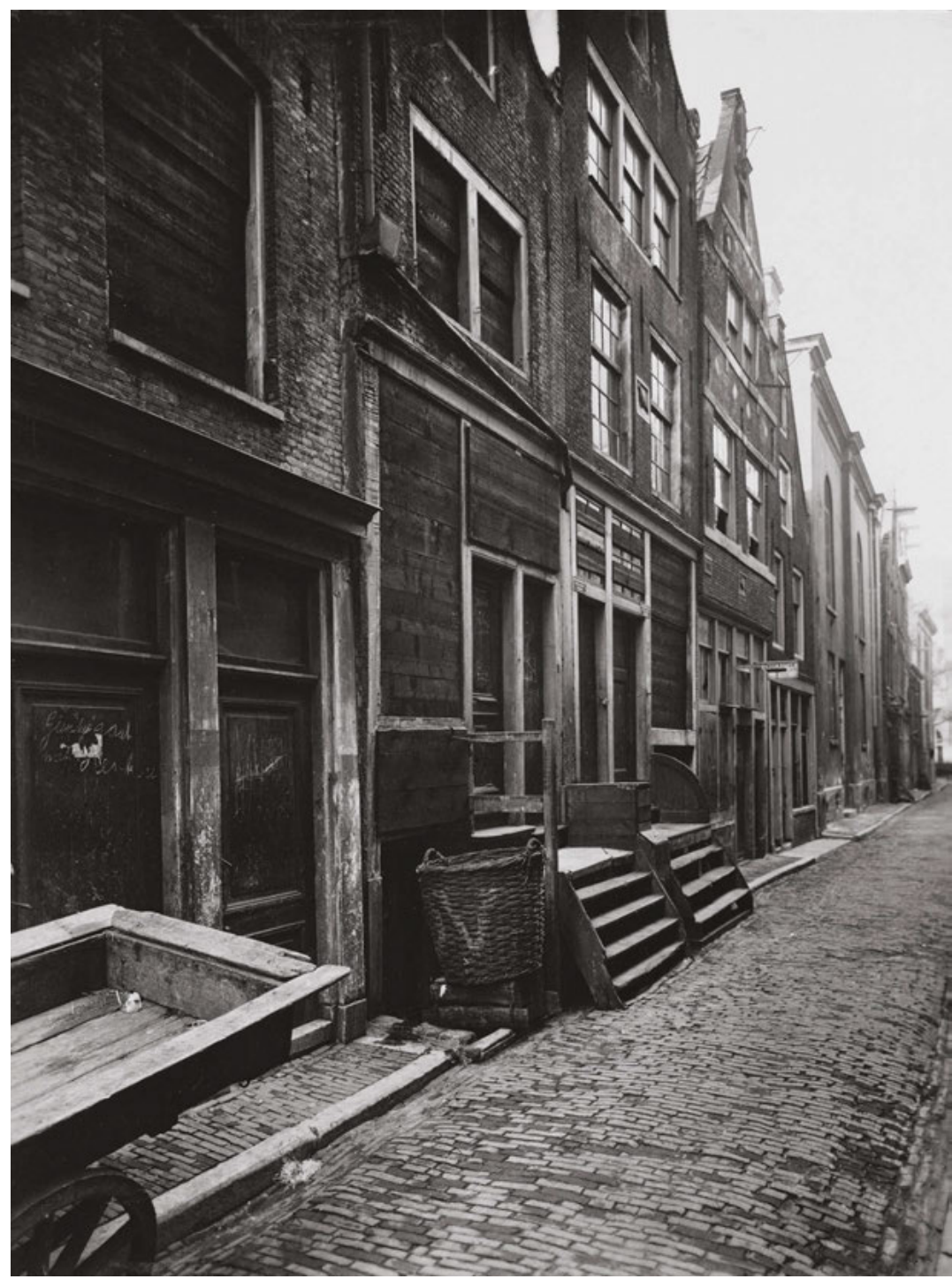

Slijkstraat gezien naar de Oudezijds Achterburgwal. Onbekende fotograaf. Bron: SAA. Beeldbank. Afbeeldingsbestand OSIM00002002413. 
Bij nader onderzoek blijkt verder dat de familie van het echtpaar Broekhuijsen niet altijd alle gewenste inlichtingen heeft verstrekt. Zo komt de boekhouder van Maatschappelijke Steun erachter dat Willemsen, een andere schoonzoon, een hoger inkomen heeft dan is opgegeven. Het komt tot een veroordeling door de kantonrechter. Willemsen moet hfl 2,00 steun per week gaan geven. Aanvankelijk doet hij dat, maar later blijft hij in gebreke.

In april 1930 wordt de woning aan de Oudezijds Achterburgwal onbewoonbaar verklaard en moeten de twee inmiddels behoorlijk oude mensen weer verhuizen. Wilhelm en Petronella kunnen vijf huizen verderop terecht aan de Oudezijds Achterburgwal 195 '.

In december 1932 wordt Wilhelm, inmiddels blind aan beide ogen, opgenomen in het Sint Bavo, een gesticht in Noordwijkerhout. Petronella zoekt hem daar regelmatig op. Hiervoor krijgt zij een reiskostenvergoeding van Maatschappelijke Steun. Ze blijft haar man bezoeken tot aan haar dood op 29 maart 1935, op 72-jarige leeftijd. Wilhelm houdt het als alleenstaande nog uit tot 13 juni 1938. Dan overlijdt hij in het gesticht. Hij heeft de hoge leeftijd van 86 jaar bereikt. Aan een geschiedenis van 52 jaar ondersteuning door de Amsterdamse gemeente komt daarmee een einde.

\subsection{CATHARINA MARIE WILLEMSE EN NICOLAAS CHRISTIAAN COR- NELISSE, BIJGENAAMD KLAASJE ZEVENSTER 1896-19384}

Het levensverhaal van Klaasje Zevenster is uitzonderlijk. In zijn contacten met armenzorg liggen list en bedrog voortdurend op de loer. Onbetrouwbaarheid op deze schaal ben ik in geen enkel ander dossier tegengekomen. Klaasje is steeds op zoek naar de mazen in de wet om in zijn levensonderhoud te voorzien. Hij is zeker geen zware crimineel, maar opereert duidelijk aan de zelfkant van de samenleving. We zien dat terug in zijn woongeschiedenis. Klaasje woont altijd in krakkemikkige panden, waar het niet altijd even hygiënisch is. Feitelijk weet de armenzorg zich geen raad met deze cliënt. Haar beleid zwalkt steeds tussen afwijzen en toewijzen. Toch kunnen we hier iets opmerkelijks in zien. De armenzorg oordeelt zonder aanzien des persoons. Elke nieuwe aanvraag wordt op haar eigen merites beoordeeld. Er vinden elke keer nieuwe afwegingen plaats, los van het voorafgaande. Hierin zien we de rationele bureaucratische handelwijze terug, die op zakelijke gronden tot beslissingen leidt. Morele overwegingen spelen geen rol, zodat het alcoholmisbruik van Klaasje er niet wezenlijk toe lijkt te doen. Wat de armbezoeker persoonlijk mag hebben gevonden van de gedragingen van Klaasje, weegt niet mee. De bureaucratisering van de armenzorg is ook zichtbaar in het recht van beroep waar Klaasje gebruik van maakt. Verzakelijking is verder te zien in de aard van de verstrekkingen. Uitkering in natura maakt plaats voor uitkering in geld. In dit geval zien we ook de toenemende specialisatie binnen de zorg. Naast de armenzorg hebben ook andere instanties bemoeienis met Klaasje Zevenster. De zorg voor Klaasje reikt tot aan het graf.

\footnotetext{
4 Het levensverhaal is gemaakt door mij aan de hand van SAA 5256. Doos 1437. Stamboeknummer 9905. De bijnaam verwijst vermoedelijk naar De lotgevallen van Klaasje Zevenster (1865), een roman van Jacob van Lennep. In de roman is Klaasje een meisje.
} 
Nicolaas Christiaan Cornelisse, alias Klaasje Zevenster, en Catharina Maria Willemse treden op 6 juni 1894 in Amsterdam in het huwelijk. Klaasje is geboren op 5 augustus 1867 in Amsterdam. Catharina is op 19 juli 1868 geboren, eveneens in Amsterdam. Op het moment van hun huwelijk zijn Klaasje en Catharina respectievelijk 26 en 25 jaar oud. Bijna twee jaar na het huwelijk wordt op 26 april 1896 dochter Maria geboren. Het jonge gezin woont dan op het adres Oude Braak 2'. Zij hebben een huur van hfl 1,10 per week. Klaasje werkt op dat moment als sjouwer en visventer, maar zijn inkomsten zijn gering. Hij vraagt kraambedeling aan, die wordt toegekend.

De Oude Braak. Klaasje woonde hier in 1896. In 1907 werden de woningen onbewoonbaar verklaard.

Afbeelding 8.2 Oude Braak september, 1907

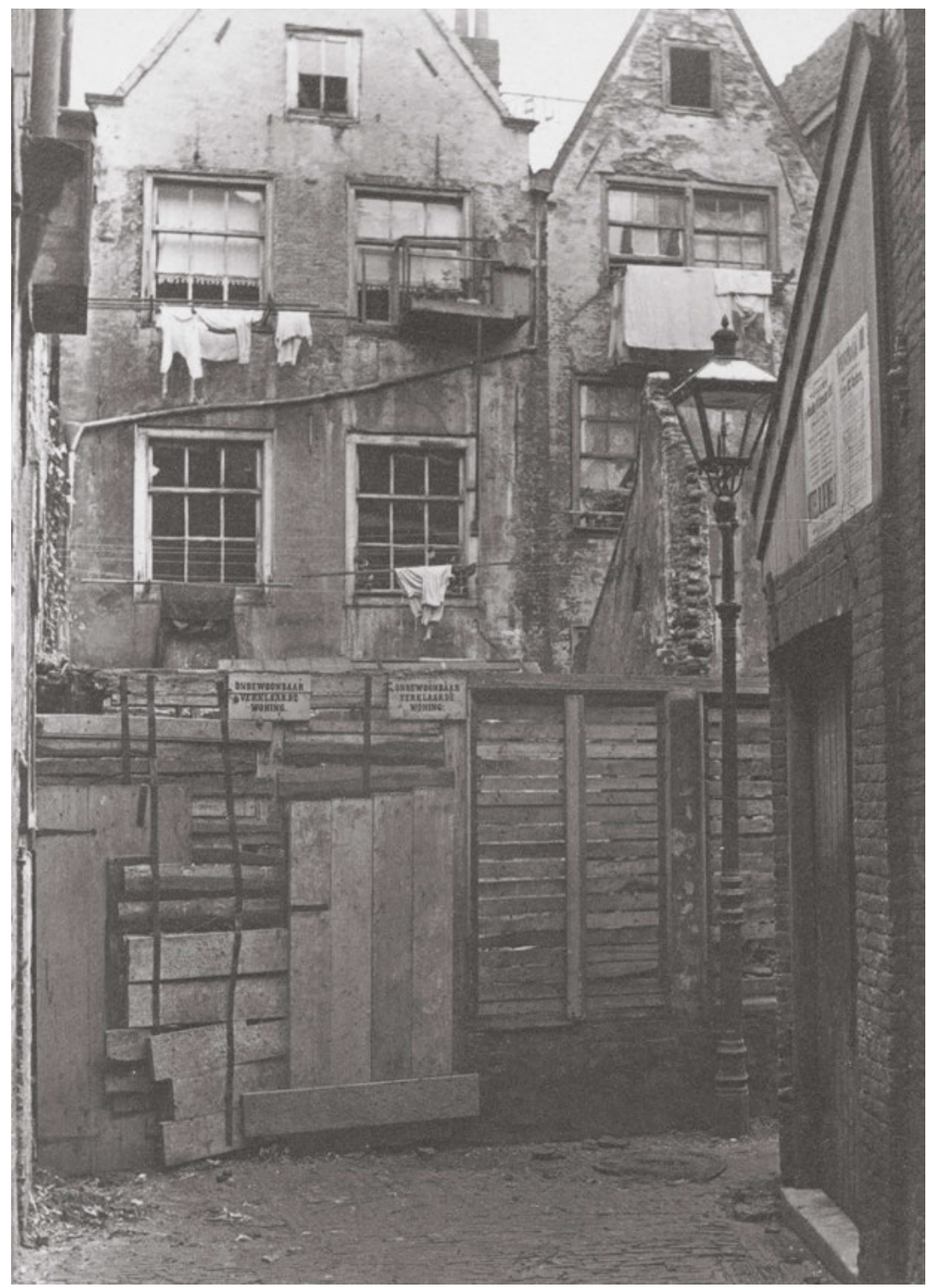

Foto door Photographie Ronkink.

Bron: SAA. Beeldbank Afbeeldingsbestand OSIM00001004145. 
Op 1 november 1900 wordt het gezin uitgebreid met een zoon. Ook voor dit kind krijgt Klaasje kraambedeling. Het gezin is inmiddels verhuisd naar de Oudezijds Armsteeg 25 hs. De huur bedraagt hier hfl 1,25. Klaasje heeft nu ongeregeld werk. Ook voor het derde kind, een tweede zoon, die op 4 februari 1902 wordt geboren, krijgt Klaasje kraambedeling. Hij is op dat moment visventer, meestal van restanten van de markt. In 1905 wordt een derde zoon geboren. In de winter van 1907/1908 woont het gezin Cornelisse inmiddels in de Kromme Elleboogsteeg, op nummer 6, waar de huur hfl 1,60 bedraagt. Dat is voor Klaasje te hoog. Hij vraagt en krijgt twee weken huur als steun. In augustus 1908 verhuist het gezin Klaasje naar Warmoesstraat 24'. De huur is er nog hoger, hfl 1,75. In eerste instantie krijgt Klaasje geen steun om de hogere huur te betalen, maar bij een tweede aanvraag, in de winter van 1908/1909, krijgt hij alsnog een bijdrage in de huur. Desondanks loopt de huurschuld op en krijgt hij een gerechtelijke huuropzegging. Verder wordt door de armbezoeker melding gemaakt van misbruik van sterke drank. Catharina is vaak dronken, Klaasje af en toe.

Kromme Elleboogsteeg. Klaasje woonde er in 1908. Dit is een ansichtkaart uit vermoedelijk het einde van de negentiende eeuw.

Afbeelding 8.3 Kromme Elleboogsteeg, circa 1900

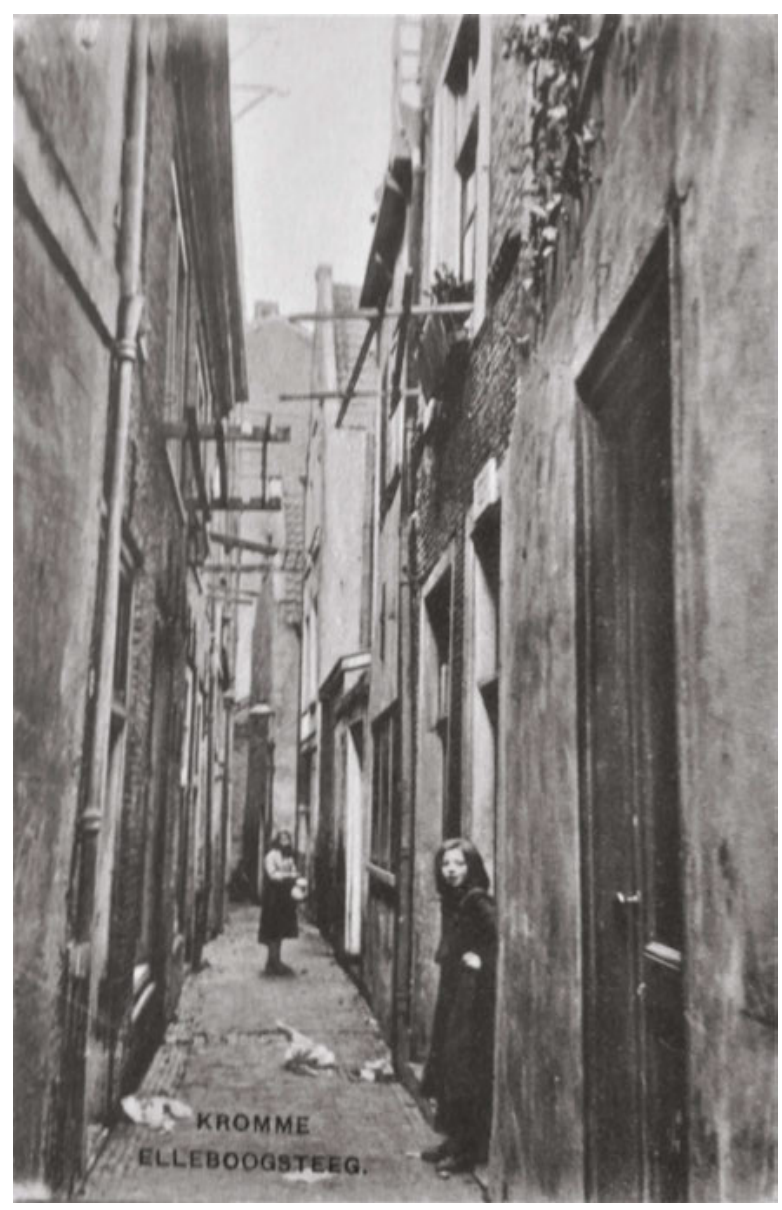

Ansichtkaart. Fotograaf onbekend.

Bron: Particulier bezit van de auteur. 
Het jaar daarop, in 1910, is het gezin verhuisd naar de Nieuwezijds Gasthuissteeg 1. De huur bedraagt hfl 1.60 per week. Klaasje vent met groente of vis; in de zomer rookt hij paling. Verder heeft hij ongeregeld werk. Hij is nog meer gaan drinken. De armbezoeker rept van een "ruim gebruik van sterken drank". Bij die gelegenheid wordt ook zijn bijnaam onthuld: "Hij staat bekend als Klaasje Zevenster". In het voorjaar van 1910 is er een nieuwe verhuizing, naar de Dirk van Hasseltssteeg 45, waar de huur hfl 1,10 is. Het echtpaar gebruikt nog steeds geregeld sterke drank. Catharina kan niet meer werken vanwege lichaamsgebreken. Het gezin staat ongunstig bekend, zo blijkt uit uitlatingen van buren.

In 1912 vraagt Klaasje om handelsgeld, maar hij trekt die aanvraag ook weer in. In 1913 dient Klaasje opnieuw een verzoek in om handelsgeld. De situatie van het gezin is verslechterd. Klaasje is venter, maar hij kan geen handelsvoorraad kopen. Wel heeft hij enige verdiensten als sjouwer in het abattoir. Catharina heeft iets aan haar been, waardoor het dagelijks moet worden verbonden door een zuster van de GGD. Het drankmisbruik heeft zodanige vormen aangenomen dat Klaasje erom gevangen heeft gezeten. In het voorjaar van 1913 is hij een paar weken nuchter door geldgebrek. Het verzoek om handelsgeld wordt gehonoreerd.

Tussen 1913 en 1916 zijn er geen berichten over het gezin. In de winter van 1916/1917 vraagt Klaasje opnieuw handelsgeld aan. Het gezin woont nog steeds in de Dirk van Hasseltssteeg. De huur is nu hfl 1,30. Klaasje vent nog steeds met waren: vis, groenten en turf. De jongste zoon is inmiddels overleden. Dochter Maria verblijft onder dubieuze omstandigheden in de Sint Olofssteeg. In 1916 heeft zij, op haar twintigste, een buitenechtelijk kind gekregen. Het kind woont bij de grootouders. Over Klaasje wordt door de armbezoeker opgemerkt dat hij "nogal eens drankmisbruik pleegt". Zijn aanvraag wordt toegekend.

In het voorjaar van 1919 vraagt Klaasje wederom handelsgeld aan. De aanvraag wordt afgewezen. Het gezin woont nu in de Zwarte Bijlsteeg, op nummer 18. De huur bedraagt hfl 1,30. In de zomer van 1919 vraagt Klaasje opnieuw om handelsgeld. De armbezoeker noteert dat hij "nu en dan" misbruik maakt van sterke drank, maar hij ziet ook een goede eigenschap: "Het is anders een man die niet lui is en al het mogelijk doet om de kost voor zijn gezin te verdienen." De aanvraag wordt toegekend. Ook in de jaren die volgen vraagt Klaasje regelmatig om handelsgeld. Deze aanvragen worden de ene keer toe- en de andere keer afgewezen. Het lijkt of de armenzorg niet goed raad weet met Klaasje en zijn grillige gedrag. Maar af en toe slaagt hij erin de armbezoeker te overtuigen. In 1922 blijkt de ongehuwde dochter met een bootwerker op een onbekend adres te wonen. Ze heeft inmiddels vier kinderen.

In de zomer van 1925 woont Klaasje in de Kattenburgerstraat, op nummer 181". Er is nog steeds sprake van drankmisbruik. De armbezoeker vermoedt dat er meer inkomsten zijn dan Klaasje beweert, op grond van uitspraken van de buren. Klaasje zou in het abattoir werken. De armbezoeker doet navraag. De informatie van de buren blijkt juist te zijn. De werkzaamheden in het abattoir zijn door Klaasje verzwegen. Deze keer wordt zijn aanvraag dan ook niet gehonoreerd.

In januari 1927 woont Klaasje in de Ridderstraat, op nummer 13 hs voor 
hfl. 2,40 per week. Het jaar daarop, in 1928, is de huur gedaald tot hfl. 2,00 per week.

In 1927 en 1928 dient Klaasje diverse verzoeken om handelsgeld in, die allemaal worden afgewezen. Bij toeval komt een armbezoeker hem op 29 november 1928 op straat tegen. Klaasje heeft een kar met savooiekool en minderwaardig fruit bij zich en dat strookt niet met zijn bewering dat hij geen handelswaar kan kopen. Deze frauduleuze handelwijze wordt in het dossier van Klaasje gerapporteerd.

Ridderstraat. 13 hs. Klaasje woonde hier in 1927 en 1928.

Afbeelding 8.4 De Ridderstraat, 1928

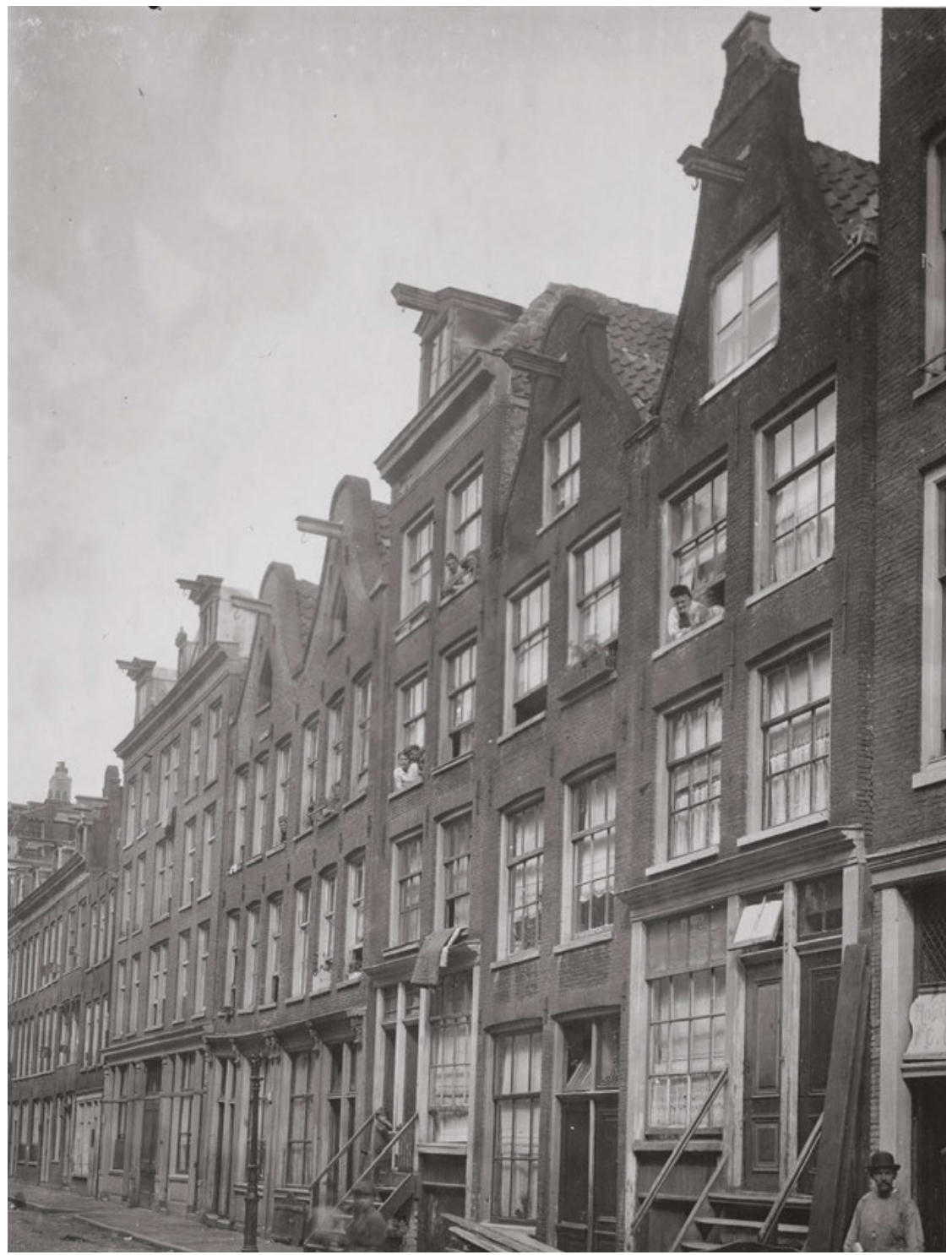

Gezicht naar de Geldersekade. Het huis met de opslagruimte op de begane grond is nummer 11. Rechts daarvan is een deel van de ingang van 13 hs. te zien. Het huisnummer 13 is aangebracht aan de deurpost. Fotograaf onbekend. Bron: SAA. Beeldbank. Afbeeldingsbestand OSIM00003000748. 
In het voorjaar van 1929 woont Klaasje aan de Oudezijds Achterburgwal 103. De huur bedraagt hfl 1,50 per week. Hij verzoekt twee maal opnieuw om handelsgeld. De ene aanvraag wordt toegekend, de andere wordt afgewezen. Dochter Maria is inmiddels getrouwd met J.R. v.d. Hilst en heeft nu negen kinderen. Het gezin woont in de Kleine Kattenburgerstraat 172.

Bij een bezoek naar aanleiding van weer een nieuw verzoek om handelsgeld, op 3 maart 1930, lijkt de armbezoeker wat minder geduld met het gezin te hebben. "Men werd reeds meermalen dezerzijds geholpen", noteert de armbezoeker. "Het is een vuil gezin, de man scharrelt in alles en nog wat. Bij bezoek was hij druk bezig met het zagen en hakken van hout op de zolder. Bovendien gaat de vrouw eenige dagen werken, zodat hulp dezerzijds niet direct noodzakelijk is. M.i. afwijzen voor onderstand". Zoals gebruikelijk wordt het advies van de armbezoeker opgevolgd en wordt de aanvraag afgewezen. Klaasje zit niet bij de pakken neer, en dient vier weken later, in april 1930, weer een nieuwe aanvraag in. Dit verzoek wordt wel ingewilligd, na overigens in eerste instantie te zijn afgewezen.

In mei 1930 volgt alweer een nieuw verzoek om handelsgeld. Het wordt afgewezen omdat Klaasje nog met handel langs de straat loopt. Klaasje gaat tegen de afwijzing in beroep bij de bezwaarschriftencommissie. Op 3 juli 1930 wordt Klaasje in het gelijk gesteld. Hij krijgt toch weer handelsgeld.

In augustus 1930 vraagt Klaasje andermaal om handelsgeld. De dienstdoende armbezoeker laat zich niet bij de neus nemen. "Hij is vischventer en mij is gebleken dat hij handelt onder de naam Klaasje Zevenster", noteert hij. "De vorige week is hij met een partij visch Noordholland ingetrokken, volgens zijn verklaring heeft (hij) het grootste gedeelte bij Alkmaar moeten vernietigen wegens bederf, hetgeen oncontroleerbaar en zeer onwaarschijnlijk is. De man is pas kort geleden geholpen en niet zeer betrouwbaar, m.i. afwijzen voor handelsgeld." En inderdaad wordt het verzoek van Klaasje deze keer afgewezen.

In september 1930 verhuist Klaasje naar de Elandstraat, nummer 183"'. De huur bedraagt hfl 1,50. Zijn aanvraag om handelsgeld wordt nu dadelijk ingewilligd. In 1931 krijgt Klaasje een bedstel voor twee personen en een tweepersoons wollen deken. Hij ontvangt ook weer handelsgeld. Dat gebeurt in 1930 en 1931 nog eens drie keer. De laatste keer noteert de armbezoeker: "nog eenmaal handelsgeld". Het volgende verzoek, gedaan in mei 1931, wordt inderdaad afgewezen. Klaasje wilde handelsgeld voor zijn vrouw om bloemen te gaan verkopen. Verzoeken in juni en juli worden eveneens afgewezen. Maar de aanhouder wint. De aanvraag van augustus 1931 wordt wel beloond. Een maand later wordt een verzoek om schoeisel en kleding voor Catharina afgewezen. De armbezoeker vermoedt dat er oneigenlijke motieven in het spel zijn: "Kortelings heeft zij zich bezeerd tijdens een val toen zij onder invloed was van sterken drank. Men (= buren) deelde mede dat bij verstrekking van kleeding, dit beleend zou worden teneinde daarvoor sterken drank te bemachtigen." Verzoeken om handelsgeld in oktober en december worden wel weer toegekend.

In januari 1932 wordt wederom om hulp gevraagd. Catharina is ziek. Zij staat onder behandeling van een gemeente-arts. Zij heeft geen inkomsten. Daarom wordt onderstand verstrekt. Dat gebeurt dan weer niet in februari 1932, hoewel Klaasje, volgens het rapport, geen kans ziet met handel in het 
gezinsonderhoud te voorzien en Catharina met 63 jaar te oud en te ziek is om te kunnen werken.

In maart 1932 wordt de huur van Elandstraat 183"I verhoogd naar hfl 1,75. Als Klaasje weer een hulpaanvraag indient, wordt bezien of de naaste familieleden niet kunnen steunen. Dat blijkt niet te kunnen. Dochter Maria, die op dat moment op de Kattenburgerkade 60 woont met tien kinderen, heeft al moeite genoeg om al die monden te voeden. Zoon Cornelisse woont op de Oostenburgervoorstraat 75 en ontvangt zelf steun. Klaasje wordt in het rapport van de armbezoeker getypeerd als "een handelaar in minderwaardige restanten vis". Verder wordt zijn drankgebruik onder de aandacht gebracht en de arbeidsongeschiktheid van Catharina. "Zijn vrouw is wegens ouderdom niet meer in staat uit werken te gaan". ${ }^{5}$ Via de orthopedische kliniek van de GGD krijgt zij een paar sloffen.

In april 1932 doet Klaasje opnieuw een aanvraag. De armbezoeker die langskomt, heeft een kritischer kijk op het echtpaar dan zijn collega: "Aanvrager is venter van beroep en scharrelt den laatsten tijd met groenten. Tot driemaal toe werd bij bezoek de deur gesloten gevonden. Er werd verondersteld dat de vrouw weer uit werken gaat. Ten kantore ontboden, ontkende de man aanvankelijk, doch hij gaf later schoorvoetend toe dat zijn vrouw 'wel een paar uurtjes hier en daar schoonmaakt'. Waar men kort geleden aan handelsgeld is geholpen en de man nog wel eens misbruik maakt van sterken drank, komt het mij nu niet gewenscht voor aan zijn verzoek te voldoen". Het verzoek wordt inderdaad afgewezen.

Ook het verzoek van mei 1932 wordt afgewezen. De armbezoeker noteert: "Verzoek om steun omdat de man wegens leeftijd en rheumatische aandoeningen niet goed kan meekomen. Tewerkstelling van de vrouw is niet waarschijnlijk: zij ziet er zeer onoogelijk uit en zal, mede door haar leeftijd, via de arbeidsbeurs zeker niet slagen." De motivering om af te wijzen is naar de mening van deze onderzoeker niet erg sterk.

Een paar maanden later, in september 1932, doet Klaasje maar weer eens een verzoek om handelsgeld. Het verzoek wordt afgewezen. De armbezoeker is enkele malen aan de deur geweest zonder iemand te ontmoeten. "Bij de buren heb ik geïnformeerd en blijkt mij dat de man nog dagelijks met handel uitgaat", zo verklaart hij.

In november 1932 tekent een armbezoeker uit de mond van Klaasje op dat hij niets verdient en "geen bezit aan geld" heeft, "noch te beschikken over een spaarbankboekje." Een maand later, in december 1932, merkt een armbezoeker op dat Klaasje "is gezien met een kar met roode kooltjes, waarmee hij naar de Overkant v/h IJ trok." Zijn conclusie: "Geen recht op uitkering."

In februari 1933 krijgt het gezin toch weer steun, maar het moet wel "in controle" worden opgenomen. Dat betekent dat het toezicht wordt verscherpt. In april 1933 krijgt Catharina schoenen via de GGD, maar een aanvraag in juni 1933 voor een herenkostuum en een japon wordt niet gehonoreerd.

Een verzoek om handelsgeld gedaan in juli 1933 wordt afgewezen op grond van leeftijd en drankmisbruik, een verzoek om steun in augustus 1933 krijgt wel weer gehoor. Inspectie van de woning in november 1933 brengt aan het licht dat de boel flink vervuild is en dat er iets aan gedaan moet wor-
5 Onder uit werken gaan wordt het verrichten van huishoudelijk werk bij derden verstaan. 
den. "Volgens de woningdienst was het geheel aangetast; alleen de matrassen kunnen nog gebruikt worden. Men krijgt geld voor beddengoed."

In november 1933 krijgt Catharina geld voor een japon, terwijl in februari 1934 Klaasje geld krijgt voor een broek en Catharina voor pantoffels. In maart 1934 wordt opgemerkt dat Klaasje en Catharina nog steeds "misbruik van sterken drank maken". Dat weerhoudt de armenzorg er niet van de hulp voort te zetten.

In april 1934 krijgt het stel een molton hemd, een molton broek, een hemd, een flanel en een directoire. ${ }^{6}$ In juni komen daar nog schoenen bij. In oktober 1934 wordt besloten de steun voort te zetten, maar kort daarop, op 20 oktober 1934, rapporteert een armbezoeker: "Man gezien met het uitventen van harde bokking. ${ }^{7}$ Hij ontkende zelf te venten, maar hij zou oppassen voor een zieke, onbekende. Een en ander is niet aan te nemen. Steun wordt niet uitbetaald". Het negatieve advies wordt opgevolgd.

In november 1934 krijgen Klaasje en Catharina ondergoed. In januari 1935 wordt de uitkering in geld voortgezet. De armbezoeker meldt: "Klachten over dit gezin worden niet vernomen". In dezelfde maand wordt een verzoek om beddengoed afgewezen. "Men vraagt bed en deken aan. Als motief wordt opgegeven dat de woning weer ontsmet moet worden en dat de ontsmettingsdienst bed en deken zouden houden om te vernietigen. Volgens informatie onjuist. De ontsmettingsdienst geeft de ontsmette voorwerpen alleen niet terug als de belanghebbende er geen prijs op stelt."

In 1935 worden enkele aanvragen ingediend die allemaal worden gehonoreerd. Klaasje en Catharina krijgen een herenkostuum en een japon, omdat "hun kleding (...) er verwaarloost uitziet". Klaasje krijgt ook een paar schoenen. "De tegenwoordige schoenen zijn geheel versleten." Het echtpaar wordt ook voorzien van ondergoed en dekens.

In 1936 worden schoenen, pantoffels en ondergoed verstrekt. Klaasje ontvangt van de destijds bekende firma Hertenburger een kostuum ter waarde van hfl 12,00. Het gezin is inmiddels overgedragen aan het Medisch Consultatie Bureau vanwege het weinig hygiënische huishouden. De uitkering in geld en de verstrekking van kleding worden voortgezet. In september 1936 wordt een huurverlaging bedongen via de Gemeentelijke Woningdienst.

In augustus 1938 wordt Klaasje wegens chronische ziekte in gezinsverpleging opgenomen. Hij wordt kostganger in een ander gezin. De armenzorg betaalt hiervoor. Klaasje overlijdt op 17 september 1938, op 71-jarige leeftijd. Omdat hij niet aangesloten is bij een begrafenisfonds is er geen geld voor een uitvaart. De armenzorg verstrekt een uitkering voor de begrafenis. Het gezin van Klaasje is 42 jaar gesteund door de armenzorg. Ondanks het rommelige leven dat zij hebben geleid, zijn Klaasje en Catharina 44 jaar lang bij elkaar gebleven. De steun aan de weduwe wordt voortgezet onder het dossier met als stamboeknummer 178716. Het dossier van Klaasje wordt gesloten.

flanellen stof.

7 Harde bokking is gerook te en gezouten haring. Tot aan de jaren '60 gold dat als volksvoedsel dat aan viskramen werd verkocht. 
In dit levensverhaal komen niet alleen de wisselvalligheden van het lot naar voren, maar ook het belang van familieleden op wie in geval van nood een beroep kan worden gedaan. We zien hier opnieuw de neiging van alleenstaande ouders om te hertrouwen of te gaan samenwonen. Daarbij spelen economische overwegingen een grote rol. In dit levensverhaal komen we, net als in de vorige verhalen, veel verhuizingen tegen. Het is een algemeen patroon dat arme mensen zelden lang op hetzelfde adres blijven wonen. Erwordt vaak verhuisd omdat de huur elders lager is. In de regel is het nieuwe huurhuis niet ver weg. De gezinnen blijven graag in hun eigen buurt, zodat hun sociale netwerk in tact blijft: een belangrijke overlevingsstrategie. Het gaat niet alleen om burenhulp, maar ook om het verwerven van (losse) arbeid. De buurt is ook belangrijk vanwege de mogelijkheid tot 'poffen' bij winkeliers. Winkeliers en klanten zijn dan wederzijds van elkaar afhankelijk.

Opmerkelijk is ook hoe lang het gezin in dit levensverhaal bedeeld werd door de gemeentelijke armenzorg: 49 jaar. Toch is dit geen zeldzaamheid. In het jaar 1898 trof ik 62 partijen aan die tot 1936 zijn gesteund. Een flink aantal van hen is ook nog na 1936 geholpen. Wie eenmaal arm was, had grote moeite zich aan die toestand te ontworstelen. De absolute recordhouder van het gezelschap, onder stamboeknummer 11714, is iemand die is gesteund van 10 december 1898 tot 25 januari 1965. Deze 66 jaren zijn door de armenzorg geboekstaafd in meer dan 200 dossiers in drie dikke banden.

De geschiedenis van het gezin Kooseman begint op 10 oktober 1888, als de vijfentwintigjarige Cornelia Klipp en de eveneens vijfentwintigjarige Jacob Kooseman in het huwelijk treden. ${ }^{9}$ Hun zoon, Wouter, is dan bijna tweeënhalf jaar. ${ }^{10}$ Een paar maanden na het huwelijk wordt er een tweede kind geboren, dochter Elisabeth Wijnanda. Om onduidelijke redenen verlaat Jacob al snel na deze geboorte zijn kersverse vrouw en kinderen. Het koppel gaat dus uit elkaar.

In 1890 komt Cornelia, dan 27 jaar, voor het eerst in aanraking met de Amsterdamse armenzorg. Zij woont op dat moment samen in de Lindenstraat 88, met een sjouwer, Harm Krediet. Vanaf haar drieëndertigste jaar, in 1896, is Cornelia op de armenzorg aangewezen. Zij heeft dan net een tweeling gekregen, Johannes Harm en Cornelis Wijnand, en krijgt kraambedeling. In datzelfde jaar overlijdt Harm Krediet, haar huisgenoot en de vader van de tweeling. Vanaf dat moment moet Cornelia in haar eentje voor vier kinderen zorgen en de huur opbrengen. De rest van haar leven zal zij afhankelijk blijven van de steun die de gemeentelijke armenzorg haar verstrekt. Voor kerkelijke armenzorg komt de Evangelisch-Lutherse Cornelia niet in aanmerking.
8 De gegevens zijn ontleend aan het onderzoeksverslag van Jordy Heijmans en Thomas Cagli op basis van SAA 5256. Doos 1307. Stamboeknummers $5571 / 5575$.

9 Jacob werd op 22 februari 1863 geboren. Cornelia werd op 20 maart 1863 geboren. Bron: Stadsarchief Amsterdam Gezinskaart Kooseman, J. - 22-02-1863 - 5422-0803-4410 (link: https://archief/indexen/ gezinskaarten_1893-1939/ zoek/query.nl.pl?i1=1\&a1= Koseman\&af1 $1=1 \& x=3 \& z=b$ $\& s=16 \# 5422-0803-4410$ ) 10 Wouter is wel erkend. Hij zal op 8 januari 1913 in het huwelijk treden met Jannetje van der Steen. Bron: Pondes (link: http://www. pondes.nl/detail/i_d_ENG. php?inum=11711911)) 
Lindenstraat. Het gezin Kooseman woonde in 1888 op nummer 88.

Afbeelding 8.5 Lindenstraat, 1920

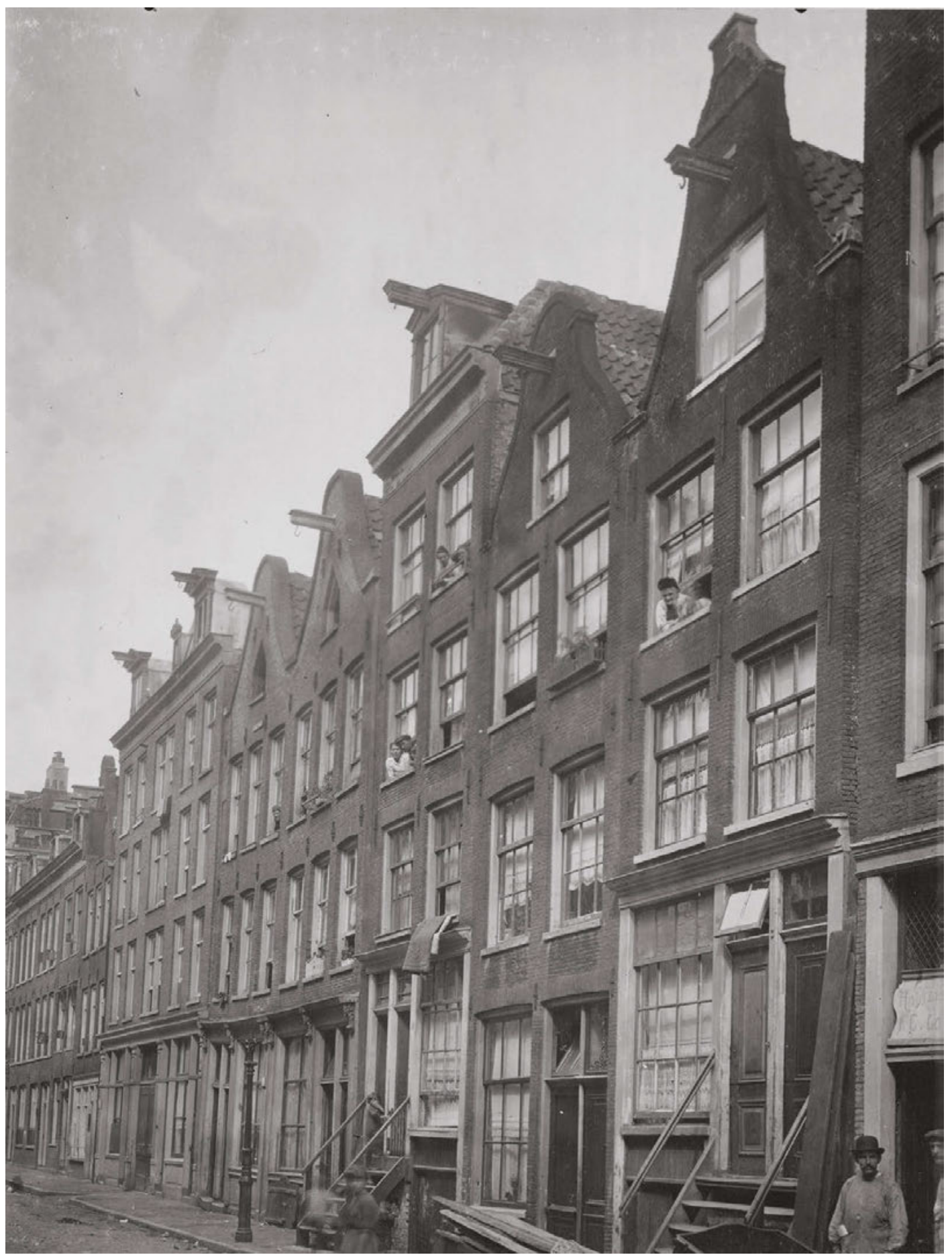

Lindenstraat 56-60. Gezien in westelijke richting vanuit de Tweede Lindendwarsstraat. Fotograaf onbekend. Bron: SAA. Beeldbank. Afbeeldingsbestand OSIM00003003764. 
Jacob Kooseman krijgt in de jaren negentig ook voor het eerst te maken met de armenzorg van Amsterdam. Hij woont aan het eind van de negentiende eeuw aan de Elandsgracht, op nummer 96.

Elandsgracht. In 1896 woonde Jacob Kooseman op no. 96.

Afbeelding 8.6 Elandsgracht, maart 1923

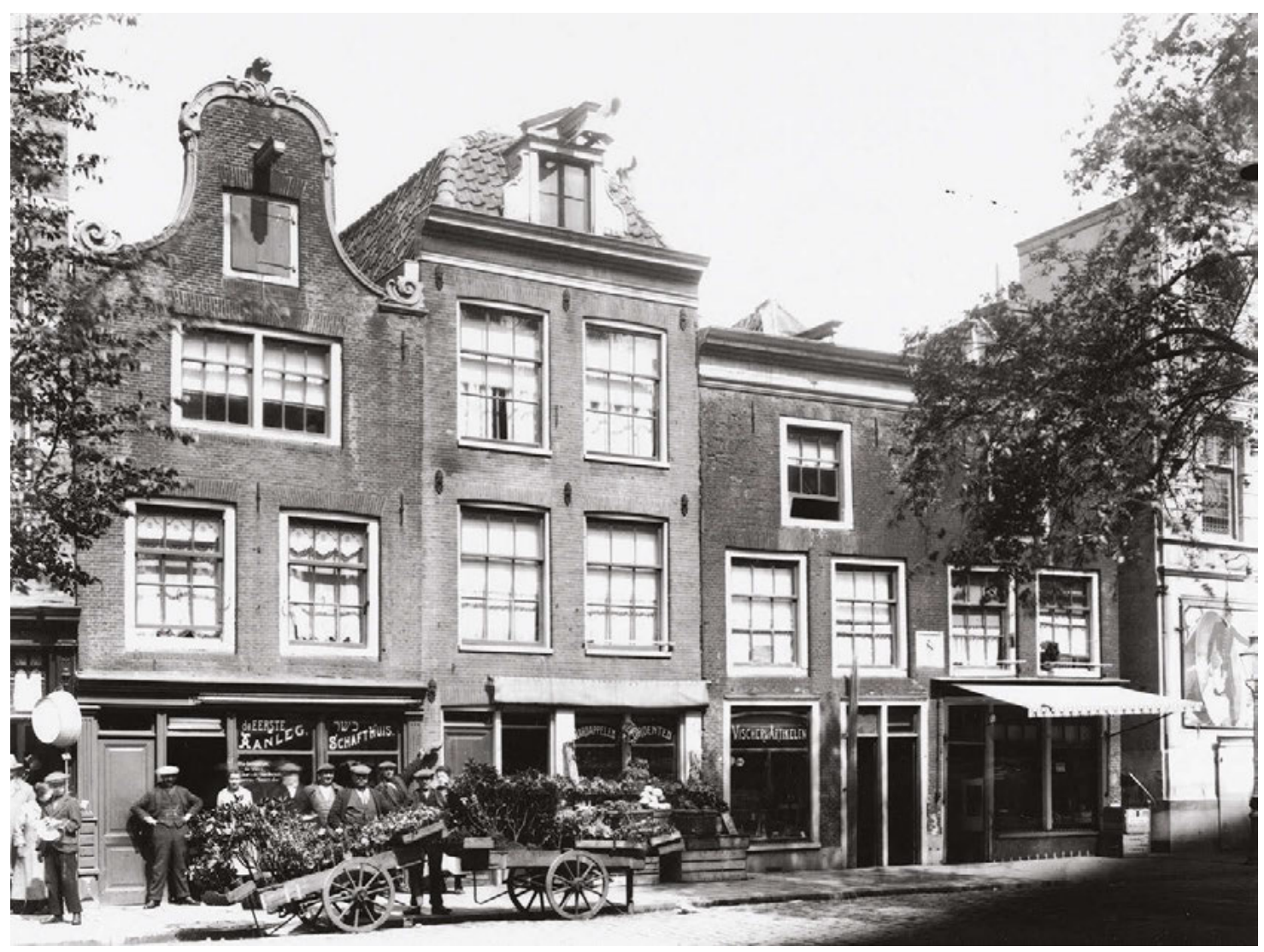

Tussen 94 en 96 is de ingang van de Hartshoorngang. Nummer 96 was volgens het oude systeem van huisnummering nummer 100. Dus de deur naast de winkel van Visscherijartikelen (op de winkelruit ontbreekt abusievelijk een s) geeft volgens het oude systeem toegang tot nummer 96. Fotograaf onbekend.

Bron: SAA. Beeeldbank. Afbeeldingsbestand OSIM00003003483.

Nadat hij Cornelia heeft verlaten, is hij ingetrokken bij zijn bejaarde moeder, zo blijkt uit de dossiers van de armenzorg. Jacob is verslaafd aan sterke drank. Volgens een medisch attest lijdt hij daardoor aan een ernstige nierziekte. Zijn alcoholisme heeft ook geleid tot enkele jaren gevangenisstraf, al wordt niet duidelijk wat hij precies op zijn kerfstok had. Als zijn gevangenisstraf erop zit, werkt Jacob een tijdlang als vaargezel en sjouwer. Maar door de nierziekte kan hij niet langer in zijn onderhoud voorzien. Hij doet een beroep op de Amsterdamse armenzorg. De Nederduits Hervormde Jacob kan, net zo min als Cornelia, een beroep doen op de kerkelijke armenzorg. Omdat zijn moeder niet wil worden opgenomen in het Nederduits Hervormd Diaconessenhuis, ontvangt ook zij geen kerkelijke bedeling. Met bedelen tracht zij het hoofd boven water te houden. Omdat de toestand van 
Jacob nauwelijks verbetert, blijft de armenzorg hem steunen. Vanaf 1907 is de gezondheid van Jacobs moeder zozeer achteruitgegaan dat zij niet meer uit bedelen kan. Ook Jacob gaat achteruit. In 1909 wordt zijn nieraandoening nog erger. Hij is dikwijls bedlegerig. Op 4 januari 1910 komt Jacob te overlijden. Zijn moeder kan zonder hulp van de buren amper rondkomen. Zij geven haar soms kleding en voedsel.

Het leven van Cornelia gaat intussen gewoon door. Zij en haar vier kinderen zijn aangewezen op de armenzorg. De tweeling wordt ernstig ziek. Volgens een doktersverklaring moeten de kinderen worden behandeld in het Diaconessenhuis. Als ze eindelijk worden opgenomen, blijkt het voor een van de twee kinderen te laat te zijn, zodat het komt te overlijden. Cornelia probeert in die tijd als werkster nog iets te verdienen, maar omdat zij ook voor de kinderen moet zorgen, is zij maar gedeeltelijk inzetbaar. Daarom is het voor haar moeilijk om vaste werkhuizen te vinden. Bedeling door de gemeentelijke armenzorg blijft steeds noodzakelijk.

Als haar kinderen wat ouder zijn, gaan ze uit werken. Haar zoon Wouter wordt loopjongen. Op zijn veertiende werkt Wouter als leerling horlogemaker in de Leliestraat, op nummer 7. De verdiensten zijn karig, zodat de gemeentelijke armenzorg moet bijspringen.

Lange tijd zijn er geen bijzonderheden te melden. Cornelia blijft arm, aangezien ze moeilijk werk kan krijgen. In 1926, als zij 63 jaar is, gaat zij werken bij het badhuis aan het Karthuizer Kerkhof, maar al na korte tijd wordt ze ontslagen. In 1935 vraagt zij om een verhoging van het steunbedrag, maar dat wordt geweigerd. De Evangelisch-Lutherse Diaconie haalt haar over zich in te schrijven voor opname in een verzorgingstehuis, omdat zij amper meer in haar eigen onderhoud kan voorzien. Bovendien heeft ze er de leeftijd voor. In 1937 wordt ze, op 74-jarige leeftijd, opgenomen in een tehuis aan het Valeriusplein. Cornelia woont een paar jaar in het tehuis, totdat ze in 1939 toestemming krijgt naar de Jordaan te vertrekken. Hoe het daarna met Cornelia verder is gegaan, is onbekend.

\subsection{HET GEZIN HOUBEN 1892-189911}

In dit verhaal komt het probleem van de dubbele bedeling voor. Tot 1896 was dubbele bedeling niet toegestaan. Wie bedeeld werd door een kerkgenootschap, ontving geen steun van de gemeentelijke armenzorg. In haar toewijzingsbeleid hanteerde de gemeentelijke armenzorg aanvankelijk het morele principe dat wie misbruik maakte van sterke drank geen hulp kreeg. In het verhaal zien we ook terug dat vaak op naaste familie werd gesteund. Meestal waren deze gezinnen niet bij machte deze ondersteuning lang vol te houden. Opvallend ten slotte is de hereniging van de aanvankelijk in onmin geraakte echtelieden. Uit de bronnen wordt niet duidelijk of de relatie werkelijk is verbeterd, of dat de hereniging een economische achtergrond had. Dit laatste valt niet te bewijzen, maar er zijn wel vermoedens dat het gezin bepaalde overlevingsstrategieën hanteerde.

11 De gegevens zijn ontleend aan het onderzoeksverslag van Esma Zhiri.
Er waren een aantal opties voor een arm gezin. Het gezin probeerde van twee walletjes te eten door zowel steun te zoeken bij de kerk als 
bij de gemeente. We zien dat zowel de kerkelijke als de gemeentelijke instanties controles inbouwden om zicht te hebben op de doeltreffendheid van de ondersteuning. Een derde overlevingsstrategie bestond erin een beroep te doen op de familie. Een vierde overlevingsstrategie was een hereniging met de eerdere partner, of het aangaan van een nieuwe relatie, al dan niet geëcht.

Dit verhaal gaat over een koppel dat in 1892 voor het eerst aanklopt bij de armenzorg. Het gaat om Jacques Louis François Houben en zijn vrouw Pepke de Vries.

Jacques wordt geboren op 12 januari 1838 in Amsterdam, Pepke op 12 februari 1837 in Leeuwarden. Voor beiden is het een tweede huwelijk. Het echtpaar woont in de Lindenstraat, nummer 32"'. Jacques is lid van de kerkelijke gemeente Waalsche Hervormde Gemeente, terwijl Pepke Nederlands Hervormd is.

Lindenstraat 32. In 1892 woonden Jacques en Pepke op drie hoog. Bouwtekening uit 1879 vanwege een verbouwing van het pand.

Afbeelding 8.7 Lindenstraat, 1879

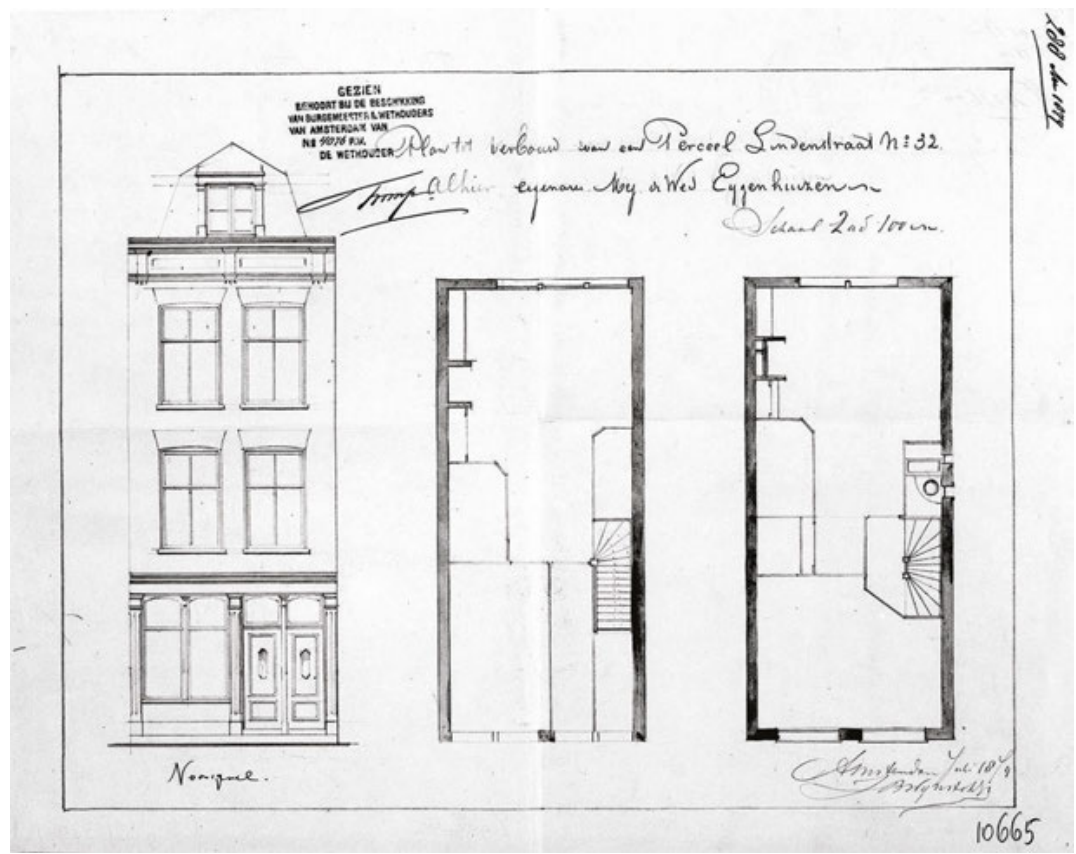

Bouwtekening. Bron: SAA. Beeldbank. Afbeeldingsbestand 5221BT910665.

Jacques en Pepke drijven een kleine handel in brandstoffen, waarbij Jacques als kruier fungeert. Het paar raakt verslaafd aan alcohol. Desondanks wordt het in 1894 gesteund met winterbedeling door de Waalsche Hervormde gemeente. ${ }^{12}$ Het drankmisbruik neemt zodanige vormen aan dat het winkeltje moet worden opgedoekt. Jacques verkoopt de inboedel van de Lindenstraat en verhuist naar de Czaar Peterstraat 135. In hetzelfde jaar verlaat Jacques zijn vrouw. Haar alcoholverslaving is de voornaamste reden. Jacques belandt uiteindelijk in het armenhuis.
12 De Waalsche Hervomde Gemeente stuurde aan de gemeentelijke armenzorg onderstaande brief, dd. 19 november 1894 over de aanvraag bij de Waalsche Hervormde gemeente voor bedeling.

Mijne Heren,

Door deze regelen heb ik de eer u mede te delen, dat J.L.F Houben en zijne vrouw deze winter de bedeling ontvangen vanwege de Waalsche gemeente, bestaande in kleederen, turf, aardappelen, grutten en brood. Ook de volgende jaren zullen zij deze bedeeling blijven ontvangen wanneer hun omstandigheden niet veranderen. Zij worden niet geregeld met geld ondersteund doch ontvangen van tijd tot tijd losse giften.

Hoogachtend verblijf ik, Uwe dienaar. J.R Guipen. Waalsche Gemeente. 
Pepke staat er nu alleen voor en kan niet in haar levensonderhoud voorzien. Zij komt niet in aanmerking voor kerkelijke bedeling. Zij is geen lidmaat, omdat zij geen belijdenis heeft gedaan en woont bovendien te kort in Amsterdam om een beroep op kerkelijke ondersteuning te kunnen doen. Zij gaat daarom inwonen bij haar dochter. Er is een nauwe familieband. Pepke's dochter is getrouwd met de zoon van Houben uit diens eerste huwelijk, dus met haar stiefbroer. Deze man, de stiefzoon van Pepke, werkt als tafelknecht, waarmee hij hfl 10 per week verdient. In de jaren '90 van de negentiende eeuw is dat een redelijk inkomen. Het echtpaar heeft drie kinderen in de leeftijd tussen vier en tien jaar.

Omdat Pepke zelf geen inkomen heeft en niets van waarde bezit, vraagt zij om ondersteuning bij de gemeentelijke armenzorg. De gemeentelijke armbezoeker stelt vast dat Pepke arm is "en totaal ten lasten voor haar dochter". De gemeentelijke armenzorg bedeelt haar, als alleenstaande vrouw, met turf voor het stookseizoen en één brood per week.

Lindenstraat 32. In 1892 woonden Jacques en Pepke op drie hoog.

Afbeelding 8.8 Lindenstraat, september 1930

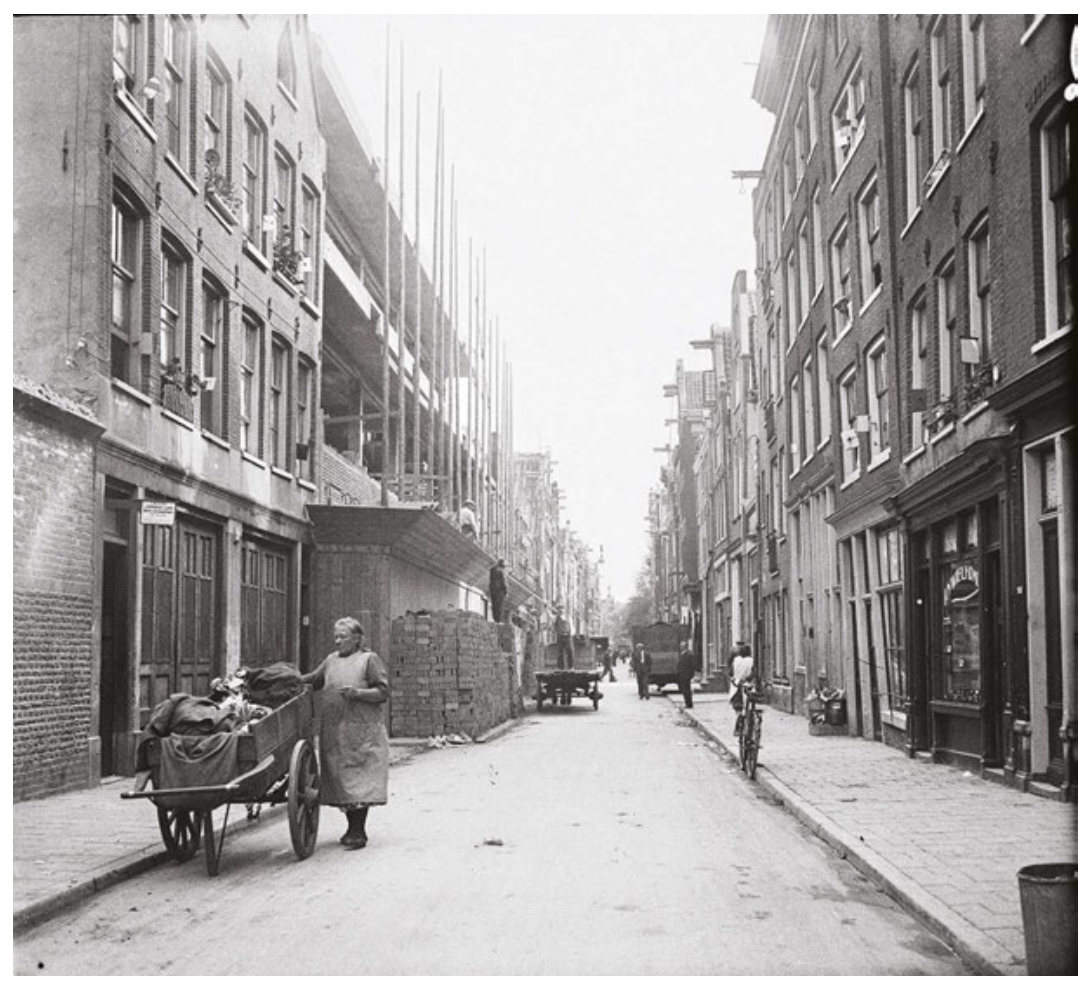

Lindenstraat 2-72 gezien naar de Noordermarkt. Fotograaf Nico Swaager (1910-1983). Bron: SAA. Beeldbank. Afbeeldingsbestand 5293FO000278.

Pepke vraagt ook winterhulp aan voor het seizoen 1895/96. Bij navraag door de armbezoeker geven de buren gunstige inlichtingen over de stiefzoon bij wie ze inwoont. De stiefzoon onderbouwt de aanvraag van zijn schoonmoeder met de verklaring dat hij haar bezwaarlijk nog langer kan verzorgen. De aanvraag van Pepke wordt afgewezen. Volgens het rapport 
van de armbezoeker is zij geen verlaten vrouw. "Zij maakt misbruik van steun, en drank en wordt volgens bewijs door de Waalsche gemeente bedeeld."

Voor het seizoen 1896/97 verzoekt Pepke andermaal om winterhulp bij de gemeentelijke armenzorg. Zij is inmiddels weer bij Jacques gaan wonen, met wie ze officieel nog steeds getrouwd is. Door de gemeentelijke armenzorg wordt navraag gedaan over Jacques bij de Waalsche Hervormde Kerk. ${ }^{13}$

Jacques verhuist naar Blankenstraat 48. Pepke krijgt geen steun van de gemeentelijke armenzorg. Het verzoek om winterbedeling 1897/98 wordt eveneens afgewezen. Haar verleden speelt een ongunstige rol bij de beoordeling. Ook de winterbedeling die zij aanvraagt voor 1898/1899 wordt niet toegekend.

In het archief van de gemeentelijke armenzorg zijn geen latere aanvragen aanwezig. Hoe de levensgeschiedenis van Jacques en Pepke eindigt, is niet bekend.

\subsection{HET GEZIN GROENEVELT 1892- 1933/1943 ${ }^{14}$}

In dit levensverhaal worden de veranderingen in de zorgarrangementen zichtbaar. Was armenzorg eerst de enige sociale voorziening, in de loop van de twintigste eeuw komen er meer gespecialiseerde zorgarrangementen. In dit geval gaat het om het Steuncomité voor werklozen. Verder zien we oudedagsvoorzieningen opkomen. Het ouderdomspensioen van staatswege is ingesteld, terwijl ook werkgevers een pensioenstelsel invoeren. In dit levensverhaal komt het verhaalrecht naar voren. Familieleden met enige welstand waren verplicht arm geworden familieleden te ondersteunen. De armenzorg kon dit via de kantonrechter afdwingen. In het onderstaande geval, en dat gebeurde wel vaker, viel er met het verhaalrecht geen succes te behalen: steun van de familie bleef uit.

Op 14 mei 1884 trouwen Jan Hendrik Groenevelt en Elisabeth de Haas. Jan Hendrik, die in Amsterdam is geboren op 13 februari 1856, is dan 28 jaar en Elisabeth 26. Zij is op 23 april 1858 geboren. Jan Hendrik is los sjouwer van beroep, maar komt in het najaar van 1892, ruim acht jaar na de huwelijksvoltrekking, zonder werk te zitten. Het gezin, dat dan drie kinderen telt, van twee, vier en zes jaar, woont in de Westerstraat 69"I. De huur bedraagt hfl 1,50 per week. Elisabeth werkt als wasvrouw. Het gezin doet een beroep op armenzorg en krijgt winterbedeling: turf voor het stookseizoen en brood.

In 1893 werkt Jan Hendrik als sjouwer in het entrepotdok, maar als de winter er weer aankomt, zit hij opnieuw zonder werk. Ook in de winter van 1893/1894 krijgt het gezin winterhulp. In het najaar van 1894 wordt voor de derde keer winterbedeling verleend, omdat Jan Hendrik dan wederom geen werk heeft als sjouwer. Het gezin is in de tussentijd verhuisd naar Westerstraat 82 hs. Hier bedraagt de huur eveneens hfl 1,50 per week.

Daarna gaat het met het gezin lange tijd goed, want pas in 1917, 23 jaar later, verzoekt Jan Hendrik weer om hulp, omdat hij geen werk meer heeft. Als beroep staat nu veemarbeider vermeld, wat niet veel verschilt van
13 Het antwoord van de Waalsche Hervormde Kerk aan de gemeentelijke armenzorg luidde:

"Ingevolge uw verlangen laat ik hier volgen de bijzonderheden betreffende het gezin JLF Houben wonende te Blankenstraat 48 hetwelk door u werd bezocht. De man behoort tot de Waalsche gemeente en wordt als zodanig ondersteund met: 1 losse giften in 13 termijnen bedragend 15 gulden; 2 kledingstukken in 1893 bedragend 19 gulden. De vrouw behoort tot de Nederlandse Hervormde Gemeente, doch is in die gemeente met voor ondersteuning vatbaar, daar zij door haar huwelijk met een lid van de Waalsche gemeente, voor ondersteuning door Waalsche gemeenten in aanmerking kan komen. Daar Houben en zijne vrouw voor lange tijd in disharmonie leefden, zodat de man zelfs een tijdlang afzonderlijk en sedert kort weder bij zijne vrouw inwoont, heb ik de vrouw persoonlijk nog geen ondersteuning gegeven, doch wil daarmee wachten totdat het mij gebleken is dat de verzoening duurzaam is. In dit geval zoude ik misschien het volgend jaar bereid kunnen zijn ook voor haar bij de Waalsche bedeeling in kleederen en misschien ook in eetwaren en brandstoffen aan te vragen, doch dit kan ik eerst het volgend jaar beslissen. Het spreekt echter vanzelf, dat de ondersteuning in giften, door mij aan de man verleend niet zijn voor deze in privé, doch in zijn rol als hoofd des gezins. En nu zij weder samenwonen ook de vrouw natuurlijk daarvan het voordeel ondervindt.

Hoogachtend, Waalsche gemeente Kantoor Keizersgracht 410" 
zijn sjouwerswerk bij het entrepotdok. Het gezin woont inmiddels aan de Houtmankade 6"'. De huur bedraagt hfl 2,20 per week. Margaretha van 21 woont nog thuis. Omdat zij lijdt aan tbc kan zij niet werken en dus ook niets inbrengen. Jan Hendrik wordt geholpen door het Steuncomité. ${ }^{15}$ Het gezin vraagt om versterkende middelen voor de zieke dochter. Het verzoek wordt ingewilligd. Margaretha krijgt een liter melk per dag.

Westerstraat 84 huis. Het gezin Groenevelt woonde hier in 1894

Afbeelding 8.9 Westerstraat, juli 1920

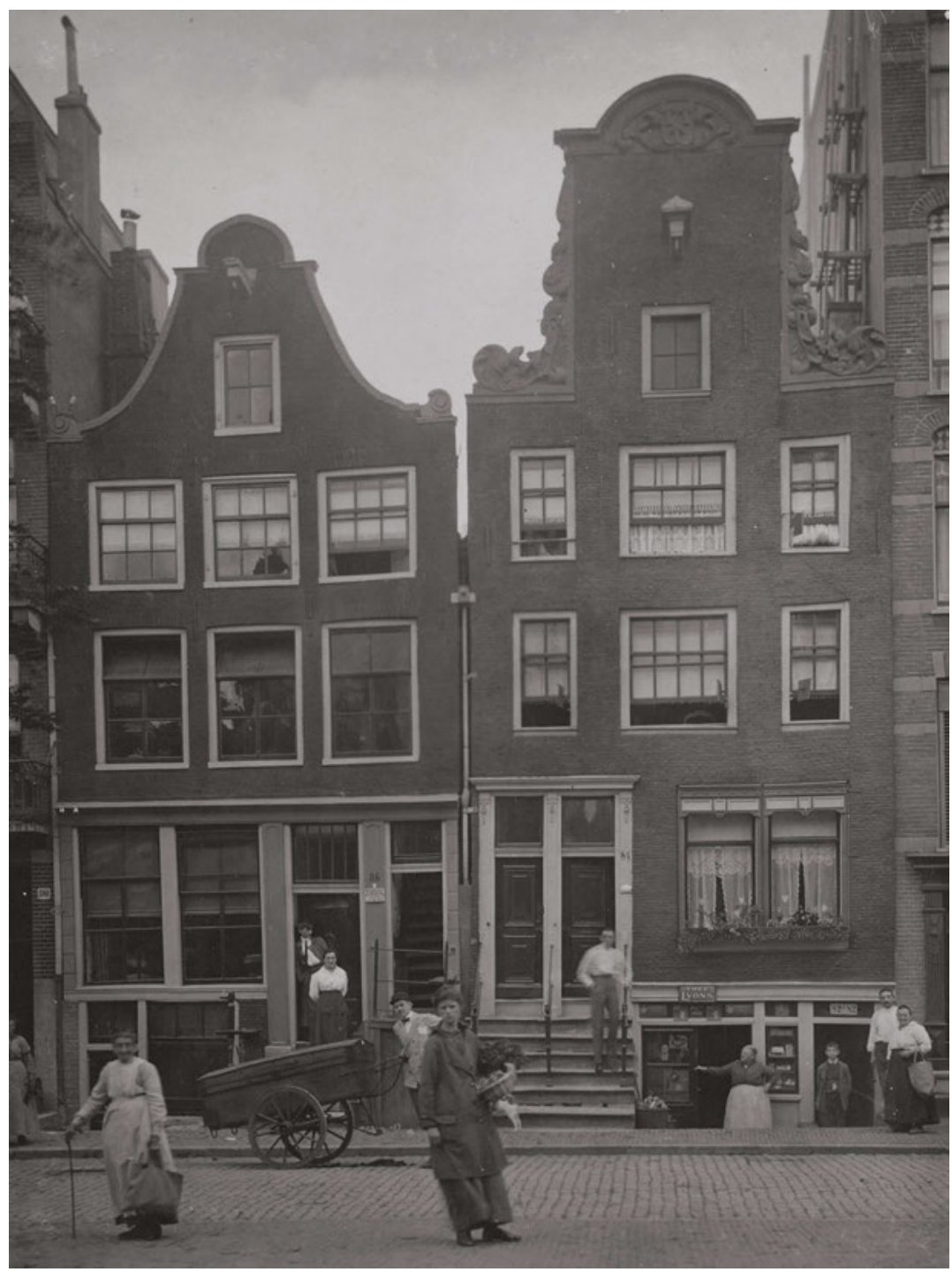

Hendrik Groenevelt is door mij samengesteld op basis SAA 5256. Doos 1021.

Stamboeknummer 7226.

15 Het Steuncomité in Amsterdam werd op 4 augustus 1914 opgericht. Het doel was het verschaffen van steun aan werklozen; andere armlastigen werden gesteund door het Burgerlijk Armbestuur. De Eerste Wereldoorlog (1914-1918) veroorzaakte veel werkloosheid.

Fotograaf onbekend. Bron: SAA. Beeldbank. Afbeeldingsbestand OSIM00003004343.

In de zomer van 1918 heeft Jan Hendrik weer werk als veemarbeider, maar het bedrijf waar hij werkt gaat failliet. Korte tijd krijgt hij een uitkering van hfl 11,00 per week uit de Veemreserve. Daarna verzoekt hij om onderstand omdat hij met 62 jaar te oud meent te zijn om nog kans op werk te 
maken. De aanvraag wordt afgewezen omdat Jan Hendrik op zijn leeftijd wel degelijk in staat wordt geacht nog werk te kunnen vinden.

In 1921 wordt Jan Hendrik 65 jaar. Hij krijgt dan als gepensioneerd veemarbeider hfl 10,00 per week. De huishuur bedraagt inmiddels hfl 2,40. Vanwege het lage gezinsinkomen krijgt het gezin nog steeds versterkende middelen voor Margaretha: een liter melk per dag op aangeven van het consultatiebureau van de Amsterdamsche vereeniging tot bestrijding der tuberculose. Deze melkverstrekking wordt in 1922, 1923 en 1924 voortgezet. De huishuur in verhoogd naar hfl 2,90. In 1924 verhuist het gezin naar de Houtmanstraat 11'. Zij betalen dezelfde huishuur als daarvoor: hfl 2,90 per week. Met Margaretha gaat het minder goed; zij brengt drie maanden door in het gasthuis.

Maatschappelijke Steun is erachter gekomen dat een schoonzoon van de Groenevelts, J.J. Symons, in goeden doen is geraakt. Hij heeft in Driebergen een zaak in elektrische werken waarmee hij 1.800 tot 2.000 gulden per jaar verdient. Hij wordt in een brief van 18 november 1924 aangemaand door Bureau Huiszittende en Weduwenhof een geldelijke bijdrage te leveren op grond van het verhaalrecht. Mocht hij in gebreke blijven, dan wordt de kwestie overgedragen aan de kantonrechter. Symons dient hfl 1,00 steun per week af te dragen aan zijn schoonouders, maar dat is hem te veel. Hij komt de verplichting niet na. Maatschappelijke Steun ziet af van verdere actie en de kantonrechter komt er niet aan te pas.

In 1925 wordt de steun voor Margaretha voortgezet. De armbezoeker merkt op dat het "een knap gezin" is. "De man is te oud voor werk; de vrouw is rheumatisch." In hetzelfde jaar wordt dochter Margaretha nogmaals in het gasthuis opgenomen. In het najaar van 1925 wordt zij ontslagen, maar ze vertrekt in 1926 naar herstellingsoord Heideheuvel in Hilversum. Het oord staat onder auspiciën van het Witte Kruis.

Op 1 mei 1933 overlijdt Elisabeth, op 75-jarige leeftijd. Jan Hendrik krijgt nu pensioen van de Scheepvaartvereniging Noord. Dochter Margaretha bestiert, kennelijk weer voldoende hersteld, nu het huishouden in de Houtmanstraat 11. De huur is intussen opgelopen tot hfl 3,50 per week.

Na 1933 verdwijnt Jan Hendrik langzaam uit beeld. Aan zijn gezinskaart valt nog wel af te lezen dat hij in 1937 nog twee maal is verhuisd: eerst naar de Oostelijke Handelskade 24, waar hij bij zijn schoonzoon inwoont. ${ }^{16}$ Vervolgens vertrekt hij naar de Breedeweg 13, waar hij eveneens inwoont. Jan Hendrik overlijdt op 87-jarige leeftijd op 9 april $1943 .{ }^{17}$
16 SAA. Gezinskaarten. Link: https://archief/ indexen/gezinskaar ten_1893-1939/zoek/ query.nl.pl?i1=1\&a1=Ko seman\&af1 $=1 \& x=3 \& z=b$ $\& s=16 \# 5422-0803-4410$ 17 Volgens het parenteel van Gerrit Groenevelt link: http://www.groeneveld-de|ft.nl/parentelen\%20groeneveld/Stam\%20DX/index. html 


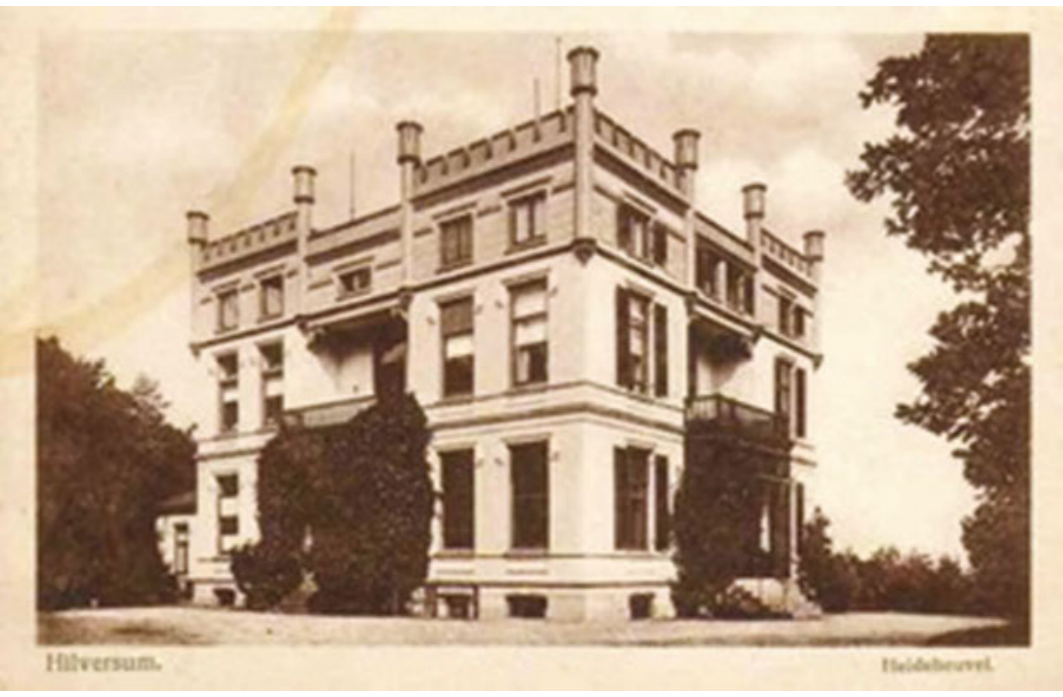

Ansichtkaart. Fotograaf onbekend. Bron: Humanitas.

\subsection{HET GEZIN AAL 1898-195018}

In dit levensverhaal komt naar voren dat het bedeelde gezinnen soms tijdelijk lukt zich aan de armoede te ontworstelen. Persoonlijk ongeluk brengt dit gezin dan toch weer in aanraking met de gemeentelijke armenzorg. Dramatisch hoogtepunt in deze geschiedenis is de zelfmoord van het gezinshoofd. Dit is zeer uitzonderlijk. In de vele duizenden dossiers die ik onder ogen heb gehad is dit ook meteen de enige zelfmoord. Opvallend in dit dossier is de zogeheten klikbrief. Buurtgenoten van steunaanvragers verstrekten desgevraagd wel mondelinge informatie aan de armbezoekers, maar soms stuurden ze ook ongevraagd - meestal anonieme - klikbriefjes aan de gemeentelijke armenzorg. In de regel gaat het in die briefjes om verzwegen inkomsten. Een nacontrole vindt dan altijd plaats. Omdat dit levensverhaal verder reikt dan de onderzoeksperiode 1870-1940 komt de invoering van de noodwet Drees in 1947 ter sprake. Deze wet komt in de plaats van oudere regelingen voor oudedagsvoorzieningen.

18 De gegevens zijn ontleend aan het onderzoeksverslag van Bob Smit en Marijke Venema op basis van SAA. Doos 1471. Stamboeknummer 11400 .
Het gezin Aal wordt gedurende de periode 1898 - 1950 gesteund door de gemeentelijke armenzorg. Jan Lodewijk Aal wordt op 29 januari 1872 geboren en Hendrika Christina Starrevelt op 5 augustus 1871. Jan en Hendrika trouwen op 2 augustus 1893 in Amsterdam. Zij krijgen acht kinderen.

Tijdens hun eerste huwelijksjaren blijft het nog stil rondom het echtpaar Aal. In het voorjaar van 1898 komt het eerste verzoek om steun binnen. Jan is, zo blijkt uit het rapport van de armbezoeker, gearresteerd omdat hij zich heeft verzet tegen de politie en is tot drie maanden celstraf veroordeeld. Daardoor heeft het gezin geen inkomsten. Omdat Hendrika slechte ogen heeft, kan zij moeilijk werk vinden. In augustus van 1898 komt een tweede 
aanvraag binnen. Jan zit dan nog steeds achter slot en grendel. De gevangenisstraf is blijkbaar verlengd. Hendrika heeft werk gevonden, maar van de fl. 1.20 die ze er per week mee verdient, kan het gezin niet rondkomen. De huur alleen al bedraagt hfl. 1,25 per week. Haar ouders stoppen het gezin regelmatig levensmiddelen toe.

Jan wordt op 17 september 1898 vrijgelaten. Vanaf dat moment komen er weer inkomsten binnen. Pas ruim zeven jaar later, in januari 1906, volgt een nieuwe steunaanvraag. Het gezin telt inmiddels zes kinderen. Omdat Hendrika voor de kinderen moet zorgen, kan zij niet meer werken. Jan vent met vis en groenten, maar hij verdient er maar zeven gulden per week mee. Dat is niet genoeg om in het onderhoud van het gezin te kunnen voorzien. De ouders van Hendrika worden zelf gesteund en de ouders van Jan kunnen ook niets missen. De steunaanvraag wordt afgewezen.

Monnikenstraat. Het gezin Aal woonde in deze straat rond 1905

Ongedateerde foto (jaren '50?)

Afbeelding 8.11 Monnikenstraat, jaren '50

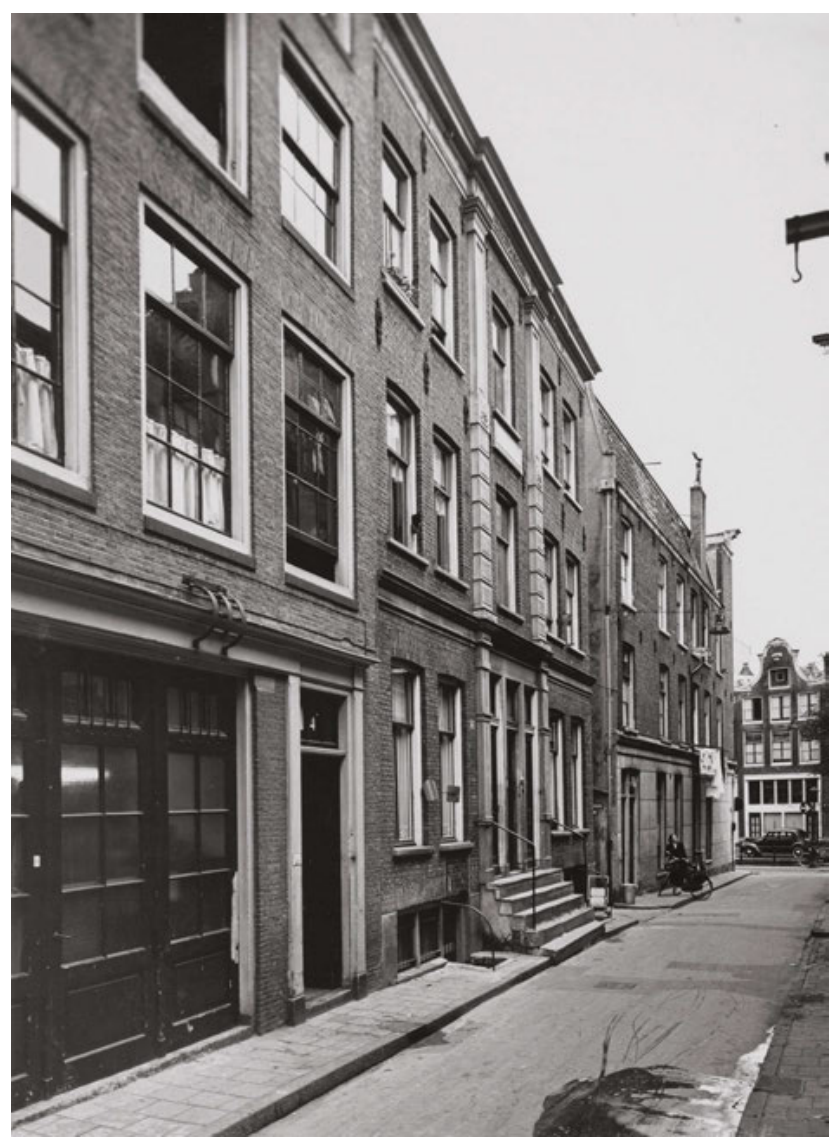

Monnikenstraat 2. Links ingang Gordijnensteeg en hoekhuis Oudezijds Achterburgwal 59. Fotograaf onbekend. Bron: SAA. Beeldbank Afbeeldingsbestand 010009001579.

Twee weken later volgt er een nieuwe aanvraag. Inmiddels is er een huurachterstand van drie gulden. Het gezin heeft geen inkomsten meer om de simpele reden dat Jan geen geld heeft om handelswaar te kopen. Hij 
heeft dus geen werk, omdat hij niet uit venten kan gaan. Met tien gulden zou hij enorm geholpen zijn. Het gezin dient ook nog een verzoek in om winterbedeling. In de wintermaanden zijn de verdiensten van Jan Lodewijk zeer gering. De winterbedeling wordt toegekend: turf voor het stookseizoen en brood. Daarna laat het gezin bijna een jaar lang niets van zich horen.

Sint Pieterssteeg. Het gezin Aal woonde circa 1906 in deze steeg.

Afbeelding 8.12 Sint Pieterssteeg, 1906

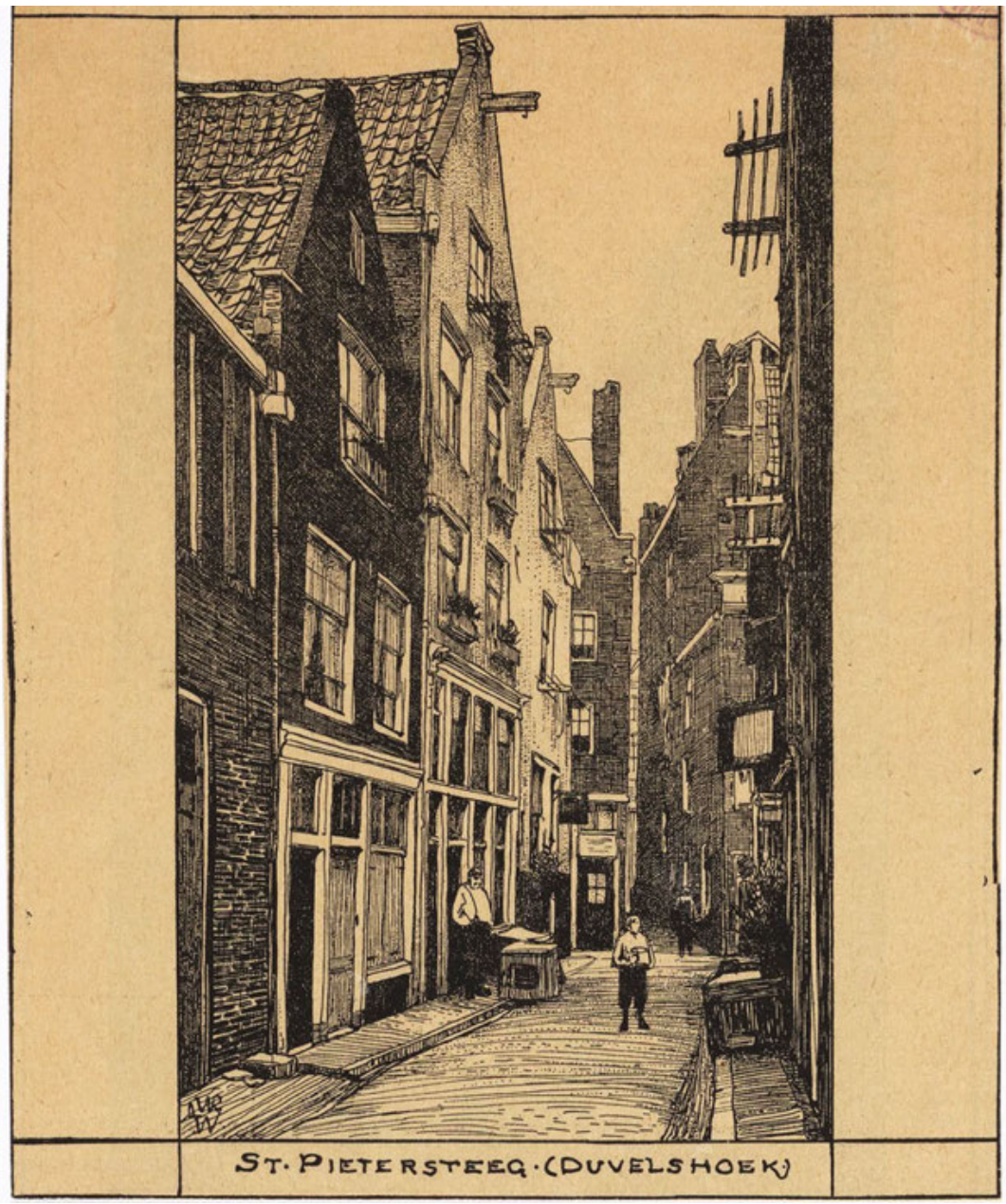

Sint Pieterssteeg (Duvelshoek). Sint Pieterssteeg 30 (gedeeltelijk)-36 (rechts v.r.n.I.). Links 13, 15 enz. (v.l.n.r.). Gezien naar Blindemansteeg, genummerd Suikerbakkerssteeg. (Hoekhuis links nr. 16). Prent door L.W.R. Wenckebach (1860-1937).Bron: SAA. Afbeeldingsbestand 010194000985.

In februari 1907 vraagt Jan om handelsgeld. Hij heeft een huurschuld van vier weken en opnieuw geen geld om nieuwe handelswaar aan te schaffen, waardoor hij niets kan verkopen. Dit patroon zal zich de komende jaren vaker aftekenen. Jan Lodewijk lijkt niet echt talent te hebben voor het doen van de juiste investeringen, zodat hij zelden winst maakt. Een paar dagen na zijn aanvraag ontvangt hij tien gulden waarmee hij handelswaar kan aanschaffen.

In oktober van datzelfde jaar, 1907, doet het gezin een aanvraag voor 
kraambedeling na de geboorte van dochter Geerdina. De gezinsinkomsten zijn laag, al is de oudste dochter inmiddels oud genoeg om haar steentje bij te kunnen dragen. Zij is echter ziekelijk en daardoor niet in staat om te werken. Het gezin vraagt in 1907 ook om winterbedeling. Jan heeft vaak last van zijn keel, wat lastig is voor een venter. Daardoor kan hij vaak niet werken en komt er geen geld binnen. Met sneeuwruimen verdient hij nog een beetje bij.

In januari 1908 vraagt Jan weer om geld om handelswaar te kunnen kopen. De handelswaar die hij nog had is namelijk bevroren door de strenge vorst. ${ }^{19}$ Daarnaast zijn er diverse schulden. Een groot deel van het huisraad is verkocht om de financiële problemen het hoofd te kunnen bieden, maar zonder hulp van buitenaf komen ze er niet. Het gezin ontvangt elf gulden en een paar werkschoenen voor Jan.

In de zomer van 1908 gaat het helemaal mis. Er zijn wel veel schulden, maar geen inkomsten. Het gezin is gedwongen te verhuizen. Voor de zeven kinderen is er geen kruimel brood meer in huis. Het gezin ontvangt onmiddellijk brood. Tot de zomer van 1911 zal deze geschiedenis zich regelmatig blijven herhalen. Vader heeft vaak geen geld om handel te drijven en kan dan dus niets verdienen. Moeder werkt erg weinig vanwege de vele kinderen. In maart 1911 komt dochter Engeltje er nog bij. De oudste dochter, Hendrika, werkt pas in 1910 voor het eerst. Daarvoor was ze steeds te zwak om te kunnen werken. Hendrika krijgt van de armenzorg diverse keren versterkende middelen toegekend. In haar geval komt dat neer op een ei per dag. Tussen oktober 1909 en oktober 1910 wordt ze opgenomen in een verpleeginrichting in Breukelen om aan te sterken. De steunaanvragen van het gezin Aal, die elkaar in flink tempo opvolgen, worden lang niet altijd gehonoreerd. De armbezoekers zijn vaak van mening dat moeder Hendrika, "een flinke vrouw", best zou kunnen werken.

Het gezin heeft soms ook gewoon pech. De keelaandoening van Jan wordt steeds erger, waardoor hij uiteindelijk zijn beroep moet opgeven. Vanaf 1912 is hij werkzaam bij een stoommaatschappij. Verder staat hij na bemiddeling door armenzorg, bij een sleepbedrijf ingeschreven. In 1912 blijkt, volgens het rapport van een armbezoeker, dat hij bij het sleepbedrijf nooit is komen opdagen. Er zou administratief iets zijn misgegaan. Bovendien wil hij helemaal niet bij het sleepbedrijf werken omdat de stoffige omgeving slecht zou zijn voor zijn keel. Zijn vrouw Hendrika, die op dat moment ook geen werk heeft, reageert hier verongelijkt op. Als híj niet hoeft te werken, dan hoeft zíj het ook niet. De twee hebben de neiging elkaar de schuld te geven van de situatie waarin het gezin verkeert. De steunaanvraag in 1912 resulteert in een afwijzing. De armbezoeker denkt dat er geen financiële problemen zouden zijn als de twee zich wat actiever opstelden.

Pas vier jaar later, eind 1916, wordt er weer iets vernomen van het gezin. Het vraagt ditmaal niet om geld, maar om versterkende middelen. Moeder Hendrika is erg verzwakt. De oudste kinderen zijn inmiddels aan het werk. Desondanks zijn er schulden, waaronder een huurschuld van maar liefst negen weken. Het gezin verlaat de woning aan de Kleersloot en verhuist naar de Korte Keizersstraat. Hendrika krijgt een liter melk per dag toegekend. Daarnaast ontvangt het gezin vier gulden per week aan bedeling.

Er gaan zes jaar in stilte voorbij. In 1922 zijn er nieuwe berichten over het
19 Van 9 januari tot 15 januari was er een koude periode, waarbij het 's nachts matig tot streng voor. Het kwam tot vier ijsdagen. Dan vriest het 24 uur per dag. 12 januari 1908 was de koudste dag met een minimum van min 11,10 Celsius. Dat is strenge vorst. $\mathrm{Na}$ een korte dooiperiode werd het opnieuw koud. Tussen 20 en 26 januari vroor het opnieuw. Ook deze keer waren er vier ijsdagen te tellen. (Bron: KNMI, metingen te De Bilt) 
20 HAR staat voor Havenarbeidsreserve. De HAR werd in 1919 ingesteld door de scheepvaartverenigingen van Amsterdam. De regeling was een versobering van de Havenreserve. In de HAR waren afspraken met de vakbeweging gemaakt over garantieloon en andere secundaire arbeidsvoorwaarden. De regelingen in de Havenreserve en de HAR kwamen tot stand omdat de vraag naar arbeid in de haven fluctueerde. Ook in het stoomtijdperk kon een vaste dienstregeling door weersinvloeden niet gegarandeerd worden. Havenreserve en HAR dienden als buffer om de fluctuaties in de vraag naar arbeid op te vangen. De regelingen worden uitvoeriger beschreven in de dissertatie van Boot (2011), 68-96. gezin Aal, dat een nieuwe steunaanvraag doet. De ouders van Hendrika zijn inmiddels overleden en drie van de acht kinderen zijn het huis uit gegaan. Van de vijf die nog thuis wonen zijn twee kinderen aan het werk. Zoon Louis heeft geen werk, Geerdina helpt thuis in het huishouden en Engeltje gaat naar school. De drie oudste dochters die niet langer thuis wonen zijn allemaal getrouwd. Af en toe gaat Jan nog uit venten, hetgeen niet veel oplevert. Het totale gezinsinkomen bedraagt ongeveer veertien gulden per week. Het grootste deel wordt door de twee werkende kinderen ingebracht. Op advies van de armbezoeker wordt een tijdelijke steun van tien gulden per week verleend. Dat is voor het levensonderhoud, maar ook om schulden af te betalen. In hetzelfde jaar, 1922, vraagt zoon Jan handelsgeld aan. Hij vent met vis en heeft niet genoeg geld om handelswaar te kopen. Deze aanvraag wordt afgewezen. Het gezinsinkomen is te hoog: vader Jan is inmiddels werkzaam in de haven.

In januari 1924 wordt er weer een steunaanvraag ingediend. Er wordt weliswaar veel verdiend binnen het gezin, maar vader en moeder werken allebei niet en hebben dus geen eigen inkomsten. Jan beweert dat de kinderen geen cent van hun verdiensten afdragen aan hun ouders. Daarom moet hij wel een beroep doen op de armenzorg. In de jaren die volgen raakt het gezin ontwricht. Jan, die aan de drank is geraakt, verlaat het gezin in 1927. Hij blijft een aantal weken weg en keert dan weer terug. Door een ongeval op zijn werk is hij ernstig gewond geraakt aan zijn rechterarm. Jan heeft een kwade dronk over zich. Als hij zich heeft laten vollopen, gaat hij regelmatig met iemand op de vuist. Hierom staat hij bekend bij de politie. Dochter Heintje is intussen getrouwd en woont niet meer thuis. Dochter Johanna heeft een gezin met twee kinderen en dochter Hendrika heeft er al drie. Zoon Louis, die aanvankelijk venter was, is met de noorderzon vertrokken. Sinds zijn vertrek lijkt het beter te gaan met Jan. Vanaf januari 1928 is hij zelfs weer aan het werk. Hij bedankt dan voor verdere steun. In de loop van 1928 wordt dan toch nog weer een steunaanvraag ingediend. Deze aanvraag wordt afgewezen, omdat er volgens de armbezoeker genoeg wordt verdiend in het gezin.

Vanaf 1930 volgen de aanvragen elkaar weer frequenter op. De meeste aanvragen worden afgewezen. Het gezin verdient gewoon teveel, zeker omdat de vele kinderen bijdragen aan het gezinsinkomen. Zoon Louis duikt in deze periode weer op. Hij blijkt bij zijn oudste zuster en haar man te wonen. In november 1931 wordt bij een bezoek van de armbezoeker over het gezin opgemerkt dat het er "ordeloos en ruw" aan toegaat. "Verhouding tussen vader en kinderen laat te wensen over".

Over het inkomen van Jan Lodewijk valt, op grond van de rapporten van de armbezoekers, wel iets interessants te melden, dat helemaal past in de naderende crisistijd. In 1930 verdiende hij op jaarbasis hfl 904,41. Dat is gemiddeld hfl 18, 00 per week. In de eerste tien maanden van 1931 verdiende hij nog hfl. 650,92: gemiddeld hfl 16,66 per week. De laatste tien weken van 1931 was zijn weekloon gemiddeld nog maar fl. 6,50. De armbezoeker meent in november 1931 dat enige steun wel gewenst is. Hij adviseert hfl 3,50 per week en broodbedeling. Een pensioenuitkering moet via de Havenarbeidsreserve, ofwel de HAR worden geregeld. ${ }^{20}$ 


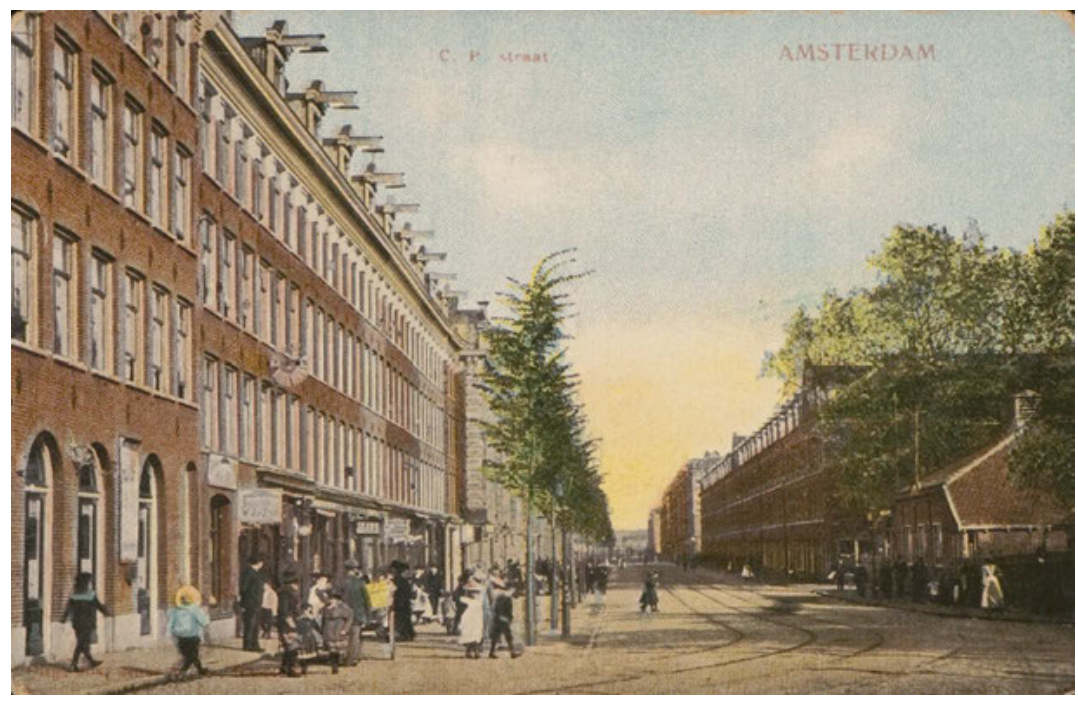

Czaar Peterstraat in noordoostelijke richting Ansichtkaart. Onbekende fotograaf. Bron: SAA. Beeldbank. AfbeeldingsbestandPBKD00139000002.

Czaar Peterstraat. Hendrika woonde in de jaren veertig in de Czaar Peterstraat Afbeelding 8.14 Czaar Peterstraat, 1936

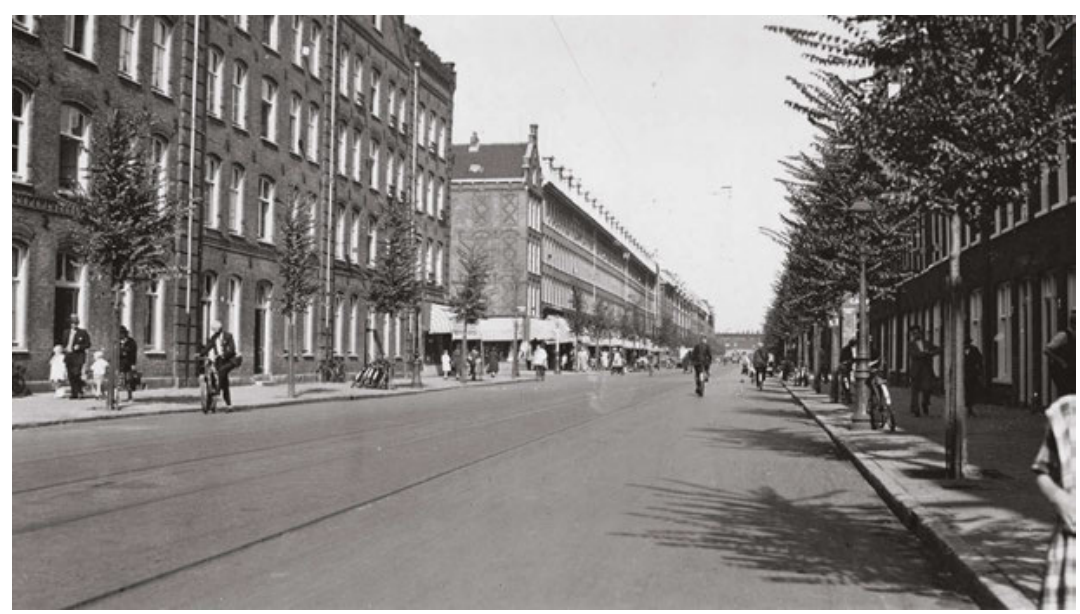

Czaar Peterstraat 45-49.

Gezien naar de Cruquiusstraat, gezien in zuidwestelijke richting.

Foto gemaakt door Jacobus van Eck (1873-1940). Bron: SAA. Beeldbank. Afbeeldingsbestand A01634000515.

Met deze regelingen komt het gezin de crisisjaren door, maar erg gezellig wordt het niet meer in huize Aal. De dan net 65-jarige Jan voelt zich door zijn gezinsleden niet serieus genomen. Hij is het zelfs zo beu dat hij in 1936 een plek aanvraagt in het armenhuis. Ook in 1937 worden zijn herhaalde verzoeken om opname in het armenhuis steeds afgewezen. Bij Hendrika wordt in datzelfde jaar een hartkwaal geconstateerd. Maar het kan nog erger. In 1938 bereikt de geschiedenis van het gezin Aal een dieptepunt. Jan pleegt 
op 23 maart zelfmoord, op 66-jarige leeftijd. Dat blijkt uit de rapportage van de armbezoeker. Omdat hij niet is aangesloten bij een begrafenisfonds moet armenzorg bijspringen. De ongetrouwde dochters zijn niet bereid hun inkomen met hun moeder te delen. Hendrika verhuist in haar eentje naar de Korte Keizersstraat. Het gezin is uiteengevallen. De alleenstaande dochters blijven achter, getraumatiseerd door de tragische dood van hun vader. De steunaanvraag die Hendrika indient, wordt toegekend. Daarnaast wordt haar hfl 14,70 gulden weduwerente toegekend. Verder worden enkele schulden van wijlen haar man kwijtgescholden.

In haar eerste jaren als weduwe is Hendrika, die tegen de zeventig loopt, zeer arm. Regelmatig vraagt ze om praktische zaken als lakens, kleding, schoenen of ondergoed. Al deze steunverzoeken worden toegekend. Als haar verzoek de steun te continueren wordt gehonoreerd, verhuist ze In het voorjaar van 1941 naar de Czaar Peterstraat, maar nog geen half jaar keert ze alweer terug naar de Korte Keizersstraat.

In het jaar 1942 duikt in haar dossier een klikbrief op. Er is op het hoofdkantoor van de armenzorg in de Regulierdwarsstraat een anonieme brief ontvangen. Daarin wordt gesuggereerd dat de twee jongste dochters bij Hendrika inwonen en haar financieel steunen. Hendrika wordt vervolgens door middel van "posten" in de gaten gehouden. Medewerkers van de armenzorg houden zich op in de nabijheid van de woning van de aanvraagster. Zij houden de aankomsttijd en de vertrektijd bij van bezoekers gedurende vijf dagen. Bovendien wordt gelet op de aanwezigheid van de bewoonster in haar woning. Hendrika blijkt opvallend vaak van huis te zijn, maar het steunbedrag wordt niet gewijzigd. In het controle-rapport valt te lezen dat de dochters hun moeder weliswaar bezoeken, maar dat ze daarna altijd terugkeren naar hun eigen woning. In september verhuist Hendrika terug naar de Czaar Peterstraat, waar de huur lager is. Het steunbedrag blijft gelijk.

In 1943 schemert voor het eerst de oorlog door in het dossier. De Amsterdamse Zuiveringsmaatschappij verlangt van Hendrika een verklaring over haar raszuiverheid. In juli 1943 volgt een soortgelijke controle. Vanaf september 1943 krijgt Hendrika hfl 2,50 per week van haar zoon Louis. In oktober 1943 verhuist Hendrika naar een woning op een lagere etage in hetzelfde pand. Vermoedelijk is Hendrika niet meer in staat om naar drie hoog te klimmen. In de nadagen van haar leven verandert er nog maar weinig. Haar zoon trekt zijn financiële steun weer in, maar dat tekort wordt opgevangen door de armenzorg. Hendrika wordt steeds slechter ter been. In een klikbrief uit 1946 wordt gesuggereerd dat dochter Engeltje bij Hendrika in zou wonen. Er wordt een controle uitgevoerd waaruit blijkt dat Engeltje niet bij haar moeder woont. Aan het steunbedrag verandert niets.

In de late jaren veertig wordt Hendrika een paar keer licht op de vingers getikt omdat ze haar inkomsten een paar centen lager voorstelde dan ze zijn. De hoogte van de verleende steun verandert niet. In 1947 ontvangt zij voor het eerst een ouderdomsuitkering in het kader van de noodwet Drees. In 1949 verzoekt Hendrika om een wollen deken. Het verzoek wordt ingewilligd, maar met inhouding van een deel van de steun. Op 12 maart 1950 overlijdt Hendrika Christina Aal-Starrevelt op bijna tachtigjarige leeftijd. Hiermee komt een einde aan ruim een halve eeuw ondersteuning door armenzorg. 


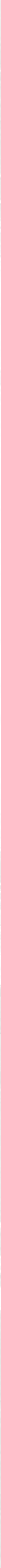




\section{HOOFDSTUK 9 \\ SLOTBESCHOUWING}

< 9.A Gemeubileerde kamer op de eerste verdieping Lindengracht 238 circa 1895. Beschrijving uit 1895 : 'Hoogte verdieping 2.45 $m$. De trap om boven te komen telt 13 treden met een aantrede van $0.11 \mathrm{~m}$ en een optrede van $0.21 \mathrm{~m}$. De kraan is boven een gootsteen in het portaal. Vloer en zoldering zijn van hout. De wanden der kamers zijn behangen en beschilderd. De beeremmer staat in een kast. Bewoners: drie generaties of twee families. Een weduwe met 5 kinderen, waarvan 4 thuis en een kindje ter opvoeding. De vrouw is gehuwd geweest met een weduwnaar, die 9 kinderen gehad heeft, terwijl zij samen nog 8 kinderen kregen. Van deze 8 zijn er 5 in leven, zodat de man met zijn eerste vrouw en 12 kinderen in het graf ligt. Het laatste kind werd enige maanden na de dood van de man geboren. Het kind dat de vrouw 'opvoed' is ongeveer 4 maanden oud. Zij krijgt voor dat 'opvoeden' $f 1.75$ per week, wat zij te weinig vindt.

Vroeger kreeg de vrouw van het armbestuur $f 1.50$ per week, doch omdat zij $f 1.75$ voor het kind lrijgt, geeft het armbestuur haar maar f 1.00 per week. De vrouw gaat één dag in de week uit werken waar zij $f 0.80$ aan verdient. Het oudste meisje is in een gesticht in Haarlem. De moeder slaapt met haar jongste kindje en de 'vroedsterling' in een bedstede. Zij verwoonde hier 1.00 per week.' Foto door Eduard H.J Weismüller (1849-?).

Bron: SAA. Beeldbank. Afbeeldingsbestand $0814 \mathrm{FO} 000080$.
In deze studie is geprobeerd na te gaan hoe de gemeentelijke armenzorg van Amsterdam tussen 1871 en 1940 te werk ging met betrekking tot beschaving en bureaucratisering. Twee vragen kwamen hierbij aan de orde.

1) Welke rol speelde het streven naar beschaving in de manier van werken van de gemeentelijke armenzorg?

2) Op welke wijze werd de organisatie van de gemeentelijke armenzorg gebureaucratiseerd?

Als eerste ga ik in op de vraag naar het streven naar beschaving. Als richtsnoer voor de beantwoording van deze vraag diende het concept burgerlijk beschavingsoffensief zoals geïnitieerd door Bernard Kruithof.

De armen moest beschaving bijgebracht worden, zo werd verondersteld, omdat zijzelf schuldig zouden zijn aan hun armoedige toestand. Door hun ruwe zeden, hun luiheid, hun schaamteloosheid en hun gebrek aan zelfbeheersing konden zij niet verstandig met geld omgaan. Zolang zij deze slechte eigenschappen hadden, zouden de armen altijd arm blijven. De remedie tegen armoede werd dan ook gezien in het opvoeden en beschaven van de armen. Dan konden zij, net als de beter gesitueerde burgers, een deugdzaam leven leiden zonder honger of gebrek.

Welke rol speelde het beschavingsoffensief in de manier van werken van de gemeentelijke armenzorg? Aan de hand van de rapporten van de armbezoeker en de jaarverslagen van de gemeentelijke armenzorg valt een bepaalde ontwikkeling te bespeuren. In 1871 speelden morele overwegingen een belangrijke rol bij het afwijzen van aanvragen. Een ongunstig oordeel van de armbezoeker over het gedrag van de aanvrager leidde eerder tot een afwijzing.

Dat gold ook voor de indruk die de armbezoeker kreeg van de welstand van de woning. In 1871 speelde deze indruk een rol bij de toe- of afwijzing van de aanvraag. In 1936 gaf de armbezoeker geen oordeel meer over de welstand van de woning. Het welstandsniveau van de woning bracht ik in verband met het bestedingspatroon van de aanvrager. Als er geen oordeel meer wordt gegeven over de besteding van het gezinsinkomen, en dus ook niet aan uitgaven die betrekking hebben op de inrichting van de woning, dan wijst dat op een afname van de behoefte om het gedrag van de armen te reguleren. Het is niet langer een zaak van de armenzorg hoe de arme zijn financiën beheert. De houding tegenover de arme is verzakelijkt.

De indruk die de armbezoeker kreeg van de hygiënische toestand van de woning speelde in 1871 een belangrijke rol in de beslissing of er al dan niet steun werd gegeven. Aanvragers met een woning die door de armbezoeker onhygiënisch werd bevonden, kregen in meer dan de helft van de gevallen geen steun. In 1911 en in 1936 werd er niet meer gerapporteerd over de hygiëne. Kennelijk speelde het geen rol meer in de besluitvorming. Hygiëne is een moeilijk objectiveerbaar criterium en zegt meer over het gedrag van de aanvrager dan over de feitelijke armoede. Het verdwijnen van het oordeel over hygiëne als criterium is geïnterpreteerd als aanwijzing dat 
het gedrag van de aanvrager niet meer ter discussie staat en dat zakelijke overwegingen in de besluitvorming nu de doorslag geven. Een onfrisse woning is geen reden meer een aanvraag af te wijzen.

Een toenemende verzakelijking zien we ook terug in de afwijzingsgronden. In 1871 werd de helft van de afwijzingen gemotiveerd door zakelijke motieven. In 1911 gaven zakelijke motieven in twee van de drie aanvragen de doorslag. In 1936 kwam het nog maar sporadisch voor dat er een morele overweging te pas kwam aan een afwijzing. De afwijzingsgronden waren praktisch helemaal verzakelijkt.

De vraag naar de rol van het beschavingsoffensief in de gemeentelijke armenzorg kan nu, al het voorafgaande in beschouwing genomen, als volgt worden beantwoord. In 1871 was die beschavingsdrang nog duidelijk aanwezig. Het gedrag van de arme was een belangrijk criterium voor het af- of toewijzen van hulp. Gaandeweg werd het idee dat de arme aan allerlei normen en waarden moest voldoen, steeds minder belangrijk bij de besluitvorming. In 1936 waren er bijna uitsluitend zakelijke motieven om toe- of afwijzingen te onderbouwen. Een proces van verzakelijking was voltooid.

Als leidraad voor de beantwoording van de tweede vraag, de vraag naar de wijze van bureaucratisering diende het ideaaltype van de bureaucratie dat Max Weber uiteen heeft gezet. De bureaucratietheorie van Weber heb ik in de onderstaande zes hoofdpunten samengevat.

1) De ontwikkeling en groei van de bureaucratie. Naarmate de overheid meer taken op zich neemt, groeit de behoefte aan een goed functionerend beheer. Oude beheerssystemen worden vervangen door een bureaucratisch beheer waarin deskundige ambtenaren werkzaam zijn.

2) De bureaucratie als onderdeel van de overheid. In de moderne samenleving is de macht van de overheid op wetten gebaseerd. De bureaucratie ontleent haar gezag aan de wetgeving.

3) De positie en de functie van de ambtenaar. Ambtenaren worden benoemd en hebben geen nevenfuncties. Ambtenaren worden opgeleid en werken volgens vaste principes, gebaseerd op wettelijke bepalingen.

4) Het permanente karakter van de bureaucratie. Een eenmaal gevestigde bureaucratie laat zich niet zomaar omverwerpen. $\mathrm{Zij}$ is onmisbaar voor de uitvoering van de beheerstaken van de overheid. Zonder bureaucratie ontstaat chaos.

5) De machtspositie van de bureaucratie. Door haar onmisbaarheid is de macht van de bureaucratie erg groot. In de visie van Weber kan de machtige bureaucratie alleen een halt worden toegeroepen door een doortastende en goed functionerende democratie. De wetgevende macht staat boven de uitvoerende macht.

6) Het rationaliteitsprincipe. Bureaucratisering staat in het teken van verzakelijking. Morele overwegingen spelen geen rol in de besluitvorming. Louter rationele overwegingen leiden tot besluiten, die zonder aanzien des persoons worden genomen.

$\mathrm{Bij}$ het beantwoorden van de vraag hoe zich de bureaucratisering tussen 1870 en 1940 voltrok, moet allereerst worden vastgesteld dat het apparaat van de gemeentelijke armenzorg al in 1871 enkele bureaucratische trekken 
vertoonde. De armenzorg ontwikkelde zich in de loop van zestig jaar tot een compleet bureaucratische organisatie. Het bureaucratiseringsproces van de gemeentelijke armenzorg laat zich voegen in de bureaucratiseringstheorie van Weber. Het Burgerlijk Armbestuur, in theorie een autonome organisatie, overwegend bezet door een stedelijke elite, werd steeds afhankelijker van het gemeentebestuur. De oprichting van de Burgerlijke Instelling voor Maatschappelijken Steun in 1927 versterkte dit proces. De armenzorg werd een volledige gemeentelijke dienst.

Drie ontwikkelingen dreven deze bureaucratisering. In de eerste plaats nam het aantal taken van de gemeentelijke armenzorg flink toe in de onderzochte periode. De behoefte aan een goed functionerend beheer, met deskundige, geschoolde ambtenaren, nam daardoor toe. Een oud beheerssysteem werd geleidelijk vervangen door een bureaucratisch beheer. In de tweede plaats was er een grote toename van het aantal steunaanvragen. En ten derde was er als gevolg daarvan een navenante groei van het aantal ambtenaren dat werkzaam was voor de gemeentelijke armenzorg. Een bureaucratisering van de werkwijze maakte het mogelijk de vele taken uit te voeren en het groeiende aantal aanvragen zakelijk en objectief af te handelen.

De bureaucratisering van het apparaat zien we ook terug in de vorm waarin hulp werd verleend. De hulp in natura maakte grotendeels plaats voor financiële steun. Deze ontwikkeling is te zien als een rationalisering van de armenzorg.

De armenzorg werd onderdeel van de stedelijke overheid. Zij ontleende sindsdien haar gezag aan de wetgeving en niet langer aan de normen en waarde van een elite. Ambtenaren gingen werken volgen vaste principes, gebaseerd op wettelijke bepalingen.

Hoewel de machtspositie van de bureaucratie groot was, wist de goed functionerende Amsterdamse gemeenteraad de invloed van al te machtsbeluste bureaucraten te beperken. De wetgevende macht bleek daadwerkelijk boven de uitvoerende macht te staan.

Beide ontwikkelingen, het verdwijnen van de invloed van het beschavingsoffensief en het bureaucratiseringsproces, versterkten elkaar. Het bureaucratiseringsproces stond in het teken van verzakelijking. Morele overwegingen speelden geen rol meer in de besluitvorming. Louter rationele overwegingen leidden tot besluiten, die zonder aanzien des persoons werden genomen.

Zijn de vragen die ik heb gesteld nu voor eens en voor al beantwoord? Bescheidenheid is op zijn plaats. Van het rijke archiefmateriaal is maar een deel geraadpleegd. Een grotere steekproef, met meer dan drie steekjaren, had mogelijk meer nuances aan het licht gebracht. Bovendien is het bestudeerde archiefmateriaal niet uitputtend geanalyseerd. Er hadden nog meer indicatoren onder de loep genomen kunnen worden. Duidelijk is wel dat de twee grote lijnen zichtbaar zijn gemaakt: a) het verdwijnen van morele beginselen in het verlenen van armenzorg en b) de ontwikkeling van de bureaucratie. Wel realiseer ik me dat dit archiefonderzoek uitsluitend betrekking heeft op de gemeentelijke armenzorg. Particuliere en kerkelijke zorg zijn om onderzoekstechnische redenen buiten beschouwing gebleven. Dit onderzoek is dus zeker niet definitief. Er kunnen bovendien nieuwe vragen 
opkomen die tot nadere onderzoeken zullen leiden. Een aspect waar ik in dit onderzoek niet op in ben gegaan is de discussie over de mogelijke onmaatschappelijkheid van de armen. Onderscheiden armen zich van de rest van de samenleving door een afwijkend gedragspatroon en zijn zij daardoor onmaatschappelijk? Zijn er naast het aanvaarden van steun andere overlevingsstrategieën van de armen in Amsterdam om zich te kunnen handhaven? Ook onderzocht zou kunnen worden of er in Amsterdam sprake is van intergenerationele overdracht van armoede. Werd armoede van vader op zoon, van moeder op dochter doorgegeven? En waar woonden de armen zoal? Was er sprake van sociale segregatie? Ook de geografische herkomst van de armen is een onderzoek waard. Hebben migranten een grotere kans tot armoede te vervallen dan autochtone Amsterdammers? Hoe zat het met de armen zelf en hun belevingswereld? Hoe ervoeren zij hun armoedige omstandigheden en wat vonden zij van de hulpverlening? Het beantwoorden van al die vragen zal veel onderzoek vergen. De geschiedschrijving is nooit af. Veel bronnen zijn nog niet of niet volledig benut. Bovendien zal elke nieuwe generatie historici met nieuwe inzichten komen. Ook dat zal dan weer leiden tot nieuwe vragen. 
HOOFDSTUK 9 SLOTBESCHOUWING 187 



\section{SAMENVATTING}

Deze studie gaat over de gemeentelijke armenzorg in Amsterdam tussen 1871 en 1940. Ik heb mij daarbij gericht op twee vragen. Welke rol speelde het streven naar beschaving in de werkwijze van de armenzorg? Hoe werd de organisatie van de armenzorg gebureaucratiseerd?

In hoofdstuk 2 is het theoretische kader te vinden, waarin het begrip burgerlijk beschavingsoffensief een belangrijke rol speelt. Onbeschaafd gedrag en gebrek aan moraal werden gezien als oorzaken van armoede. Door opvoeding en regulering moest deugdzaamheid worden bijgebracht. Dan zou de armoede vanzelf verdwijnen. Het concept burgerlijk beschavingsoffensief heeft in Nederland ingang gevonden door toedoen van Bernard Kruithof. Hij grijpt terug op de ideeën van Norbert Elias, samengevat in het civilisatieproces.

Om het bureaucratiseringsproces van de Amsterdamse armenzorg beter te kunnen begrijpen is de bureaucratiseringstheorie van Max Weber als referentiekader gebruikt. Kern van deze theorie is dat een moderne overheid streeft naar een beheersysteem dat beslissingen neemt op rationele gronden. Die beslissingen worden genomen zonder aanziens des persoon door geschoolde ambtenaren die in een hiërarchisch verband opereren.

De drang naar beschaving en moraliteit en de drang naar bureaucratiseren zie ik niet als tegengestelde bewegingen. De drang naar beschaving hoort bij negentiende-eeuwse burgerlijke opvattingen, terwijl het rationaliteitsprincipe van de bureaucratie thuishoort in de gemoderniseerde samenleving van de twintigste eeuw.

In hoofdstuk 3 worden de gebruikte bronnen besproken: de dossiers van de armbezoekers en de jaarverslagen van de gemeentelijke armenzorg. In de talrijke dossiers van de armbezoekers zijn de verslagen te vinden van onderzoeken die werden uitgevoerd om steunaanvragen te beoordelen. Deze dossiers geven uitvoerige informatie over de huishoudens van diverse steunaanvragers. In de jaren '30 van de twintigste eeuw werden jaarlijks een half miljoen onderzoeken verricht. In de grote rijkdom van het bronnenmateriaal schuilt ook een gevaar. Het is ondoenlijk in één onderzoek alle dossiers te bestuderen, zodat er met een beperkt aantal jaargroepen is gewerkt. De jaarverslagen van de armenzorg zijn minder gedetailleerd, maar geven wel een heldere inkijk in de grote lijn van het functioneren van de gemeentelijke armenzorg.

In hoofdstuk 4 geef ik een overzicht van armoede en armenzorg in de pre-industriële en industriële periode. In de pre-industriële periode ging het om primaire armoede: wie arm was had te weinig middelen om in het levensonderhoud te kunnen voorzien. De samenleving was doordrongen van de ernst van deze noodsituatie. De armenzorg was erop gericht, voor zover er middelen aanwezig waren, de ergste nood te lenigen. De charitas-gedachte stond hierbij voorop. De arme medemens werd welwillend tegemoet getreden.

Geleidelijk veranderde er iets in de benadering van de noodlijdenden. Valide armen, krachtig en gezond genoeg om te kunnen werken, werden op zeker moment uitgesloten van hulp. De opvatting won terrein dat gezonde 
en sterke mensen de armoede aan zichzelf te wijten hadden. Ze moesten maar werk zien te vinden. Hulp werd nog wel geboden aan mensen die arm waren, maar daar zelf niets aan konden doen. Het ging dan om wezen, ouden van dagen, lammen en blinden.

Hulpverlening was aanvankelijk een kerkelijke aangelegenheid. In de vijftiende en zestiende eeuw kwam er ook hulpverlening op gang die door steden en dorpen werd georganiseerd. Inmiddels had de pure charitas-gedachte afgedaan. Er kwamen maatregelen om het aantal armen terug te dringen. Men paste een selectief soort repressie toe. De armenzorg werd niet meer alleen ingezet om de ergste nood te lenigen, maar ook om de arbeidsmarkt voor ongeschoolde arbeid te reguleren. De armenzorg werd gebruikt om arbeidsgeschikte armen aan hun stad of dorp te binden.

Op den duur werd er niet alleen hulp geboden aan thuiswonende armen, de huiszittenarmen, maar werden er ook gestichten opgericht voor armen die niet zelfstandig woonden. Deze gestichtsarmen werden daarmee feitelijk uit de samenleving geweerd.

Tijdens de industriële periode veranderde de visie op het armoedevraagstuk. De algemene welvaartsverbetering bracht een andere definitie van armoede met zich mee. Het doel was niet alleen meer om de armen in leven te houden. Voortaan werden mensen als arm gezien als ze over te weinig middelen beschikten om maatschappelijk te kunnen functioneren. Sociale uitsluiting lag dan op de loer. In deze periode was de armenzorg erop gericht de armen op een bepaald maatschappelijk peil te laten functioneren. De armenzorg was niet langer een lokale aangelegenheid; er kwamen landelijke regelingen. Nieuw was ook dat armoede niet meer alleen een kwestie was van particulieren, kerk en hogere burgerij, maar dat de overheid steeds meer de verantwoordelijkheid voor de armenzorg op zich nam. Naast armenzorg kwamen er andere zorgarrangementen tot stand om maatschappelijke risico's en problemen het hoofd te bieden.

In hoofdstuk 5 behandel ik de aanpak van de armoede in Amsterdam. Na 1578 kwam de stedelijke kerkelijke armenzorg onder auspiciën te staan van de gereformeerde kerk. Het stadsbestuur accepteerde het gezag van de gereformeerde kerk. Opvallend is dat de gereformeerde kerk niet het monopolie op de armenzorg verwierf. De andere geloofsrichtingen konden hun eigen armenzorg organiseren. Wel was het zo dat degenen die niet tot een kerkgenootschap behoorden automatisch onder de diaconie van de gereformeerde kerk kwamen te vallen. Zo nam de gereformeerde kerk een taak van de wereldlijke autoriteit over. De hulp werd niet alleen uit menslievendheid geboden. Het belang van de bovenlaag was ook een belangrijke factor. Die bovenlaag wilde niet alleen voorkomen dat er oproer ontstond onder de armen, maar ook een goedkope arbeidsreserve in stand houden.

In de zeventiende en achttiende eeuw was de armenzorg een lokale aangelegenheid. In de negentiende eeuw werden wel pogingen gedaan om een landelijke organisatie op te zetten, maar die pogingen strandden. De armenzorg bleef vooral een plaatselijke kwestie en formeel berustte het primaat nog steeds bij de kerkelijke instellingen. In de armenwet van 1854 was dit nog steeds het uitgangspunt, al kwam in de loop van de tweede helft van de negentiende eeuw de armenzorg in de praktijk steeds meer te vallen onder de verantwoordelijkheid van de lokale overheden. De armen- 
wet van 1912 bracht geen officiële verandering in de opzet. De ontwikkeling van de Amsterdamse armenzorg past in dit beeld. De oprichting van het Burgerlijk Armbestuur bracht de stedelijke verantwoordelijkheid voor de armenzorg dichterbij, maar de scheiding tussen particuliere en stedelijke zorg bleef bestaan. Wel breidde de stedelijke zorg zich steeds verder uit, terwijl de particuliere zorg aan betekenis inboette. De stad bemoeide zich dus steeds meer met de armen en riep op den duur ook andere zorgarrangementen in het leven.

In de loop van de tweede helft van de negentiende eeuw veranderde Amsterdam van een pre-industriële samenleving in een moderne maatschappij. Daardoor veranderde ook de armenzorg in Amsterdam van karakter. De stadsbevolking groeide flink tussen 1871 en 1940. Ook de stad zelf groeide, door enkele annexaties van omliggende gemeenten. De nijverheid kreeg eveneens een nieuw karakter. De ambachtelijke manier van werken werd steeds meer vervangen door een industriële productiewijze. Deze vernieuwing bracht met zich mee dat de oriëntatie op handel en consumptie veranderde van vroegkapitalistisch naar modern-kapitalistisch. De Amsterdamse economische conjunctuur ging parallellen vertonen met de internationale conjunctuur. Er ontstond een nieuw soort werkloosheid: de conjuncturele werkloosheid die grote groepen arbeiders kon treffen. Amsterdam bleef in de periode 1870-1940 een commercieel centrum voor de nationale en internationale markt, maar werd op havengebied voorbijgestreefd door Rotterdam. De gebrekkige bereikbaarheid van het achterland, vooral het westen van het Duitse Rijk, kan hiervoor als voornaamste oorzaak worden aangewezen.

Het ontstaan van de moderne Amsterdamse samenleving ging ook gepaard met een toenemende sociale segregatie. Waar voorheen armen en rijken dicht bij elkaar woonden, ontstonden er nu stadskwartieren waar het merendeel van de bewoners een laag inkomen had tegenover stadskwartieren waar in hoofdzaak meer welgestelden woonden. In termen van de stadsgeografie was er sprake van cityvorming en residentiële segregatie, met woonwijken die een homogenere sociale samenstelling lieten zien. Veel welgestelden verlieten in de onderzoeksperiode 1870-1940 de stad omdat de reismogelijkheden sterk waren toegenomen. Het gevolg was dat Amsterdam een echte arbeidersstad werd. Het ontstaan van een moderne samenleving vormt de achtergrond van de beschavings- en de bureaucratiseringsdrang.

In hoofdstuk 6 behandel ik de hoofdvraag in hoeverre de gemeentelijke armenzorg zich liet leiden door het burgerlijk beschavingsoffensief. In 1871 was dat burgerlijk beschavingsoffensief heel duidelijk bespeurbaar in de benadering van de armen. Op politiek en maatschappelijk gebied had in 1871 vooral de gegoede burgerij het voor het zeggen. De politieke invloed van de gegoede burgerij verminderde daarna geleidelijk door de uitbreiding van het kiesrecht. Daardoor wijzigde de sociaal-politieke samenstelling van de gemeenteraad. De gegoede burgerij voerde niet meer de boventoon. We zien dat terug in de gemeentelijke armenzorg: motieven vanuit het burgerlijk beschavingsoffensief om hulp te verlenen werden vervangen door zakelijke motieven. Morele maatstaven verdwenen goeddeels. Een rationele benadering kwam ervoor in de plaats. 
De rationalisering van de gemeentelijke armenzorg had niet alleen een ideologische kant. Ook in de organisatievorm trad een belangrijke verandering op tussen 1870 en 1940. In hoofdstuk 7 bespreek ik hoe de bureaucratisering van de gemeentelijke armenzorg toenam. De groei van de stad en de nog sterkere groei van het aantal steunaanvragen zorgden ervoor dat de organisatie uitdijde tot een gemeentelijke dienst van bijna 700 medewerkers. Een krachtig bureaucratiseringsproces was daarbij zichtbaar. De werkwijze van de armenzorg kreeg steeds meer weg van het ideaaltype van de bureaucratie zoals Max Weber voor ogen had. Toen het Burgerlijk Armbestuur in 1927 werd opgeheven om plaats te maken voor een volledig gemeentelijke dienst, was het bureaucratiseringsproces afgerond. Toch werden de bureaucraten niet almachtig. De macht van de gemeenteraad bleek groter dan die van de bureaucratische instelling die de armenzorg was geworden.

De verzakelijking en de bureaucratisering van de gemeentelijke armenzorg kunnen als een onderdeel worden gezien van het algehele moderniseringsproces dat binnen de samenleving gaande was. Een pre-industriële samenleving had plaats gemaakt voor een moderne maatschappij waarin rationalisering de boventoon voerde. Ook de Amsterdamse armenzorg was onttoverd. 


\section{SUMMARY}

This study has attempted to investigate how the municipal poor relief of Amsterdam between 1871 and 1940 operated with regard to civilization and bureaucracy. Two questions were raised.

1) What role did the pursuit of civilization play in the way municipal poor relief works?

2) How was the organization of municipal poor relief bureaucratised? First, I will address the question of the pursuit of civilization. The concept of a bourgeois civilization offensive as initiated by Bernard Kruithof served as a guideline for answering this question.

The poor had to be educated, it was supposed, because they themselves would be guilty of their impoverished condition. Their rough manners, their laziness, their shamelessness, and their lack of self-control meant that they could not use money wisely. As long as they had these bad qualities, the poor would always remain poor. The remedy for poverty was therefore seen in the education and civilization of the poor. Then, like the better-off citizens, they could lead a virtuous life without hunger or want.

What role did the civilization offensive play in the way of working for municipal poor relief? On the basis of the reports of the visitor of the poor and the annual reports of the municipal poor relief, a certain development can be discerned. In 1871, moral considerations played an important role in the rejection of applications. An unfavourable opinion of the visitor to the poor about the applicant's behaviour was more likely to lead to a rejection.

This also applied to the impression the visitor to the poor got of the wellbeing of the home. In 1871 this impression played a role in the granting or rejection of the application. In 1936, the visitor to the poor no longer gave an opinion on the well-being of the home. I related the level of prosperity of the home to the spending habits of the applicant. If no more judgment is given about the use of family income, and therefore also not about expenditure related to the furnishing of the home, this indicates a decrease in the need to regulate the behavior of the poor. It is no longer a matter for poor relief how the poor manage their finances. Attitude towards the poor has become more value-free.

The impression the visitor got of the hygienic condition of the house in 1871 played an important role in the decision whether or not to provide support. Applicants with a home that was considered unsanitary by the visitor to the poor received no support in more than half of the cases. In 1911 and 1936 there were no more reports on hygiene. Apparently it no longer played a role in decision-making. Hygiene is a criterion that is difficult to objectify and says more about the behavior of the applicant than about the actual poverty. The disappearance of the judgment about hygiene as a criterion has been interpreted as an indication that the behavior of the applicant is no longer in question and that business considerations in the decision-making are now decisive. An unsavoury home is no longer a reason to reject an application.

We also see an increasing objectivation in the grounds for rejection. In 1871 , half of the rejections were motivated by value-free motives. In 1911, 
value-free motives were decisive in two of the three applications. In 1936 it happened only sporadically that a moral consideration was involved in a rejection. The reification of grounds for rejection was practically completely.

The question of the role of the civilization offensive in municipal poor relief can now be answered as follows, taking all the foregoing into consideration. In 1871 this urge to civilization was still clearly present. The poor person's behavior was an important benchmark for refusing or allocating help. Gradually the idea that the poor had to comply with all kinds of norms and values became less and less important in decision-making. In 1936, there were almost exclusively value-free motives to substantiate acceptance or rejection. A process of reification was completed.

As a guideline for answering the second question, the question of the method of bureaucratization, served by the ideal type of bureaucracy that Max Weber explained. I have summarized Weber's theory of bureaucracy in the six main points below.

1) The development and growth of bureaucracy. As the government takes on more tasks, the need for well-functioning management grows. Old management systems are being replaced by bureaucratic management in which expert officials are employed.

2) The bureaucracy as part of the government. In modern society, government power is based on law. The bureaucracy derives its authority from legislation.

3) The position and function of the civil servant. Civil servants are appointed and have no additional positions. Civil servants are trained and work according to fixed principles, based on legal provisions.

4) The permanence of the bureaucracy. Once a bureaucracy has been established, it cannot simply be overthrown. It is indispensable for the performance of government management tasks. Chaos ensues without bureaucracy.

5) The dominance of the bureaucracy. Due to its indispensability, the power of the bureaucracy is very great. In Weber's view, the powerful bureaucracy can only be stopped by a bold and well-functioning democracy. The legislature is above the executive.

6) The principle of rationality. Bureaucratization is all about reification. Moral considerations do not play a role in decision-making. Purely rational considerations lead to decisions that are taken without regard to persons. In answering the question of how bureaucratization took place between 1870 and 1940, it must first be noted that the apparatus of municipal poor relief already exhibited some bureaucratic features as early as 1871 . Poor relief developed over the course of sixty years into a completely bureaucratic organization. The Poor Relief Committee (Burgerlijk Armbestuur), in theory an autonomous organization, became increasingly dependent on the municipal administration. The establishment of the Civil Institution for Social Support (Burgerlijke Instelling voor Maatschappelijken Steun) in 1927 strengthened this process. Poor relief became a full municipal service.

Three developments drove this bureaucratization. In the first place, the number of tasks of municipal poor relief increased considerably in the peri- 
od studied. Second, there was a significant increase in the number of applications for aid. And thirdly, as a result, there was a corresponding increase in the number of civil servants working for municipal poor relief. A bureaucratization of the method made it possible to carry out the many tasks and to handle the growing number of requests in a business-like and objective manner.

We also see the bureaucratization of the apparatus in the form in which aid was provided. Most of the aid in kind gave way to financial support. This development can be seen as a rationalization of poor relief.

The bureaucratization process of municipal poor relief can be incorporated into Weber's bureaucratization theory. The Poor Relief Committee (Burgerlijk Armbestuur), in principle an autonomous organization, predominantly occupied by urban elite, became increasingly dependent on the municipal administration. The establishment of the Burgerlijke Instelling voor Maatschappelijken Steun (the Civic institution for public aid) in 1927 strengthened this process. Poor relief became an entirely municipal service.

The bureaucracy also grew because the government took on more and more tasks. The need for well-functioning management, with expert, trained civil servants, increased as a result. An old management system was gradually replaced by bureaucratic management.

Poor relief became part of the city government. It has since derived its authority from legislation and no longer from the norms and values of elite. Civil servants started working according to fixed principles, based on legal provisions.

Although the bureaucracy's position of power was great, the well-functioning Amsterdam city council managed to limit the influence of overly power-hungry bureaucrats. Legislative power actually turned out to be above executive power.

Both developments reinforced each other. The bureaucratization process was dominated by reification. Moral considerations no longer played a role in decision-making. Purely rational considerations led to decisions taken without regard to persons.

Have the questions I asked been answered once and for all? Modesty is in order. Only part of the rich archive material has been consulted. A larger sample, with more than three sample years, may have revealed more nuances. Moreover, the archival material studied has not been exhaustively analysed. More indicators could have been examined. It is clear, however, that the two broad outlines have been made visible: a) the disappearance of moral principles in the provision of poor relief and b) the development of bureaucracy. I do realize that this archival research only relates to municipal poor relief. Private and ecclesiastical care has been left out of consideration for technical research reasons. This research is certainly not definitive. Moreover, new questions may arise that will lead to further investigations. One aspect that I have not addressed in this study is the discussion about the possible anti-social nature of the poor. Do poor people distinguish themselves from the rest of society by a different behavioural pattern and are they therefore anti-social? Besides accepting support, are there any other survival strategies of the poor in Amsterdam to survive? It could also be investigated whether there is intergenerational transmission of poverty in 
Amsterdam. Was poverty passed on from father to son, from mother to daughter? And where did the poor live? Was there social segregation? The geographic origin of the poor is also worth investigating. Are migrants more likely to fall into poverty than native inhabitants of Amsterdam? What about the poor themselves and their world of experience? How did they experience their poor circumstances and what did they think of the assistance? Answering all those questions will take a lot of research. The historiography is never finished. Many resources have not yet been or have not been fully utilized. Moreover, every new generation of historians will come up with new insights. That too will lead to new questions. 


\section{GERAADPLEEGDE ARCHIEVEN}

\section{Amsterdam: Stadsarchief Amsterdam (SAA)}

Toegangsnummer $\mathbf{3 4 3}$ Archief van de

Regenten van het Aalmoezeniersweeshuis en rechtsvoorganger

Toegangsnummer $\mathbf{3 4 7}$ Archief van het Spin- en Nieuwe Werkhuis

Toegangsnummer $\mathbf{3 4 9}$ Archief van het Nieuwezijds en het Oudezijds Huiszittenhuis en van de Regenten over de Huiszittende Stadsarmen

Toegangsnummer $\mathbf{3 5 0}$ Archief van het Burgerlijk Armbestuur

Toegangsnummer 5154 Archief van de Commissie inzake Reorganisatie van het Burgerlijk Armbestuur

Toegangsnummer 5186 Archief van de Secretarie; Afdeling Sociale Zaken en rechtsvoorgangers

Toegangsnummer 5256 Archief Gemeentelijke Sociale Dienst en rechtsvoorgangers

Toegangsnummer 5379 Archief van het CrisisComité Amsterdam 1931

Toegangsnummer 15030 Collectie Stadsarchief Amsterdam
DOSSIERS VAN DE BEZOEKEN

VAN DE ARMBEZOEKER ARCHIEF

GEMEENTELIJKE SOCIALE DIENST EN

RECHTSVOORGANGERS 5256

\section{JAARGROEP 1871}

\section{Doos 993}

Stamboeknummers 251; 252; 254; 255; 256; 257; $258 ; 259 ; 260 ; 261 ; 262 ; 263 ; 264 ; 268 ; 272 ; 277$; 278; 284 285; 288.

\section{Doos 996}

Stamboeknummers 1159; 1162; 1163.

\section{Doos 997}

Stamboeknummers 1301; 1303; 1304; 1305; 1306; 1307; 1364.

\section{Doos 1000}

Stamboeknummers 2014; 2016; 2017; 2018; 2019; 2020; 2021; 2026; 2027; 2063; 2065.

\section{Doos 1005}

Stamboeknummers 1642; 1644.

\section{Doos 1010}

Stamboeknummers 4635; 4646; 4647; 4648; 4649 ; 4650; 4651; 4652; 4653; 4654; 4655; 4656; $4657 ; 4658 ; 4659 ; 4660 ; 4670 ; 4674$.

\section{Doos 1175A}

Stamboeknummers 10a; 11; 12; 13; 14; 15; 16; 17; $18 ; 19 ; 21 ; 22 ; 23 ; 24 ; 25 ; 71 ; 72 ; 73 ; 74 ; 75 ; 76$; $77 ; 78 ; 79 ; 80$.

\section{Doos 1177}

Stamboeknummers 181; 182; 183; 184; 185; 187; 188 ; 189; 190; 201; 203; 204; 205; 206; 207; 208; $209 ; 210 ; 241 ; 242 ; 243 ; 244 ; 245 ; 246 ; 247 ; 248$; $249 ; 250 ; 261 ; 263 ; 264 ; 265 ; 266 ; 268 ; 269$.

\section{JAARGROEP 1911}

\section{Doos 1044}

Stamboeknummers 12631; 12632; 12633; 12634; $12635 ; 12636$; 12637; 12638; 12639; 12640; $12676 ; 12712 ; 12713 ; 12714 ; 12715 ; 12716 ; 12717$; $12718 ; 12719 ; 12720 ; 12761 ; 12762 ; 12764 ; 12765$; 
12766; 12768; 12769; 12770; 12870; 12872; 12873; 12874; 12875; 12876; 12877; 12878; 12879; 12880; 12921; 12923; 12924; 12925; 12926; 12927; 12928; 12929; 12930; 12982; 12983; 12984; 12985; 12986; 12987; 12988; 12989; 12990; 12991; 12992; 12993; 12994; 12995; 12996; 12997; 12998; 12999; 13041; $13042 ; 13043 ; 13044 ; 13045 ; 13046 ; 13047$; $13049 ; 11350$.

\section{Doos 1305}

Stamboeknummers 5481.

\section{Doos 1467}

Stamboeknummers 11237; 11249; 11250.

\section{Doos 1469}

Stamboeknummers 11293; 11312; 11253; 11259; 11268.

\section{Doos 1470}

Stamboeknummers 11328; 11329; 11337; 11339; 11351; 11365; 11369; 11378.

\section{Doos 1471}

Stamboeknummers 11396; 11399; 11403; 11400; $11405 ; 11419$.

\section{Doos 1472}

Stamboeknummers 11450; 11468.

\section{Doos 1473}

Stamboeknummers 11049; 11436.

\section{Doos 1474}

Stamboeknummers 11556; 11559; 11532; 11040; 11041.

\section{Doos 1475}

Stamboeknummers 11586; 11593; 11595; 11598; $11609 ; 11612$.

\section{Doos 1476}

Stamboeknummers 11638; 11643; 11665; 11672.

\section{Doos 1478}

Stamboeknummers 11731; 11735; 11749; 11755; 11772; 11775; 11777; 11691; 16695; 11717.

\section{Doos 1479}

Stamboeknummers 11839; 11836; 11833; 11828; 11825; 11820; 11818; 11808; 11805; 11800.

\section{JAARGROEP 1936}

\section{Doos 7520}

Stamboeknummers 163971; 163972; 163973; 163974; 163975; 163976; 163977; 163978; 163979; 163980; 163981; 163982; 163983; 163984; 163985; 163986; 163987; 163989; 163990; 163991; 163993; 163994; 163995; 163996; 163997; 163998; 163999; 164000; 164001; 164002; 164003; 164004; 164005; 164006; 164007; 164008; 164009; 164010; 164011; 164012; 164013; 164014; 164015; 164016; 164017; 164018; 164019; 164020; $164021 ; 164022 ; 164023 ; 164024 ; 164025$; $164026 ; 164027$.

\section{Doos 7522}

Stamboeknummers 164028; 164029; 164030; 164031; 164032; 164033; 164034; 164035; 164036 ; 164037; 164038; 164039; 164040; $164041 ; 164042 ; 164043 ; 164044 ; 164045$; 164046; 164047; 164048; 164049; 164050; $164051 ; 164052 ; 164053 ; 164054 ; 164055$; 164056 ; 164057; 164058; 164059; 164060; $164061 ; 164062 ; 164063 ; 164064$.

\section{Doos 7523}

Stamboeknummers 164065; 164067; 164068; 164070; 164071; 164072; 164073; 164074; 164075; 164077; 164078; 164079; 164081; $164085 ; 164090 ; 164091$.

\section{Doos 7524}

Stamboeknummers 164100; 164113; 164116; 164118; 164123.

\section{Doos 7525}

Stamboeknummers 164133; 164136; 164137; $164139 ; 164141 ; 164142$.

\section{Doos 7526}

Stamboeknummers 164155; 164156; 164162; 164163. 
ABEL, WILHELM (1966), Agrarkrisen und Agrarkunjunktur. Eine Geschichte der Land- und Ernährungswirtschaft Mitteleuropas seit dem Hohen Mittelalter. Hamburg/Berlin: Verlag Paul Parey. (tweede druk/eerste druk 1935)

ABEL, WILHELM (1974), Massenarmut und Hungerkrisen im Vorindustriellen Europa: Versuch einer Synopsis. Hamburg/Berlin: Verlag Paul Parey.

ABEL, WILHELM (1981), Stufen der Ernährung. Eine historische Skizze. Göttingen: Vandenhoeck \& Ruprecht.

ADANG, MARC (2008), Voor sociaal-democratie, smaakopvoeding en verheffend genot. De Amsterdamse vereniging Kunst aan het Volk, 1903-1928. Amsterdam: Aksant.

ALTENA, BERT (1994), 'Bürger in der Sozialdemokratie. Ihre Bedeutung für die Entwicklung der Sozialdemokratischen Arbeiterpartei (SDAP) in den Niederlanden 1894-1914' in: Geschichte und Gesellschaft 20, 533-548.

AMSENGA, JUDITH (2005), 'Het beschavingsoffensief van de negentiende eeuw. Het volk is 'bandeloos, onbeschaafd, zuipend en onverstaanbaar' ' in: Historisch Nieuwsblad.

BAGGERMAN, A. EN DEKKER, R. (1998), Het dagboek van Otto van Eck (1780-1797). Hilversum: Verloren.

BEEKERS, W. (2012), Het bewoonbare land. Geschiedenis van de volkshuisvesting in Nederland. Meppel: Boom.

BERTING, J. (1968), In het brede maatschappelijke midden: een studie over middelbare administratieve employés in 9 grote organisaties in Amsterdam. Amsterdam: Boom \& Zn.

BERTING, J. (1985), 'In het brede maatschappelijke midden: de veranderende positie van de middengroepen in de Nederlandse samenleving tussen 1850-1980', in: Holthoon, F.L. van (red.), De Nederlandse samenleving sinds 1815. Assen: Van Gorcum, 119-138.

\section{BLOCKMANS, W.P. EN PREVENIER, W.}

(1975), 'Armoede in de Nederlanden van de $14 \mathrm{e}$ tot het midden van de 16 e eeuw: bronnen en problemen' in: Tijdschrift voor Geschiedenis 88, 501-535.
BLOEMGARTEN, S. (1993), Henri Polak, sociaal democraat, 1868-1943. 's-Gravenhage: SDU.

BOELE, ANITA (2013), Leden van één lichaam. Denkbeelden over armen, armenzorg en liefdadigheid in de Noordelijke Nederlanden 1300 1650. Hilversum: Verloren.

BOOT, J.P. (HANS) (2011), Opstandig volk. Neergang en terugkeer van losse havenarbeid. Amsterdam: Solidariteit.

BORNEWASSER, J.A. (1975), 'Ministeriele verantwoordelijkheid voor en na 1848' in: Vaderlands Verleden in Veelvoud. Den Haag: Martinus Nijhoff, 453-480.

BORRIE, G.W.B. (1968), F.M. Wibaut. Mens en magistraat. Ontstaan en ontwikkeling der socialistische gemeentepolitiek. Assen: Van Gorcum \& Comp. N.V.

BOS, DENNIS (2001), Waarachtige volksvrienden. De vroege socialistische beweging in Amsterdam, 1848-1894. Amsterdam: Bakker.

BOSCH KEMPER, J. DE (1860), Geschiedkundig onderzoek naar de armoede in ons vaderland, hare oorzaken en de middelen die tot hare vermindering zouden kunnen worden aangewend. Haarlem: De Erven Loosjes.(tweede druk 1860/eerste druk 1851)

BRAAM, A. VAN (1957), Ambtenaren en bureaukratie in Nederland. Zeist: W. De Haan.

BRAAM, A. VAN (1977), 'Bureaucratiseringsgraad van de plaatselijke bestuursorganisatie van Westzaandam ten tijde van de Republiek' in: Tijdschrift voor Geschiedenis 90, 457-484.

\section{BRAAM, A. VAN EN BEMELMANS-VIDEC,}

M.L. (1986), Leerboek bestuurskunde. Muiderberg: Coutinho.

BRAUN, RUDOLF (1979), Industrialisierung und Volksleben. Veränderungen der Lebensformen unter Einwirkung der verlagsindustriellen Heimarbeit in einem ländlichen Industriegebiet (Zürcher Oberland) vor 1800. Göttingen: Vandenhoeck \& Ruprecht. (tweede druk/eerste druk 1960)

BRINK, G. VAN DEN (2004), Schets van een beschavingsoffensief. Over normen, normaliteit en normalisatie in Nederland. Amsterdam: Amsterdam University Press.

BRUGMANS, I.J. (1960), 'Standen en klassen 
in Nederland gedurende de negentiende eeuw', in: Bijdragen en Mededelingen betreffende de Geschiedenis der Nederlanden 74, *30-*50.

(paginering volgens apart tekstdeel Verslag van de Algemene Vergadering van de leden van het Historisch genootschap, gehouden op 2 november 1959)

BRUGMANS, I.J. (1961), Paardenkracht en Mensenmacht. Sociaal-economische geschiedenis van Nederland 1795-1940. Den Haag: Martinus Nijhoff.

BUCHNER, THOMAS (2013), 'Arbeitsmärkte ordnen oder konstruieren? Öffentliche Arbeitsnachweise in Deutschland (circa 1890 bis 1914)' in: Vierteljahrschrift für Sozial- und Wirtschaftsgeschichte 100, 292-310.

BURKE, P. (1978), Popular culture in early modern Europe. New York: New York University Press.

BURKE, P. (2015), The French historical revolution. The Annales School 1929-2014. Cambridge: Polity Press.

CHEVALIER, LOUIS (1958), Classes laborieuses et classes dangereuses pendant la première moitié du XIXe siècle. Paris: Editions Perrin.

CLERCQ, GERRIT DE (1848), 'De buitengewone Armenbedeeling te Amsterdam in 1847. Rapport der Algemeene Commissie ter ondersteuning van behoeftigen aan Heeren Burgemeesteren en Wethouderen der stad Amsterdam, 1847' in: De Gids 12, 369-380.

COUPERUS, STEFAN (2009), De machinerie van de stad. Stadsbestuur als idee en praktijk, Nederland en Amsterdam 1900-1950. Amsterdam: Aksant.

DAMSMA, D. (1999), Familieband. Geschiedenis van het gezin in Nederland. Utrecht en Antwerpen: Kosmos-Z\&K.

DASSEN, PATRICK (1999), De onttovering van de wereld. Max Weber en het probleem van de moderniteit in Duitsland, 1890-1920. Amsterdam: Van Oorschot.

DAVIDS, K., EN HART, M. 'T (2011), De wereld \& Nederland. Een sociale en economische geschiedenis van de laatste duizend jaar. Amsterdam: Boom.

DELMOTTE, FLORENCE (2010), 'Une théorie de la civilisation face à "l'effondrement de la civilisation " ' in: Vingtième Siècle. Revue d'histoire (avril-juin 2010), 55-70.

DELSEN, LEI (2019), 'Armoede meten was, is en blijft arbitrair, maar zinvol' in: Annalen van het Thijmgenootschap 107 afl. 1, 30-57.

DELUERMOZ QUENTIN (2010), 'Norbert Elias et le XXe siècle. Le processus de civilisation à l'épreuve' in: Vingtième Siècle. Revue d'histoire (avril-juin 2010), 19-28.

DERLIEN, HANS-ULRICH, BÖHME, DORIS EN HIENDL, MARKUS (2011), Bürokratietheorie.

Einführung in eine Theorie der Verwaltung. Wiesbaden: VS Verlag für Sozialwissenschaften.

DIJK, HENK VAN (1976), Rotterdam 1810-

1880. Aspecten van een stedelijke samenleving. Schiedam: Interbook International B.V.

DILLEN, J.G. VAN (1949), Omstandigheden en psychische factoren in de economische geschiedenis van Nederland. Groningen etc.: Noordhoff. (inaugurele rede)

DRUKKER, J.W. (1990), Waarom de crisis hier langer duurde. Over de Nederlandse economische ontwikkeling in de jaren dertig. Nederlandsch Economisch-Historisch Archief: Amsterdam.

DRUKKER, J.W. (2003), De revolutie die in haar eigen staart beet. Amsterdam: Boom Lemma Uitgevers.

DUERR, HANS PETER (1988-2002), Der Mythos vom Zivilisationsprozeß. Band 1: Nacktheit und Scham (1988); Band 2: Intimität (1990); Band 3: Obszönität und Gewalt (1993); Band 4: Der erotische Leib (1997); Band 5: Die Tatsachen des Lebens (2002). Frankfurt am Main: Suhrkamp.

EIJL, C. VAN EN SANDERS, B. (1986), Beschavingsbeleid en realiteit. Vooruitgang en stagnatie in de ontwikkeling van de levensomstandigheden van Amsterdamse arbeiders 1850 - 1920. (Onuitgegeven doctoraalscriptie RUU)

EIJL, C. VAN, GROOT, G. DE EN SANDERS, B. (1990), 'Armenzorgrapporten als historische bron. Een blik op het dagelijks leven' in: Jansen, G.J. e.a., Hoe krijg ik mijn bronnen aan de praat? Ideeën voor een geschiedschrijving van onderaf. Utrecht: Vulga, 54-76.

ELIAESON, SVEN (2005), 'Max Weber: made in the USA?', in: Etica \& Politica / Ethics \& Politics. $\mathrm{VI}, 2,1-30$.

ELIAS, N. (1969), Die höfische Gesellschaft. Untersuchungen der Soziologie des Königtums und der höfischen Aristokratie. Neuwied-Berlin: 
Luchthand.

ELIAS, NORBERT (1969), Über den Prozeß der Zivilisation. Soziogenetische und psychogenetische Untersuchungen. Bern: Verlag Franke AG (eerste druk 1939). Band I Wandlungen des Verhaltens in den weltlichen Oberschichten des Abendlandes. Band II Wandlungen der Gesellschaft. Entwurf zu einer Theorie der Zivilisation.

ENGBERSEN, GODFRIED (1991), 'Moderne armoede: feit en fictie' in: Sociologische Gids (38) 7-23.

ENGBERSEN, GODFRIED (2000), Arm Nederland. Balans van het armoedebeleid. Vijfde jaarrapport. Armoede en sociale uitsluiting. Amsterdam: Amsterdam University Press.

FABER, J.A. (1976), Dure tijden en hongersnoden in preïndustrieel Europa. Zp: Rodopi. (inaugurele rede)

FILARSKI, RUUD (2014), Tegen de stroom in. Binnenvaart en vaarwegen vanaf 1800. Utrecht: Matrijs.

\section{FRIJHOFF, WILLEM EN WESSELS, LEO (2006)}

EDS., Veelvormige dynamiek. Europa in het ancien régime 1450-1800. Amsterdam/Heerlen: SUN/Open Universiteit Nederland.

\section{GEMEENTELIJK BUREAU VAN STATISTIEK}

(1897-1941), Statistisch jaarboek der Gemeente Amsterdam. 1895-1939. Amsterdam: Gemeente Amsterdam/J.M. Meulenhoff.

GEREMEK, BRONISLAW (1991), Geschichte der Armut. Elend und Barmherzigkeit in Europa. München: Deutscher Taschenbuch Verlag.

GEUZEBROEK, NANDA (2020), Vondelingen.

Het Aalmoezeniersweeshuis van Amsterdam 1780-1830. Hilversum: Verloren.

GIELE, J. (1976), 'Arbeidersbestaan. Levenshouding en maatschappijbeeld van de arbeidende klasse in Nederland in het midden van de negentiende eeuw'. in: Jaarboek voor de geschiedenis van socialisme en arbeidersbeweging 1976, 21 91.

\section{GIELE, JACQUES EN OENEN, GERT JAN}

VAN (2019), 'De sociale structuur van de $\mathrm{Ne}$ derlandse samenleving rond 1850.'in: Giele, Jacques, Hoe zag Nederland er in 1850 uit? Utrecht: Kelderuitgeverij, 58-95. Oor. in Mededelingenblad. Orgaan van de Nederlandse vereniging ten behoeve van sociale geschiedenis 45 (1974), 2-32.
GINKEL, ROB VAN (1995), 'A Dutch Sodom and Gomorrah: Degenerates, Moralists and Authority in Yerseke, 1870-1914' in: Crime, Law and Social Change, 24, 223-239.

GINKEL, ROB (2004), 'Re-creating 'Dutchness': cultural colonisation in post-war Holland' in: $\mathrm{Na}$ tions and Nationalism 10 (4), 421-438.

GINKEL, ROB VAN (2015), 'Containing the urban poor - coercion or consent? Disciplining missions and civilising offensives in the Netherlands' in: Human Figurations $(4,1) \mathrm{http}: / /$ hdl. handle.net/2027/spo.11217607.0004.107

GOODARE, JULIAN (2016), The European Witch-Hunt. London: Routledge.

GOUDA, FRANCES (1995), Poverty and political culture. The rhetoric of social welfare in the Netherlands and France, 1815-1854. Amsterdam: Amsterdam University Press.

GOODMAN, A. (1988), The New Monarchy: England, 1471-1534. Oxford: Blackwell Publishers.

GOUDSBLOM, J. (1995), 'De civilisatietheorie: kritiek en perspectief' in: Amsterdams Sociologisch Tijdschrift 22, 262-282.

GRIFFITHS, R.T. (1979), Industrial retardation in the Netherlands 1830-1850. Den Haag: Martinus Nijhoff.

GROENVELD, S., DEKKER, J.J.H. EN WILLEMSE, TH.R.M. (1997), Wezen en boefjes. Zes eeuwen zorg in wees- en kinderhuizen. Hilversum: Verloren.

GROOT, F. (1987) ' "Het zou een Janboel worden". Steunfraude en haar bestrijding in Amsterdam 1930-1940' in: Tijdschrift Voor Sociale Geschiedenis 13, 243-271.

GROOT, G. DE (1988), 'Door slapte "gedaan" gekregen. Losse arbeiders en hun gezinnen in Amsterdam tussen 1880 en 1920' in: Tijdschrift Voor Sociale Geschiedenis 14 (1988) 160-187.

HAGOORT, L., Inventaris van het Archief van de Secretarie; Afdeling Sociale Zaken en rechtsvoorgangers, SAA 5186 ( zj, zp).

HAKS, D. (1982), Huwelijk en gezin in Holland in de 17de en 18de eeuw. Assen: Van Gorcum. HALL, C. (1979), 'The early formation of Victorian domestic ideology' in: Berman, S. (ed.), Fit work for women. New York: St. Martin's Press, 15-33.

HALL, C. (1980), 'The history of the housewife' 
in: Madus, E., The politics of housework. London: Allison \& Busby, 45-71.

HARDING, DAVID J., LAMONT, MICHĖLE EN SMALL, MARIO LOUIS (2010), 'Reconsidering Culture of Poverty' in: The annals of the American Academy of political and social science (mei 2010), 629-656.

HEERMA VAN VOSS, A.F (1992),' "Het subtiel te beoordelen begrip der gezondheid". Was de crisis van de jaren dertig slecht voor de gezondheidstoestand?' in: Blockmans, W.P. en Valk, L.A. van der (red.), Van particuliere zorg naar openbare zorg en terug? Amsterdam: Neha, 121-138.

HEERMA VAN VOSS, L. (2011), 'Nieuwe mogelijkheden, nieuwe waarden en normen: sociaal-culturele ontwikkelingen' in: Davids, K., en Hart, M. 't (red.), De wereld \& Nederland. Een sociale en economische geschiedenis van de laatste duizend jaar. Amsterdam: Boom, 277-328. HEERMA VAN VOSS, L. EN LEEUWEN, M.H.D. VAN (2012), 'Charity in the Dutch Republic: an introduction', in: Continuity and Change 27, 175-197.

HELDRING, OTTO GERHARD (1844), In het zweet uwes aanschijns zult gij brood eten! Een volksboek, behandelende de vraag: Hoe de armoede te stuiten, en eigen verdiend brood den huisgezinnen te verschaffen? Arnhem: G. van Eldik Thieme.

\section{HEIJDEN, MANON VAN DER HEIJDEN EN} SCHMIDT, ARIADNE (2007), 'In dienst van de stad. Vrouwen in stedelijke ambten, Holland 1500-1800', in: Tijdschrift voor sociale en economische geschiedenis,3-34.

HICKEY, DANIEL (1997), Local hospitals in Ancien Régime France. Rationalization, resistance, renewal 1530-1789. London/Buffelo: McGill-Queen's University Press.

HIRSCH, J. (1995), Der Nationale Wettbewerbsstaat. Staat, Demokratie und Politik im globalen Kapitalismus. Berlin/Amsterdam: Edition ID-Archiv.

HOFFER, W. J. H. (2007), To enlarge the machinery of government. Congressional debates and the growth of the American state, 1858-1891.

Baltimore: Johns Hopkins University Press.

HOFLAND, PETER (1998), Leden van de Raad. De Amsterdamse gemeenteraad 1814-1941. Amsterdam: Gemeentearchief Amsterdam.
HOLTHOON, F.L. VAN (1985), 'De armenzorg in Nederland' in: F.L. van Holthoon (red.), De Nederlandse samenleving sinds 1815. Wording en samenhang. Assen-Maastricht: Van Gorcum, 175-186.

HOOGENBOOM, MARCEL (2004), Standenstrijd en zekerheid. Een geschiedenis van oude orde en sociale zorg in Nederland. Amsterdam: Boom.

HOOP, L. DE (2010), De rode dominee. A.S. Talma. Amsterdam: Boom.

HOUWAART, E.S. (1991), De hygiënisten. Artsen, staat en volksgezondheid in Nederland 1840 - 1890. Groningen: Historische Uitgeverij Groningen.

HUFTON, OLWEN H. (1974), The Poor of eighteenth-century France, 1750-1789. Oxford: Clarendon Press.

HÜBINGER, G. (2019), Max Weber. Stationen und Impulse einer intellektuellen Biographie. Tübingen: Mohr Siebeck.

HUNT, L. (1986), 'French history in the last twenty years: The rise and fall of the Annales paradigm' in: Journal of Contemporary History 21, 209-224.

INVENTARIS ARCHIEF VAN DE WERKLOOSHEIDSCOMMISSIES, 5408 SAA (z.j.; z.p.) IGGERS, GEORG, (1978), Neue Geschichtswissenschaft. Vom Historismus zur historischen Sozialwissenschaft. Ein internationaler Vergleich. München: Deutscher Taschenbuch Verlag.

JANSEN, P.C. (1975), 'Armoede in Amsterdam aan het einde van de achttiende eeuw' in: Tijdschrift voor Geschiedenis 88, 613-625.

JONES, GARETH STEDMAN (2013), Outcast London: A study in the relationship between classes in Victorian society. London: Verso Books. (herdruk/eerste druk 1971).

JONG, HERMAN DE EN ZANDEN, JAN LUITEN VAN (2014), 'Debates on industrialisation and economic growth in the Netherlands' in: Tijdschrift voor Sociale en Economische geschiedenis 11, 85-111.

JONGE, J.A., DE (1976), De industrialisatie in Nederland tussen 1850 en 1914. Amsterdam:

Scheltema \& Holkema.

JÜTTE, ROBERT (1994), Poverty and deviance in Early Modern Europe. Cambridge (etc.): Cambridge University Press. 
KAAIJ, MEINDERT VAN DER (2012), Een eenzaam staatsman. Dirk de Geer (1870-1960). Hilversum: Verloren.

KAAL, H. (2008), Het hoofd van de stad. Amsterdam en zijn burgemeester tijdens het interbellum. Amsterdam: Aksant. (over W. de Vlugt)

KAPPELHOF, TON EN KINGMA, VIBEKE (2004), Onderzoeksgids Sociale Zekerheid 18901967. Den Haag: Huygens Instituut voor Nederlandse Geschiedenis.

KAPPELHOF, A.C.M. (2005), 'Inleiding' in:

Broncommentaren 6. Bronnen met betrekking tot armenzorg en sociale zekerheid in de negentiende en twintigste eeuw. Den Haag: Instituut voor Nederlandse geschiedenis, 7-36.

KAPTEIN, HERMAN (1984), Armenzorg in de aanslag. Armoede en bedeling in De Rijp 18501914. Bergen (NH): Octavo.

KAPTEIN, HERMAN (2017), Nijverheid op windkracht. Energietransities in Nederland 15001900. Hilversum: Verloren.

KARSTEN, SJOERD (2019), De rode bovenmeester. De humanistische pedegoog en sociaaldemocratische politicus A.H. Gerhard, 18581948. Zp: Papieren tijger.

KNIPPENBERG, H., EN PATER B. DE (1988), De eenwording van Nederland. De eenwording van Nederland: schaalvergroting en integratie sinds 1800. Nijmegen: SUN.

KNÖBL, WOLFGANG (2003), 'Theories that won't pass away: The never-ending story of modernization theory' in: Gerard Delanty, Engin F. Isin, (eds.), Handbook of historical sociology. London: Sage, 96-107.

KNOTTER, A. EN MUSKEE, H. (1986), 'Conjunctuur en levensstandaard in Amsterdam 1815$1855^{\prime}$ in: Tijdschrift voor Sociale Geschiedenis 12, 153-181 (ingrijpende bewerking van de M.O. scriptie van Hans Muskee)

KNOTTER, AD (1991), Economische transformatie en stedelijke arbeidsmarkt. Amsterdam in de tweede helft van de negentiende eeuw. Zwolle/ Amsterdam: Waanders Uitgevers/Gemeentearchief Amsterdam.

KNOTTER, AD (1997), 'De steundossiers in de archieven van de gemeentelijke sociale dienst en voorgangers te Amsterdam (1870-1995)', in: Klep, P.M.M. (red.), Steekproeven uit massale archiefbestanden ter wille van het historisch belang. Den Haag: Koninklijke Vereniging van Archivarissen in Nederland, 65-94.

KNOTTER, AD (1998), 'Gezinsarmoede-gezinsarbeid: de invloed van de gezinscyclus op de inkomsten van gezinnen van losse (haven)arbeiders in Amsterdam in de eerste helft van deze eeuw' in: Tijdschrift voor Sociale Geschiedenis 24, 371-401.

KNOTTER, A. EN KOK, P.T. (2005), 'De persoonsdossiers van de gemeentelijke armenzorg tot aan de invoering van de Algemene Bijstandswet (1965)' in: Broncommentaren 6. Bronnen met betrekking tot armenzorg en sociale zekerheid in de negentiende en twintigste eeuw. Den Haag: Instituut voor Nederlandse geschiedenis, 73-101. KNOX, PAUL L. EN MARSTON, SALLIE A. (2016), Human geography. Places and regions in global context. Harlow: Pearson Education Limited. (zevende druk/eerste druk 1988)

KOK, JAN (1999), Levensloop en levenslot. Arbeidsstrategieën van gezinnen in de negentiende en twintigste eeuw. Groningen/Wageningen: Nederlands Agronomisch Historisch Instituut.

KOK, J., MANDEMAKERS K. EN WALS, H. (2003) '"Toen scharrelde ze met haar hele zoodje naar een derde-achterkamer". Verhuizen als bestaansstrategie', Amsterdam 1890-1940.' in: Tijdschrift voor Sociale Geschiedenis 29, 333360.

KOK, P. T. (2000), Burgers in de bijstand. Werklozen en de ontwikkeling van de sociale zekerheid in Leeuwarden van 1880 tot 1930. Franeker: Van Wijnen.

KOOIJ, P. (1985), 'Stad en platteland' in: Holthoon, F.L. van (red.), De Nederlandse samenleving sinds 1815. Wording en Samenhang. Assen/ Maastricht: Van Gorcum, 93-118.

KOOIJ, PIM (1987), Groningen 1870-1914. Sociale verandering en economische ontwikkeling in een regionaal centrum. Assen: Van Gorcum.

KORT, ALBERT (2001), Geen cent te veel. Armoede en armenzorg op Zuid-Beveland, 1850 1930. Hilversum: Verloren.

KRIEDTE, PETER (1978), 'Die Proto-Industrialisierung zwischen Industrialisierung und De-Industrialisierung' in: Kriedte, Peter, Medick, Hans en Schlumbohm, Jürgen, Industrialisierung vor der Industrialisierung. Göttingen: Vandenhoeck \& Ruprecht. 
KRIEDTE, PETER (1980), Spätfeudalismus und Handelskapital. Grundlinien der europäischen Wirtschaftsgeschichte vom 16. bis zum Ausgang des 18. Jahrhundert. Göttingen: Vandenhoeck \& Ruprecht.

KRIEKEN, R. VAN (1989), 'Violence, self-discipline and modernity: beyond the "civilizing process"' in: Sociological Review 37, 193-218.

KRIEKEN, R. VAN (1999) 'The barbarism of civilization: cultural genocide and the "stolen generations"' in: British Journal of Sociology 50 (2), 297-315.

KRUITER, ALBERT JAN (2010), Mild despotisme. Democratie en verzorgingsstaat door de ogen van Alexis de Tocqueville. Amsterdam: Van Gennep.

KRUITHOF, BERNARD (1980), 'De deugdzame natie. Het burgerlijk beschavingsoffensief van de Maatschappij tot Nut van 't Algemeen tussen 1784 en 1860' in: Symposion, Tijdschrift voor maatschappijwetenschappen,22-37.

KRUITHOF, BERNARD (1983), 'De deugdzame natie. Het burgerlijk beschavingsoffensief van de Maatschappij tot Nut van 't Algemeen tussen 1784 en 1860' in: Kruithof, Bernard, Noordman, Jan en Rooy, Piet de (red.), Geschiedenis van opvoeding en onderwijs. Inleiding, bronnen, onderzoek. Nijmegen: SUN, 371-385. (tweede, herziene druk)

KRUITHOF, B. (2015), 'The Dutch bourgeois civilising offensive in the nineteenth century' in: Human Figurations $(4,1)$ http://hdl.handle. net/2027/spo.11217607.0004.102

LABRIJN, A. (1945), Het klimaat van Nederland gedurende de laatste twee en een halve eeuw. Schiedam: H.A.M. Roelants.

LALOLI, H. Dockworkers moving through the city: residential mobility and social segregation in Amsterdam 1890-1940. (zp, zj, zu)

LALOLI, H. (2007), Beter Wonen. Woningmarkt en residentiële segregatie in Amsterdam 18501940. (zp, zu)

LASCH, CHRISTOPHER (1977), Haven in a Heartless World. The Family Besieged. New York: Basic Books.

LAUWEN, LUSANNE (2017), 'Zo verklaaren wy ons te stellen gelyk wy doen mits deezen tot Borgen...' Een historisch-sociolinguïstisch onderzoek naar de uniformiteit in laat 18e-eeuwse borgbrieven uit Noord-Brabant. Masterscriptie
Neerlandistiek: Taalkunde MA Neerlandistiek Universiteit Leiden.

LEEUWEN, M. H.D. VAN (1992), Bijstand in Amsterdam, ca. 1800-1850. Armenzorg als beheersings- en overlevingsstrategie. Zwolle: Waanders. (proefschrift uit 1990)

LEEUWEN, M.H.D. VAN (1994), Sociale zorg. Zutphen: Walburgpers.

LEEUWEN, M.H.D. VAN (1996), 'Amsterdam en de armenzorg tijdens de Republiek' in: NEHA-Jaarboek voor economische-, bedrijfs- en techniekgeschiedenis 95, 132-161.

LEEUWEN, M.H.D. VAN (1998)A, 'Armenzorg 1800-1912: erfenis van de Republiek' in: Gerwen, J. van en Leeuwen, M.H.D. van (red.), Studies over zekerheidsarrangementen. Risico's, risicobestrijding en verzekeringen in Nederland vanaf de Middeleeuwen Amsterdam/Den Haag: Nederlandsch Economisch Historisch Archief, 276-326.

LEEUWEN, M.H.D. VAN (1998)B, 'Armenzorg 1912-1965: van centrum naar periferie' in: Gerwen, J. van en Leeuwen, M.H.D. van (red.), Studies over zekerheidsarrangementen. Risico's, risicobestrijding en verzekeringen in Nederland vanaf de Middeleeuwen Amsterdam/Den Haag: Nederlandsch Economisch Historisch Archief, 520-569.

LEEUWEN, M.H.D. VAN (1998)C, 'Opbloei van de charitas na 1965' in: Gerwen, J. van en Leeuwen, M.H.D. van (red.), Studies over zekerheidsarrangementen. Risico's, risicobestrijding en verzekeringen in Nederland vanaf de Middeleeuwen Amsterdam/Den Haag: Nederlandsch Economisch Historisch Archief, 759-806.

LEEUWEN, MARCO M.H. VAN (2000), The logic of charity. Amsterdam 1800-1850. Londen: Macmillan Press.

LEEUWEN, MARCO H.D. VAN, MAAS, INEKE, MILES, ANDREW (2002), HISCO. Historical international standard classification of occupations. Leuven: Leuven University Press.

LEEUWEN, MARCO H.D, VAN (2003), 'Kerk, staat en burger. Armenzorg en modern charitas, 1795-2001' in: Geschiedenis van Holland deel IIIB 1795 tot 2000. Hilversum: Verloren, 434-483.

LEEUWEN, M.H.D. VAN EN MAAS, I, (2007) 'Economische specialisering en veranderende sociale verhoudingen in de 19 e en 20 e eeuw. Een studie op basis van de Nederlandse volkstel- 
lingen en huwelijksakten', in: Boonstra, O.W.A. e.a. (red.), Twee eeuwen Nederland geteld. Onderzoek met de digitale Volks-, Beroeps- en Woningtellingen 1795-2001. Den Haag: DANS Symposium publicaties, 181-205.

LEEUWEN, M.H.D. VAN (2007), Poor relief and guild welfare in the early modern era, bureaucracies or not? Church, state and citizen in the Dutch republic. Paper for the conference 'Civil society and public services in Early Modern Europe, z.p.

LEEUWEN, MARCO H.D. VAN, MAAS, INEKE (2011), HISCLASS. A historical international social class scheme. Leuven: Leuven University Press. LEHMANN, HARTMUT (2008), Die Entzauberung der Welt. Studien zu Themen von Max Weber. Göttingen: Wallstein Verlag.

LEYDESDORFF, SELMA (1987), Wij hebben als mens geleefd. Het Joodse proletariaat van Amsterdam 1900-1940. Amsterdam: Meulenhoff. LIAGRE BÖHL, H. DE (2013), Wibaut de machtige: een biografie. Amsterdam: Prometheus.

LIMPERG, TIES EN VAN DER LINDE, MAARTEN (2019), Liefdadigheid naar Vermogen. Door en voor Amsterdamse burgers 1871-1941. Hilversum: Verloren.

LINDE, MAARTEN VAN DER (2016), Basisboek. Geschiedenis sociaal werk in Nederland. Amsterdam: Uitgeverij SWP. (zesde druk/eerste druk 2007)

\section{LINDE, JANINE TER, EN ZON, SASCHA VAN} DER (1998), Armoede in Nederland in de jaren '20 en '30. (Scriptie Educatieve Faculteit Amsterdam, afdeling Geschiedenis)

LIS, C. EN SOLY, H. (1977), 'Food Consumption in Antwerp between 1807 and 1859: a Contribution to the Standard of Living Debate' in: The Economic History Review: a journal of economic and social history 30, 460-486.

LIS, CATHERINA EN SOLY, HUGO (1980), Armoede en kapitalisme in pre-industrieel Europa. Antwerpen/Amsterdam: Standaard/Wetenschappelijke uitgeverij.

LOO, L.F. VAN. (1982), "Den arme gegeven...": een beschrijving van armoede, armenzorg en sociale zekerheid in Nederland, 1784-1965. Meppel: Boom.

LOO, L. F. VAN, (1986), Armelui. Armoede en bedeling te Alkmaar 1850-1914. Bergen: Octavo.
MAAS, JAN VAN DER (1981), De consumptie van de aardappel van het midden van de achttiende tot het begin van de negentiende eeuw in Holland. (Onuitgegeven doctoraalscriptie Economisch-Historisch Seminarium, Universiteit van Amsterdam)

MAAS, JAN VAN DER EN NOORDEGRAAF, LEO (1983), 'Smakelijk eten. Aardappelconsumptie in Holland in de achttiende eeuw en het begin van de negentiende eeuw' in: Tijdschrift voor sociale geschiedenis, 9, 188-221.

MALTHUS, R. (1798), An Essay on the Principle of Population. London: St. Paul's church-yard. (Onder het pseudoniem J. Johnson uitgegeven) MANDEMAKERS, C.A (2001), 'De sociale structuur in Nederland rond 1900. De samenleving in het perspectief van de modernisering 18501990', in: Maarseveen, J.G.S.J. van en Doorn, P.K. (red.), Nederland een eeuw geleden geteld. Een terugblik op de samenleving rond 1900. Amsterdam/Voorburg: UITGEVERIJ, 185-207.

MARTIN, A.M. (1997), Tussen traditie en vernieuwing. Ruimtelijke transformaties van Maastricht 1650-1905. Zwolle: Waanders.

MARTIN, A.M. (2003), 'De ruimtelijke transformaties van Maastricht na 1800' in: Bulletin KNOB, [S.I.], , juni 2003, 29-42.

MAYNTZ, RENATE (1965), 'Max Weber Idealtypus der Bürokratie und die Organisationssoziologie. ' in: Kölner Zeitschrift für Soziologie und Sozialpsychologie 17, 493-502. (geraadpleegd in de Franse vertaling: 'L'idéaltype wébérien de la bureaucratie et la sociologie des organisations' in: Trivium Revue franco-allemande de sciences humaines et sociales - Deutsch-französische Zeitschrift für Geistes- und Sozialwissenschaften 2010.)

MEER, F. VAN DER, RAADSCHELDERS, J. EN KERKHOFF, T. (RED.) (2011), Duizend jaar openbaar bestuur in Nederland. Bussum: Couthino. MEUVRET, JEAN (1946), 'Les crises de subsistances et la démographie de la France d'Ancien Régime' in: Population 1 1er année, 643-650. MIERLO, J.G.A. VAN (1995), 'Bureaucratie en bureaucratisering. Een theoretische en praktische verkenning van recente ontwikkelingen in de publieke sector en de particuliere sector' in: $\mathrm{He}$ mels, J.M.H.J. en Tuyll van Serooskerken, W.L.A van (red.), Handboek voor bestuurders. Houten: 
Uitgeverij Bohn, Stafleu en Van Loghum.

MILIKOWSKI, H. PH. (1977), Lof der onaangepastheid: een studie in sociale aanpassing, niet-aanpassing, onmaatschappelijkheid. Boom: Meppel, (tiende druk/eerste druk onder de titel Sociale aanpassing, niet-aanpassing, onmaatschappelijkheid: tevens een bijdrage tot de discussie over probleemgezinnen, 1961)

MOLLAT, MICHEL (1978), Les pauvres au moyen âge, étude sociale. Paris: Hachette. Littérature \& sciences humaines.

MUCHEMBLED, R. (2011), A history of violence. From the end of the Middle Ages to the present. Cambridge: Polity Press.

MULLER-LULOFS, M.G. (1905), 'Eenige grondregels voor de praktijk der armverzorging' in: Tijdschrift voor Armenzorg en kinderbescherming, 6, 317-322 en 325-329.

NETELENBOS, BENNO (2014), Four faces of political legitimacy: An analytical framework. SI:Sn. NETELENBOS, BENNO (2016), Political Legitimacy beyond Max Weber. An analytical Framework. Basingstoke: Palgrave-Macmillan.

NETELENBOS, BENNO (2018), 'Bringing back Max Weber into Network Governance Research' in: Critical Policy Studies 12, online:

DOI: 10.1080/19460171.2018.1523738.

NUSTELING, H.P.H. (1974), De Rijnvaart in het tijdperk van stoom en steenkool 1831-1914. Een studie van het goederenverkeer en de verkeerspolitiek in de Rijndelta en het achterland, mede in verband met de opkomst van de spoorwegen en de concurrentie van vreemde zeehavens. Amsterdam: Holland University Pers.

OLDEWELT, W.F.H. (1969), 'Het aalmoezeniersweeshuis' in: Jaarboek Amstelodamum 61, 126-140.

OORT, A.J. (1857), Handleiding voor het patronaat over armen. Amsterdam: Muller; Deventer: J.H. de Lange; Leiden: A.W. Sijthoff.

OOSTEN, ROOS VAN (2015), De stad, het vuil en de beerput. Een archeologisch-historische studie naar de opkomst, verbreiding en neergang van de beerput in stedelijke context (dertiende tot achttiende eeuw). Leiden: Sidestone Press. OTTENS, EGBERT (1975), Ik moet naar een kleinere woning omzien want mijn gezin wordt te groot. 125 jaar sociale woningbouw in Amsterdam. Amsterdam: Gemeentelijke Dienst Volks- huisvesting.

OUD, P.J., (1971), Honderd jaren, Een eeuw van staatkundige vormgeving in Nederland 18401940 Assen: Van Gorcum. (vijfde druk)

PARKER, GEOFFREY (1976), 'The "Military Revolution", 1560-1660. A myth?' in: The Journal of Modern History 48, 195-214.

PERSOONSDOSSIERS: EEN GEVAL APART. NOTA VOOR HET BESTUUR VAN HET INSTITUUT VOOR NEDERLANDSE GESCHIEDENIS EN HET NATIONAAL ARCHIEF (2005). (z.p.) PERSSON, KARL GUNNAR EN SHARP, PAUL (2015), An economic history of Europe. Knowledge, institutions and growth. 600 to the present. Cambridge: Cambridge University Press. PLOEG, R. VAN DER EN ZINKSTOK, R. (1986), Wij zijn allen werklieden. De opkomst van de moderne arbeidsmoraal in Nederland in de negentiende eeuw. Baarn: Ambo.

POWELL, RYAN (2013), 'The theoretical concept of the 'Civilising Offensive' (Beschavingsoffensief): Notes on its origins and uses', in: Human Figurations (2; 2013) http://hdl.handle.net/2027/ spo.11217607.0002.203.

RAADSCHELDERS, J.C.N. (1990), Plaatselijke bestuurlijke ontwikkelingen 1600-1900. Een historisch bestuurskundig onderzoek in vier Noord-Hollandse gemeenten. VNG-uitgeverij: 's-Gravenhage.

RAADSCHELDERS, J. C.N. (1998), Handbook of administrative history. New Brunswick: Transactions Publishers.

RAADSCHELDERS, J. C.N. (2008), 'The early years of the administrative state: was there a "second state"?' in: Public Administration Review (sept/okt 2008), 945-948.

RAADSCHELDERS, J.C.N. (2010), 'Did Max Weber's agony and ecstasy influence his scholarship?' in: Public Administration Review (maart/ april 2010), 304-316.

RAADSCHELDERS, J. (2011), 'Van nachtwakersstaat naar waarborgstaat. Proliferatie en vervlechting van het Nederlandse openbare bestuur in de lange twintigste eeuw (1880-2005)' in: Van der Meer, F. Raadschelders, J. en Kerkhoff, T. (red.) (2011), Duizend jaar openbaar bestuur in Nederland. Bussum: Couthino, 221-287.

RAPPORT VAN DE ALGEMEENE COMMISSIE TER ONDERSTEUNING VAN BEHOEFTIGEN 
AAN HEEREN BURGEMEESTER EN WETHOUDEREN DER STAD AMSTERDAM (1847).

Amsterdam: A. Spin en Zoon.

RATHMAYR, BERNHARD (2014), Armut und Fürsorge: Einführung in die Geschichte der Sozialen Arbeit von der Antike bis zur Gegenwart. Leverkusen: Budrich.

REGT, A., DE (1984), Arbeidersgezinnen en beschavingsarbeid. Ontwikkelingen in Nederland 1870-1940. Meppel: Boom.

REGT, A. DE (1993), 'Arbeiders, burgers en boeren: gezinsleven in de negentiende eeuw' in: Zwaan, T. (red.), Familie, huwelijk en gezin in West-Europa. Van middeleeuwen tot moderne tijd. Amsterdam: Boom; Heerlen: Open Universiteit, 193-218.

REMIEG A. EN ROOY, PIET DE (RED.) (2006), Geschiedenis van Amsterdam deel III, Hoofdstad in aanbouw 1813-1900. Amsterdam: SUN.

RIDDER, J. (1935), Een conjunctuur-analyse van 1848-1860. Amsterdam: Paris.

RIEL, A. VAN EN ZANDEN, J. L. VAN, (2000), Nederland 1780-1914. Staat, instituties en economische ontwikkeling. Amsterdam: Balans.

RIEL, A. VAN EN ZANDEN, J. L. VAN (2002), 'Economische geschiedenis met een menselijk gezicht' in: Bijdragen en Mededelingen betreffende de Geschiedenis van Nederland 117, 364369.

RIEL, A. VAN (2018), Trials of convergence. Prices, markets and industrialization in the Netherlands, 1800-1913. Utrecht: in eigen beheer. RIGHART, HANS (1988), 'Moraliseringsoffensief in Nederland in de periode 1850-1880' in: Peeters, Harry e.a. (ed.) , Vijf eeuwen gezinsleven. Liefde, huwelijk en opvoeding in Nederland. Nijmegen: SUN,194-209.

ROBERTS, MICHAEL (1956), The Military Revolution, 1560-1660. Belfast: The Queen's University of Belfast.

ROMMELSE, ANTON (2011), Een geschiedenis van het arbeidsongeschiktheidsbeleid in Nederland. Leiden: Stichting instituut GAK.

ROMON, CHRISTIAN (1982), 'Le monde des pauvres à Paris au XVIIle siècle' in: Annales. Économies, Sociétés, Civilisations 37, 729-763.

ROOY, P. DE (1979), Werklozenzorg en werkloosheidsbestrijding 1917-1940. Landelijk en Amsterdams beleid. Amsterdam: Van Gennep.
ROOY, P. DE (ED.) (2007)A, Geschiedenis van Amsterdam deel IV, Tweestrijd om de hoofdstad 1900-2000. Amsterdam: SUN.

ROOY, P. DE (2007)B, 'Het middelpunt van het Vaderland 1901-1914' in: Geschiedenis van Amsterdam. Tweestrijd om de hoofdstad 1900-2000. Amsterdam: SUN, 17-72.

ROOY, P. DE (2007)C, 'De donkerte der tijden 1920-1940' in: Geschiedenis van Amsterdam. Tweestrijd om de hoofdstad 1900-2000. Amsterdam: SUN, 127-235.

ROSS, E.A. (1901), Social control. A survey of the foundations of order. New York: The Macmillan company.

SACHSSE, CHRISTOPH EN TENNSTEDT, FLORIAN (1998), Geschichte der Armenfürsorge in Deutschland: Vom Spätmittelalter bis zum 1. Weltkrieg. Stuttgart: Kohlhammer.

SALAIS, ROBERT, NICOLAS BAVEREZ, BÉNÉDICTE REYNAUD, (1986), L'invention du chômage. Paris: Presses Universitaires de France.

SALAIS, ROBERT (2007), 'Europe and the deconstruction of the category "unemployment"', in: Archiv für Sozialgeschichte 47, 371 401.

SANDICK, A.A. (1936), 'Conjunctuurtheorie en bankpolitiek' in: De Economist 85, Nummer 1, 112-125.

SCAFF, LAWRENCE A. (2013), Max Weber in Amerika. Berlin: Duncker \& Humblot. (Vertaling van Scaff, Lawrence A. (2011), Max Weber in America. New York: Princeton University Press.) SCHADE, C. (1981), Woningbouw voor arbeiders in het 19de-eeuwse Amsterdam. Amsterdam: Van Gennep.

SCHENKEVELD, WILLEMIEN (2003), Het Kinderwetje van Van Houten: sociale wetgeving in de negentiende eeuw. Hilversum: Verloren.

SCHREUDER, J.C. (1932), 'J.W. Jurrema en de burgerlijke armverzorging in Amsterdam' in: Tijdschrift voor Armwezen, Maatschappelijke Hulp en Kinderbescherming 11, 3389-3394.

SCHUURMAN, A.J. (1991), Historische demografie: bevolkings- en gezinsgeschiedenis. Zutphen: Walburg Pers.

SCOTT, J. W. EN TILLY, L. A. (1978), Women, work and the family. Eastbourne: Holt-Saunders. SCOTT, ANNE M. (2016), 'Preaching poverty' in: Mews, Constant J. en Welch, Anna (ed.), Po- 
verty and devotion in mendicant cultures 1200 1450. Church, faith, and culture in the Medieval West. New York: Routledge.

SEEBOHM ROWNTREE, B. (2000), Poverty. A Study of Town Life. Centennial Edition. Bristol: Policy Press. (herdruk/eerste druk 1901)

SLAVIN, A.J. (1964), The New Monarchies and representative assemblies. Medieval constitutionalism or modern absolutism? Lexington, Mass.: D.C. Heath Company.

SLEEBE, V. C.(1994), In termen van fatsoen. Sociale controle in het Groningse kleigebied 1770-1914. Assen: Van Gorcum.

SLIJKERMAN, DIEDERIK (2016), Enfant terrible. Wim Treub (1858-1931). Amsterdam: Prometheus.

SMIT, CHRISTIANNE (2015), De volksverheffers. Sociaalhervormers in Nederland en de wereld 1870-1914. Verloren: Hilversum.

SMIT, C.A.L. (2019), 'Van 'weldadig verschil' naar 'huilende armoe-weedom' - veranderende opvattingen over armoede in de negentiende eeuw' in: Annalen van het Thijmgenootschap 107 afl. 1, 84-106.

SMITS, FRANS (1993), '“Van de wind kan men niet leven". De gemeentelijke armenzorg te Amsterdam in het laatste kwart van de 19de eeuw' in: Tijdschrift voor sociale geschiedenis 19, 94114.

SPAANS, JOKE (1997), Armenzorg in Friesland 1500-1800. Publieke zorg en particuliere liefdadigheid in zes Friese steden. Leeuwarden, Bolsward, Franeker, Sneek, Dokkum en Harlingen. Hilversum/Leeuwarden: Verloren/Fryske Akademy.

SPAANS, JOKE (1999), 'Religie in Amsterdam in de Gouden Eeuw. Een reactie op Willem Frijhof' in: Amstelodamum (91), 104-107.

SPIERENBURG, P. (1998), De Verbroken

Betovering. Mentaliteit en cultuur in pre-industrieel Europa. Hilversum: Verloren. (derde druk/ eerste druk 1988)

SPIERENBURG, PIETER (2004), 'Social control and history: an introduction', in: Roodenburg, Herman en Spierenburg, Pieter (ed.), Social control in Europe Volume I, 1500-1800. Columbus: The Ohio State University Press, 1-22. gemeentelijk bureau voor statistiek; (1897-1921) Amsterdam: Johannes Müller; (1922-1944) Amsterdam: J.M. Meulenhoff.

STAVENUITER, MONIQUE (1993), Verzorgd of Zelfstandig. Ouderen en de levensloop in Amsterdam in de tweede helft van de negentiende eeuw. Zwolle/Amsterdam: Waanders.

STEARNS, PETER, N. EN STEARNS, CAROL

Z. EDS. (1988), Emotion and social change. Toward a new psychohistory. New York en London: Holmes and Meier.

STEINMETZ, STEPHAN (2016), Asterdorp. Een Amsterdamse geschiedenis van verheffing en vernedering. Amsterdam/Antwerpen: Atlas Contact.

STOETT, F.A. (1923-1925), Nederlandsche spreekwoorden, spreekwijzen, uitdrukkingen en gezegden. Zutphen: Thieme \& Cie.

STOIANOVICH, TRAIAN (1976), French Historical Method: The Annales Paradigm. Ithaca and London: Cornell University Press.

STUURMAN, SIEP (1979),'Staatsvormingsprocessen in Europa en Azië na 1750' in: Amsterdams Sociologisch Tijdschrift 6, 690-717.

SWAAN, ABRAM DE (1989), Zorg en de staat. Welzijn, onderwijs en gezondheidszorg in Europa en de Verenigde Staten in de nieuwe tijd. Amsterdam: Bakker. Vertaling van: In care of the state. Health care, education and welfare in Europe and the USA in the modern age. (Eerste druk 1988)

TAAL, G. (1980), Liberalen en Radicalen in Nederland, 1872-1901. Martinus Nijhoff: Den Haag. TEEUWEN, DANIËLLE (2016), Financing Poor Relief through Charitable Collections in Dutch Towns, c. 1600-1800. Amsterdam: Amsterdam University Press.

TOPALOV, CHRISTIAN (1994), Naissance du chômeur 1880-1910. Paris: Albin Michel.

TIJN, T. VAN (1965), Twintig jaren Amsterdam. De maatschappelijke ontwikkeling van de hoofdstad van de jaren '50 der vorige eeuw tot 1876. Amsterdam: Scheltema \& Holkema.

VALK, A. VAN DER (1989), Amsterdam in aanleg. Planvorming en dagelijks handelen 18501900. Amsterdam: Planologisch en Demografisch Instituut van de Universiteit van Amsterdam.

VALK, LOES VAN DER (1986), Van Pauperzorg tot bestaanszekerheid. Armenzorg in Nederland 
1912-1965. Amsterdam: Stichting Internationaal Instituut voor Sociale geschiedenis.

VELDEN, HENK VAN DER (1993), Financiële toegankelijkheid tot gezondheidszorg in $\mathrm{Ne}$ derland, 1850-1941. Medische armenzorg, ziekenfondsen en de verenigingen op nationaal en lokaal niveau (Schiedam, Roordahuizum en Amsterdam). Amsterdam: Stichting beheer IISG.

VERDOORN, J.A., (1965), Volksgezondheid en sociale ontwikkeling. Beschouwingen over het gezondheidswezen te Amsterdam in de 19de eeuw. Utrecht/Antwerpen: Het Spectrum.

VERKADE, W. (1974), Thorbecke als Oost-Nederlands patriot. Zutphen: De Walburgpers.

VIVES, JUAN LUIS (2015), Over de hulp aan de armen. Zoetermeer: Klement (oorspronkelijk: De subventione pauperum. 1526)

VOLTMER, RITA (2012), Hexen und Hexenverfolgung in der frühen Neuzeit. Darmstadt: Wissenschaftliche Buchgesellschaft.

VRANKEN, JAN (2006), Jaarboek Armoede en sociale uitsluiting 2006. Leuven: Acco.

VRIES, BOUDIEN DE (1986), Electoraat en elite. Sociale structuur en sociale mobiliteit in Amsterdam 1850-1895. Amsterdam: De Bataafsche Leeuw.

VRIES, B.M.A. DE (RED.) (2000), Van agrarische samenleving naar verzorgingsstaat. Demografie, economie, maatschappij en cultuur in West-Europa, 1450-2000. Groningen: Wolters-Noordhoff. (derde druk/eerste druk 1987 als Diederiks, H.A. (ed,) Van agrarische samenleving naar verzorgingsstaat. De modernisering van West-Europa sinds de vijftiende eeuw)

VRIES, H. DE (1971), Landbouw en bevolking tijdens de agrarische depressie in Friesland (1878-1895). Wageningen: Veenman.

VRIES, JOH. DE (1979), 'Het economisch leven in Nederland 1918-1940' in: Algemene geschiedenis der Nederlanden. Deel 14 Nederland en België 1914-1940. Haarlem: Fibula-Van Dishoeck, 102-146.

VUGT, THIJS VAN (2015), Een arbeidersbuurt onder de rook van 'De Sphinx'. Een sociaal-ruimtelijke geschiedenis van het Boschstraatkwartier-Oost te Maastricht, 1829-1904. Hilversum: Verloren.

WAGENAAR, F.P. (1999), "Dat de regeringe niet en bestaet by het corpus van de magistraet van Den Hage alleen". De Sociëteit van 's-Gravenhage (1587-1802). Een onderzoek naar bureaucratiering. Hilversum: Verloren.

WAGENAAR, MICHIEL (1990), Amsterdam 1876-1914. Economisch herstel, ruimtelijke expansie en de veranderende ordening van het stedelijk grondgebruik. Amsterdam: Historisch Seminarium van de Universiteit van Amsterdam.

WANSINK, H. (1975), 'Holland en zes bondgenoten: de Republiek der Zeven Verenigde Provinciën' in: Vaderlands Verleden in Veelvoud. 31 opstellen over de Nederlandse geschiedenis na 1500. Den Haag: Martinus Nijhoff, 252-273. (tweede druk/eerste druk 1971)

WARTENA, L.J., (2003), H. Goeman Borgesius (1847-1917). Vader van de verzorgingsstaat. Een halve eeuw liberale en sociale politiek in Nederland. Amsterdam: Aksant 2003.

WEBER, MAX (1972), Wirtschaft und Gesellschaft. Grundriß der verstehenden Soziologie. Tübingen: J.C.B.Mohr (Paul Siebeck) (vijfde editie, bezorgd door Johannes Winckelmann/eerste druk 1922). \{geciteerd als: $W_{u G} 5$ \}

WEBER, MAX (1988), 'Wissenschaft als Beruf' in: Weber, Max, Gesammelte Aufsätze zur Wissenschaftslehre. Tübingen: J.C.B. Mohr (Paul Siebeck), 582-613. (lezing uit 1917)

WEBER, MAX (2009), Wirtschaft und Gesellschaft. Die Wirtschaft und die gesellschaftlichen Ordnungen und Mächte. Nachlaß.Teilband 4:

Herrschaft. Studienausgabe der Max Weber-Gesamtausgabe. Band I/22 Tübingen: J.C.B. Mohr (Paul Siebeck) 12-46. \{geciteerd als: WuG: Herrschaft, MWS I/22-4\}

WELSHMAN, JOHN (2006), 'The Concept of the Unemployable' in: Economic History Review 59, 578-606.

WINCKELMANN, JOHANNES (1980), 'Die Herkunft von Max Webers "Entzauberungs"-Konzeption. Zugleich ein Beitrag zu der Frage, wie gut wir das Werk Max Webers kennen können' in: Kölner Zeitschrift für Soziologie und Sozialpsychologie 32, 12-53.

WOLFF, BETJE (1779), Proeve over de opvoeding. Amsterdam Meppel: Boom. (ed. H.C. de Wolf uit 1977 naar de tweede uitgave van 1780) WOOLF, STUART (1986), The Poor in Western Europe in the Eighteenth and Nineteenth century. Londen/New York: Methuen. 
WOOLF, STUART (2013), 'Order, class and the urban poor' in: Bush, M.L. (ed.), Social orders and social classes in Europe since 1500. Studies in social stratification. London: Routledge. (herdruk/ eerste druk 1988).

WOUDE, A.M. VAN DER (1985), 'Bevolking en gezin in Nederland' in: Holthoon, F.L. (red.), De Nederlandse samenleving sinds 1815. Wording en samenhang. Assen/Maastricht: Van Gorcum, 19-71.

WOUD, AUKE VAN DER (2010), Koninkrijk vol sloppen. Achterbuurten en vuil in de negentiende eeuw. Amsterdam: Uitgeverij Bert Bakker.

IJSSELMUIDEN, P.G. VAN (1988), Binnenlandse zaken en het ontstaan van de moderne overheidsbureaucratie in Nederland 1813-1940. Kampen: J.H. Kok.

ZANDEN, J.L. VAN (1981), De economische ontwikkeling van de Nederlandse landbouw in de negentiende eeuw, 1800-1914. Utrecht: H\&S. ZANDEN, J.L. VAN (1987), De industrialisatie van Amsterdam 1825-1914. Bergen: Octavo.

ZANDEN, JAN LUITEN VAN (1997), Een klein land in de 20e eeuw. Economische geschiedenis van Nederland 1914-1995. Utrecht: Het Spectrum.

ZANDEN, JAN LUITEN VAN, RIEL, ARTHUR VAN (2000), Nederland 1780-1914. Staat, instituties en economische ontwikkeling. Amsterdam: Balans.

ZANDEN, JAN LUITEN VAN (2000), Dutch GNP and its Components 1800-1913. Groningen: N.W. Posthumus Instituut.

ZANDEN, J. L. VAN (2009), The long road to the Industrial Revolution. The European economy in a global perspective, 1000-1800. Leiden: Brill. ZIMMERMANN, BENEDICTE (2006), Arbeitslosigkeit in Deutschland. Zur Entstehung einer sozialen Kategorie. Frankfurt: Campus Verlag.

ZANDEN, JAN LUITEN VAN (2014), 'Debates on industrialisation and economic growth in the Netherlands' in: Tijdschrift voor Sociale en Economische geschiedenis 11, 85-111.

ZANDEN, J.L. VAN EN MOOR, T. DE (2006), Vrouwen en de geboorte van het kapitalisme in West-Europa. Amsterdam: Boom.

ZANDEN, J.L. VAN, MOOR, T. DE EN CARMICHAEL, S. (2019), Capital women. The European marriage pattern, female empowerment in Western Europe, 1300-1800. Oxford: Oxford University Press.

ZUURMOND, A. (1994). De infocratie: een theoretische en empirische heroriëntatie op Weber's ideaaltype in het informatietijdperk. Delft: Paedrus.

ZWAAN, T. (RED.) (1993), Familie, huwelijk en gezin in West-Europa. Van Middeleeuwen tot moderne tijd. Amsterdam/Heerlen: Boom/Open Universiteit 1993.

ZWAAN, TON (2001), Civilisering en decivilisering. Studies over natievorming en geweld, nationalisme en vervolging. Amsterdam: Boom. 


\section{BIJLAGE 1}

VOORBEELD VAN EEN VRAGENLIJST MET

INSTRUCTIE VOOR DE ARMBEZOEKER

\begin{tabular}{|c|c|c|c|}
\hline stamboeknummer & datum & & \\
\hline Vraag & Onderwerp & & $\begin{array}{l}\text { Wekelijkse inkomsten } \\
\text { aan geld }\end{array}$ \\
\hline 1 & Woonplaats & & \\
\hline 2 & Naam en voornaam & & \\
\hline 3 & $\begin{array}{l}\text { Waar en wanneer geboren alzoo } \\
\text { oud: } \\
\text { De Vader is genaamd: } \\
\text { De Moeder is genaamd: }\end{array}$ & & \\
\hline 4 & Wanneer en waar gehuwd? & & \\
\hline 5 & $\begin{array}{l}\text { Naam en voornaam van den Man } \\
\text { Wanneer en waar overleden? }\end{array}$ & & \\
\hline 6 & Sedert wanneer alhier woonachtig? & & \\
\hline 7 & $\begin{array}{l}\text { Tot welke kerkelijke gemeente? } \\
\text { Sedert wanneer lidmaat door belij- } \\
\text { denis? Sedert wanneer alhier inge- } \\
\text { schreven? }\end{array}$ & & \\
\hline 8 & Welk beroep en waar werkzaam? & & \\
\hline 9 & Verdiensten en inkomsten & & \\
\hline 10 & Lichaamsgebreken, en zoo ja, welke? & & \\
\hline 11 & Huur en staat der woning? & & \\
\hline 12 & Het getal inwonende kinderen & $\begin{array}{l}\text { Namen } \\
\text { Ouderdom } \\
\text { Wanneer geboren } \\
\text { Vaccine. } \\
\text { Kerkgenootschap of doop }\end{array}$ & \\
\hline 13 & $\begin{array}{l}\text { Welke van genoemde kinderen gaan } \\
\text { school, of zijn daarvoor ingeschre- } \\
\text { ven? Welke blijven van school terug } \\
\text { en waarom? }\end{array}$ & & \\
\hline 14 & $\begin{array}{l}\text { Wat zijn de verdiensten der kinderen } \\
\text { en bij wie zijn zij in dienst? }\end{array}$ & & \\
\hline 15 & $\begin{array}{l}\text { Wat is bekend van het gedrag van dit } \\
\text { gezin? }\end{array}$ & & \\
\hline
\end{tabular}




\begin{tabular}{|c|c|c|c|}
\hline 16 & $\begin{array}{l}\text { Heeft dit gezin ook betrekkingen, } \\
\text { die volgens de burgerlijke wet ver- } \\
\text { plicht en ook in staat zijn voor het } \\
\text { onderhoud te zorgen en zo ja, wel- } \\
\text { ke zijn de namen en de graad van } \\
\text { bloedverwantschap? }\end{array}$ & & \\
\hline 17 & $\begin{array}{l}\text { Mist dit gezin het radikaal om door } \\
\text { een kerkelijke gemeente onder- } \\
\text { steund te worden en waarom? }\end{array}$ & & \\
\hline 18 & Welke indruk maakt dit gezin op u? & & \\
\hline 19 & Opmerkingen van verschillende aard & & \\
\hline Zonder nummer & $\begin{array}{l}\text { Aldus opgemaakt na mijn bezoek en } \\
\text { onderzoek op den (=datum) } \\
\text { Armbezoeker, (ondertekening - als } \\
\text { handtekening) } \\
\text { Nagezien en met de bescheiden ac- } \\
\text { coord bevonden: Beambte Chef voor } \\
\text { de inschrijving en het Armbezoek }\end{array}$ & $\begin{array}{l}\text { Besluit der commissie: } \\
\mathrm{Hfl} \\
\text { Tot } \\
\text { Dagtekening }\end{array}$ & $\begin{array}{l}\text { Het lid der Commissie: } \\
\text { parafering }\end{array}$ \\
\hline
\end{tabular}

Bron: SAA 5256. Doos 1305. Stamboeknummer 5492

\section{Enkele bepalingen uit de instructie voor de armbezoeker (1871)}

- De armbezoekers zijn belast met het onderzoek naar de toestand der armen. (art. 2)

- Voor dit onderzoek wordt hun een zakboekje verstrekt waarin zij alles moeten aanteekenen wat zij kunnen vernemen dat dienstig is om de partijen in onderzoek wel te doen kennen en beoordeelen. Zij moeten dit zakboekje, desgewenst, steeds aan hun superieuren kunnen vertonen. (art. 3)

- Zij moeten, zoveel mogelijk uit officiële bescheiden, nauwkeurig alle vragen van het vastgestelde formulier beantwoorden en zodanige verdere informatie inwinnen als door hunne superieuren noodig geoordeeld worden. Deze informatie moet bij de invulling van het formulier opgetekend worden in de rubriek "aanteekeningen".

- (art. 4)

- De formulieren moeten door hen worden ondertekend en behoorlijk ingevuld.

- (art. 5)

- 'De armbezoekers moeten bij alle onderzoek een voorbeeld zijn van beleefdheid en bescheidenheid aan de armen geven; worden de armbezoekers bij het onderzoek onheusch en kwalijk bejegend, dan staken zij dat werk met kennisgeving van het gebeurde aan den hoofdbeambte. (art. 6)

- Zij mogen geen giften of beloningen, in welke vorm dan ook, aannemen die hen in hun kwaliteit wordt aangeboden of toegezegd. (art. 11)

Bron: SAA 5256. 


\section{VOORBEELD VAN EEN VRAGENLIJST VOLGENS HET OUDE MODEL}

Bron: Knotter, A. en Kok, P.T. (2005), 87

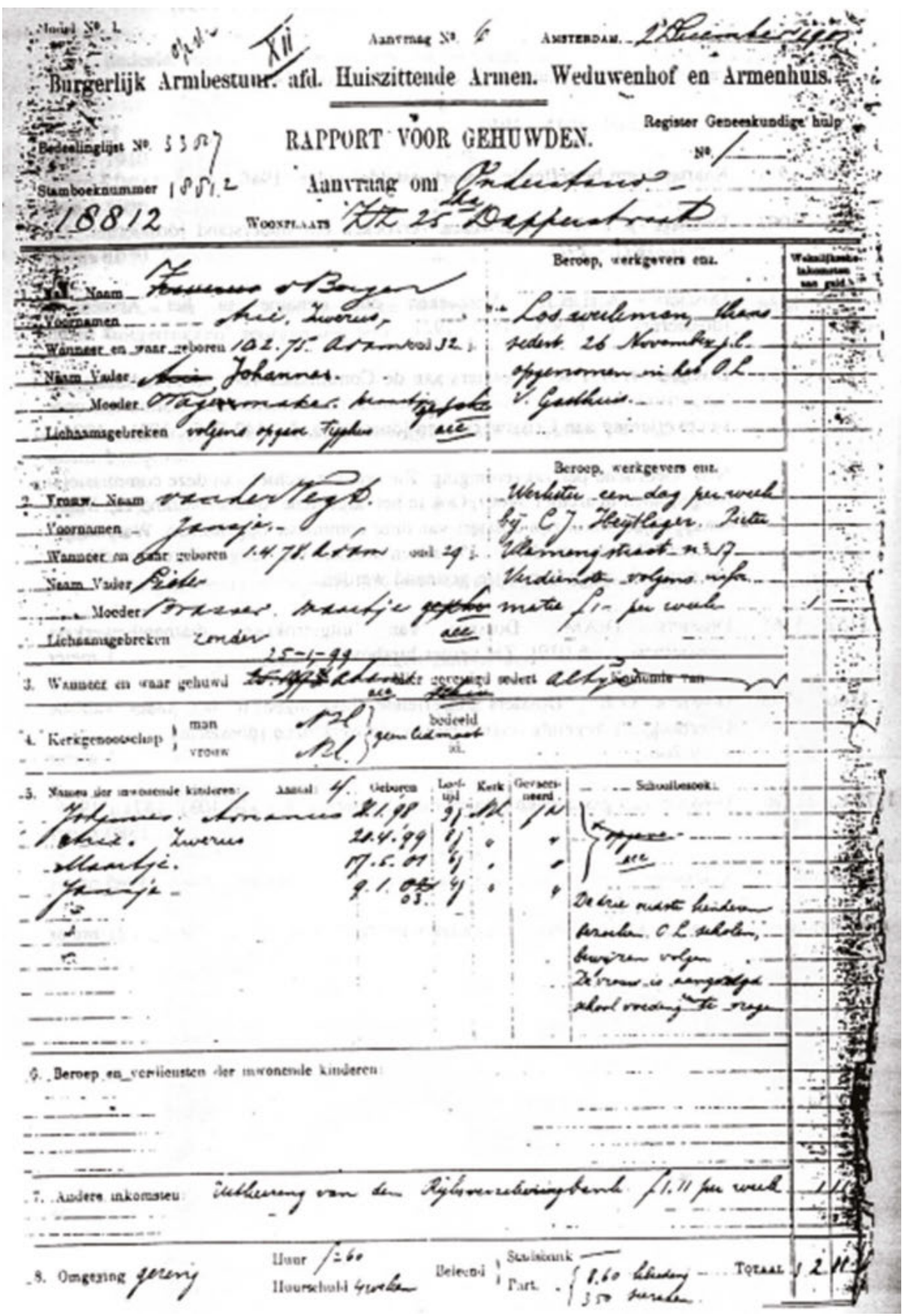




\section{BIJLAGE 3}

\section{VOORBEELD VAN EEN VRAGENLIJST VOLGENS HET NIEUWE MODEL}

Vernieuwing van de vragenlijst:

- Gebruik van een mantelvel

- Gebruik van keuzeformulier met invulvak

Bron: SAA 5256.

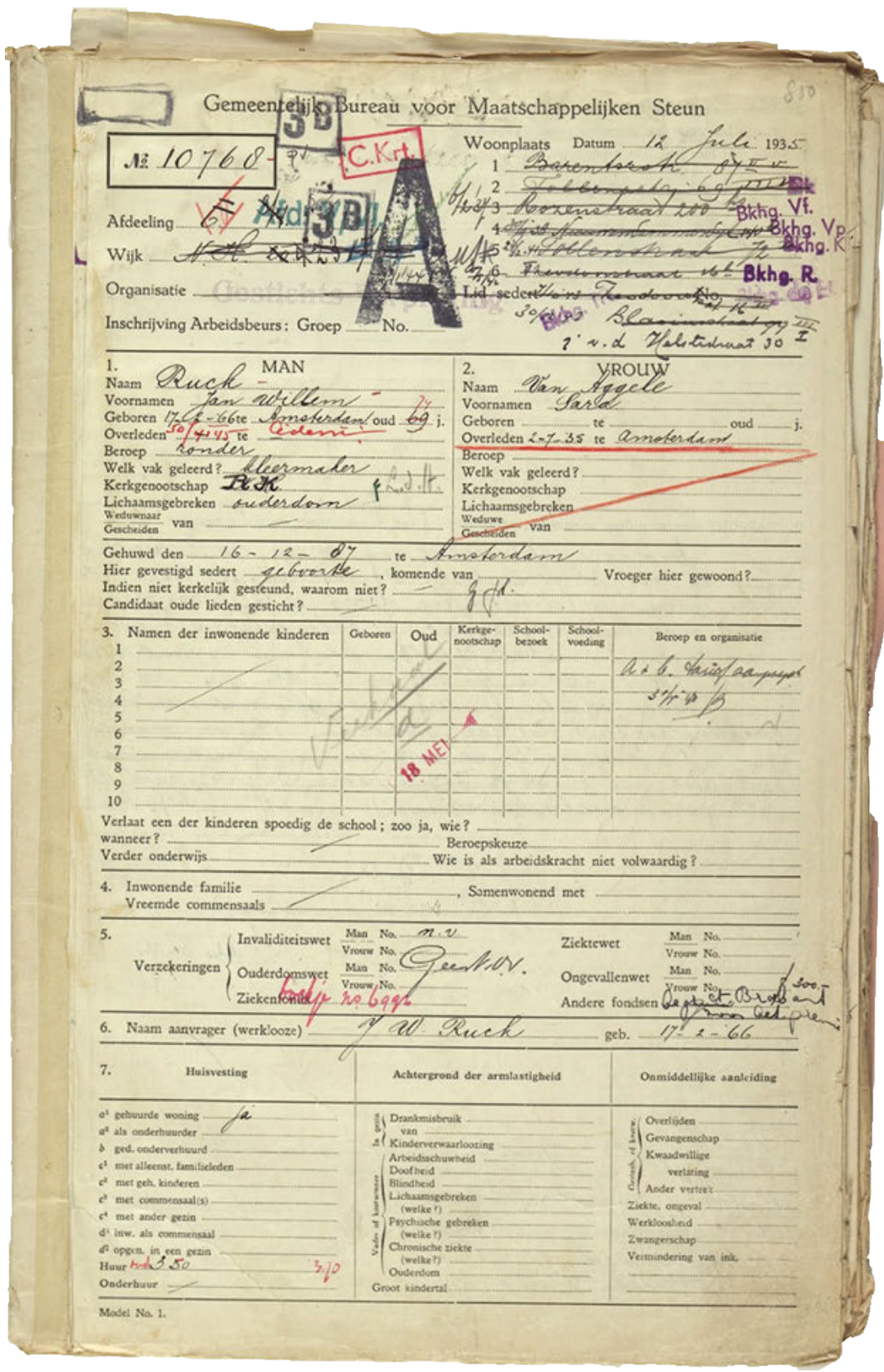




\section{AANTAL VRIJWILLIGE ARMBEZOEKERS}

1910-1940

(v.a. = vrijwillige armbezoekers; gezin = bezochte gezinnen)

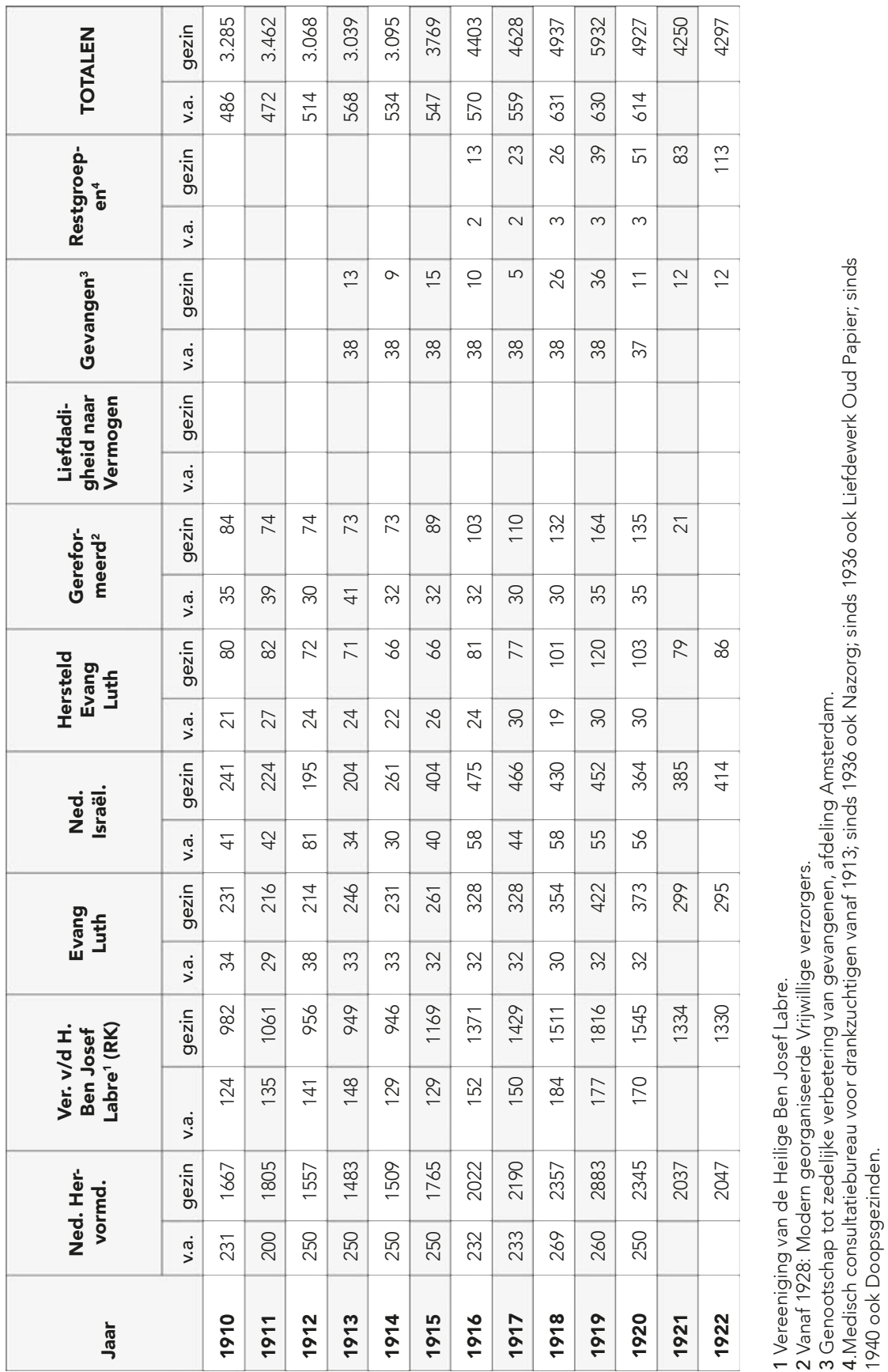




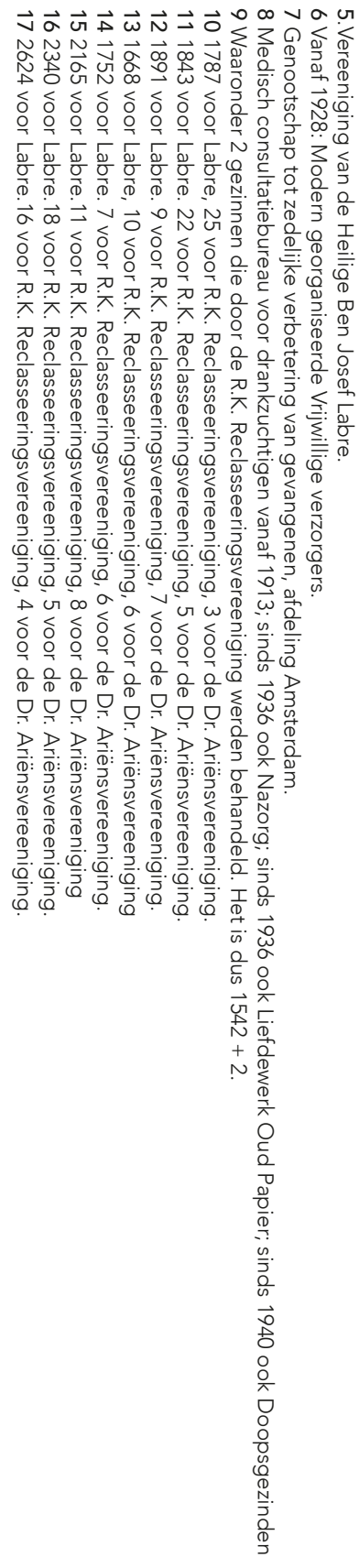

\begin{tabular}{|c|c|c|c|c|c|c|c|c|c|c|}
\hline$\underset{\Xi}{\vec{\omega}}$ & $\overrightarrow{\stackrel{े}{\sharp ٌ ~}}$ & $\begin{array}{l}\vec{D} \\
\text { N }\end{array}$ & $\begin{array}{l}\vec{p} \\
\text { D్ }\end{array}$ & $\overrightarrow{\mathrm{N}}$ & $\begin{array}{l}\overrightarrow{0} \\
\text { Na }\end{array}$ & $\begin{array}{l}\overrightarrow{0} \\
\text { vin }\end{array}$ & $\overrightarrow{\stackrel{D}{5}}$ & 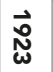 & & ڤั๊ \\
\hline$\stackrel{P}{A}$ & $\vec{t}$ & $\underset{\omega}{\omega}$ & $\stackrel{D}{N}$ & & & & & & ب̣ & \multirow{2}{*}{ 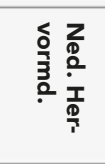 } \\
\hline $\begin{array}{l}\omega \\
\stackrel{0}{\circ} \\
\alpha\end{array}$ & $\underset{\vec{N}}{\stackrel{\omega}{\sim}}$ & $\begin{array}{l}\omega \\
\grave{d} \\
\omega\end{array}$ & $\underset{\vec{N}}{\omega}$ & 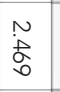 & $\begin{array}{l}\tilde{N} \\
\tilde{O} \\
\widetilde{O}\end{array}$ & $\underset{N}{N}$ & $\begin{array}{l}\widetilde{\alpha} \\
\text { of } \\
\forall\end{array}$ & $\underset{\infty}{\mathbb{N}}$ & $\begin{array}{l}\stackrel{O}{0} \\
\stackrel{N}{J} \\
\stackrel{3}{J}\end{array}$ & \\
\hline$\stackrel{\omega}{\tilde{O}}$ & $\stackrel{\sim}{\sim}$ & N్ల & $\tilde{\sigma}$ & & & & & & ب̂ & \multirow{2}{*}{ 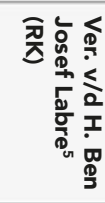 } \\
\hline$\underset{\widetilde{\alpha}}{\tilde{\sigma}}$ & $\underset{\substack{\omega \\
\omega \\
\tilde{\alpha}}}{\tilde{\omega}}$ & $\begin{array}{l}\stackrel{N}{\vec{O}} \\
\stackrel{N}{\vec{v}} \\
\vec{v}\end{array}$ & $\begin{array}{l}\vec{a} \\
\text { G } \\
\vec{A}\end{array}$ & 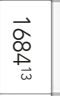 & $\underset{\stackrel{D}{~}}{\overrightarrow{0}}$ & $\underset{\stackrel{\infty}{\grave{J}}}{\stackrel{\Xi}{\exists}}$ & $\begin{array}{l}\vec{\infty} \\
\vec{ज} \\
\overrightarrow{0}\end{array}$ & $\begin{array}{l}\overrightarrow{\mathrm{r}} \\
\text { 点 }\end{array}$ & $\begin{array}{l}\infty \\
\mathbb{D} \\
\stackrel{N}{J} .\end{array}$ & \\
\hline जै & $\stackrel{\circ}{\circ}$ & A & $\omega$ & & & & & & ب̂ & \multirow{2}{*}{ 巨赛 } \\
\hline$\stackrel{g}{\Xi}$ & જे & 总 & $\overrightarrow{\text { oे }}$ & $\stackrel{\omega}{\widetilde{O}}$ & 宫 & $\stackrel{\omega}{=}$ & $\begin{array}{c}\omega \\
\alpha\end{array}$ & $\underset{\infty}{\omega}$ & $\begin{array}{l}0 \\
\mathbb{N} \\
\mathbb{N} .\end{array}$ & \\
\hline $\overrightarrow{\vec{a}}$ & $\overrightarrow{\vec{o}}$ & $\overrightarrow{\&}$ & $\stackrel{\sim}{\sim}$ & & & & & & 乌̊ & \multirow{2}{*}{ 离: } \\
\hline$\vec{\sigma}$ & ๙ั & d & 胥 & $\underset{\omega}{\mathcal{W}}$ & 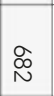 & 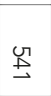 & $\stackrel{G}{\vec{D}}$ & 空 & $\begin{array}{l}0 \\
\mathbb{D} \\
N \\
\end{array}$ & \\
\hline & & $\infty$ & $\tilde{\perp}$ & & & & & & 乌் & \multirow{2}{*}{ 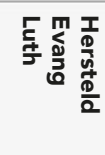 } \\
\hline & & $\overrightarrow{\omega_{N}}$ & $\overrightarrow{\vec{N}}$ & 8 & $\vec{\omega}$ & $\vec{\omega}$ & $\overrightarrow{\vec{\omega}}$ & 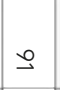 & $\begin{array}{l}0 \\
\mathbb{D} \\
\stackrel{N}{J}\end{array}$ & \\
\hline U్ & શે & U & $\rightarrow$ & & & & & & ب̣ & \multirow{2}{*}{ 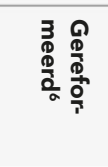 } \\
\hline$\tilde{\vartheta}$ & $\vec{\circ}$ & $\stackrel{a}{\omega}$ & U & & & & & & $\begin{array}{l}\mathscr{0} \\
\mathbb{D} \\
\stackrel{N}{J}\end{array}$ & \\
\hline$\stackrel{\infty}{\sim}$ & 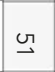 & $\stackrel{\sigma}{-}$ & & & & & & & ب̣ & \multirow{2}{*}{ 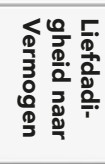 } \\
\hline$\vec{\omega}$ & $\overrightarrow{\tilde{N}}$ & $\overrightarrow{\vec{A}}$ & & & & & & & $\begin{array}{l}0 \\
0 \\
\mathbb{N} \\
N .\end{array}$ & \\
\hline G & $\omega$ & $\sim$ & $N$ & & & & & & ب̂? & \multirow{2}{*}{ 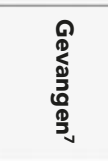 } \\
\hline$\vec{b}$ & $\vec{\infty}$ & $\vec{\omega}$ & $\alpha$ & $\overrightarrow{0}$ & $\overrightarrow{\mathrm{v}}$ & $\vec{a}$ & $\vec{a}$ & $v$ & $\begin{array}{l}0 \\
0 \\
\mathbb{D} \\
\stackrel{5}{J}\end{array}$ & \\
\hline$\rightarrow$ & $N$ & $N$ & $N$ & & & & & & ب̣ & \multirow{2}{*}{ 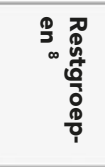 } \\
\hline$\vec{\infty}$ & $\vec{\alpha}$ & $\stackrel{\circ}{\hookrightarrow}$ & ১ & $\sigma$ & $\alpha$ & $\overrightarrow{8}$ & $\vec{N}$ & $\vec{\omega}$ & $\begin{array}{l}\frac{O}{\mathbb{D}} \\
\text { N. } \\
\frac{N}{5} .\end{array}$ & \\
\hline $\overrightarrow{\vec{\omega}}$ & 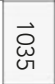 & 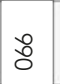 & ৪ి & & & & & & ب̣ & \multirow{2}{*}{ 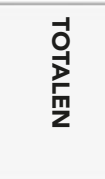 } \\
\hline$\stackrel{\circ}{\vec{V}}$ & $\underset{్}{\stackrel{్}{~}}$ & $\begin{array}{l}\stackrel{o}{o} \\
\tilde{\omega} \\
\tilde{o}\end{array}$ & $\begin{array}{l}\stackrel{\sigma}{\vec{N}} \\
\infty\end{array}$ & $\stackrel{\vec{\omega}}{\vec{\omega}}$ & $\stackrel{\sigma}{\vec{N}}$ & $\underset{\text { ల్ }}{\tilde{\sigma}}$ & $\begin{array}{l}\text { ज } \\
\text { on } \\
\text { w }\end{array}$ & $\stackrel{\stackrel{\infty}{\perp}}{\stackrel{\infty}{D}}$ & $\begin{array}{l}\frac{6}{D} \\
\text { N. } \\
\text { J. }\end{array}$ & \\
\hline
\end{tabular}




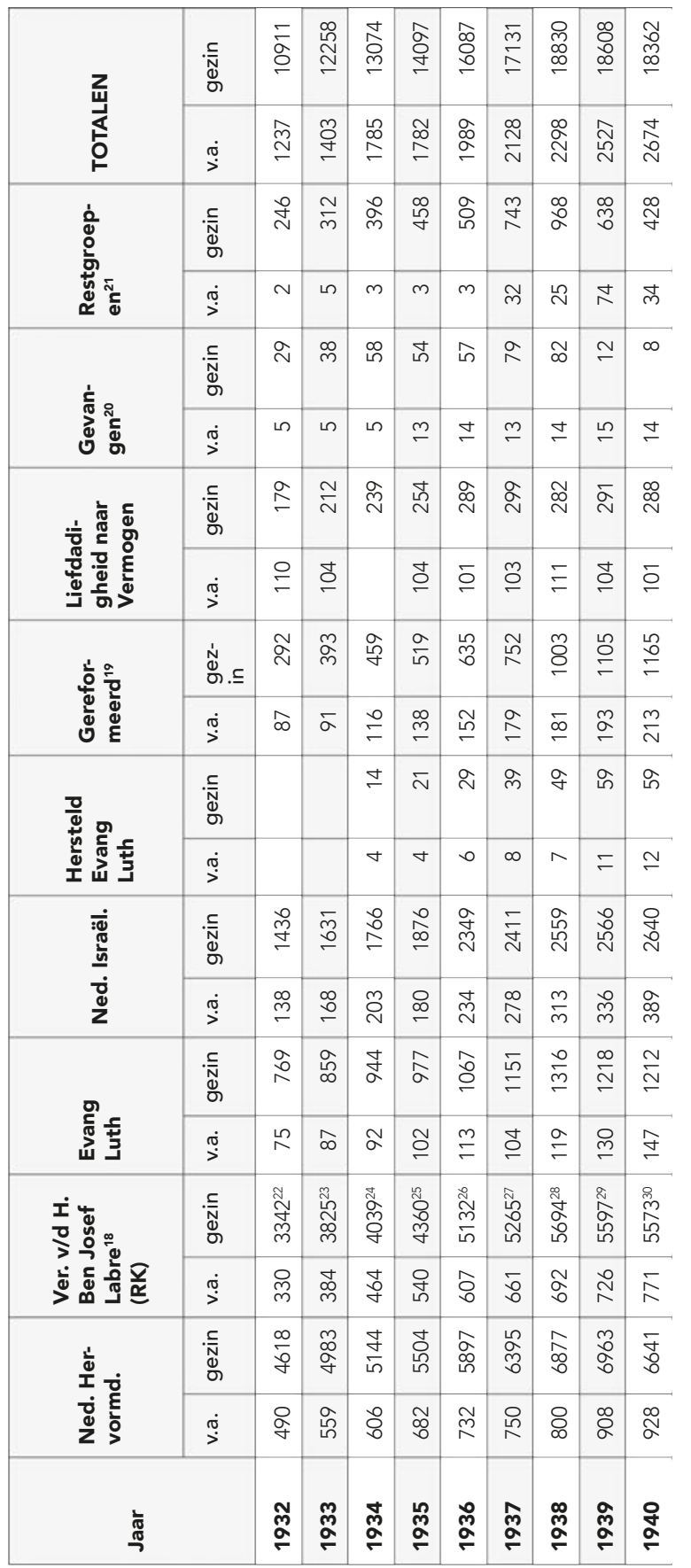

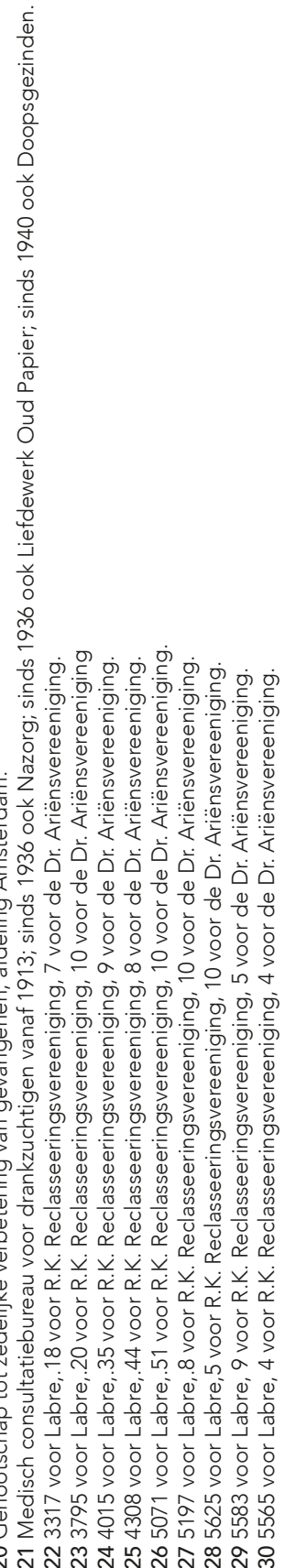


BIJLAGE 5

MAXIMALE UITKERINGEN 1909-1932

\begin{tabular}{|c|c|c|c|}
\hline Jaar & Geld per week $\ln \boldsymbol{f}^{1}$ & Brood per jaar In $f$ & Brandstof per jaar $\ln f$ \\
\hline 1909 & 3.50 & 50.00 & 5.00 \\
\hline 1910 & 3.50 & 50.00 & 5.00 \\
\hline 1911 & 3.50 & 50.00 & 5.00 \\
\hline $1912^{2}$ & 3.50 & 50.00 & 5.00 \\
\hline 1913 & 4.50 & & 5.00 \\
\hline 1914 & 4.50 & & 5.00 \\
\hline 1915 & 4.50 & & 5.00 \\
\hline 1916 & 4.50 & & 5.00 \\
\hline 1917 & 4.50 & & 5.00 \\
\hline 1918 & 6.50 & & 5.00 \\
\hline \multirow[t]{2}{*}{$1919^{3}$} & 8.50 & & 5.00 \\
\hline & \multicolumn{3}{|c|}{ (hoogste bedrag dat aan één gezin per week wordt uitgekeerd) } \\
\hline 1917 & 17.50 & Gezin met 14 pers. & \\
\hline 1918 & 17.50 & & \\
\hline 1919 & 21.50 & & \\
\hline $1920^{4}$ & 26.00 & & \\
\hline 1921 & 27.00 & & \\
\hline 1922 & 27.50 & & \\
\hline 1923 & 25.00 & & \\
\hline 1924 & 25.00 & & \\
\hline 1925 & 22.50 & & \\
\hline 1926 & 24.00 & & \\
\hline 1927 & 23.00 & & \\
\hline 1928 & 24.00 & & $\mathrm{Hfl} 1$ week $^{5}$ \\
\hline 1929 & 23.50 & & \\
\hline 1930 & 24.25 & & \\
\hline 1931 & $25.00^{6}$ & & \\
\hline 1932 & $25.00^{7}$ & & \\
\hline
\end{tabular}

Bron: SAA. 5256. Jaarverslagen Burgerlijk Armbestuur van Amsterdam. 1909-1932 Bestanddeel 832,833 en 834.

1 Maximum bedrag door Gemeenteraad vastgesteld.

2 In 1913 werd de afzonderlijke broodbedeling afgeschaft. Het maximum aan geldbedeling werd daarom verhoogd.

3 Sinds 1919 stelt de Gemeenteraad geen maximumbedragen meer vast. Daarom nu: hoogste bedragen

4 De afzonderlijke verstrekking van brandstof werd in de winter van 1920/1921 afgeschaft. In de winter van 1919/1920 is dus voor het laatst brandstof uitgedeeld. In plaats daarvan kwam een brandstoftoeslag van $\mathrm{Hfl} 1$ per week tijdens de winter.

5 Vanwege de zeer koude winter 1928/1929 werd er een extra brandstoftoeslag verstrekt van 17 november 1928 tot 28 maart 1929. De winter van 1928/1929 neemt de vijfde plaats in van de koudste winters sinds 1901 gemeten in De Bilt volgens het classificatiesysteem van de Hellmann-koude getallen. (Bron: KNMI: https://www.knmi.nl/nederland-nu/klimatologie/lijsten/ hellmann).

6 Categorie Meer dan hfl 25.00. Het bedrag is hoger van $25 \mathrm{hfl}$ per week.

7 Categorie Meer dan hfl 25.00. Het bedrag is hoger van $25 \mathrm{hfl}$ per week. 
AANTALLEN DUBBEL BEDEELDEN

BURGERLIJK ARMBESTUUR AMSTERDAM

1896-1922

\begin{tabular}{|c|c|c|c|c|c|c|c|}
\hline Jaar & \multicolumn{2}{|c|}{ Met geld } & \multirow[t]{2}{*}{$\begin{array}{l}\text { Met geld } \\
\text { en brood }\end{array}$} & \multirow[t]{2}{*}{$\begin{array}{l}\text { Met geld } \\
\text { alleen }\end{array}$} & \multirow[t]{2}{*}{$\begin{array}{l}\text { Met brood } \\
\text { alleen }\end{array}$} & \multirow[t]{2}{*}{$\begin{array}{l}\text { Met } \\
\text { turf }\end{array}$} & \multirow[t]{2}{*}{ Totaal bedeelde partijen } \\
\hline & Doorlopend & Tijdelijk & & & & & \\
\hline 1896 & & 110 & 167 & 3 & 15 & & 125 \\
\hline 1897 & 222 & 70 & 285 & 7 & 62 & & 354 \\
\hline 1898 & 230 & 201 & 413 & 18 & 113 & 326 & 544 \\
\hline 1899 & 277 & 240 & 495 & 22 & 107 & 380 & 624 \\
\hline 1900 & 339 & 286 & 605 & 20 & 147 & 466 & 742 \\
\hline 1901 & 363 & 331 & 670 & 24 & 147 & 568 & 841 \\
\hline $1902^{2}$ & 424 & 508 & 876 & 56 & 189 & 741 & 1121 \\
\hline 1903 & & & & & & & 1090 \\
\hline 1904 & & & & & & & 1135 \\
\hline 1905 & & & & & & & 1110 \\
\hline 1906 & & & & & & & 1059 \\
\hline 1907 & & & & & & & 1124 \\
\hline 1908 & & & & & & & 1323 \\
\hline 1909 & & & & & & & 1428 \\
\hline 1910 & & & & & & & 1426 \\
\hline 1911 & & & & & & & 1380 \\
\hline 1912 & & & & & & & 1353 \\
\hline 1913 & & & & & & & 1358 \\
\hline 1914 & & & & & & & 1153 \\
\hline 1915 & & & & & & & 1038 \\
\hline 1916 & & & & & & & 1261 \\
\hline 1917 & & & & & & & 1210 \\
\hline 1918 & & & & & & & 1331 \\
\hline 1919 & & & & & & & 1504 \\
\hline 1920 & & & & & & & 1495 \\
\hline 1921 & & & & & & & 1373 \\
\hline 1922 & & & & & & & 1310 \\
\hline
\end{tabular}

Bron: SAA 5256. Jaarverslagen Burgerlijk Armbestuur van Amsterdam Jaarverslagen 1896-1922.Bestanddeel 832,833 en 834

1 Vanaf 1907 briketten.

2 Vanaf 1902 kunnen ook Isrälieten aangesloten bij het Nederlands Israëlitisch Kerkgenootschap dubbel bedeeld worden.

Over de Joodse armenzorg uitvoeriger: Leydesdorff (1987), 235-265.Als zij stelt dat deze zorg "niet alleen (was voor) het verschaffen van brood, of geld voor de huur, maar ook (om) de mensen in staat (te) stellen materieel (te kopen om) de Joodse levenswijze met al haar rituelen te handhaven"(235), dan kan daaraan toegevoegd worden dat dit streven tot behoud van de eigen identiteit ook gold voor de overige religieuze zorg. 


\section{TAKEN VAN DE GEMEENTELIJKE ARMENZORG EN UITBREIDING VAN WERKZAAMHEDEN ${ }^{1}$}

1871 Bij de instelling van het Burgerlijk Armbestuur in 1871 was de voornaamste taak het bedelen van brood, turf en goederen. Voor 1871 werden deze taken verricht op het stadhuis en door de 50 buurtcommissarissen. Daarnaast zorgde het Burgerlijk Armbestuur voor genees-, heel- en verloskundige hulp.

1872 Extra taak: onderzoek naar bewijzen van onvermogen.

Extra taak: kosteloze plaatsing op openbare scholen

1875 Onderzoek naar personen die in het Armenhuis opgenomen wilden worden

1878 Onderzoek naar aanvragen voor kosteloos ziekenvervoer (per vigilante of per draagbaar).

1879 Onderzoek naar gezinnen met zoons die milicien zijn. ${ }^{2}$

1891 Onderzoek ten bate van het Statistisch Instituut naar het Armwezen.

1897 Invoering vrijwillige (onbezoldigde) armbezoekers bracht veel extra kantoorwerk met zich mee. ${ }^{3}$

1900 Per 1900 werd het Burgerweeshuis onder beheer van het BA geplaatst. Ook de Gasthuizen gaan onder het directe beheer van het BA vallen. ${ }^{4}$

1902 De verzorging van "maatschappelijk ongeschikten" wordt een taak voor het BA. ${ }^{5}$

1909 Het herstellingsoord in Bergen aan Zee werd in gebruik genomen. ${ }^{6}$ De administratieve afhandeling geschiedde via het BA.

1912 De nieuwe Armenwet van 1912 heeft als nieuwe eis dat de ondersteuning niet langer dan voor een periode van drie maanden mag worden verstrekt. Hierdoor moet nu elke drie maanden een nieuw onderzoek gedaan worden. Dat betekent een aanzienlijke uitbreiding van de werkzaamheden. ${ }^{7}$

1914 In 1914 werd het Algemeen Steuncomité Amsterdam opgericht, gesubsidieerd door de gemeente en het Koninklijk Nationaal Steuncomité. De gemeentelijke armenzorg controleerde het Algemeen Steuncomité Amsterdam. In 1919 werden de werkzaamheden van het Algemeen Steuncomité beëindigd.

1919 Door de opheffing van het Algemeen Steuncomité werden veel behoeftigen naar het Burgerlijk Armbestuur verwezen. ${ }^{8}$

1921 Door de annexatie van 1921 werden de oude Burgerlijke Armbesturen opgeheven en alle werkzaamheden en bezittingen werden overgedragen aan het Amsterdamse Burgerlijk Armbestuur. Het gaat om de Burgerlijke Armbesturen van Sloten, Watergraafsmeer, Nieuwendam, Buiksloot, het college van Algemeene armenvoogden te Ransdorp en het weldadigheidsfonds te Zunderdorp. ${ }^{9}$

1927 De gemeentelijke armenzorg (Maatschappelijke Steun) krijgt er een aantal taken bij: de behandeling van zaken betreffende de Vereniging Hulp voor Onbehuisden en de aangelegenheden betreffende de Federatie van instellingen van kinderbescherming.

1930 Er komt een systematische aanpak van bedelarij in samenwerking met de politie. Er komt een speciale ambtenaar voor bedelarij. ${ }^{10}$

1931 Het ministerie van Binnenlandse Zaken wil tot 40\% bijdragen in de kosten voor de werklozen, op voorwaarde dat alle regelingen vooraf door het departement moesten worden goedgekeurd. De gemeentelijke armenzorg (MS) moet deze procedure administratief ondersteunen. ${ }^{11}$

Jaren'30 MS voerde diverse administratieve regelingen door in verband met de werkloosheid. Zo onderzocht de gemeentelijke armenzorg de aanvragen die werklozen deden bij de Crisiscommissie. Ook het stempelen en het uitbetalen van werklozen geschiedde aanvankelijk onder auspiciën van MS. Later in de jaren '30 kwamen er aparte bijkantoren en speciale stempellokalen. Georganiseerde werklozen konden terecht bij de kantoren van hun vakbonden. ${ }^{12}$

1935 MS wordt betrokken bij de Amsterdamse Stichting voor Vereenigde Woekerbestrijding

1937 MS wordt betrokken bij de Stichting Amsterdamsch Borgstellingsfonds voor den Middenstand

1 Door het ontbreken van het beleidsarchief is het mogelijk dat een aantal nieuwe taken niet zijn beschreven.

2 Bovenstaande gegevens over 1871 tot 1879 in SAA. 15030. Bestanddeel 1320171880 Jaarverslag Burgerlijk Armbestuur van Amsterdam 1880.

3 SAA. 15030. Bestanddeel 132030. Jaarverslag Burgerlijk Armbestuur van Amsterdam 1897.

4 SAA. 15030. Bestanddeel 132031. Jaarverslag Burgerlijk Armbestuur van Amsterdam 1899.

5 Volgens een raadsbesluit van 12 maart 1902 SAA. Toegangsnummer 15030 Bestanddeel 132034. Jaarverslag Burgerlijk

Armbestuur van Amsterdam 1902.

6 SAA. 15030. Bestanddeel 133310 Jaarverslag Burgerlijk Armbestuur van Amsterdam 1908 (Gemeenteverslag 1908, Bijlage $\mathrm{X})$.

7 SAA. 5256 Bestanddeel 833. Jaarverslag Burgerlijk Armbestuur van Amsterdam 1913.

8 SAA. 15030. Bestanddeel 133324. Gemeenteverslag 1919.

9 SAA. 15030. Bestanddeel 133328. Gemeenteverslag 1923.

10 SAA. 5256. Bestanddeel 834. Verslag van de Burgerlijke Instelling voor Maatschappelijke Steun 1930.

11 SAA. 5256. Bestanddeel 834. Verslag van de Burgerlijke Instelling voor Maatschappelijke Steun 1931.

12 De werkloosheidsbestrijding in Amsterdam wordt uitvoeriger behandeld door De Rooy (1979), 38, 43-57, 79-92,127-

$133,153-174,185-208$. 


\section{BIJLAGE 8}

\section{STATISTISCHE BIJLAGE ${ }^{1}$}

In deze bijlage is een selectie opgenomen van kwantitatieve gegevens uit de database die ik heb opgesteld aan de hand van de rapporten van de armbezoekers van de gemeentelijke armenzorg in Amsterdam. ${ }^{2}$

Dit kwantitatieve materiaal heb ik in grafieken (lijngrafieken, kolomdiagrammen en cirkeldiagrammen) en tabellen verwerkt. De grafieken zijn in het tekstgedeelte opgenomen. Zij zijn bedoeld om de cijfers wat aanschouwelijker te maken. Het "laatste woord" hebben de tabellen.

Nota: de vermelding - in de tabellen betekent nihil.

Tabel 8.1 Inkomensverdeling (1900, 1910, 1921 en 1931)

In percentages

\begin{tabular}{|c|c|c|c|c|}
\hline Inkomensklasse & $\begin{array}{l}\text { Fiscaal jaar } \\
1899 / 1900\end{array}$ & $\begin{array}{l}\text { Fiscaal jaar } \\
1909 / 1910\end{array}$ & $\begin{array}{l}\text { Fiscaal jaar } \\
1920 / 1921\end{array}$ & $\begin{array}{l}\text { Fiscaal jaar } \\
1930 / 1931\end{array}$ \\
\hline $\begin{array}{l}\text { Onvermogenden } \\
\text { (=minder dan belastingvrije voet) }\end{array}$ & 65.9 & 44.6 & 15.0 & 10.1 \\
\hline Laagst aangeslagen tot $f 1.000$ * & 18.9 & 36.3 & 13.1 & 16.9 \\
\hline$f 1.001-1.500$ & 5.5 & 8.3 & 30.2 & 21.3 \\
\hline$f 1.501-2.500$ & 4.5 & 5.4 & 26.3 & 34.6 \\
\hline$f 2.501-5.000$ & 3.0 & 2.9 & 8.4 & 12.4 \\
\hline$>f 5.001$ & 2.3 & 2.1 & 7.1 & 4.6 \\
\hline Totaal & 100.0 & 100.0 & 100.0 & 100.0 \\
\hline
\end{tabular}

* In 1899/1900 en in 1909/1910 bedroeg de belastingvrije voet $f$ 600. In 1920/1921 was dat $f 700$ en in 1930/1931 $f 800$. Bron: Van der Velden (1993), 153.

1 Tenzij anders vermeldt komen de gegevens in deze bijlage uit mijn database. De dossiers die zijn opgenomen in deze database zijn vermeld bij de opgave van de geraadpleegde archieven. Vanwege de privacywetgeving worden de gegevens uit 1936 pas in 2041 openbaar. Gegevens uit de database uit 1871 en 1911 zijn wel openbaar.De database is beschikbaar via een email aan javdmaas@gmail.com. Ook in DANS (https://doi.org/10.34894/DIBZ1O) is de database terug te vinden.

2 SAA 5256. 
Tabel 8.2 Mening armbezoekers over de afgewezen aanvragen (1871, 1911 en 1936)

\begin{tabular}{|c|c|c|c|}
\hline Mening & 1871 & 1911 & 1936 \\
\hline & $\mathbf{N}$ & $\mathbf{N}$ & $\mathbf{N}$ \\
\hline \multicolumn{4}{|l|}{ Positieve mening } \\
\hline Een gunstige & 8 & 12 & - \\
\hline Fatsoenlijk & 10 & - & - \\
\hline Geen bemerkingen & - & 55 & - \\
\hline Heel gunstig & 15 & - & - \\
\hline Net & - & 6 & - \\
\hline $\begin{array}{l}\text { Niets ongunstig + niets } \\
\text { dan gunstigs }\end{array}$ & 68 & 37 & - \\
\hline Van onbesproken gedrag & 2 & - & - \\
\hline Vrij gunstig & 16 & 7 & - \\
\hline Werkende lieden & 3 & - & - \\
\hline \multicolumn{4}{|l|}{ Negatieve mening } \\
\hline Hooghartig & 4 & - & - \\
\hline Ongunstig & 43 & 44 & 2 \\
\hline Ordeloos & - & - & - \\
\hline Zeer ongunstig & 24 & & 1 \\
\hline Zeer vuil & 8 & - & - \\
\hline Vermelding mening & 201 & 161 & 3 \\
\hline Geen vermelding mening & 77 & 99 & 122 \\
\hline Totaal & 278 & 260 & 125 \\
\hline
\end{tabular}


Tabel 8.3 Mening armbezoekers over de toegekende aanvragen (1871, 1911 en 1936)

\begin{tabular}{|c|c|c|c|}
\hline Mening & 1871 & 1911 & 1936 \\
\hline & $\mathbf{N}$ & $\mathbf{N}$ & $\mathbf{N}$ \\
\hline \multicolumn{4}{|l|}{ Positieve mening } \\
\hline Beklagenswaardig & 5 & - & - \\
\hline Een gunstige & 33 & 13 & 1 \\
\hline Fatsoenlijk & 20 & - & - \\
\hline Geen bemerkingen & 13 & 53 & - \\
\hline Heel gunstig & 30 & - & - \\
\hline $\begin{array}{l}\text { Niets ongunstig + niets } \\
\text { dan gunstigs }\end{array}$ & 19 & 14 & - \\
\hline Van onbesproken gedrag & 2 & - & - \\
\hline Vrij gunstig & 6 & - & - \\
\hline Zeer treurig & 4 & 6 & - \\
\hline \multicolumn{4}{|l|}{ Negatieve mening } \\
\hline Niet zindelijk & 4 & - & - \\
\hline Ongunstig & 2 & - & - \\
\hline Ordeloos & - & 9 & - \\
\hline Zeer ongunstig & 8 & - & - \\
\hline Vermelding mening & 146 & 95 & 1 \\
\hline Geen vermelding mening & 63 & 82 & 154 \\
\hline Totaal & 209 & 177 & 155 \\
\hline
\end{tabular}


Tabel 8.4 Indruk armbezoekers van de woning van afgewezen aanvragers

(1871, 1911 en 1936)

In absolute aantallen

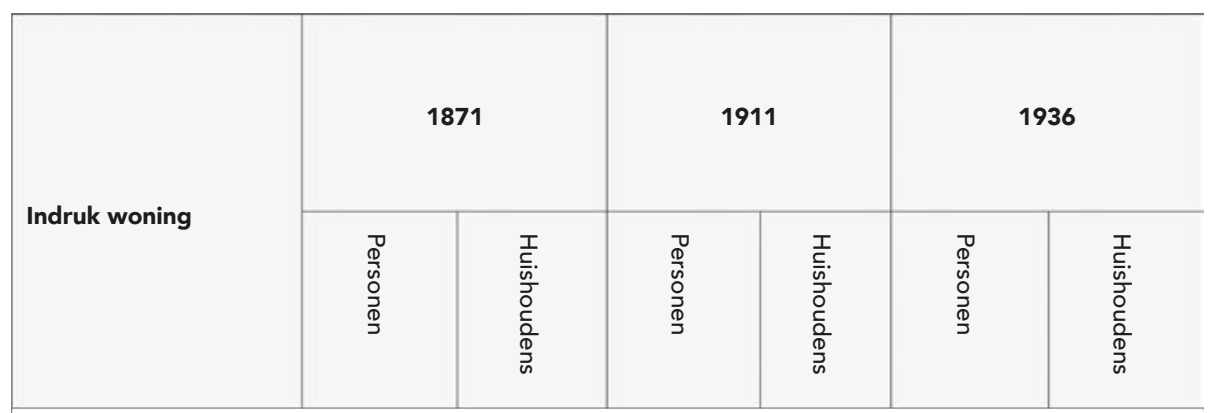

\section{Welstandscriteria}

\begin{tabular}{|l|r|r|r|r|r}
\hline Armoedig & 48 & 11 & 6 & 1 & - \\
\hline Bijna niets aanwezig & 2 & 1 & - & - & - \\
\hline Eenvoudig & - & - & 26 & - & - \\
\hline Ellendige kuil & 2 & 1 & - & - & - \\
\hline Gering & - & - & 144 & - & - \\
\hline Goed gemeubeld & 14 & 4 & - & - & - \\
\hline Redelijk gemeubeld & 11 & 3 & 1 & - & - \\
\hline Weinig meubelen & 6 & 5 & - & - & - \\
\hline Zonder meubelen & 19 & - & - & - \\
\hline
\end{tabular}

Criteria betreffende hygiëne

\begin{tabular}{|c|c|c|c|c|c|c|}
\hline Knap & 40 & 10 & 7 & 2 & - & - \\
\hline Nogal knap & 13 & 2 & - & - & - & - \\
\hline Smerig & 8 & 2 & - & - & - & - \\
\hline Vies & 17 & 3 & 3 & 1 & - & - \\
\hline Vies en waterachtig & 9 & 2 & - & - & - & - \\
\hline Zeer nette indruk & 7 & 1 & - & - & - & - \\
\hline Zeer slordig & 2 & 1 & - & - & - & - \\
\hline Zindelijk & 16 & 3 & - & - & - & - \\
\hline $\begin{array}{l}\text { Opgaven van } \\
\text { welstandscriteria }\end{array}$ & 102 & 26 & 176 & 43 & 3 & 1 \\
\hline $\begin{array}{l}\text { Opgaven betreffende } \\
\text { hygiëne }\end{array}$ & 112 & 24 & 10 & 3 & - & - \\
\hline Geen opgaven & 64 & 13 & 74 & 29 & 122 & 62 \\
\hline Totaal & 278 & 63 & 260 & 75 & 125 & 63 \\
\hline
\end{tabular}


Tabel 8.5 Indruk armbezoekers van de woning toegekende aanvragen

(1871,1911 en 1936)

In absolute aantallen

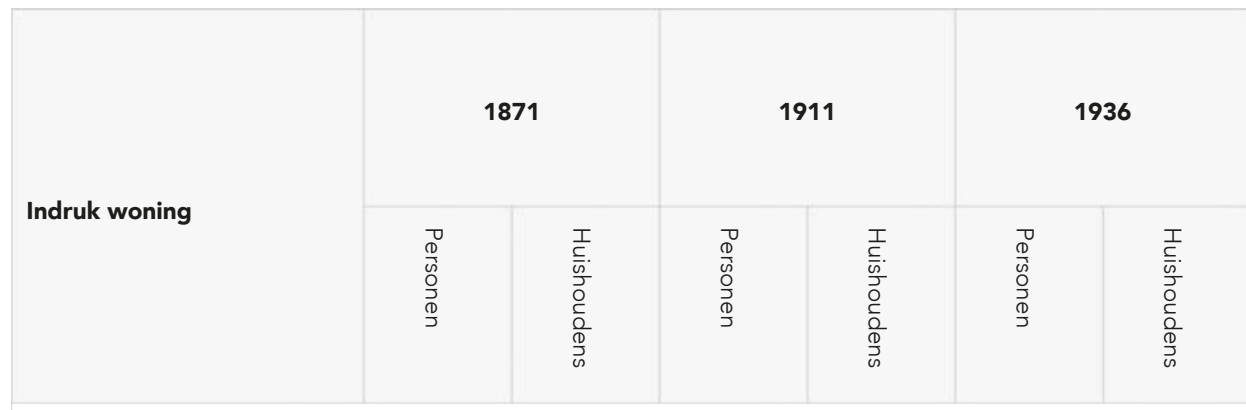

\section{Welstandscriteria}

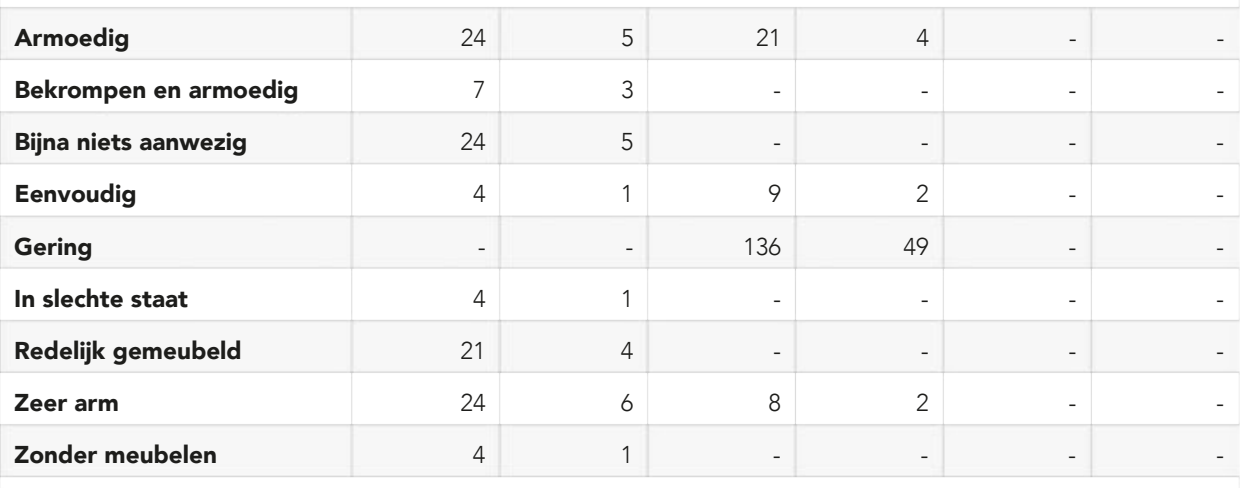

\section{Criteria betreffende hygiëne}

\section{Knap}

Netjes

Niet knap

Tamelijk zindelijk

Vies

Zeer nette indruk

Zindelijk

$4 \quad 1$

11

$8 \quad 1$

Niet van toepassing

\begin{tabular}{|c|c|c|c|c|c|c|}
\hline Nogal groot & 4 & 1 & - & - & - & - \\
\hline Opgaven naar welstand & 108 & 26 & 174 & 57 & - & - \\
\hline Opgaven naar hygiëne & 34 & 9 & - & - & - & - \\
\hline $\begin{array}{l}\text { Opgaven niet van toepas- } \\
\text { sing }\end{array}$ & 4 & 1 & - & - & - & - \\
\hline Geen opgaven & 63 & 25 & 3 & 3 & 155 & 60 \\
\hline Totaal & 209 & 61 & 177 & 60 & 155 & 60 \\
\hline
\end{tabular}




\begin{tabular}{|c|c|c|c|c|c|c|}
\hline \multirow[t]{2}{*}{ Afwijzingsgrond } & \multicolumn{2}{|c|}{$\begin{array}{c}\text { Huishoudens } \\
1871\end{array}$} & \multicolumn{2}{|c|}{$\begin{array}{c}\text { Huishoudens } \\
1911\end{array}$} & \multicolumn{2}{|c|}{$\begin{array}{c}\text { Huishoudens } \\
1936\end{array}$} \\
\hline & $\mathbf{N}$ & $\%$ & $\mathbf{N}$ & $\%$ & $\mathbf{N}$ & $\%$ \\
\hline Kerk kan steunen (verwezen naar) & 16 & 21 & 4 & 4 & - & - \\
\hline Kerk steunt & 5 & 7 & - & - & - & - \\
\hline Dubbele bedeling & 21 & 28 & 4 & 4 & - & - \\
\hline Deelname staking & - & - & 1 & 1 & - & - \\
\hline Drankmisbruik & 6 & 7 & 10 & 10 & - & - \\
\hline Geen schoolbezoek & 2 & 3 & - & - & - & - \\
\hline Luiheid & 1 & 2 & 2 & 2 & - & - \\
\hline Ongunstig gedrag & 2 & 3 & 2 & 2 & - & - \\
\hline Ontslag door eigen schuld & - & - & - & - & 1 & 2 \\
\hline Onzedelijkheid & 5 & 6 & 1 & 1 & 1 & 2 \\
\hline Morele motieven & 16 & 21 & 16 & 16 & 2 & 4 \\
\hline $\begin{array}{l}\text { Aanvrager heeft andere uitkeringsin- } \\
\text { stantie }\end{array}$ & - & - & - & - & 2 & 3 \\
\hline Aanvrager weggelopen & - & - & - & - & 4 & 5 \\
\hline Door aanvrager bedankt & - & - & 13 & 13 & 2 & 3 \\
\hline Komt niet opdagen (op kantoor) & - & - & 1 & 1 & - & - \\
\hline Niet de juiste instantie & - & - & 1 & 1 & 3 & 4 \\
\hline Terug in gezin & - & - & - & - & 1 & 2 \\
\hline Neutrale motieven & - & - & 15 & 15 & 12 & 17 \\
\hline
\end{tabular}




\begin{tabular}{|c|c|c|c|c|c|c|}
\hline \multirow[t]{2}{*}{ Afwijzingsgrond } & \multicolumn{2}{|c|}{$\begin{array}{c}\text { Huishoudens } \\
1871\end{array}$} & \multicolumn{2}{|c|}{$\begin{array}{l}\text { Huishoudens } \\
1911\end{array}$} & \multicolumn{2}{|c|}{$\begin{array}{l}\text { Huishoudens } \\
1936\end{array}$} \\
\hline & $\mathbf{N}$ & $\%$ & $\mathbf{N}$ & $\%$ & $\mathbf{N}$ & $\%$ \\
\hline Aanvrager heeft inmiddels werk & 1 & 2 & 1 & 1 & 10 & 13 \\
\hline Aanvrager kan inwonen bij familie & - & - & 2 & 2 & 1 & 2 \\
\hline Aanvrager kan werken & 1 & 2 & 7 & 7 & - & - \\
\hline Aanvrager nam zelf ontslag & - & - & - & - & 1 & 2 \\
\hline Aanvrager verstrekt geen inlichtingen & 3 & 4 & 13 & 13 & 10 & 13 \\
\hline $\begin{array}{l}\text { Aanvrager woont nog geen jaar zelf- } \\
\text { standig }\end{array}$ & - & - & - & - & 6 & 8 \\
\hline Fraude in opgaven & 5 & 7 & 3 & 3 & 3 & 4 \\
\hline Kan worden opgenomen & - & - & 2 & 2 & 2 & 3 \\
\hline Leeftijd & 3 & 4 & - & - & - & - \\
\hline Onderhoudsplichtigen (kunnen) steunen & 1 & 2 & 6 & 6 & 2 & 3 \\
\hline Overlijden aanvrager & - & - & 1 & 1 & 1 & 2 \\
\hline Vermoeden van fraude & 4 & 5 & 3 & 3 & 4 & 5 \\
\hline Verwezen naar weeshuis & - & - & - & - & - & - \\
\hline Voldoende inkomsten & 19 & 23 & 27 & 27 & 18 & 24 \\
\hline Ziekenhuisopname & 1 & 2 & - & - & - & - \\
\hline Zakelijke motieven & 38 & 51 & 65 & 65 & 58 & 79 \\
\hline $\begin{array}{l}\text { Totaal aantal motieven om af te wijzen } \\
\star\end{array}$ & 75 & 100 & 100 & 100 & 72 & 100 \\
\hline $\begin{array}{l}\text { Aantal huishoudens die zonder opgave } \\
\text { van een motief zijn afgewezen }\end{array}$ & 6 & & 1 & & 2 & \\
\hline
\end{tabular}

* Bij sommige afwijzingen werden twee motieven genoemd. 


\begin{tabular}{|c|c|c|c|c|c|c|}
\hline \multirow[t]{2}{*}{ Afwijzingsgrond } & \multicolumn{2}{|c|}{$\begin{array}{c}\text { Huishoudens } \\
1871\end{array}$} & \multicolumn{2}{|c|}{$\begin{array}{c}\text { Huishoudens } \\
1911\end{array}$} & \multicolumn{2}{|c|}{$\begin{array}{c}\text { Huishoudens } \\
1936\end{array}$} \\
\hline & $\mathbf{N}$ & $\%$ & $\mathbf{N}$ & $\%$ & $\mathbf{N}$ & $\%$ \\
\hline Dubbele bedeling & 21 & 28 & 4 & 4 & 0 & 0 \\
\hline Morele motieven & 16 & 21 & 16 & 16 & 2 & 4 \\
\hline Neutrale motieven & 0 & 0 & 15 & 15 & 12 & 17 \\
\hline Zakelijke motieven & 38 & 51 & 65 & 65 & 58 & 79 \\
\hline Totaal aantal motieven om af te wijzen* & 75 & 100 & 100 & 100 & 72 & 100 \\
\hline $\begin{array}{l}\text { Aantal huishoudens die zonder opga- } \\
\text { ve van een motief zijn afgewezen }\end{array}$ & 6 & & 1 & & 2 & \\
\hline
\end{tabular}

* Bij sommige afwijzingen werden twee motieven genoemd.

Tabel 8.8 Aard van de woning (1871,1911 en 1936)

\begin{tabular}{|l|r|r|r|r|r|r|}
\hline \multirow{2}{*}{ Categorie } & \multicolumn{2}{|c|}{1871} & \multicolumn{2}{|c|}{1911} & \multicolumn{2}{|c|}{1936} \\
\cline { 2 - 6 } & \multicolumn{1}{|c|}{$\mathbf{N}$} & \multicolumn{1}{|c|}{ \% } & \multicolumn{1}{|c|}{$\mathbf{N}$} & \multicolumn{1}{|c|}{$\mathbf{N}$} & \multicolumn{1}{c|}{$\%$} \\
\hline Kelders en gangen & 87 & 29 & 13 & 8 & - \\
\hline Kamerwoningen & 160 & 52 & 29 & 17 & 54 & 21 \\
\hline Twee- en meerkamerwoningen & 59 & 19 & 130 & 75 & 209 & 79 \\
\hline & 306 & 100 & 172 & 100 & 263 & 100 \\
\hline
\end{tabular}

Tabel 8.9 Lichaamsgebreken aanvragers (1871,1911 en 1936)

\begin{tabular}{|c|c|c|c|c|c|c|}
\hline & \multicolumn{2}{|c|}{1871} & \multicolumn{2}{|c|}{1911} & \multicolumn{2}{|c|}{1936} \\
\hline Medische gesteldheid & 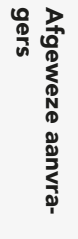 & 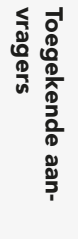 & 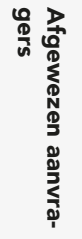 & 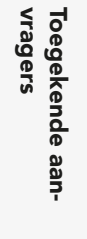 & 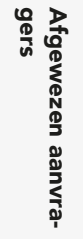 & 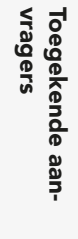 \\
\hline Lichaamsgebreken vermeld & 24 & 29 & 26 & 33 & 10 & 15 \\
\hline $\begin{array}{l}\text { Aanvrager heeft geen lichaamsge- } \\
\text { breken }\end{array}$ & 32 & 4 & 27 & 4 & 50 & 45 \\
\hline Aantal vermeldingen & 56 & 33 & 53 & 37 & 60 & 60 \\
\hline Geen vermeldingen & 7 & 28 & 22 & 23 & 3 & 0 \\
\hline Totaal & 63 & 61 & 75 & 60 & 63 & 60 \\
\hline $\begin{array}{l}\text { Lichaamsgebreken } \\
\text { in \% van vermeldingen }\end{array}$ & 43 & 88 & 49 & 89 & 16 & 25 \\
\hline
\end{tabular}




\begin{tabular}{|c|c|c|c|c|c|c|}
\hline \multirow[b]{2}{*}{ Sociale klasse } & \multicolumn{2}{|c|}{1871} & \multicolumn{2}{|c|}{1911} & \multicolumn{2}{|c|}{1936} \\
\hline & 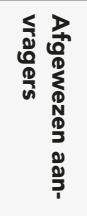 & 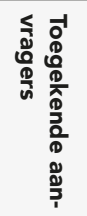 & 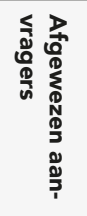 & 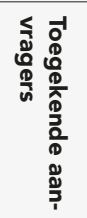 & 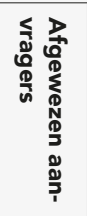 & 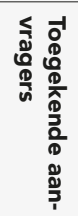 \\
\hline $\begin{array}{l}\text { Hogere professionals en leidinggeven- } \\
\text { den }\end{array}$ & - & - & - & - & 2 & 8 \\
\hline $\begin{array}{l}\text { Lagere professionals, administratief, } \\
\text { verkooppersoneel en lagere bedienden }\end{array}$ & 3 & 6 & 4 & 4 & 24 & 33 \\
\hline Voormannen & 6 & 2 & - & 28 & - & - \\
\hline Middelgeschoolde werknemers & 17 & 21 & 23 & 12 & 24 & 21 \\
\hline Laaggeschoolde werknemers & 20 & 18 & 21 & 32 & 28 & 18 \\
\hline Ongeschoolde arbeiders & 54 & 53 & 50 & 16 & 22 & 20 \\
\hline Ongeschoolde landarbeiders & - & - & 2 & 8 & - & - \\
\hline Totaal & 100 & 100 & 96 & 100 & 74 & 59 \\
\hline
\end{tabular}

Om meer zicht te krijgen op de ontwikkeling heb ik vervolgens de scholingsgraad van de beroepen verdeeld in meer geschoold en minder geschoold. In onderstaande tabel wordt deze indeling weergegeven.

Tabel 8.11 Scholingsgraad aanvragers

\begin{tabular}{|l|l|}
\hline Sociale klasse & $\begin{array}{l}\text { Typering scholingsgraad } \\
\text { van het beroep }\end{array}$ \\
\hline Hogere professionals en leidinggevenden & Meer geschoold \\
\hline $\begin{array}{l}\text { Lagere professionals, administratief, verkooppersoneel en } \\
\text { lagere bedienden }\end{array}$ & Meer geschoold \\
\hline Voormannen & Meer geschoold \\
\hline Middelgeschoolde werknemers & Meer geschoold \\
\hline Laaggeschoolde werknemers & Minder geschoold \\
\hline Ongeschoolde arbeiders & Minder geschoold \\
\hline Ongeschoolde landarbeider & Minder geschoold \\
\hline
\end{tabular}


Tabel 8.12 Uitgaven ondersteuning per jaar (1917-1939)

\begin{tabular}{|c|c|c|c|c|c|}
\hline \multirow{2}{*}{$\begin{array}{l}\text { Op } 31 \\
\text { december }\end{array}$} & \multicolumn{2}{|c|}{ Wekelijkse ondersteuning } & \multirow[b]{2}{*}{$\begin{array}{l}\text { Waarvan } \\
\text { georganiseerde } \\
\text { werklozen } \\
\text { Aantal }\end{array}$} & \multirow[b]{2}{*}{$\begin{array}{l}\text { Waarvan } \\
\text { ongeorganiseerde } \\
\text { werklozen } \\
\text { Aantal }\end{array}$} & \multirow[b]{2}{*}{$\begin{array}{l}\text { Waarvan bedeel- } \\
\text { den } \\
\text { Aantal }\end{array}$} \\
\hline & Aantal huishoudens ${ }^{1}$ & In hfl. & & & \\
\hline 1917 & 12.826 & 1.005 .000 & & & \\
\hline 1918 & 11.551 & 1.378 .000 & & & \\
\hline 1919 & 12.160 & 1.880 .000 & & & \\
\hline 1920 & 9.512 & 1.626 .000 & & & \\
\hline 1921 & 11.642 & 2.126 .000 & & & \\
\hline 1922 & 12.171 & 3.091 .000 & & & \\
\hline 1923 & 14.506 & 3.640 .000 & & & \\
\hline 1924 & 14.148 & 3.196 .000 & & & \\
\hline 1925 & 12.379 & 3.008 .000 & & & \\
\hline 1926 & 13.383 & 3.472 .000 & & & \\
\hline 1927 & 15.554 & 4.114.000 & & & \\
\hline 1928 & 13.083 & 3.706 .000 & & & \\
\hline 1929 & 13.042 & 3.682 .000 & & & \\
\hline 1930 & 14.734 & 4.030 .000 & & & \\
\hline 1931 & 24.768 & 9.942 .000 & 8.616 & 8.417 & 7.705 \\
\hline 1932 & 36.551 & 19.393 .000 & 13.012 & 14.066 & 9.473 \\
\hline 1933 & 39.779 & 22.309 .000 & 12.397 & 16.734 & 10.648 \\
\hline 1934 & 43.360 & 22.259 .000 & 13.836 & 17.750 & 11.774 \\
\hline 1935 & 51.402 & 25.389 .000 & 16.255 & 21.517 & 13.360 \\
\hline 1936 & 52.365 & 29.318 .000 & 14.107 & 23.656 & 14.602 \\
\hline 1937 & 52.148 & 26.935 .000 & 13.765 & 22.718 & 15.655 \\
\hline 1938 & 54.154 & 28.617 .000 & 13.322 & 24.157 & 16.675 \\
\hline 1939 & 45.836 & 25.846 .000 & 10.497 & 17.946 & 17.393 \\
\hline
\end{tabular}

Bron: Statistisch jaarboek der gemeente Amsterdam. 
Tabel 8.13 Gemiddelde ondersteuning per huishouden (1917-1939)

\begin{tabular}{|c|c|}
\hline Jaar & $\begin{array}{l}\text { Steunbedrag } \\
\text { per jaar in hfl }\end{array}$ \\
\hline 1917 & 78 \\
\hline 1918 & 119 \\
\hline 1919 & 155 \\
\hline 1920 & 171 \\
\hline 1921 & 183 \\
\hline 1922 & 254 \\
\hline 1923 & 251 \\
\hline 1924 & 226 \\
\hline 1925 & 243 \\
\hline 1926 & 259 \\
\hline 1927 & 264 \\
\hline 1928 & 283 \\
\hline 1929 & 282 \\
\hline 1930 & 274 \\
\hline 1931 & 401 \\
\hline 1932 & 530 \\
\hline 1933 & 560 \\
\hline 1934 & 513 \\
\hline 1935 & 493 \\
\hline 1936 & 560 \\
\hline 1937 & 516 \\
\hline 1938 & 528 \\
\hline 1939 & 564 \\
\hline
\end{tabular}

Het gemiddelde steunbedrag is berekend uit de gegevens van tabel 8.12 naar de totale uitgaven per jaar aan wekelijkse bedeling en het aantal ondersteunde huishoudens. 
Tabel 8.14 Uitgaven Burgerlijk Armbestuur (1871-1928)

\begin{tabular}{|c|c|c|c|}
\hline Jaar & $\begin{array}{l}\text { Totale uitgaven in } \\
\mathrm{hfl} \times 1.000\end{array}$ & $\begin{array}{l}\text { Tekort gedekt door de gemeentekas } \\
\text { in hfl x } 1.000\end{array}$ & $\begin{array}{c}\text { Aandeel gemeentekas in percen- } \\
\text { tages }\end{array}$ \\
\hline 1871 & 39 & 0 & 0 \\
\hline 1872 & 35 & 0 & 0 \\
\hline 1873 & 34 & 3 & 8 \\
\hline 1874 & 36 & 5 & 14 \\
\hline 1875 & 34 & 4 & 12 \\
\hline 1876 & 37 & 7 & 19 \\
\hline 1877 & 34 & 3 & 9 \\
\hline 1878 & 34 & 4 & 12 \\
\hline 1879 & 36 & 5 & 14 \\
\hline 1880 & 42 & 10 & 24 \\
\hline 1881 & 41 & 10 & 24 \\
\hline 1882 & 41 & 9 & 22 \\
\hline 1883 & 39 & 10 & 26 \\
\hline 1884 & 40 & 10 & 25 \\
\hline 1885 & 42 & 11 & 26 \\
\hline 1886 & 45 & 14 & 31 \\
\hline $1887^{1}$ & 68 & 36 & 53 \\
\hline 1888 & 56 & 25 & 45 \\
\hline 1889 & 58 & 27 & 47 \\
\hline 1890 & 66 & 36 & 55 \\
\hline 1891 & 86 & 56 & 65 \\
\hline 1892 & 110 & 73 & 66 \\
\hline 1893 & 117 & 83 & 71 \\
\hline 1894 & 126 & 95 & 75 \\
\hline 1895 & 127 & 94 & 74 \\
\hline 1896 & 117 & 85 & 73 \\
\hline 1897 & 115 & 80 & 70 \\
\hline 1898 & 128 & 96 & 75 \\
\hline 1899 & 131 & 100 & 76 \\
\hline 1900 & 139 & 107 & 77 \\
\hline 1901 & 165 & 130 & 79 \\
\hline $1902^{2}$ & 176 & 146 & 83 \\
\hline 1903 & 193 & 164 & 85 \\
\hline 1904 & 204 & 174 & 85 \\
\hline 1905 & 214 & 184 & 86 \\
\hline
\end{tabular}




\begin{tabular}{|c|c|c|c|}
\hline Jaar & $\begin{array}{l}\text { Totale uitgaven in } \\
\text { hfl } \times 1.000\end{array}$ & $\begin{array}{l}\text { Tekort gedekt door de gemeentekas } \\
\text { in } \mathrm{hfl} \times 1.000\end{array}$ & $\begin{array}{l}\text { Aandeel gemeentekas in percen- } \\
\text { tages }\end{array}$ \\
\hline 1906 & 217 & 170 & 78 \\
\hline 1907 & 248 & 211 & 85 \\
\hline 1908 & 307 & 268 & 87 \\
\hline 1909 & 332 & 302 & 91 \\
\hline 1910 & 342 & 309 & 90 \\
\hline 1911 & 355 & 325 & 92 \\
\hline 1912 & 393 & 365 & 93 \\
\hline 1913 & 390 & 359 & 92 \\
\hline 1914 & 426 & 397 & 93 \\
\hline $1915^{3}$ & 749 & 719 & 96 \\
\hline 1916 & 937 & 901 & 96 \\
\hline 1917 & 1.161 & 1.123 & 96 \\
\hline 1918 & 1.581 & 1.546 & 97 \\
\hline 1919 & 2.188 & 2.127 & 97 \\
\hline 1920 & 2.066 & 2.036 & 99 \\
\hline $1921^{4}$ & 3.800 & 3.772 & 99 \\
\hline 1922 & 5.661 & 5.633 & 99 \\
\hline 1923 & 7.337 & 7.302 & 99 \\
\hline $1924^{5}$ & 5.913 & 5.879 & 99 \\
\hline 1925 & 5.365 & 5.309 & 99 \\
\hline 1926 & 6.107 & 6.056 & 99 \\
\hline 1927 & 6.103 & 6.049 & 99 \\
\hline 1928 & 6.094 & 6.047 & 99 \\
\hline
\end{tabular}

Bron: Statistisch Jaarboek der gemeente Amsterdam.

1 In 1887 had een buitengewone winterbedeling plaats.

2 Sinds 1 juli 1902 met inbegrip van de Nederlandsch-Israëlitische ondersteunden door het Burgerlijk Armbestuur.

3 Sinds 1915 wordt het Weduwenhof apart berekend. In 1915 bedragen de kosten hfl 6.184,05 die in zijn geheel door de gemeente worden gedragen.

4 Sinds 1921 behoorde de voormalige gemeente Sloten ook bij de gemeente Amsterdam.

5 Vanaf 1924 zijn er gesplitste kosten: Gemeentelijke bureau voor Maatschappelijken steun en Burgerlijke Instelling voor Maatschappelijken Steun. Deze laatste instelling is in werking sinds 1 januari 1927, maar voor de statistiek is er teruggerekend naar rechtsvoorgangers c.q. het Burgerlijk Armbestuur. In mijn statistiek vindt geen splitsing plaats, maar is het cijfer de optelsom van de kosten voor het Gemeentelijk bureau voor Maatschappelijke steunen en de Burgerlijke Instelling voor Maatschappelijken Steun. 
Tabel 8.15 Aanvragen om ondersteuning; toegekende aanvragen; omvang huishoudens (1886-1895)

\begin{tabular}{|l|r|r|r|}
\hline Jaar & $\begin{array}{c}\text { Aantal } \\
\text { aanvragen }\end{array}$ & $\begin{array}{c}\text { Aantal } \\
\text { toegekende aanvragen }\end{array}$ & $\begin{array}{c}\text { Omvang huishoudens } \\
\text { in personen }\end{array}$ \\
\hline $\mathbf{1 8 8 6}$ & 2086 & 1037 & 3.9 \\
\hline $\mathbf{1 8 8 7}$ & 2600 & 1945 & 3.8 \\
\hline $\mathbf{1 8 8 8}$ & 1548 & 1218 & 4.3 \\
\hline $\mathbf{1 8 8 9}$ & 2020 & 1520 & 4.3 \\
\hline $\mathbf{1 8 9 0}$ & 3552 & 1505 & 3.9 \\
\hline $\mathbf{1 8 9 1}$ & 4194 & 2239 & 3.9 \\
\hline $\mathbf{1 8 9 2}$ & 4784 & 2630 & 3.8 \\
\hline $\mathbf{1 8 9 3}$ & 6469 & 3099 & 3.8 \\
\hline $\mathbf{1 8 9 4}$ & 8473 & 3429 & 3.9 \\
\hline $\mathbf{1 8 9 5}$ & 8144 & 3223 & 3.7 \\
\hline
\end{tabular}

Bron: Statistisch Jaarboek der gemeente Amsterdam 1895, deel II 23.

NB aanvragers zijn hoofden van gezinnen of alleenstaanden ("alleenlopenden"): het gaat dus om "huishoudens". 
Tabel 8.16 Onderzoeken Burgerlijk Armbestuur naar huiszittenarmen (1905-1940)

\begin{tabular}{|c|c|}
\hline Jaar & Aantal \\
\hline 1905 & 41.032 \\
\hline 1906 & 43.503 \\
\hline 1907 & 44.098 \\
\hline 1908 & 50.700 \\
\hline 1909 & 50.425 \\
\hline 1910 & 52.746 \\
\hline 1911 & 51.078 \\
\hline 1912 & 54.732 \\
\hline 1913 & 53.342 \\
\hline $1914^{1}$ & 85.886 \\
\hline 1915 & 100.630 \\
\hline 1916 & 125.806 \\
\hline 1917 & 131.898 \\
\hline 1918 & 165.947 \\
\hline 1919 & 155.375 \\
\hline 1920 & 100.246 \\
\hline 1921 & 135.331 \\
\hline 1922 & 157.845 \\
\hline 1923 & 190.244 \\
\hline 1924 & 195.306 \\
\hline 1925 & 187.294 \\
\hline 1926 & 210.190 \\
\hline 1927 & 208.811 \\
\hline 1928 & 191.255 \\
\hline 1929 & 178.834 \\
\hline 1930 & 196.000 \\
\hline $1931^{2}$ & 284.849 \\
\hline 1932 & 406.747 \\
\hline 1933 & 555.148 \\
\hline 1934 & 452.138 \\
\hline 1935 & 487.860 \\
\hline 1936 & 512.333 \\
\hline 1937 & 506.988 \\
\hline 1938 & 504.402 \\
\hline 1939 & 501.620 \\
\hline $1940^{3}$ & 608.642 \\
\hline
\end{tabular}

Bron: SAA 5256 Bestanddelen 832, 833, 834. Jaarverslagen Burgerlijk Armbestuur van Amsterdam 1905-1940.

1 Toename door onderzoekingen naar "uitgetrokken" diamantbewerkers. Daarnaast waren meer uitgebreide onderzoeken 2 Sinds 1931 ook Crisiscomité en Ondersteuning werklozen.

3 Opgesplitst in armlastigen: 293.521; ongeorganiseerde werklozen 190.850; georganiseerde werklozen 124.271. 
Tabel 8.17 Aandeel Burgerlijk Armbestuur in het aantal ondersteunde armen (1885-1905)

In percentages ${ }^{1}$

\begin{tabular}{|c|c|}
\hline Jaar & Aandeel Burgerlijk armbestuur \\
\hline 1885 & 3 \\
\hline 1886 & 4 \\
\hline 1887 & 4 \\
\hline 1888 & Opgave ontbreekt \\
\hline 1889 & 4 \\
\hline 1890 & 5 \\
\hline 1891 & 7 \\
\hline 1892 & 8 \\
\hline 1893 & 10 \\
\hline 1894 & 18 \\
\hline 1895 & 17 \\
\hline 1896 & 23 \\
\hline 1897 & 12 \\
\hline 1898 & 15 \\
\hline 1899 & 15 \\
\hline $1900^{2}$ & 29 \\
\hline 1901 & 30 \\
\hline 1902 & 32 \\
\hline 1903 & Opgave ontbreekt \\
\hline 1904 & 35 \\
\hline 1905 & 35 \\
\hline 1906 & 31 \\
\hline 1907 & 32 \\
\hline
\end{tabular}

Bron: SAA 5186 Secretarie; Afdeling Sociale Zaken en rechtsvoorgangers (armengelden).Bestanddeel13 1808 - 1894. Bestanddeel 141895 - 1900. Bestanddeel 15 1901- 1902. Bestanddeel 161903 - 1906. Bestanddeel 171906 - 1908.

Tabel 8.18 Aandeel Burgerlijk Armbestuur in totale bedeling (1917-1921)

In percentages

\begin{tabular}{|l|r|}
\hline Jaar & \multicolumn{2}{|c|}{ Aandeel Burgerlijk Armbestuur } \\
\hline 1917 & 38 \\
\hline 1918 & 42 \\
\hline 1919 & 44 \\
\hline 1920 & 43 \\
\hline 1921 & 53 \\
\hline
\end{tabular}

Bron: Verkort verslag van den Armenraad met Centraal bureau voor maatschappelijk hulpbetoon te Amsterdam over het jaar 1921,12

1 Deze gegevens werden verzameld om de zogeheten Armengelden te verdelen. De Armengelden waren een jaarlijkse Koninklijke gift. De uitkeringen werden door het Rijk aan de gemeente verstrekt, zodat zij die kon verdelen. De verdeling geschiedde naar rato van het aantal armen dat door de instellingen werd verzorgd.

2 De Nota armengelden d.d. 11 juni 1900 (SAA 5186 Secretarie; Afdeling Sociale Zaken en rechtsvoorgangers (Armengelden) Bestanddeel 15) wijst erop dat het aantal armen dat opgegeven werd door de verschillende besturen onderlinge verschillen vertoonden. De vorm waarin de respectievelijke armen werden ondersteund verschilde. De opgaven waren daarom onderling moeilijk te vergelijken. 
Tabel 8.19 Bedeelden door gemeentelijke, particuliere en kerkelijke armenzorg (1895 en 1930)

\begin{tabular}{|c|c|c|c|c|}
\hline \multirow[b]{2}{*}{ Instelling } & \multicolumn{2}{|c|}{1895} & \multicolumn{2}{|c|}{1930} \\
\hline & $\begin{array}{l}\text { Aantal bedeel- } \\
\text { den N }\end{array}$ & $\begin{array}{l}\text { Aantal bedeel- } \\
\text { den in \% }\end{array}$ & $\begin{array}{l}\text { Aantal bedeel- } \\
\text { den N }\end{array}$ & $\begin{array}{l}\text { Aantal bedeelden } \\
\text { in } \%\end{array}$ \\
\hline Gemeentelijk bedeelden & 3.729 & 17,2 & 14.553 & 70,9 \\
\hline $\begin{array}{l}\text { De particuliere armenzorg (o.a. Liefda- } \\
\text { digheid naar Vermogen) }\end{array}$ & 3.184 & 14,7 & 1.035 & 5,1 \\
\hline Protestantse gezindten & 5.069 & 23,4 & 985 & 4,8 \\
\hline Katholieke gezindten & 7.411 & 34,2 & 2.829 & 13,8 \\
\hline $\begin{array}{l}\text { De armenzorg der Oud- Bisschoppelijke } \\
\text { Cleresie }\end{array}$ & 36 & 0 & 0 & 0 \\
\hline \multirow[t]{2}{*}{ De armenzorg der Israëlitische gezindten } & 2.268 & 10,5 & 1.100 & 5,4 \\
\hline & 21.697 & 100,0 & 20.502 & 100,0 \\
\hline
\end{tabular}

Bron: Statisch Jaarboek der gemeente Amsterdam 1932-1933

Tabel 8.20 Bedeelden door algemene en kerkelijke armenzorg (1895 en 1930)

In percentages

\begin{tabular}{|l|r|r|}
\hline Instelling & $\mathbf{1 8 9 5}$ & \multicolumn{2}{|c|}{1930} \\
\hline Algemene instellingen & 32 & 76 \\
\hline Religieuze instellingen & 68 & 24 \\
\hline
\end{tabular}

Bron: Statisch Jaarboek der gemeente Amsterdam 1932-1933. 


\begin{tabular}{|c|c|c|c|c|c|c|c|}
\hline 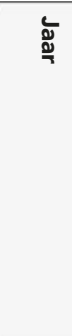 & 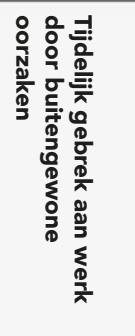 & 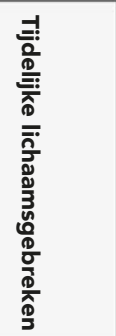 & 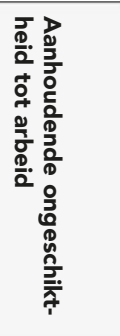 & 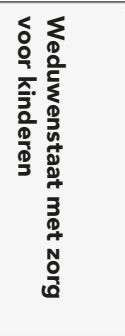 & 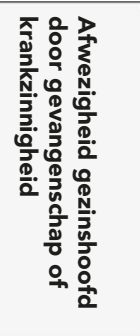 & 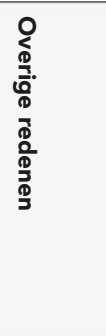 & 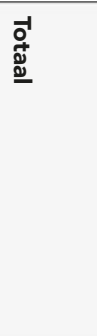 \\
\hline 1886 & 23,9 & 0,2 & 46,6 & 27,3 & 2,0 & & 100.0 \\
\hline 1887 & 29,5 & 1,9 & 39,9 & 27,0 & 1,7 & & 100.0 \\
\hline 1888 & 42,0 & 3,6 & 29,9 & 22,9 & 1,6 & & 100.0 \\
\hline 1889 & 40,2 & 4,4 & 31,9 & 22,1 & 1,6 & & 100.0 \\
\hline 1890 & 28,5 & 3,0 & 36,5 & 30,5 & 1,5 & & 100.0 \\
\hline 1891 & 29,3 & 2,5 & 38,4 & 28,5 & 1,3 & & 100.0 \\
\hline 1892 & 30,2 & 3,6 & 37,9 & 26,5 & 1,8 & & 100.0 \\
\hline 1893 & 34,9 & 3,5 & 35,4 & 24,4 & 1,8 & & 100.0 \\
\hline 1894 & 36,7 & 4,7 & 32,8 & 24,7 & 1,1 & & 100.0 \\
\hline 1895 & 34,2 & 2,6 & 34,2 & 28,1 & 0,9 & & 100.0 \\
\hline 1896 & 24,2 & 2,0 & 39,9 & 33,1 & 0,8 & & 100.0 \\
\hline 1897 & 21,3 & 2,7 & 44,1 & 30,8 & 1,1 & & 100.0 \\
\hline 1898 & 21,5 & 3,5 & 42,7 & 30,8 & 1,5 & & 100.0 \\
\hline 1899 & 19,1 & 2,8 & 44,2 & 32,4 & 1,5 & & 100.0 \\
\hline 1900 & 15,4 & 4,3 & 44,7 & 34,3 & 1,3 & & 100.0 \\
\hline 1901 & 14,4 & 4,9 & 46,8 & 32,8 & 1,1 & & 100.0 \\
\hline 1902 & 16,1 & 7,3 & 47,0 & 26,9 & 2,7 & & 100.0 \\
\hline 1903 & 13,2 & 14,2 & 47,1 & 22,6 & 2,9 & & 100.0 \\
\hline 1904 & 12,0 & 12,9 & 48,5 & 23,3 & 3,3 & & 100.0 \\
\hline 1905 & 12,0 & 10,3 & 50,9 & 23,5 & 3,3 & & 100.0 \\
\hline 1906 & 7,9 & 9,3 & 53,4 & 24,2 & 2,8 & 2,4 & 100.0 \\
\hline 1907 & 10.9 & 10,0 & 49,9 & 23,2 & 2,2 & 3,8 & 100.0 \\
\hline 1908 & 13,0 & 9,2 & 49,1 & 22,1 & 2,4 & 4,2 & 100.0 \\
\hline
\end{tabular}

Bron: Statistisch Jaarboek der gemeente Amsterdam 1895, deel II, 27; Statistisch Jaarboek der gemeente Amsterdam 1905-1909, 288 NB percentages 1890 en 1894 aangepast door Jan van der Maas. 
Tabel 8.22 Armbezoekers/ ambtenaren voor sociale arbeid in vaste dienst (1871-1918)

\begin{tabular}{|c|c|}
\hline Jaren & Aantal armbezoekers in vaste dienst \\
\hline $1871-1878$ & 5 \\
\hline 1878-1887 & 6 \\
\hline 1887-1892 & 8 \\
\hline $1892-1893$ & 9 \\
\hline 1893-1898 & 11 \\
\hline 1898-1899 & 14 \\
\hline 1899-1901 & 15 \\
\hline $1901-1903$ & 18 \\
\hline 1903-1906 & 19 \\
\hline 1906-1909 & 21 \\
\hline 1909-1913 & 22 \\
\hline 1913-1914 & 25 \\
\hline 1914-1915 & 21 \\
\hline 1915-1916 & 20 \\
\hline 1916-1917 & 22 \\
\hline 1917-1918 & 21 \\
\hline
\end{tabular}

Bron: Jaarverslagen Burgerlijk Armbestuur; SAA 5256 Archief van de Gemeentelijke Sociale Dienst en rechtsvoorgangers 831-838. (Sinds 1918 worden armbezoekers aangeduid als ambtenaren voor sociale arbeid)

Tabel 8.23 Werknemers armenzorg/maatschappelijk hulpbetoon (1918-1940)

\begin{tabular}{|l|l|}
\hline Jaar & Totaal in dienst \\
\hline 1918 & 101 \\
\hline 1925 & 229 \\
\hline 1930 & 264 \\
\hline 1935 & 559 \\
\hline 1940 & 688 \\
\hline
\end{tabular}

Bron: SAA 5256. Bestanddelen 831-838. Jaarverslagen Burgerlijk Armbestuur. 


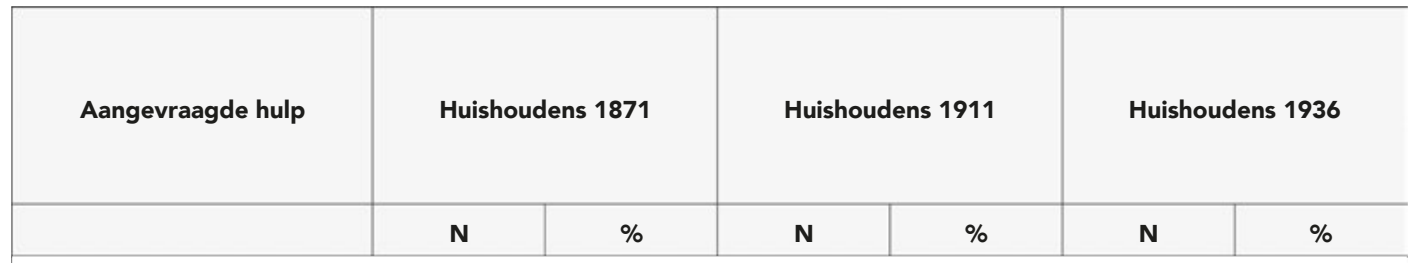

\section{Aanvragen in geld}

\begin{tabular}{|l|r|r|r|r|r|r|}
\hline Geld $^{1}$ & 2 & 6 & 49 & 75 & 63 & 100 \\
\hline Handelsgeld $^{2}$ & - & - & 2 & 3 & - \\
\hline Lossing van panden & - & - & 1 & 2 & - \\
\hline
\end{tabular}

\section{Aanvragen in natura}

\begin{tabular}{|c|c|c|c|c|c|c|}
\hline Kraamzorg & 2 & 6 & 2 & 3 & - & - \\
\hline Onderstand ${ }^{3}$ & 15 & 43 & - & - & - & - \\
\hline Opname armenhuis & - & - & 6 & 9 & - & - \\
\hline Reisgeld & 1 & 2 & - & - & - & - \\
\hline Versterkende middelen & - & - & 3 & 5 & - & - \\
\hline Winterbedeling & 15 & 43 & 2 & 35 & - & - \\
\hline Totaal & 35 & 100 & 65 & 100 & 63 & 100 \\
\hline \multirow[t]{2}{*}{ Geen specifieke aanvraag } & 28 & & 10 & & - & - \\
\hline & 63 & & 75 & & 63 & \\
\hline Aanvragen in geld & & 6 & & 78 & & 100 \\
\hline Aanvragen in natura & & 94 & & 22 & & 0 \\
\hline Totaal & & 100 & & 100 & & 100 \\
\hline
\end{tabular}

1 Geld wordt gebruikt voor directe gezinsconsumptie.

2 Handelsgeld is bedoeld om een winkel of een nering te kunnen voortzetten. Handelsgeld wordt meestal gebruikt om goederen aan te kopen.

3 "Onderstand" moet in 1871 als een aanvraag voor steun in natura worden opgevat. In 1911 en in 1936 werd met onderstand een uitkering in geld bedoeld. De dossiers geven niet enkel de hulpvraag aan, maar maken ook duidelijk wat er werd toegekend. Hierdoor blijkt wat onder onderstand moest worden begrepen. 


\begin{tabular}{|l|r|r|}
\hline Toegekende hulp & \multicolumn{2}{|c|}{ Huishoudens } \\
\hline & N & 36 \\
\hline Geldbedeling & 22 & 38 \\
\hline Brood (zomerbedeling) & 23 & 22 \\
\hline Brood en turf (winterbedeling) & 14 & 2 \\
\hline Brood en turf (zomer- en winterbedeling)1 & 1 & 2 \\
\hline Brood en geld & 1 & 100 \\
\hline Totaal & 61 & 36 \\
\hline & & 2 \\
\hline Toegekende aanvragen in geld & & 62 \\
\hline Toegekende aanvragen zowel in geld als in natura & & 100 \\
\hline Toegekende aanvragen in natura & & \\
\hline Totaal & & \\
\hline
\end{tabular}

Tabel 8.26 Toegekende hulp in 1911 en 1936

\begin{tabular}{|c|c|c|c|c|}
\hline \multirow[t]{2}{*}{ Toegekende aanvraag } & \multicolumn{2}{|c|}{1911} & \multicolumn{2}{|c|}{1936} \\
\hline & $\mathbf{N}$ & $\%$ & $\mathbf{N}$ & $\%$ \\
\hline \multicolumn{5}{|l|}{ Toegekend in geld } \\
\hline Geld & 12 & 20 & 53 & 92 \\
\hline Geld en brandstoftoeslag & 10 & 17 & - & - \\
\hline Handelsgeld & 1 & 2 & 1 & 2 \\
\hline \multicolumn{5}{|l|}{ Toegekend in geld en natura } \\
\hline Brood, briketten en geld & 22 & 38 & 1 & 2 \\
\hline \multicolumn{5}{|l|}{ Toegekend in natura } \\
\hline Kraamzorg & - & - & 2 & 4 \\
\hline Opname Armenhuis & 1 & 2 & - & - \\
\hline Schoenen & 2 & 3 & - & - \\
\hline Winterbedeling & 6 & 10 & - & - \\
\hline Zomer- en winterbedeling & 3 & 5 & - & - \\
\hline Zomerbedeling & 2 & 3 & - & - \\
\hline Totaal & 59 & 100 & 57 & 100 \\
\hline Geen opgave aard toekenning & 1 & & 3 & \\
\hline Generaal totaal & 60 & & 60 & \\
\hline Toegekende aanvragen in geld & 23 & 39 & 54 & 94 \\
\hline Toegekende aanvragen in geld en natura & 22 & 37 & 1 & 2 \\
\hline Toegekende aanvragen in natura & 14 & 24 & 2 & 4 \\
\hline Totaal & & 100 & & 100 \\
\hline
\end{tabular}

1 Deze partijen kregen voor 12 maanden steun, dus in één keer zowel winterbedeling (met turf) als zomerbedeling (zonder turf). 
Tabel 8.27 Burgerlijk overheidspersoneel in Nederland (1849-1930)

\begin{tabular}{|l|r|r|}
\hline Jaar & Omvang van het personeel x $\mathbf{1 . 0 0 0}$ & In \% van de totale beroepsbevolking \\
\hline $\mathbf{1 8 4 9}$ & 20 & 1.6 \\
\hline $\mathbf{1 8 8 9}$ & 55 & 3.1 \\
\hline 1899 & 69 & 3.4 \\
\hline 1909 & 91 & 3.7 \\
\hline 1920 & 204 & 6.9 \\
\hline 1930 & 212 & 6.2 \\
\hline
\end{tabular}

Bron: Van Braam (1957), 22 en 25.

Tabel 8.28 Woningen in Amsterdam (1859-1930

\begin{tabular}{|c|c|c|c|c|c|c|c|c|}
\hline Volkstellingen & 1859 & 1869 & 1879 & 1889 & 1899 & 1909 & 1920 & 1930 \\
\hline Bevolking buurten & 239.281 & 263.425 & 312.143 & 404.172 & 507.887 & 562.017 & 643.704 & 753.369 \\
\hline Bevolking bewoonde huizen & 230.825 & 255.180 & 305.071 & 395.039 & 495.982 & 550.557 & 631.735 & 740.220 \\
\hline Bewoonde huizen & 23.223 & 24.007 & 25.877 & 29.862 & 37.535 & 40.955 & 45.425 & \\
\hline Onbewoonde huizen & 1.180 & 333 & 275 & 1.987 & 967 & 929 & 195 & \\
\hline Huizenvoorraad & 24.403 & 24.340 & 26.152 & 31.849 & 38.502 & 41.884 & 45.620 & \\
\hline$\%$ onbewoonde huizen & 4,84 & 1,37 & 1,05 & 6,24 & 2,51 & 2,22 & 0,43 & \\
\hline Huishoudens & 50.398 & 56.070 & 67.273 & 84.561 & 104.684 & 118.544 & 141.609 & 182.333 \\
\hline Afzonderlijk levenden & 7.240 & 8.111 & 11.049 & 7.930 & 12.725 & 16.698 & 24.953 & 33.046 \\
\hline Huishoudens totaal & 57.638 & 64.181 & 78.322 & 92.491 & 117.409 & 135.242 & 166.562 & 215.379 \\
\hline Alle huishoudens/huis & 2,48 & 2,67 & 3,03 & 3,10 & 3,13 & 3,30 & 3,67 & \\
\hline Gezinshuishoudens/huis & 2,17 & 2,34 & 2,60 & 2,83 & 2,79 & 2,89 & 3,12 & \\
\hline \multicolumn{9}{|l|}{ Woningtellingen } \\
\hline Bewoonde woningen & & & & & 116.903 & 135.070 & 142.200 & 215.379 \\
\hline Bewoners/woning & & & & & 4,2 & 4,1 & 4,4 & 3,4 \\
\hline $\begin{array}{l}\text { Gemiddelde omvang Gezins- } \\
\text { huishouden }\end{array}$ & 4,45 & 4,37 & 4,40 & 4,61 & 4,63 & 4,50 & 4,28 & 3,87 \\
\hline
\end{tabular}

Bron: berekend uit de Volkstelling of Woningtelling van het betreffende jaar. Alle gegevens hebben betrekking op de bevolking minus de bewoners van gestichten en schepen;

De afdeling 'Bevolking buurten' is inclusief de bewoners van gestichten. 


\section{CURRICULUM VITAE}

Jan Adriaan van der Maas is in Amsterdam in 1951 geboren. Na het eindexamen HBS in 1969 studeerde hij geschiedenis aan de deeltijdse opleiding leraar geschiedenis van het Nutsseminarium aan de Universiteit van Amsterdam. Hij behaalde de volledige MO-akte. Deze studie werd voortgezet aan de Universiteit van Amsterdam, met als hoofdvak economische en sociale geschiedenis (cum laude doctoraalexamen in 1981). Postdoctoraal studeerde hij nog economie en kunstgeschiedenis aan de Universiteit van Amsterdam. Na vanaf 1969 in het bedrijfsleven te hebben gewerkt, was hij van 1972 tot 2017 lerarenopleider geschiedenis, zowel bij de bachelor als bij de masteropleiding van de Hogeschool van Amsterdam en diverse rechtsvoorgangers. Hij was ook opleidingscoördinator van de deeltijdse opleiding leraar geschiedenis. Tussen 1985 en 2010 was hij ook verbonden als docent sociaaleconomische geschiedenis aan de masteropleiding van Fontys Lerarenopleiding Tilburg. Na zijn pensionering in 2017 is hij nog actief als docent op het terrein van Europese cultuur, cultureelmentale geschiedenis en historiografie voor de masteropleiding van de Hogeschool van Amsterdam. Verder verzorgt hij cursussen bij de HOVO in Alkmaar. 



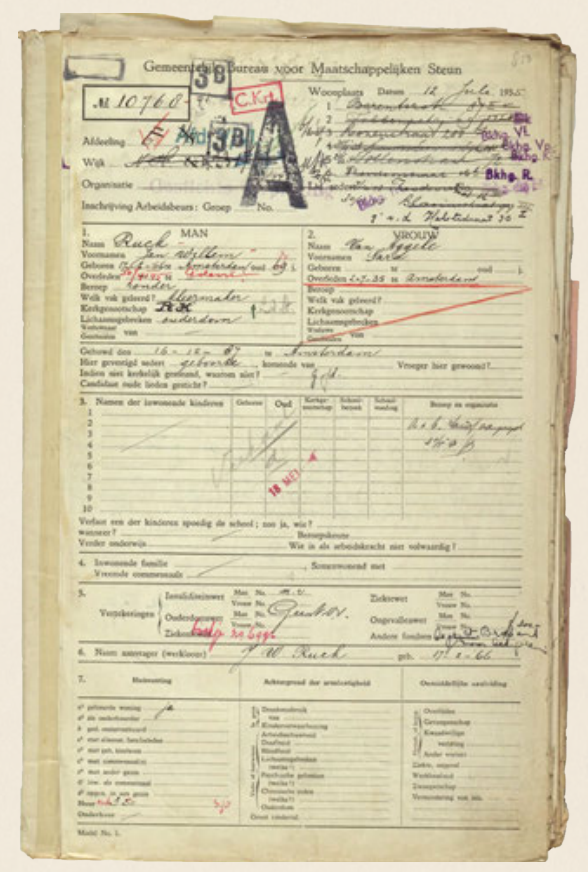

"ER HEERSCHT DOODELIJKE ARMOEDE". Zo beschreef een armbezoeker de situatie van een gezin in 1871. Hulp was dringend nodig. Waarom werd bijstand verleend? Deze studie beschrijft de ontwikkeling van de motieven om hulp te verlenen aan de armen tussen 1870 en 1940. Hulp aan de armen door de gemeentelijke armenzorg van Amsterdam. In het begin werden veel morele principes gehanteerd. Wie zich niet beschaafd gedroeg, had een grote kans geen hulp te krijgen. Maar geleidelijk werd de hulpverlening steeds meer zakelijk gemotiveerd: als je inkomen te laag werd geschat, dan verleende de gemeentelijke armenzorg steun. Naast deze verzakelijking is er een proces van bureaucratisering van de armenzorg waar te nemen. Het onderzoek naar deze bureaucratisering is een tweede pijler van dit boek. De gemeentelijke armenzorg wordt geanalyseerd aan de hand van de bureaucratiseringstheorie van Max Weber. Aan het einde van deze studie wordt in een zestal levensverhalen het leven van arme gezinnen in detail belicht. Hierdoor is een inkijk mogelijk in het dagelijks leven van heel gewone Amsterdammers. 